A Revision of the Genus Anthurium (Araceae) of Mexico and Central America. Part I: Mexico and Middle America

Author(s): Thomas B. Croat

Source: Annals of the Missouri Botanical Garden, Vol. 70, No. 2 (1983), pp. 211-416

Published by: Missouri Botanical Garden Press

Stable URL: http://www.jstor.org/stable/2399049

Accessed: 09-05-2015 01:34 UTC

Your use of the JSTOR archive indicates your acceptance of the Terms \& Conditions of Use, available at http://www.jstor.org/page/ info/about/policies/terms.jsp

JSTOR is a not-for-profit service that helps scholars, researchers, and students discover, use, and build upon a wide range of content in a trusted digital archive. We use information technology and tools to increase productivity and facilitate new forms of scholarship. For more information about JSTOR, please contact support@jstor.org. 


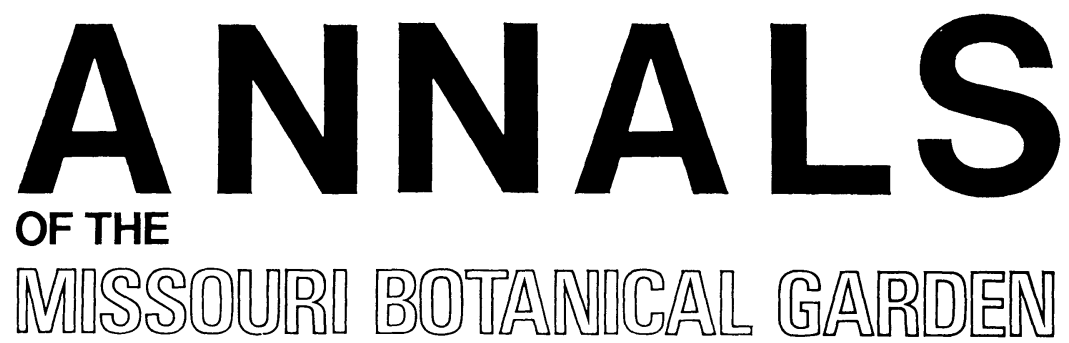

\title{
A REVISION OF THE GENUS ANTHURIUM (ARACEAE) OF MEXICO AND CENTRAL AMERICA. PART I: MEXICO AND MIDDLE AMERICA ${ }^{1}$
}

\author{
Thomas B. CROAT ${ }^{2}$
}

\begin{abstract}
Anthurium (Araceae), a distinct neotropical genus with more than 700 species, is a member of the subfamily Pothoideae. The genus ranges from Northern Mexico and the Greater Antilles to Southern Brazil and Northern Argentina and Paraguay. Species diversity is greatest at lower to middle elevations of northern South America, Panama, and Costa Rica, while the upper Amazonian forests and lower Amazonian forests are relatively poor in species. In this paper, 122 species from Mexico and Middle America are revised. The 152 Panamanian species will be treated in a subsequent paper. In Mexico and Middle America, Costa Rica is richest in species, with 65. The remainder of Middle America is relatively poor in species, with Nicaragua having only 25 known species, Honduras having only 13 known species, Guatemala having 25 known species, and Belize fewer than 10 species. Mexico has 41 known taxa with 26 species endemic. In all, six new taxa from Mexico and Middle America were described in this revision: A. armeniense, A. chamulense Matuda ssp. oaxacanum, A. halmoorei, A. lancetillense, A. nelsonii, and A. rzedowskii. In addition, five new combinations have been proposed, including A. chiapasense ssp. tlaxiacense (Matuda) Croat, A. cuneatissimum (Engler) Croat, A. pedatoradiatum ssp. helleborifolium (Schott) Croat, A. schlechtendalii ssp. jimenezii (Matuda) Croat, and A. subcordatum ssp. chlorocardium (Standl. \& L. O. Wms.) Croat.
\end{abstract}

Anthurium, a neotropical genus with more than 700 species, is a member of subfamily Pothoideae. Pothoideae contains ten genera, with only Anthurium and Heteropsis occurring in the American tropics. The Pothoideae is tropical, except for the tribe Acoreae, which contains the widespread genus Acorus and the Australian en- demic Gymnostachys. The tribes Culcasieae and Zamioculcaseae with 26 species are strictly African. Four Asian genera, Pothoidium, Anadendrum, Pothos, and Pedicellarum, account for eight percent of the species of the subfamily. Only Pothos, with about 50 species, is very large.

Araceae contains 110 genera and more than

${ }^{1}$ This study was completed with support from National Science Foundation grant DEB 77-14414. The revision was based on field observations in Mexico and Central America during 1976, 1977, and 1979 and on studies in Panama since 1967. In addition, all but 12 of the 122 species are in cultivation at the Missouri Botanical Garden, and extensive observations on these living collections have been carried out. I acknowledge the assistance of D. Nicolson, who reviewed the manuscript, and of B. McAlpin, B. Virden, and H. Kamemoto, who provided critical living material. Descriptions are largely based on living collections, but descriptive data were supplemented by the extensive collections at $\mathrm{MO}$ and borrowed collections from A, BR, CAS, CR, F, G, $\mathrm{H}, \mathrm{K}, \mathrm{M}, \mathrm{MEXU}, \mathrm{MICH}, \mathrm{NY}, \mathrm{P}, \mathrm{UC}$, and US. I thank the curators of these herbaria for the loan of materials. Finally, I acknowledge the technical assistance of Frances Mazanec, Patricia Croat, Ann Ruger, and Emily Colletti.

${ }^{2}$ Missouri Botanical Garden, P.O. Box 299, St. Louis, Missouri 63166.

AnN. Missouri Bot. Gard. 70: 211-420. 1983. 
2,500 species. It is worldwide in distribution but has most species in tropical areas. Its centers of distribution include both Asia and America (Croat, 1979). There are 14 genera restricted to Africa, and a few genera restricted to temperate regions of the northern hemisphere, including the Mediterranean region. Important local centers of diversity include subtropical and warm temperate South America, with eleven endemic genera, and the Indomalayan region, with thirteen endemic genera. At least 1,350 species, roughly 55 percent of the total, occur in the New World tropics and subtropics. Roughly half of these are Anthurium.

\section{Materials And AcKNowledgments}

The terminology and usage in the descriptions in this paper are defined in "Standardization of Anthurium Descriptions" (Croat \& Bunting, 1979). Colors referenced in the descriptions that follow are taken from the color chart by Berlin and Kay (1969). This color chart, available from the University of California Press, is a reproduction of the Munsell Color Array of 40 hues, at maximum saturation, with nine degrees of brightness. The B \& K (Berlin \& Kay) color chart, as it is referred to here, represents 40 hues in the vertical columns and 9 degrees of brightness in the horizontal rows. Colors are arranged in 10 basic clusters with 4 different hues per cluster, ranging from red through yellow, green, blue, purple, and finally red-purple. The four columns for each color cluster are numbered 2.5, 5, 7.5, and 10. These numbers are repeated for each basic color type. The colors from the B \& K color chart are read by first reporting the color, then the row followed by the column. For example, the third color in the fifth row in the red area would be called Red 5/7.5. The second color in the eighth row would be called Red $8 / 5$. I have preceded the color references by $\mathrm{B} \& \mathrm{~K}$ to indicate which color chart is being used.

Although a more complete discussion of flowering behavior of Anthurium has been published elsewhere (Croat, 1980), mention should be made here of the descriptions of flowering behavior, especially with regard to the development of stigmatic droplets and the progressive development of stamens. Most observations reported here are based on the study of cultivated material, and references to the degree of accumulation of stigmatic fluid might be inaccurate in the absence of pollinators to remove it. Nevertheless, these observations show that important taxonomic characters are exhibited by the timing and amount of stigmatic fluid and particularly by the developmental sequence of the stamens. They are therefore recorded here as part of the description of the species where they have been observed.

All estimates of ecological zones given in this paper are based on either Holdridge Life Zone maps for most Central American countries and for Panama or on the "Mapa de tipos de vegetacion de la Republica Mexicana" (Flores et al., 1971). As yet no study has been made to correlate the vegetation types represented on the Mexican map with those of the Holdridge Life Zone system. For an understanding of this system see Holdridge, et al. (1971).

\section{Distribution OF ANTHURIUM}

Anthurium ranges from Mexico (Tamaulipas on the Caribbean slope and Nayarit on the Pacific slope) to northern Argentina and Paraguay. Species diversity is greatest in the low and middle elevations of northern South America, Panama, and Costa Rica, with less important centers in the mountains of southern Mexico and southeastern Brazil. While the upper Amazon forests of Bolivia and especially Peru, Ecuador, and Colombia are rich in species, the lower Amazon is relatively poor in species.

\section{Distribution of Central American ANTHURIUM}

Because of the large size of the genus and its taxonomic difficulty, revisionary work on $A n$ thurium must progress in stages. There are approximately 219 species of Anthurium in Mexico and Central America (including Panama). This paper, the first of a series, will deal with 122 Mexican and Middle American taxa, but will exclude a revision of the Panamanian species, which number 152 species alone. The latter will be presented in Part II of this paper. Owing to the great morphological variability in most parts of Anthurium, it has been very difficult to prepare a key to large numbers of species. In addition, the Panamanian species are not yet sufficiently well known to complete a key to the species occurring in Panama. This is due to the fact that Panama has almost as many species as the rest of Central America and Mexico put together. 
Most of these species have been discovered only in recent years and many are still poorly known.

The Costa Rican Anthurium flora is more closely related to that of Panama than to that of the remainder of Central America, but it is relatively well known (Croat \& Baker, 1979), and thus will be included here.

Although Nicaragua is beginning to receive serious botanical attention as the result of the Flora of Nicaragua Project conducted by W. D. Stevens (Missouri Botanical Garden), its aroid flora is proving to be relatively poor. Most Anthurium species collected in Nicaragua represent species of Costa Rica and Panama that reach their limit in Nicaragua. These are found principally in the very wet southeastern corner in the Department of Zelaya. Examples of these are A. acutangulum Engl., A. hacumense Engl., A. ochranthum C. Koch, A. ramonense Engl. ex K. Krause, A. spathiphyllum N. E. Brown, and A. upalaense Croat $\&$ Baker. Other species are basically Mexican species that just reach Nicaragua from the north. Examples of these are $A$. huixtlense Matuda and A. schlechtendalii Kunth.

Additional Nicaraguan Anthurium species include wide ranging species that range from Mexico or Middle America to South America, such as $A$. cubense Engl. (also in West Indies), A. clavigerum Poepp., A. friedrichsthalii Schott, $A$. gracile (Rudge) Lindl., $A$. interruptum Sodiro, $A$. microspadix Schott, $A$. obtusilobum Schott, $A$. ravenii Croat \& Baker, A. scandens (Aubl.) Engl., and $A$. trinerve Miq. Still others are species that range throughout Central America, such as $A$. bakeri Hook. f. and A. pentaphyllum (Aubl.) G. Don var. bombacifolium (Schott) Madison. These are also expected to be found in Colombia. The only endemic species of Anthurium known from Nicaragua is $A$. beltianum Standl. \& L. O. Wms.

To date, only 25 species are known for Nicaragua and, although it is certain that more species will be added to the flora with the ongoing collecting by Stevens and his associates, there is little doubt that species diversity of Anthurium is greater south of the San Juan depression, which separates Costa Rica and Nicaragua. Costa Rica, although appreciably smaller, has approximately 65 species of Anthurium (Croat \& Baker, 1979). Panama is even richer with 152 species. Nicaraguan forests that I have investigated were poor in species. For example, the cloud forest on Volcán Mombacho east of Lake Nicaragua had only a few species of aroids. Even the much wetter cloud forest regions between Jinotega and Matagalpa produced relatively few species. In a comparable cloud forest of Costa Rica or Panama, many species can be encountered in a small area.

The remainder of Middle America is, like Nicaragua, relatively poor in species. Honduras has only 13 known species with an additional four species, namely $A$. friedrichsthalii Schott, $A$. $m i$ crospadix Schott, A. schlechtendalii Kunth, and $A$. trinerve Miq., expected there. Like Nicaragua, Honduras is expected to have only a single endemic species, namely $A$. lancetillense Croat.

Belize has no more than eight to ten species (none of them endemic) but Guatemala, with about 25 species, is richer.

Although the greater number of species in Guatemala can perhaps be attributed in part to the fact that it has been much better explored than the remainder of Middle America, the chief reason for its greater number of known species is that it shares with Mexico a number of typically Mexican species. These include $A$. chiapasense Standl., A. huixtlense Matuda, A. montanum Hemsl., A. seleri Engl., and $A$. titanium Standl. \& Steyerm. A number of other species from Chiapas are to be expected in Guatemala. These include $A$. berriozabalense Matuda, $A$. chamulense Matuda, $A$. cordatotriangulum Matuda, $A$. nakamurae Matuda, $A$. ovandense Matuda, and $A$. pedatoradiatum Schott.

Still, Guatemala is much richer in species in its own right than the remainder of Middle America, with three endemic species. These are A. armeniense Croat, A. parvispathum Hemsl., and $A$. retiferum Standl. \& Steyerm. However, all of these might possibly also be discovered in Chiapas with further collecting there.

Mexico, with 41 known taxa and an additional four or five species to be expected, has a relatively rich Anthurium flora with 26 endemic taxa. Some of the endemic taxa are relatively widespread within Mexico, such as $A$. andicola Liebm., $A$. chiapasense Standl., A. schlechtendalii ssp. jimenezii (Matuda) Croat, $A$. nizandense Matuda, $A$. ovandense Matuda, $A$. pedatoradiatum Schott, and $A$. podophyllum (Cham. \& Schlecht.) Kunth. The majority, however, are relatively narrow endemics, mostly known only from northern Oaxaca (seven taxa, $A$. cerropelonense Matuda, $A$. chamulense ssp. oaxacanum Croat, A. longipeltatum Matuda, A. machetioides Matuda, A. nelsonii Croat, $A$. subovatum Matuda, $A$. umbrosum 
Liebm., A. yetlense Matuda); northern Chiapas (four taxa, A. berriozabalense Matuda, A. clarinervium Matuda, A. leuconeurum Lem., A. lezamae Matuda); or southeastern Chiapas (two taxa, A. cordatotriangulum Matuda, A. nakamurae Matuda).

Many of the Mexican species appear closely related, and their current isolation is perhaps due to changes in the environment brought about by increasingly arid conditions and the formation of broad expanses of intervening desert or extremely arid areas. Thus, for example, $A$. halmoorei Croat, $A$. schlechtendalii ssp. jimenezii (Matuda) Croat, and A. nizandense Matuda all appear to have been derived from $A$. schlechtendalii Kunth, a common species from the Caribbean slope (or from a common ancestor). Speciation here would appear to have resulted from the onset of arid conditions with the resulting isolation of these species in specific parts of western Mexico. Similar isolation of species has occurred in Chiapas, where relatively close species are now endemic to northern Chiapas or to southeastern and southwestern Chiapas.

That Mexico and Middle America were isolated from Costa Rica and Panama during the evolution of many Mexican Anthurium species seems obvious from the fact that only six Mexican species, including A. flexile Schott, $A$. microspadix Schott, $A$. pentaphyllum var. bombacifolium (Schott) Madison, A. salviniae Hemsl., A. scandens (Aubl.) Engl., and A. trinerve Miq., reach Costa Rica. The same six species extend also to Panama and the latter two range throughout much of South America as well. The situation in Guatemala is little better with only ten species reaching Costa Rica. These include (in addition to the Mexican species already mentioned) $A$. bakeri Hook. f., A. cubense Engl., A. gracile (Rudge) Lindl., and $A$. interruptum Sodiro. The three latter species are also present in South America.

Further evidence of this isolation can be seen in the distinctive nature of many Mexican species and the predominance of D-shaped or broadly sulcate petioles that are uncommon elsewhere in Anthurium. This feature is exhibited in several leaf forms, including species with oblong leaf blades and ovate-cordate blades, as well as in pedatisect species, such as $A$. podophyllum (Cham. \& Schlecht.) Kunth and A. pedatoradiatum Schott. The Mexican species in this group will be referred to as the Anthurium andicola alliance. They may ultimately prove to be a sec- tion in their own right, but final judgment on this will be deferred until further work can be done with the South American species of the genus.

\section{History of Work With CENTRAL AMERICAN ANTHURIUM}

The last revision of Anthurium was that of Engler (1905), who reported 58 species for Central America. The work was completed at a time before serious botanical activity had begun in many parts of Central America, and the number of species is now estimated at 219 , almost a fourfold increase.

Since Engler's time, most work conducted on Anthurium in Central America has been the piecemeal description of new species and the compilation of floras for Guatemala, Costa Rica, and Panama. Most of the treatments were prepared by P. C. Standley, who also made a substantial number of collections. The Flora of Guatemala treatment was completed by P. C. Standley and J. A. Steyermark (1958). Steyermark also made many collections, especially in Guatemala, and must be mentioned as one of the few collectors who paid any attention to descriptive detail of the plants in his notes.

The most serious student of Anthurium was Eizi Matuda, who, over the course of approxi-. mately 30 years (beginning about 1949), worked with the Araceae of Mexico. In all, Matuda described 36 species (many of these now in synonymy) of Anthurium from Mexico. Matuda played an important role in botanizing in Mexico, especially in Chiapas. Several of the species he collected and described have not been seen since. Matuda's most important work (1954) summarized the Araceae flora of Mexico as it was known then, but he also described a number of species after the publication of that revision.

Also important in the study of Mexican Araceae was G. S. Bunting, whose "Commentary on Mexican Araceae," published in 1965, summarized his knowledge gained from four extensive field trips to Mexico during 1959, 1961, and 1962. Some of his commentary was useful in preparing my own field trips to Mexico. A revision of the palmately-lobed species of Anthurium by $\mathrm{M}$. Madison (1978) has also been useful during the preparation of this revision.

Only 35 of the 122 species inhabiting Mexico and Middle America were described before Engler's time. Of these, the largest number (19 species) were described by Schott with lesser 
numbers by Hemsley (three species), Poeppig and Endlicher (two species), Masters (two species), and Liebmann (two species). The remaining seven species were each published by a different author: Hooker, Rudge, Lemaire, Chamisso \& Schlechtendal, Aublet, Kunth, and Miquel.

Engler published an additional thirteen species near the turn of the century and Luis Sodiro, working in Ecuador, described two Central American species that range there during the same period.

Matuda, leading the list of Anthurium workers subsequent to Engler's time, published 19 species. Standley and his co-workers, L. O. Williams and J. A. Steyermark, published five species as a result of their work with the floristics of Central America. A single species each was described by J. F. Macbride, T. G. Yuncker, and L. H. Bailey during the same general period. Recently described material includes 20 species by Croat and Baker (1979) and a single taxon each by R. Sheffer and G. M. Barroso. This paper will describe six additional new species.

Several people, although not describers of $\mathrm{An}$ thurium, nevertheless made significant contributions by means of their collecting efforts. These include D. Breedlove (Chiapas), R. Baker and W. C. Burger (Costa Rica), H. Kennedy (Mexico and Central America), T. MacDougall (Mexico especially Oaxaca), and D. Neill and W. D. Stevens (Nicaragua). Special mention should be made regarding collections of Thomas MacDougall because he had the unusual practice of recollecting a species in the same area. When he did, he frequently (if not always) assigned the recollected plant the same number he had assigned it originally, using only a different date to distinguish different specimens. This practice has led in several cases to mixed collections when his later collections were in fact a different species that occurred in the same area.

\section{TAXONOMIC CHARACTERS}

Morphological characters used in the taxonomy of Anthurium depend to some extent upon the section being dealt with, but the characters that have been used most frequently have been shape and venation of the leaves, internode length, and the color and shape of the spathe and spadix. Many of these characters are already discussed elsewhere (Croat \& Bunting, 1979).

Roots. Although roots have not been used traditionally as taxonomic characters, they dis- play a wide variety of qualitative characters. Typically, roots develop one or more at each node. In section Polyphyllium Engl., the roots are numerous, short, and slender and are borne along the internodes. In most species of section Pachyneurium Schott, and in other shortstemmed species as well, the roots per node are much more numerous. Since the internodes are very short, the root mass can be large and dense, with the roots contiguous or nearly so. In many cases, there has been a divergence in the function of roots so that some are utilized exclusively for support while others are negatively geotropic and are directed upward where they collect debris, or they extend into the rosette of leaves and collect debris. In other cases, the support roots of the plant are negatively geotropic, such as in the case of pendent species (Madison, 1978). Commonly, roots appear smooth when fresh; when they are dry it can be seen that they actually consist of a dense mass of woolly trichomes that are so closely matted they look contiguous before shrinkage of the root. Anthurium gracile (Rudge) Lindl. has roots with a thick white layer of velamen useful in absorption of moisture from the air. Other species that have been investigated lack this velamen layer.

Stems and cataphylls. Although stem anatomy has not been adequately studied, the outward appearance of the stem provides few good taxonomic characters except for a considerable range in length and width of the internodes. Stems are usually scurfy and brown in age. While there is a considerable difference in the size, shape, and degree of indentation of the petiole scars, these characters have not been used systematically.

Much more important are the cataphylls that frequently persist on the stem. The color, texture, and the degree of weathering they undergo are useful taxonomic characters. Growth in Anthurium is sympodial with each shoot bearing a bicarinate prophyll and a larger, single-keeled cataphyll, a foliage leaf, and terminating in an inflorescence. The inflorescence, although always potential, may abort (Engler, 1877). The cataphylls, which are usually green, promptly turn brownish, reddish, or yellowish and may be deciduous. More frequently they persist, either remaining intact, such as in section Calomystrium Schott and some other species, or they are marcescent, variously weathering into a network of persistent fibers that may accumulate debris. The 
color, degree of weathering, and degree of persistence of the cataphylls frequently provide useful taxonomic characters.

Leaves. Among the more useful taxonomic characters that have been overlooked previously is the cross-sectional shape of petioles (Fig. 1). Most Anthurium species have petioles that are terete or subterete in cross-section and frequently also narrowly and obtusely channelled. However, considerable variation exists, and at least sometimes this is believed to be taxonomically significant. Many Mexican species have petioles that are D-shaped or broadly sulcate in crosssection. Petiole cross-sectional shape, within limits, has proven useful in the separation of species of Anthurium in the section Pachyneurium Schott, where leaf blades of many of the bird's-nest species are otherwise almost identical. However, petiole shape cannot be relied on entirely. Some of the more variable, wide-ranging species, such as $A$. schlechtendalii Kunth, have considerable variation in petiole cross-sectional shape even within a single population (see that species for a discussion of this). Some species of Anthurium have sharply triangular petioles, others trapezoidal, square, or terete with several to many sharp ridges. The degree of channelling of the petiole also provides useful taxonomic characters. The length of petioles, like overall size of any morphological part of Anthurium, is highly unreliable because plants often flower when quite young and thus the overall size of leaves, inflorescences, and other parts vary remarkably in size over the course of the life of the plant. More useful is the relative length of the petiole in comparison to the length of the inflorescence.

The most widely used taxonomic characters in Anthurium are the shape and venation of the leaves, since these are perhaps more diverse than in any other genus of plants (Croat \& Bunting, 1979). In addition, glandular punctations on the leaf blades provide useful characters and are valid, at least sometimes, at the sectional level. For example, sections Porphyrochitonium Schott, Tetraspermium Schott, and Digitinervium Sodiro consistently have glandular punctations on one or both surfaces. Still, some species in otherwise epunctate sections, such as section $\mathrm{Cal}$ omystrium Schott, have evolved glandular punctations independently. While many members of section Calomystrium Schott have brownish spots resembling the glandular punctations of section Porphyrochitonium Schott and others, at least one unknown isolated Brazilian species (Rosa \& Lira 2325) has definite glandular punctations on the lower blade surface. A group of coriaceous, cordate species from Mexico (A. verapazense alliance) has also developed glandular punctations.

Other useful features in the leaf include the presence of papillate epidermal cells, such as in section Cardiolonchium Schott, and the presence of easily visible raphide cells so prevalent in section Calomystrium Schott.

Inflorescences. The inflorescence, although generally critical for identification of species of Anthurium, has been under utilized, perhaps be-

FIgURE 1. Cross-sectional petiole shapes in Anthurium.-A. Basically terete: ranging from esulcate (1), to shallowly and acutely sulcate ( $2 \& 3)$, to obtusely and broadly sulcate (4), to narrowly and obtusely sulcate (5), to narrowly and acutely sulcate (6), broadly and acutely sulcate (7), shallowly and broadly sulcate (8), flat adaxially (9), flat adaxially with marginal ribs (10), to flat adaxially with marginal and medial ribs (11). - B. D-Shaped or broader than thick: ranging from flat adaxially with obtuse margins (1), to broadly sulcate with obtuse margins (2), broadly sulcate with acute margins (3), flat adaxially with acute margins (4), flat adaxially with erect margins (5), flat adaxially with erect margins and with 1 or more medial ribs (6 \& 7). - C. U-shaped or thicker than broad: ranging from broadly and obtusely sulcate (1) to narrowly and obtusely sulcate (2), narrowly and acutely sulcate with acute margins* (3), shallowly and acutely sulcate* (4), sulcate with acute margins (5), sulcate with sharp margins and a medial rib* $(6)$. - D. Markedly angular: ranging from quadrangular with acute angles (1) to quadrangular with obtuse angles (2), trapezoidal (3), obtusely triangular (4), acutely triangular (5), acutely triangular with two marginal ribs (6), basically triangular with two abaxial ribs (7), obtusely triangular, narrowly and sharply sulcate with convex sides (8). - E. Markedly ribbed abaxially: ranging from trapezoidal or quadrangular, sharply and broadly sulcate adaxially, 3-ribbed abaxially (1), to obtusely and broadly sulcate adaxially, 3 -ribbed abaxially (2), broadly and obtusely sulcate adaxially 5-ribbed abaxially (3), broadly and sharply sulcate adaxially, narrowly and sharply ribbed around the remaining circumference (4), or with one or more ribs on the sulcus (5).

* Not yet observed but to be expected. 
A. Basically terete

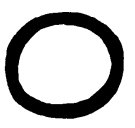

1

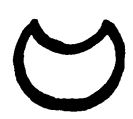

7

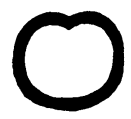

2

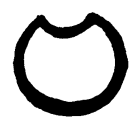

8

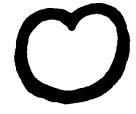

3

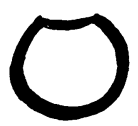

9

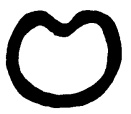

4

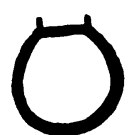

10

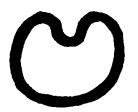

5

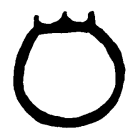

11

B. D-shaped or broader than thick

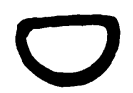

1

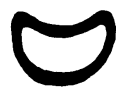

2

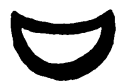

3

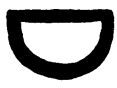

4

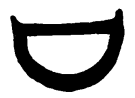

5

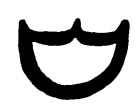

6

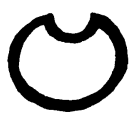

6

C. U-shaped or thicker than broad

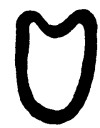

1

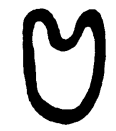

2

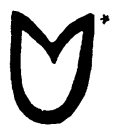

3

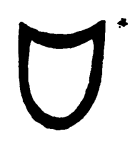

4

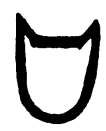

5

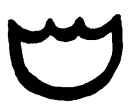

7

D. Markedly angular

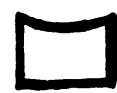

1

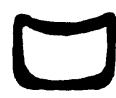

2

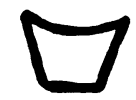

3

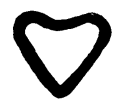

4

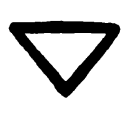

5
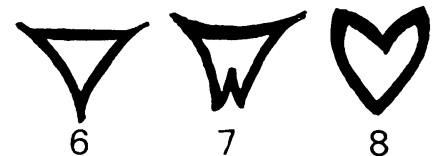

E. Markedly ribbed abaxially

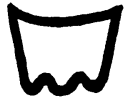

1

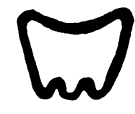

2
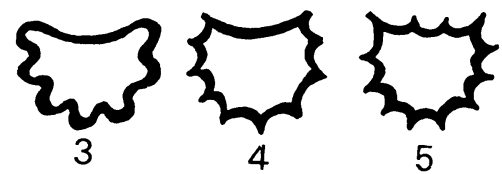
cause of too much reliance on herbarium material, which greatly diminished the value of the inflorescence. Peduncle length has frequently been used as a taxonomic character, yet length alone is extremely variable on plants of different ages and even in populations of plants of the same age. However, the ratio of the peduncle length to the petiole length is usually relatively constant and often provides a useful character. Like most vegetative parts, the overall dimensions of the spathe and spadix are not very useful, but again the ratio of the length of the spathe to the length of the spadix is relatively reliable. The shape of both the spathe and spadix and the texture of the spathe are usually much more reliable than size.

The spadix and the many characters it embodies is perhaps one of the least used taxonomically. This is no doubt due to the fact that too few species have been critically compared in live condition. The dried spadix is difficult to study and loses many of the characters that are apparent before drying. One of the most useful characters exhibited by the spadix is color. Spadix color when seen at anthesis is usually stable, and species vary considerably in the colors exhibited. In some species, however, the spadix varies from green to violet-purple. While many spadices are green before the spathe opens, most quickly assume the color they will have at anthesis. Some species may be green when stamens begin to emerge and later may turn violet-purple. Some species change colors after anthesis, so it is important to make note of the color at anthesis. Anthurium huixtlense Matuda and A. formosum Schott, for example, have spadices that become noticeably darker after anthesis.

Other characters exhibited by the spadix include scent, size, shape, and texture of the flowers; the number of flower spirals and the number of flowers per spiral; the disposition of the stigmas and timing of the stigmatic droplets; the rate of emergence and disposition of the stamens, as well as the shape of anthers and pollen color. Many of these characters are discussed in detail in Croat (1980), but a summary of the important points will be included here as well.

Although there has been no success as yet in determining scents of flowering Anthurium, there is little doubt that a large percentage of them have distinctive aromas. Those with attractive bright spadices have sweet aromas, such as of mint or lilac, and are no doubt bee-pollinated. Euglossine bees have been seen in several cases visiting Anthurium (Croat, 1980). Species with purple or drab colored spadices generally have yeasty or rotting fruit aromas (the scent of one species is like that of fresh cucumbers) and are probably fly-pollinated. Scents are usually not evident at night, and some species are phenologically active, presenting their aromas only during midday. Aromas of some species are sometimes so intense as to be smelled easily from a distance of several meters, but most species give only faint but distinct aromas.

Flowers are closely aggregated in spirals and are quite variable in size and shape. Their overall shape at the apex may be square, rhombic, or 4-lobed. The tepals themselves may be 3,4 , or 5 -sided. The texture of the surface, presence of droplets, raphide cells, and other features, all may be taxonomically important.

Stigmas may be slitlike or brushlike and exserted. The production of stigmatic droplets varies considerably from species to species, with both timing and duration being important. The sequence and duration of stamens as well as their method of presentation is similarly important. While most anthers are merely exserted just above the tepals, the stamens in some species are exserted and later the filament shrinks and retracts the anther to the surface of the tepals. Stamens in other species do not retract and the filament and anthers remain exposed. Stamens in still others retract completely below the surface of the tepals and thus out of sight. The sequence of staminal emergence is also quite variable (Croat, 1980), with the rate of emergence being an additional variable. Most species with typically long-tapered spadices have emergence beginning at the base of the spadix and progressing toward the apex. Species with cylindroid or clavate spadices have staminal emergence generally scattered or even beginning at the apex or middle. In all types of spadices the rate of emergence may be quite different. For example some species develop all of their lateral stamens before the third (alternate) stamen and finally the fourth (alternate) stamen emerge. Still other species have all stamens of the flowers in any spiral fully exserted before many flowers in succeeding spirals have their lateral stamens exserted. In other words, the leading spirals in the staminal development progression are few. In contrast, other species may have, for example, ten or more of the leading spirals with only lateral stamens exposed, with another ten or more of the preceding spirals bearing three stamens (i.e., the laterals plus the third, usually anterior, stamen) and finally all of 
the lower (basal) spirals with a full complement of four stamens exposed.

All of the characters mentioned here have proven to be useful taxonomic characters, yet most have never been mentioned previously by other workers.

Fruits. Anthurium fruits consist of 2-loculed berries. The berries provide a number of useful characters including size, shape, and color, the nature of the pericarp and mesocarp, the presence or absence of raphide cells, as well as the number, size, and shape of seeds. Engler (1905) appeared to realize the significance of the berries in classification, but unfortunately he had not seen berries on the majority of the species he studied. Because Anthurium has markedly protogynous flowers (Croat, 1980), they do not readily set fruit on greenhouse collections without manipulation. Often this is not possible without a second individual of the species. A great deal of attention has been given to those species in the living collections for which fruits were not known, in order to encourage them to set fruit.

The number of seeds per locule has long been considered an important character, with such groups as sections Tetraspermium Schott, Gymnopodium Engl., and Porphyrochitonium Schott having more than one seed per locule, while the remaining sections usually have one per locule.

Seeds themselves are as individually different from species to species as are the berries. Most have sticky, mucilaginous appendages firmly associated with them (Croat, 1980) often attached to one or both ends. In some cases the seed is completely enclosed in a mucilaginous envelope. These extremely sticky structures seem ideally suited to being attached to bird beaks, and $A n$ thurium berries seem ideally suited for bird dis- persal. Many of the Mexican species of Anthurium lack a sticky appendage on the seeds.

\section{Sectional Classification of Central AMERICAN ANTHURIUM}

In many cases the existing sectional classification systems of Schott and of Engler are inadequate. While some species assigned to various sections by Engler (1905) may be related, most sectional descriptions have many overlapping characteristics, and I believe that many species assigned to a particular section by Engler bear little relationship to each other, e.g., A. gracile (Rudge) Lindl. and $A$. friedrichsthalii Schott in Schott's section Leptanthurium, and A. protensum Schott and $A$. durandii Engl. in Engler's section Urospadix. Anthurium friedrichsthalii Schott is a typical member of section Porphyrochitonium Schott, as is $A$. durandii Engl., while $A$. protensum Schott is a member of section $\mathrm{Pa}$ chyneurium Schott.

A review of the sectional classification of $A n$ thurium will be published elsewhere and, although an attempt will eventually be made to revise the sectional classification of Anthurium, it is premature to arrange Central American species in any subgeneric classification system in this treatment. An attempt will be made here, however, tentatively to assign all Central American species to a section. In some cases species will be placed within an alliance of species that may later be ranked at the sectional level.

It is hoped that ongoing studies with live material including cytological, anatomical, and chemical studies will prove adequate to provide a thorough analysis of the sectional classification of the genus.

\section{Provisional Sectional Placement of Anthurium Species of Mexico And Middle America*}

1a. Leaf blades prominently 3-lobed or palmatifid to palmatisect.

2a. Leaf blades with the lobes united at the base.

3a. Leaf blades with three lobes (the lateral or posterior lobes often smaller than the central lobe)

Section Semaeophyllium Schott

A. subsignatum Schott

A. tilaranense Standl.

\footnotetext{
* Three sections do not occur in Central America: section Gymnopodium Engl. is represented by a single species $A$. gymnopus Griseb. from Cuba; section Chamaerepium Schott, represented by a single species $A$. radicans C. Koch \& A. Haage, is restricted to Brazil; section Urospadix Engl. may be restricted to South America and is concentrated in eastern and southeastern Brazil. Some Panamanian species are tentatively placed in section Urospadix.
} 
3b. Leaf blades with five or more lobes.

Section Schizoplacium Schott

A. pedatoradiatum Schott

A. pedatoradiatum ssp. helleborifolium (Schott) Croat

A. podophyllum (Cham. \& Schlecht.) Kunth

2b. Leaf blades with the lobes free to the base. Section Dactylophyllium Schott

A. clavigerum Poepp.

A. kunthii Poepp.

A. pentaphyllum (Aubl.) G. Don var. bombacifolium (Schott) Madison

A. trisectum Sodiro

1b. Leaf blades entire or nearly so, sometimes with the anterior lobe markedly constricted at the base but never distinctly 3 -lobed.

4a. Leaf blades conspicuously dark glandular-punctate at least on the lower surface.

5a. Leaf blades cordate, hastate, or otherwise with usually definite posterior lobes; most basal veins usually merging with the margin of the blade proximal to the middle of the blade. Section Belolonchium Schott (Anthurium verapazense alliance)
A. chiapasense Standl.
A. longipeltatum Matuda
A. lucens Standl. ex Yuncker
A. riograndicolum Matuda
A. verapazense Engl.

A. chiapasense ssp. tlaxiacense (Matuda) Croat

5b. Leaf blades acute to obtuse or subcordate at base with usually only a single collective vein extending along the margin to the apex (Sections Tetraspermium and Porphyrochitonium) or with several basal veins prominently arcuate-ascending to the apex with many close, parallel primary lateral veins extending between all the basal veins giving the blade the appearance of a melastomataceous leaf blade (Section Digitinervium).

6a. Leaf blades with several pairs of basal veins sharply arcuate-ascending, extending to or almost to the apex; primary lateral veins numerous, distinct, parallel, and extending more or less straight between all the basal veins, giving the leaf blade the appearance of a melastomataceous blade; pistils often prominently exserted and quadrangular; number of ovules and seeds per locule unknown.

\section{A. lentii Croat \& Baker} Section Digitinervium Sodiro

6b. Leaf blades with usually no more than one pair of basal veins (usually merely the collective vein) extending along the margin to the apex; primary lateral veins usually not numerous or closely parallel; pistils not quadrangular; ovules and seeds usually two or more per locule.

7a. Plants mostly scandent; stems slender, mostly less than $6 \mathrm{~mm}$ diam.; internodes somewhat elongate; acute at apex.
A. scandens (Aubl.) Engl.
A. scandens ssp. pusillum Sheffer
A. tonduzii Engl.
A. trinerve Miq. Section Tetraspermium Schott

7b. Plants usually more or less caespitose, at least lacking slender scandent stems; stems usually more than $1 \mathrm{~cm}$ diam.; berries often more or less truncate and indented at the apex.

A. acutangulum Engl. Section Porphyrochitonium Schott

A. alatipedunculatum Croat \& Baker

A. austinsmithii Croat \& Baker

A. bakeri Hook. f.

A. durandii Engl.

A. friedrichsthalii Schott

A. hacumense Engl.

A. lancifolium Schott

A. louisii Croat \& Baker

A. paludosum Engl.

A. ramonense Engl.

A. scherzerianum Schott

A. utleyi Croat \& Baker

A. wendlingeri $\mathrm{G}$. M. Barroso

4b. Leaf blades epunctate or at least not conspicuously dark glandular-punctate.

8a. Petioles D-shaped in cross-section or broadly channelled with more or less acute lateral margins. Section Belolonchium Schott

(Anthurium andicola alliance)

$A$. andicola Liebm.

A. berriozabalense Matuda 


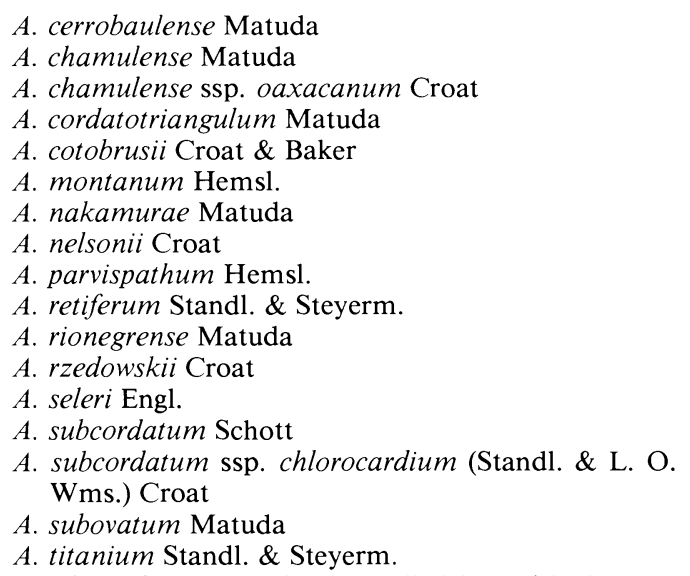

8 b. Petioles usually terete or subterete in cross-section often narrowly channelled but with the margins rounded; sometimes square, triangular, trapezoidal, or otherwise, but not usually D-shaped.

9a. Vernation of leaf blades involute (i.e., with both margins rolled inward toward the midrib in bud); plants frequently with a "bird's-nest" habit, i.e., short stems and rosulate leaves; blades often thick, frequently more or less oblanceolate or obovate to elliptic; the primary lateral veins (at least the lower ones) joining the margins. ......... Section Pachyneurium Schott

A. acutifolium Engl.

A. brenesii Croat \& Baker

A. consobrinum Schott

A. cubense Engl.

A. cuneatissimum (Engl.) Croat

A. cuspidatum Mast.

A. eximium Engl.

A. fatoense $\mathrm{K}$. Krause

A. halmoorei Croat

A. machetioides Matuda

A. michelii Guillaumin

A. nizandense Matuda

A. oerstedianum Schott

A. prolatum Croat \& Baker

A. protensum Schott

A. purpureospathum Croat

$A$. ranchoanum Engl.

A. salvadorense Croat

A. salviniae Hemsl.

A. schlechtendalii Kunth

A. schlechtendalii ssp. jimenezii (Matuda) Croat

A. schottianum Croat \& Baker

A. seibertii Croat \& Baker

A. spathiphyllum N. E. Brown

A. spectabile Schott

A. standleyi Croat \& Baker

A. upalaense Croat \& Baker

A. validifolium $\mathrm{K}$. Krause

A. watermaliense Hort. ex L. H. Bailey

$9 \mathrm{~b}$. Vernation of leaf blades supervolute (i.e., with one margin rolled inward toward the midrib but with the alternate margin rolled around the midrib and then rolled up opposite margin, giving the "cut-away" view a cochleate appearance); plants usually lacking a bird's-nest habit; leaves various; the primary lateral veins frequently joining into a collective vein before reaching the margin.

10a. Stems scandent and wiry; internodes elongate, usually less than $3 \mathrm{~mm}$ thick, with numerous, short adventitious roots scattered along their length; flowering branches bearing one to six leaves; 1-ribbed cataphylls lacking. Section Polyphyllium Engl. A. clidemioides Standl

A. flexile Schott

A. flexile ssp. muelleri (Macbr.) Croat \& Baker

10b. Stems short or scandent but not slender and wiry; internodes short or long but not 
slender and wiry, usually more than $8 \mathrm{~mm}$ diam.; the adventitious roots restricted to the nodes; flowering branches bearing a single leaf (branches are short and do not appear like branches); 1-ribbed cataphylls present and usually conspicuous.

11a. Roots white, bearing velamen; blades thin, narrowly oblanceolate, the primary lateral veins numerous and scarcely more prominent than the interprimary veins, ${ }^{*}$ stems rarely more than $1 \mathrm{~cm}$ diam. with persistent reddish-brown, intact cataphylls; spadix with no more than three flowers visible per spiral (from any angle); chromosome numbers $2 n=10$ or 20 .

A. gracile (Rudge) Lindl.

Section Leptanthurium Schott

$11 \mathrm{~b}$. Roots usually greenish, lacking velamen; blades various, usually with the primary lateral veins conspicuously more prominent than the interprimary veins; stems various; cataphylls usually weathering (except section Calomystrium with cordate blades); number of flowers per spiral various but usually more than three per spiral.

12a. Leaf blades velvety, usually metallic green or blackish-green in color; the epidermal cells papillate or otherwise elevated; petioles frequently ribbed; B-chromosomes present.
A. clarinervium Matuda
A. leuconeurum Lem.
A. lezamae Matuda

12b. Leaf blades not velvety, usually smooth and semiglossy to glossy; the epidermal cells flat, not papillate or raised; petioles various but not commonly ribbed; B-chromosomes lacking.

13a. Stems bearing conspicuous, thick, intact, persistent, reddish-brown cataphylls; leaf blades usually thick; the minor veins usually not prominently raised; the upper blade surface usually with linear raphide cells visible; spadix often colored, often sweetly scented; spathe usually thick, often broad. ........... Section Calomystrium Schott
A. armeniense Croat
A. beltianum Standl. \& L. O. Wms.
A. clavatum Croat \& Baker
A. formosum Schott
A. hoffmannii Schott
A. huixtlense Matuda
A. monteverdense Croat \& Baker
A. obtusilobum Croat \& Baker
A. ravenii Croat \& Baker

13b. Stems usually with cataphylls deciduous or weathering into a mass of fibers (sometimes persisting intact, as in A. eximium); leaf blades thick or thin; the minor veins conspicuous or not; the upper surface usually lacking raphide cells; spadix various, less frequently scented; spathe various, often lanceolate.

14a. Leaf blades much longer than broad, oblong to linear (rarely ovate but then thin, veiny, and weakly bullate as in $A$. $d a$ vidsoniae).

15a. Stems elongate, erect to scandent 7-20 mm diam.

16a. Leaf blades thin, veiny, and weakly bullate; the reticulate veins often conspicuous; spathe and spadix usually green or greenish-yellow; spadices commonly cylindrical; berries commonly pale green. Section Xialophyllium Schott (A. microspadix alliance)

A. davidsoniae Standl.

A. microspadix Schott

A. pallens Schott

16b. Leaf blades usually coriaceous or thickly chartaceous, smooth; the reticulate veins usually not conspicuous; spathe and spadix various or not known. Section Xialophyllium Schott (A. caucanum alliance)

* Section Urospadix centered in Brazil and apparently not represented in Central America have leaf blades that also have this characteristic. 

A. angustispadix Croat \& Baker
A. burgeri Croat \& Baker
A. carnosum Croat \& Baker
A. interruptum Sodiro
A. tenerum Engl.
A. testaceum Croat \& Baker

15b. Stems short; the internodes short; stems mostly less than $10 \mathrm{~mm}$ diam.

17a. Pistils prominently exserted long before anthesis and many times longer than the stamens when they appear.

A. pittieri Engl.

A. pittieri var. fogdenii Croat

17b. Pistils not prominently exserted long before anthesis, about as long or no more than a few times longer than stamens. .... Section Xialophyllium Schott

A. burgeri Croat \& Baker (usually with longer stems)

14b. Leaf blades not much longer than broad (or at least not oblong or linear), mostly more or less ovate with posterior lobes.

18a. Blades moderately thin, often conspicuously veiny or even bullate; anterior lobe usually with numerous, close, more or less parallel veins; berries frequently green.

A. caperatum Croat \& Baker Section Polyneurium Schott

A. panduriforme Schott

A. williamsii $\mathrm{K}$. Krause

18b. Blades coriaceous or nearly so, usually smooth and not noticeably veiny or bullate; anterior lobe lacking numerous close parallel veins.
A. brownii Mast.
A. cerropelonense Matuda
A. concinnatum Schott
A. lancetillense Croat
A. ochranthum C. Koch
A. ovandense Matuda
A. pluricostatum Croat \& Baker
A. silvigaudens Standl. \& Steyerm.
A. umbrosum Liebm.
A. yetlense Matuda

Section Belolonchium Schott

Key to Anthurium of Mexico and Middle America

1a. Leaves palmately lobed or divided; leaf segments more than three or if three, then divided to the base.

1b. Leaves simple, sometimes lobed.

2a. Leaf blades 3-lobed, the margins constricted near the base of the anterior lobe.

2b. Leaf blades not 3-lobed.

3a. Leaf blades cordate or subcordate at base.

4a. Leaf blades with prominent posterior lobes, conspicuously black punctate below. ........... KEY C

4b. Leaf blades with posterior lobes, not punctate below or not conspicuously so. ................... KEY D

3b. Leaf blades not cordate or subcordate at base.

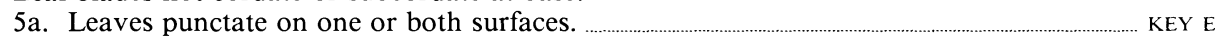

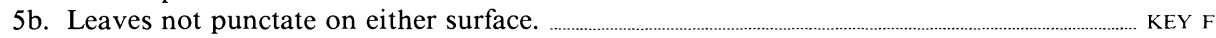

KEY A

Leaves palmately lobed or divided; leaf segments more than three or if three, then divided to the base.

1a. Leaves 3-foliolate with the segments free to the base; plants terrestrial.

1b. Leaves 5-13-foliolate or lobed (if 3-foliolate, then the peduncle less than $5 \mathrm{~cm}$ long).

2a. Blade segments all free to the base.

3a. Plants huge, scandent, epiphytic; leaflets lobed; peduncle elongate; spadix to $75 \mathrm{~cm}$ long; spathe dark violet-purple. A. clavigerum Poepp.

3b. Plants relatively small, scandent, with long internodes; leaflets not lobed (except the basal leaflet); peduncle long or short; spadix less than $25 \mathrm{~cm}$ long; spathe green to purplish. 
4a. Leaf segments all more or less equal, petiolules 4-6 cm long; peduncles slender and long, usually more than $20 \mathrm{~cm}$ long, longer than spadix; spadix whitish to greenish at anthesis. A. kunthii Poepp.

4b. Leaf segments unequal, the lowermost more or less auriculate and usually markedly inequilateral; petiolules usually short, less than $2 \mathrm{~cm}$ long with the leaf tissue decurrent, often almost to the base; peduncles short and stout, usually less than $6 \mathrm{~cm}$ long, usually shorter than the spadix; spadix lavender at anthesis.

A. pentaphyllum var. bombacifolium (Schott) Madison

2b. Blade segments united at the base; plants terrestrial or on rocks on steep slopes.

5a. Blade segments generally pinnatifid with 5-12 narrow divisions, the segments rarely entire but then subcoriaceous; the peduncle longer than the petioles. A. podophyllum (Cham. \& Schlecht.) Kunth

5b. Blade segments entire, the peduncle shorter than the petioles.

6a. Blades evenly segmented. ................................. A. pedatoradiatum Schott ssp. pedatoradiatum

6b. Blades unevenly divided, at least the median segment free or nearly so. A. pedatoradiatum ssp. helleborifolium (Schott) Croat

KEY B

Leaves simple, 3-lobed, the margins constricted near the base of the anterior lobe.

1a. Posterior lobes usually more or less orbicular; lower blade surface glossy, yellow-green when dry; primary lateral veins numerous, prominent, more or less straight and parallel; tepals yellow.

A. panduriforme Schott

1b. Posterior lobes not as above; lower blade surface not glossy; primary lateral veins either not numerous or not prominent or neither; tepals purple or yellow to green.

2a. Basal lobes at more or less right angles to the anterior lobe.

3a. Plants scandent with long internodes; spadix yellow-green to yellow; berries violet-purple. A. subsignatum Schott

3b. Plants more or less acaulescent with short internodes; spadix neither yellow-green nor yellow; berries red or violet-purple.

4a. Posterior lobes curved toward anterior lobe; spadix creamy-white or greenish to reddishbrown; berries red, at least at apex. A. tilaranense Standl.

4b. Posterior lobes extended away from anterior lobe; spadix green tinged with violet-purple; berries violet-purple. A. seleri Engl.

2b. Basal lobes not at more or less right angles to anterior lobe.

5a. Posterior lobes broadly rounded, the sinus usually spathulate; spadix violet-purple; blade margin often undulate; Costa Rica to Ecuador. A. brownii Mast.

5b. Posterior lobes narrow, the sinus not spathulate; spadix usually greenish; blade margins not markedly undulate; Mexico and Guatemala.

6a. Blades with the posterior lobes usually longer than the anterior lobe; the margin between the anterior and posterior lobes straight to convex; the collective vein arising usually from the uppermost basal vein in the anterior lobe.

A. berriozabalense Matuda

$6 \mathrm{~b}$. Blades with the posterior lobes usually shorter or no longer than the anterior lobe; the margin between the anterior and posterior lobes usually markedly concave; the collective vein arising from one of the lowermost basal veins and extending along the margin of both the posterior and the anterior lobes. A. seleri Engl.

KEY C

Leaves simple, cordate, or subcordate at base; with prominent posterior lobes, black punctate below.

1a. Leaf blades usually subcordate, stiffly coriaceous with two or more basal veins strongly ascending, roughly parallel to the midrib to beyond the middle of the blade; pistils early emergent, quadrangular in cross-section; berries white; Costa Rica, Panama, Colombia. A. lentii Croat \& Baker

1b. Leaf blades usually conspicuously lobed at the base, subcoriaceous, the basal veins not as above, usually forming a collective vein near the margin, usually only the uppermost extending above the middle of the blade; pistils not markedly early emergent, terete in cross-section; berries red, orange, or purplish at maturity.

2a. Blades mostly 2-3 times longer than broad, the anterior lobe usually more or less oblong and sometimes constricted at the base or narrowly triangular.

3a. Posterior lobes mostly less than 1.25 times longer than broad, the sinus parabolic to spathulate, often closed; northern Oaxaca in the Sierra Madre Oriental. A. longipeltatum Matuda

3b. Posterior lobes mostly more than 1.5 times longer than broad, usually directed prominently outward; the sinus campanulate to spathulate, not closed; southern Oaxaca and Chiapas to Belize, Guatemala and Honduras.

4a. Inflorescences usually 1.5-3 times longer than the petioles; berries subglobose, red-orange to orange-red; seeds $6-9$ per berry, less than $3 \mathrm{~mm}$ long. A. verapazense Engl. 
4b. Inflorescences usually less than 1.5 times longer than petioles.

5a. Spadix olive green at anthesis; primary lateral veins prominently raised below (fresh and dry); restricted to southwestern Oaxaca.

A. chiapasense ssp. tlaxiacense (Matuda) Croat

5b. Spadix dark violet-purple at anthesis; primary lateral veins flat or prominulous below; southeastern Chiapas and western Guatemala. ... A. chiapasense Standl. ssp. chiapasense

2b. Blades mostly 1.25-1.5 times longer than broad, rarely more than 2 times longer than broad, the anterior lobe usually more or less ovate (rarely with the anterior lobe somewhat oblong or narrowly triangular).

6a. Blades conspicuously coriaceous, acute at the apex with a short apiculum; southeastern Oaxaca. A. riograndicolum Matuda

6b. Blades usually only subcoriaceous (at least when dry), acuminate at apex; widespread from Chiapas to Honduras.

7a. Inflorescences usually 1.5-3 times longer than petioles; spathe usually less than half as long as the spadix; berries subglobose, red-orange to orange-red; seeds 3-5 per locule (79 per berry), less than $3 \mathrm{~mm}$ long. A. verapazense Engl.

7b. Inflorescence usually less than 1.5 times as long as the petioles; spathe usually more than half as long as spadix; berries obovoid, bright red; seeds 1 per locule ( 2 per berry), more than $4.5 \mathrm{~mm}$ long. A. lucens Standl. ex Yuncker

KEY D

Leaves simple, cordate or subcordate at base, with posterior lobes, epunctate below.

1a. Plants scandent and twining or at least with long slender stems with elongate internodes, held erect usually by rooting onto or being supported by trees; blades mostly less than $27 \mathrm{~cm}$ long.

2a. Leaves bullate; peduncle nearly non-existent, obscured by the base of spathe, rarely to $5 \mathrm{~cm}$.

2b. Leaves not bullate (except $A$. davidsoniae); peduncles conspicuous

3a. Stems mostly more than $2 \mathrm{~cm}$ diam.; blades $16-48 \mathrm{~cm}$ long, 11-44 cm wide.

A. subsignatum Schott

3b. Stems mostly less than $1 \mathrm{~cm}$ diam.; blades mostly less than $27 \mathrm{~cm}$ long, $16 \mathrm{~cm}$ wide.

4a. Stems 2-4 mm diam., usually several meters long, twining, flexible; internodes with many short roots; sea level to $1,700 \mathrm{~m}$.

5a. Leaves usually palminerved, lanceolate, cordate at base and broadest below the middle of the blade; spadix usually with a conspicuous stipe 1-2 cm long; Mexico to northern Guatemala, 1,000-1,700 m.

A. flexile ssp. muelleri (Macbr.) Croat \& Baker

5b. Leaves plinerved, elliptic to narrowly elliptic, narrowly subcordate at base, broadest at or near the middle of the blade; spadix sessile or with the stipe to $2 \mathrm{~mm}$ long; Mexico to Panama, sea level to $1,000 \mathrm{~m}$.

A. flexile Schott ssp. flexile

4b. Stems usually 5-10 mm diam., usually $1 \mathrm{~m}$ or less long, usually stiffly erect, usually supported by a tree, not twining, the internodes lacking roots; roots long, few, restricted to the nodes; usually $1,200-2,300 \mathrm{~m}$.

6a. Leaf blades all cordate or, rarely, subcordate.

A. davidsoniae Standl.

6b. Leaf blades subcordate intermixed with blades that are rounded or truncate, rarely cordate.

A. microspadix Schott

1b. Plants not scandent; internodes short.

7a. Species of Costa Rica and Panama, often extending into South America, sometimes into Nicaragua (A. ravenii as far north as Honduras).

8a. Geniculum situated at least $10 \mathrm{~cm}$ below the base of the blade; blades subcordate; terrestrial.

8b. Geniculum immediately subtending the leaf blade.

A. oerstedianum Schott

9a. Spadix more or less clavate, broader in circumference at apex than at base; spathe ovateelliptic with a long-cuspidate apex, long-decurrent at base; blades drying dark brown or gray-brown; middle elevations, Cordillera de Talamanca. ............... A. clavatum Croat \& Bake

9b. Spadix cylindroid or tapering from base to apex, never clavate; spathe mostly oblong, lanceolate, or ovate.

10a. Spathe purple to dark maroon or mottled green and purple throughout (excluded are species with spathe predominantly green with purple tinged margins and/or veins).

11a. Spathe twisted and contorted; peduncle short (less than $20 \mathrm{~cm}$ ), dwarfed by the elongate petioles (to $1 \mathrm{~m}$ long); sinus narrow; Atlantic lowlands near Bribrí, $100 \mathrm{~m}$. A. schottianum Croat \& Baker

11b. Spathes flat; peduncles more than $20 \mathrm{~cm}$ long, or if shorter, not dwarfed by the petioles; sinus narrow or broad; mostly 400-2,400 m.

12a. Leaf blades shallowly cordate or subcordate at base; spathe solid maroon 
to more commonly green and purple mottled; leaves basically lanceolate in outline.

13a. Leaf blades thin; spadix sessile, berries purple-violet becoming red; major veins of leaf reddish beneath on drying. .... A. cuspidatum Mast.

13b. Leaf blades subcoriaceous; spadix on a stipe 3-25 mm long; berries orange; major veins of leaf not reddish beneath.

A. ranchoanum Engl.

12a. Leaf blades deeply cordate at base or shallowly cordate and triangular in outline.

14a. Spathe usually dark purple-violet; stipe $0.5-2.5 \mathrm{~cm}$ long; stamens long-exserted. A. watermaliense Hort. ex L. H. Bailey

14b. Spathe usually green tinged with purple; stipe $2-6 \mathrm{~mm}$ long; stamens weakly exserted. A. cotobrusii Croat \& Baker

10b. Spathe white, yellow, green, or green with purple-tinged veins and/or margins.

15a. Leaf blades generally lanceolate or broadly lanceolate in outline, cordate or subcordate basally, the lobes never overlapping each other; spathe green or green tinged with purple, never white.

16a. Petiole 4-sided; blades pendent; peduncle less than $25 \mathrm{~cm}$ long, much shorter than the petioles. A. spectabile Schott

16b. Petioles terete or subterete; blades not pendent; peduncles usually more than $25 \mathrm{~cm}$ long, slightly shorter to longer than petioles.

17a. Spathe oblong-lanceolate; berries purple-violet to reddish-violet; major veins of leaf maroon below; blades almost always drying with a purplish tint or with purplish blotches; $400-1,700 \mathrm{~m}$. A. cuspidatum Mast.

17b. Spathe lanceolate to ovate; berries orange; major veins of leaf not maroon below; blades not drying purplish or with purplish blotches; (500) $1,000-2,300 \mathrm{~m}$. A. ranchoanum Engl.

15b. Leaf blades generally heart-shaped in outline, with conspicuous and deep basal sinus, the lobes often overlapping each other; spathe white, green or green tinged with purple.

18a. Blades hastate, the posterior lobes usually orbicular; spadix golden yellow. A. panduriforme Schott

18b. Blades not hastate, the posterior lobes not orbicular; spadix white, green, purple, or occasionally yellow.

19a. Plants growing at elevations above $2,000 \mathrm{~m}$; flowering spadix 5$26 \mathrm{~cm}$ long, on a stipe $1-2.5 \mathrm{~cm}$ long. A. concinnatum Schott

$19 \mathrm{~b}$. Plants usually growing at elevations below $2,000 \mathrm{~m}$; spadix various lengths, usually sessile $(A$. standley $i$ with a stipe $0.6-6 \mathrm{~cm}$ long.

20a. Largest leaf blades less than $55 \mathrm{~cm}$ long.

21a. Spadix dark purple; spathe dark green, sometimes tinged purple.

22a. Blades subcoriaceous, the basal veins coalesced 4-6 $\mathrm{cm}$, the sinus much broader than deep when flattened; spathe ovate to narrow; berries pale orange. A. cotobrusii Croat \& Baker

22b. Blades thin, the basal veins scarcely or not at all coalesced, the sinus much deeper than broad, sometimes closed with the lobes overlapping; spathe lanceolate; berries deep red-violet. A. williamsii $\mathrm{K}$. Krause

$21 \mathrm{~b}$. Spadix white to yellow or pale green, sometimes tinged purplish.

23a. Collective vein continuous from near base of basal lobe to apex of blade. ... A. obtusilobum Schott

23b. Collective vein formed only in upper half of blade, arising from upper basal veins, the lower basal veins running to margin.

24a. Blades ovate-triangular, the sides of the anterior lobe nearly straight; cataphylls weathering into tan fibers; spathe usually purple, at least tinged purplish; plants terrestrial.

A. watermaliense Hort. ex L. H. Bailey

24b. Blades ovate, the sides convex; cataphylls 
persisting more or less intact, reddishbrown; spathe pale, not tinged purplish plants epiphytic or terrestrial.

25a. Spathe 5-6(8.5) $\mathrm{cm}$ wide, broadly ovate. ..... A. monteverdense Croat \& Baker

25b. Spathe less than $3 \mathrm{~cm}$ wide, lanceolate to oblong-ovate.

20b. Largest leaf blades more than $55 \mathrm{~cm}$ long.

A. hoffmannii Schott

26a. Leaf blades with tertiary veins sunken above, giving the blade a bullate appearance, drying pale yellowgreen with a wrinkled, chartaceous character; submarginal collective vein usually continuous from near the base; spathe pale green, brittle; spadix pale green; berries pale green or white. .... A. caperatum Croat \& Baker

26b. Leaf blades not appearing bullate; submarginal collective vein often beginning well above base; spathe color various, often tinged purplish; spadix white, yellow, purple, or green tinged with purple; berries orange, reddish, or purplish.

27a. Plants epiphytic.

28a. Spadix violet-purple, long tapered, to 28 $\mathrm{cm}$ long; blade prominently undulate.

A. brownii Mast.

28b. Spadix white, pale green, greenish-yellow, or violet, short and only slightly tapered, to $18 \mathrm{~cm}$ long.

29a. Spathe soon reflexed; spadix cream, white or pale yellow-green; berries red, round at apex.

A. ravenii Croat \& Baker

29b. Spathe remaining close to spadix even in fruit; spadix white to violet; berries dark purple-violet with redorange base, sharp pointed at apex. A. formosum Schott

27b. Plants terrestrial.

30a. Collective vein arising well above the middle; spathe green; spadix green when immature, soon heavily tinged violet-purple, turning yellow-brown; berries orange. A. standleyi Croat \& Baker

30b. Collective vein usually arising from one of the basal veins; spathe white, pale green or pale violet or tinged with pale violet; spadix white, yellow, lavender, or pale green tinged with lavender; berries not orange.

31a. Blades usually drying with large, conspicuous, purplish blotches; spathe pale green becoming pale violet; spadix white to violet; berries dark purple-violet with red-orange base; common plants of the Atlantic slopes at middle elevations, sometimes seen as the dominant plant on disturbed steep banks.

A. formosum Schott

31b. Blades lacking dark splotches; spathe and spadix various colors; berries not colored as above.

32a. Spadix bright yellow at anthesis, the anthers not visible (pollen oozing out in slender ribbons); leaf blades with the posterior lobes elongated, the 
anterior lobe usually somewhat straight along its margins; petiole rounded and smooth abaxially. A. ochranthum C. Koch

32b. Spadix pale lavender or green tinged with lavender; anthers clearly visible, held just above the tepals; leaf blades with posterior lobes scarcely longer than broad; anterior lobe usually broadly convex along its margins; petiole subterete with seven or eight low ridges around its circumference.

.... A. pluricostatum Croat \& Baker

7b. Species of Mexico and northwestern middle America, northwest of Río San Juan depression (Nicaragua), sometimes in El Salvador and Honduras, rarely in Nicaragua.

33a. Petioles broadly sulcate or D-shaped in cross-section, the adaxial margins often acute, sometimes merely obtuse.

34a. Leaf blades merely subcordate, lacking well developed posterior lobes.

35a. Leaf blades with the basal veins and primary lateral veins usually reddish; Sierra de Oaxaca in northern Oaxaca. A. subovatum Matuda

35b. Leaf blades with all veins greenish; Guerrero and southern Oaxaca to Chiapas, Guatemala, El Salvador, or Honduras.

36a. Blades less than $12 \mathrm{~cm}$ long; southwestern Chiapas near border with Oaxaca. A. cerrobaulense Matuda

36b. Blades usually more than $15 \mathrm{~cm}$ long; Oaxaca, Chiapas, Guerrero in Mexico, Guatemala, Honduras, or El Salvador.

37a. Collective vein arising from one of the lower basal veins; posterior lobes usually longer than broad and directed prominently outward; northern Chiapas to Guatemala. A. seleri Engl.

37b. Collective vein arising from the first (or second) basal vein or one of the primary lateral veins, the posterior lobes usually not longer than broad and not directed prominently outward.

38a. Blades more or less oblong, three to four times longer than broad, often broader near the base. A. nakamurae Matuda

$38 \mathrm{~b}$. Blades triangular to ovate, less than three times longer than broad, broadest at base.

39a. Leaf blades with margins of the anterior lobe usually concave. A. cerrobaulense Matuda

39b. Leaf blade with margins of the anterior lobe broadly convex.

40a. Spadix pale green; blades with the collective vein often arising from the first basal vein, frequently with a secondary collective vein extending irregularly along the margin to the apex or nearly to the apex; second basal vein merging with the margin in the upper half of the blade; Mexico, in Guerrero and southern Oaxaca and Chiapas.

A. rzedowskii Croat

40b. Spadix dark violet-purple or green tinged with violet-purple; blades with the collective vein arising from the first or second basal vein, lacking a secondary collective vein; the second basal vein often merging with the margin below the middle of the blade; Oaxaca and Chiapas, Guatemala, El Salvador, and Honduras.

41a. Leaf blades with tertiary veins obscure above (fresh); western Guatemala to northern El Salvador and western Honduras.

... A. chamulense Matuda, A. subcordatum Schott, A. subcordatum ssp. chlorocardium (Standl. \& L. O. Wms.) Croat, A. subovatum Matu$\mathrm{da}$

41 b. Leaf blades with tertiary veins minutely sunk- 
en and visible above when fresh; Oaxaca and Chiapas.

42a. Leaf blades with tertiary veins below scarcely visible; blades subcoriaceous; occurring in "bosque pin-encino" (see Flores, et al., 1971).

A. chamulense Matuda ssp. chamulense

42b. Leaf blades with the tertiary veins clearly visible below; blades of medium thickness; occurring in "selva alta perrennifolia."

A. chamulense ssp. oaxacanum Croat

43a. Spathe ovate to narrowly ovate; berries orange (?); Honduras on Cerro Santa Bárbara (Dept. Santa Bárbara).

..... A. subcordatum ssp. chlorocardium

(Standl. \& L. O. Wms.) Croat

43b. Spathe lanceolate (rarely narrowly ovate); berries bright red; western Guatemala to El Salvador and Honduras along the Continental Divide.

34b. Leaf blades with conspicuous, well developed posterior lobes.

A. subcordatum Schott ssp. subcordatum

44a. Blades about as broad as long.

45a. Leaf blades whitish-matte beneath; north central Oaxaca. ........ A. nelsonii Croat

$45 \mathrm{~b}$. Leaf blades not whitish beneath.

46a. Tertiary veins prominently raised even on fresh leaves; leaf blades usually less than $40 \mathrm{~cm}$ long; Veracruz and Oaxaca. ...... A. andicola Liebm.

46b. Tertiary veins not prominently raised on fresh material, weakly prominulous on drying; leaf blades variable in size; southeastern Chiapas and Guatemala.

47a. Blades less than $25 \mathrm{~cm}$ long, thin. A. rionegrense Matuda

47b. Blades more than $40 \mathrm{~cm}$ long, subcoriaceous.

44b. Blades substantially longer than broad.

A. titanium Standl. \& Steyerm.

48a. Lower blade surface matte, drying whitish; north central Oaxaca.

48b. Lower blade surface not conspicuously matte and whitish.

49a. Blade with the anterior lobe conspicuously concave along the margin; southwestern Chiapas. A. cerrobaulense Matuda

49b. Blade with the anterior lobe usually convex along the margin.

50a. Blades with the tertiary veins prominently raised even on fresh leaves; Veracruz and Oaxaca. A. andicola Liebm.

50b. Blades with the tertiary veins not prominently raised on fresh leaves, weakly prominulous on drying.

51a. Blades ovate-triangular (ovate in A. subcordatum), the posterior lobes poorly developed, usually rounded, the collective vein always arising from the first basal vein, the second basal vein only rarely loop-connected to the collective vein, usually merging with the margin well below the middle of the blade, the sinus usually broad, usually parabolic or arcuate; northern and southeastern Chiapas and northern Oaxaca.

52a. Blades ovate-triangular.

53a. Major veins of the blade and apex of the petiole reddish; Sierra de Juárez in northern Oaxaca. A. subovatum Matuda

53b. Major veins of the blade and the apex of the petiole green; northern and southeastern Chiapas.

52b. Blades ovate. A. chamulense Matuda ssp. chamulense

54a. Spathe ovate to narrowly ovate; berries or- 
ange (?); Honduras on Cerro Santa Bárbara (Dept. Santa Bárbara). ..... A. subcordatum ssp. chlorocardium (Standl. \& L. O. Wms.) Croat

54b. Spathe lanceolate (rarely narrowly ovate); berries bright red; western Guatemala to El Salvador and Honduras along the Continental Divide.

A. subcordatum Schott ssp. subcordatum

51b. Blades ovate to narrowly ovate or ovate-triangular; posterior lobes usually well developed, often longer than broad (except in $A$. rzedowskil), often curved inward; collective vein sometimes arising from one of the primary lateral veins, the second basal vein often loop-connected to the collective vein, usually merging with the margin well above the middle of the blade, the sinus hippocrepiform to spathulate, sometimes parabolic, rarely arcuate; Guerrero, Oaxaca or southeastern Chiapas to Guatemala. 55a. Blades coriaceous, the margins not markedly undulate; petioles not glaucous; frequently with a secondary collective vein extending irregularly along the margin to the apex or nearly to the apex; Guerrero, Oaxaca, and Chiapas. A. rzedowskii Croat

55b. Blades subcoriaceous to medium thick, usually markedly undulate (except $A$. titanium); petioles usually glaucous.

56a. Blades broadly ovate to rounded in outline, the margin of the anterior lobe convex; spadix usually more than $17 \mathrm{~cm}$ long.

A. titanium Standl. \& Steyerm.

56b. Blades ovate-triangular to narrowly ovate, the margins of the anterior lobe more or less straight; spadix usually less than $20 \mathrm{~cm}$ long. 57a. Blades ovate-triangular; major veins of the lower surface prominently elevated when dry; spathe lanceolate, usually about as long as the spadix; southeastern Chiapas.

A. cordatotriangulum Matuda

57b. Blades broadly to narrowly ovate; major veins of the lower surface not prominently elevated on drying; spathe ovate, usually much shorter than the spadix; southeastern Chiapas to Guatemala. A. montanum Hemsl.

33b. Petioles terete or subterete.

58a. Peduncles usually less than one-third as long as longest petioles.

59a. Spadix dark purple.

60a. Leaves coriaceous, glossy; endemic to Sierra de Juárez, 2,400-2,800 m.

60b. Leaves subcoriaceous, semiglossy; Lancetilla Valley, ca. $300 \mathrm{~m}$.

A. cerropelonense Matuda

A. lancetillense Croat

59b. Spadix green, white or lavender; leaves subcoriaceous.

61a. Spadix green; cataphylls dilacerating; peduncle less than $10 \mathrm{~cm}$ long; endemic to Central Guatemala, 1,500-2,000 m or to northern Oaxaca, 600$1,500 \mathrm{~m}$.

62a. Spathe broadly lanceolate, more than 2.5 times longer than broad, rounded to acute at the base; spadix more than 5 times longer than broad, markedly tapered toward the apex; endemic to northern Oaxaca. A. yetlense Matuda

62 b. Spathe broadly ovate, less than 1.5 times longer than broad, usually cordate at the base; spadix less than 4 times longer than broad, scarcely tapered toward the apex; endemic to central Guatemala. A. silvigaudens Standl. \& Steyerm.

61b. Spadix white to lavender; cataphylls remaining intact; peduncles $21-39 \mathrm{~cm}$ long; Chiapas to Nicaragua. A. huixtlense Matuda 
58b. Peduncles more than half as long as longest petioles.

63a. Upper blade surface papillate (with the epidermal cells cone-like) or alveolate; fresh leaves usually conspicuously velvety; Mexico.

64a. Leaf blades with veins conspicuously paler than the surface; primary lateral veins not conspicuously more prominent when dry than the interprimary and tertiary veins; epidermal cells of leaf blade drying minutely alveolate (honey-combed). A. lezamae Matuda

64b. Leaf blades with veins conspicuously paler than the blade surface; primary lateral veins conspicuously more prominent when dry than the interprimary and tertiary veins; epidermal cells obviously papillate with individual cells obviously raised, cone-like.

65a. Leaf blades almost as broad as long, the sinus closed or very narrow; basal veins free or, if united into a posterior rib, the rib not marginal to the sinus.

A. clarinervium Matuda

$65 \mathrm{~b}$. Leaf blades conspicuously longer than broad, the sinus obovate or hippocrepiform; basal veins united into a conspicuous, naked (i.e., marginal to the sinus) posterior rib. A. leuconeurum Lem.

63b. Upper blade surface smooth, not minutely papillate (the epidermal cells not raised and cone-like) or alveolate (with a raised, net-like reticulum); fresh leaves glossy or matte but not velvety; Mexico and Middle America.

66a. Posterior lobes longer than the anterior lobe. .......... A. berriozabalense Matuda

66b. Posterior lobes not longer than the anterior lobe.

67a. Cataphylls remaining intact, usually reddish-brown, conspicuous; leaf blades with raphide cells usually visible on upper surface.

68a. Spadix at anthesis with the tepals turned upward on the inner margin to give the spadix a distinctly bumpy surface, the color pale reddish-violet, the stipe usually conspicuous, often curved, the spathe ovate-oblong, white; southwestern Guatemala.

A. armeniense Croat

68b. Spadix at anthesis with tepals not conspicuously upturned, the spadix relatively smooth, rose-violet to lavender or cream, the stipe absent or short, not both elongate and curved; widespread from Chiapas to western Nicaragua. A. huixtlense Matuda

67b. Cataphylls usually weathering into fibers or deciduous; leaf blades usually lacking raphide cells.

69a. Inflorescences nodding with spathe hooding spadix; endemic to Nicaragua on limestone outcrops.

A. beltianum Standl. \& L. O. Wms.

$69 \mathrm{~b}$. Inflorescences not typically nodding with spathe hooding spadix.

70a. Plants occurring above $2,000 \mathrm{~m}$ elevation.

71 a. Second pair of basal veins (counting from the midrib) joining leaf margins below the middle of the blade.

72a. Sinus of leaf broad, shallow, arcuate; petioles not glaucous; leaf margins not undulate; blade coriaceous; principally northern Chiapas.

A. chamulense Matuda

72b. Sinus usually narrow, deep, hippocrepiform to parabolic; petioles glaucous; blades subcoriaceous with undulate margins; southeastern Chiapas to Guatemala.

A. montanum Hemsl.

71b. Second pair of basal veins joining leaf margin well above middle of leaf blade.

73a. Leaf blades broadly ovate, nearly as broad as long; spadix dark purple at anthesis; endemic to Sierra de Juárez in northern Oaxaca, 2,400$2,800 \mathrm{~m}$. A. cerropelonense Matuda

$73 \mathrm{~b}$. Leaf blades narrowly ovate to ovate or ovatetriangular, longer than broad; spadix green or green tinged with purple.

74a. Petioles glaucous; sinus usually spathulate to hippocrepiform, rarely parabolic; southeastern Oaxaca to Guatemala, $1,200-2,900 \mathrm{~m}$. A. montanum Hemsl. 
74b. Petioles not glaucous; sinus usually arcuate to parabolic, rarely spathulate; Guerrero, northern Oaxaca and Chiapas, 1,400-2,900 m. .... A. rzedowskii Croat

70b. Plants occurring below $2,000 \mathrm{~m}$.

75a. Leaf blades not coriaceous.

76a. Leaf blades ovate-triangular, nearly as broad as long; rare, known only from an area near the border of Oaxaca and Chiapas.

A. rionegrense Matuda

76b. Leaf blades ovate, longer than broad.

77a. Spadix green at anthesis, sometimes tinged with purple; petioles weakly glaucous (except $A$. rzedowskii).

$78 \mathrm{a}$. Blades frequently with a secondary collective vein extending irregularly along the margin to the apex or nearly to the apex; Guerrero, Oaxaca, and Chiapas. A. rzedowskii Croat

78 b. Blades lacking a secondary collective vein extending irregularly along the margin to the apex or nearly to the apex; Guerrero, Oaxaca, and Chiapas.

79a. Leaf blades with margins flat to broadly undulate; southeastern Chiapas and southwestern Guatemala, $1,200-2,900 \mathrm{~m}$.

A. montanum Hemsl.

79b. Leaf blades with margins minutely undulate to subcrispate; endemic to southern Oaxaca and Chiapas, 800-1,600 m.

$A$. ovandense Matuda

77b. Spadix dark purple at anthesis; petioles usually not glaucous.

$80 \mathrm{a}$. Inflorescences noticeably shorter than the leaves; Honduras, near sea level. A. lancetillense Croat

$80 \mathrm{~b}$. Inflorescences nearly as long as or longer than leaves; Mexico and Guatemala, 800-2,900 m.

81a. Leaf margins flat to slightly undulate, the anterior lobe with its margins straight to slightly convex; northern Oaxaca, 1,200-1,800 m. A. umbrosum Liebm.

81 b. Leaf margins usually markedly undulate; anterior lobe with at least one margin often concave; southwestern Chiapas to Guatemala, 1,200-2,900 m. A. montanum Hemsl.

75b. Leaf blades coriaceous.

82a. Collective vein arising from one of the lower basal veins, extending along margin from near apex of posterior lobe to apex of anterior lobe; eastern Mexico to central Chiapas to west central Guatemala, 700-1,900 m...... A. seleri Engl.

$82 \mathrm{~b}$. Collective vein arising from one of the upper basal veins, usually extending along only part 
of the margin of the anterior lobe, sometimes loop-connected to lower basal veins.

83a. Sinus relatively shallow, usually arcuate with posterior lobes relatively short, never narrow; southeastern Chiapas to Oaxaca, 1,500-3,000 m. A. chamulense Matuda

83b. Sinus deep, spathulate to hippocrepiform or parabolic, the posterior lobes often elongate, sometimes longer than broad.

84a. Posterior lobes (at least on well developed leaves) elongate, two or more times longer than broad; anterior lobe usually markedly concave; petioles not glaucous; southwestern Chiapas.

A. cerrobaulense Matuda

84b. Posterior lobes broadly rounded to elongate but less than 1.5 times longer than broad; anterior lobe convex to sometimes weakly concave; petioles weakly glaucous; southeastern Chiapas to south central Guatemala.

A. montanum Hemsl.

KEY E

Leaves simple, not lobed; blades neither cordate nor subcordate, punctate on one or both surfaces.

1a. Spadix coiled or spiralled.

2a. Spathe showy, red to red-orange, ovate; leaf blades narrowly elliptic. A. scherzerianum Schott

2b. Spathe not showy, reddish or green tinged purplish, linear or lanceolate-oblong; leaf blades oblong or ovate.

3a. Leaf blades oblong, to $80(150) \mathrm{cm}$ long. A. wendlingeri G. M. Barroso

3 b. Leaf blades ovate, to $20 \mathrm{~cm}$ long. A. louisii Croat \& Baker

1b. Spadix not coiled or spiralled.

4a. Stipe $3-20 \mathrm{~cm}$ long; leaf blades oblanceolate; spadix pale violet-purple.

4b. Stipe less than $1 \mathrm{~cm}$ long (usually the spadix sessile).

5a. Submarginal collective vein markedly impressed above, raised below and significantly more prominent than the primary lateral veins; berries bright red; leaves narrowly elliptic to narrowly oblanceolate, the apex acuminate. A. bakeri Hook. f.

5b. Submarginal collective vein equally as prominent as the primary lateral veins; berries pale violet, white, yellow-orange or rarely red; leaves of various shapes.

6a. Plants slender, scandent, with persisting, dilacerating cataphylls enclosing the internodes (except $A$. tonduzii with cataphylls entire, not dilacerating, deciduous); plants with long slender stems, often hanging from trees; berries translucent white or pale violet or purple; blades usually much less than $14 \mathrm{~cm}$ long.

7a. Internodes $2-21 \mathrm{~cm}$ long, not clothed in persistent cataphylls; leaf blades usually rounded at base; primary lateral veins usually three to six per side. ....... A. tonduzii Engl.

7b. Internodes usually less than $2 \mathrm{~cm}$ long, rarely more than $4 \mathrm{~cm}$ long, at least the younger stems clothed in persistent, dilacerated cataphylls; leaf blades usually obtuse to acute at base; primary lateral veins usually numerous.

8a. Flowering spadix purplish, the pistil whitish, noticeably quadrangular, emerging prominently before stamens emerge; spathe persistently erect and more or less parallel to the spadix; berries broadly ovate to obovate, usually acute to apiculate at apex; plants growing at elevations from 0 to $800 \mathrm{~m}$. A. trinerve Miq.

8 b. Flowering spadix greenish, the pistil greenish, round to weakly quadrangular, emerging only after the stamens have opened; spathe strongly reflexed soon after opening; berries depressed-globose to globose, rounded to flat at apex; plants growing at elevations from 0 to $2,700 \mathrm{~m}$.

9a. Spadix 16-60 flowered, 11-30 mm long at anthesis; blade punctate or not on upper surface, $4-16 \mathrm{~cm}$ long. A. scandens (Aubl.) Engl. ssp. scandens

9b. Spadix 5-12(16) flowered, 2-10 $\mathrm{mm}$ long at anthesis; blade punctate on upper surface, $2-7.5 \mathrm{~cm}$ long. A. scandens ssp. pusillum Sheffer 
6b. Plants acaulescent or with short caudex and short internodes; plants never hanging (except A. friedrichsthalii); berries various colors; leaf blades usually much longer than $15 \mathrm{~cm}$, occasionally slightly smaller.

10a. Leaf blades oblong, strap-like; berries pale yellow-orange, broader in direction of axis than perpendicular to axis, sunken at apex.

11a. Spathe to $5 \mathrm{~mm}$ wide, early deciduous; leaf blades mostly $1-4 \mathrm{~cm}$ wide; spadix sessile. A. friedrichsthalii Schott

11b. Spathe $1-1.5 \mathrm{~cm}$ wide, usually persisting; leaf blades mostly $4-7.5 \mathrm{~cm}$ wide; spadix short-stipitate. A. utleyi Croat \& Baker

10b. Leaf blades not oblong; berries various.

12a. Peduncle filiform, long and very fragile, the spadix often pendent; spathe tinged reddish-violet; berries peach-orange; all vegetative parts brittle; 0$800(1,400) \mathrm{m}$. A. acutangulum Engl.

12b. Peduncle erect, elongate or short; spathe of various colors, usually green or purple; berries of various colors; vegetative parts not brittle; $0-1,700 \mathrm{~m}$.

13a. Peduncle 3-sided and alate; petiole triangular in cross-section; Osa Peninsula. A. alatipedunculatum Croat \& Baker

13b. Peduncle terete or nearly so (except $A$. austinsmithii sharply angulate); petiole not triangular in cross-section; primarily Atlantic watershed.

14a. Leaf blades narrowly elliptic, the apex acuminate; spadix short (to $15 \mathrm{~cm}$ ), on a stipe $1-6 \mathrm{~mm}$ long. ………........ A. utleyi Croat \& Baker

14b. Leaf blades lanceolate, oblanceolate, elliptic, or obovate; spadix very long or short (A. lancifolium, $A$. paludosum); spadix sessile or nearly so.

15a. Leaf blades lanceolate to ovate-lanceolate or oblong-lanceolate, the apex long-acuminate; spadix grayish-white to violet-purple.

16a. Peduncle terete; spadix grayish- or greenish-white, with four or five flowers visible in each spiral from any angle; berries violet-purple at maturity.

\section{A. lancifolium Schott}

16b. Peduncle 2- or 3-sided, sharply angular; spadix becoming violet-purple (may be green prior to anthesis), with no more than three flowers visible in each spiral from any angle; berries white, tinged with violet-purple at apex. A. austinsmithii Croat \& Baker

15b. Leaf blades lanceolate to obovate but never long-acuminate at apex; spadix color various.

17a. Cataphylls thick, persistent, not dilacerating; petioles one six th to one third as long as blades; blades almost oblong, coriaceous drying equally light green or yellow-green on both surfaces; fresh material with a conspicuous whitish midrib; berries orange; near sea level. A. paludosum Engl.

17b. Cataphylls thin, soon weathering and deciduous; petioles various; blades mostly elliptic to oblanceolate or narrowly obovate, chartaceous or rarely coriaceous, drying usually brownish or grayish to blackened, usually paler on lower surface when fresh, the midrib not noticeably paler; berries orange to red; elevation various.

18a. Leaves usually with moderately short petioles (one sixth to one third the length of the blade) and oblanceolate to narrowly obovate blades; peduncle and spadix usually stout; spadix usually very long, 4-10 mm diam. near base, gradually tapered to apex; berries pale red, flat at apex; 0-1,400 m.

A. ramonense Engl. ex K. Krause

18b. Leaves usually with longer petioles (one third to fully as long as blade) and elliptic or narrowly elliptic blades; peduncle slender or stout; spadix slender or stout, tapered or not, usually less than $5 \mathrm{~mm}$ diam. in $A$. acutangulum but sometimes to $10 \mathrm{~mm}$ diam. at base in $A$. durandii; berries orange to peach-orange. 
19a. Blades short-acuminate, the acumen almost rounded or even emarginate at apex; cataphylls usually either deciduous or with few persisting as thin fibers, not forming a dense fibrous network. ........ A. durandii Engl.

19b. Blades noticeably acuminate, the acumen obtuse at apex; cataphylls usually persisting as a dense fibrous network. A. acutangulum Engl.

\author{
KEY F
}

Leaves simple, not lobed; blades neither cordate nor subcordate at base, epunctate.

1a. Geniculum situated at least $7 \mathrm{~cm}$ below the base of the blade; plants terrestrial. .... A. oerstedianum Schott

1b. Geniculum immediately subtending the leaf blade.

2a. Plants scandent, the stem elongate, with long internodes, the leaves dispersed throughout much of the length of the stem.

3a. Spathe decurrent on the peduncle $(0.5) 1-1.5 \mathrm{~cm}$; berries yellow to orange or white.

3b. Spathe essentially not decurrent; berries green, yellow, orange or bright red to red-violet.

A. pittieri Engl.

4a. Stem with two or more successive, abbreviated internodes alternating with greatly elongated internodes, 8-33 cm long; leaves drying brownish-green or olive-green; berries bright red or purple-red; below $1,000 \mathrm{~m}$.

A. interruptum Sodiro

4b. Stem with internodes nearly uniform length, decreasing slightly toward the apex of the stem; leaves drying dark brown to blackish or pale green; berries green, red or orange; usually above $1,200 \mathrm{~m}$ elevation, rarely below $1,000 \mathrm{~m}$.

5a. Petioles less than $3 \mathrm{~cm}$ long; peduncles less than $4 \mathrm{~cm}$ long, enclosed at base in an elongate leaf sheath.

5b. Petioles more than $3 \mathrm{~cm}$ long, peduncles more than $5 \mathrm{~cm}$ long.

6a. Blades drying black or blue-black, dark brown on the upper surface, medium brown on the lower surface; leaves fleshy when fresh; veins obscure; 1,500-2,600 $\mathrm{m}$. A. carnosum Croat \& Baker

6b. Blades drying dark green to pale green above, pale yellow-green or occasionally brownish beneath; leaves thickly chartaceous; veins prominent below; 700-2,300 m.

6'a. Spadix more than $7 \mathrm{~cm}$ long at anthesis, slender and narrowly tapered to apex; berries red, early emergent, oblong. A. testaceum Croat \& Baker

$6^{\prime} \mathrm{b}$. Spadix less than $5 \mathrm{~cm}$ long at anthesis, blunt and scarcely tapered to apex; berries yellow-green, not early emergent, more or less globose.

7a. Petioles mostly more than $15 \mathrm{~cm}$ long; leaf base acute to rounded; stipe 1-5 mm long; leaves usually clustered at the ends of branches (internodes short) with the more elongate lower nodes usually leafless. A. pallens Schott

7b. Petioles mostly less than $15 \mathrm{~cm}$ long; leaf base often truncate or subcordate; stipe 2-10 $\mathrm{mm}$ long; leaves evenly distributed along the branches and persistent, the apical internodes not usually shortened.

\title{
A. microspadix Schott
}

2b. Plants not scandent, either appearing more or less acaulescent with the stem short or the stem elongate but with the internodes short, the existing leaves clustered near the end of the stem.

8a. Petioles terete or subterete, never quadrangular, rectangular, or triangular, often narrowly or broadly sulcate on upper side with the margins sharp or blunt but merely rounded on lower side, never prominently ribbed on lower side.

9a. Major lateral veins mostly free to the margins, sometimes weakly loop-connected in apical half of blade, never with a conspicuous, almost straight collective vein arising from near the base.

10a. Peduncle usually shorter than petiole, never more than two times longer than petiole; spadix usually more or less oblong, usually short and thick, never long, lineartapered; peduncle less than twice as long as spadix; berries red.

A. cubense Engl.

10b. Peduncle mostly two or more times longer than petiole; spadix usually elongate, cylindroid-tapered, never oblong (except $A$. consobrinum), if short then not thick; peduncle more than twice as long as spadix; berries red, white, cream, greenish, orange or yellow, not violet-purple.

11a. Pistils acutely pointed at apex; berries white, cream, yellow, orange, sometimes white tipped with orange, yellow or reddish at apex only; species of the Atlantic slope.

12a. Mature spadix cylindroid, not tapered, to ca. $9 \mathrm{~cm}$ long and $1.5 \mathrm{~cm}$ 
(including pistils) diam. at anthesis, the pistils exserted well above the stamens and emerging weeks ahead of the stamens; berries white at base, reddish at apex; midrib rounded on lower leaf surface near the base of the blade. A. consobrinum Schott

12b. Mature spadix cylindroid-tapered, $12-15 \mathrm{~cm}$ long and ca. $8 \mathrm{~mm}$ diam. at base at anthesis, the pistils not apparent before anthesis, obscured by the stamens when stamens are exserted; berries white, cream, yellowish, or orange, usually a solid color throughout; midrib usually more or less trapezoidal with two sharp ribs on the lower leaf surface near the base of the blade. A. fatoense K. Krause

11b. Pistils not emerging early, rounded at apex; berries greenish-white or red, usually blunt at apex; roots $3 \mathrm{~mm}$ or more thick, free-ending or not but not all uniformly turned upward, not conspicuously acute at apex.

13a. Spathe ovate, pale green, erect, and enshrining the spadix; spadix pale green, moderately stubby, usually less than $6.5 \mathrm{~cm}$ long; plants usually terrestrial or on soil deposits on rocks; blades usually elliptic; roots mostly $1 \mathrm{~cm}$ diam. when fresh; eastern Guatemala and western El Salvador on the Pacific slope. A. salvadorense Croat

13b. Spathe lanceolate (except $A$. halmoorei), usually green to violet-purple, reflexed or spreading; spadix green to pale lavender or purplish, usually rather slender and long-tapered, usually more than $6.5 \mathrm{~cm}$ long; plants usually epiphytic or epipetric (except $A$. nizandense); blades usually oblanceolate-elliptic to oblanceolate (except sometimes elliptic on $A$. nizandense); roots mostly less than $6 \mathrm{~mm}$ diam. when fresh; Mexico to Colombia.

14a. Leaf blades obovate-elliptic, 1.3-2.5 times longer than petioles, less than 3 times longer than broad; Mexico in southern Oaxaca and Guerrero. A. nizandense Matuda

14b. Leaf blades generally oblanceolate or oblanceolate-elliptic, 3 or more times longer than petioles; usually 3 or more times longer than broad.

15a. Spathe ovate to broadly ovate; berries pale greenish-yellow; western Mexico in Nayarit, Jalisco, Colima, and Michoacán. A. halmoorei Croat

15b. Spathe lanceolate to linear-lanceolate; berries bright red; Mexico from Guerrero to Chiapas and Veracruz and to Colombia.

16a. Cataphylls cucullate (hooded), fist-shaped before opening; inflorescence frequently pendent at anthesis; spadix usually long-tapered, pale lavender, weakly glaucous; spathe long and narrowly tapered to apex, spreading, thin, almost as long as the spadix; Pacific slope except from Nicaragua to Panama.

A. salviniae Hemsl.

16b. Cataphylls lanceolate; inflorescence usually erect; spadix short-tapered, green to violet-purple, not glaucous; spathe moderately short, reflexed, coriaceous, usually much shorter than spadix.

17a. Plants occurring on rocky, dry slopes; Pacific slope of Mexico in Guerrero and southern Oaxaca.

A. schlechtendalii ssp. jimenezii (Matuda) Croat

17b. Plants occurring as epiphytes or on rocks in usually moist areas; Atlantic slope, principally from Veracruz to Honduras.

A. schlechtendalii Kunth ssp. schlechtendalii

9b. Major lateral veins mostly joining into a straight or conspicuously loop-connected collective vein, this arising usually in the lower half of the blade; plants with or without the rosulate habit.

18a. Spadix with no more than two to five flowers exposed across its diameter in any spiral from any angle of view.

19a. Leaf blades broadest above the middle, tapered to a long cuneate base; spathe red-violet; spadix purple-brown; berries red; roots usually white. A. gracile (Rudge) Lindl.

19b. Leaf blades broadest at or below the middle, acute to rounded at base; spathe 
green; spadix green, yellow or orange, sometimes tinged purple; berry color various.

20a. Spathe decurrent onto peduncle $(0.5) 1-1.5 \mathrm{~cm}$; pistils early emergent many times longer than stamens at anthesis; berries yellow or orange.

A. pittieri Engl. ssp. pittieri

20b. Spathe not long-decurrent onto peduncle; pistils scarcely longer than stamens at anthesis; berries green or red (not known in A. pittieri var. fogdenii but probably orange).

21 a. Spathe to $7 \mathrm{~cm}$ long; spadix 4-12 cm long; berries red. A. testaceum Croat \& Baker

$21 \mathrm{~b}$. Spathe less than $3.5 \mathrm{~cm}$ long; spadix less than $4.5 \mathrm{~cm}$ long; berries greenish (A. pallens) or probably orange (A. pittieri var. fogdenii).

22a. Leaf blades less than $10 \mathrm{~cm}$ long, thick, veins shallowly etched above, obscure below; primary lateral veins three to four per side. A. pittieri var. fogdenii Croat

22b. Leaf blades more than $15 \mathrm{~cm}$ long, moderately thin, tertiary veins prominulous below (dry), primary lateral veins five to nine per side. A. pallens Schott

18b. Spadix with more than five flowers exposed across its diameter in each spiral from any angle of view.

23a. Petioles mostly less than $10 \mathrm{~cm}$ long; blades usually six or more times longer than petioles.

24a. Collective vein arising from one of the primary lateral veins, well above the base; berries white at base, reddish or purplish at apex; pistils early long-exserted, much longer than the stamens. ............. A. consobrinum Schott

24b. Collective vein arising from the base of the blade; berries red (not seen for A. machetioides); pistils not long-exserted, held at about the same level as stamens.

25a. Spadix stubby, creamy-white; spathe lanceolate-ovate, clasping at the base; cataphylls thick, persisting intact; Costa Rica on the Pacific slope. A. eximium Engl.

25b. Spadix slender and long-tapered, greenish; spathe lanceolate, acute or obtuse at the base; cataphylls thin, weathering into fibers; Mexico in Oaxaca. A. machetioides Matuda

23b. Petioles usually $11 \mathrm{~cm}$ or longer; blades no more than four times longer than petioles.

26a. Species of Mexico and Middle America, ranging as far south as northern Honduras; petioles broadly sulcate adaxially, the margins obtuse or acute.

27a. Leaf blades lacking any obvious basal veins, the lowermost primary lateral veins more or less equal or less prominent than those higher up on the blade.

28a. Tertiary and higher order veins conspicuously elevated (at least when dry). A. retiferum Standl. \& Steyerm.

28b. Tertiary and higher order veins obscure, much less prominent than the primary lateral veins. ..... A. parvispathum Hemsl.

27b. Leaf blades with usually well developed basal veins which are more prominent than the primary lateral veins or at least unite to form a posterior rib.

29a. Collective vein arising from one of the lowermost basal veins; primary lateral veins numerous or apparently so, scarcely more prominent than the interprimary or tertiary veins; blade often conspicuously broadened at the base.

A. seleri Engl.

29b. Collective vein arising from the uppermost basal vein or even from one of the primary lateral veins; primary lateral veins usually conspicuously more prominent than the interprimary or tertiary veins; blade usually not conspicuously broadened at the base (sometimes so in A. nakamurae).

30a. Blades broadest near or even above the middle, six or more times longer than broad; southwestern Chiapas. A. nakamurae Matuda

30b. Blades broadest near the base, usually ca. three times longer than broad. 
31a. Major veins of lower blade surface reddish (at least on younger leaves); northern Oaxaca. A. subovatum Matuda

31b. Major veins of lower blade surface green; Guatemala to Honduras. A. subcordatum Schott

26b. Species of Costa Rica and Panama or possibly as far north as Nicaragua; petioles sulcate or not.

32a. Major lateral veins obscure (prominulous when dry but scarcely more prominent than the tertiary venation); the midrib reddish in lower half of blade (less noticeable after drying); cataphylls not dilacerating, soon deciduous. A. burgeri Croat \& Baker

32b. Major lateral veins prominent, much more conspicuous than the tertiary veins; midrib not reddish; cataphylls usually dilacerating at least at base, usually persisting for a considerable time.

33a. Cataphylls less than $15 \mathrm{~cm}$ long and less than $1 \mathrm{~cm}$ wide at the middle, weathering into mostly longitudinal fibers; stem mostly ca. $1 \mathrm{~cm}$ diam., elongate, with many white to tan roots among the existing leaves; inflorescences usually erect at anthesis, arching in fruit; spadix usually less than $6 \mathrm{~mm}$ diam. at base, berries pale green.

33b. Cataphylls more than $15 \mathrm{~cm}$ long or more than $1.5 \mathrm{~cm}$ wide at the middle, often weathering into a net-like structure (with coarse longitudinal fibers underlain by finer, diagonally directed fibers), or remaining intact near apex; stem mostly $2 \mathrm{~cm}$ diam. or more, usually lacking white to tan roots among the existing leaves; inflorescences usually spreading to pendent at anthesis, pendent in fruit (except A. cuspidatum); spadix mostly more than $7 \mathrm{~mm}$ diam. at base (except $A$. protensum and $A$. cuspidatum); berries not pale green.

34a. Leaf blades ovate to oblong-ovate, mostly more than $20 \mathrm{~cm}$ wide, truncate to subcordate at base, the basal veins united into a short trunk vein.

A. cuspidatum Mast.

34b. Leaf blades oblong to oblong-elliptic, mostly less than $20 \mathrm{~cm}$ wide, acute to attenuate or subrounded at base, lacking a posterior rib.

35a. Spathe and spadix less than $8.5 \mathrm{~cm}$ long; spathe ovate, cordate at base, ca. half as wide as long. A. brenesii Croat \& Baker

35b. Spathe and spadix more than $10 \mathrm{~cm}$ long; spathe lanceolate to linear, not cordate, much more than twice as long as wide.

36a. Leaves much paler and whitish beneath; spadix yellow-green; rosulate plant with erect-spreading leaves; blades to $54 \mathrm{~cm}$ long. A. michelii Guillaumin

36b. Leaves more or less concolorous; spadix purplish or purplish tinged; plant and/or leaves usually pendent; blades often more than $60 \mathrm{~cm}$ long.

37a. Spadix 30-75 times longer than wide, to ca. $60 \mathrm{~cm}$ long, the fruiting spadix more than $30 \mathrm{~cm}$ long; flowers more than $1.8 \mathrm{~mm}$ wide (dry) at apex; plants occurring below $600 \mathrm{~m}$. A. prolatum Croat \& Baker

37b. Spadix less than 20 times longer than wide at anthesis, to $20 \mathrm{~cm}$ long, the fruiting spadix usually less than 25 $\mathrm{cm}$ long; apex of flowers less than $1.5 \mathrm{~mm}$ wide; plants occurring above $900 \mathrm{~m}$. ........ A. protensum Schott

8 b. Petioles quadrangular, rectangular, decidedly triangular or prominently 1 - or more ribbed on lower (abaxial) side. 
38a. Major lateral veins mostly free to the margin, sometimes loop-connected in apical half of blade, never with a continuous, almost straight collective vein arising from near the base; plants rosulate epiphytes with usually short stems and massive root clusters among the petioles; berries pale orange, yellow or red.

39a. Stem usually $1-1.5 \mathrm{~cm}$ diam., comparatively elongate, at least the lower internodes not completely obscured by the roots; inflorescences usually arched-spreading; infructescence pendent, the spadix greenish to white or pale reddish to pale purple. 40a. Leaf blades thickly chartaceous; berries cream to pale orange or yellow; roots many, compact, more or less contiguous, tapering, slender, ascending; petioles mostly less than $10 \mathrm{~cm}$ long. A. fatoense $\mathrm{K}$. Krause

40b. Leaf blades subcoriaceous; berries red; roots moderately dense, thick, blunt, not ascending; petioles mostly more than $10 \mathrm{~cm}$ long.

A. upalaense Croat \& Baker

39b. Stem usually more than $2.5 \mathrm{~cm}$ diam. (at least on mature individuals), the internodes mostly completely obscured by the roots, the roots moderately stout, usually more than $3 \mathrm{~mm}$ diam., not all elongate tapered and regularly directed upwards; inflorescence erect or spreading; infructescence erect or pendent; spadix dark violetpurple or green or green tinged purplish.

41a. Species occurring from Mexico to El Salvador, frequently on rocks; berries red or pale greenish-yellow or greenish-white.

42a. Leaf blades obovate-elliptic, less than three times longer than broad, 1.3-2.5 times longer than petioles; southern Oaxaca and Guerrero.

A. nizandense Matuda

42b. Leaf blades generally oblanceolate or oblanceolate-elliptic usually three or more times longer than broad; blades three or more times longer than petioles.

43a. Spathe green, ovate.

44a. Spathe erect and enshrining the spadix; berries orange-red; eastern Guatemala and western El Salvador on the Pacific slope. ........................................................................ A. salvadorense Croat

44b. Spathe reflexed; berries pale greenish-yellow; petiole obtusely 3-sided; western Mexico in Nayarit, Jalisco, Colima, and Michoacán. A. halmoorei Croat

43b. Spathe green or usually violet-purple, lanceolate.

45a. Plants from the Pacific slope in Guerrero and Oaxaca; dry rocky slopes. ..... A. schlechtendalii ssp. jimenezii (Matuda) Croat

45b. Plants principally from the Atlantic slope; epiphytes or on rocks in generally moist areas.

A. schlechtendalii Kunth ssp. schlechtendalii

41b. Species of Costa Rica and Panama to as far north as Nicaragua.

46a. Peduncles usually shorter than petioles, rarely to 1.5 times longer than petioles; petioles usually sharply quadrangular, flat or 3-ribbed on lower side (abaxial), the sides unribbed; spathe purplish; spadix often short, $5-22 \mathrm{~cm}$ long; pistils emerging early; berries red, acute at apex. A. purpureospathum Croat

46b. Peduncles usually 1.5-3 times longer than petioles; petioles subquadrangular, lacking abaxial ribs; spathe $16-17 \mathrm{~cm}$ long, green; spadix 15$23 \mathrm{~cm}$ long; pistils not emerging early; berries orange, flattened at apex. A. validifolium $\mathrm{K}$. Krause

38b. Major lateral veins mostly joining into a straight or conspicuously loop-connected collective vein, this usually arising in the lower half of the blade; plants with or without the rosulate habit; berries green, red, violet-purple or orange.

47a. Spadix cylindroid to clavate, as broad as or broader toward apex as at middle; spathe broadly ovate or narrowly ovate; berries greenish to white or red.

48a. Spadix usually clavate or subclavate; cataphylls soon weathering to longitudinal, persistent, pale fibers; spathe cucullate, ovate; berries greenish; plants of the Atlantic slope from 0-650 m.

49a. Blades with 20-30 pairs of primary lateral veins, these prominently sunken; spathe lanceolate to broadly lanceolate, about twice as long as the spadix; petiole commonly triangular, 3-5-ribbed.

A. spathiphyllum N. E. Brown

49b. Blades with (5)10-15 pairs of primary lateral veins, these weakly sunken; spathe ovate, about as long as the spadix; petiole commonly quadrangular. A. cuneatissimum (Engl.) Croat

48b. Spadix usually cylindroid; spathe more or less planar, lanceolate-ovate; cata- 
phylls persistent, turning brown but not dilacerating; berries red; plants of the Pacific slope in tropical wet forest from $0-50 \mathrm{~m}$.................... A. eximium Engl.

47b. Spadix usually conspicuously tapered toward the apex; spathe narrowly ovate to lanceolate or oblong-lanceolate; berries greenish, violet-purple, orange or red.

50a. Petioles triangular, acutely 1-ribbed on lower (abaxial) side; blades markedly bicolorous, the lower surface creamy-green, drying black to olive-brown, lower surface with the major veins conspicuously darker than the surface, scarcely or not at all raised, the tertiary veins obscure; berries bright violetpurple, acute at apex. ............................................................................ A. michelii Guillaumin

50b. Petioles quadrangular, usually 3-ribbed on lower (abaxial) side; blades not markedly bicolorous but usually somewhat paler beneath, usually drying green, lower surface with the major lateral veins usually somewhat lighter than the lower surface, usually conspicuously raised (scarcely raised in $A$. upalaense but with the tertiary veins prominently visible); berries greenish, orange or red.

51a. Plants terrestrial; blades attenuate at base (broadly concave between lower third of blade and geniculum); berries greenish-yellow.

51b. Plants epiphytic; blades acute to truncate or rounded at base; berries A. acutifolium Engl. orange or red.

52a. Major lateral veins scarcely raised; blades acute at base, the tertiary veins clearly visible but not at all raised (except after drying), about as prominent as the collective vein and the distal parts of the major lateral veins; cataphylls turning brown, remaining intact, not dilacerating; berries bright red.

A. upalaense Croat \& Baker

52b. Major lateral veins prominently raised; blades acute to truncate or subcordate at base, tertiary veins weakly raised (even on fresh material), much less conspicuous than the collective vein and distal parts of the major lateral veins; cataphylls usually tan, dilacerating at least at base; berries orange (presumed orange for A. spectabile).

53a. Peduncles usually greatly exceeding petioles when fully mature; blades usually less than $16 \mathrm{~cm}$ wide; spadix usually less than $20 \mathrm{~cm}$ long at anthesis; stamens held just above tepals, the filaments usually not visible; anthers ca. 0.5 $\mathrm{mm}$ long. A. seibertii Croat \& Baker

53b. Peduncles usually shorter than petioles; blades usually more than $20 \mathrm{~cm}$ wide; spadix usually more than $20 \mathrm{~cm}$ long at anthesis; stamens prominently exserted above the tepals, the filaments exposed; anthers ca. $0.9 \mathrm{~mm}$ long.

A. spectabile Schott

Anthurium Schott, Wiener Z. Kunst 3: 828. 1829.

Herbs, usually epiphytic, rarely terrestrial (more commonly so in cloud forests where they grow on deposits of debris), the growth habit monophyllous or polyphyllous sympodial; stems nontuberous, the internodes short to elongate (plants then often scandent), the leaf scars often very conspicuous; cataphylls usually \pm lanceolate (rarely cucullate), usually green, soon drying and then variously colored, with a medial rib beginning somewhere above the middle, usually extending to the apex (the rib sometimes ending in a subapical apiculum), deciduous or persisting, often weathering into coarse or fine fibers. LEAVES commonly clustered at or near the apex of the stem; petioles usually firm, stiff or flexible, sheathed near the base, geniculate at apex, the cross-sectional shape variable, frequently subterete and narrowly sulcate, sometimes with few to several ribs, the sulcus various, with the margins sharp or blunt; blades usually coriaceous to subcoriaceous, very variable in form, simple and usually ovate, elliptic or lanceolate or digitately lobed, net-veined, the primary lateral veins and/ or basal veins often forming a collective vein, the basal veins often united at base forming a posterior rib on leaves with posterior lobes. INFLORESCENCE one per node (often aborting), held below or above the leaves; peduncle terete or angular, usually elongate; spathe usually flat, usually not convolute at base, persistent, usually free well before anthesis of the flowers, usually 
spreading or strongly reflexed from the spadix, sometimes erect, sometimes hooding spadix, often colored, usually \pm lanceolate, often \pm elliptic or ovate, usually inserted on the peduncle at an oblique angle and often also decurrent; spadix uniform, usually cylindroid-tapered, sometimes cylindroid, clavate, or subglobose, sessile or stipitate, many flowered, variously colored, elongated in fruit, usually flowering from the base upward in a slow or rapid progression, sometimes beginning from the middle and developing rapidly throughout the spadix; flowers perfect, usually protogynous, closely aggregated in spirals, truncate and usually rhombic in outline at apex, sometimes the outline sub-4-lobed (i.e., margins of apex) straight or gradually or jaggedly sigmoid; principal spirals with flowers aligned, their lateral margins forming a straight row; alternate spirals (opposite direction) with flowers aligned, their lateral margins not forming a straight row; tepals flattened throughout most of their length, broader and truncate at apex (somewhat accrescent in fruit), usually triangular, the inner margin usually rounded, held above the ovary, sometimes turned up against the emerging ovary, sometimes overlapping before anthesis, the surface glossy to matte, sometimes with nectar droplets, especially while anthers are emerging; the space between the tepals (exposed part of pistil) usually square or rectangular, sometimes elliptic; pistil simple, 2-celled, included or exserted at anthesis, green or variously colored, usually rounded at apex, rarely acute to truncate; style usually absent; stigma usually a slitlike depression lined with papillae, usually linear to elliptic, sometimes inverted and brushlike with rather elongate papillae, usually forming stigmatic droplets at anthesis; ovules usually 1 or 2 per cell, rarely 3 or more; stamens 4 , usually weakly exserted, sometimes well exserted, less frequently included with only the pollen emerging from beneath the tepals, usually the lateral pair of stamens emerging first one at a time, followed by the anterior and posterior ones, the filaments flattened, somewhat rounded abaxially when exserted, usually narrowed to the connective, usually included and not visible, sometimes exserted, then frequently withdrawing after anthesis to position the anther at the level of the tepal, sometimes withdrawing the anther below the tepals; anthers usually broader than long, the thecae broadly ovate to oblong-ovate, opening by a longitudinal slit. INFRUCTESCENCE usually pendent, rarely erect; berries ovoid, oblong- ovoid, oblong, or obovoid, less frequently depressed-globose, usually acute to rounded or truncate at apex, sometimes with a depression at apex, exserted and dangling on 4 threads at maturity, succulent and juicy, variously colored, 2 celled, usually 2 -seeded, sometimes 4 - or more seeded.

\section{DISCUSSION OF MORPHOLOGICAL \\ CHARACTERS PRESENTED OR OMITTED FROM SPECIES DESCRIPTIONS}

In order to provide detailed descriptions of the species presented here and at the same time to provide relatively short descriptions, a number of assumed character states will be listed for the genus. While these might be apparent upon rereading the generic description, this list should more readily elucidate assumed characters.

Stems: Usually assumed short unless a specific length is given.

Internodes: As above.

Cataphylls: Assumed 1-ribbed.

Petiole: Color mentioned only if other than green.

Geniculum: Shape and color given only if different from petiole.

Leaf Color: Mentioned only if other than green or if lower surface is substantially paler than upper surface.

Leaf Texture: Usually mentioned only if other than semiglossy.

Venation: Basal veins and midrib assumed raised unless otherwise indicated.

Inflorescence: All colors given are assumed to be at anthesis unless otherwise stated; spadix assumed to be cylindroid-tapered unless otherwise stated.

Flower size: "Length" is actually the width of the apical, thickened part of the flower in the direction of the axis; "width" is the width of the apical part of the flower, perpendicular to the axis (only the visible portion is measured); "sides of the flower" refers to the line formed by the 4 outer margins of the apex of the flower (see Croat \& Bunting, 1979).

Filaments: Length and width is the measurement of the area exposed. 
See Croat and Bunting (1979) and Croat (1980) for details of flowering behavior to understand the necessarily abbreviated discussion of staminal behavior in Anthurium. The discussion of flowering behavior under the section of this paper entitled "Taxonomic Characters" (Inflorescences) gives information essential to understanding the descriptions of this behavior in the following treatment of species.

Anthurium acutangulum Engl., Bot. Jahrb. Syst. 25: 371. 1898. TyPE: Costa Rica. San José: near San José, 1,200 m., Tonduz 10360 (B, hololectotype; CR, isolectotype; designated Croat \& Baker, 1979).

Anthurium porschianum K. Krause, Ann. Naturhist. Mus. Wien 46: 231. 1932. TYPE: Costa Rica. Limón Prov.: La Castilla-Los Negritos, $12 \mathrm{~km}$ from the mouth of the Río Reventazon, $20 \mathrm{~m}$, Cufondontis 611 (W, holotype; $\mathrm{B}$, isotype).

Epiphyte or rarely terrestrial; roots numerous; cataphylls subcoriaceous, 2.5-5(11) cm long, acuminate (the acumen apiculate), drying tan to light brown, persisting as linear fibers. LEAVES erect to spreading; petioles narrowly sulcate, rounded to sometimes 1-ribbed abaxially, 3-22 cm long, 4-7 mm diam.; geniculum $1-1.5 \mathrm{~cm}$ long; blades elliptic to narrowly obovate, subcoriaceous, short-acuminate at apex, acute to obtuse at base, $15-34 \mathrm{~cm}$ long, 5-14 $\mathrm{cm}$ wide, broadest at middle or slightly above, both surfaces semiglossy, the lower surface punctate; midrib convexly raised above and below; primary lateral veins $8-10$ per side, departing midrib at $55^{\circ}-60^{\circ}$ angle, \pm straight to collective vein, loop-connected from base; collective vein rising from base, sunken on upper surface, 3-8 mm from margin. INFLORESCENCE spreading to pendent, equal to or longer than leaves; peduncle $12-61 \mathrm{~cm}$ long, 4-4.5 $\mathrm{mm}$ diam., terete or strongly ribbed abaxially, sometimes 3 -ribbed adaxially, rarely 4-6 ribbed, the ribs irregularly spaced, tinged with red-violet near base, much longer than petioles; spathe green, tinged with red-violet (B \& K Yellow-green 8/10), oblanceolate, $7-11.5 \mathrm{~cm}$ long, $1.2-1.5 \mathrm{~cm}$ wide, broadest at base, inserted at $40^{\circ}$ angle on peduncle, sometimes slightly twisted; stipe 6-7 mm long in front, 2-3 mm long in back; spadix yellow-green (B \& K Yellow-green 6/7.5), 8.5-21 cm long, 4-6 mm diam. at base, 3-4 $\mathrm{mm}$ diam. at apex; flowers rhombic, 4.2-6 $\mathrm{mm}$ long, $2.5-3.5 \mathrm{~mm}$ wide, the sides \pm straight; ca. 5 flowers visible in the principal spiral and ca. 4-6 flowers visible in the alternate spiral; tepals glossy, weakly punctate, papillate; lateral tepals $3-3.3 \mathrm{~mm}$ wide, the inner margins straight and flat; pistils emergent, green; stigma brushlike with droplets, dry and brown as stamens emerge; stamens emerging rapidly from base or middle, the first lateral stamens emerging at apex as third and fourth emerge at base, exserted on transparent filaments, 0.3-0.5 $\mathrm{mm}$ long, $0.7-1 \mathrm{~mm}$ wide, retracting and holding anthers at sides of pistil, not contiguous; anthers creamy white, $0.5 \mathrm{~mm}$ long, $0.7-0.8 \mathrm{~mm}$ wide; thecae ellipsoid, divaricate; pollen white, abundant. INFRUCTESCENCE pendent; berries pale orange, \pm obovoid, ca. $5 \mathrm{~mm}$ long. Figs. 2 and 3.

The species is known from Honduras (la Mosquitia) to Panama from sea level to $1,400 \mathrm{~m}$. It is found only on the Atlantic slope in Honduras and Nicaragua, but on both slopes in Costa Rica and Panama. In Panama it occurs on the Pacific slope near the Continental Divide. Anthurium acutangulum is known from wetter parts of tropical moist, premontane wet, and tropical wet forest.

Anthurium acutangulum is recognized by its long-petiolate, more or less elliptic, glandularpunctate leaves, which are abruptly acuminate at apex; its slender, pendulous inflorescence; its peduncle and spathe that are usually tinged redviolet, and its pale orange berries.

This species is a typical member of section Porphyrochitonium despite its erroneous placement in section Leptanthurium by Engler (1905). The species is most easily confused with smaller specimens of $A$. ramonense but that species has a much stouter peduncle and the inflorescence is either held semierect or, if it is pendent, it is held stiffly downward and outward, not hanging loosely as in the case of $A$. acutangulum. In addition, the pistils of $A$. ramonense are not at all raised, the exposed portion being markedly squared and violet-purple. In $A$. acutangulum the pistils are green, appear somewhat rounded, and are promptly raised well above the tepals, giving the spadix a weakly knobby appearance.

Costa Rica. alajuela: between Cañas and Upala, N of Bijagua, Croat 36481 (MO); Santa María National Park, Liesner 5130 (MO); NW of Zarcero, Croat 43581 (MO). CARTAGO: valley of Río Tuis, Tonduz 8217 (BR). GUANACASTE: Le Tejonia, Standley \& Valerio 46028 (US). LIMÓN: S of Siguirres, Croat 43340 (MO). SAN JosÉ: between División and Palmital, Pittier 3868 (BR).

HONDURAS. GRACIAS A DIOS: near Río Plátano, Clewell \& Cruz 4121 (MO). 


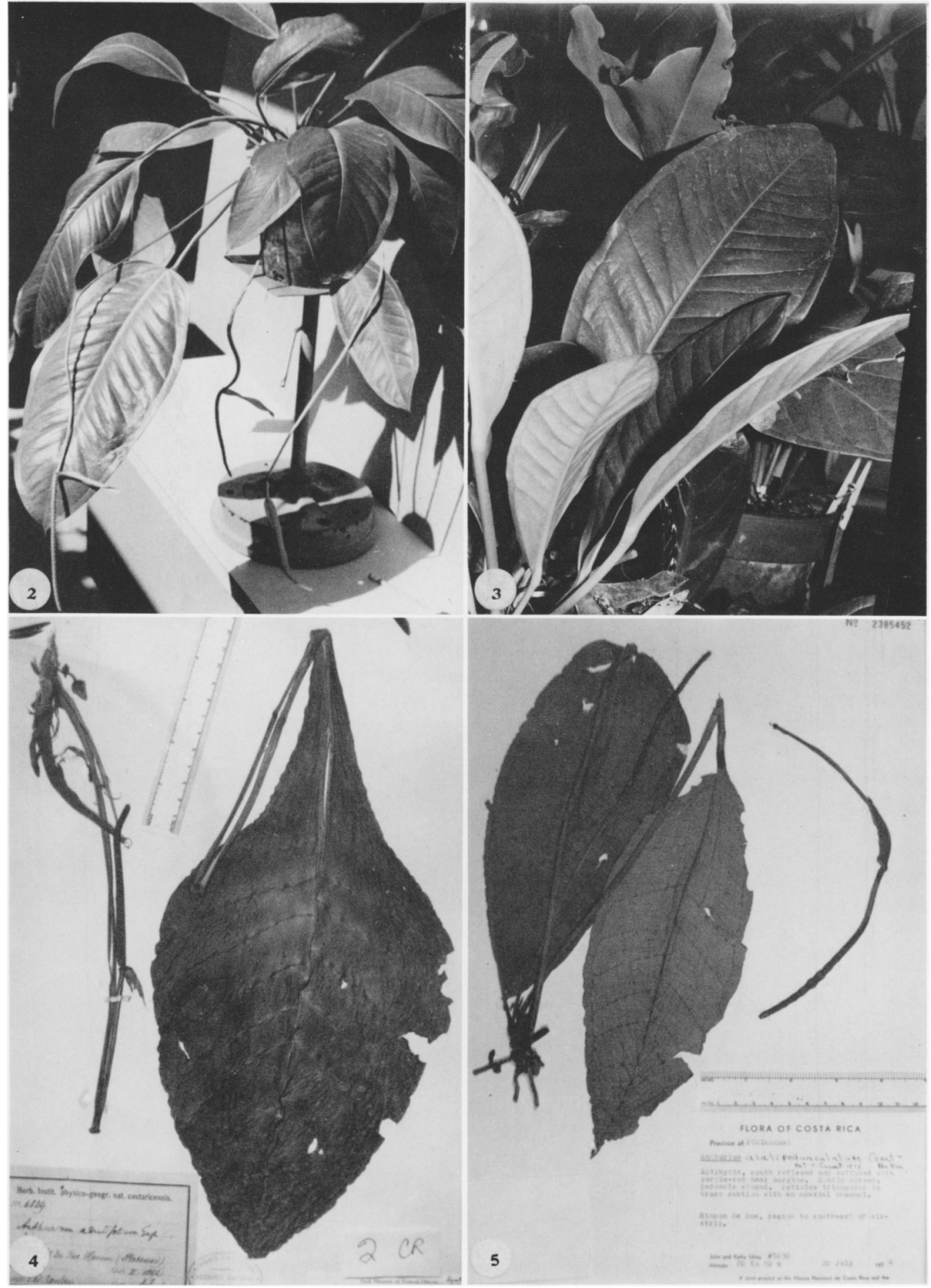

Figures 2-5. 2. Anthurium acutangulum Engl., Croat 43340.-3. Anthurium acutangulum Engl., Croat 6740.-4. Anthurium acutifolium Engl., Pittier 6539 (Lectotype). -5. Anthurium alatipedunculatum Croat \& Baker, Utley 1030 (Type). 
NiCARAgUa. Río SAN JUAN: near Caño Chontaleño, NE of El Castillo, Neill 3422 (MO). ZELAYA: Caño Zamora, Stevens 8834 (MO); Stevens et al. 8862 (MO); Caño Majagua, Stevens 6976 (MO); S slope of Cerro El Inocente, Stevens 6804 (MO); SE of Cerro San Isidro, Río Kama, Proctor et al. 26993 (LL, NY); Cerro Saslaya, W of Siuna, Neill 1875 (MO); road to Colonia Agricola Yolaina \& Colonia La Esperanza, Stevens 6309A; Vincelli 167 (MO); near El Recreo, Neill \& Atwood AN 226 (MO); beyond Kururia, on road to San Jerónimo, Stevens 7557 (MO); $8 \mathrm{~km} \mathrm{~N}$ of La Cruz, Neill 4347 (MO); new road to Mina Nueva America, $\mathrm{N}$ of El Empalme, Stevens 8335, 8412 (MO); between Rosita and Puerto, SW of Río Kukalaya, Stevens 8506 , 8645 (MO); W of Rosita Empalme, Neill 4111 (MO); Caño at Salto La Oropéndola, Stevens 8947 (MO); along road from Siuna to Matagalpa, Stevens 7523 (MO); near Tala Has and Puente Mango, Stevens 7608 (MO); $\mathrm{N}$ of Limbaika, near Río Prinzapolka, Stevens 8253 (MO).

Anthurium acutifolium Engl., Bot. Jahrb. Syst. 25: 365. 1898. TYPE: Costa Rica. Puntarenas: along the Río Hakum, Buenos Aires (SE of San Isidro del General), elev. $250 \mathrm{~m}$, Pittier 6539 (B, hololectotype; BR, CR, isolectotypes; designated Croat \& Baker, 1979).

Anthurium scopulicola Standl. \& L. O. Wms., Ceiba 3: 105. 1952. TYPE: Costa Rica. Puntarenas: vicinity of Palmar Norte, elev. near sea level, P. H. Allen 5788 (EAP, holotype; F, isotype).

Terrestrial or rarely epiphytic; roots numerous, thick, velutinous; cataphylls persisting as fibrous network, subcoriaceous, $6-10 \mathrm{~cm}$ long, acuminate at apex (the acumen apiculate), drying dark tan (B \& K Yellow 5/5). LEAVES erect to spreading; petioles (2)6-22 cm long, (3)6-9 mm diam., flattened to broadly sulcate adaxially, sharply 3-ribbed abaxially; blades epunctate, oblanceolate to broadly oblanceolate, gradually acuminate at apex, long attenuate at base, (11)25$62 \mathrm{~cm}$ long, (3.5)5.5-27 cm wide, broadest at middle; midrib raised above and below, paler than surface, sometimes yellow; primary lateral veins $8-12$ per side, departing the midrib at $40^{\circ}-$ $45^{\circ}$ angle; collective vein arising from the third to fifth primary lateral vein, $3-5 \mathrm{~mm}$ from the margin. INFLORESCENCE erect, usually shorter than leaves; peduncle $24-53 \mathrm{~cm}$ long, 3-5 $\mathrm{mm}$ diam., much longer than petioles; spathe green, linear-lanceolate, $5-12 \mathrm{~cm}$ long, $0.7-1.1 \mathrm{~cm}$ wide; spadix sessile, green to white, sometimes tinged with red-violet, $7-16 \mathrm{~cm}$ long, $6-8 \mathrm{~mm}$ diam. at base, 3-4 $\mathrm{mm}$ diam. at apex; flowers square to rhombic, ca. $2 \mathrm{~mm}$ in both directions, the sides \pm straight; 5-6 flowers visible in the principal spiral, 5-7 flowers visible in the alternate spiral; lateral tepals $0.5 \mathrm{~mm}$ wide, the inner margins turned up. INFRUCTESCENCE with greenishyellow, obovoid berries often not developing in apical one quarter to one half of spadix. Fig. 4.

The species is known from Costa Rica and Panama in tropical moist, premontane wet, and tropical wet forest life zones at elevations of sea level to $900 \mathrm{~m}$. The species has been collected once on the Atlantic slope and lowlands in San José and Puntarenas Provinces of Costa Rica, including the Osa Peninsula. It has been collected in Panama only on the Burica Peninsula in Chiriquí Province.

Anthurium acutifolium is a member of section Pachyneurium and is distinguished by being a terrestrial plant (rarely epiphytic) with thin, oblanceolate to broadly oblanceolate leaf blades that are attenuate at the base. The petiole is broadly sulcate to flattened on the upper side and sharply 3-ribbed on the lower side. The syntype Pittier 4099 at MO is unusually small for the species but appears to differ in no other way.

Anthurium acutifolium is similar vegetatively to $A$. consobrinum but that species is an epiphyte (apparently restricted to the Atlantic slope) with early emergent, narrowly acute pistils, an oblong spadix, and a petiole that is rounded on the lower side. Pistils of $A$. acutifolium are not early emergent and are rounded at the apex.

Costa Rica. alajuela: El Rodeo, Hunnewell 16560 (GH). Guanacaste: Cabecera, Pittier 11129 (BR, US). Puntarenas: Boruca, Pittier 4656 (BR); Buenos Aires, Pittier 6539 (BR); Burica Peninsula, S of Puerto Armuelles, Croat 22127 (MO); Quebrada Palito, Croat 22614 (MO); Osa Peninsula, at Sirena, Liesner 2921 (MO); above Palmar Norte, Croat 32926 (MO). SAN José: Puriscal, Cerro Turrubares, Jiménez 628 (US); between Río Cañas and Buenos Aires, Pittier 3862 (BR); S of bridge over Río del General, Harmon \& Fuentes 6210 (UMO); basin of El General, Skutch 4749 (MO); Pacaca, Pittier 4099 (BR); near Santa Ana, Burger \& Liesner 7171 (MO); NW of Santa Ana, Taylor 17387 (NY, US).

Anthurium alatipedunculatum Croat \& Baker, Brenesia 16 (Supl. 1): 19. 1979. TYPE: Costa Rica. Puntarenas: Rincón de Osa, region SW of air strip, 20-60 m elevation, 20 July 1974 , Utley \& Utley 1030 (F, holotype; MO, isotype).

Epiphyte; stems $1-1.5 \mathrm{~cm}$ diam.; roots few, descending, 2-3 mm diam.; cataphylls moderately thin, $2-3 \mathrm{~cm}$ long, acuminate at apex, drying brown, weathering into fibers, subpersistent. 
LEAVES erect; petioles 4-26 cm long, 5-6 mm wide, triangular, sulcate, drying with a narrow, almost membranous wing; geniculum $0.5-1.2 \mathrm{~cm}$ long; blades lanceolate-elliptic, acuminate at apex, obtuse to rounded at base, $15-23.5 \mathrm{~cm}$ long, 6$10 \mathrm{~cm}$ wide, broadest below the middle, obscurely and sparsely punctate above, densely punctate below, the punctations reddish-brown, the margin drying conspicuously undulate; lower surface paler than upper; primary lateral veins 10-20 per side, departing midrib at $55^{\circ}$ angle, almost straight to collective vein; interprimary veins numerous; collective vein arising from the base, $3-8 \mathrm{~mm}$ from margin. INFLORESCENCE shorter than leaves; peduncle $12-19 \mathrm{~cm}$ long, ca. $3 \mathrm{~mm}$ wide, winged, 0.5 to 5 times longer than petioles; spathe green suffused with purple-red at margin, lanceolate-linear, 3-4.5 $\mathrm{cm}$ long, 6-8 $\mathrm{mm}$ wide, broadest at base, short-acuminate at apex (the acumen apiculate), inserted at ca. $30^{\circ}$ angle on peduncle; spadix sessile, green, 10-12 cm long, 3-5 mm diam. at base, $2-3 \mathrm{~mm}$ diam. at apex; flowers rhombic, 2.3-2.8 mm long (dry), 1.8-2.3 $\mathrm{mm}$ wide (dry), the sides \pm straight to weakly sigmoid; 4-5 flowers visible in the principal spiral, 3-5 flowers visible in the alternate spiral; tepals drying matte, the lateral tepals ca. $2 \mathrm{~mm}$ wide (dry), the inner margins broadly rounded; stamens emerging just above the tepals, the anthers ca. $0.4 \mathrm{~mm}$ long, $0.9 \mathrm{~mm}$ wide (dry); thecae strongly divaricate. INFRUCTESCENCE not seen. Fig. 5.

The species is known only from the Osa Peninsula in tropical wet forest at less than $100 \mathrm{~m}$ elevation.

Anthurium alatipedunculatum is most closely allied to A. acutangulum but differs in having a winged, angulate peduncle and a triangular petiole which is sharply sulcate adaxially. The species is a member of section Porphyrochitonium.

COSTa Rica. PUntarenas: Rincón de Osa, region SW of air strip, Utley \& Utley 1030 (F, holotype; MO, isotype).

Anthurium andicola Liebm., Vidensk. Meddel. Dansk Naturhist. Foren. Kjøbenhavn 1: 22. 1849. TYPE: Mexico. Veracruz: Santa María Alpatlahua (NE of Coscomatepec) on slopes of Volcán Orizaba, 2,500 m. Liebmann (K, hololectotype here designated).

Anthurium cucullatum C. Koch, Index Sem. Hort. Berol. App. 6. 1853. Anthurium andicola var. cu- cullatum (C. Koch) Engl., Monogr. Phan. 2: 169, N. 97. 1879. TYPE: Origin unknown (cultivated). Anthurium macdougallii Matuda, Anales Inst. Biol. Univ. Nac. México 25: 216, fig. 55, 1954. TYPE: Mexico. Oaxaca: Tenango, 1,300-1,700 m, MacDougall s.n. (MEXU, holotype).

Anthurium oaxacamonticolum Matuda, Anales Inst. Biol. Univ. Nac. México 27: 344. 1957. TyPE: Mexico. Oaxaca: vic. La Gloria, near the OaxacaChiapas border, MacDougall s.n. March 5, 1953 (MEXU, holotype).

Anthurium campii A. D. Hawkes (not published). TYPE: Mexico. Oaxaca: near Ayutla, Camp 2362 (NY). Anthurium chochotlensis Matuda, Cact. Suc. Mex. 20: 11. 1975. TYPE: Mexico. Oaxaca: Chochotla (probably Santa María Chilchotla at $18^{\circ} 14^{\prime} \mathrm{N}$; $\left.96^{\circ} 49^{\prime} \mathrm{W}\right)$, Huatla de Jiménez, Matuda 38620 (MEXU, holotype).

Epiphytic or on rocks, sometimes in soil on rocky cliffs; stems less than $20 \mathrm{~cm}$ long; leaf scars ca. $1.7 \mathrm{~cm}$ wide; roots thick, descending; cataphylls subcoriaceous, $2-4.5 \mathrm{~cm}$ long, tinged red at margins and apex, the apex round, minutely apiculate, drying medium brown (B \& K Yellow $5 / 5$ ), weathering to fibrous network at base. LEAVES with petioles erect to spreading, 18-47 cm long, 4-8 mm diam., sharply sulcate, weakly glaucous; geniculum $1.5-2 \mathrm{~cm}$ long, faintly tinged red; blades broadly ovate-deltoid, thick, narrowly acuminate at apex (rarely rounded), usually prominently lobed at base (rarely merely obtuse), 20-37.5 cm long, 13-27 cm wide, broadest at point of petiole attachment; anterior lobe 19-29 $\mathrm{cm}$ long, the margins broadly rounded; posterior lobes 7.5-13 cm long; sinus arcuate with decurrent petiole to parabolic to sometimes hippocrepiform; both surfaces matte to semiglossy, the lower surface weakly glaucous; midrib convexly raised above, diminished and flat at apex, more acutely raised below; basal veins 36 pairs, the first free to base, those remaining coalesced 1-3 cm, posterior rib naked, weakly curved, the outer margin scarcely turned up; primary lateral veins $3-5$ per side, departing midrib at $55^{\circ}$ angle, \pm straight to collective vein, sunken above, raised below, interprimary veins sunken above, raised below, tertiary vein prominulous above, obscure below (drying prominent on both surfaces); collective vein arising from the first basal vein or from one of the lowermost primary lateral veins, sunken above, raised below, 4-8 $\mathrm{mm}$ from margin, sometimes the second basal vein running almost to apex. INFLORESCENCE erect, shorter than or equal to leaves; peduncle $16-40 \mathrm{~cm}$ long, 4-6 $\mathrm{mm}$ diam., terete, sometimes with a single ridge tinged reddish; 
spathe thin, medium green (B \& K Yellow-green $5 / 5$ ), narrowly ovate to ovate-lanceolate, 5.5-7.5 $\mathrm{cm}$ long, $2-2.8 \mathrm{~cm}$ wide, narrowly acuminate at apex, rounded to subcordate at base, inserted at $45^{\circ}$ angle on peduncle; spadix green heavily tinged purple or dark purple (B \& K Blue-purple $2 / 10$ ), 4-10.5 cm long, 5-9 mm diam. at base, $2-5 \mathrm{~mm}$ diam. at apex; flowers square $3-3.6 \mathrm{~mm}$ in both directions, the sides straight parallel to spirals, weakly to jaggedly sigmoid perpendicular to spirals; 5-6 flowers visible in the principal spiral, 6-7 flowers visible in the alternate spiral; tepals matte, weakly punctate, very minutely papillate, the lateral tepals $2.1-2.2 \mathrm{~mm}$ wide, the inner margin broadly rounded; pistils weakly emergent, green to purplish (paler than tepals); stigma linear, ca. $7 \mathrm{~mm}$ long, with large, clear droplets ca. 1 month before stamens emerge; lateral stamens emerging from the base, followed by alternates in rapid progression, leading stamens preceding the next in the series by 2 or 3 spirals; anthers white to pale yellow, ca. $0.7 \mathrm{~mm}$ long, $0.8 \mathrm{~mm}$ wide, held over pistil then retracting and held at sides of pistil; thecae ellipsoid, somewhat divaricate; pollen yellow, fading to white. INFRUCTESCENCE pendent, spathe deciduous; berries orange, obovoid, rounded at apex, $1.5 \mathrm{~cm}$ long, $8 \mathrm{~mm}$ diam., $6 \mathrm{~mm}$ thick; mesocarp fleshy, orange; seeds 2 , greenish orange, flattened, ca. 9 $\mathrm{mm}$ long, $5 \mathrm{~mm}$ wide. Figs. 6, 7 and 10 .

Anthurium andicola is endemic to Mexico, at 1,000 to $2,500 \mathrm{~m}$ elevation, occurring in both the Sierra Madre Oriental where it ranges from central Veracruz to northern Oaxaca and in the Sierra Madre del Sur south of Oaxaca City. One collection by MacDougall supposedly from La Gloria on the Chiapas-Oaxaca border is worthy of mention regarding its range and elevation. The only La Gloria near the border of the states of Oaxaca and Chiapas is near the Pacific Coast at an elevation of near sea level. This locality is out of place for $A$. andicola both geographically (being ca. $270 \mathrm{~km}$ east of the nearest other collecting locality) and altitudinally (all other collections from above $1,000 \mathrm{~m}$ ). Yet the specimen differs little from collections made in the Sierra Madre del Sur (especially those from Pochutla). A collection from La Gloria (MacDougall s.n., March 5,1953 ) was designated the type of $A$. oaxacamonticolum. A MacDougall s.n. collection from La Gloria was studied that bears the date "Mar./ 53" (MEXU 110308) but it is uncertain whether this is the type because the type description describes a plant with larger leaves and inflorescences.

Anthurium andicola is recognized by its usually ovate, reniform or ovate-triangular leaves with prominently raised tertiary venation (especially on drying), and D-shaped or broadly sulcate petiole with sharp margins and green to dark violet-purple spadix. Both the petiole and the lower leaf blade surface are often covered with a thin waxy bloom. The species is among the most variable in Mexico and even within a single population variation in leaf shape can be great, varying from conspicuously lobed at the base to not at all lobed. Plants from central Veracruz in the type locality are uniformly ovate to broadly ovate with rounded lobes and an arcuate to parabolic or horse-shoe shaped sinus. Further south at the type locality of $A$. macdougallii the posterior lobes are often directed inward with the sinus almost reniform. The same variation occurs in the Sierra Madre del Sur but leaves there are often more diminutive with less pronounced posterior lobes and more frequently an arcuate sinus. Sometimes the anterior lobe is considerably reduced and almost rounded at the apex such as in the case of Reko 6064 from Pochutla (Oaxaca) and MacDougall s.n. from La Gloria (Chiapas), which is the type of $A$. oaxacamonticolum. It has been placed in section Belolonchium.

The species is not easily confused with any other although some specimens, especially those with poorly developed posterior lobes from the southern cordillera, are similar to those of $A$. chamulense.

One specimen collected at an unknown locality in the Sierra de Oaxaca (September, 1961) and assigned a Matuda collecting number (38275) is sterile but probably is also $A$. andicola. This collection bears the herbarium name $A$. glaucotitanioides Matuda. The blade is thinner than most and does not have the pronounced venation of typical $A$. andicola.

The herbarium name $A$. campii A. D. Hawkes based on Camp 2762 represents a form of $A$. andicola not much unlike the typical form from Veracruz, even though it was collected relatively near the type of $A$. macdougallii.

Matuda 38721, presumably collected near Mitla, SW of Oaxaca, has blades thinner and with less conspicuous venation than most $A$. andicola 


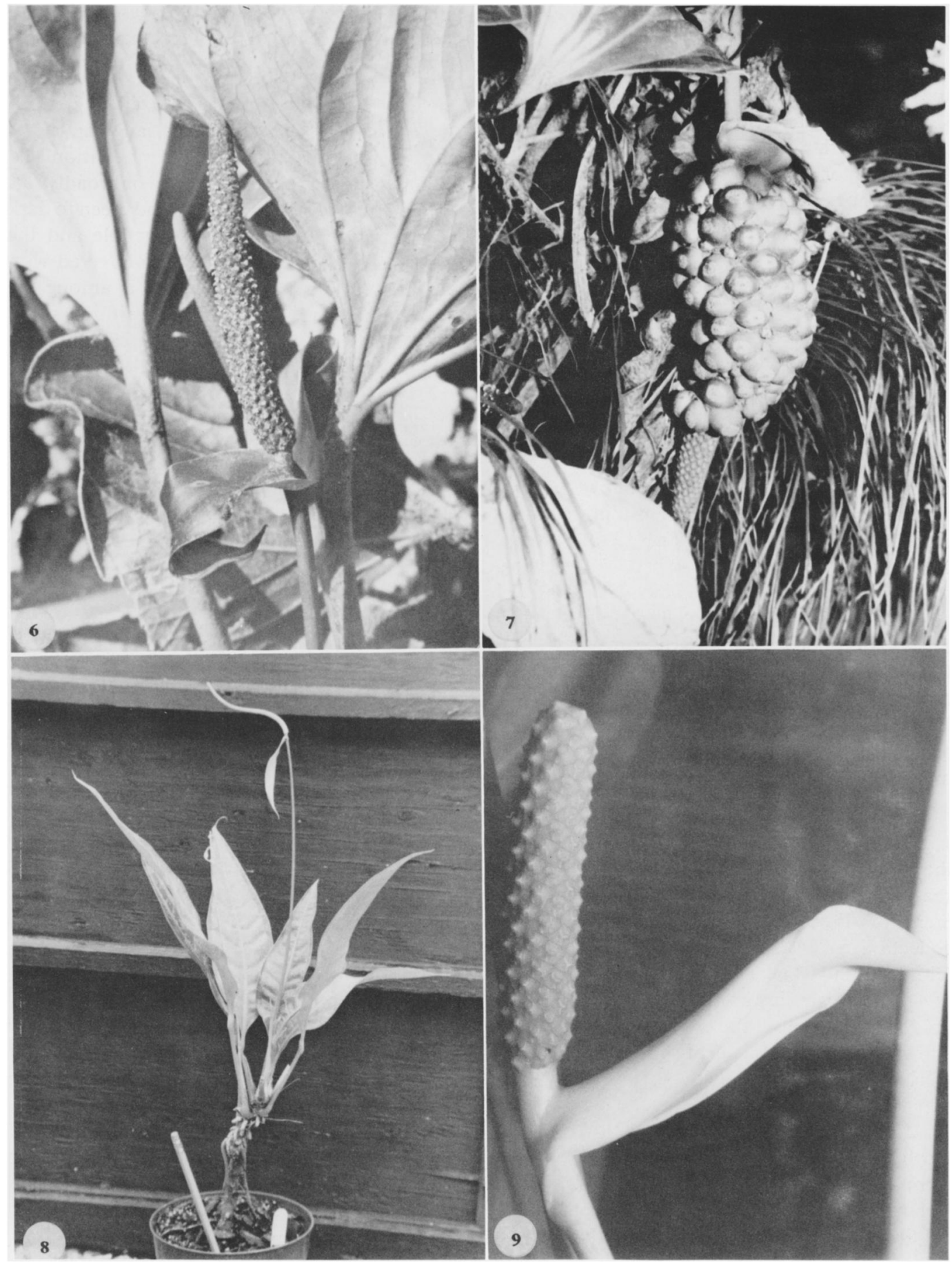

Figures 6-9. 6-7. Anthurium andicola Liebm., Croat 48215. -8. Anthurium angustispadix Croat \& Baker, Croat 26600 (Type). -9. Anthurium armeniense Croat, Croat 40905 (Type). 


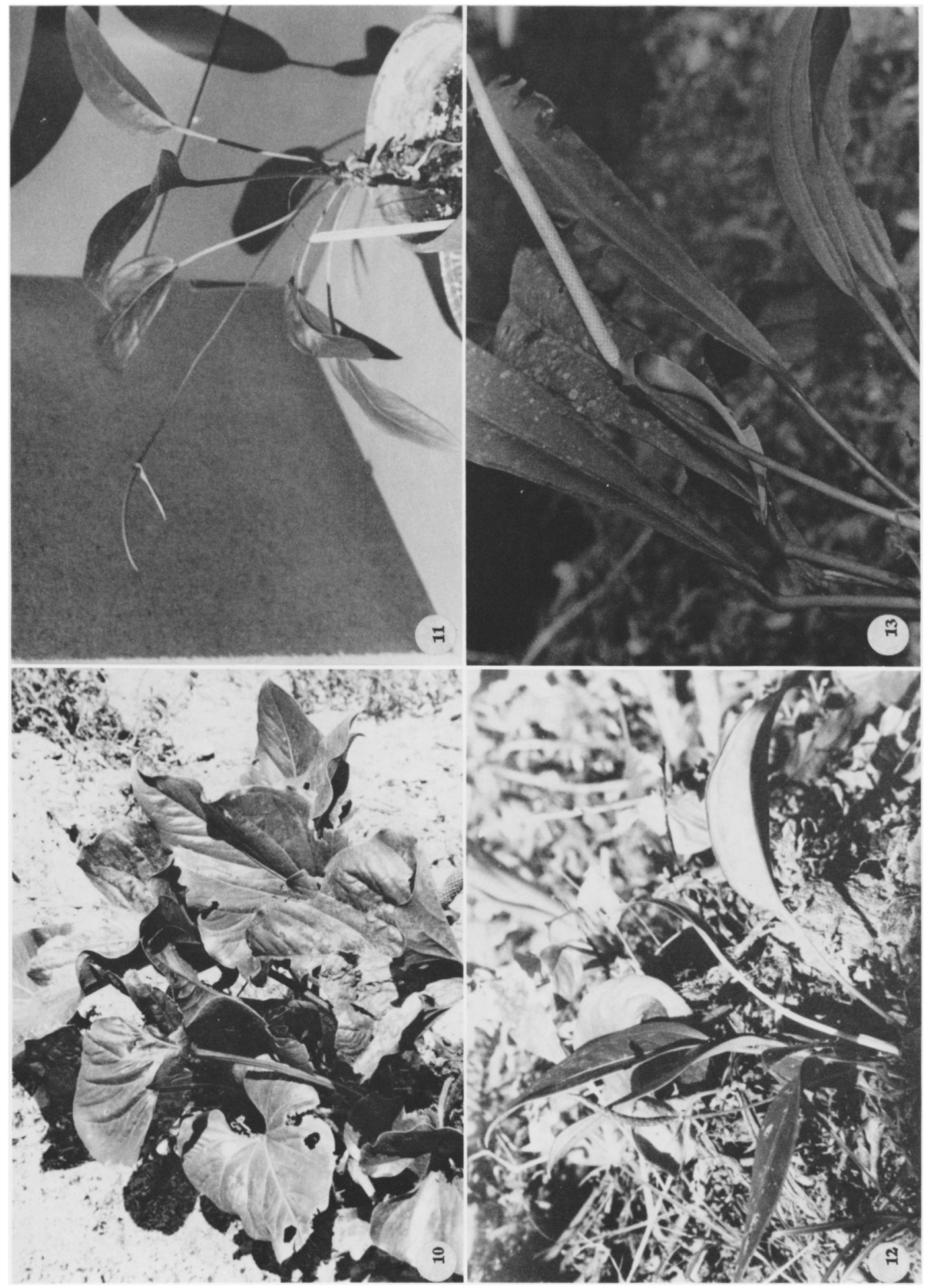


collections. The region was visited recently and turned up no obvious habitat for Anthurium so the live plants could not be investigated further. They are presumably only unusually thin-leaved collections of $A$. andicola, since that species occurs on both the Atlantic and Pacific slopes, but no other collections have been made in the vicinity of Mitla.

Mexico. No other location, Galeotti 6096 (BR); Liebmann 22348 (MO, Photo). MÉxICO: S of Toluca de Lerdo, Matuda 28025 (MEXU). OAXACA: no other location, Galeotti 6056 (P); Cañon of Río Tlahuitoltepec, near Ayutla, Camp 2762 (NY); Huatla de Jiménez, Croat 48215 (MO); Matuda 38620 (MEXU); ESE of Ixtlán de Juárez, Graham \& Frolich 1046 (MICH); La Gloria, MacDougall s.n. (MEXU); near Mitla, SW of Oaxaca, Matuda 20321, 38721 (MEXU); District Pochutla, Cerro del Machete, Reko $6064(\mathrm{GH})$; Lachivia, Matuda 38421 (MEXU); Sierra de Oaxaca, Matuda 38275 (MEXU); SW of Sola de Vega, Davidse 9665 (MO); S of Sola de Vega, Rzedowski 21300 (ENCB, US, MICH); Tenango, MacDougall 26027 (MEXU). VERACRUZ: Calcahualco, Hernandez \& Cedillo 1129 (MEXU, F); near Córdoba, Valdivia 2137 (MEXU); NE of Cosocomatepec, Croat 43933 (MO); SW of Huatusco, Rzedowski 19049 (ENCB, MICH); Ixhuapan, Cházaro 813 (MEXU); NW of Jalapa, Ventura 4665 (CAS, ENCB); Munc. Juchique de Ferrer, Hernandez 1585, 1596 (F); Orizaba, Botterie 85, $135(\mathrm{GH})$; $M a-$ tuda $1540(\mathrm{MICH})$.

Anthurium angustispadix Croat \& Baker, Brenesia 16 (Supl. 1): 23. 1979. TYPE: Costa Rica. Puntarenas: primary forest along Río Coto Brus in the vicinity of Alturas, $23 \mathrm{~km}$ $\mathrm{N}$ of La Unión (on Panamanian border), elev. ca. 1,500 m, Croat 26600 (MO2251852, holotype; CR, F, K, PMA, SEL, US, isotypes; Live at MO).

Epiphyte, sometimes secondarily terrestrial; stems $18-30 \mathrm{~cm}$ long, $1-1.5 \mathrm{~cm}$ diam., branching, creeping, elongate; internodes $0.8-2 \mathrm{~cm}$ long; roots numerous, dense, $3-4 \mathrm{~mm}$ thick, directed downward; cataphylls thin, 6-11 cm long, gradually long-acuminate at apex (the acumen 2-4 $\mathrm{cm}$ long and inrolled) drying tan, persisting, dilacerating. LEAVES spreading; petioles $5-22 \mathrm{~cm}$ long, 4-7.5 mm diam., narrowly, deeply, and acutely sulcate, rounded abaxially; geniculum 1.5-2 cm long; blades lanceolate to oblong-lanceolate, thin to medium thick, gradually longacuminate at apex (the acumen acute or very minutely inrolled), acute to attenuate at base, 13$30 \mathrm{~cm}$ long, 4-7.5 cm wide, broadest slightly below the middle; the upper surface glossy, dulling with age, lower surface glossy or semiglossy; midrib raised, triangular above, diminishing to- ward apex, convexly raised below; primary lateral veins $11-16$ per side, departing midrib at $55^{\circ}-65^{\circ}$ angle, sunken above, raised below, straight to arcuate-ascending, loop-connecting; collective vein arising from the base or the first or second pair of lateral veins, $3-4 \mathrm{~mm}$ from margin, sunken above, raised below. INFLORESCENCE erect-spreading; shorter to longer than leaves; peduncles $20-40 \mathrm{~cm}$ long, $1.5-3 \mathrm{~mm}$ diam., terete, equalling or longer than petioles; spathe medium green (B \& $\mathrm{K}$ Yellow-green 5/ 10), linear-lanceolate, $4.5-8.5 \mathrm{~cm}$ long, $4-9 \mathrm{~mm}$ wide, broadest near the base, long-acuminate at apex, acute at base inserted at a $50^{\circ}-70^{\circ}$ angle on peduncle; stipe $3 \mathrm{~mm}$ long in front, $1 \mathrm{~mm}$ long in back, 4-5 mm diam., or spadix sessile; spadix greenish-yellow at base, paler at apex (B \& $\mathrm{K}$ Yellow-green 8/5 to 6/7.5), 4.5-10 cm long, 3$6 \mathrm{~mm}$ diam. at base, $2-4 \mathrm{~mm}$ diam. at apex; flowers rhombic, $1.7-2.8 \mathrm{~mm}$ wide in both directions, the sides sigmoid; 5-6 flowers visible in the principal spiral, 5-10 flowers visible in the alternate spiral; tepals glossy to matte, papillate, green to greenish-yellow, brown in fruit, the lateral tepals $0.8-1 \mathrm{~mm}$ wide, the inner margin thin, turned up against pistil; pistils slightly emergent, green, at first covered by tepals and flat, rapidly emergent into a pointed mound; stigma $0.3-0.5$ $\mathrm{mm}$ long, ellipsoid, brushlike, white, exserted, small droplet persisting for 1-2 days before stamens emerge, dry and gray when stamens emerge, usually not emerging in the apical half to third of spadix; stamens emerging rapidly from the base in a regular sequence, laterals first followed by alternates, held at the side of pistil, sometimes contiguous; anthers pale yellow, $0.2-0.3 \mathrm{~mm}$ long, ca. $0.4 \mathrm{~mm}$ wide; thecae ellipsoid, prominently divaricate, opening bowl-shaped; pollen orangeyellow, fading creamy white; strong sweet aroma present when stigma droplets appear and continuing while pollen is fresh. INFRUCTESCENCE spreading-pendent; the spathe green, intact; spadix 5-9 cm long; berries obovoid to depressed-globose, almost flat at apex, pale yellow-green, to $5 \mathrm{~mm}$ long; mesocarp watery, clear, sweet; seeds 2, pale green, flattened, to $2.8 \mathrm{~mm}$ long and $2.5 \mathrm{~mm}$ wide, each enveloped in a clear, gelatinous substance to $4 \mathrm{~mm}$ long. Fig. 8 .

Anthurium angustispadix is known from eastern Costa Rica and western Panama at elevations from 100 to $1,500 \mathrm{~m}$ in premontane wet and tropical wet forest life zones.

The species is perhaps best placed in section 
Xialophyllium and is recognized by its slender elongate stems with weathered, tan to pale brown cataphylls; its lanceolate leaves with a narrowly cuneate or attenuate leaf base; and its greenishyellow, relatively long and slender, tapering spadix with pale yellow-green berries. It is not easily confused with any other species.

The species often branches from near the base in pots in the greenhouse. Plants sometimes set seed in the greenhouse without apparent manipulation.

Costa Rica. puntarenas: 10-15 km ENE of La Unión, Utley 4802 (DUKE); cloud forest above Wilson's Finca, $6 \mathrm{~km} \mathrm{~S}$ of San Vito de Java, Raven 20877 (F); Finca Alturas, NE of Sabilito, Croat 44381 (MO); along Río Coto Brus, $23 \mathrm{~km} \mathrm{~N}$ of La Unión, Croat 26600 (CR, F, K, MO, PMA, SEL, US), 26650, 26690 (MO); between Río Cotón and Río Negro (ca. $15 \mathrm{~km}$ from Sabalito) near Las Alturas lumber camp, Burger \& Matta 4553 (CR, F, NY); E of Las Cruces, 5-6 km $\mathrm{S}$ of San Vito on and around the property of Robert Wilson, Burger \& Matta 4437, 4455 (F); near Cañas Gordas, Pittier 11127 (US).

Anthurium armeniense Croat, sp. nov. TYPE: Guatemala. San Marcos: ca. 2 km from Finca Armenia above San Rafael, 1,100-1,250 m, Croat 40905 (MO-2599479, holotype; Live at MO).

Planta epiphytica; cataphyllum persistens intactum, brunneum; petiolus $19-28 \mathrm{~cm}$ longus; lamina ovata, $20-40 \mathrm{~cm}$ longa, $11.5-21 \mathrm{~cm}$ lata, basi cordata profunde; inflorescentia erecta aut effusa; spatha alba; spadix caesius aut roseus, $3-5.7 \mathrm{~cm}$ longus, fragrans; tepala marginibus elevatis; baccae aurantiacae.

Epiphyte; stems $1.5 \mathrm{~cm}$ diam.; leaf scars ca. $1.5 \mathrm{~cm}$ wide; roots $4-5 \mathrm{~mm}$ diam., descending; cataphylls subcoriaceous, $7 \mathrm{~cm}$ long, rounded to emarginate and cuspidate at apex, drying reddish-brown and persisting intact. LEAVES erectspreading; petiole 19-28 cm long, 4-6 mm diam., terete; geniculum $2-3 \mathrm{~cm}$ long; blades narrowly ovate, gradually acuminate and downturned at apex, deeply lobed at base, $20-40 \mathrm{~cm}$ long, $11.5-$ $21 \mathrm{~cm}$ wide, broadest at middle; anterior lobe 5$15 \mathrm{~cm}$ long, the margins broadly rounded; posterior lobes 5-12 cm long, directed downward to inward; sinus usually spathulate sometimes hippocrepiform, acute to rounded at apex; both surfaces semiglossy, the upper surface with \pm conspicuous, minute, linear, raphide cells; midrib obtusely raised above, weakly sunken at apex, raised on lower surface; basal veins 4-6 pairs, the second to third pairs coalesced ca. $1.5 \mathrm{~cm}$, the fourth to sixth coalesced ca. $2.8 \mathrm{~cm}$, raised above and below, diminishing and flat at collective vein; primary lateral veins $2-4$ per side, flat above, sunken below, departing midrib at $55^{\circ}-$ $60^{\circ}$ angle, curved to margin, loop-connected; collective vein arising from the first basal vein, 4$15 \mathrm{~mm}$ from margin. INFLORESCENCE erect or spreading; peduncle $11.5-23 \mathrm{~cm}$ long, $2-3 \mathrm{~mm}$ diam., terete, as long as or longer than petioles; spathe white, narrowly ovate-elliptic or lanceolate-oblong, 4.5-9(12) cm long, 1.9-3 cm wide, broadest near base, long acuminate, green at apex, obtuse to acute at base, decurrent ca. $2 \mathrm{~mm}$, inserted on peduncle at $70^{\circ}$ angle; the stipe $2 \mathrm{~cm}$ long in front, 3-5 $\mathrm{mm}$ long in back, usually curved; spadix pale lavender (B \& K Purple 6/ 5), fading to pink (B \& K Red-purple 6/2.5) at anthesis, 3-5.7 cm long, 7-9 $\mathrm{mm}$ diam. at base, 6-7 mm diam. at apex, the flowers rhombic to weakly 4-lobed, 2.1-2.9 mm long, 2.8-3.6 mm wide, the sides straight to weakly and irregularly sigmoid, ca. 6 flowers visible in the principal spiral, 9 flowers visible in the alternate spiral; the tepals matte; lateral tepals $1.6-1.9 \mathrm{~mm}$ wide, the inner margins straight to convex; pistils white, emergent ca. $0.5 \mathrm{~mm}$, the stigma broadly elliptic, whitish, brushlike with short papillae exserted above pistil; first lateral stamens emerging irregularly throughout, followed rapidly by second lateral stamens then alternates in rapid succession; anthers white, broadly ovate, $0.5-0.8 \mathrm{~mm}$ long, $0.8-1.4 \mathrm{~mm}$ wide; thecae broadly ovate, shallowly cupular; pollen white, abundant, strong sweet lilac scented. INFRUCTESCENCE pendent; spathe greenish-white, spadix $18 \mathrm{~cm}$ long, $3.5 \mathrm{~cm}$ diam., with berries exserted ca. $1 \mathrm{~mm}$ (early stages); berries obovoid, style dark, beaked at apex, pale orange (B \& K Yellow-red 8/7.5), $1.2-1.5 \mathrm{~cm}$ long, 6-8 $\mathrm{mm}$ wide; mesocarp orange, juicy, gelatinous with numerous silvery raphide cells; seeds (1)2, ovoid-ellipsoid, pale whitish-green,darkergreen atbase, reddish-brown at apex, weakly flattened, $4.5 \mathrm{~mm}$ long, 3-3.2 $\mathrm{mm}$ wide, 1.4-2.2 $\mathrm{mm}$ thick, surrounded by sticky, gelatinous, translucent substance, more prominent at lateral margins, extending beyond ends. Figs. 9 and 14.

The species is known only from the type locality from 1,100 to $1,600 \mathrm{~m}$ in moist to wet forests on steep slopes in southwestern Guatemala in the Department of San Marcos.

The species is a member of section Calomystrium and is recognized by its ovate-cordate, moderately coriaceous leaves with raphide cells 
evident on upper surface and by its thick, persistent cataphylls that dry reddish-brown, but especially by its pale lavender to pink fragrant spadix that has a distinctly bumpy surface owing to the slightly upturned edges of the tepals. The species also is characterized by its white spathe.

It is confused with $A$. huixtlense, which has similar leaves and cataphylls (both are in the section Calomystrium), but that species generally has a greenish spathe and a spadix that varies from white to lavender, and has tepals more nearly level with the surface of the spadix so that it does not have the bumpy appearance. In addition, $A$. huixtlense lacks the strong lilac scent of $A$. armeniense.

Guatemala. San marcos: Finca Armenia above San Rafael, Croat 40905, 40923 (MO).

Anthurium austinsmithii Croat \& Baker, Brenesia 16 (Supl. 1): 25. 1979. TyPE: Costa Rica. Alajuela: San Luis de Zarcero, elev. 1,450 m, Austin Smith 637 (NY, holotype; $\mathrm{F}$, isotype).

Epiphyte; roots numerous, slender, green drying grayish; stem moderately elongate, $\mathrm{ca} .1 \mathrm{~cm}$ diam., $16-20 \mathrm{~cm}$ long, scurfy; cataphylls $2-2.5 \mathrm{~cm}$ long, drying dark reddish-brown, persisting as linear fibers. LEAVES spreading; petioles subterete, narrowly sulcate, 4-22 cm long, 2-4 $\mathrm{mm}$ diam.; geniculum 7-20 mm long; blades subcoriaceous, oblong-lanceolate, $11-21 \mathrm{~cm}$ long, 3-6.5 cm wide, long-acuminate at apex (the acumen flat), obtuse to acute (rarely attenuate) at base, broadest at or below the middle, the margin revolute on drying; both surfaces semiglossy, lower surface dark glandular-punctate; midrib acutely raised above, diminished and sunken toward apex, convexly raised below; primary lateral veins $7-15$ per side, departing midrib at $45^{\circ}$ angle, \pm straight to the collective vein, slightly sunken above, prominulous below; interprimary veins sunken above, scarcely visible below; collective vein arising from the base, $4-8 \mathrm{~mm}$ from the margin, about equally as prominent as the primary lateral veins, sunken above, prominulous and darker below. INFLORESCENCE erect-spreading, equalling or exceeding the leaves; peduncle terete to sharply angulate, 2-3-ribbed, sometimes with only one rib, 21-25 cm long, 2-3 mm diam.; spathe pale green, lanceolate, $2.5-3 \mathrm{~cm}$ long, $4-8 \mathrm{~mm}$ wide, broadest just above the base, acuminate at apex, rounded at base, inserted at ca. $30^{\circ}$ angle on the peduncle; spadix sessile, pale greenish-yellow, 5-
$7.5 \mathrm{~cm}$ long, 3-4 mm diam. at base, $2-2.5 \mathrm{~mm}$ diam. at apex, green at anthesis, becoming violetpurple; flowers rhombic, 3.3-3.5 mm long, ca. 2 $\mathrm{mm}$ wide, the sides \pm straight; ca. 3 flowers visible in the principal spiral, ca. 5 flowers visible in the alternate spiral; tepals semiglossy, the lateral tepals $2-2.5 \mathrm{~mm}$ long, the inner margin broadly rounded to straight; pistil green soon turning purple, emergent to $0.5-0.6 \mathrm{~mm}$; stigma elliptic; stamens emerging from the base in a slow complete progression, the laterals preceding the alternates by no more than 2 spirals, held above tepals and against pistil then retracting to edge of tepals, scarcely visible after anthesis; anthers $0.3 \mathrm{~mm}$ long, $0.7 \mathrm{~mm}$ wide; thecae ovate-elliptic, divaricate. INFRUCTESCENCE often developing berries only in the basal half of the spadix, berries subglobose to depressed-globose, ca. 7 $\mathrm{mm}$ diam., white tinged with violet-purple at apex, with a circular depression around the style ca. $2 \mathrm{~mm}$ diam.; locules 2 , with 3 seeds per locule; seeds narrowly ovoid, $2.5-2.6 \mathrm{~mm}$ long, 1.3-1.5 $\mathrm{mm}$ wide, $1.1-1.3 \mathrm{~mm}$ thick, pale brown, weakly flattened to subterete in cross-section, smooth. Figs. 11 and 12.

Anthurium austinsmithii is known only from Costa Rica in lower montane rain, lower montane wet, lower montane moist, and premontane wet forest, primarily on the Atlantic slope at elevations of 1,200 to $1,560 \mathrm{~m}$.

The species is a member of section Porphyrochitonium and can be distinguished by its acuminate leaf blades, conspicuously punctate on the lower surface which dry a dirty gray, slender spadix with ca. 3 flowers visible in the principal spiral and by its whitish berries tinged with purple-violet bearing a circular depression at the apex.

Anthurium austinsmithii is similar to $A$. acutangulum, $A$. durandii, and the species allied to them. It is also similar to $A$. alatipedunculatum because of its angulate peduncle, but the latter species also has a triangular petiole and is known currently only from the Osa Peninsula at much lower elevations than $A$. austinsmithii.

Costa Rica. Alajuela: San Luis de Zarcero, Austin Smith 637 (F, NY); 1332 (NY); one mile S of La Balsa de San Ramón, Lent 3524 (F, MO); road from Zapote to Santa Elena, ca. $1 \mathrm{~km} \mathrm{~S}$ of Zapote, Utley 4663 (DUKE); along Hwy. 15 between Naranjo and Quesada in vicinity of Laguna, 3.2 miles $\mathrm{N}$ of Zapote, Croat 46915,46921 (MO). HEREDIA: 4 miles N of Vara Blanca, Croat 35570 (MO); $7.5 \mathrm{~km} \mathrm{~N}$ of Vara Blanca, Croat 36046 (MO). 
Anthurium bakeri Hook. f., Bot. Mag. pl. 6261. 1876. TYPE: Costa Rica. Bull s.n. (K).

Anthurium turrialbense Engl., Bot. Jahrb. Syst. 25: 406. 1898. TYPE: Costa Rica. Cartago: Turrialba, 500 m, Donnell Smith 4978 (B).

Epiphyte, stems less than $10 \mathrm{~cm}$ long, $1.5 \mathrm{~cm}$ diam.; roots moderately slender; leaf scars ca. $1.7 \mathrm{~cm}$ wide; cataphylls coriaceous, $3-6 \mathrm{~cm}$ long, acuminate at apex (the acumen apiculate to 2 $\mathrm{mm}$ ), drying brown, persisting as fibers. LEAVES erect to spreading; petioles (3) $11-17 \mathrm{~cm}$ long, to $5 \mathrm{~mm}$ diam., subterete to sharply sulcate; geniculum 1-1.5 cm long; blades narrowly ellipticlanceolate to narrowly oblanceolate, $19-55 \mathrm{~cm}$ long, $2.8-9 \mathrm{~cm}$ wide, broadest at middle, acuminate at apex, narrowly rounded at base; upper surface matte, lower surface paler and matte with reddish-brown glandular punctations; midrib convexly raised below; primary lateral veins nearly obscure, flat, departing midrib at $45^{\circ}$ angle, straight to collective vein; collective vein arising from base, sunken, significantly more prominent than the primary lateral veins, continuous to apex of leaf, 2-4 $\mathrm{mm}$ from margin. INFLORESCENCE erect-spreading, much shorter than leaves; peduncle $5.5-30 \mathrm{~cm}$ long, 3$5 \mathrm{~mm}$ diam., half as long or as long as petioles; spathe coriaceous, pale yellow-green (B \& K Yellow-green $9 / 10$ ), the edges sometimes tinged with purple, $2-5.5 \mathrm{~cm}$ long, 7-28 $\mathrm{mm}$ wide, oblonglanceolate, inserted at ca. $60^{\circ}$ angle on peduncle, obtuse at apex and base; stipe $3 \mathrm{~mm}$ long, $2 \mathrm{~mm}$ diam.; spadix creamy white (B \& K Yellow-red 9/5), 2-11 cm long, 5-15 mm diam. at base, 4.5$12 \mathrm{~mm}$ diam. at apex; flowers square to 4-lobed, 1.6-3.5 $\mathrm{mm}$ long, $1.7-3.2 \mathrm{~mm}$ wide, the sides jaggedly sigmoid, 7-8 flowers visible in the principal spiral, 5-6 flowers visible in the alternate spiral; tepals glossy, minutely papillate, lateral tepals $1.5 \mathrm{~mm}$ wide, the inner margin convex; pistils not emergent; stigma minute, slitlike, ca. $0.1 \mathrm{~mm}$ long, droplets apparent before stamens emerge; stamens emerging in an irregular pattern, usually lateral stamens first followed by alternates, anthers scarcely exposed, pushing pollen out around pistil, white, ca. $0.2 \mathrm{~mm}$ long, 0.3 $\mathrm{mm}$ wide; pollen white. INFRUCTESCENCE erect, spathe reflexed against peduncle; spadix $7.5-8.5 \mathrm{~cm}$ long, $1.2-1.4 \mathrm{~cm}$ diam.; berries red, pointed at apex, obovoid ca. $6 \mathrm{~mm}$ long; mesocarp juicy, pulpy, transparent with numerous oblong raphide cells; seeds 2 , ovoid, cream-colored, flattened, $3.2 \mathrm{~mm}$ long, $2 \mathrm{~mm}$ wide, 1.2 mm thick, enveloped by a gelatinous substance extending below the base. Figs. 13 and 15 .

The species is known from Guatemala to Colombia in wetter parts of tropical moist, premontane wet, and tropical wet forest at elevations from sea level to $660 \mathrm{~m}$. In Panama, the species ranges to $1,000 \mathrm{~m}$ elevation. In Colombia it is known from a single collection from Norte de Santander (Camp 84 on Pipeline, $600 \mathrm{~m}$ ), $M$. B. \& R. Foster 1716 (A).

Anthurium bakeri can be distinguished by its moderately thin, elliptic-lanceolate blades that are reddish-brown punctate on the lower surface and have many weak primary lateral veins and conspicuously sunken collective veins. The lower leaf surface usually dries much paler than upper surface, sometimes yellowish, contrasting sharply with the green upper surface. Other distinguishing features include the creamy white, almost cylindrical spadix and bright red berries. The species is a member of section Porphyrochitonium.

Belize. BELIZE DISTRICT: near Quamina Creek, Gentle 3426 (MICH). STANN CREEK DISTRICT: Middlesex, Gentle 2898 (MICH); Silk Grass Creek, Gentle 2626 (K, MICH, NY); South Stann Creek, Schipp S-16 (MICH); north of Victoria Peak, Gentry 8037 (MO). TOLEDO: Columbia Forest Station, Croat 24225 (MO); Proctor 36124 (MO); Maya Mountains, Boutin \& Schlosser 5013, 5114 (MO); San Jose, Croat 24453, 24359 (MO).

Costa Rica. alajuela: N of Ángeles Norte, Luteyn 3381 (DUKE); NNE of Bijagua, Croat 36283, 36326 , 36430 (MO); Utley \& Utley 5335 (DUKE); south of Canalete, Burger \& Baker 9977 (DUKE, MO); Hacienda Santa María, Liesner 5131 (MO); NW of New Volcan Arenal, Taylor 11588 (NY); NE of Quesada, Croat 46944 (MO). CARTAgo: Turrialba, Croat 994 (MO); LePoole s.n. (U); near Tuis, Luteyn 749 (DUKE). GuANACASTE: NW of Lake Arenal, Croat 259 (MO). HEREDIA: near Puerto Viejo, Croat 35692, 35753A (MO); Jiménez 105 (MO); Taylor 4549, 4572 (NY); Vara Blanca, Skutch 3651 (MICH). LIMÓN: Hacienda Tapezco-Hacienda La Suerte, Davidson \& Donahue 8254 (MO); Finca Castilla, Dodge \& Goerger 9272 (MO). Puntarenas: Osa Peninsula, Dodge \& Goerger 10021, 10022, 10150 (MO); Liesner 3097 (MO); Rincón de Osa, Utley \& Utley 1032 (DUKE). SAN JOSÉ: from San Isidro del General to Dominical, Burger \& Baker 10106 (MO)

Guatemala. alta verapaz: vicinity Cubilihuitz, Steyermark 44382 (NY); vicinity Laguna Sapalau, Steyermark 44917 (MO); Oxec Rd., Croat 41606, 41653 (MO). IZABAL: vicinity Exmibal, Jones \& Facey $3280 A$ (NY). PETÉN: NW of Chinajá, Steyermark 45481 $(\mathrm{MICH})$

Honduras. ATLÁNTIDA: La Ceiba, Yuncker et al. 8739 (MO, NY); Lancetilla, Chickering 16, 104, 163 (MICH); Lancetilla Valley, Croat 42638 (MO); Web- 

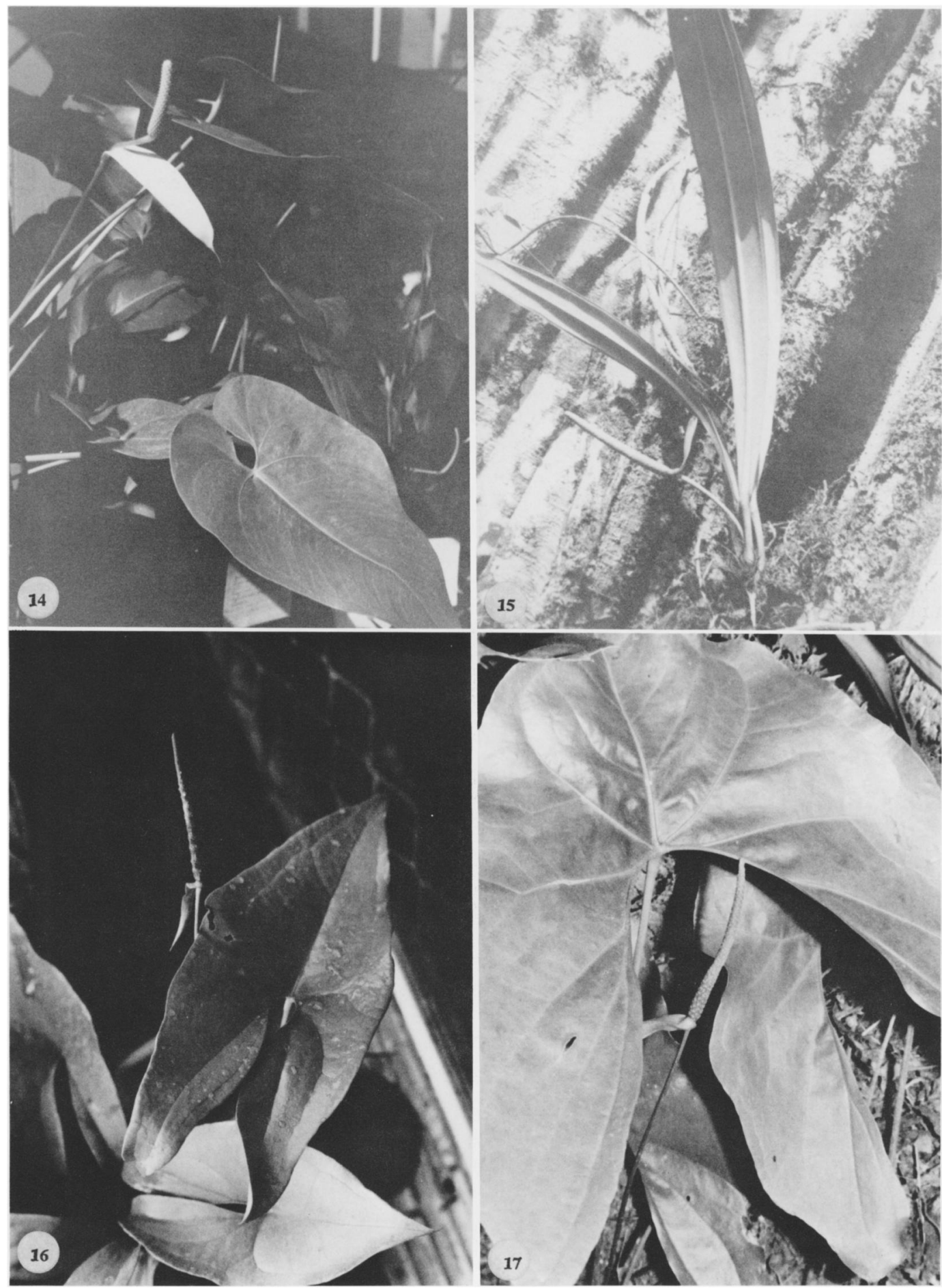

Figures 14-17. 14. Anthurium armeniense Croat, Croat 40923. - 15. Anthurium bakeri Hook. f., Croat 34344. - 16. Anthurium berriozabalense Matuda, Honolulu Botanic Garden 77-1275.-17. Anthurium berriozabalense Matuda, Croat 47715. 
ster et al. 12704 (DAV); Yuncker 4960 (MICH, MO). COMAYAGUA: NW of Siguatepeque, Molina 26062 (NY). GRACIAS A DIOS: vicinity Río Plátano, Clewell \& Cruz 4061 (MO). YORO: Coyolito, Carleton 552 (US); Yuncker et al. 8187 (NY, S).

MeXico. ChIAPAs: Mun. of Las Margaritas, Breedlove \& McClintock 34076 (CAS).

NiCARAGUA. CHONTALES: no other location, Levy 1420 (P); N of Cuapa, Neill 7471 (MO). MATAGAlPA: Cerro Musún, Neill 1808 (MO); E of Matagalpa, Neill 2353 (MO). RIVAs: Volcán Maderas, Neill \& Vincelli 3247 (MO); Stevens 6507 (MO). Zelaya: Caño Zamora, Stevens 8824, 8826 (MO); Cerro El Inocente, Neill 1906 (MO); Stevens 6714 (MO); Cerro Waylawás, Stevens 8756 (MO); SW of Colonia Naciones Unida, Stevens 5023 (MO); trail from Colonia San José, NNE to Parcela, Stevens 9008 (MO); Colonia Agricola Yolaina, Stevens 4827 (MO); Stevens et al. 6437 (MO); Río Rama, Proctor et al. 27414 (LL, NY); Stevens 8909 (MO); west of Río Ulí, Neill 1927 (MO); vicinity of Siuna, Neill 4499 (MO); Neill 4225 (MO); near Tala Has and Puente Mango, Stevens 7620 (MO).

Anthurium beltianum Standl. \& L. O. Wms., Ceiba 3: 103. 1952. TYPE: Nicaragua. Dept. of Jinotega: mountains east of Jinotega, along trail to Cerro la Cruz, elev. 1,050-1,350 m. Standley 10255 (F, holotype; EAP, isotype).

Terrestrial; stems thick, to $4 \mathrm{~cm}$ diam., leaf scars $4 \mathrm{~cm}$ wide; roots sparse, descending, tan; cataphylls coriaceous, 4-12 cm long, caudate and apiculate at apex, drying yellow (B \& K Yellow $5 / 10$ ), persisting as moderately coarse longitudinal fibers. LEAVES erect-spreading; petioles 13-73 cm long, 5-8 mm diam., subterete, shallowly and bluntly sulcate, sometimes merely flattened adaxially; geniculum $1.5-2.5 \mathrm{~cm}$ long; blades subcoriaceous, triangular-ovate to ovate, acuminate at apex, deeply lobed at base, 14-51 cm long, 8-36 cm wide, broadest at point of petiole attachment, the margin undulate; posterior lobes $5-18 \mathrm{~cm}$ long from sinus to tip, the sinus hippocrepiform to triangular, acute to round at apex; both surfaces matte to semiglossy, sometimes with punctiform or linear raphide cells (more conspicuous on dry specimens); midrib raised above and below; basal veins 5-6 pairs, the first and second free, the remaining coalesced $2.7-4 \mathrm{~cm}$, raised above and below; posterior rib turned up along the outer margin; primary lateral veins $4-8$ per side, departing midrib at $40^{\circ}-55^{\circ}$ angle, flat to weakly raised above, raised below; interprimary veins flat above, raised below; lesser veins scarcely visible; collective vein arising from the first basal vein or one of the primary lateral veins, $1-2.5 \mathrm{~cm}$ from margin, flat above, raised below. INFLORESCENCE erect-spread- ing; peduncle $20-67 \mathrm{~cm}$ long, 3-6 $\mathrm{mm}$ diam., slightly curved near base of spadix, shorter to longer than leaves; spathe green (B \& K Green $6 / 2.5$ ), subcoriaceous, narrowly ovate or boatshaped, 8-15 cm long, 2-5 cm wide, broadest just above middle, long-acuminate at apex, decurrent and clasping at base, inserted at $65^{\circ}-80^{\circ}$ angle on peduncle, held behind and hooding spadix; spadix pale green (B \& K Green 7/2.5), glaucous, $6.5-12 \mathrm{~cm}$ long, $5-8 \mathrm{~mm}$ diam. at base, 4-5 mm diam. at apex, slightly curved just below middle so that the tip turns down; flowers 4-lobed, 2-3 mm long, 2.5-3.5 $\mathrm{mm}$ wide, the sides jaggedly sigmoid; $4-5$ flowers visible in the principal spiral, 5-10 flowers visible in the alternate spiral; tepals matte, densely and minutely papillate, with droplets, lateral tepals $1.5 \mathrm{~mm}$ wide, the inner margin convex; pistils emergent, bright green; stigma slitlike with blunt papillae and a large droplet for 3 or 4 days before first stamens emerge; stamens emerging very slowly in a complete sequence from base, held in tight circle around pistil just above the tepals; anthers pale yellow, slanting over pistil before opening, ca. $0.6 \mathrm{~mm}$ long, $1.1 \mathrm{~mm}$ wide; thecae ellipsoid, somewhat divaricate; pollen pale yellow, fading white. INFRUCTESCENCE pendent, spathe persisting; berries obovoid-ellipsoid, yellow to yellow-orange, 13-15 mm long, 9-11 mm wide; pericarp thick, darker colored and lacking raphide cells near apex, numerous granular raphide cells in the lower half; mesocarp juicy, fragrant, sweet; seeds 1-2, semicircular to broadly ellipsoid, brown with numerous minute granular projections on surface, flattened, 8-9 mm long, 8$9 \mathrm{~mm}$ wide, $3 \mathrm{~mm}$ thick, encased in a thin envelope. Figs. 18 and 19.

Anthurium beltianum is endemic to central Nicaragua in the departments of Jinotega and Matagalpa at elevations of 1,000 to $1,500 \mathrm{~m}$ in premontane wet forest life zones, on limestone outcrops.

The species was named in honor of the famous English naturalist Thomas Belt, author of the "The Naturalist in Nicaragua." It is a member of section Calomystrium and is recognized by its moderately thick, ovate-cordate leaves with an obovate or hippocrepiform sinus, but especially by its semi-erect inflorescence with the moderately short, tapered, pale green spadix directed downward and by its lanceolate-elliptic to narrowly ovate spathe, which curves outward forming a protective covering above the spadix. 


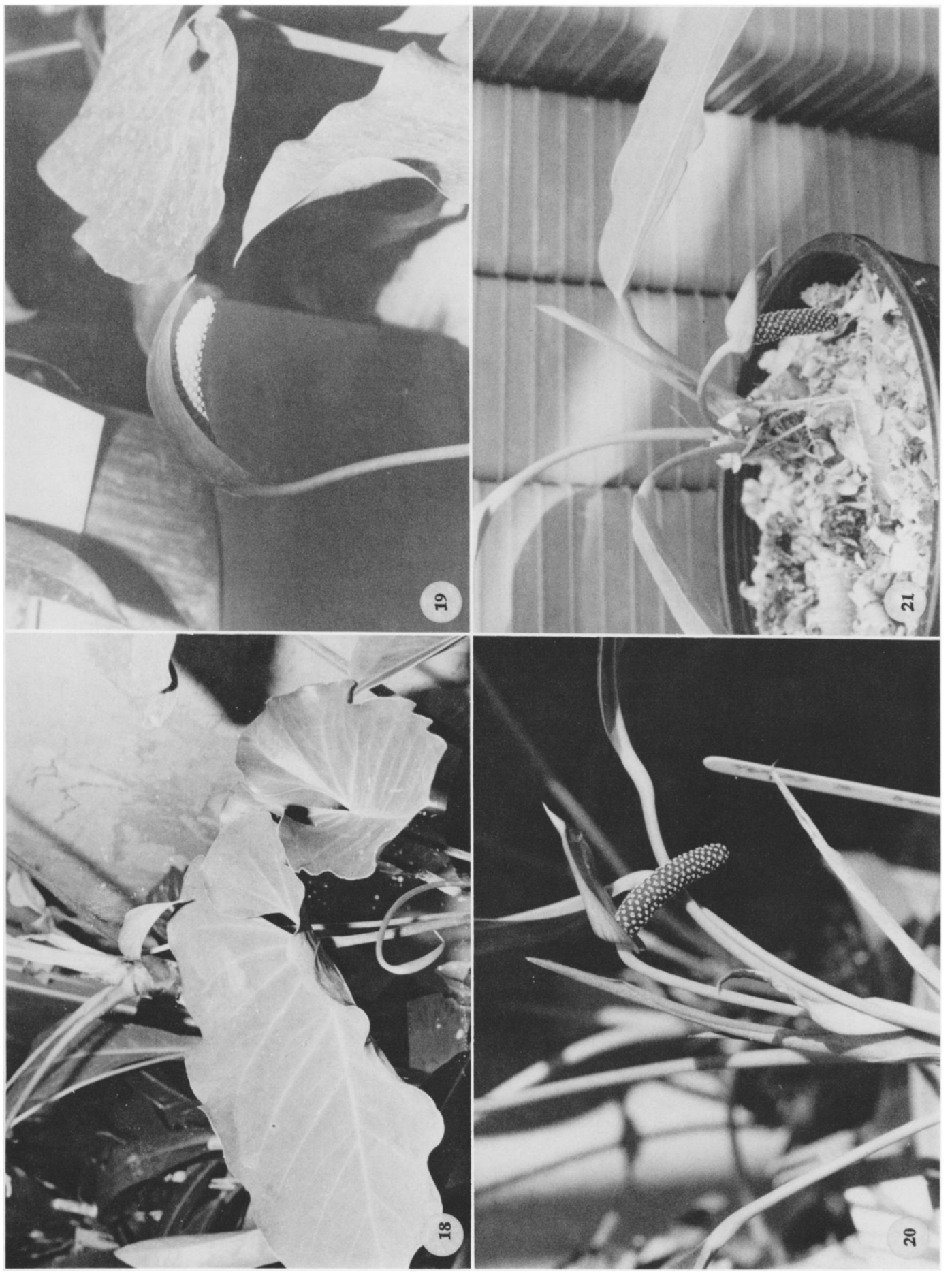

๙ิे 
Anthurium beltianum is similar to A. cotobrusii, which has generally similar leaves and inflorescences but does not have the hooded inflorescences of $A$. beltianum.

Nicaragua. Jinotega: vicinity of Jinotega, Croat 43003 (MO); Standley 10255, 10359, 10883 (F); Williams et al. 24733 (F); MATAGALPA: vicinity of Aranjuez, Neill 3020, 3452 (MO); Finca Santa María de Ostuma, Williams et al. 27887 (MO).

Anthurium berriozabalense Matuda, Anales Inst. Biol. Univ. Nac. México 25: 214. 1954. TYPE: Mexico. Chiapas: Las Vistas north of Berriozábal, $1,250 \mathrm{~m}$ elev., Miranda 6707 (MEXU, holotype).

Terrestrial on rocky, steep slopes to $0.6 \mathrm{~m}$ tall; stems $10 \mathrm{~cm}$ long, $1.5-3 \mathrm{~cm}$ diam.; leaf scars ca. $1.5 \mathrm{~cm}$ wide; roots ca. $5 \mathrm{~mm}$ thick, directed downward; cataphylls subcoriaceous, $3-5 \mathrm{~cm}$ long, acute at apex, the acumen minutely apiculate, drying light brown (B \& K Yellow 4/5), persisting intact at apex, splitting into linear fibers at base. LEAVES erect to spreading; petioles 13-56 cm long, 3-7 mm diam., subterete, weakly flattened adaxially; geniculum 1.5-2 cm long broadly and shallowly sulcate; blades triangular, acuminate at apex, broadly lobed at base, 12-33 cm long, 11-23 cm wide, broadest at base; anterior lobe 9-16 cm long; posterior lobes 12-18 $\mathrm{cm}$ long, directed outward; sinus triangular to parabolic to sometimes hippocrepiform; upper surface semiglossy to glossy, lower surface semiglossy, the midrib convexly raised above and below, diminishing at apex above; basal veins 4-5 pairs, the first and sometimes the second free, second to fourth coalesced ca. $1.5 \mathrm{~cm}$, third to fifth coalesced $2.3-4 \mathrm{~cm}$, raised in weak valleys above, raised below; posterior ribs curved, naked, the outer margin upturned; primary lateral veins $4-5$ per side, departing midrib at $45^{\circ}-50^{\circ}$ angle, raised or flat above, raised below; collective vein arising from uppermost basal vein (sometimes with lower basal veins loop-connecting to the collective vein), sunken above, raised below, 6-10 $\mathrm{mm}$ from margin. INFLORESCENCE spreading to erect, shorter than the leaves; peduncle 16-40 cm long, 2-4 $\mathrm{mm}$ diam., terete, sometimes tinged with violet-purple, longer than the petioles; spathe medium thick, green tinged with purple at margins, lanceolate to oblong-lanceolate, $4.5-9 \mathrm{~cm}$ long, $0.9-2.7 \mathrm{~cm}$ wide, broadest at base, acuminate at apex, clasping to truncate or rounded at base, inserted at $45^{\circ}-60^{\circ}$ angle on peduncle; spadix green (B \& K
Yellow-green 5/7.5), 5-10 cm long, 7-9 $\mathrm{mm}$ diam. at base, 2-3 $\mathrm{mm}$ diam. at apex; flowers square or rhombic, 3-5 $\mathrm{mm}$ long, 3-4 $\mathrm{mm}$ wide, the sides \pm straight to jaggedly sigmoid; 3-5 flowers visible in either spiral; tepals matte, green, inconspicuously punctate, minutely papillate, tinged with violet at margins, sparse droplets appearing when anthers are open, lateral tepals 1.5$2.5 \mathrm{~mm}$ wide, inner margins straight; pistil scarcely emergent, green, densely purple spotted; the stigma oblong, shallow, green, $0.8-1 \mathrm{~mm}$ long, opening with minutely exserted papillae, small droplets apparent for 7-10 days, dry and black for 2 or 3 days before first stamens emerge; stamens emerging \pm rapidly from the base, the second, third, and fourth stamens emerging soon after leading stamen; anthers brown, held on short filaments that quickly retract, anthers held at edge of pistil but not contiguous; thecae ellipsoid, divaricate; pollen yellow, fading to white. INFRUCTESCENCE pendent; spathe withered; spadix to $10 \mathrm{~cm}$ long, $20 \mathrm{~mm}$ diam.; berries orange (B \& K Yellow-red 7/5), broadly obovoid, round at apex with a conspicuous indentation, 8-11 mm long, 7-10 mm wide; pericarp transparent, somewhat thickened, lacking raphide cells; mesocarp fleshy, juicy, with numerous raphide cells; seeds 1 or 2 , flattened on one side if 2 , ellipsoid in cross-section if only one, pale green, 6-8 $\mathrm{mm}$ long, 4.5-5(9) $\mathrm{mm}$ wide, 3.23.5(6.5) $\mathrm{mm}$ thick. Figs. 16, 17, and 26.

Anthurium berriozabalense is restricted to Mexico and is known for certain only from northeastern Chiapas at 1,000 to $1,300 \mathrm{~m}$. A collection from eastern Oaxaca (MacDougall 311) from Río Grande (presumably near Matías Romero) is probably also this species. The forest type near El Bosque where I have collected the species is "bosque caducifolia" and the forest type where it has been collected north of Berriozabal is "selva baja caducifolia."

The species is tentatively placed in section $B e$ lolonchium and is recognized by its semiglossy sagittate leaf blades with long, slender, posterior lobes that are usually as long or longer than the anterior lobes, and also by its green spathe and spadix and subglobose orange berries.

Anthurium berriozabalense is perhaps related to $A$. seleri, a more wide ranging species whose range overlaps that of $A$. berriozabalense. Forms of $A$. seleri with long, slender posterior lobes have been confused with $A$. berriozabalense but they can be distinguished from $A$. berriozabalense by 


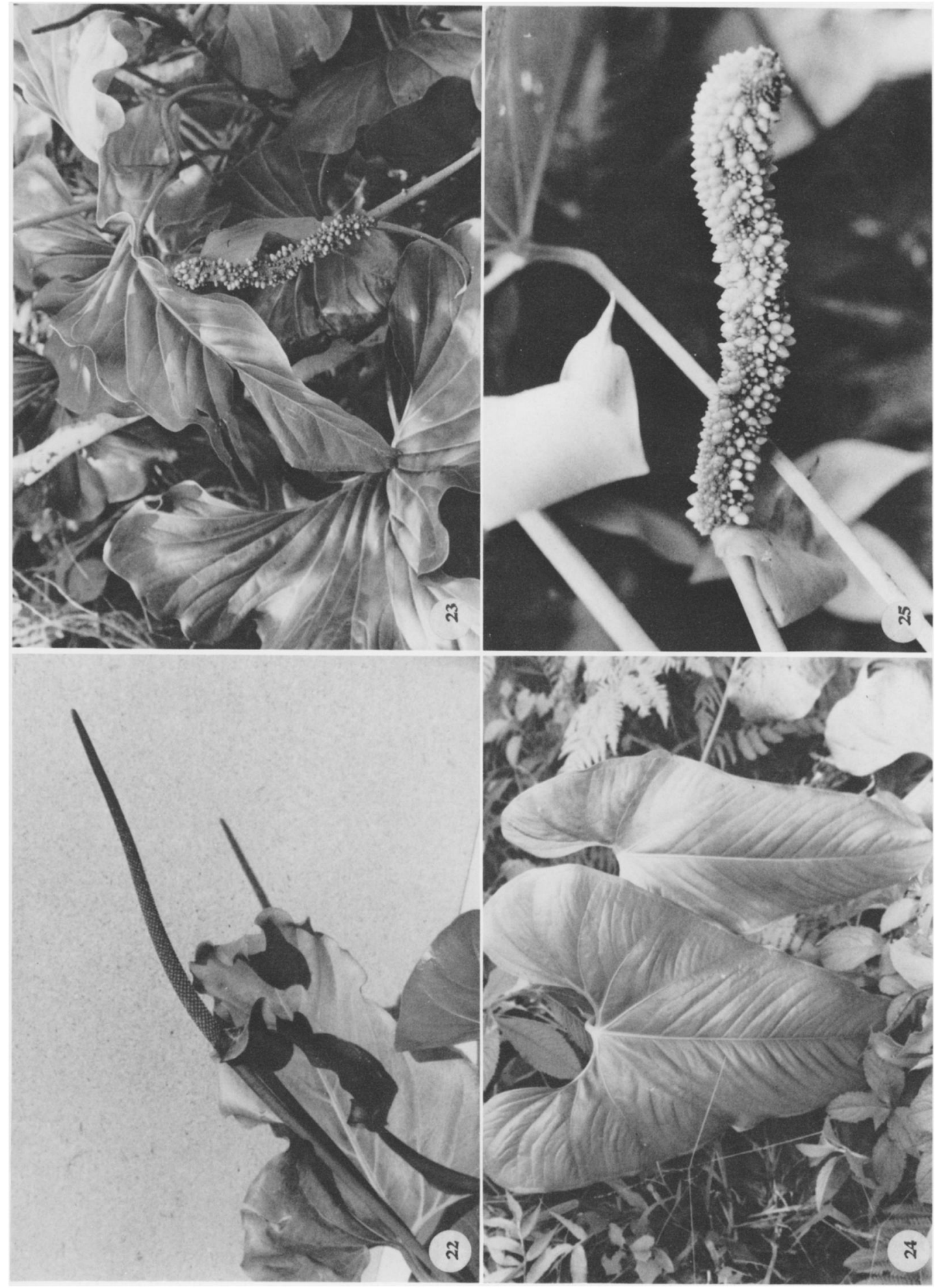

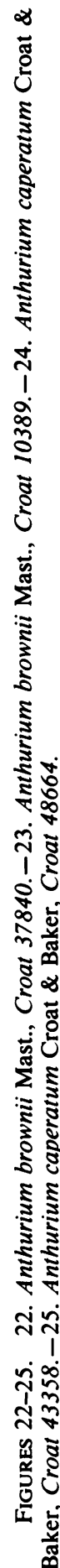




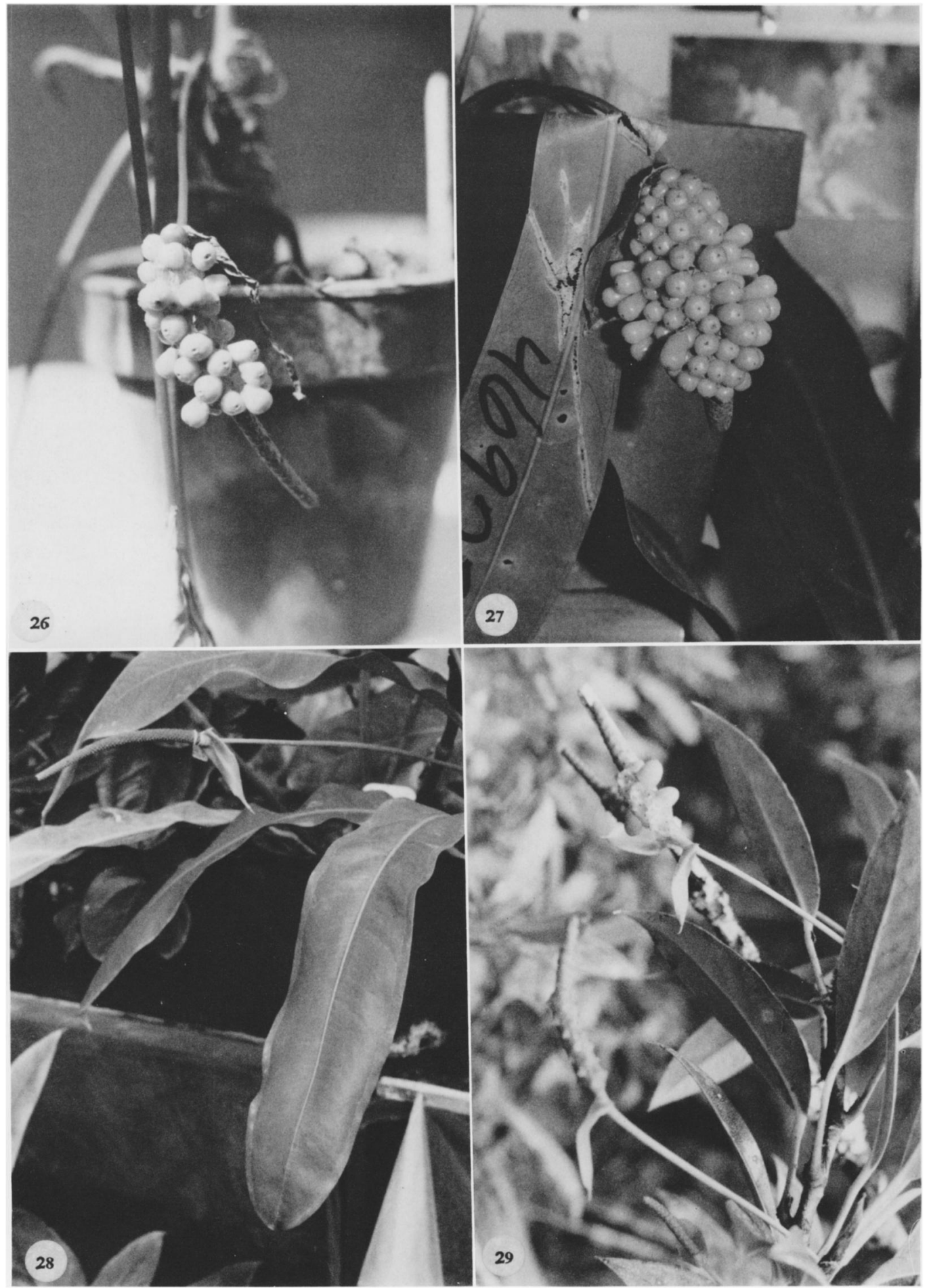

FIGURES 26-29. 26. Anthurium berriozabalense Matuda, Croat 47715.-27. Anthurium brenesii Croat \& Baker, Croat 46923 (Type). - 28. Anthurium burgeri Croat \& Baker, Burger \& Baker 10096 (Type). -29. Anthurium carnosum Croat \& Baker, Croat 48619. 
the much longer (or at least equally as long) anterior lobes and by the anterior lobe and posterior lobes forming a broad concave edge. In $A$. berriozabalense, the margin is either straight or convex and the posterior lobes are usually as long or longer than the anterior lobes. In addition, the leaves of $A$. berriozabalense are thin whereas the leaves of $A$. seleri are subcoriaceous. Still another difference is that the collective vein of $A$. berriozabalense usually arises from the uppermost basal veins or has the lower basal veins conspicuously loop-connected with the collective vein. In $A$. seleri the collective vein arises from one of the lowermost basal veins and extends rather uniformly along the margin of both the posterior lobes and the anterior lobe to the apex.

In the type description Matuda discussed the similarity of $A$. berriozabalense to A. umbrosum but these two species are not at all similar except that both have orange berries.

MeXico. ChIAPAS: vicinity Berriozábal, MacDougall 445 (MEXU); Miranda 6707 (MEXU); vicinity Simojovel de Allende, Croat 47715 (B, CAS, F, K, M, MEXU, MO, NY, RSA, SEL, US, VEN). OAXACA: Río Grande, MacDougall 311 (MEXU).

Anthurium brenesii Croat \& Baker, Brenesia 16 (Supl. 1): 28. 1979. TYPE: Costa Rica. Alajuela: along Hwy. 15 between Naranjo and Quesada, 3.2 miles $\mathrm{N}$ of Zapote, 1,560 m, Croat 46923 (MO-2682420, holotype; COL, CR, DUKE, F, GH, K, NY, PMA, RSA, SEL, US, VEN, isotypes; Live at MO).

Epiphyte; stems short, $1.5-2.5 \mathrm{~cm}$ diam.; roots moderately few, to ca. $5 \mathrm{~mm}$ diam.; cataphylls moderately thick, $10-25 \mathrm{~cm}$ long, acuminate at apex, tinged red at margins, weathering into fibers, drying light brown. LEAVES pendent; petioles 14-45 cm long, ca. $6 \mathrm{~mm}$ diam., terete; geniculum to $1.5 \mathrm{~cm}$ long; blades oblong, moderately coriaceous, abruptly to gradually shortacuminate at apex, acute to weakly attenuate at base, 32-68 cm long, $6-10.3 \mathrm{~cm}$ wide, broadest near the middle, the midrib raised above and below; the primary lateral veins $13-15$ per side, departing midrib at $55^{\circ}$ angle, sunken above, prominulous below; collective vein arising from the base, $2-5 \mathrm{~mm}$ from the margin, sunken above, raised below. INFLORESCENCE erect or pendent, shorter than the leaves; peduncle (10)28$43 \mathrm{~cm}$ long, 4-5 $\mathrm{mm}$ diam., terete, shorter or longer than petioles; spathe moderately thick, medium green sometimes tinged reddish at an- thesis, ovate to ovate-elliptic, $5.5-8.5 \mathrm{~cm}$ long, $3.5-5.5 \mathrm{~cm}$ wide, broadest from $1 \mathrm{~cm}$ above the base to about the middle, acute to rounded and apiculate at apex, cordate and somewhat clasping at base, inserted at $25^{\circ}-40^{\circ}$ angle on peduncle, \pm erect and held close to spadix or at ca. $45^{\circ}$ angle to peduncle; spadix sessile or subsessile, green, reddish-brown to red-violet, $7-8 \mathrm{~cm}$ long, to $8 \mathrm{~mm}$ diam., at base, to $6 \mathrm{~mm}$ diam. at apex; flowers square to weakly 4-lobed, $1.7-2.5 \mathrm{~mm}$ long in both directions; $6-10$ flowers visible in the principal spiral, 6-9 flowers visible in the alternate spiral; the lateral tepals to $1.2 \mathrm{~mm}$ wide, the inner margin concave, pistil green scarcely emergent, the stigma oblong, $0.5-0.6 \mathrm{~mm}$ long; stamens emerging rapidly throughout, lateral stamens first, quickly followed by alternate stamens, exserted on short, translucent filaments, retracting to hold anthers just above the margins of the tepals; anthers orange, ca. $0.6 \mathrm{~mm}$ long, $0.8 \mathrm{~mm}$ wide; thecae ovate-ellipsoid, slightly divaricate; pollen orange, faintly spicy scented at anthesis. INFRUCTESCENCE spreading to pendent, the spathe usually withered, the spadix to $9 \mathrm{~cm}$ long, $2 \mathrm{~cm}$ diam.; berries exserted ca. 1 $\mathrm{mm}$, before maturity, obovoid, flattened, orange (B \& K Yellow-red 7/5), 9-11 mm long, 5-7.5 mm diam., rounded at apex; mesocarp juicy with sparse, thick raphide cells; seeds 2 (rarely 1 ), tan, 3-4.5 mm long, $2.2-3 \mathrm{~mm}$ wide, $1.8-2.2 \mathrm{~mm}$ thick, enveloped in almost translucent (tinged orange) casing, ca. $10 \mathrm{~mm}$ long and as wide as the seed. Figs. 20, 21, and 27.

Anthurium brenesii is presently known only from the Cordillera Central in the Province of Alajuela between San Ramón and Quesada at 1,000 to $1,560 \mathrm{~m}$ elevation.

The species is related to $A$. protensum with which it shares similar leaf texture and cataphylls, and similar altitudinal range. It differs from that species, however, by its abruptly acuminate leaf blades, its short, broad spathe, which is subcordate at the base, and its shorter, broader spadix. It is also similar, especially vegetatively, to $A$. prolatum, but differs in having much shorter, broader leaves. It is placed in section Pachyneurium.

Costa Rica. alajuela: La Palma de San Ramón, Brenes 5738 (F); Cordillera Central ca. $15 \mathrm{~km} \mathrm{~N}$ of Zarcero, Williams et al. 29034 (F); along Hwy. 15 between Naranjo and Quesada, 3.2 miles $N$ of Zapote, Croat 46923 (COL, CR, DUKE, F, GH, MO, NY, PMA, RSA, SEL, US, VEN). 
Anthurium brownii Mast., Gard. Chron. 6: 744, Figs. 139, 140. 1876. TYPE: Colombia (Nueva Granada). Wallis s.n. (K, exact status unknown).

Epiphyte; stems short, $2.5-3 \mathrm{~cm}$ diam.; roots few, thick, puberulent to densely velutinous; cataphylls coriaceous, 9-15 cm long, caudateacuminate at apex, drying reddish-brown (B \& $\mathrm{K}$ Yellow 4/2.5), persisting \pm intact, ultimately weathering to a network of fibers at base. LEAVES erect to spreading; petioles $13-100 \mathrm{~cm}$ long, 3$10 \mathrm{~mm}$ diam., subterete, shallowly and bluntly sulcate; geniculum $2-2.5 \mathrm{~cm}$ long, sometimes tinged red-violet (B \& K Red-purple 4/10); blades narrowly ovate-triangular, moderately thick, $15-$ $66 \mathrm{~cm}$ long, 11-48 $\mathrm{cm}$ wide, broadest at base, gradually acuminate at apex (the acumen flat, apiculate), prominently lobed at base; anterior lobe $11-40 \mathrm{~cm}$ long, the margins straight to convex; posterior lobes $4-13 \mathrm{~cm}$ long, directed sharply upward; the upper surface matte to semiglossy, lower surface paler; midrib convexly raised above, sometimes tinged reddish, sunken at apex, acutely raised below; basal veins 5-6 pairs, the first to fourth coalesced $2-6 \mathrm{~cm}$, the posterior rib naked, upturned along outer margin; primary lateral veins $4-8$ per side, departing midrib at $25^{\circ}-$ $35^{\circ}$ angle, raised in valleys at base above, sunken at apex, raised below; lesser veins visible but less prominent; collective vein arising from first basal vein or lowest primary lateral vein, $2-7 \mathrm{~mm}$ from margin. INFLORESCENCE erect, longer than leaves; peduncle 51-65.6 cm long, 4-6 mm diam., terete, green mottled with red-violet, longer than petioles; spathe lanceolate, green (B \& K Yellowgreen 6/10), 8-23 cm long, $1.5-4.5 \mathrm{~cm}$ wide, acuminate at apex, round to cordate at base; spadix stipitate to ca. $11 \mathrm{~cm}$, violet-purple, $7-28 \mathrm{~cm}$ long, 4-15 mm diam.; flowers rhombic, 2.5-3.2 $\mathrm{mm}$ long, 2-3 $\mathrm{mm}$ wide, the sides straight to sigmoid; 7-10 flowers visible in the principal spiral, 5-12 flowers visible in the alternate spiral; tepals matte, punctate, minutely papillate, sometimes with droplets, lateral tepals $1.8-2 \mathrm{~mm}$ wide, the inner margin broadly rounded; pistils emergent; stigmas linear, ca. $0.5 \mathrm{~mm}$ long, large droplet apparent ca. 1 week before first stamens appear, turning glossy then gray and drying when anthers open; stamens emerging rapidly in a \pm systematic progression from base, lateral stamens emerging in basal one third before alternates emerge, held in circle around pistil; anthers yellow or tinged purple, thecae moderately di- varicate, pollen purple fading to white sometimes yellow, with a pungent fruity aroma at anthesis. INFRUCTESCENCE pendent-spreading, $38 \mathrm{~cm}$ long, $3 \mathrm{~cm}$ diam.; berries ellipsoid to obovoid, 5-8 $\mathrm{mm}$ long, ca. $5 \mathrm{~mm}$ wide, orange to red-orange (B \& $\mathrm{K}$ Yellow-red 7/2.5); pericarp thick; mesocarp juicy; seeds 2, oblong, greenishwhite, flattened with transparent sticky appendages at both ends, elongated at apex, rounded at base. Figs. 22 and 23.

The species is known from Costa Rica to Colombia at elevations from near sea level to 1,200 $\mathrm{m}$. In Costa Rica the species occurs in premontane wet and tropical wet forest. In Panama it also occurs rarely in premontane moist and tropical moist forest.

The species was confused with $A$. denudatum Engl. from Colombia by Standley (1944) in the Flora of Panama, but that species has a peduncle much shorter than the petioles, as well as a shorter spadix.

Anthurium brownii is a member of section $\mathrm{Be}$ lolonchium and is distinguished by its thick blades with usually undulate margins and reticulate veins that dry very prominent. The leaf tends to dry silver or grayish on both surfaces. Also distinctive are the long, slender, violet-purple spadix and the red-orange berries.

Costa Rica. Alajuela: NNE of Bijagua, Burger \& Baker 9855 (F, MO). HEREDIA: vicinity Río La Paz Grande, Croat 35859 (MO). PUNTARENAS: near Rincón de Osa, Koch 5065 (MO). SAN JOSÉ: SW of San Isidro del General, Utley \& Utley 4926 (DUKE).

Anthurium burgeri Croat \& Baker, Brenesia 16 (Supl. 1): 30. 1979. TyPE: Costa Rica. San José: ridges and steep slopes above Alfombra along road from San Isidro del General to Dominical (on Pacific coast) $\left(9^{\circ} 18^{\prime} \mathrm{N}\right.$, $\left.83^{\circ} 46^{\prime} \mathrm{W}\right)$, ca. $1,000 \mathrm{~m}, 19$ November 1975 , Burger \& Baker 10096 (F 1769194, holotype; CR, K, MO, US, isotypes; Live at MO).

Epiphyte or terrestrial on steep banks; stem short or long, 1-1.3 cm diam.; roots few, directed downward; cataphylls moderately thin, 6-14 cm long, blunt to acuminate at apex, drying brown (B \& K Red-yellow 4/10), remaining intact, subsequently deciduous. LEAVES usually held \pm erect to spreading; petioles $15-20 \mathrm{~cm}$ long, 4-6 $\mathrm{mm}$ diam. midway, terete; geniculum (0.5)1.5$2 \mathrm{~cm}$ long, weakly flattened adaxially; blades oblong-oblanceolate, moderately thick (drying 
somewhat reddish-brown or gray with purplish splotches), gradually acuminate at apex, narrowly cuneate at base, $36-48 \mathrm{~cm}$ long, $6.8-8 \mathrm{~cm}$ wide, broadest at or just above the middle; upper surface glossy to semiglossy or matte, lower surface semiglossy; midrib prominently raised above and below, broad at the base, becoming acute and narrow, then diminished and sunken at apex above, obtusely angled, sometimes tinged reddish near the base below; primary lateral veins 10-20 per side, departing midrib at ca. $60^{\circ}$ angle, \pm straight to the collective vein, flat and somewhat obscure above, raised below; collective vein arising from near the base, more conspicuous than the primary lateral veins, 2-9 $\mathrm{mm}$ from margin, weakly sunken above, prominulous below. INFLORESCENCE spreading, as long as or longer than the leaves; peduncle $40-53 \mathrm{~cm}$ long, to $4 \mathrm{~mm}$ diam., terete, longer than petioles; spathe moderately thin, light green sometimes tinged purple at margins (B \& K Yellow-green 7/10) oblong-lanceolate to lanceolate, $6.5-9 \mathrm{~cm}$ long, $1.3-2.3 \mathrm{~cm}$ diam., broadest near the base, acuminate-cuspidate at apex, rounded to weakly cordate and slightly clasping at base, the margins sometimes joining petiole at slightly different levels; spadix sessile, greenish-brown to purplish-brown (B \& K Yellow 6/7.5), 9-12.2 cm long, $5-7 \mathrm{~mm}$ diam. at base, to $3 \mathrm{~mm}$ diam. at apex; flowers rhombic to weakly 4-lobed, 2-3 $\mathrm{mm}$ wide in both directions, the sides straight to weakly sigmoid; 5-9 flowers visible in either spiral; tepals weakly glossy to matte, pale yellowgreen with purplish inner edges, pale punctate, with a few scattered droplets, lateral tepals 1-1.3 $\mathrm{mm}$ wide, the inner margin broadly convex to almost straight; pistils weakly emergent, greenish; stigma ellipsoid-circular, ca. $5 \mathrm{~mm}$ long, brushlike and exserted, dark violet-purple, with a conspicuous droplet appearing briefly, well before first anthers emerge, dry and dark when anthers emerge; stamens emerging promptly from near the middle of the spadix or from the base, held ca. $1 \mathrm{~mm}$ above the tepals at anthesis, the filament ca. 3 times longer than the anthers, soon retracting the anther to the level of the tepals; anthers yellow-brown, 0.4-0.5 mm long, 0.7-0.8 $\mathrm{mm}$ wide, not contiguous; thecae weakly divaricate, oblong-elliptic; pollen orange (B \& $\mathrm{K}$ Yellow 8/2.5), drying tan to whitish, quickly disappearing. INFRUCTESCENCE pendentspreading; spadix ca. $12 \mathrm{~cm}$ long, ca. $1.9 \mathrm{~cm}$ diam., bearing berries in the basal half only; berries narrowly ovate, 6-6.7 $\mathrm{mm}$ long, 3-3.4 $\mathrm{mm}$ wide, acute to narrowly rounded at apex, red-orange (B \& K Yellow-red 5/2.5); pericarp red-orange; mesocarp gelatinous, pale orange, with numerous raphide cells; seeds 1 or 2, elliptic, pale yellow, sometimes weakly flattened, $3.2-3.5 \mathrm{~mm}$ long, 2-2.1 mm wide, $1.2-2 \mathrm{~mm}$ thick, surrounded by a sticky amber envelope. Fig. 28 .

The species is known only from the type locality in Costa Rica in premontane rain forest.

Anthurium burgeri can be distinguished by its oblong-oblanceolate leaf blades with obscure primary lateral veins, and more or less straight, weakly depressed collective veins arising from near the base. The midrib on the lower surface is sometimes tinged reddish and the cataphylls turn brown and remain intact. The inflorescence is equal to or longer than the leaves and the spadix is greenish to purplish-brown with dark violet-purple stigmas. It does not seem to be closely related to any other species in Central America. The sectional placement of $A$. burgeri is as yet uncertain but is probably best placed in section Xialophyllium despite the fact that it may sometimes have short stems.

COSTA RICA. SAN JOSÉ: above Alfombra along road from San Isidro del General to Dominical, Burger \& Baker 10096 (CR, F, K, MO, US).

Anthurium caperatum Croat \& Baker, Brenesia 16 (Supl. 1): 32. 1979. TYPE: Costa Rica. Heredia: vicinity of Bajo la Hondura, along road between Paracito and the Río Claro, 1,100-1,400 m elev.; Croat 44518 (MO2598657-58, holotype; CR, F, US, isotypes; Live at MO).

Epiphytic near the ground or terrestrial; roots (1)3-5 mm diam., directed outward and downward; stem $60-120 \mathrm{~cm}$ long, $2.5-5 \mathrm{~cm}$ diam.; leaf scars $2.5-4.5 \mathrm{~cm}$ wide, cataphylls coriaceous, green tinged with purple, $14-40 \mathrm{~cm}$ long, narrowly rounded at apex with a subapical apiculum ca. $3 \mathrm{~mm}$ long, drying pale brown, weathering into fine fibers. LEAVES erect-spreading; petioles 24-109 cm long, 6-15 mm diam., subterete, shallowly and bluntly sulcate; geniculum 1.5-5 $\mathrm{cm}$ long; blades ovate to narrowly ovate, subcoriaceous, usually weakly bullate, abruptly to gradually acuminate at apex, prominently lobed at base, $46-120 \mathrm{~cm}$ long, 30-69 $\mathrm{cm}$ wide, broadest at point of petiole attachment; anterior lobe 26-90 cm long, the margins \pm straight; posterior lobes $12-30 \mathrm{~cm}$ long, flat or directed inward, 
often overlapping, the sinus spathulate, obovate or hippocrepiform, broadly acute to obtuse or rounded at apex; upper surface semiglossy or almost matte; lower surface matte; midrib sharply raised in a weak valley above, diminished and sunken near apex, convexly raised below, sometimes weakly ribbed or striate; basal veins 4-9 pairs, (second) fourth to seventh coalesced (2)4.5$9 \mathrm{~cm}$, raised above and below, the posterior rib stout, curved or nearly straight, naked, rolled up along the outer margin; primary lateral veins 918 per side, departing midrib at $55^{\circ}$ angle, \pm straight to slightly ascending to a weak collective vein, sharply raised in weak valleys above, raised below; collective vein usually arising from fourth or fifth basal vein, sunken above and raised below, 1-4(10) $\mathrm{mm}$ from the margin, loop-connecting the basal and primary lateral veins. INFLORESCENCE erect, much shorter than the leaves; peduncle 6-54 cm long, 8-13 $\mathrm{mm}$ diam., subterete or terete, as long as petioles; spathe thin, pale green (B \& K Yellow-green 7/10), lanceolate-oblong, $10-28 \mathrm{~cm}$ long, $3.3-4.8 \mathrm{~cm}$ wide, broadest in lower third, sometimes erect, usually spreading to reflexed, often twisted and rolled up, inserted at $10^{\circ}-30^{\circ}$ angle on peduncle; spadix sessile, pale green (B \& K Green 8/2.5), (3)7$18(28) \mathrm{cm}$ long, $10-20 \mathrm{~mm}$ diam. at base, 6-12 $\mathrm{mm}$ diam. at apex; flowers 4-lobed, to $1.8 \mathrm{~mm}$ long, to $1.5 \mathrm{~mm}$ wide, the sides jaggedly sigmoid; 12-15 flowers visible in the principal spiral, 1719 flowers visible in the alternate spiral; tepals semiglossy, the lateral tepals to $1 \mathrm{~mm}$ wide, the inner margin \pm straight; pistils slightly emergent, very glossy, whitish green with darker green stigmatic area; the stigma elliptic, $0.2 \mathrm{~mm}$ long, glossy, exserted with glistening papillae; stamens emerging scattered throughout the spadix, sometimes with the alternate stamens preceding the lateral ones; filaments ca. $1 \mathrm{~mm}$ long, anthers pale yellow, ca. $4 \mathrm{~mm}$ long and 5-6 mm wide; thecae oblong; pollen yellow, fading white. INFRUCTESCENCE usually pendent, spathe often absent; spadix $15-40 \mathrm{~cm}$ long, to $2.5 \mathrm{~cm}$ diam.; berries ovate to ovate-elliptic, acute to rounded and green at apex, greenish-white to yellowishgreen at base (white fide label of Allen 2419) to $9 \mathrm{~mm}$ long, ca. $5 \mathrm{~mm}$ wide; seeds 2 , oblong and \pm flattened, dark brown, 3.5-5 mm long, 2.2$2.4 \mathrm{~mm}$ wide, $1.5-1.8 \mathrm{~mm}$ thick. Figs. 24 and 25 .

The species is known from Costa Rica and Panama and is to be expected in Colombia on the southwestern slopes of the Serranía de Pirre. It occurs on both the Atlantic and Pacific slopes. In Costa Rica, it ranges between 850 and 2,000 $\mathrm{m}$ but in Panama it has been collected as low as $400 \mathrm{~m}$. The species inhabits premontane wet forest, premontane rain forest and lower montane rain forest.

Anthurium caperatum is recognized by its large, ovate leaves that have most of the veins of the upper surface sunken, giving the leaf a slightly bullate appearance, and a collective vein which arises from one of the lower pairs of basal veins. Other characteristic features include the green, brittle spathe, the pale green spadix, prominently exserted stamens, exserted pistils, greenish berries, and the dominance of pale green and yellowish pigments on all parts of the dried plant.

The species is similar to Anthurium panamense Croat (ined.), but that species has more elongate blades which are glossier on the upper surface, less protruded styles, weakly ribbed petioles, and red berries. The sectional placement of $A$. caperatum is as yet uncertain. It appears to be related to South American species in the A. corrugatum Sodiro complex. These were placed in section Polyneurium by Engler.

Costa Rica. Border of Puntarenas \& Alajuela: around Monteverde Nature Reserve, Burger \& Baker 9676 (F); Dryer 423 (CR, F); Utley \& Utley 2419 (F). alajuela: Catarata de San Ramón, Brenes 13510 (F); stream near road from Cariblanco to Lake Hule about $2 \mathrm{~km}$ W of Hwy. 9, Baker et al. 226 (F); woods along Río Aquilar on road to Lake Hule, Lent 3255 (F); above Zapote, $A$. Smith 928 (F). CARTAGO: Cerro Carpintera, Standley 35575, 35663 (US); near Copey, Cordillera de Talamanca, Williams 16417 (EAP, F); near Moravia along road to Turrialba, Burger \& Ramirez 4015 (CR, F); Pacuare, Turrialba, Ocampo 1431, 1433 (CR); below Palo Verde, Luteyn 3330 (DUKE); near Río Tapemechin, Lent $3734(\mathrm{~F})$; lower slopes of Alto Patillos, SE of Tapantí, Lent 1082 (CR, F); forest above Río Grande de Orosi, S of Tapantí, Lent 941 (F); Hwy. 32 to Limón, NE of Turrialba, Croat 43358 (MO); S of Tapantí on E slope above the Río Grande de Orosi, Burger \& Stolze 5659 (CR, F); Burger \& Liesner 6855 (F); Burger \& Burger 7584 (MO), 7585 (F, NY); Burger \& Gentry 9203 (F); Tapantí Hydroelectric Reserve, Croat 36069, 36211, 36216 (MO); road from Moravia to Quebrada Platanillo, Croat 36616, 36679 (MO); Tapantí Watershed Preserve, SW of Paraíso, Croat 47041 (MO). HEREDIA: 3 miles S of Cariblanco, Croat 35832, 35835 (MO); above San Miguel, valley of Río Sarapiquí, Moore $6580(\mathrm{BH})$; E slopes of Volcán Barba between Río Las Vueltas and Río Nuevo, Burger \& Baker 9475 (F, MO); vicinity Río El Angel between Vara Blanca and Cariblanco, Moore $6613(\mathrm{BH})$; near Río Las Vueltas, NE of Volcán Barba, Lent 2637 (CR, F); vicinity of Bajo La Hondura, Croat 44518 (CR, F, 
MO, US). HEREDIA \& SAN JOSÉ: Cerro de Zurquí, Burger \& Baker 9323 (F). SAN JOSÉ: Valley of Río La Hondura, below La Palma, NE of San Jerónimo, Burger \& Stolze 4921 (CR, F); Bajo La Hondura, Utley \& Utley 4994 (DUKE); forest above Río La Hondura, Lent 3784 (F); between San Isidro del General and Dominical, Croat 35243, 35322 (MO).

Anthurium carnosum Croat \& Baker, Brenesia 16 (Supl. 1): 36. 1979. TYPE: Costa Rica. San José and Cartago Provinces: along InterAmerican Highway near Trinidad and $\mathrm{Km}$ 72 (about $20 \mathrm{~km} \mathrm{SE}$ of El Empalme), cut over area, 2,600-2,800 m elevation; Burger \& Baker 9545 (F-1831851, holotype; MO2385461 , isotype).

Epiphytic vine, rarely terrestrial; stems slender, canelike, erect or trailing, to $1 \mathrm{~m}$ or more long, 5-7 mm diam., with thin, grayish, smooth periderm; internodes $2-9 \mathrm{~cm}$ long, shorter near apex; roots slender, elongate, frequently branching; cataphylls moderately thick, $2-6.5 \mathrm{~cm}$ long, with a subapical apiculum 2-3 mm long, encircling stem, persistent at upper nodes, drying thin, dark brown, deciduous except for a few pale, threadlike fibers. LEAVES with petioles $3-12 \mathrm{~cm}$ long, 2-3 mm diam., weakly sulcate; geniculum 1-2 cm long; blades coriaceous, succulent, lanceolate-elliptic, narrowly elliptic or sometimes oblanceolate-elliptic, gradually long-acuminate at apex, acute to attenuate at base, (7)9-15(17) $\mathrm{cm}$ long, (1.7)2.5-5(7) $\mathrm{cm}$ wide, broadest at or about the middle; both surfaces semiglossy, the lower surface slightly paler; midrib convexly raised above, diminished and sunken before the distal two thirds, raised throughout its length below; primary lateral veins 9-13(20) per side, departing midrib at $25^{\circ}-50^{\circ}$ angle, weakly sunken above, prominulous below, lesser veins inconspicuous above, prominulous below; collective vein arising from near the base, 2-7(12) mm from the margin, obscure to weakly sunken above, slightly raised below. INFLORESCENCE spreading, \pm equalling leaves; peduncle $7-13 \mathrm{~cm}$ long, ca. $2 \mathrm{~mm}$ diam., $2 / 3$ to 2 times longer than petioles; spathe thin, pale green, broadly lanceolate to oblong, $2.5-4.3 \mathrm{~cm}$ long, $8-14 \mathrm{~mm}$ wide, broadest in the lower third, acuminate at apex, obtuse to weakly lobed at base, inserted at ca. $45^{\circ}$ angle on peduncle; stipe $5-8 \mathrm{~mm}$ long in front, $2-5 \mathrm{~mm}$ long in back, ca. $2 \mathrm{~mm}$ diam., green; spadix green, becoming yellowish and finally orange in fruit, (2.5)3-5.5 cm long, $3-4 \mathrm{~mm}$ diam. at base, $1.5-3 \mathrm{~mm}$ diam. at apex; flowers rhombic to 4-lobed, to $4 \mathrm{~mm}$ long, to $1.5 \mathrm{~mm}$ wide, the sides sigmoid; 1-2 flowers visible in the principal spiral, ca. 2 flowers visible in the alternate spiral; tepals dark green, the lateral tepals (1.5)2.5-3.5 $\mathrm{mm}$ wide, the inner margin convex; pistil emergent, green; stigma ellipsoid, ca. $0.3 \mathrm{~mm}$ long; stamens held just above tepals, the anthers yellowish-white, $0.3-0.5 \mathrm{~mm}$ long, $0.7-0.8 \mathrm{~mm}$ wide; thecae broadly ovate to suborbicular, weakly divaricate; pollen yellowishwhite, drying white. INFRUCTESCENCE pendent, the spathe persisting; the spadix $6-10 \mathrm{~cm}$ long, $8-10 \mathrm{~mm}$ diam.; berries ovoid, acute at apex, yellow becoming bright orange, $9-11 \mathrm{~mm}$ long, 6-8 mm diam.; mesocarp thick, gelatinous, pale orange; seeds usually 2 , sometimes 3 or 4 , broadly ovate, rounded on both ends, flattened, ca. $3 \mathrm{~mm}$ long, $2 \mathrm{~mm}$ wide, $0.8 \mathrm{~mm}$ thick. Figs. 29 and 30.

Anthurium carnosum ranges from Costa Rica to Panama at elevations from (700)1,500 to $2,600(3,000) \mathrm{m}$. It inhabits premontane rain forest, lower montane wet forest, lower montane, and montane rain forest life zone formations. In Costa Rica it is known from the Cordillera Central, Volcán Turrialba, as well as on the western end of the Cordillera de Talamanca in the vicinity of Tapantí and Cerro de la Muerte, but it is to be expected throughout the Talamanca range to Panama. The species is common at 2,400 to 2,600 m elevation on Cerro de la Muerte and shares this habitat with only one other aroid, the cordate-leaved Anthurium concinnatum Schott. In Panama, the species has been found more widely, being known from a number of localities in Chiriquí Province.

Anthurium carnosum is recognized by its scandent habit, its thick, succulent leaves with strongly discolorous surfaces, and its usual montane habitat. It is closely related to $A$. flavescens Poepp. of Peru, but differs from that species in fewer lateral veins, a shorter peduncle, dark green tepals (white for $A$. flavescens), and a longer, thinner spadix. Among Central American species, $A$. carnosum is most closely related to $A$. pittieri Engler and A. interruptum Sodiro. Anthurium carnosum differs from $A$. pittieri by its longer internodes, viney habit, non-decurrent spathe, and its thick, succulent leaves. No intermediates have been found and they do not appear to be variants of one another. Anthurium carnosum differs from $A$. interruptum in its higher altitu- 


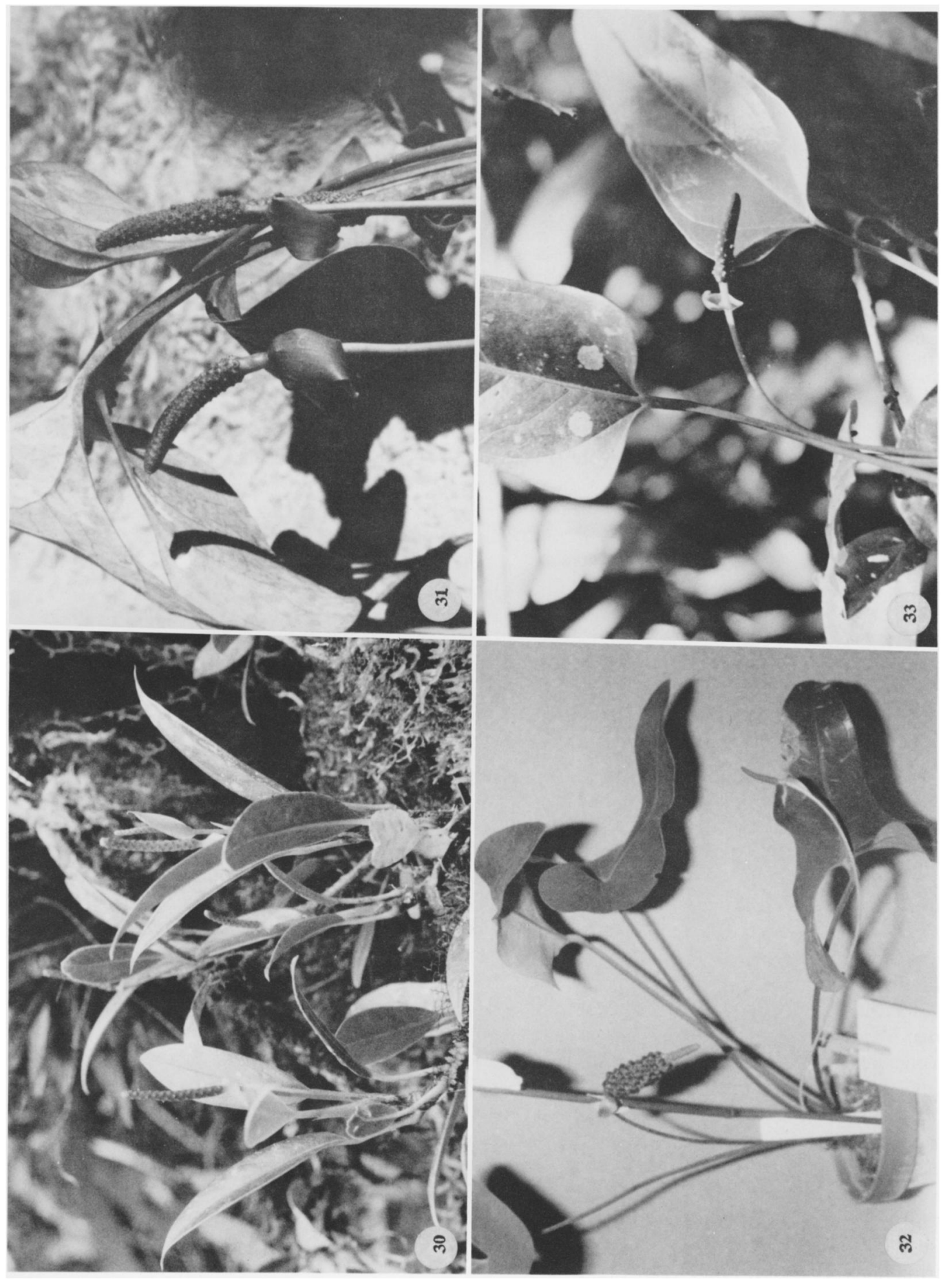

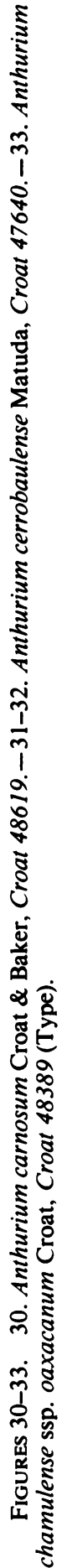


dinal range, short-stipitate spadix, orange (vs. red) berry color, shorter internode length, and thicker leaves. The sectional placement of $A$. carnosum is uncertain but it has been tentatively placed in section Xialophyllium.

Costa Rica. No other location, O. Jiménez 29 (US). Probably CARTAGO or SAN JOSÉ: El Páramo, Pittier 10534 (CR). CARTAGO: S of Cartago, Cordillera de Talamanca, Williams et al. 28115 (EAP, F); 28247 (F); slopes of Volcán Turrialba, Utley 151 (DUKE); Cerro del Roble (Copey), Tonduz 11829 (CR); Trinidad, SE of El Empalme, M. Jiménez 2199 (CR, F); NW slope of Cerro de la Muerta along Interamerican Hwy. Croat 35416 (MO); S of Tapantí above Río Grande de Orosi, Burger \& Liesner $6724 b(\mathrm{~F})$; SE of El Empalme on the Interamerican Hwy. Utley \& Utley 856, 1698 (CR, F). CARTAGO \& SAN JOSÉ: SE of El Empalme along the Interamerican Hwy. Burger 7978 (CR, F); near Trinidad, along the Interamerican Hwy. Burger \& Stolze 5227 (CR, F); Burger \& Baker 9545 (F, MO). SAN JOSÉ: N of Santa María de Dota, Standley 43087, 43096, 43100 (US); near Finca La Cima, N of Copey, Standley 42635, 42682, 42726, 42732, 42747 (US); Lake Chonta, NE of Santa María de Dota, Standley 42161, 42307, 42313, 42364 (US); near Lake La Escuadra, NE of Copey, Standley 41956, 41990, 42060, 42061 (US); near Río Parrita Chiquita, N of Santa María de Dota, Lent 3911 (CR, F).

Anthurium cerrobaulense Matuda, Anales Inst. Biol. Univ. Nac. México 30: 112-113. 1960. TYPE: Mexico. Oaxaca: Cerro Baúl (on the border of Oaxaca and Chiapas NW of Rizo de Oro located on Hwy. 190), November 15, 1957, MacDougall 276 (MEXU, holotype).

Epiphyte or on rocks, rarely terrestrial $17-40$ $\mathrm{m}$ tall; stems $2.5-4 \mathrm{~cm}$ diam.; leaf scars $1-2 \mathrm{~cm}$ wide; roots 4-5 $\mathrm{mm}$ diam., tan, descending; cataphylls $2-5 \mathrm{~cm}$ long, green tinged with red-violet, rounded at apex with a subapical apiculum extending beyond the apex ca. $3 \mathrm{~mm}$, drying medium brown and weathering into fibers. LEAVES erect-spreading; petiole 15-45 cm long, 3-6 mm diam., broadly and sharply sulcate adaxially, rounded abaxially (sometimes tinged with redviolet); geniculum $1-1.7 \mathrm{~cm}$ long; blades ovate to triangular (when flattened), often with midrib arching upward, thick, acute at apex, broadly lobed at base, (10)23-37 cm long, 13-18.5 cm wide, broadest at point of attachment or just below (often broader at base when flattened); anterior lobe 14-25.5 cm long, the margins convex at base becoming straight or markedly concave; posterior lobes 7-13 cm long, directed upward at almost $90^{\circ}$ angle or directed outward when flattened, the upper surface glossy, lower surface semiglossy; midrib convexly raised to midway, then sunken to apex, sharply raised nearly to apex below, then sunken; basal veins 3-5 pairs, the first free to base, the third to fifth coalesced 4-5 cm, raised and darker than surface above and below, the posterior rib naked, the outer margin rolled up; primary lateral veins $5-9$ per side, departing the midrib at $45^{\circ}$ angle, sunken above, prominulous and darker than surface below; interprimary veins sunken, lesser veins scarcely visible; collective vein arising from the first basal vein, sometimes loop-connected with the third or fourth basal vein, $0.5-1.5 \mathrm{~cm}$ from margin, sunken above, raised below. INFLORESCENCE erect-spreading; peduncle 22-40 $\mathrm{cm}$ long, 4-5 $\mathrm{mm}$ diam., terete, pale green; spathe relatively thin, green sometimes tinged with violet, lanceolate, $2.3-5 \mathrm{~cm}$ long, $1.2-1.7 \mathrm{~cm}$ wide, broadest just above the base, abruptly acuminate at apex, inserted at $45^{\circ}$ angle on peduncle; the stipe $6 \mathrm{~mm}$ long in front, $2 \mathrm{~mm}$ long in back, pale green sometimes tinged with red at base of spadix; spadix green, heavily tinged red-violet along inner edges of tepals, 4-4.4 cm long, 7-8 $\mathrm{mm}$ diam. at base, $4-5 \mathrm{~mm}$ diam. at apex; the flowers 4-lobed, ca. $3 \mathrm{~mm}$ long, $3.5 \mathrm{~mm}$ wide, the sides sigmoid; 5-8 flowers visible per principal spiral, 3-6 flowers visible in the alternate spiral; tepals matte, with copious droplets when stamens are emerging; lateral tepals $1.2-1.5 \mathrm{~mm}$ wide, the inner margin turned up; pistil slightly emergent, purple; stigma a shallow depression; stamens developing from the base, the laterals followed by the alternates in rapid succession, with the leading spirals preceding the alternates by 1 or 2 spirals; stamens held above pistil on transparent filaments $0.4-0.6 \mathrm{~mm}$ long, $0.6-0.9$ $\mathrm{mm}$ wide, then retracting to edge of tepals before next one appears; anthers pale yellow; thecae \pm oblong, somewhat divaricate; pollen cream, soon dispersing. INFRUCTESCENCE spreading-pendent; spathe persisting; spadix 9.5-12 cm long, $2.3 \mathrm{~cm}$ diam.; immature berries emergent ca. 4 $\mathrm{mm}$, dull violet-purple; mature berries red, to red-orange, obovoid, mammilliform at apex, 1.5$1.6 \mathrm{~cm}$ long, $1-1.7 \mathrm{~cm}$ wide, mesocarp thickly gelatinuous to mealy with numerous short raphide cells; seeds 1-2, obovoid, green to yellowgreen, 9-10 mm long, 7.6-8 $\mathrm{mm}$ wide, flattened, with a flattened truncate gelatinous appendage at the base. Figs. 31, 32, and 34 .

Anthurium cerrobaulense is restricted to Mexico in the SW corner of Chiapas in the Munici- 


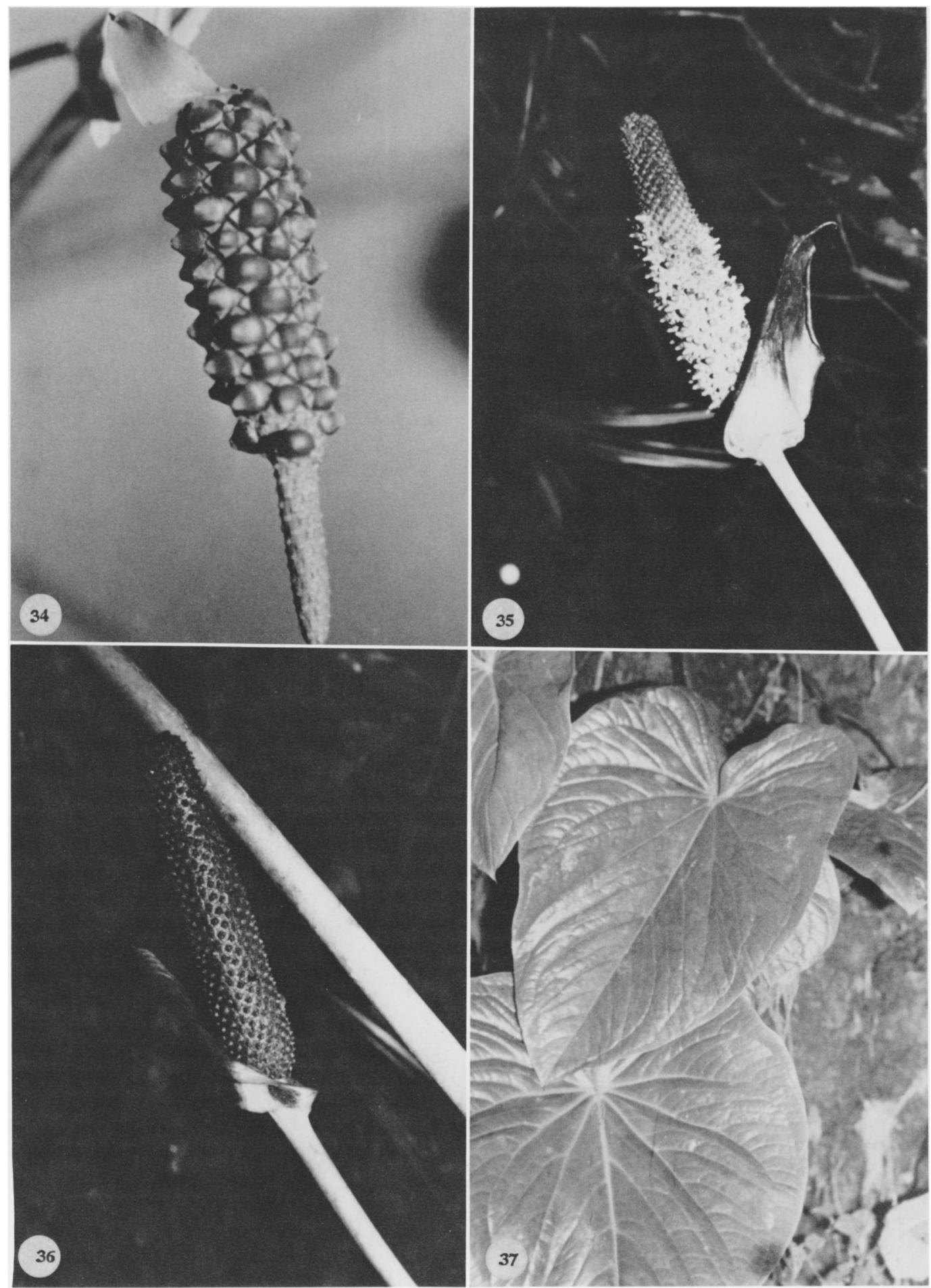

FIGURES 34-37. 34. Anthurium cerrobaulense Matuda, Croat 47640.-35-37. Anthurium cerropelonense Matuda, Croat 48180. 
pios of Cintalapa and Arriaga at elevations of 830 to $1,600 \mathrm{~m}$ in "bosque pino-Encino."

The species is tentatively placed in section $\mathrm{Be}$ lolonchium and is distinguished by its thick leaf blades with usually prominent, elongate, narrow posterior lobes that are directed usually upward at an angle of $45^{\circ}$ to $90^{\circ}$ to the midrib, and also by its relatively much paler lower blade surface with only obscurely visible tertiary veins.

Anthurium cerrobaulense is most easily confused with $A$. chamulense, which has leaves of similar coloration and texture, but that species is distinguished by having the blades merely subcordate or by having the posterior lobes merely rounded.

Mexico. Chiapas: north of Arriaga, Breedlove \& Thorne 30579 (DS); vicinity Cerro Baúl, Breedlove 21695, 24716, 31356 (DS); Croat 47640 (MO); east of San Pedro Tapanatepec, Breedlove 9975 (DS).

Anthurium cerropelonense Matuda, Bol. Soc. Bot. México 24: 37. 1959. TyPE: Mexico. Oaxaca: road between Cerro Pelón and Yetla, 2,600 m, MacDougall 405 (MEXU).

Epiphyte or on rocks; to ca. $1 \mathrm{~m}$ tall; stems 4$8 \mathrm{~cm}$ diam.; leaf scars $4-6 \mathrm{~cm}$ wide; roots thick, tan, descending; cataphylls coriaceous 9-13 cm long, acuminate at apex, subapical apiculum 1 $\mathrm{cm}$ long, drying dark brown, persisting intact at apex, splitting at base into coarse fibers. LEAVES erect to spreading; petioles $27-78 \mathrm{~cm}$ long, 5-17 mm diam., subterete, weakly sulcate; geniculum 2-3 cm long; blades subcoriaceous, ovate, acute at apex (the acumen minutely apiculate), deeply lobed at base, 30-65 cm long, 20-50 cm wide, broadest near point of petiole attachment, the margins somewhat irregular and undulate; anterior lobe $23-50 \mathrm{~cm}$ long, the margins convex; posterior lobes 7-20 cm long directed upward or flat; the sinus spathulate, acute at apex; both surfaces matte to semiglossy; midrib convexly raised above and below, diminishing and sunken at apex above; basal veins 8 pairs, the first and second (sometimes third) free, up to 5 coalesced $1-2 \mathrm{~cm}$, raised above and below; posterior ribs not marginal; leaf tissue turned up at margins; primary lateral veins 5-7 per side, departing midrib at $35^{\circ}$ angle, sunken above, raised below, arcuateascending, loop-connected near the apex; lesser veins conspicuous and flat on upper surface, prominulous on lower surface; collective vein arising from first basal vein or one of the up- permost primary lateral veins, $10-18 \mathrm{~mm}$ from margin, sunken above, raised below. INFLORESCENCE spreading, shorter than leaves; peduncle $22-45 \mathrm{~cm}$ long, $8 \mathrm{~mm}$ diam., terete, $1 / 2-$ $2 / 3$ as long as petioles; spathe subcoriaceous, medium green (B \& K Yellow-green 6/7.5), tinged at margins with purple or very heavily tinged with purple inside, narrowly ovate, $9.5 \mathrm{~cm}$ long, $2.3-4 \mathrm{~cm}$ wide, broadest near base, caudateacuminate at apex (the acumen ca. $1 \mathrm{~cm}$ long), obtuse to rounded at base and clasping, inserted at $30^{\circ}$ angle on peduncle; spadix violet-purple, sometimes green turning violet-purple (B \& $\mathrm{K}$ Red-purple 2/5), 5-11 cm long, 0.8-1.5 cm diam. at base, 5-7 $\mathrm{mm}$ diam. at apex; flowers square, 2.7-3 $\mathrm{mm}$ in both directions, the sides weakly sigmoid; 10-14 flowers visible in the principal spiral, 8-12 flowers visible in the alternate spiral; tepals matte, with dense, pale punctations, minutely papillate; lateral tepals $1.8-2.2 \mathrm{~mm}$ wide, the inner margin convex; pistil not visible before anthesis; stamens developing from the base in a complete sequence, the leading lateral stamens 1-2 spirals ahead of the fourth stamen; anthers ca. $1.2 \mathrm{~mm}$ long, $0.5 \mathrm{~mm}$ wide; thecae ovateoblong, scarcely divaricate. INFRUCTESCENCE pendent; spadix to $15 \mathrm{~cm}$ long, $4 \mathrm{~cm}$ diam.; berries obovoid, mammilliform at apex, orange (?), 9-10 $\mathrm{mm}$ long, 7-9 $\mathrm{mm}$ diam.; mesocarp fleshy, thick; seeds usually $2,7 \mathrm{~mm}$ long, 4.5-5.5 mm wide. Figs. 35, 36, and 37.

Anthurium cerropelonense is endemic to the Sierra de Juárez in the Sierra Madre Oriental in Oaxaca at 2,400 to $2,800 \mathrm{~m}$ in cloud forests near the summit of the Atlantic slope. The forest type is "selva alta perennifolia." All collections have been made along Highway 175.

The species is characterized by its large, thick, ovate-cordate blades, narrow or closed sinus, posterior rib rather distant from the leaf margin, and by conspicuous tertiary veins, and also by its thick, dark violet-purple spadix.

Unlike most Mexican species, which appear to be related to several other species, $A$. cerropelonense seems to be unrelated to or confused with any other species. It is tentatively placed in section Belolonchium.

Mexico. oaxaca: between Cerro Pelón \& Yetla, MacDougall 405 (MEXU); vicinity of Ixtlán de Juárez, Almeda \& Luteyn 1666 (DUKE); Graham \& Frohlich 1105 (MICH); between Tuxtepec \& Oaxaca, Croat 48180 (MO). 
Anthurium chamulense Matuda, Anales Inst. Biol. Univ. Nac. México 27: 339. Fig. 2. 1957.

a. Anthurium chamulense ssp. chamulense. TYPE: Mexico. Chiapas: San Juan Chamula (just NW of San Cristóbal de Las Casas) MacDougall 348 (MEXU, holotype-not found).

Anthurium motozintlense Matuda, Anales Inst. Biol. Univ. Nac. México 43, Ser. Bot. (1): 55. Fig. 4. 1972 (Publ. 1974). TYPE: Mexico. Chiapas: Sierra Madre, El Rosario, Motozintla, 1,800 m elev. MacDougall 393A (MEXU, holotype).

Anthurium monserratense Matuda, Anales Inst. Biol. Univ. Nac. México 27: 342. Fig. 3. 1957. TYPE: Mexico. Chiapas: Municipio of Cintalapa, near Finca Monserrate, alt. 1,000 m. MacDougall 285 (MEXU, not seen).

Epiphyte or on rocks; roots tan (dry), ca. $2 \mathrm{~mm}$ diam.; cataphylls subcoriaceous, $3.5-10 \mathrm{~cm}$ long, rounded at apex (subapical apiculum ca. $2 \mathrm{~mm}$ long), drying medium to dark brown (B \& $\mathrm{K}$ Yellow-red 4/10), persisting as reticulate fibers. LEAVES usually erect; petioles D-shaped, 1432(47) cm long, 2-6 mm diam., sharply and broadly sulcate; geniculum $1.5-2 \mathrm{~cm}$ long; blades coriaceous, narrowly to broadly triangular, 13$37 \mathrm{~cm}$ long, $5-26.5 \mathrm{~cm}$ wide, broadest $1-2 \mathrm{~cm}$ above base, acute to narrowly rounded and apiculate at apex (the apiculum 1-2 mm long), truncate to obtuse or broadly lobed at base; anterior lobe 13.5-30 cm long; posterior lobes $3.2-12 \mathrm{~cm}$ long; sinus arcuate to arcuate with decurrent petiole, rounded at apex; upper surface semiglossy, the lower surface matte to semiglossy; midrib bluntly raised at base, diminished and sunken at apex above, raised at base, flat at apex below; basal veins $3-5$, the uppermost free (sometimes all free), third or fourth coalesced to $3.5 \mathrm{~cm}$; posterior rib naked, turned up; primary lateral veins $7-19$ per side, departing midrib at $45^{\circ}$ angle, sunken but scarcely more conspicuous than lesser veins above, prominulous and darker than surface below; submarginal collective vein arising from first or second basal veins; third basal vein loop-connected to collective vein, $2-15 \mathrm{~mm}$ from margin. INFLORESCENCES erect to spreading, shorter than or as long as the leaves; peduncle $27-48 \mathrm{~cm}$ long, $3 \mathrm{~mm}$ diam.; spathe moderately thin, pale green tinged pink at base and apex, ovate to ovate-lanceolate, $3.5-14 \mathrm{~cm}$ long, $1.3-6 \mathrm{~cm}$ wide, broadest just above base, abruptly to gradually acuminate at apex, rounded to truncate at base, inserted at $10^{\circ}$ angle on pe- duncle, the area around stipe thickened, donutshaped; stipe $3 \mathrm{~mm}$ long in front, $1.5 \mathrm{~mm}$ long in back, green; spadix green becoming slightly to heavily tinged with violet-purple (B \& K Redpurple 2/5), 3-13 cm long, $5.5-10 \mathrm{~mm}$ diam. at base, 3-6 $\mathrm{mm}$ at apex; the flowers rhombic, 2.2$2.3 \mathrm{~mm}$ long, $2.4-2.5 \mathrm{~mm}$ wide, the sides straight to broadly sigmoid; 5-6 flowers visible in the principal spiral, ca. 5 flowers visible in the alternate spiral; tepals matte, sparsely punctate, minutely papillate, lateral tepals $1.6 \mathrm{~mm}$ wide, the inner margins broadly rounded; pistil emergent, bright green; stigma a nearly obscure slit; stamens emerging in a prompt and complete sequence beginning at base, sometimes with as many as 3 emerging simultaneously, the leading stamens no more than 3 spirals ahead of completed sequence; anthers cream-colored, held in a tight cluster obscuring pistil, $0.8 \mathrm{~mm}$ long, 0.9 $\mathrm{mm}$ wide, shrinking to $0.4 \mathrm{~mm}$ wide; thecae ovate, slightly divaricate; pollen white. INFRUCTESCENCE pendent, 7-10 cm long, 1.5 $\mathrm{cm}$ diam.; spathe persistent, berries red, obovate to round; seeds not seen. Fig. 38 .

The species is known only from southern Mexico in Oaxaca and Chiapas and consists of two subspecies. Subspecies oaxacanum Croat is known only from the type locality in northwest Oaxaca in "selva alta perennifolia," while subspecies chamulense is widespread in Chiapas and is expected also in Guatemala. It ranges from 1,500 to $3,000 \mathrm{~m}$ and is perhaps restricted to regions of "bosque pino-encino." Most collections have been made from northern Chiapas but the species has also been collected in the Municipio of Motozintla in southeast Chiapas and also in the Municipio Villa Corzo in south central Chiapas. One of the collections from the latter collecting area (MacDougall 376) is somewhat aberrant in that it has a thicker blade with more conspicuous posterior lobes. This specimen perhaps represents a distinct species but it is too incomplete to be certain.

Anthurium chamulense is tentatively placed in section Belolonchium and is distinguished by its coriaceous, ovate-triangular leaf blade usually with short lobes and broad sinus (when flattened). Live plants (especially those populations seen at Pueblo Nuevo Solistahuacán) exhibit a characteristic vein pattern with the tertiary veins scarcely visible on the lower surface but clearly visible and minutely etched on the upper surface. 


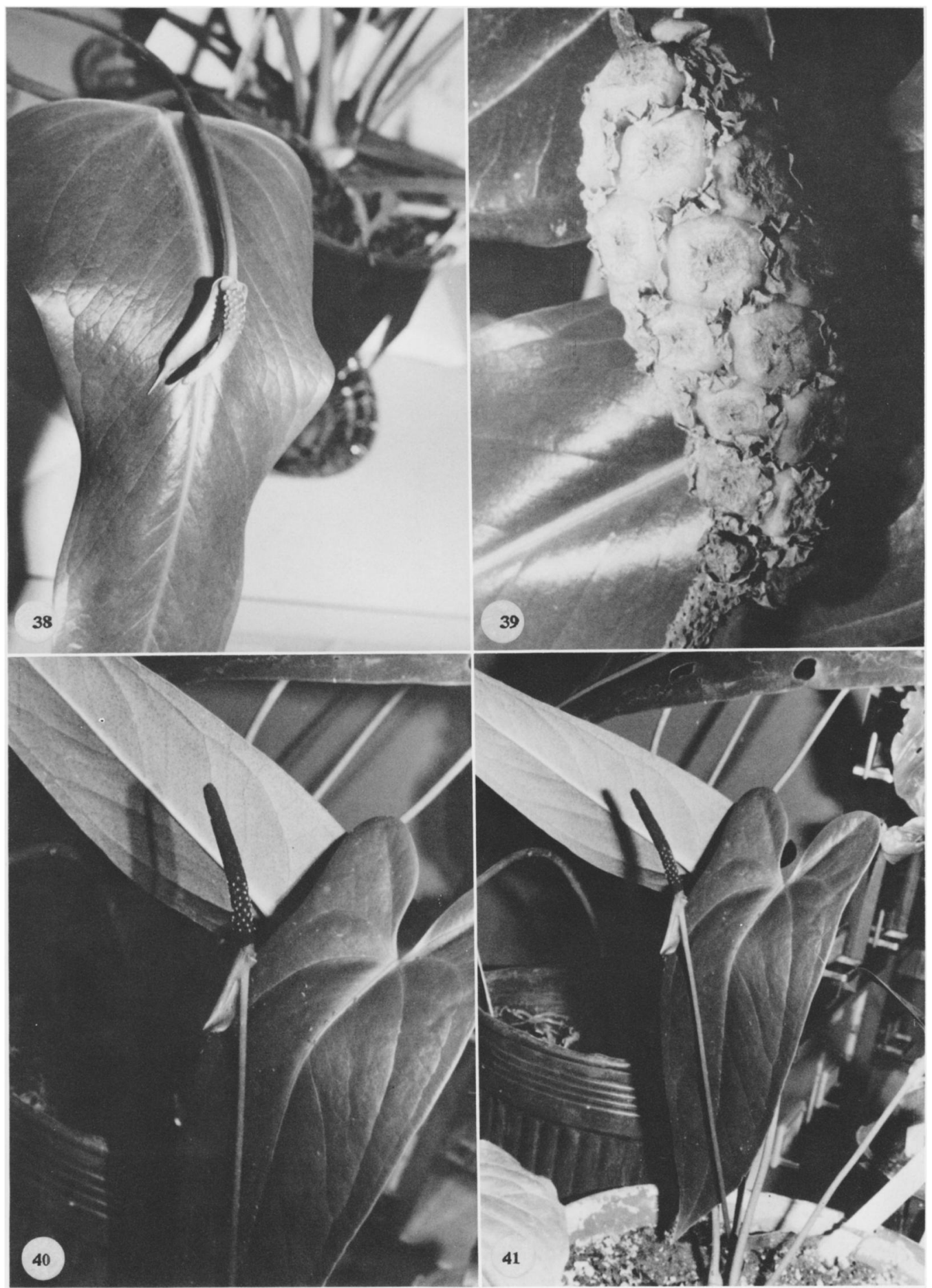

Figures 38-41. 38. Anthurium chamulense Matuda, Croat 46426. - 39. Anthurium chamulense ssp. oaxacanum Croat, Croat 48389 (Type).-40-41. Anthurium chiapasense Standl., Croat 40900. 
The species is probably closest to $A$. andicola, but that species can be distinguished by having usually conspicuous tertiary veins on the surface that are weakly elevated and darker than the surface. Anthurium chamulense is also very similar to $A$. cerrobaulense from southwest Chiapas because they both have leaves with similar coloration and texture, but that species has blades with usually conspicuous narrow, rather elongate, posterior lobes.

The type of Anthurium monserratense Matuda was not seen but the description, illustration, and the location of the collection make it rather conclusively synonymous with $A$. chamulense.

Mexico. Chiapas: NE of Bochil, Breedlove 34643 (DS); Cerro Tres Picos, Breedlove 24972, 30125 (DS); MacDougall 376 (MEXU); El Rosario, MacDougall 393 A (MEXU); Matuda 37603 (DS, MEXU); near Ocosingo, Breedlove 16021, 16033, 16034 (DS); Pueblo Nuevo Solistahuacán, Croat 46426, 47765 (MO); Luteyn \& Almeda 3443 (DUKE); Mill 220, 595, 673 (DS); Raven \& Breedlove 20034 (DS, ENCB); Roe et al. 1239 (US); Thorne \& Lathrop 40392 (DS); Tenejapa, Breedlove \& Raven 12916 (DS); vicinity Tuxtla Guttiérrez, Clarke 175 (DS); Munc. Zinacantán, Laughlin 536 (DS, DUKE, ENCB).

b. Anthurium chamulense ssp. oaxacanum Croat, ssp. nov. TYPE: Mexico. Oaxaca: along road from Teotitlán del Camino to Santa María Chilchotla, $4.4 \mathrm{mi}$ beyond turnoff to Huatla de Jiménez, elev. 1,980 m, steep slopes with huge boulders, Croat 48389 (MO-2682519, holotype; F, K, MEXU, SEL, US, isotypes; Live at MO).

Anthurium chamulense ssp. oaxacanum a ssp. chamulense laminis tenuioribus, nervis tertiaribus supra vix impressis subtus manifestis differt.

Epiphyte; stems narrow, $1.5 \mathrm{~cm}$ diam.; leaf scars $1.2 \mathrm{~cm}$ wide; roots thick, brown; cataphylls subcoriaceous, 4-7 cm long, drying medium brown (B \& K Yellow 4/10), persisting as reticulate fibers. LEAVES erect-spreading; petioles 22-30 cm long, 4-6 mm diam., D-shaped, bluntly sulcate, the margins sharper near base of blade; geniculum 1-1.3 cm long, sometimes tinged redviolet; blades subcoriaceous, triangular, 24-48 cm long, 8-13 cm wide, broadest $1-2 \mathrm{~cm}$ from base, gradually acuminate at apex, obtuse to truncate at base; anterior lobe $23.5-27 \mathrm{~cm}$ long, the margins straight; posterior lobes $4-5.5 \mathrm{~cm}$ long, directed upward; sinus arcuate to arcuate with petiole decurrent, rounded at apex; upper surface glossy, lower surface matte; midrib blunt- ly raised at base, sunken to flat at apex above, raised below; basal veins 3-4 pairs, the second to fourth coalesced $1-1.5 \mathrm{~cm}$, prominulous above and below; posterior ribs naked, the outer margins rolled up; primary lateral veins 3-6 per side, departing midrib at $30^{\circ}-45^{\circ}$ angle, sunken above, raised below, straight to collective vein; lesser veins scarcely visible; collective vein arising from the first or second basal vein, running to the apex, 3-5 $\mathrm{mm}$ from margin, sunken above, raised below. INFLORESCENCE spreading, shorter or as long as leaves; peduncle terete, green, tinged with red-violet, $30-32 \mathrm{~cm}$ long, 3-4 $\mathrm{mm}$ diam.; spathe green, subcoriaceous, \pm triangular, ca. 3 $\mathrm{cm}$ long, $1 \mathrm{~cm}$ wide; spadix violet-purple, $\tan$ at anthesis, $4.5-5 \mathrm{~cm}$ long, 5-6 mm diam. at base, 3-4 $\mathrm{mm}$ diam. at apex; flowers rhombic, $3 \mathrm{~mm}$ in both directions, the sides straight to weakly sigmoid; 3-6 flowers visible in the principal spiral, 4-8 flowers visible in the alternate spiral; tepals matte, weakly punctate, minutely papillate, lateral tepals ca. $1.5 \mathrm{~mm}$ wide, the inner margin convex; pistils weakly emergent; stigma linear; stamens emerging from base, laterals first, preceding alternates by 3-4 spirals, held over pistil in tight cluster; anthers white; thecae ellipsoid, not divaricate; pollen white to cream. INFRUCTESCENCE pendent; berries pale orange, truncate at apex, trapezoidal in side view, ca. 10 mm long, 8-11 mm diam.; mesocarp juicy, fleshy with numerous, whitish raphide cells; seeds 2 , greenish white, obovate, depressed at apex, round at base, flattened, ca. $7 \mathrm{~mm}$ long, $6 \mathrm{~mm}$ wide, 3.1-3.4 mm thick, enveloped in a thin, sticky substance, slightly longer on ends than at sides of seeds. Figs. 33 and 39.

Anthurium chamulense ssp. oaxacanum is known only from the type locality in northern Oaxaca in "selva alta perennifolia" at nearly $2,000 \mathrm{~m}$. The taxon is recognized by its relatively thinner, usually truncate, narrowly triangular leaves, sulcate petiole, green spathe and short, usually stipitate, violet-purple spadix. It is a member of section Belolonchium.

The subspecies oaxacanum is not confused with any other taxon from that part of Mexico. It is separated from $A$. chamulense ssp. chamulense by having thinner leaf blades with less conspicuously impressed tertiary veins on the upper surface but with the tertiary veins on the lower surface clearly visible. In subspecies chamulense the tertiary veins on the lower surface 
are scarcely visible. In addition the subspecies oaxacanum occurs in much wetter forest ("selva alta perennifolia") than ssp. chamulense ("bosque pino-encino").

Mexico. Oaxaca: between Teotitlán and Santa María Chilchotla, beyond turnoff to Huatla de Jiménez, Croat 48389 (F, K, MEXU, MO, SEL, US).

Anthurium chiapasense Standl., Publ. Field Mus. Nat. Hist., Bot. Ser. 22: 67. 1940.

a. Anthurium chiapasense ssp. chiapasense. TYPE: Mexico. Chiapas: Monte Ovando (just NW of Escuintla) Matuda 1562 (MO, holotype).

Anthurium cuspidatum Matuda, Madroño 10: 169. 1950, non Mast., 1875. Anthurium cruxiphyllum Matuda, Revista Soc. Mex. Hist. Nat. 11: 93. 1950. TYPE: Mexico. Chiapas: near Colonia Jalapa, 32 $\mathrm{km}$ E of Escuintla, elev. $700 \mathrm{~m}$, Matuda 18316 (MEXU, holotype; $F$, isotype).

Epiphyte; stems 2-4 cm long, $2.5 \mathrm{~cm}$ diam.; internodes and leaf scars obscured by cataphylls; roots moderately thick, green, descending; cataphylls subcoriaceous, 3-6 cm long, acute at apex (apiculate to $2 \mathrm{~mm}$ ), drying brown (B \& K Yellow $3 / 10$ ), weathering to reticulate fibers and persisting. LEAVES erect-spreading; petioles 10-51 cm long, 3-6 mm diam., terete; geniculum 1.7$2 \mathrm{~cm}$ long, sometimes shallowly sulcate; blades moderately thick, narrowly triangular, long acuminate at apex, broadly lobed at base, $13-42 \mathrm{~cm}$ long, $5.5-25 \mathrm{~cm}$ wide, broadest at base; anterior lobe $11.5-36 \mathrm{~cm}$ long, the margins \pm straight; posterior lobes $2.5-10.5 \mathrm{~cm}$ long; sinus arcuate, round at apex; both surfaces matte, lower surface densely glandular-punctate; midrib acutely raised at base above, flat at middle, sunken at apex, acutely raised throughout below; basal veins 34 pairs, the third and fourth coalesced $1.5-2 \mathrm{~cm}$, flat to weakly sunken above, raised below; the posterior rib naked, the outer margin turned up; primary lateral veins $2-3$ per side, departing midrib at $30^{\circ}$ angle, weakly sunken, nearly obscure above, prominulous below, \pm straight to collective vein, lesser veins obscure; collective vein arising from the uppermost basal vein, 0.7$1.5 \mathrm{~mm}$ from margin, sunken above, raised below. INFLORESCENCE erect-spreading; as long as or longer than leaves; petiole $30-57 \mathrm{~cm}$ long, $2.5-4 \mathrm{~cm}$ diam., terete; spathe green, tinged with violet-purple, lanceolate; $4.5-7 \mathrm{~cm}$ long, 1-1.8 $\mathrm{cm}$ wide, cuspidate-acuminate at apex, rounded at base, broadest just above base, inserted at $50^{\circ}$ angle on peduncle; spadix deep purple (B \& K
Red-purple 2/2.5), 7.4-10.5 cm long, 5.5-8 mm diam. at base, 3-4 mm diam. at apex, the flowers square to sub-4-lobed, $2.3-2.5 \mathrm{~mm}$ in both directions, the sides straight to jaggedly sigmoid; 4-7 flowers visible in the principal spiral, 7-8 flowers visible in the alternate spiral; tepals matte to weakly glossy, obscurely punctate, minutely papillate; lateral tepals $1.2-1.5 \mathrm{~mm}$ wide, the inner margins broadly rounded; pistils raised, not emergent until just before stamens emerge, green tinged with purple, weakly papillate; stigma linear, ca. $0.3 \mathrm{~mm}$ long, scarcely distinguishable; stamens emerging from base, lateral stamens emerging to midway, before alternates emerge at base; anthers yellow, $0.5 \mathrm{~mm}$ long, 0.6 $\mathrm{mm}$ wide, held just above tepals; thecae oblongelliptic, slightly divaricate; pollen yellow, fading cream. INFRUCTESCENCE not known. Figs. 40 and 41.

The species consists of two subspecies. Anthurium chiapasense ssp. chiapasense occurs in Mexico in southeastern Chiapas and southwestern Guatemala at elevations of 800 to $1,900 \mathrm{~m}$. The type locality is probably tropical wet forest and is mapped as "bosque de oyamel" (Flores et al., 1971) on the Mexican vegetation map, but the species also occurs in "bosque cauducifolio" and "bosque pino-encino." Subspecies tlaxiacense (Matuda) Croat is endemic to southern Oaxaca and differs from the typical subspecies in having an olive green spadix at anthesis and blades with the primary lateral veins prominently raised on the lower surface.

Anthurium chiapasense is in section Belolonchium and is characterized by its thick blades that are much paler and conspicuously punctate on the lower surface with an oblong or narrowly triangular anterior lobe, $3-9 \mathrm{~cm}$ wide midway.

The species is closely related to $A$. lucens and may prove to be only subspecifically distinct from that species. Although both species share a relatively short, dark violet-purple spadix, subcoriaceous, glandular-punctate leaf blades, and bright red berries, $A$. chiapasense differs from $A$. lucens in having slender anterior lobes with concave margins. The margins of the anterior lobe of $A$. lucens are generally conspicuously convex.

Anthurium chiapasense has a leaf shape more similar to that of $A$. verapazense, which also has subcoriaceous, glandular-punctate leaves. It differs from $A$. verapazense in having a porportionally much shorter spadix with the spathe more than half as long as the spadix at anthesis. In 
addition, $A$. verapazense occurs from sea level to less than 1,000 meters, whereas $A$. chiapasense occurs from 800 to $1,800 \mathrm{~m}$. Typical $A$. verapazense has a long, slender spadix well over twice as long as the spathe at anthesis.

Anthurium chiapasense differs from both $A$. lucens and $A$. verapazense in usually drying blackened while the other two species usually dry greenish to greenish-brown. It is tentatively placed in section Belolonchium.

Guatemala. San marcos: Finca Armenia above San Rafael, Croat 40900 (MO).

Mexico. ChIAPAs: Escuintla, Matuda 18315 (DS, MEXU, UCLA); Matuda 18443 (CAS, MEXU, NY); Matuda 18159A, 18159, 18316, 18363, 18491 (MEXU); Matuda 18573 (CAS, DS, MEXU); Matuda 18629 (MEXU, NY); Montebello, SE of Comitán, Carlson s.n. (MEXU); Monte Ovando, Matuda 1562 (MEXU, MICH, MO); Matuda 17930 (MEXU); Motozintla, Breedlove \& Thorne 31026 (CAS, DS); Porvenir, Matuda 30186 (MEXU). MÉXICO: San Angel, De la Cerda 81 (MEXU).

\section{b. Anthurium chiapasense ssp. tlaxiacense (Ma-} tuda) Croat, comb. nov. Anthurium tlaxiacense Matuda, Anales Inst. Biol. Univ. Nac. México 32: 149, Fig. 6. 1961. TYPE: Mexico. Oaxaca: Cerro de la Virgin, Tlaxiaco (just E of Tlaxiaco); elev. 1,500 m. MacDougall s.n. (MEXU, holotype).

Epiphytic or epipetric; stems to $6 \mathrm{~cm}$ long, 2 $\mathrm{cm}$ diam.; internodes and leaf scars obscured by cataphylls; roots moderately thick, green; cataphylls subcoriaceous, $6.7-8 \mathrm{~cm}$ long, acute at apex (apiculate to $1 \mathrm{~mm}$ ), drying brown (B \& K Yellow 4/5), weathering into coarse fibers, persisting around stem. LEAVES erect-spreading; petioles $37-64 \mathrm{~cm}$ long, $6-8 \mathrm{~mm}$ diam., \pm terete; geniculum $2.5-4 \mathrm{~cm}$ long, sometimes weakly sulcate; blades subcoriaceous, narrowly triangular, $35-56 \mathrm{~cm}$ long, $13-30 \mathrm{~cm}$ wide, acuminate at apex (apiculate $5 \mathrm{~mm}$ ), deeply lobed at base, broadest at base; anterior lobe $28-45 \mathrm{~cm}$ long, the margins round to convex; posterior lobes 9$12 \mathrm{~cm}$ long, directed upward; sinus hippocrepiform, acute at apex; upper surface matte to semiglossy, lower surface matte, glandular-punctate; midrib flat to convexly raised above, weakly sunken at apex, prominently raised below; basal veins $4-5$ pairs, the third to fifth coalesced 1.5 $\mathrm{cm}$, flat to weakly sunken above, raised below; posterior rib naked, turned up; primary lateral veins 5-6 per side, departing midrib at $20^{\circ}-25^{\circ}$ angle, sunken above, raised below, straight to collective vein; lesser veins obscure above, prominulous below; submarginal collective vein usually arising from the uppermost basal vein, 7-9 $\mathrm{mm}$ from the margin, sunken above, raised below. INFLORESCENCE spreading-pendent, equalling leaves; peduncle $53-57 \mathrm{~cm}$ long, 5-7 $\mathrm{mm}$ diam., terete; spathe subcoriaceous, yellowgreen (B \& K Yellow-green 7/5), lanceolate, 6$7 \mathrm{~cm}$ long, $1.5-1.7 \mathrm{~cm}$ wide, margins thin, transparent, soon withering, inserted at $40^{\circ}$ angle on peduncle; spadix dark yellow-green to gray-green, heavily tinged red-violet at outer margins of tepals, $5.5-8.5 \mathrm{~cm}$ long, 6-9 $\mathrm{mm}$ diam. at base, 3$5 \mathrm{~mm}$ diam. at apex; the flowers 4-lobed, 2.3-3 $\mathrm{mm}$ long, $2.4-2.8 \mathrm{~mm}$ wide, the sides sigmoid; 6-8 flowers visible in the principal spiral, 6-7 flowers visible in the alternate spiral; tepals matte, weakly punctate, densely papillate, lateral tepals 1.3-1.6 $\mathrm{mm}$ wide, the inner margin convex; pistil raised, green, glossy; stigma elliptic, $0.4-0.5 \mathrm{~mm}$ long, deep purple with large globose droplet ca. 1 week before stamens emerge; stamens emerging from base, lateral stamens emerging throughout, alternates following within a few days, exserted well over pistil on fleshy, red-violet tinged filaments, retracting when anthers open; filaments ca. $5 \mathrm{~mm}$ long, ca. $6 \mathrm{~mm}$ wide, anthers pale yellow, ca. $0.6 \mathrm{~mm}$ long, $1.9 \mathrm{~mm}$ wide; thecae oblong, scarcely divaricate; pollen yellow fading cream. INFRUCTESCENCE archingpendent; spathe usually absent; spadix 10-12(20) cm long, $1.5-3.5 \mathrm{~cm}$ diam. (5-6 cm diam. with berries fully emerged); berries \pm obovoid to oblong-elliptic, rounded at apex, bright red (B \& K Red 4/5); mesocarp translucent, juicy, with numerous raphide cells; seeds $1-2$, green, streaked with purple, weakly flattened, $4.5-5 \mathrm{~mm}$ long, ca. $3 \mathrm{~mm}$ wide, $1 \mathrm{~mm}$ thick, enveloped in a transparent, amber, gelatinous sack. Figs. 42, 43, and 46.

Anthurium chiapasense ssp. tlaxiacense is endemic to southern Oaxaca and has been collected at 1,400 to $1,500 \mathrm{~m}$ in seasonally dry forest.

Anthurium chiapasense ssp. tlaxiacense is distinguished from ssp. chiapasense by its olive green spadix at anthesis and blades with the primary lateral veins prominently raised on the lower surface. It is recognized by its coriaceous, narrowly triangular-hastate leaf blade, dark green above and much paler and conspicuously glandularpunctate beneath.

Mexico. oAxaca: between Pinotepa Nacional and Tlaxiaco, Croat 45927 (MO); S of Miahuatlán on road between Oaxaca and Pochutla, Croat 46126 (MO); Tlaxiaco, MacDougall s.n. (MEXU). 


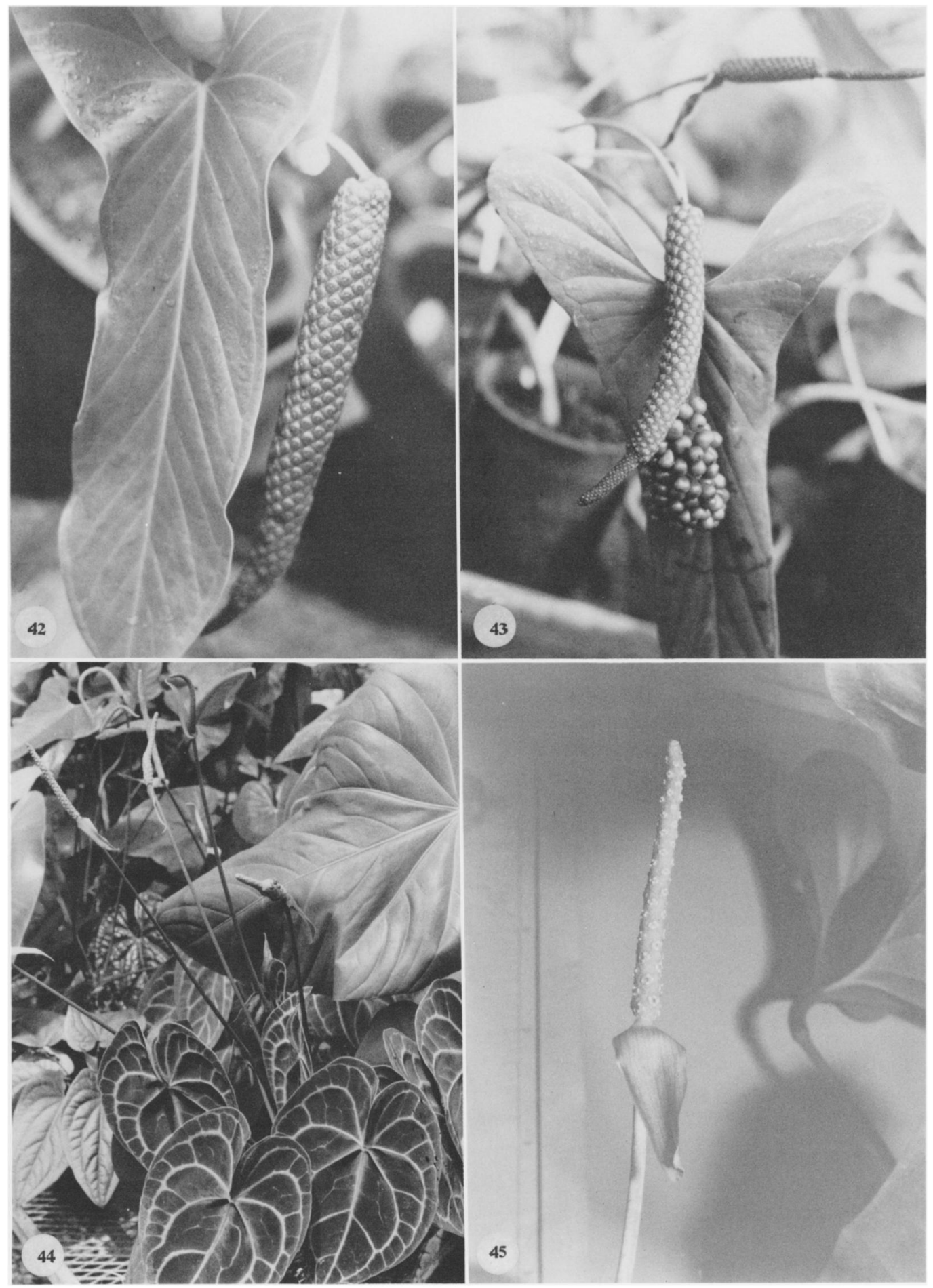

Figures 42-45. 42-43. Anthurium chiapasense ssp. tlaxiacense (Matuda) Croat, Croat 46126. -44. Anthurium clarinervium Matuda, Selby 9-75-59.-45. Anthurium clarinervium Matuda, Croat 40646. 


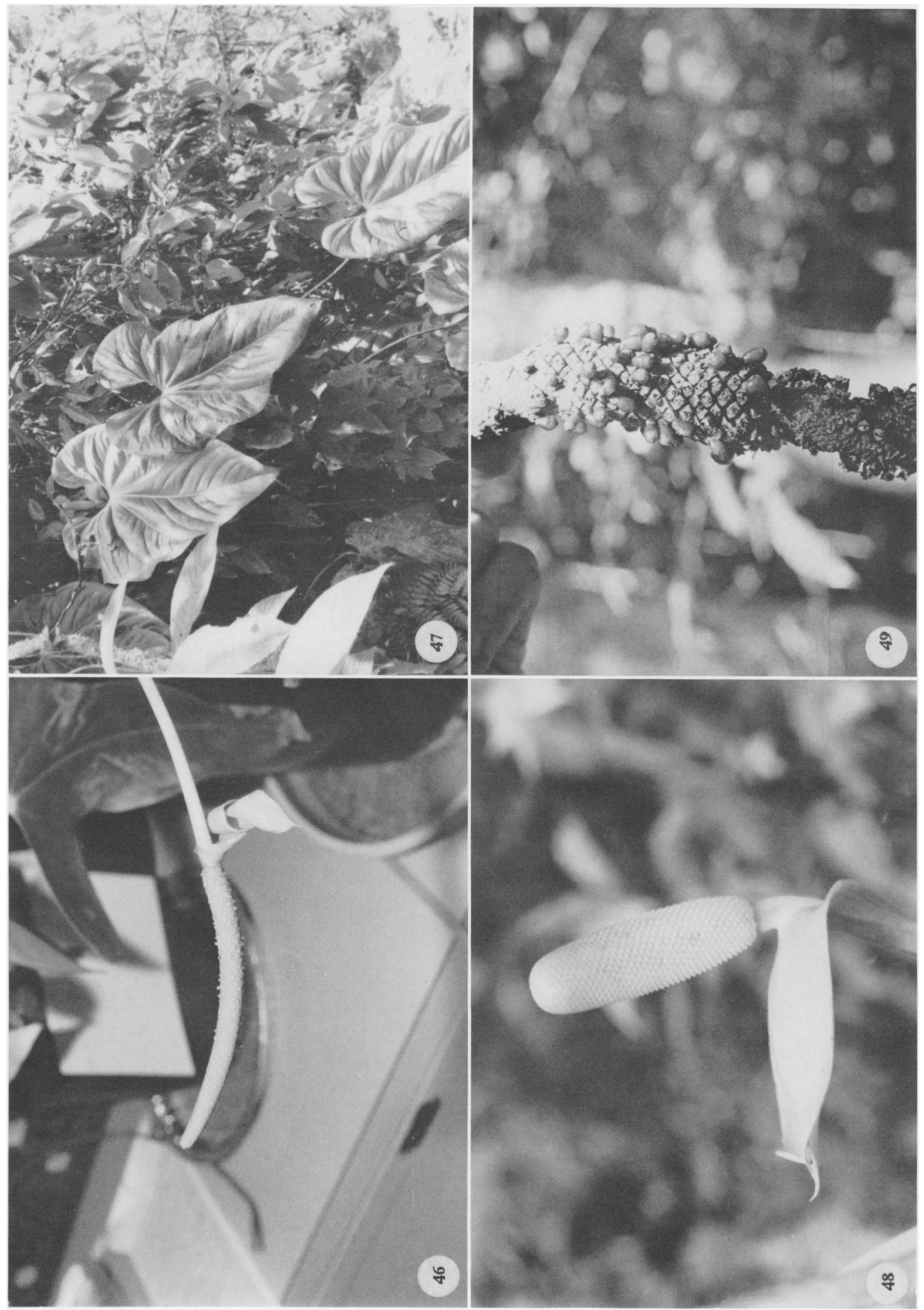


Anthurium clarinervium Matuda, Anales Inst. Biol. Univ. Nac. México 25: 203. 1954. TyPE: Mexico. Chiapas: NE of Ocozocoautla (collected by Ing. Ramirez August 5, 1951) $\mathrm{Ma}$ tuda 25894 (MEXU, holotype).

Terrestrial, deeply rooted among rocks, less frequently epipetric in thin soil on rocks; stems 1-2 cm diam.; leaf scars $1.7 \mathrm{~cm}$ wide; cataphylls subcoriaceous, 3-4 cm long, obtuse at apex with subapical apiculum, pale red-violet with pale green speckles, drying brown (B \& $\mathrm{K}$ Yellow $5 / 2.5$ ), splitting and persisting. LEAVES erect to spreading; petioles 7-16 cm long, 4-6 mm diam., terete, green or pale red-violet with green speckles; geniculum 1-1.5 cm long; blades ovate, moderately coriaceous, abruptly to gradually acuminate at apex, deeply lobed at base, 11-25.5 cm long, $6.5-17 \mathrm{~cm}$ wide, broadest at middle or just below, the margin flat, drying conspicuously undulate; anterior lobe $6.5-18 \mathrm{~cm}$ long, the margins convex; posterior lobes $2.5-9 \mathrm{~cm}$ long; sinus spathulate to obovate, the lobes sometimes overlapping, acute at apex; upper surface matte, velvety, dark green, lower surface paler, matte; midrib convexly raised, diminishing at apex above, raised below; primary lateral veins 3-5 per side, raised above, flat below; interprimary veins conspicuous; basal veins 4-5 pairs, free to base or sometimes the third to fourth veins coalesced, the first curving to apex, the second to fourth arcuate-ascending to margin, loop-connecting; collective vein arising from first basal vein; all veins clearly outlined by white or greenish white area. INFLORESCENCE erect-spreading, longer than leaves; peduncles $16-38 \mathrm{~cm}$ long, 2-4 mm diam., terete, green tinged with red-violet, longer than petioles; spathe chartaceous, pale green tinged with violet-purple near margins (B \& K Yellow-green 6/7.5), lanceolate, $3.7-6.5 \mathrm{~cm}$ long, $1-1.5 \mathrm{~cm}$ wide, broadest at base, narrowly acuminate at apex, obtuse at base, inserted at $40^{\circ}-$ $70^{\circ}$ angle on peduncle; stipe to $5 \mathrm{~mm}$ long in front, to $2 \mathrm{~mm}$ long in back; spadix green, tinged with violet-purple sometimes appearing brown (B \& K Yellow-green 5/5 to Yellow 4/10), 4.7$7.5 \mathrm{~cm}$ long, 4-7 mm diam. at base, $3-3.5 \mathrm{~mm}$ diam. at apex; flowers sub-4-lobed to square, 3.8$5 \mathrm{~mm}$ long, $3.2-5 \mathrm{~mm}$ wide, the sides jaggedly sigmoid; 3-4 flowers visible in the principal spiral, 5-8 flowers visible in the alternate spiral; tepals matte, papillate, densely and conspicuously punctate, large droplets visible as stamens emerge, lateral tepals $2.8-3.1 \mathrm{~mm}$ wide, the inner margin weakly concave; the pistils weakly emer- gent usually as soon as spathe opens, green; stigma elliptic, $0.6-1 \mathrm{~mm}$ long, brushlike, exserted with large droplets 2-3 days before stamens emerge; stamens emerging rapidly from base on flattened, translucent filaments $1 \mathrm{~mm}$ long, 1.5 $\mathrm{mm}$ wide, lateral stamens emergent to midway before alternates appear, retracting and held just above tepals; anthers yellow, 0.4-0.8 mm long, $0.7-1.5 \mathrm{~mm}$ wide, thecae elliptic, not divaricate, pollen cream fading to white. INFRUCTESCENCE with bright orange, subglobose berries, ca. $1.5 \mathrm{~mm}$ long; mesocarp mealy, seeds not seen. Figs. 44 and 45.

Anthurium clarinervium is probably endemic to Mexico, known only from areas with limestone outcrops between the Río Grijalva and Río de la Venta, north of Ocozocoautla de Espinosa, Chiapas, at 800 to $1,200 \mathrm{~m}$ elevation. Mr. Larry Bussle, a Tampa based horticulturist, claims to have seen Anthurium clarinervium along the Interamerican highway in Guatemala, near the Mexican border, but no collections were made to substantiate this report.

The species is a member of section Cardiolonchium and is recognized by its broadly ovate, velvety leaf blades with all principal veins much paler than the surface and with a very narrow or closed sinus. The blades have basal veins usually free to the base or coalesced into a short posterior rib that is never marginal.

The species has been confused with $A$. leuconeurum, which also purportedly originates from southern Mexico but whose exact origin is unknown. The latter species is distinguished by having a generally larger, more narrowly ovate blade with an obovate or hippocrepiform sinus and a conspicuously well developed, naked, posterior rib (i.e., it is marginal to the sinus).

Anthurium clarinervium often occurs in mixed stands with $A$. pedatoradiatum, a species that flourishes in the same limestone outcrop habitats in southern Mexico. The two species readily hybridize to form a somewhat intermediate plant, having the velvety texture of $A$. clarinervium but displaying a somewhat shallowly lobed margin representative of $A$. pedatoradiatum (see Croat 40647).

In Chiapas the species is known as "Hoja de corazon." It is now widespread in cultivation, at least in the United States.

MEXICO. ChIAPAS: N of Berriozábal, Breedlove 20274, 24822 (DS); Breedlove \& Dressler 29713 (CAS, DS); 
vicinity Ocozocoautla de Espinosa, Breedlove 9990 (DS, MEXU); Breedlove 10365 (DS); Breedlove \& Raven 13582 (CAS, DS); Breedlove 38172 (CAS, DS); Croat 40646 (MO); Matuda 25894 (MEXU).

Anthurium clavatum Croat \& Baker, Brenesia 16 (Supl. 1): 39. 1979. TyPE: Costa Rica. Cartago: Tapantí Hydroelectric Reserve along Río Grande Orosi, $4.5 \mathrm{~km}$ beyond small bridge which crosses the river inside the preserve, along road to diversion dam, elev. 1,500-1,700 m, Croat 36079 (MO-2381175, holotype; CR, F, NY, US, isotypes; Live at $\mathrm{MO}$ ).

Epiphytic or terrestrial; stems to $1 \mathrm{~m}$ long, 2$3 \mathrm{~cm}$ diam.; internodes $1.5-2.5 \mathrm{~cm}$ long; roots 1 or 2 per node, ca. $5 \mathrm{~mm}$ thick, woolly-pubescent on drying; cataphylls moderately thick, 13-28 $\mathrm{cm}$ long, narrowly rounded at apex with a subapical apiculum, drying reddish-brown (B \& $\mathrm{K}$ Yellow-red 4/10), subpersistent. LEAVES erectspreading; petioles 90-140 cm long, $1-1.5 \mathrm{~cm}$ diam., subterete, narrowly and obtusely sulcate; geniculum 3-3.5 cm long; blades ovate, moderately thick, short-acuminate at apex (the acumen minutely apiculate), deeply lobed at base, $35-70 \mathrm{~cm}$ long, $26-50 \mathrm{~cm}$ wide, broadest near point of petiole attachment; anterior lobe 25-48 $\mathrm{cm}$ long, the margins broadly convex; posterior lobes 12-22 cm long, directed downward; the sinus hippocrepiform, rounded to obtuse at apex; both surfaces semiglossy; midrib convexly raised above, diminished and sunken toward apex, acutely raised below; basal veins 5-7 pairs, up to 5 of them coalesced $2.5-6 \mathrm{~cm}$, raised above and below, the posterior rib broadly curved, naked; primary lateral veins 4-7 per side, departing midrib at ca. $55^{\circ}$ angle, then spreading at $35^{\circ}-$ $45^{\circ}$ angle, loop-connected, sunken above, raised below; lesser veins less conspicuous; collective vein arising from uppermost basal vein, 5-15 $\mathrm{mm}$ from the margin. INFLORESCENCE usually slightly shorter than or about as long as the leaves; peduncle $43-110 \mathrm{~cm}$ long, to ca. $8 \mathrm{~mm}$ diam. midway, half as long as or equalling the petioles; spathe moderately coriaceous, pale green (B \& K Yellow-green 8/7.5), ovate-elliptic, 7-12 $\mathrm{cm}$ long, $3.5-5 \mathrm{~cm}$ wide, broadest $1-2 \mathrm{~cm}$ above point of attachment, cuspidate-acuminate at apex (the acumen inrolled, 6-10 $\mathrm{mm}$ long), acute to obtuse at base, inserted on peduncle at ca. $80^{\circ}$ angle; stipe $1-6 \mathrm{~cm}$ long in front, $2-8 \mathrm{~mm}$ long in back, ca. $6 \mathrm{~mm}$ diam.; spadix clavate, green (B \& K Yellow-green 8/10) to orange-tan, 4.5-
$7.5 \mathrm{~cm}$ long, $1.2-1.5 \mathrm{~cm}$ diam. at base, $1.5-2.2$ $\mathrm{cm}$ diam. at apex; flowers 4-lobed, (1.4)2.3-2.7 $\mathrm{mm}$ (dry) in both directions, the sides sigmoid; 20 or more flowers visible in the principal spiral, 13-16 flowers visible in the alternate spiral; tepals semiglossy, the lateral tepals $1.2-1.3 \mathrm{~mm}$ wide (dry), the inner margin broadly rounded; pistil emergent but not raised, green; stigma oblong-elliptic, slitlike, ca. $0.5 \mathrm{~mm}$ long; stamens emerging, scattered, beginning near the middle, the lateral stamens exserted throughout the spadix before the alternates emerge; anthers white, held in a moderately close circle, contiguous or nearly so at upper edge of tepals, ca. $0.4 \mathrm{~mm}$ long and $0.5 \mathrm{~mm}$ wide; thecae ovate, moderately divaricate; pollen white. Immature INFRUCTESCENCE to $10 \mathrm{~cm}$ long and $3.3 \mathrm{~cm}$ wide; berries not seen. Figs. 47 and 48 .

The species is known only from central Costa Rica on the Atlantic slope of the Cordillera de Talamanca in the region of the type locality. It inhabits lower montane rain forest from 1,300 to $1,800 \mathrm{~m}$ elevation.

Anthurium clavatum belongs in section Calomystrium and is perhaps most closely related to $A$. fraternum Schott, $A$. hoffmanii, and $A$. nymphiifolium $\mathrm{C}$. Koch \& Bouché, which all share thick, persistent cataphylls. Anthurium clavatum differs from all of these by its clavate spadix. Another distinguishing feature is the broad spathe with a long cusp.

Costa Rica. CARTAGO: no other location, Utley \& Utley 1624 (F); above the Río Grande de Orosi, S of Tapantí, Cochrane et al. 6334 (F); Lent 940 (CR, F); 998 (F); SE of Orosi, above Finca La Concordia, Lellinger \& White 1508 (CR, F, US); road from Tapantí to Taus-Tausito, beyond bridge over Río Grande de Orosi at Tapantí, Utley \& Utley 5616 (DUKE); Tapantí Hydroelectric Reserve, Croat 36079 (CR, F, MO, NY, US), 47050 (MO); road between Trinidad and Hacienda El Volcan Turrialba, Luteyn 3259 (DUKE).

Anthurium clavigerum Poepp. in Poepp. \& Endl., Nov. Gen. \& Sp. 3: 84. 1845. TyPE: Peru. Pampayacu, Poeppig 1423 (W, not seen; F, photo).

Anthurium panduratum Mart. ex Schott, Oesterr. Bot. Wochenbl. 5: 273. 1855. TYPE: Brazil. Rio Negro, Martius 3115 (M, not seen; US, photo).

Anthurium holtonianum Schott, Oesterr. Bot. Wochenbl. 7: 317. 1857. TyPE: Colombia. La Paila, Holton s.n. (K, not seen; SEL, photo).

Anthurium repandum Schott, Oesterr. Bot. Wochenbl. 7: 317. 1857. TyPE: Colombia. Santa Marta, Purdie s.n. (K, not seen; SEL, photo). 
Anthurium wendlandii Schott, Oesterr. Bot. Z. 8: 182. 1858. TyPE: Costa Rica. San Miguel, Wendland 957 (GOET).

Anthurium kalbreyeri N. E. Brown, Gard. Chron. pt. 2: 117. 1881. TYPE: Colombia. Antioquia, Kalbreyer s.n. (K, not seen).

Anthurium burchellianum (Engl.) Macbr., Field Mus. Nat. Hist., Bot. Ser. 11: 7. 1931.

Anthurium panduratum var. burchellianum Engl., Pflanzenr. IV 23 B: 279. 1905. TYPE: Brazil. Pará, Burchell 9632 (K, not seen).

Anthurium obovatum Gleason, Bull. Torrey Bot. Club 56: 9. 1929. TYPE: Br. Guiana. Kopinang River, Anandabaru, Alston 475 (K, not seen; F, photo). Anthurium monsteroides Steyerm., Fieldiana, Bot. 28: 93. 1951. TYPE: Venezuela. Mérida: Río Onia near Bolero, N. of Mesa Bolivar, Steyermark 56727 (F).

Epiphyte; scandent; stems $2 \mathrm{~m}$ long, 3-4 cm diam.; roots dense, 3-10 mm diam., brownishgreen; cataphylls coriaceous, to $12 \mathrm{~cm}$ long, weathering to medium brown fibers, ultimately deciduous. LEAVES erect-spreading; petiole 65$150 \mathrm{~cm}$ long, terete or weakly sulcate; geniculum $1.5-2 \mathrm{~cm}$ long; blades digitately discoid to reniform in outline, to $2 \mathrm{~m}$ wide, the leaflets 25 $100 \mathrm{~cm}$ or more long, $4-12 \mathrm{~cm}$ wide, sinuate or lobate, acuminate at apex, acute at base, the upper surface matte, the lower surface semiglossy; the midrib of the leaflets convexly raised above and below, diminished and sunken at apex above; the primary lateral veins 3-4 per side, raised in valleys above, raised below, departing midrib at $45^{\circ}$ angle, arcuate-ascending to form collective vein in apical portion of leaflet. INFLORESCENCE arching-pendent; peduncle to $90 \mathrm{~cm}$ long, terete, shorter than petioles; spathe coriaceous, violet-purple, lanceolate, 30-65 cm long, 3-11 $\mathrm{cm}$ wide; spadix lavender-purple (B \& K Purple $6 / 2.5$ ), $20-75 \mathrm{~cm}$ long, to $2 \mathrm{~cm}$ diam. at base, to $9 \mathrm{~mm}$ diam. at apex; flowers rhombic, ca. $3 \mathrm{~mm}$ in both directions, the sides straight to slightly sigmoid; ca. 14 flowers visible in the principal spiral, ca. 8 flowers visible in the alternate spiral; tepals matte; pistil emergent but not raised, lavender; stigma linear, darker purple than pistil; stamens emerging from base, covering pistil; anthers purplish-brown; thecae irregular, not divaricate; pollen white to pinkish. INFRUCTESCENCE pendent; berries obovate, purple, developing in basal portion only, seeds $1-2$, white, oblong. Figs. 49 and 50.

Anthurium clavigerum is found from Nicaragua to the Guianas, Brazil, and Bolivia. In Costa Rica it occurs in premontane wet forest and trop- ical wet forest life zones at sea level to $700 \mathrm{~m}$. In Panama, the species also occurs in premontane moist forest and tropical moist forest. It has also been collected at a reportedly $1,000 \mathrm{~m}$ elevation in what is apparently lower montane wet forest or lower montane rain forest.

This species is not confused with any other in Central America and can be recognized by its pedatisect leaves with sinuate to lobed margins and by its huge pendent inflorescence. The species may have leaf blades to about $2 \mathrm{~m}$ broad making it the largest species of Anthurium in Central America. It is a member of section Dactylophyllium and is most closely related to $A$. sinuatum Benth. ex Schott of South America.

Costa RicA. Alajuela: vicinity Artezalea, NE of Villa Quesada, Molino et al. 17843 (F, NY); between Cañas and Upala, NNE of Bijagua, Croat 36291 (MO); S of Canalete near Río Zapote, Burger \& Baker 9963 (F, MO); vicinity Colonia Blanca, Almeda \& Nakai 4002 (MO); vicinity Volcán Arenal, Lent 2672 (F, MO). LIMón: NE of Bribrí, Croat 43244 (MO); Hacienda Tapezco \& Hacienda La Suerte, W of Tortuguero, $D a$ vidson et al. 7135 (LAM); Donahue 8500 (MO); between Limón and Puerto Viejo, Baker \& Burger 176 (DUKE, F, MO, NY). PUNTARENAS: above Golfito, Burger \& Matta 4770 (F, NY); Playa Blanca Road near Rincón de Osa, Liesner 2153 (MO); SW of Rincón de Osa, Raven 20864 (CAS, NY).

NiCaragua. Río SAN JUAN: near Caño Chontaleño, NE of El Castillo, Neill 3378 (MO). ZELAYA: along Río Escondido, $\mathrm{N}$ of Bluefields, Harmon \& Fuentes 5083 (MO); vicinity Siuna, at Caño Majagua, Neill 1818 (MO); Stevens $6882(\mathrm{MO})$; trail from Cerro Saslaya to San José del Hormiguero, Stevens 7067 (MO); S of bridge at Colonia Agrícola Yolaina on road to Colonia Manantiales, Stevens 4856 (MO); road to Colonia Agrícola Yolaina \& Colonia La Esperanza, Stevens 6363 (MO); along Río Sucio, Stevens 8028 (MO); SW of Río Wawa ferry on road from Puerto Cabezas to Rosita, Stevens 7904 (MO); near Río Okanwás, E of Rosita, Neill 4433 (MO); between Rosita and Puerto Cabezas, Stevens 8501 (MO); NE of Siuna, along CañoMadriguera, Neill 3727 (MO).

Anthurium clidemioides Standl., Publ. Field Mus. Nat. Hist., Bot. Ser. 22: 3. 1940. TyPE: Costa Rica. Alajuela: Villa Quesada, San Carlos, altitude $800 \mathrm{~m}$, Valerio 1726 (F-933729, holotype).

Epiphyte; stem scandent; internodes elongate, 2-15 cm long, 2-3 mm thick, covered with corky, lenticel-like tubercles; cataphylls absent. LEAVES spreading; petioles $2-5.5 \mathrm{~cm}$ long, sheathed half their length or less, the base encircling the stem, narrowly flattened with a medial ridge adaxially, faintly multi-ridged abaxially; geniculum less than 


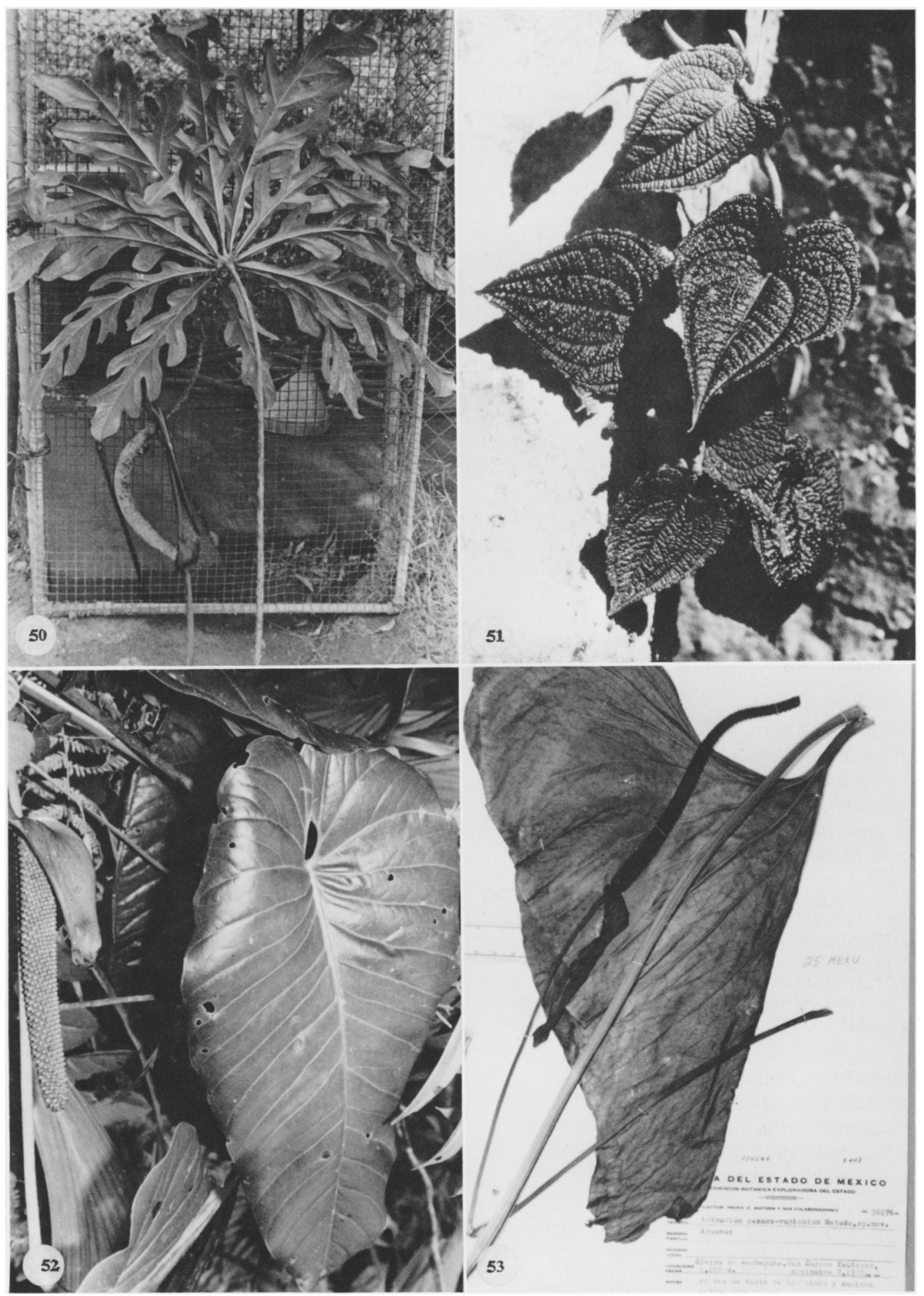

Figures 50-53. 50. Anthurium clavigerum Poepp., Croat 4654.-51. Anthurium clidemioides Standl. Daniels s.n.-52. Anthurium concinnatum Schott, Croat 26493. - 53. Anthurium cordatotriangulum Matuda, Matuda 38276 (Type). 
$5 \mathrm{~mm}$ long, weakly tuberculate; blades ovatecordate, bullate, chartaceous, acuminate at apex, lobed at base, 7-14 $\mathrm{cm}$ long, $4-9.5 \mathrm{~cm}$ wide, broadest $1-2 \mathrm{~cm}$ above point of petiole attachment; the anterior lobe $6-11 \mathrm{~cm}$ long; the posterior lobes rounded, 1-2 cm long; the upper surface matte; basal veins 4-5 pairs, sunken above; the lower surface paler; collective vein arising from the first basal vein. INFLORESCENCE spreading; peduncle obscured by base of spathe or rarely to $5 \mathrm{~cm}$ long; spathe green, lanceolate, ca. $5 \mathrm{~cm}$ long, ca. $1 \mathrm{~cm}$ wide; spadix purplish, $4.2-6 \mathrm{~cm}$ long, 5-7 $\mathrm{mm}$ diam. at base, 3-4 $\mathrm{mm}$ diam. at apex: the flowers rhombic to 4-lobed, $5.3 \mathrm{~mm}$ long, $3.5 \mathrm{~mm}$ wide; $3-5$ flowers visible in the principal spiral, 4-5 flowers visible in the alternate spiral; tepals semiglossy; pistil weakly raised; stigma punctiform, ca. $0.6 \mathrm{~mm}$ diam. INFRUCTESCENCE spreading-pendent; berries orange, obovoid-oblong-ellipsoid, (5)8-9 $\mathrm{mm}$ long, 4-6 $\mathrm{mm}$ wide, drying dark maroon; seeds (1)2-6, obovate-elliptic, flattened, brown or black, $7 \mathrm{~mm}$ long, $3.5 \mathrm{~mm}$ wide. Fig. 51 .

This species is known from the Atlantic and Pacific lowlands of Costa Rica in tropical wet forest from sea level to $800 \mathrm{~m}$ elevation.

Anthurium clidemioides is placed in section Polyphyllium (Croat \& Baker, 1978) and is easily one of the most distinctive species of Anthurium due to its bullate leaves and near absence of a peduncle. In its sterile state, it could be mistaken for species of Piper, Dioscorea, Pilea, or even some Melastomataceae.

Costa Rica. alajuela: San Carlos, Villa Quesada, Valerio 1726 (F). HEREDIA: Finca La Selva, Puerto Viejo, Hartshorn 939 (MO); Moore 9998 (BH); Opler 2091 (F). LIMÓN: Hacienda Tapezco and Hacienda La Suerte, W of Tortuguero, Davidson \& Donahue 8735, 8824 (MO). PUNTARENAS: Corcovado National Park, Liesner 2922 (MO).

Anthurium concinnatum Schott, Prod. Aroid. 522. 1860. Anthurium bogotense Schott var. concinnatum (Schott) Engl., Monogr. Phan. 2: 184. 1879. TYPE: Costa Rica. Cartago: Turrialba, Oersted s.n. (Photo of Schott Aroid Drawing \#709; NYBG Neg. \#N.S. 3905).

Usually epiphytic or sometimes terrestrial; stems to $1 \mathrm{~m}$ or more long, $2.5-4 \mathrm{~cm}$ diam.; internodes obscured by weathering cataphylls; cataphylls coriaceous, 7-15 cm long, drying brown, splitting at base, remaining intact at apex. LEAVES erect to spreading; petioles subterete, weakly and bluntly sulcate, $35-75 \mathrm{~cm}$ long, $0.6-$ $1.2 \mathrm{~cm}$ diam.; geniculum $1.5-3 \mathrm{~cm}$ long; blades subcoriaceous, narrowly ovate, $37-58 \mathrm{~cm}$ long, 21-34 cm wide, abruptly acuminate at apex, deeply lobed at base; the sinus spathulate, the lobes often overlapping; both surfaces glossy; the midrib and primary lateral veins raised above and below, lesser veins prominulous; basal veins to 7 pairs, all basal veins coalesced to $1.5 \mathrm{~cm}$; the collective vein arising from the first basal vein, loop-connecting the primary lateral veins and running to apex. INFLORESCENCE spreading-pendent; peduncle $35-65 \mathrm{~cm}$ long, shorter than petioles; spathe oblong-lanceolate, pale green turning purplish, 8.5-27 cm long, 1.5$5 \mathrm{~cm}$ wide, abruptly cuspidate at apex; stipe to $2.5 \mathrm{~cm}$ long, sometimes arching; spadix green turning purplish, 5-26 cm long, sometimes arched at base, $8-16 \mathrm{~mm}$ diam. at base, 3-8 $\mathrm{mm}$ diam at apex; flowers rhombic; 8-9 flowers visible in the principal spiral, 12 or more flowers visible in the alternate spiral; pistils raised; stamens well exserted, held at the edge of tepals and \pm above pistil; anthers white; thecae brown, persistent, giving spadix spiny appearance. INFRUCTESCENCE pendent; spadix to $30 \mathrm{~cm}$ long; berries orange; mesocarp pulpy, orange with numerous, linear raphide cells; seeds $1-2$ obovoid, $4.3 \mathrm{~mm}$ long, $3.5 \mathrm{~mm}$ wide, pale yellow, indented at base, darker area at apex. Figs. 52 and 54.

The species is found in Costa Rica and possibly also in Colombia and Ecuador at elevations of 2,000 to $3,000 \mathrm{~m}$ in lower montane rain forest. The species grows at higher elevations than any other Anthurium in Costa Rica or Panama.

Anthurium concinnatum is a member of section Belolonchium and is recognized by its large, subcoriaceous, cordate blade and its curved stipe, its persistent, exserted stamens and high altitudinal range. The species usually has long stems that, although sometimes rooted in the soil, are usually leaning on trees for support.

Costa Rica. alajuela: Volcán Poás, Lems s.n. (NY). CARTAGO: Cerro Carpintera, Standley 34416 (US); Cerro de La Muerte, Croat 35378, 35407 (MO); near El Cañón, S of Cartago, Williams et al. 28244 (NY, US); vicinity El Empalme, Almeda \& Nakai 3807 (MO); Almeda 3823 (CAS); Wilbur et al. 16151, 16175 (Duke); Lems s.n. (NY, US); NE of El Retiro, Almeda \& Nakai 3788 (MO); La Estrella, Standley 39515 (US); Irazú National Park, Davidson 8231 (MO); Pittier 4401 (BR); 


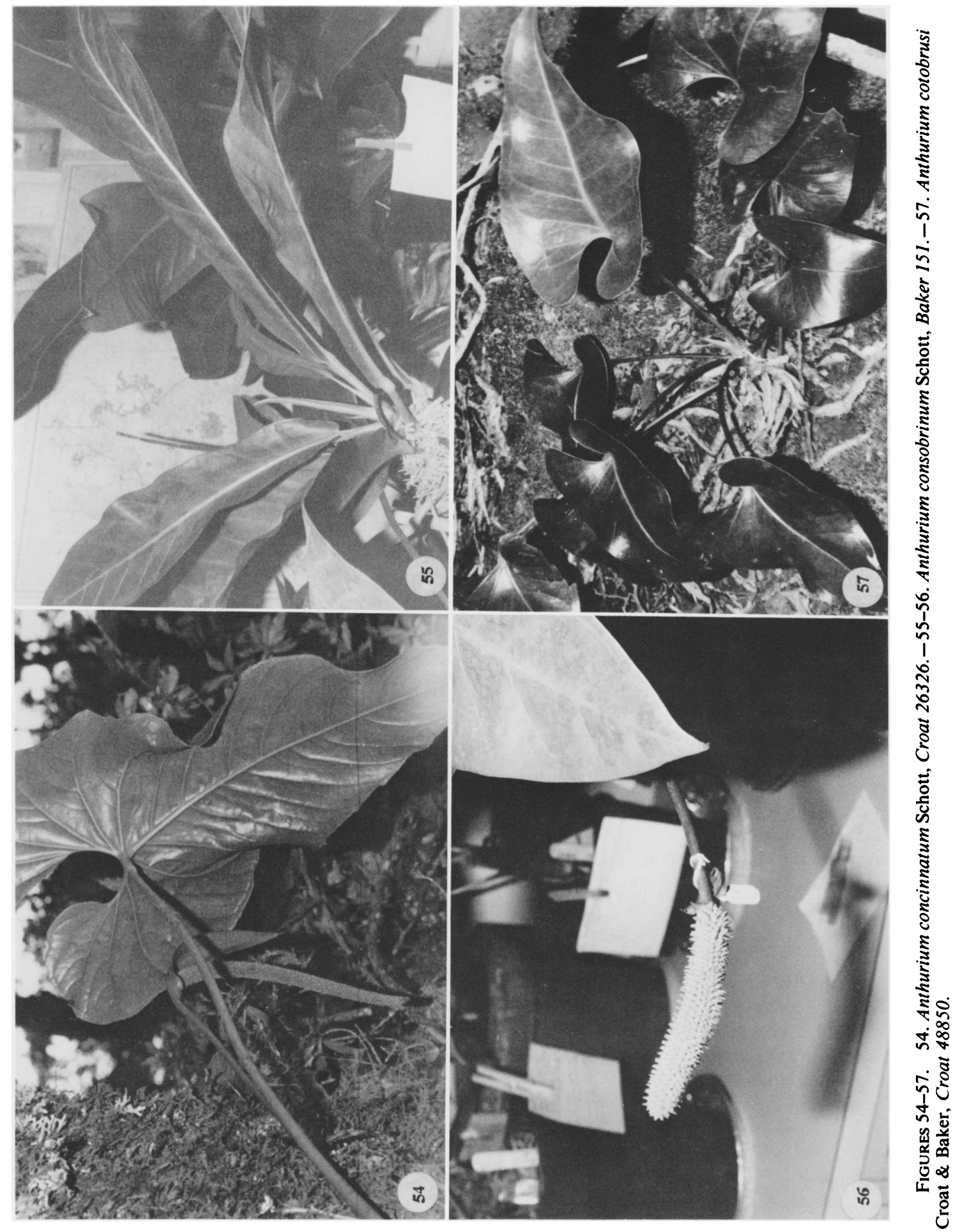


vicinity Poás, Tonduz 10681 (BR). CARTAGo \& SAN JOSÉ BORDER: along Interam Highway, Burger \& Liesner 6479 (F, MO); 7018 (F, NY); Burger \& Baker 9537 (F, DUKE); Luteyn 2975 (DUKE); Raven 20945 (MO); Tablazo, Brade 2537 (BR). HEREDIA: Cerro Caricias, N of San Isidro, Standley \& Valerio 52301 (US); between Cerro Chompipe \& SE slope of Volcán Barba, Baker et al. 238 (F, MO); Volcán Barba, Pittier \& Durand 1345 (BR); Utley 4571, 4572, 4573 (DUKE). PUNTARENAS: vicinity Boruca, Pittier 10483 (BR). SAN JOSÉ: no other location, Jiménez 937 (US); vicinity Aserri, Almeda 3672 (CAS); western ascent to Cerro de la Muerte, Croat 32854, 32892 (MO); near Finca La Cima, N of Copey, Standley 42059, 42636 (US); La Lagunilla, Pittier 10447 (BR, US); NE of Santa María de Dota, Standley 42241 (US); near Vaca \& Chino, Dodge \& Thomas 5422 (MO).

Anthurium consobrinum Schott, Oesterr. Bot. Wochenbl. 5: 66. 1855. TYPE: Nicaragua, Dept. of Río San Juan, Río San Juan, Friedrichsthal s.n. (Photo of Schott Aroid Drawing \#353; NYBG Neg. \#N.S. 3874).

Rosulate epiphyte; stems short, $1.5-2 \mathrm{~cm}$ diam.; roots very dense, short, ascending, narrowly tapered, white to greenish white; cataphylls subcoriaceous, 5.5-15 cm long, caudate-acuminate at apex, drying rusty brown (B \& K Yellow $6 / 2.5$ ), persisting intact, ultimately deciduous. LEAVES erect; petioles broadly sulcate, rounded abaxially, $2.5-9 \mathrm{~cm}$ long, $0.6-1 \mathrm{~cm}$ diam.; geniculum $0.5-2 \mathrm{~cm}$ long; blades oblanceolate, subcoriaceous, 19-64 cm long, 3.5-20 cm wide, abruptly acuminate at apex, acute to narrowly rounded at base; both surfaces matte to semiglossy; the midrib flat at base above, acutely raised toward apex, convexly raised below; primary lateral veins $12-18$ per side, raised above and below, departing midrib at $40^{\circ}-60^{\circ}$ angle, straight to near margin then arching and joining margin; collective vein lacking or arising from one of the primary lateral veins near middle of blade, 5-12 $\mathrm{mm}$ from margin. INFLORESCENCE erect to arching, shorter than leaves; the peduncle 20-43 $\mathrm{cm}$ long, 5-6 $\mathrm{mm}$ diam., several times longer than petioles, terete; spathe linear-lanceolate, subcoriaceous, green, $4.5-7.5 \mathrm{~cm}$ long, $0.8-2.5$ $\mathrm{cm}$ wide, abruptly acuminate at apex, round to truncate at base; spadix greenish-white, turning pinkish-tan, strongly curved, 6-9 $\mathrm{cm}$ long, 1-1.5 $\mathrm{cm}$ diam.; the flowers 4-lobed, $2.7-3.4 \mathrm{~mm}$ in both directions, the sides weakly to jaggedly sigmoid; 11-15 flowers visible in the principal spiral, 15-16 flowers visible in the alternate spiral; tepals matte; the pistil pyramidal and exserted to $2.2 \mathrm{~mm}$; the stigma ellipsoid, $0.5-0.7 \mathrm{~mm}$ long, becoming brushlike; stamens emerging slowly from base of spadix, exserted on fleshy, colorless filaments ca. $1 \mathrm{~mm}$ long, then retracting to surface of tepals; anthers ovate-triangular, white, $0.8-1 \mathrm{~mm}$ long, $0.8-1 \mathrm{~mm}$ wide; thecae narrowly ovate; pollen white. INFRUCTESCENCE pendent; spadix to $13 \mathrm{~cm}$ long; berries translucent, greenish-white with apex reddish to purplish, narrowly acute to prominently beaked, ca. $1 \mathrm{~cm}$ long, $5 \mathrm{~mm}$ wide; mesocarp juicy; seeds 2, greenish-white, oblong-elliptic, 3-3.4 $\mathrm{mm}$ long, ca. $2 \mathrm{~mm}$ wide, $1.5 \mathrm{~mm}$ thick, enveloped in a gelatinous, transparent envelope that extends ca. $1 \mathrm{~mm}$ beyond seed on both ends, broader at apex. Figs. 55 and 56.

The species ranges from Nicaragua to Costa Rica from sea level to $700 \mathrm{~m}$ elevation. It is a common species from tropical wet forest and premontane wet basal belt transition life zones on the Caribbean slope. It is to be expected in Panama in Bocas del Toro Province.

The species is distinguished by its rosulate habit, oblanceolate blades, short sulcate petioles, massive whitish root system, spreading inflorescence with upturned, nontapered spadix, markedly protrudant styles, and berries that are greenish-white at the base and reddish at the apex.

Anthurium consobrinum is probably most closely related to $A$. fatoense of Costa Rica and Panama and differs from that species by its abaxially rounded petioles, by its nearly oblong spadix, and by berry coloration. Anthurium fatoense has a quadrangular petiole, a cylindroid-tapered spadix, and pale yellow or orange berries. $A n$ thurium consobrinum was placed in section $E p$ iseiostenium by Schott but is probably a member of section Pachyneurium.

Costa Rica. no other location, Proctor 32168 (LL); Taylor 11593 (NY). ALAJUELA: vicinity of Bijagua, Almeda \& Nakai 4043 (MO); Burger \& Baker 9857 (DUKE, F, MO, NY); Croat 36264, 36423 (MO); Utley \& Utley 3907 (DUKE, MO); road between Cañas \& Upala near Río Zapote, Croat 36383 (MO); NE of Interamerican Highway toward Upala, Wilbur 20094 (DUKE); west of La Marina, Molina et al. 17329 (NY, US); between Naranjo \& Aguas Zarcas, NE of Quesada, Croat 46949 (MO); Santa María National Park, Liesner 5072 (MO); Zapote, Taylor 18163 (NY); Finca Los Ensayos, NW of Zarcero, Croat 43615 (MO). HEREDIA: near Puerto Viejo, Croat 35671, 35695 (MO); Taylor 4571 (NY); Burger \& Stolze 5934 (PMA); near Tirimbina, E of Río Sarapiquí, Burger \& Burger 8090 (F, MO). LIMÓN: road between Cahuita \& Limón, Baker \& Burger 151 (F, MO); Finca Castilla, Dodge \& Goerger s.n. (MO); Hacienda Tapezco \& Hacienda La Suerte, 
W of Tortuguero, Davidson \& Donahue 6723, 6768, 8413, 8461, 8733 (MO).

NiCARAgUA. RíO SAN JUAN: near Caño Chontaleño, NE of El Castillo, Neill 3332, 3376, 3420, 3421 (MO); Neill \& Vincelli 3622 (MO). ZELAYA: Bluefields, N of Base Camp, Proctor et al. 26913, 27010 (LL, MICH, NY, US); Caño Costa Riquita, SW of Colonia Naciones Unida, Stevens 4966, 5058, 6411, 6412 (MO); Caño Zamora on Río Rama, Stevens 8861 (MO); S of bridge at Colonia Agrícola Yolaina, Stevens 4819, 4826, 6308 (MO); road to Colonia Agrícola Yolaina \& Colonia La Esperanza, Vincelli 166, 168 (MO); Salto La Oropéndola, Stevens 8954 (MO).

Anthurium cordatotriangulum Matuda, Anales Inst. Biol. Univ. Nac. México 36: 109. 1966. TYPE: Mexico. Chiapas: Motozintla; Sierra Madre de Chiapas, El Rosario (ca. $8 \mathrm{mi} \mathrm{S}$ of Motozintla), 1,800 m elev., MacDougall 393 (MEXU, holotype).

Stems short; cataphylls broadly triangular, 5$7 \mathrm{~cm}$ long, drying and weathering into persistent fibers. LEAVES with petiole $50-55 \mathrm{~cm}$ long, 5$8 \mathrm{~mm}$ diam., broadly sulcate, stiff; geniculum 2$3 \mathrm{~cm}$ long; blades broadly ovate-triangular, subcoriaceous, gradually acuminate at apex, broadly lobed at base, 37-64 cm long, 26-46 cm diam., broadest at point of petiole attachment or just below; the anterior lobe $30-44 \mathrm{~cm}$ long; the posterior lobes $11-23 \mathrm{~cm}$ long, directed outward at ca. $45^{\circ}$ angle from petiole; the sinus parabolic to hippocrepiform, round at apex; the midrib raised above and below; basal veins 5 or 6 pairs, the third to sixth coalesced 3-6 cm, raised above and below; primary lateral veins 5 or 6 per side, departing midrib at $60^{\circ}$ angle, \pm straight, usually prominently loop-connected into collective vein in apical half of blade; the collective vein arising from the first basal vein or sometimes from one of the lower primary lateral veins. INFLORESCENCE usually longer than leaves; peduncle subterete, to $57 \mathrm{~cm}$ long, ca. $5 \mathrm{~mm}$ diam.; spathe moderately thick, green, lanceolate, $14-18 \mathrm{~cm}$ long, $2.5-4.5 \mathrm{~cm}$ wide, long-acuminate at apex, rounded and \pm clasping at base; stipe to $15 \mathrm{~mm}$ long in front, $6 \mathrm{~mm}$ long in back; spadix purplish (dried), $10-13 \mathrm{~cm}$ long, $8-10 \mathrm{~mm}$ diam. at base, 4-5 mm diam. at apex; the flowers rhombic, 2.7$3.1 \mathrm{~mm}$ long, $1.5-2.2 \mathrm{~mm}$ wide; 7-9 flowers visible in the principal spiral; tepals weakly punctate; pistils not emergent; stigma 3-3.5 mm long, broadly elliptic; stamens emerging from base and held just above tepals in a tight cluster; thecae oblong-elliptic, scarcely divaricate. INFRUCTESCENCE not seen. Figs. 53 and 58.
Anthurium cordatotriangulum is known for certain only from the southeastern corner of Chiapas near the Guatemalan border in Motozintla and Unión Juárez in the Sierra Madre de Chiapas at 1,800 to $1,900 \mathrm{~m}$ in oak-pine forest. Two other closely related species, $A$. montanum and $A$. chamulense, have been collected at the type locality of $A$. cordatotriangulum. A collection from San Carlos Yautepec in the Sierra de Lacheguia in South Central Oaxaca matches the type of $A$. cordatotriangulum very well but it is difficult to explain the otherwise apparent endemism of this species. (This specimen bears the unpublished herbarium name of $A$. oaxacarupicolum Matuda but since the collection differs in no appreciable way from $A$. cordatotriangulum it will not be recognized here.) The region around San Carlos Yautepec is very arid and nearly devoid of habits for Anthurium. I suspect that the label data referring to San Carlos Yautepec was intended to refer to the municipio of the same name which is very large and no doubt includes good Anthurium habitats in the southern part.

The species is placed in section Belolonchium and is distinguished by its almost deltoid blades, its coarsely elevated basal and primary lateral veins (on drying), broad ovate-lanceolate spathe, and long-tapered, violet-purple spadix. Although Matuda compared the species with $A$. macdougalii ( $A$. andicola), it is perhaps most easily confused with $A$. montanum, which occurs in the same area in southeastern Chiapas, but that species differs in having narrowly ovate blades, scarcely raised veins (on drying), a generally much smaller spathe, and a spadix that is less conspicuously long-tapered.

Mexico. Chiapas: El Rosario, MacDougall 393 (MEXU); Matuda 38628 (MEXU); Volcán Tacaná, Matuda 38626 (MEXU). OAXACA: San Carlos Yautepec, Matuda 38276 (MEXU).

Anthurium cotobrusii Croat \& Baker, Brenesia 16 (Supl. 1): 43. 1979. TyPE: Panama. Chiriquí: above San Felix, along mining road, 18-27 miles off Pan-American Highway (above Chamé on turnoff to Escopeta), elev. 1,200-1,500 m, Croat 33058 (MO2381190-91, holotype; CR, F, NY, US, isotypes; Live at MO).

Terrestrial or sometimes epipetric or epiphytic; stem 1-3 cm diam. usually less than $15 \mathrm{~cm}$ long; roots greenish or grayish-brown, thick and 

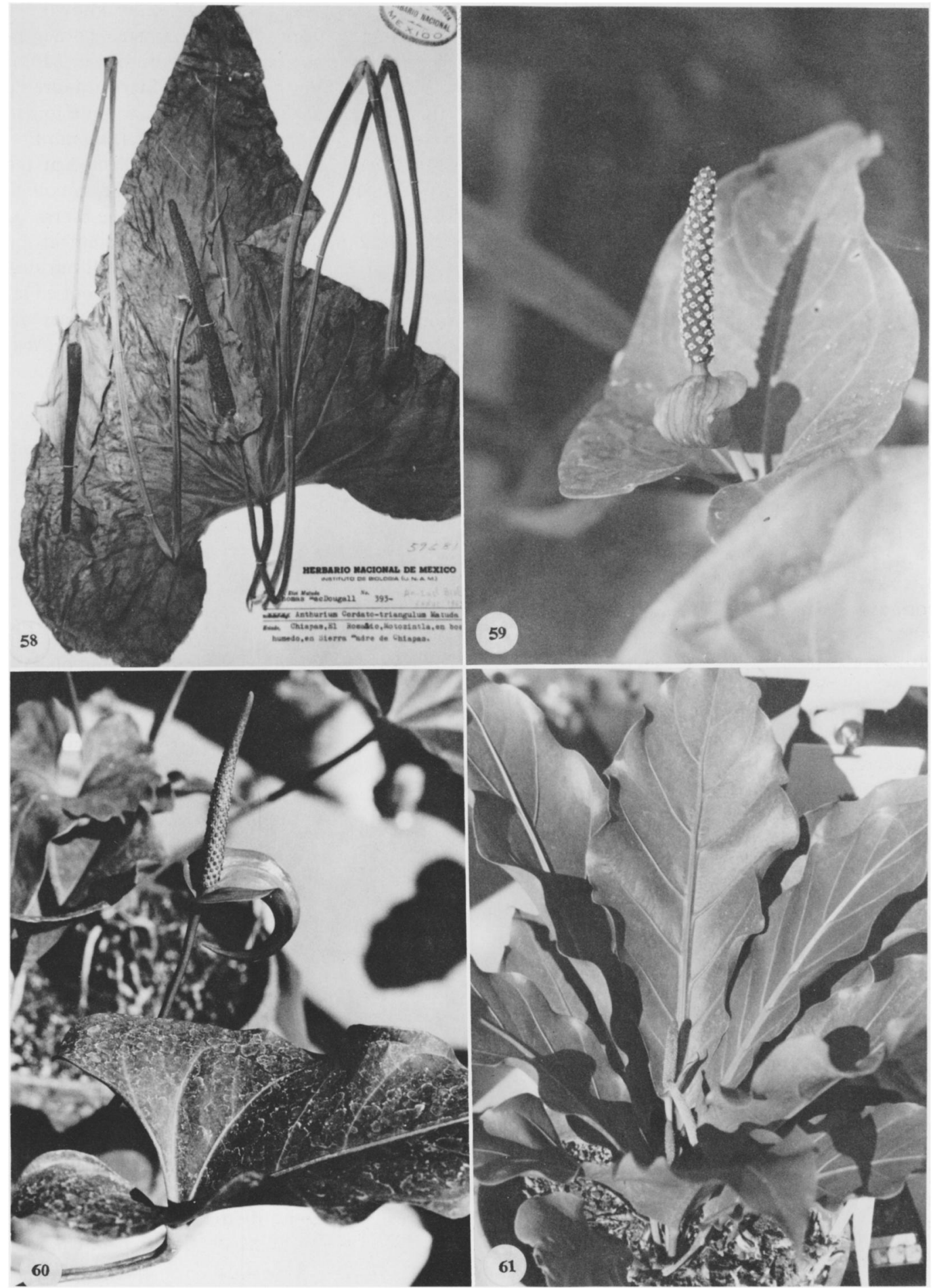

Figures 58-61. 58. Anthurium cordatotriangulum Matuda, MacDougall 393 (Type). -59-60. Anthurium cotobrusi Croat \& Baker, Croat 33058 (Type).-61. Anthurium cubense Engl., Neill 2730. 
smooth, to ca. $6 \mathrm{~mm}$ diam.; cataphylls $9-11 \mathrm{~cm}$ long, green, sometimes tinged purplish, turning tan, ultimately weathering to fine persisting fibers. LEAVES erect-spreading; petioles 15-65 $\mathrm{cm}$ long, 5-7 mm diam., \pm terete, weakly sulcate or flattened; geniculum 1-3 cm long; blades narrowly ovate to triangular, subcoriaceous, narrowly long-acuminate at apex, the acumen often turned down sharply, shallowly and broadly lobed at base, $16-56 \mathrm{~cm}$ long, $9.5-25 \mathrm{~cm}$ wide, widest at the base; the anterior lobe (13) $18-30(37) \mathrm{cm}$ long, the margin \pm straight to convex; the posterior lobes (5)8-11(15) cm long, turning up; the sinus much broader than deep when flattened, obtuse to acute at apex; both surfaces semiglossy; midrib obtusely raised on both surfaces at base, more sharply raised toward apex on upper surface, finally diminishing at apex; primary lateral veins 5-8 per side, weakly to sharply raised (especially toward base) above, weakly raised below, arcuate-ascending; basal veins $3-5$ pairs, 3 or 4 of them coalesced $4-6 \mathrm{~cm}$; posterior rib naked throughout its length, gradually curved to almost straight, turning under; lesser veins less conspicuous; the collective vein arising from the lowermost primary lateral vein, from a primary lateral vein above the middle or from the first basal vein. INFLORESCENCE erect-spreading, shorter to longer than the leaves; peduncles terete, (4.5)20-46 cm long; spathe green, pale green, or green with purplish veins or heavily suffused with purple on inner surface, sometimes tinged purple only at base medially, ovate to narrowly ovate, (2.5)5-9.5(12) cm long, (1.7)2.7-4.5 cm wide, weakly boat-shaped to flat, acuminate at apex, acute to rounded or shallowly cordate at the base, inserted at $60^{\circ}-70^{\circ}$ angle on peduncle; stipe green or green tinged with purple, 10-20 $\mathrm{mm}$ long in front, 2-6 $\mathrm{mm}$ long in back; spadix green to dark purple-violet at anthesis, (2.5)5$25 \mathrm{~cm}$ long, 7-15 mm diam. at base, 3-7 mm diam. at apex, with a pungent, sweet scent when droplets are fresh; flowers sub-4-lobed, $3.5-5 \mathrm{~mm}$ long, $3.5-4 \mathrm{~mm}$ wide, sometimes ca. $3.5 \mathrm{~mm}$ in both directions; 3-6 flowers visible in the principal spiral, 7-10 flowers visible in the alternate spiral; tepals dark violet-purple or yellow-green with purple margins, sparsely punctate, more densely so near margins, semiglossy to matte, the inner margins broadly convex; pistil green; stigma linear, purple-violet or green, ca. $0.6 \mathrm{~mm}$ long, forming conspicuous droplets for $1-3$ weeks before emergence of stamens, droplets persisting when the first and second stamens are opening; stigma drying and covered by thecae when third and fourth stamens are emerged; stamens weakly exserted in a close circular cluster; anthers orange to yellowish, held just above the tepals, 0.6-0.9 $\mathrm{mm}$ long, $1 \mathrm{~mm}$ wide; filament short, retracting; pollen pale orange, fading white. INFRUCTESCENCE erect-spreading; berries pale orange (B \& K Yellow-red 8/7.5), obovoid, 12-15 mm long, 8-11 mm diam., rounded at apex, the apex darker, depressed with 4 short, slightly elevated ridges; mesocarp juicy, orange; seeds usually 2 , oblongelliptic, $6.5-7.5 \mathrm{~mm}$ long, $2.5-4 \mathrm{~mm}$ wide, encased in a flattened, translucent envelope that projects up to $3 \mathrm{~mm}$ beyond the apex of the seed and up to $1 \mathrm{~mm}$ beyond the lateral margins. Figs. 57,59 , and 60 .

Anthurium cotobrusii is found in Costa Rica and Panama in premontane wet forest at elevations of 1,000 to $1,500 \mathrm{~m}$.

This species is most easily distinguished by its subcoriaceous leaves which have more or less obscure reticulate veins when fresh but have conspicuous reticulate veins when dry, and by its prominently tapered, violet-purple spadix with a tight cluster of stamens. In a dried state the flowers have their tepals turned somewhat upwards, which, in conjunction with the clustered stamens, gives the spadix a rough appearance. Other diagnostic features are the primary lateral veins often free to the margin in the basal half of the blade, the thick, grayish roots that are densely long-pubescent on drying and the early emergent berries that are quadrangular with prominent ridges radiating from the center to the corners.

The species is now placed in section Belolonchium. It was erroneously placed previously in the section Cardiolonchium by Croat and Baker, 1980. It is most easily confused with $A$. ranchoanum, which has similar leaves, but the latter has a short cylindroid, scarcely tapered spadix that is usually nodding and hooded by the spadix when in flower (the spathe remaining erect in fruit). In contrast, A. cotobrusii has an erect, prominently tapered spadix and a prominently reflexed spathe. In addition, the berries of $A$. ranchoanum are smoothly rounded at apex.

Costa Rica. PUntarenas: above coffee fincas along Río Coto Brus, near Cotán, $\mathrm{N}$ of La Unión (on Panama border), Croat 26674 (MO).

Anthurium cubense Engl., Bot. Jahrb. Syst. 25: 364. 1898. TYPE: Cuba. Ad Monte Toro, alt. 
300 m, Eggers 5402 (K, holotype; B, isotype).

Epiphytic or terrestrial; to $40 \mathrm{~cm}$ tall; stem short, to $3 \mathrm{~cm}$ diam.; roots green, pubescent at base, to $8 \mathrm{~mm}$ diam., ascending at upper nodes; cataphylls subcoriaceous, to $6 \mathrm{~cm}$ long, drying brown, remaining \pm intact and persisting between leaves. LEAVES rosulate, erect; petioles 5-10 cm long, 5-11 mm diam., subterete or obscurely quadrangular, broadly sulcate; geniculum 0.5-1 cm long, sometimes tinged purplish; blades oblanceolate-elliptic, subcoriaceous, gradually acuminate at apex, obtuse to narrowly rounded at base, $26-83 \mathrm{~cm}$ long, $9-25 \mathrm{~cm}$ wide; the upper surface semiglossy; the midrib bluntly raised above and below; primary lateral veins 6-7 per side, raised above and below; lesser veins less conspicuous. INFLORESCENCE erect; peduncle 8-16 cm long, 5-6 mm diam., terete, green suffused with violet; spathe subcoriaceous, subovate, olive green, tinged with violet-purple at margins, $2.5-16 \mathrm{~cm}$ long, $0.6-5 \mathrm{~cm}$ wide; spadix weakly ellipsoidal, $5.5-10 \mathrm{~cm}$ long, $0.8-1 \mathrm{~cm}$ diam. midway, white or lavender (B \& K Purple 6/7.5); flowers rhombic or weakly 4-lobed, 2.1$2.5 \mathrm{~mm}$ long, 2.4-2.6 mm wide, the sides weakly sigmoid; 9-12 flowers visible in the principal spiral, 14-16 flowers visible in the alternate spiral; tepals matte, lateral tepals $1.2-1.4 \mathrm{~mm}$ wide; pistil weakly raised, greenish; stigma linear to 0.4 $\mathrm{mm}$ long; stamens emerging in scattered pattern throughout, the lateral stamens emerging almost to the apex before third or alternates emerge, held just above tepals against pistil, obscuring pistil when all stamens develop; anthers white tinged red-violet; thecae oblong; pollen white. INFRUCTESCENCE spreading; berries red, oblong-elliptic, 9-12 $\mathrm{mm}$ long, 4.5-6 $\mathrm{mm}$ wide; seeds 1 or 2, 5-5.5 $\mathrm{mm}$ long, $3 \mathrm{~mm}$ wide. Figs. 61 and 62 .

Anthurium cubense is found in Cuba, Yucatan, and drier parts of eastern Guatemala on the Atlantic slope; also Nicaragua to Panama along the Pacific slope. The species is also known from northern Colombia and Venezuela. It is known from tropical dry forest and drier parts of tropical moist forest at low elevations. The species is apparently rare except in Nicaragua where it is locally common.

Anthurium cubense is placed in section Pachyneurium and is recognized by its short petioles, short inflorescences (much shorter than the leaves; the peduncle as short as or only slightly longer than the spadix), its cylindroid, pale violet-purple spadix usually weakly tapered toward both ends, and its bright red berries.

Engler (1905) also recognized material of this species under the name $A$. recussatum Schott from Cuba. That name, however, has been misapplied and actually refers to $A$. hookeri Kunth from the Lesser Antilles and northeastern South America. Anthurium hookeri is not related to A. cubense, although it has a similar rosulate habit. It differs chiefly in having punctate leaves with unusual scaliform secondary veins and by having supervolute vernation.

Costa Rica. Guanacaste: S of Peñas Blancas, Liesner 4652 (MO). PUNTARENAS: vicinity of Cabo Blanco Nature Reserve, Burger \& Liesner 6627 (F, MO).

GuATEMAla. Alta verapaz: Cubilhuitz, Tuerckheim 8606 (US).

Nicaragua. Chontales: S of Acoyapa, Nichols 1725 (MO); N of Cuapa, Stevens 3662, 6107 (MO); Vincelli 86, 87 (MO). GRANADA: NE side of Volcán Mombacho, Atwood \& Neill AN82 (MO); Neill 2730 (MO). MANAGUA: vicinity of Managua, Maxon et al. 7538 (US). MASAYA: Volcán Masaya National Park, Stevens 4444 (MO). RIVAS: Isla de Ometepe on Volcán Masearas near Santa Cruz, Stevens 6626 (MO). zelayA: along Caño Majagua, Stevens 6894 (MO).

Anthurium cuneatissimum (Engl.) Croat, comb. nov. Anthurium consobrinum var. cuneatissimum Engl., Pflanzenr. IV 23B: 176. 1905. TYPE: Costa Rica. Limón: Llanuras de Santa Clara, 250 m, Donnell Smith 6811 (B, holotype; US, isotype).

Epiphyte; stems very short; roots dense, descending, fuzzy (dried), ca. $3 \mathrm{~mm}$ thick; cataphylls coriaceous, 6-9 cm long, acuminate at apex, drying tan (B \& K Red 9/10), weathering into longitudinal fibers. LEAVES erect-spreading; petioles usually quadrangular with sharp edges, sometimes bluntly angular abaxially, often with a sharp medial rib abaxially, 6-32(40) cm long, 5-7 mm wide; geniculum $0.8-2.5 \mathrm{~cm}$ long; blades obovate-elliptic, subcoriaceous; (20)25-60 cm long, $8.5-21 \mathrm{~cm}$ wide, long-acuminate at apex, acute to cuneate at base; upper surface semiglossy to glossy, lower surface semiglossy; the midrib broad, scarcely raised above, sometimes with a weak medial rib, narrowing and sunken at apex, prominently raised below, sometimes with 1-2 sharp ribs; primary lateral veins (5)1015 per side, departing midrib at $30^{\circ}-40^{\circ}$ angle, \pm straight to collective vein or weakly arcuateascending, raised in shallow valleys above, raised 


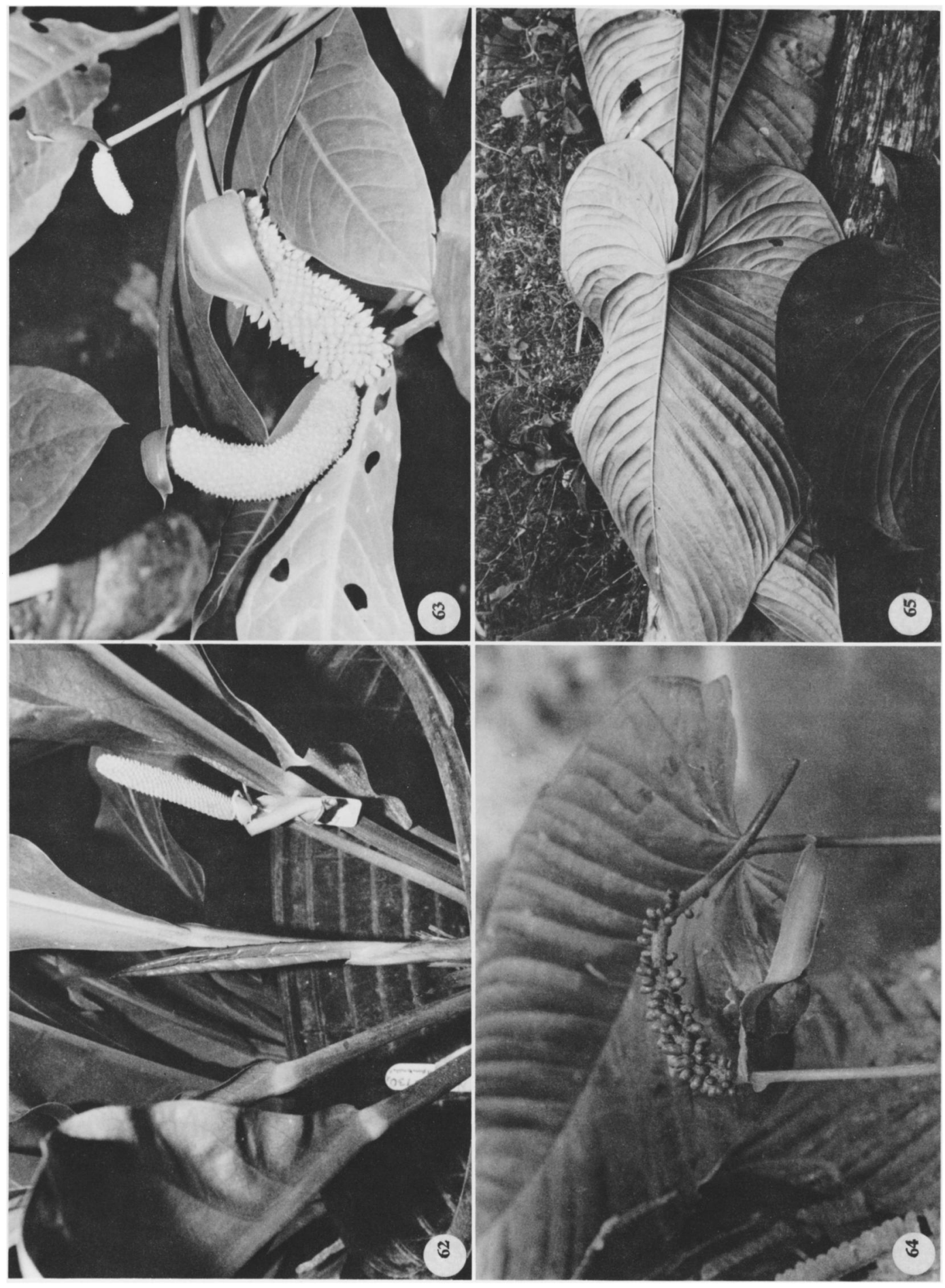

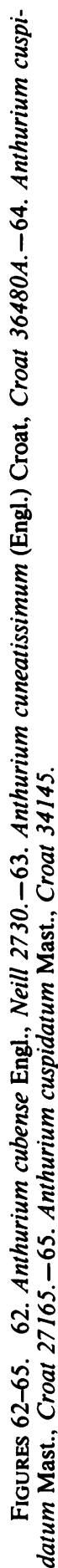


below; lesser veins flat above, flat and conspicuous below; collective vein arising from one of the primary lateral veins, $1-3 \mathrm{~mm}$ from the margin. INFLORESCENCE erect-spreading, usually shorter than leaves; peduncle 21-58 $\mathrm{cm}$ long, sharply 1-ribbed abaxially, 2-4-ribbed from base to just above middle; spathe ovate, cucullate, dark green, coriaceous, 2.5-6(9) cm long, 2.1-4 $\mathrm{cm}$ wide, abruptly to gradually acuminate at apex, rounded to truncate at base, inserted at $50^{\circ}-70^{\circ}$ angle on peduncle; spadix sessile, clavate, pale yellow-green or lemon-yellow, $1.9-5 \mathrm{~cm}$ long, $\mathrm{ca}$. $8 \mathrm{~mm}$ diam. midway, weakly tapered at base, round at apex; flowers 4-lobed, 1.6-2.2 mm long, 2-2.5 mm wide, the sides jaggedly sigmoid; $16-$ 20 flowers visible in the principal spiral, 13-16 flowers visible in the alternate spiral; tepals matte, conspicuously papillate, lateral tepals $0.6-0.9 \mathrm{~mm}$ wide, the inner margin straight to convex and turned up against pistil; the pistil emergent to $0.5 \mathrm{~mm}$, white to pale greenish-white; stigma brushlike, ca. $0.2 \mathrm{~mm}$ long, with small droplets ca. 2 weeks before drying, 2-3 days before first stamens emerge; lateral stamens emerging simultaneously on all flowers, soon followed by third and fourth stamens, exserted on long, whitish filaments, $0.3-1 \mathrm{~mm}$ long, $0.2-0.3 \mathrm{~mm}$ wide, which slowly retract holding anthers in a tight circle around and above pistil; anthers pale yellow, 0.3-0.4 $\mathrm{mm}$ long, 0.5-0.6 mm wide; thecae ellipsoid; pollen pale yellow fading to white. INFRUCTESCENCE with spadix 5-11 cm long; berries obovoid, greenish-yellow to white, 4-4.3 $\mathrm{mm}$ long, $2.5 \mathrm{~mm}$ thick, sharply pointed at apex; seeds 2. Fig. 63.

Anthurium cuneatissimum is known from the Atlantic slopes in Costa Rica and Panama in tropical wet forest life zones from 20 to $450 \mathrm{~m}$ elevation in Costa Rica and at much higher elevations of 800 to $1,000 \mathrm{~m}$ in Panama.

The species is in section Pachyneurium and is distinguished by its long, usually quadrangular, sharply margined petiole, broad leaf blade, cupulate, coriaceous, ovate spathe, short clavate, lemon-yellow spadix, and white obovoid berries.

It is confused only with $A$. spathiphyllum, which shares a similar short clavate, sometimes yellowish spadix. That species differs, however, in having much narrower leaves with 20-30 prominently sunken primary lateral veins (versus (5) 10 15 scarcely sunken veins for $A$. cuneatissimum), commonly 3 -sided petioles, and a spathe that is lanceolate to broadly lanceolate and about twice as long as the spadix (versus ovate and about as long as the spadix for $A$. cuneatissimum).

This species was not distinguished in the treatment of the genus Anthurium for Costa Rica (Croat \& Baker, 1979) even though we initially had material separated along these lines before finding that the 3-sided versus 4-sided petiole character breaks down. Special thanks go to Michael H. Grayum (University of Massachusetts) for pointing out additional characters that made their separation possible.

Costa Rica. alajuela: NNE of Bijagua, Burger \& Baker 9820 (MO); Croat 36275; 36296; 36454; 36480A (MO). HEREDIA: near Puerto Viejo along road near Río Sucio, Croat 35751 (MO).

Anthurium cuspidatum Mast., Gard. Chron. 3: 428. 1875. TYPE: Colombia? Hort. Vietch., January $1875(\mathrm{~K})$.

Anthurium talamancae Engl., Bot. Jahrb. Syst. 25: 386. 1898. TYPE: Costa Rica. Limón: Talamanca, near Shirores, $100 \mathrm{~m}$, Tonduz 9233 (B, hololectotype, designated Croat \& Baker, 1979).

Anthurium donnellsmithii Engl., Bot. Jahrb. Syst. 25: 389. 1898. TYPE: Costa Rica. Limón: Río Jiménez, Llanos de Santa Clara, 280 m, April 1894, $J$ Donnell Smith 4979 (B, holotype; US, isotype).

Anthurium orteganum Engl., Bot. Jahrb. Syst. 25: 387. 1898. TYPE: Colombia. Cauca: near Popoyán, 1,500-1,700 m, Lehmann 5989 (B, holotype; F, $\mathrm{K}$, isotypes).

Anthurium johnii Engl., Pflanzenr. IV 23B: 119. 1905. TYPE: Costa Rica. Limón: Suerre, Llanos de Santa Clara, 300 m, J Donnell Smith 6812 (B).

Epiphyte or terrestrial; stems often to $50 \mathrm{~cm}$ long, ca. $3 \mathrm{~cm}$ diam.; internodes short; cataphylls $7-15 \mathrm{~cm}$ long, subcoriaceous, drying pale reddish-brown, weathering into fibers. LEAVES erect-spreading; petioles terete, $30-118 \mathrm{~cm}$ long, 4-12 mm diam.; geniculum 2-3 cm long; blades usually ovate-oblong, sometimes narrowly ovate, moderately chartaceous, abruptly acuminate at apex, truncate to subcordate to rarely prominently lobed at base, $25-62 \mathrm{~cm}$ long, $11-40 \mathrm{~cm}$ wide; the sinus (when blade is lobed) hippocrepiform to spathulate; midrib convexly raised above and below; primary lateral veins $11-15$ per side, sunken above, raised below, often reddish beneath; lesser veins sunken above, raised below; collective vein arising from one of the lowermost basal veins, sunken above, raised below, 1-2 mm from margin. INFLORESCENCE erect-spreading, shorter than or equal to the leaves; peduncle 28-46 cm long, terete; spathe membranaceous, 
oblong-lanceolate, pale green, sometimes tinged purple, $7.5-18 \mathrm{~cm}$ long, $1.8-2.5 \mathrm{~cm}$ wide, gradually acuminate at apex, round at base; spadix green to usually dark violet-purple, $6.5-18 \mathrm{~cm}$ long, ca. $5.5 \mathrm{~mm}$ diam. at base, $4.5 \mathrm{~mm}$ diam. at apex; flowers rhombic, 3.5-3.8 mm long, 2.8$3 \mathrm{~mm}$ wide, the sides straight to weakly sigmoid; 4-5 flowers visible in the principal spiral, 5-6 flowers visible in the alternate spiral; tepals glossy; pistils weakly emergent, violet-purple; stigma linear, ca. $0.5 \mathrm{~mm}$ long; stamens emerging in scattered manner from base, the basal one quarter of spadix with 4 stamens before those in the apical one half emerge, held in tight contiguous cluster obscuring pistil; anthers violet-purple; thecae oblong, scarcely divaricate; pollen pale purple fading to white. INFRUCTESCENCE pendent; spadix to $27 \mathrm{~cm}$ long; berries purpleviolet to reddish-violet, ovoid-ellipsoid, 6-8 $\mathrm{mm}$ long, ca. $5.3 \mathrm{~mm}$ wide. Figs. 64 and 65 .

The species is found from Nicaragua to Ecuador at elevations from 400 to 1,700 m or rarely lower in very wet areas, in premontane wet, tropical wet, premontane rain, and lower montane rain forest life zones. It is one of the more common species of Anthurium.

Anthurium cuspidatum is distinguished by its thin, usually oblong-ovate blades with many veins (these often drying reddish-brown or with purplish splotches on the blade) and by its long, slender, weakly tapered, violet-purple spadix and early exserted, oblong berries that are exserted a long time before they ultimately ripen red. An unusual feature not previously seen on any other Anthurium is exhibited by Croat 25605 . In that specimen the uppermost roots were subtended by and enveloped in cataphylls.

Anthurium cuspidatum was placed in section Polyneurium by Engler but has since been shown to be an atypical member of section Pachyneurium because of its involute vernation. It is superficially close to A. williamsii of Costa Rica, Panama, and northwestern South America, with which it shares a nearly identical inflorescence and similar thin, veiny leaves. Anthurium williamsii, in section Polyneurium, differs in having supervolute vernation and a more ovate blade with more basal veins that are free or nearly free to the base. Anthurium cuspidatum is quite variable in leaf shape with blades sometimes ovate, similar to $A$. williamsii, but when this is the case,
A. cuspidatum can be distinquished by having a definite posterior rib (coalesced basal veins).

Anthurium cuspidatum has a number of sibling species in the coastal and sub-Andean portions of Colombia and Ecuador. Many of these species may prove to be synonymous but others have radically different inflorescences while sharing similar leaf blades with numerous primary lateral veins. Included in the complex are $A$. monticolum Engl., A. longicaudatum Engl., A. oreophilum Sodiro, and others.

Costa Rica. Alajuela: NNE of Bijagua, Croat 36258 , 36312 (MO); road from Cariblanco to Lake Hule, Baker et al. 224 (F, MO); Finca Los Ensayos, NW of Zarcero, Croat 43590 (MO); E rim of Lake Hule, Luteyn 3353 (MO); between Naranjo and Aguas Zarcas, Croat 46958 (MO); N of Río Naranjo along road to Upala, Utley \& Utley 5343 (DUKE); San Carlos, Smith 1658 (MO); between Volcán Poás and Volcán Barba, Croat 35466 (MO). CARTAGO: road between Juan Vinas and Turrialba, Croat 36830 (MO); road between Moravia to Quebrada Platanillo, Croat 36653, 36673 (MO); along Río Grande de Orosi between bridge and Tapantaí, Gentry 976 (MO); between Trinidad and Coliblanco, Utley \& Utley 2724 (MO). HEREDIA: vicinity Bajo La Hondura, Croat 44511 (MO); S of Cariblanco, Croat 35776 (MO); near Puerto Viejo, along road near Río Sucio, Croat 35694, 35763 (MO); near Río Pará Blanco, Lent 2856 (MO); N of Vara Blanca, Croat 35607 (MO). LIMÓN: Hacienda Tapezco-Hacienda La Suerte, W of Tortuguero, Davidson 6746, 6991 (MO); between Siguerres and Limón, Baker 185 (F, MO); Burger et al. 10522 (F, MO); SW of Siguerres, Utley \& Utley 5445 (DUKE); Talamanca, Pittier \& Tonduz 9233 (BR, US); between Turrialba and Limón, Croat 43307 (MO). SAN JOSÉ: slopes above Alfombra along road from San Isidro del General to Dominical, Burger \& Baker 10094 (F, MO); Burger \& Visconti 10677 (F, MO); Bajo La Hondura, Utley \& Utley 4997 (DUKE, MO); between Río Cascajal and Río Hondura, Lent 3785 (MO); between San Isidro del General and Dominical, Croat 35321 (MO).

Nicaragua. matagalpa: Cerro Musún, Neill 1815 (MO). Río SAN JUAN: near Caño Chontaleño, NE of El Castillo, Neill 3426 (MO).

Anthurium davidsoniae Standl., Publ. Field Mus. Nat. Hist., Bot. Ser. 22: 4. 1940. TYPE: Panama. Chiriquí: Bajo Chorro, Boquete District, 1,800 m, 17 January $1938, M . E . D a-$ vidson 134 (F 915728, holotype; MO, US, isotype).

Usually terrestrial, rarely epiphytic; stems elongate, less than $1 \mathrm{~cm}$ diam.; internodes short at apex, longer in lower portion of stem; cataphylls moderately thick, to $12 \mathrm{~cm}$ long, drying reddish-brown. LEAVES \pm erect; petioles shallowly sulcate with sharp marginal ribs adaxially, 
13-27 cm long, 2.5-3.5 mm wide; blades ovate to narrowly ovate, \pm chartaceous, usually conspicuously bullate, $15-23 \mathrm{~cm}$ long, $9.5-15.5 \mathrm{~cm}$ wide, long-acuminate at apex, shallowly and broadly lobed at base; the upper surface pale green, the lower surface slightly paler; the midrib narrowly raised; primary lateral veins $10-12$ per side, sunken, straight or weakly arched to collective vein; collective vein arising from the first or second basal vein, 6-8 $\mathrm{mm}$ from margin. INFLORESCENCE erect, shorter than leaves; peduncle 9-19 cm long; spathe lanceolate, pale green, 3-5 cm long, 5-10 mm wide; spadix pale yellow-green, 2-4 $\mathrm{cm}$ long, 5-7 $\mathrm{mm}$ diam. at base, 2-3 mm diam. at apex; flowers rhombic to 4-lobed, 2.3-2.7 mm long, 2.7-3 mm wide; 3-5 flowers visible in the principal spiral, 4-7 flowers visible in the alternate spiral; tepals matte, lateral tepals 1-1.2 $\mathrm{mm}$ wide; pistil emergent, green; stigmas exserted, brushlike; stamens emerging but may retract (not evident on dry specimens). INFRUCTESCENCE with spadix $3.5-6 \mathrm{~cm}$ long; berries greenish-yellow; mesocarp syrupy; seeds obovoid, yellow-green, darker at apex with numerous raphide cells visible on the surface. Fig. 70 .

Anthurium davidsoniae is known from Costa Rica and western Panama, from 1,300 to 2,000 $m$ elevation in premontane rain and lower montane rain forest.

The species is related to both $A$. pallens and $A$. microspadix, although more closely to the latter. All of these species share a similar habit with elongate stems and a similar inflorescence. $A n$ thurium davidsoniae differs from both others by having a much broader, more ovate, more conspicuously bullate leaf blade.

All three of the above species occur in similar cloud forest habitats and evaluation of herbarium material alone is unsatisfactory in separation considering the variability of Anthurium. Field observations have convinced me, however, that they are all good species. Anthurium davidsoniae and $A$. microspadix are both semi-erect plants and are usually terrestrial but require something to lean on for support. Anthurium pallens is usually a pendent epiphyte. Anthurium davidsoniae is placed in section Xialophyllium in an alliance I refer to as the A. microspadix alliance. This group, which differs substantially from other members of section Xialophyllium such as A. caucanum Engl., may ultimately have to be considered a separate section. All species in the group share thin, prominently veined, often bullate leaves, elongate slender stems, and commonly green inflorescences and fruits.

COSTA RICA. ALAJUELA: no other location, Smith 1123 (NY); Zarcero, Smith 431 (MO). CARTAGO: vicinity Orosí, Standley 39928 (US); S of Tapantí, Burger \& Burger 8434 (F, MO, U). GUANACASTE: no other location, Primack et al. 433 (DUKE). HEREDIA: N of Vara Blanca, Croat 36023 (MO); Skutch 3644 (MICH, MO, NY). PUNTARENAS \& alajuela: Monteverde reserve, Burger \& Baker 9734 (F, MO). SAN JOSÉ \& HEREDIA: Cerro Zurquí, Almeda 3687 (CAS). SAN JOSÉ: NW of Cascajal, Taylor 11303 (NY).

Anthurium durandii Engl., Bot. Jahrb. Syst. 25: 401. 1898. TYPE: Costa Rica. Inter la Division et l'Alto del Palmital, January 1891, Pittier 3868 (B, hololectotype; BR, CR, isolectotypes, designated Croat \& Baker, 1979).

Anthurium littorale Engl., Bot. Jahrb. Syst. 25: 405. 1898. TYPE: Costa Rica. Marais de Sierpe, March 1892, Pittier 6837 (BR, holotype; CR, isotype).

Epiphytic or rarely terrestrial; stems short; internodes sometimes to $3 \mathrm{~cm}$ long; roots short, sometimes purplish; cataphylls moderately thin, $5.4-6 \mathrm{~cm}$ long acuminate at apex, drying pale brown, weathering to reticulate fibers, ultimately deciduous. LEAVES erect-spreading; petioles 9$25 \mathrm{~cm}$ long, 4-5 mm diam., broadly and sharply sulcate adaxially, rounded abaxially, sparsely, dark glandular-punctate; geniculum $1.5-3 \mathrm{~cm}$ long; blades elliptic, coriaceous, short-acuminate at apex, obtuse at base, $10-31 \mathrm{~cm}$ long, $4-15 \mathrm{~cm}$ wide, broadest near middle; both surfaces matte, dark glandular-punctate, the lower surface paler, the upper surface drying with an alveolate pattern; midrib convexly raised at base above, acute at middle, weakly sunken toward apex, convexly raised below, narrowing toward apex; primary lateral veins $8-15$ per side, departing midrib at $45^{\circ}$ angle, straight to collective vein, flat to weakly sunken above, raised below, lesser veins obscure; collective vein arising from the base, 9$15 \mathrm{~mm}$ from the margin, a secondary collective vein sometimes extending to about the middle of the blade. INFLORESCENCE spreading, shorter than or equalling leaves; peduncle 12-40 $\mathrm{cm}$ long, ca. $3 \mathrm{~mm}$ diam.; spathe moderately thin, pale green to pinkish green (B \& K Yellowgreen 7/7.5), oblong-lanceolate, 4-7 cm long, 1$1.5 \mathrm{~cm}$ wide, broadest near the base, abruptly acuminate at apex, acute at base, inserted at ca. 


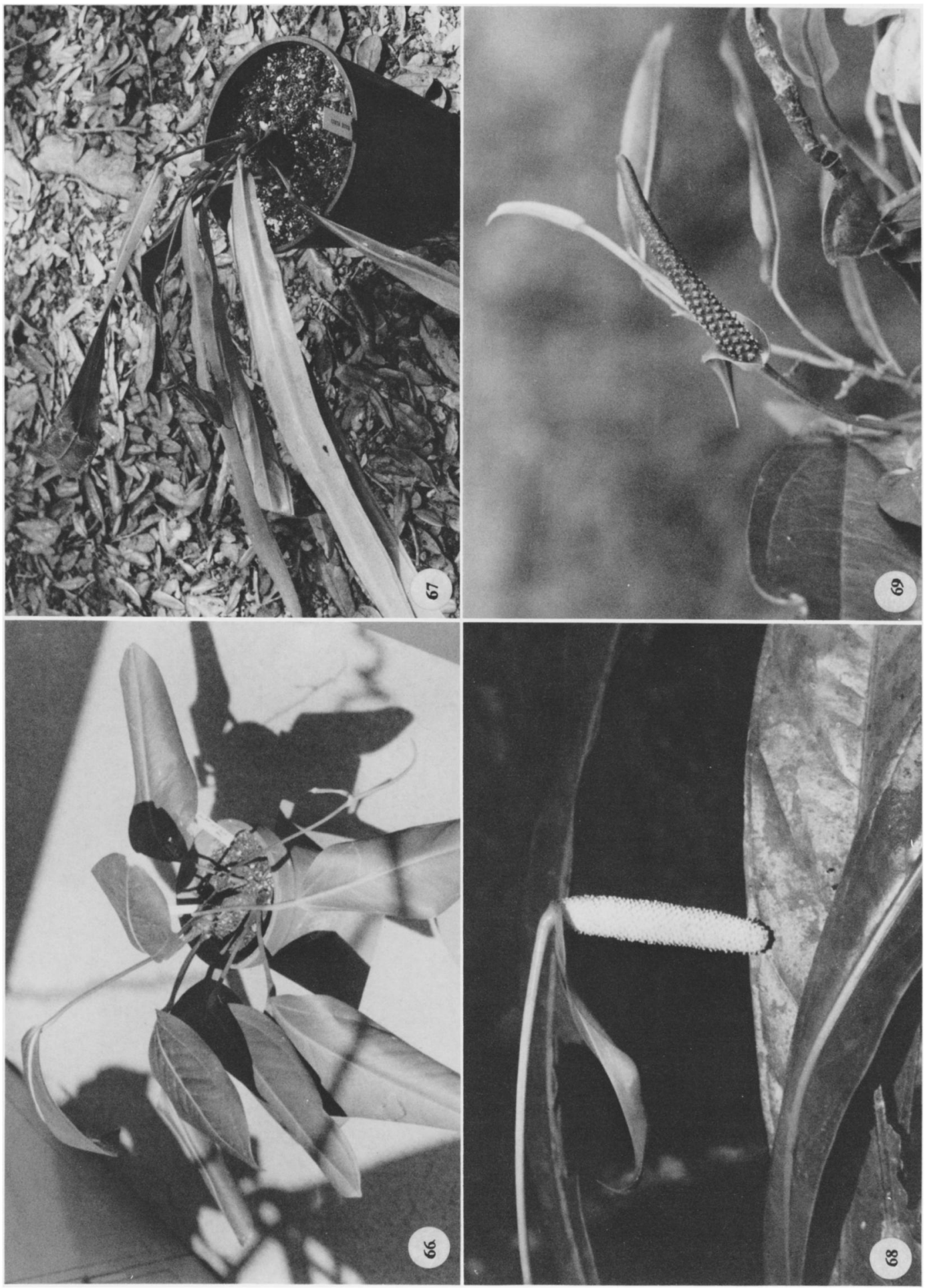

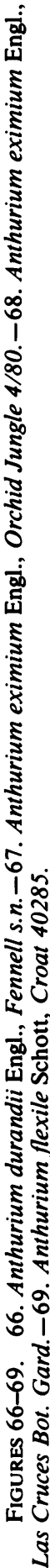




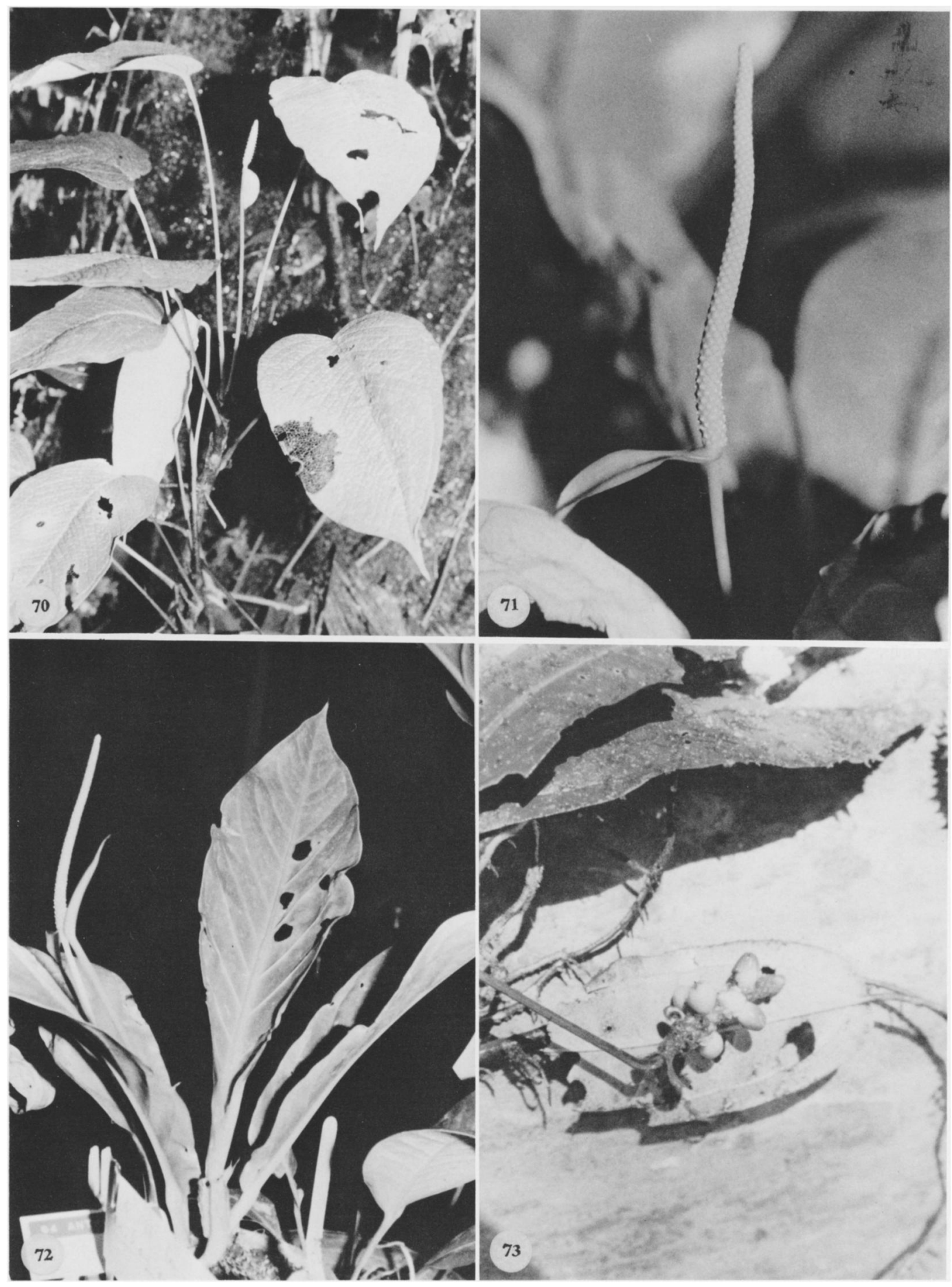

FIGURES 70-73. 70. Anthurium davidsoniae Standl., Croat 48592. -71-72. Anthurium fatoense K. Krause, Folsom 2949.-73. Anthurium flexile Schott, Croat 36467. 
$65^{\circ}$ angle on peduncle; spadix pale green turning reddish brown, narrowly tapered toward apex, 10-16.5 cm long, 4-9 $\mathrm{mm}$ diam. at base, 2-4 $\mathrm{mm}$ diam. at apex; flowers 4-lobed, 3-4 $\mathrm{mm}$ long, $2.5-3 \mathrm{~mm}$ wide, the sides straight in the direction of the principal spiral, sigmoid perpendicular to the spiral; ca. 3 flowers visible in the principal spiral, ca. 5 flowers visible in the alternate spiral; tepals semiglossy, lateral tepals 1.8$2.2 \mathrm{~mm}$ wide, the inner margin convex; pistils emergent but not raised, square, green; stigmas scarcely visible, ca. $0.2 \mathrm{~mm}$ long, drying black; stamens emerging from the base, laterals first, scarcely exposed, quickly retracting before alternates emerge; pollen white. INFRUCTESCENCE with spadix to $22 \mathrm{~cm}$ long; berries ovoid, probably orange. Fig. 66.

Anthurium durandii is known only from Costa Rica on the Pacific slope in San José and Puntarenas Province at elevations from near sea level to $1,600 \mathrm{~m}$ in tropical wet and premontane rain forest.

It was initially confused with $A$. paludosum by Standley, which was reported from the Atlantic slope of Costa Rica. Anthurium durandii resembles $A$. paludosum superficially but differs in having the cataphyll weathering into a dense fibrous network and in having longer petioles, one third to equally as long as the blade and in having a more or less elliptic leaf blade. It is a member of section Porphyrochitonium.

Engler cited two specimens in his original description of $A$. durandii. The second of these, Tonduz 8422 (BR) is $A$. gracile (Rudge) Lindl.

Costa RicA. No other location, Pittier 3868, 6837 (BR). PUNTARENAS: Finca Loma Linda, SW of Cañas Gordas, Liesner 645 (NY, US); 231 (MO, NY, US); along Fila Las Cruces, Luteyn 3855 (DUKE); Osa Peninsula, W of Rincon de Osa, Burger \& Liesner 7322 (MO); Liesner 1845 (MO); Raven 21510 (DS); S of San Vito de Java, Raven 21758, 21841 (DS). SAN JOSÉ: below Santa Maria de Doto, Croat 55203 (MO).

Anthurium eximium Engl., Bot. Jahrb. Syst. 25: 412. 1898. TYPE: Costa Rica. Puntarenas: in forest near Punta Mala, Tonduz 6768 (BR, hololectotype (two sheets); CR, isolectotype; designated Croat \& Baker, 1979).

Epiphyte; stem elongate, ca. $1 \mathrm{~cm}$ diam.; roots thick; cataphylls persisting intact, overlapping at base, drying yellow-brown. LEAVES spreading; petioles broadly sulcate, rounded to 3-ribbed abaxially, 7-12 cm long, 6-7 mm diam.; blades narrowly oblanceolate, subcoriaceous, $40-80 \mathrm{~cm}$ long, $5-11.5 \mathrm{~cm}$ wide, narrowly attenuate at base, long-acuminate at apex; primary lateral veins 10 12 per side, raised above and below (dry), departing midrib at $40^{\circ}-45^{\circ}$ angle, weakly arched to collective vein; the collective vein arising from the base or one of the lowermost primary lateral veins, 1-4 $\mathrm{mm}$ from margin. INFLORESCENCE shorter than leaves; peduncle 29-32 cm long; spathe lanceolate-ovate, green, $5-7.7 \mathrm{~cm}$ long, 2-2.6 cm wide, clasping at base; spadix creamy white, oblong to clavate, $4.5-6 \mathrm{~cm}$ long, $0.8-1 \mathrm{~cm}$ diam. at base, $9 \mathrm{~mm}$ diam. at apex; 10-12 flowers visible in the principal spiral; tepals matte, longer than wide; stamens exserted, emerging in a somewhat irregular fashion in a complete sequence, the leading stamens 1-2 spirals ahead of the third and fourth; pollen yellow, faintly aromatic at anthesis. INFRUCTESCENCE with spadix to $13 \mathrm{~cm}$ long; $1.5-1.7 \mathrm{~cm}$ diam.; berries bright red, obovoid, ca. 4.6-7 mm long, 4-5 $\mathrm{mm}$ wide; seeds $2,2.7-2.9 \mathrm{~mm}$ long, $1.5-1.7 \mathrm{~mm}$ wide. Figs. 67 and 68 .

The species is found in Costa Rica in tropical wet forest formations from sea level to $800 \mathrm{~m}$ elevation. Until recently it was known only from the Osa Peninsula and the adjacent Golfo Dulce region, but now it has been collected in San José Province on the road to Purrita.

Anthurium eximium can be distinguished by the oblanceolate, epunctate leaves, the persisting cataphylls, the clasping, lanceolate spathe, the cylindrical to clavate spadix, and the bright red berries. The species resembles $A$. spathiphyllum, which is restricted to the Atlantic slope, in spadix and leaf characters, but can be distinguished by the persisting cataphylls.

In his monograph, Engler (1905) cited A. eximium as a synonym of $A$. consobrinum. The leaf shapes in both species are very similar. However, Schott's illustration of $A$. consobrinum clearly shows a long, slightly tapering spadix with pistils and berries greatly exceeding the tepals. Anthurium consobrinum is a common species of the Atlantic lowlands and numerous collections are consistent with Schott's drawing. The berries of A. consobrinum are white with purple, pink or orange apices as opposed to the solid bright red berries of $A$. eximium. In addition, the pistils of A. consobrinum are early long-exserted and are held at about the level of the stamens at anthesis.

Anthurium eximium is a member of section Pachyneurium despite certain features it shares with section Calomystrium, including the thick, 
persistent, intact cataphylls and the presence of linear raphide cells on both blade surfaces.

Costa Rica. No other location, Pittier 6768 (BR). PUNTARENAS: Osa Peninsula, Corcovado National Park, Liesner 2846, 2996 (MO); above Palmar Norte, Croat 35121 (MO); Punta Mala, Tonduz 6768 (BR); Rincón de Osa, Burger \& Liesner 7286 (MO, NY); Liesner 1934 (MO); Santo Domingo of Golfo Dulce, Tonduz 7260 (BR, CR, US). SAN JOSÉ: below Santa Maria de Doto, Croat 55204 (MO)

Anthurium fatoense $\mathrm{K}$. Krause, Notizbl. Bot. Gart. Berlin-Dahlem 11: 611. 1932. TYPE: Panama. Colón: Dos Bocas, Río Fato Valley, 40-80 m elev., Pittier 4227 (US).

Rosulate epiphyte; stems to $60 \mathrm{~cm}$ long, usually much shorter, ca. $1 \mathrm{~cm}$ diam.; dense mass of greenish roots, acute and ascending at tips; cataphylls subcoriaceous, sometimes tinged with red, 5-10 cm long, drying medium brown, persisting \pm intact. LEAVES erect-spreading; petioles quadrangular, sulcate, $2.5-5(9.5) \mathrm{cm}$ long, 5-7 mm wide; geniculum 7-10(20) $\mathrm{mm}$ long; blades oblong-oblanceolate, gradually acuminate at apex, acute at base, $24-83 \mathrm{~cm}$ long, $6-26 \mathrm{~cm}$ wide, broadest at middle or above; both surfaces semiglossy; midrib acutely raised above, square and prominently raised below; primary lateral veins $8-16$ per side, departing midrib at $45^{\circ}$ angle, arcuate-ascending, acutely raised above, raised and sometimes reddish below; submarginal collective vein arising in the apical quarter of blade, 2-9 $\mathrm{mm}$ from margin. INFLORESCENCE erect-spreading to arching-pendent, shorter than or equalling leaves; peduncle 14-48 $\mathrm{cm}$ long, subterete, faintly ribbed; spathe pale green, sometimes tinged purplish, narrowly lanceolate, 5.5-9 cm long, $0.7-1.3 \mathrm{~cm}$ wide, narrowly long-acuminate to abruptly acuminate at apex, obtuse to subcordate at base; spadix pale reddish or green tinged reddish, $5-15 \mathrm{~cm}$ long, 4-8 $\mathrm{mm}$ diam. at base, 2.5-4 $\mathrm{mm}$ diam. at apex; flowers rhombic to weakly 4-lobed, $1.8-2.8 \mathrm{~mm}$ long, 2-3 $\mathrm{mm}$ wide, the sides straight parallel to principal spiral, gradually sigmoid on alternate sides; 5-9 flowers visible in the principal spiral and 5-12 flowers visible in the alternate spiral; tepals matte to weakly glossy, lateral tepals 1.2$1.5 \mathrm{~mm}$ wide, the inner margins straight to broadly rounded; pistils emergent $1-6 \mathrm{~mm}$, pale green or white; stigma brushlike, ca. $0.5 \mathrm{~mm}$ long; stamens emerging in a slow progression from the base in a \pm complete sequence, well exserted and held against sides of exserted pistils; anthers white, $0.5-0.6 \mathrm{~mm}$ long, $0.5-0.8 \mathrm{~mm}$ wide; thecae broadly ovate; pollen white. INFRUCTESCENCE with spadix to $26 \mathrm{~cm}$ long; berries cream to greenish-yellow or orange, oblong-ovoid, 4-7 mm long, acute at apex. Figs. 71 and 72 .

The species is known from southern Costa Rica and Panama, occurring principally on the Caribbean slope from sea level to $1,000 \mathrm{~m}$ in wetter parts of tropical moist forest as well as in tropical wet, premontane wet and lower montane wet forest. It also occurs on the Pacific slope in the Fortuna area of Chiriquí Province.

Anthurium fatoense is a member of section Pachyneurium and is considerably variable in the size of the leaves and inflorescences as well as in berry color. It is most easily confused with A. consobrinum in Costa Rica and is distinguished by its tapered, greenish spadix, which has the stamens emerged in a close cluster with the pistil not at all apparent. In the flowers of $A$. consobrinum, the pistil emerges well ahead of the stamens and dwarfs the stamens in size, extending several millimeters above the stamens. Despite the close vegetative resemblance of the two species, they are probably not closely related.

Costa Rica. alajuela: between Naranjo \& Aguas Zarcas, NE of Villa Quesada, Croat 46976 (MO). LIMÓN: S of Punta Cahuita, Croat 43197 (MO); between Río Bananito \& Cahuita, Burger et al. 10485 (MO).

Anthurium flexile Schott, Oesterr. Bot. Z. 8: 180. 1858.

a. Anthurium flexile ssp. flexile. TYPE: Costa Rica. Heredia: Pedregel, Wendland 932 (GOET, holotype).

Anthurium myosuroides (H.B.K.) Endl. var. angustifolia Engl., Bot. Jahrb. Syst. 25: 382. 1898. TYPE: Costa Rica. Limón: Matina, Pittier 9797 (Pittier 9767?) (BR, CR, US).

Scandent epiphyte; the stem elongate; internodes $2-6 \mathrm{~cm}$ long, ca. $3 \mathrm{~mm}$ thick; roots slender, 1-2 cm long, scattered along the internodes; cataphylls to $4 \mathrm{~cm}$ long. LEAVES spreading; petioles 4-11 cm long, flattened to sulcate adaxially; blade elliptic or narrowly elliptic, (10)13-26.5 cm long, (2.5)3-9(10.5) cm wide, acuminate to long-acuminate at apex, narrowly subcordate, pliveined at base, the upper surface semiglossy; midrib sunken; collective vein arising from the base or fused with the midrib for $0.2-2.5 \mathrm{~cm}$ from base. INFLORESCENCE usually arching-pendent; penduncle 4-23 cm long, terete; spathe green, 
lanceolate, $3.5-9.5 \mathrm{~cm}$ long, $0.7-1.8 \mathrm{~cm}$ wide; stipe absent or to $2 \mathrm{~mm}$ long; spadix violet-purple at anthesis, $4.5-13 \mathrm{~cm}$ long, $0.3-0.5 \mathrm{~cm}$ diam. at base, usually less than $1 \mathrm{~cm}$ diam. at apex. INFRUCTESCENCE with spadix to $2 \mathrm{~cm}$ diam.; berries oblong-ellipsoid to narrowly ellipsoid or narrowly ovoid (with four longitudinal ridges on drying), orange to red, $0.5-1.2 \mathrm{~cm}$ long, with numerous round to slightly elongated raphide cells visible on drying; mesocarp orange, pulpy; seeds (1)2(3), black, suborbicular, flattened, ca. 6-9 mm long. Figs. 69, 73, and 75.

Anthurium flexile is a member of section Polyphyllium and consists of two subspecies. The ssp. flexile ranges from Mexico to Panama at 0 to $1,000 \mathrm{~m}$ elevation in tropical wet forest life zones. It is distinquished from ssp. muelleri by the characters listed in the Key. For a discussion of these differences see the discussion of ssp. muelleri.

Belize. CAyo District: Maya Mountains, Cockscomb, Schipp S-192 (MICH, MO). STANN CREEK DISTRICT: Sittee River, Kendal, Schipp 192 (F, NY). TOLEDO DISTRICT: Colombia Forest Station, Proctor 36087 (MO); Maya Mountains, Gabriel Camp, Boutin \& Schlosser 5153 (MO); near Monkey River, Gentle 3852 (MO, NY); Río Blanco branch, Stevenson 110 (F).

Costa Rica. alajuela: vicinity of Bijagua, Burger \& Baker 9871 (F); Croat 36467 (MO); Llanura de San Carlos, Molina et al. 17658 (EAP, F). GuANACASTE: vicinity of Tilarán, Gentry 2025 (MO); Standley \& Valerio 44253, 44290, 45020, 45997, 46112 (US). HEREDIA: Pedregal, Wendland 932 (GOET). LIMÓN: Los Diamantes, Schubert 1133 (US); Matina, Pittier 9767 (CR, US). PUNTARENAS: SE of the Río Claro, Burger \& Matta 4803 (F). SAN JosÉ: Tucurrique, Tonduz 12750 (US).

Guatemala. IZABal: Río Chacón Machaca, Johnson 1257 (UCLA): Cerro San Gil, along Río Bonito, Steyermark $41693(\mathrm{~F}) ; 41886(\mathrm{~F}, \mathrm{NY})$. SAN MARCOS: vicinity Finca Armenia, above África, Croat 40954 (MO). SUCHITEPÉQUEZ: no other location, Lind 73 (WIS).

honduras. atlantida: near Point Triunfo, Wilson 439 (NY); vicinity La Ceiba, Yuncker et al. 8202 (F, $\mathrm{MICH}, \mathrm{MO}, \mathrm{NY}, \mathrm{US})$; Lancetilla Valley, Chickering 206 (MICH); Croat 42654 (MO); Molina 10454 (EAP, F); Standley 53105, 53349 (F, US); 56544 (F); Yuncker 4615 (F, MO). GRACIAS A DIOS: Mosquitia Region, Río Plátano, Gentry et al. 7518 (MO).

MeXico. ChIAPAS: vicinity Nuevo Amatenango, $\mathrm{Ma}$ tuda 30187 (MEXU); vicinity of Munic. Palenque, Breedlove 24248, 26513, 28889, 35342 (CAS, DS); 34994 (DS); vicinity of Palenque, Croat 40285 (MO); Hoover 135 (MO); Matuda 3644 (MEXU); N of Pichucalco, Miranda 6628 (MEXU); between Ranchería Coamapa \& Campamento San Joaquín, Gilly \& Hernandez 169 (MEXU). TABASCO: vicinity Cerro de Azufre, Gilly \& Hernandez 277, 289 (MEXU); E of Teapa, Conrad et al. 2881 (MO); Croat 40129 (MO);
Zunú, vicinity Tapijulapa, Magaña 3127 (MO). verACRUZ: no other location, Rosas 1055 (XAL); Biological Station at Tuxtla, Calderon 2186 (F, XAL); Goméz-Pompa 4565 (F); Rosas \& Villalpando 1408 (XAL); vicinity Lake Catemaco, Beaman 5304 (F, MEXU); Moore 6253 (BH); Cerro de San Martín, Calzada 577 (F, XAL); vicinity Hidalgotitlán, Dorantes 2529 (XAL, MEXU); Goméz-Pompa \& Nevling 5185 (XAL); Vazquez 854 (XAL); NW of La Palma, Toledo 4 (MEXU); Río Solosúchil, Vazquez 1625 (XAL).

Nicaragua. No other location, Tate 405 (B). MATAGAlPa: Cerro Musún, Neill 1726 (MO). RIvas: Isla de Ometepe, NW slope of Volcán Maderas, Stevens 6614 (MO). ZELAYA: along Caño Majagua, Stevens 6975 (MO); S slopes of Cerro El Inocente, Stevens 6790 (MO); trail from Cerro Saslaya to San José del Hormiguero, Stevens 7089 (MO); S of bridge at Colonia Agrícola Yolaina, Stevens 6466 (MO); Vincelli 212 (MO); W of Río Wawa ferry on road from Puerto Cabezas, Stevens 8650 (MO); near Río Okanwás, E of Rosita, Neill 4428 (MO); vicinity Waní including Río Ulí, Stevens 7252 (MO).

b. Anthurium flexile ssp. muelleri (Macbr.) Croat \& Baker, Selbyana 2: 236. 1978. Anthurium muelleri Macbr., Candollea 5: 348. 1934. Anthurium mexicanum Engl., Monogr. Phan. 2: 105. 1879, non Liebm., 1849. TYPE: Mexico. Veracruz: Orizaba, Mueller 993 (NY, hololectotype; BR, LE, isolectotypes, here designated).

Anthurium flexile ssp. muelleri differs from the typical subspecies in that the leaves are lanceolate, broadest below the middle, weakly cordate at the base and the first pair of basal veins are not fused with the midrib or very rarely so. The spadix may be stipitate $1-1.5 \mathrm{~cm}$. Fig. 74 . It occurs in Mexico and Guatemala at elevations of 1,000 to $1,700 \mathrm{~m}$ and is replaced by the typical subspecies in southern Central America.

Mexico. No other location, Linden 136 (BR). CHIAPAs: Pueblo Nuevo Solistahuacán, Clark 289 (DS); vicinity of Rayón, Selva Negra, Breedlove 26132 (CAS, DS). veracruz: Cerro de San Martín, Calzada 207 (F); Orizaba, Mueller \& Schlumberger 993 (F, US, (Photo)); Santa Marta, Los Tuxtla, Sousa 3586 (MEXU); San Andrés Tuxtla, Beaman \& Alvarez 5349 (F, MEXU); Sousa 3445 (CAS, MEXU).

Guatemala. chimaltenango: Panajabal, Standley 62121 (F); near Sibajá, Standley 62281 (F). Quezaltenango: between Finca Pirineos and Patzulín, Standley 86955, 86977, 86990 (F); along Quebrada San Jerónimo, Finca Pirineos, vicinity Santa María de Jesús, Steyermark 33336, 33450 (F); Standley 68324 , 84858 (F). SAN MARCOS: La Trinidad, Croat 40875 (MO); above Finca El Porvenir, Standley 37414 (F); Steyermark 37212, 37240 (F). SOLALÁ: Volcán Atitlán, above Finca Mocá, Steyermark 47925 (F, MO). 


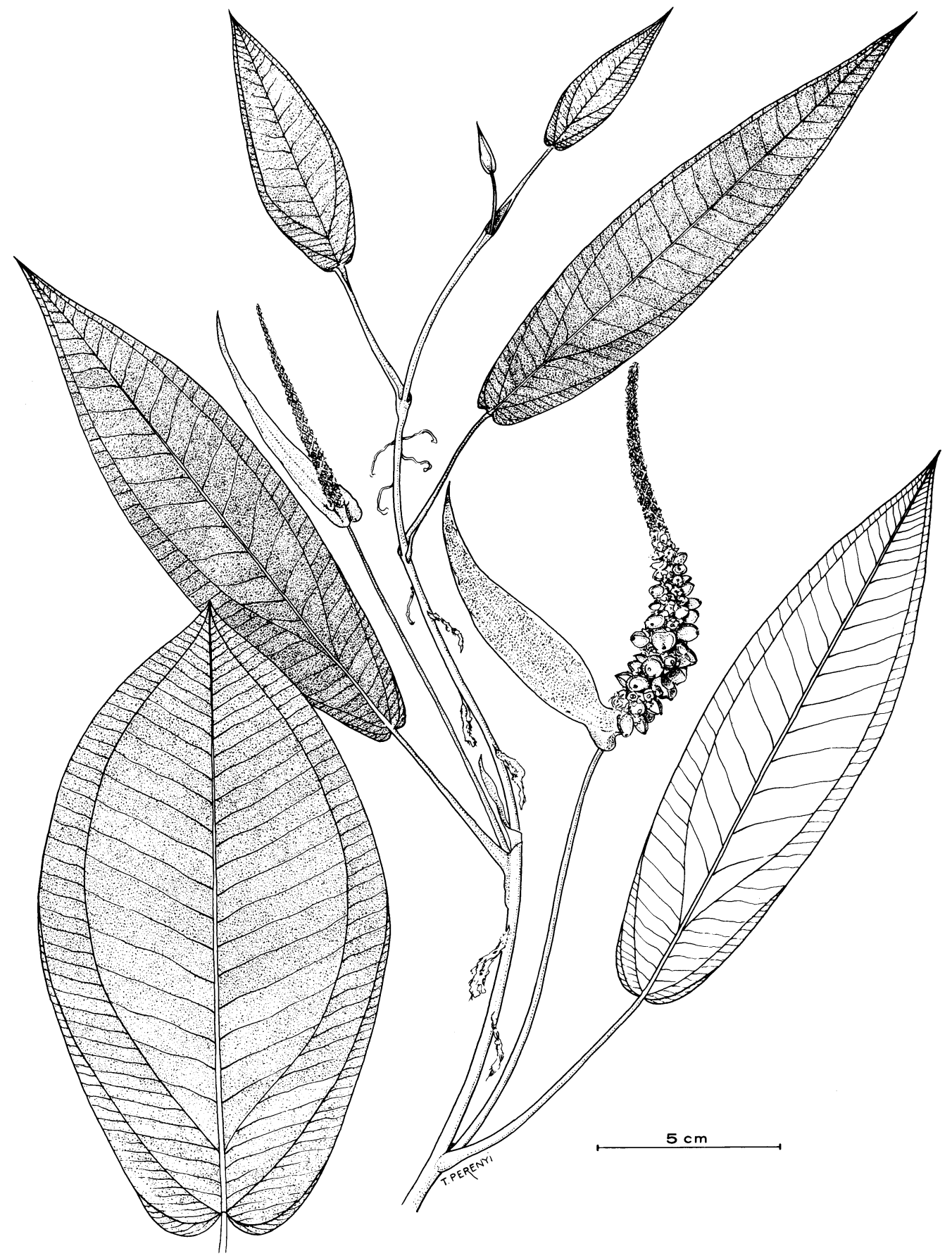

74

Figure 74. Anthurium flexile ssp. muelleri (Macbr.) Croat \& Baker, Molina et al. 17658. 


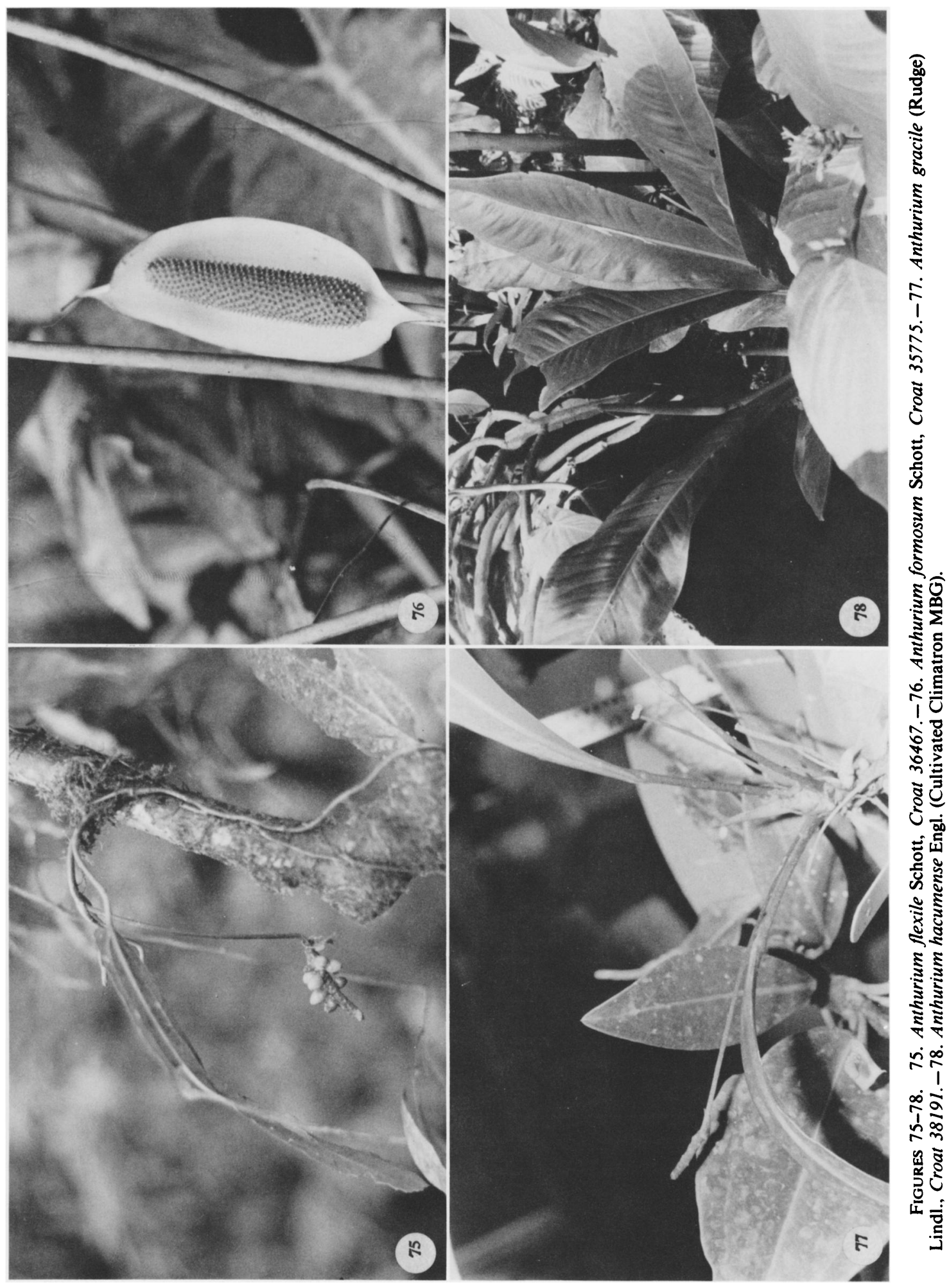


Anthurium formosum Schott, Oesterr. Bot. Z. 8: 181. 1858. TYPE: Costa Rica. Cartago?: near Naranjo, Wendland 583 (GOET).

Anthurium lactiflorum Engl., Bot. Jahrb. Syst. 6: 277. 1885. TYPE: Colombia, Lehmann 2582 (B).

Epiphytic or often terrestrial; stems often to 1 $\mathrm{m}$ long; roots thick, directed downward; cataphylls coriaceous, narrowly rounded at apex, with subapical apiculum, drying tan, persisting intact. LEAVES erect-spreading; petioles $40-150 \mathrm{~cm}$ long, $0.6-1 \mathrm{~cm}$ diam., subterete, weakly flattened or weakly sulcate adaxially; geniculum $2-2.2 \mathrm{~cm}$ long, tinged pinkish; blades ovate, $30-80 \mathrm{~cm}$ long, $20-52 \mathrm{~cm}$ wide, acuminate and turning down at apex, deeply lobed at base; anterior lobe 31-54 cm long; the posterior lobes 13-20 cm long; sinus broadly hippocrepiform to spathulate; both surfaces glossy; midrib acutely raised above and below; primary lateral veins 7-9 per side, sunken in valleys above, raised below; interprimary veins sunken above, raised below; basal veins $7-8$ pairs, the fourth to sixth coalesced $2.5-3 \mathrm{~cm}$; the posterior rib naked, turned up; collective vein usually arising from one of the lowermost basal veins, frequently from the second or third basal vein, 2-4 $\mathrm{mm}$ from the margin. INFLORESCENCE erect-spreading; peduncle $21-47 \mathrm{~cm}$ long, stout; spathe subcoriaceous, ovate or oblong-elliptic, pale greenish white to pale violet, $12.5-24 \mathrm{~cm}$ long, $3-8.5 \mathrm{~cm}$ wide, cuspidate at apex, round at base, held close to spadix even in fruit, inserted at $45^{\circ}$ angle on peduncle; spadix stipitate $12-15$ $\mathrm{mm}$ in front, $2-3 \mathrm{~mm}$ in back, white to violetpurple, \pm oblong to tapered to both ends, 5.5$14.5 \mathrm{~cm}$ long, $1.2-1.5 \mathrm{~cm}$ diam. at middle, $7-9$ $\mathrm{mm}$ at base and apex; flowers rhombic to 4lobed, $2.3-3 \mathrm{~mm}$ long, $3-3.8 \mathrm{~mm}$ wide, the sides jaggedly sigmoid; 9-15 flowers visible in the principal spiral, 10-20 flowers visible in the alternate spiral; tepals glossy, the lateral tepals 1$1.5 \mathrm{~mm}$ wide, the inner margins rounded to angulate; pistils early emergent; stigmas deep purple, ultimately brushlike; stamens emerging from base of spadix, the lateral stamens emerging throughout before alternate stamens emerge, held in a tight cluster over pistil; filaments pale lavender; anthers pale lavender to deep red-violet, sometimes white tinged with red-violet at margins; pollen white. INFRUCTESCENCE with spadix 18-32 cm long; berries dark reddish-violet to violet-purple, often reddish-orange at base, narrowly acute at apex, 10-12 $\mathrm{mm}$ long, 4-5 mm wide; seeds 2, 7-8.4 $\mathrm{mm}$ long, 3-3.5 $\mathrm{mm}$ wide. Figs. 76 and 79 .
The species is found in Costa Rica, Panama, Colombia, and perhaps also Ecuador [see Gentry 9621 (MO)] at elevations of 500 to $1,500 \mathrm{~m}$. In Costa Rica and Panama the species occurs in premontane wet forest and more commonly in premontane rain forest and lower montane rain forest. It is often one of the most common species at middle elevations, where it is generally found along shady road banks and sometimes forms large stands.

Anthurium formosum is variable both in size of leaves and inflorescences and in the color of the spathe and spadix, both of which vary from white to purplish-violet at anthesis. The spathe and spadix, if white at anthesis, tend to become more colored with age. The collective vein is also quite variable, sometimes arising from one of the lowermost basal veins or sometimes from the second or third basal vein.

The species is a member of section Calomystrium and is distinguished by its usually large cordate blade with a prominent posterior rib, by its large ovate or oblong-elliptic, subcoriaceous spathe, glossy tepals, sharp, early-emergent pistils and reddish-violet to violet-purple berries. Leaf blades usually dry olive green with characteristic reddish-brown veins and with purplish and/or brownish blotches.

Costa Rica. Cartago: Finca Navarro, Maxon 647 (NY); between Tuis \& Bajo Pacuare along road from Turrialba to Moravia, Burger et al. 10031 (DUKE, $\mathrm{MO}$ ); road from Turrialba to Moravia, Croat 36552, 36571 (MO); road from Moravia to Quebrada Platanillo, Croat 36680 (MO); SW of Paraiso, Croat 47051 (MO); SE of Platanillo, Croat 36716, 36745 (MO); vicinity Platanillo, Donnell Smith 251, 252 (US); valley of Río Tuis, Tonduz 8216 (BR); near Narajo, Wendland 583 (GOET). HEREDIA: S of Cariblanco, Croat 35775, 35834 (MO); Tirimbina, Proctor 32286 (LL); $\mathrm{N}$ of Vara Blanca, Croat 35567, 35634 (MO); $\mathrm{S}$ of Siguirres, Croat 43308 (MO). PUNTARENAS: Las Cruces Botanical Garden, Croat 32967 (MO). SAN JOSÉ: vicinity Bajo La Hondura, Croat 44498, 44519 (MO); Luteyn 3317 (DUKE, MO); Utley \& Utley, 4995, 4996 (DUKE).

Anthurium friedrichsthalii Schott, Oesterr. Bot. Wochenbl. 5: 65. 1855. Anthurium gracile (Rudge) Lindl. var. friedrichsthalii (Schott) Engl., Bot. Jahrb. Syst. 25: 370. 1898. TYPE: Guatemala. Insula Cativo, Friedrichsthal s.n. (W, Type destroyed; Photo of Schott Aroid Drawing \#332, NYBG Neg. \#N.S. 3819).

Anthurium linearifolium Engl., Bot. Jahrb. Syst. 25: 370. 1898. TYPE: Panama. Canal Zone: Río Chagres, Lehmann 4538 (B, K). 


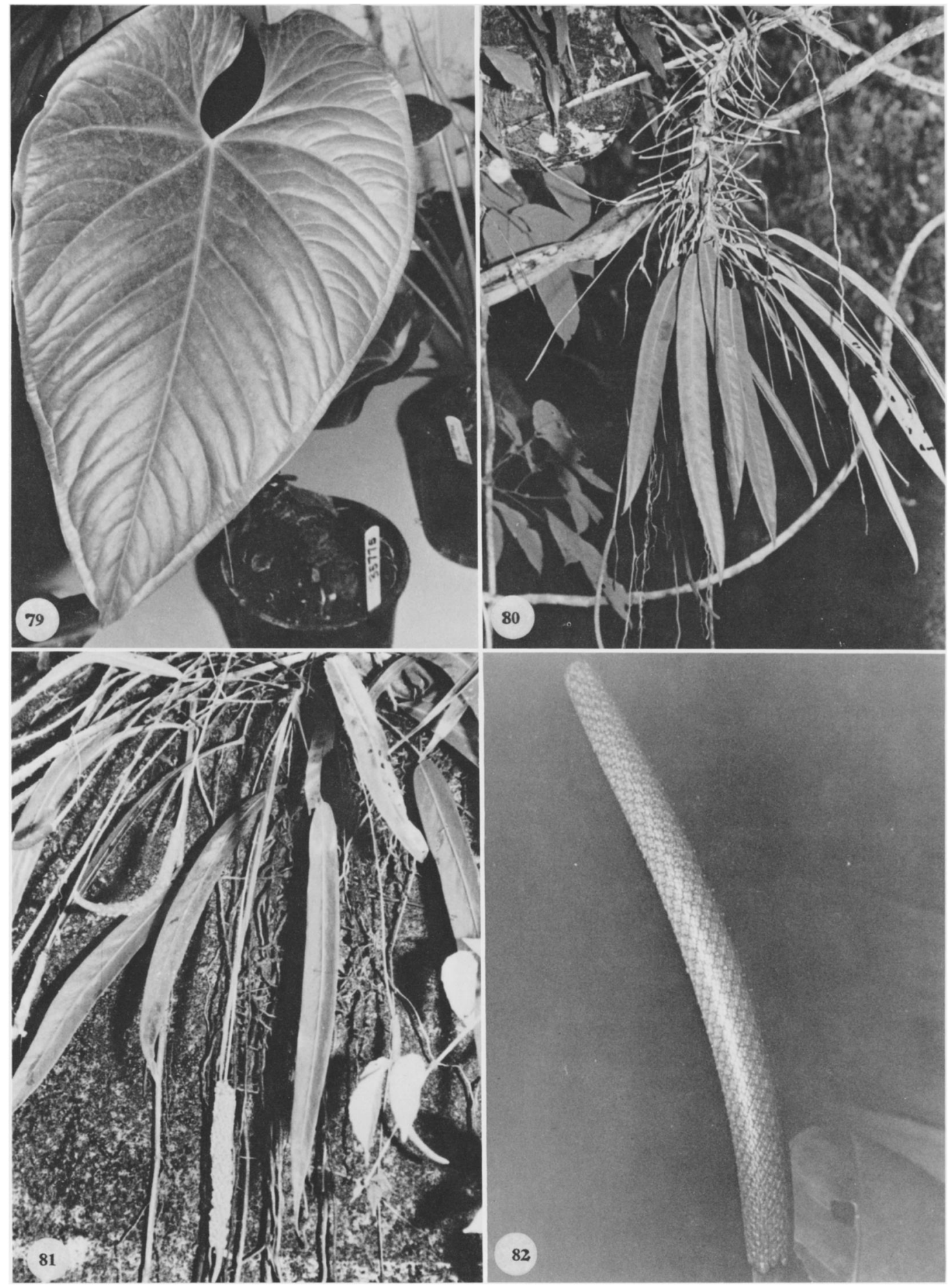

FIGURES 79-82. 79. Anthurium formosum Schott, Croat 35775. -80. Anthurium friedrichsthalii Schott, Croat 14187.-81. Anthurium friedrichsthalii Schott, Croat 16557.-82. Anthurium hacumense Engl., Croat 32903. 
Epiphyte, usually pendent, often loosely attached by only a few roots; stem usually less than $15 \mathrm{~cm}$ long, $1-1.5 \mathrm{~cm}$ diam.; roots thin; cataphylls weathering to coarse linear-fibers. LEAVES pendent; petioles $1.5-14 \mathrm{~cm}$ long, mostly less than $10 \mathrm{~cm}$ long, ca. $2-3 \mathrm{~mm}$ diam., terete or flattened adaxially; geniculum 5-8 $\mathrm{mm}$ long; blades linear, $12-56 \mathrm{~cm}$ long, $0.8-4 \mathrm{~cm}$ wide, acuminate at apex, subacute at base; upper surface matte to semiglossy, the lower surface conspicuously glandular-punctate; the midrib acutely raised, becoming sunken at apex above, convexly raised at base, flattened at apex below; primary lateral veins 8 or more per side, flat above, obscure below; collective vein arising from the base, 3-5 $\mathrm{mm}$ from margin. INFLORESCENCE pendent; peduncles $19-30 \mathrm{~cm}$ long, ca. $2.5 \mathrm{~mm}$ diam., terete; spathe linear, pale green, 1-5 $\mathrm{cm}$ long, 3-5 $\mathrm{mm}$ wide, rounded at base, gradually acuminate at apex, withering and soon deciduous; spadix pale green, sometimes tinged purplish, turning brownish, 3-15 cm long, 4-5 $\mathrm{mm}$ diam.; the flowers 4-lobed, $2.8-3.8 \mathrm{~mm}$ in both directions, the sides straight to weakly sigmoid; 3-4 flowers visible in the principal spiral, 2-3 flowers visible in the alternate spiral; tepals matte, minutely papillate, lateral tepals $1.6-2 \mathrm{~mm}$ wide; pistil not exserted; the stigma linear, $3 \mathrm{~mm}$ long; stamens emerging \pm slowly from base, held at edge of pistil, soon completely retracting; anthers cream, ca. $0.3 \mathrm{~mm}$ long, $0.9 \mathrm{~mm}$ wide; thecae ellipsoid; pollen white. INFRUCTESCENCE pendent; spathe absent; spadix to $25 \mathrm{~cm}$ long, $2 \mathrm{~cm}$ diam.; berries pale yellow-orange, irregularly shaped broader than long, ca. $5 \mathrm{~mm}$ long, 5-8 $\mathrm{mm}$ wide, narrowing to apex, truncate with a central depression; seeds $3-4, \pm$ ovate, greenish or yellowish, ca. $2.7 \mathrm{~mm}$ long. Figs. 80 and 81 .

The species is found from Guatemala to Colombia at elevations from sea level to usually $800 \mathrm{~m}$. In Costa Rica and Panama it is common in tropical moist forest and is also known from premontane wet and tropical wet forest.

Anthurium friedrichsthalii is recognized by its pendent habit and the thick, linear, bicolored, punctate leaves. Juvenile plants have short, elliptic leaves. See the discussion under $A$. gracile for differences with that species. It is a member of section Porphyrochitonium differing from the more typical members of that section only in its linear leaves and pendent habit.
Costa Rica. alajuela: N of San Miguel, Croat 35650 (MO). CARTAGO: vicinity Santa Teresa, Luteyn 3249 (DUKE); E of Cachí, Croat 47085 (MO). HEREDIA: vicinity La Virgin, Lent 1510 (NY). LIMÓN: Hacienda Tapezco-Hacienda La Suerte, Davidson 7102, 7104 (LAM). PUNTARENAS: vicinity Monteverde, Luteyn 3398 (DUKE); Primack et al. 428 (DUKE); Wilbur et al. 15822 (DUKE); Rincón de Osa, Liesner 1809, 1930 (MO). SAN JosÉ: La Palma, Luteyn 3308 (DUKE).

Anthurium gracile (Rudge) Lindl., Edward's Bot. Reg. 19: t. 1635. 1833. Pothos gracilis Rudge, Pl. Guian. Rar. 23, T. 32. 1805. TYPE: French Guiana, Martin s.n. (Herb. Rudge, BM).

Anthurium scolopendrinum (W. Ham.) Kunth, Enum. Pl. 3: 68. 1841. Pothos scolopendrinus W. Ham. TYPE: French Guiana, Desvaux s.n. (P).

Anthurium longipes Matuda, Bol. Soc. Bot. México 14: 23. 1952, non N. E. Brown, 1882. TYPE: Belize, Gentle 2624A (MICH).

Epiphyte, usually erect; roots white; stems 1.5$30 \mathrm{~cm}$ long, 7-10 mm diam.; internodes short; cataphylls membranaceous, $2-9.5 \mathrm{~cm}$ long, drying reddish or brown, persisting intact, ultimately deciduous. LEAVES \pm erect; petioles $1-20 \mathrm{~cm}$ long, ca. $3 \mathrm{~mm}$ diam., subterete flattened adaxially; the geniculum ca. $5 \mathrm{~mm}$ long; blades moderately thin, oblanceolate, $11-32 \mathrm{~cm}$ long, 3-8.5 $\mathrm{cm}$ wide, acuminate at apex, gradually tapered to long-cuneate at base; the upper surface matte to semiglossy; the midrib prominently raised almost to apex above, raised below; primary lateral veins numerous, nearly obscure; collective vein arising from base, $4-7 \mathrm{~mm}$ from margin. INFLORESCENCE \pm erect; peduncles $13-40 \mathrm{~cm}$ long, 1-3 mm diam., longer than petioles; spathe membranaceous, red-violet, lanceolate to oblong-elliptic or ovate-elliptic, $1.3-2.5 \mathrm{~cm}$ long, 3-7 mm wide, abruptly acuminate at apex, rounded at base; spadix sessile, purplish-brown, $0.6-6 \mathrm{~cm}$ long, 2-4 $\mathrm{mm}$ diam. midway; flowers 4-lobed, 5-5.6 mm long, 3.8-4.3 $\mathrm{mm}$ wide, the sides jaggedly sigmoid; $2-3$ flowers visible in the principal spiral, 3-4 flowers visible in alternate spiral; tepals matte to semiglossy, punctate and minutely papillate; pistils weakly emergent, the apex \pm flat; stigma exserted, buttonlike, 0.8-0.9 $\mathrm{mm}$ wide; stamens emerging in scattered manner; anthers cream, ca. $0.7 \mathrm{~mm}$ long, inclined inward over pistil; thecae ovoid, slightly divaricate; pollen white. INFRUCTESCENCE pendent; peduncle to $60 \mathrm{~cm}$ long; spadix to $10 \mathrm{~cm}$ long, $1.5 \mathrm{~cm}$ diam.; berries bright red, \pm globose, slightly longer than broad, 6-8 $\mathrm{mm}$ long; me- 
socarp gelatinous, \pm translucent, lacking raphide cells; seeds 2, cylindroid, rounded on both ends, ca. $4 \mathrm{~mm}$ long, 1.6-1.8 $\mathrm{mm}$ diam., with an oblique depression at one end and the other end greenish, sticky gelatinous appendages at both ends. Fig. 77.

The species is found from Guatemala and Belize to the Guianas, southern Brazil and Peru. It is also known in the West Indies from Trinidad and Hispañola. In Costa Rica and Panama, the species is known only from topical moist forest.

Anthurium gracile has a large root system that may sometimes become infested with black, stinging ants. It is distinguished by its thin, oblanceolate, epunctate leaves, persistent, intact cataphylls, the relatively few-flowered spadix, the whitish roots, and the bright red, globose berries.

Anthurium gracile has been confused with $A$. friedrichsthalii, which differs in having coriaceous, broadly linear leaves, conspicuously punctate on the lower surface, cataphylls that soon weather to persistent fibers, flowers more numerous on the spadix, and berries that are pale yellow-orange, broader than long, and truncate at the apex. Anthurium gracile is also confused with $A$. bakeri Hook. f., which has punctate leaves with a collective vein that is sunken and more conspicuous than the primary lateral veins.

Anthurium gracile is the only described species of section Leptanthurium and is either an extremely variable species or comprised of some additional undescribed sibling species in the Andes of South America (Croat, 1976).

Belize. Belize District: Gracy Rock, Gentle 1694 (MICH). STANN CREEK DISTRICT: Middlesex, Gentle 2803 (MICH); Silk Grass Creek Reserve, Gentle 2624A (MICH); Stann Creek Railroad, Gentle 2108A (MICH); $\mathrm{N}$ of Victoria Peak, Gentry 7954 (MO). TOLEDO DISTRICT: S of Columbia Forest Station, Vanderveen 616, 618, 621 (MO); Monkey River, Gentle 3804 (MICH).

Costa Rica. alajuela: vicinity of Las Chiles, Holm \& Iltis $653(\mathrm{P})$. CARTAGO: vicinity of Turrialba, Godfrey 66241 (MO); Tonduz 8422 (BR). LIMÓN: vicinity of Siguerres, Burger \& Liesner 6921 (MO); N of Puerto Viejo, Baker \& Burger 91 (DUKE): Shirores, Tonduz 9231 (BR).

GuATEMAla. IZABAL: vicinity Lechuga, Steyermark 39615 (MO). PETÉN: vicinity El Ceibal, Steyermark $46166(\mathrm{MICH})$.

Honduras. ATLANTIDA: vicinity La Ceiba, Yuncker et al. 8666 (MICH, NY, RS). YORO: village of Las Flores, Yuncker et al. 8187 (MO).

Nicaragua. BOACO: N of Río Las Cañas, Stevens \& Krukoff 5846 (MO). CHONTALES: E of Santo Tomás, Neill 549, 7396 (MO). MATAGALPA: SW of Río Tuma bridge, Stevens 6020 (MO). RÍO SAN JUAN: no other location, Atwood 5169 (MO). ZELAYA: no other location, Nichols 584 (MO); Svenson 5100 (MO); NW of Alamikamba, Stevens 8172 (MO); S of Cerro Bakan, Vincelli $319 A$ (MO); N of El Empalme, Stevens 8411, 8413 (MO); N of Limbaika, Stevens 8254 (MO); road from Puerto Cabezas to Rosita, Stevens 7925 (MO); vicinity Quebrada El Toro, along Río Iyas, Vincelli 375 (MO); SW of Río Kukalaya, Stevens 8505 (MO); E of Rosita, Neill 4444 (MO); Road from Siuna to Matagalpa, Stevens 7522 (MO); vicinity Siuna, Neill 3807, 4151 (MO); W of Siuna, Stevens 6899 (MO).

Anthurium hacumense Engl., Bot. Jahrb. Syst. 25: 363. 1898. TYPE: Costa Rica. Puntarenas: along banks of Río Hacum (Platanar) near Buenos-Aires, $250 \mathrm{~m}$ elev., Tonduz 6536 (B, holotype; BR, CR, isotypes).

Rosulate, epiphyte; stem short; roots few, directed upward; cataphylls coriaceous, ca. $9 \mathrm{~cm}$ long, drying dark brown, weathering to coarse linear fibers. LEAVES \pm erect; petioles sulcate, rounded to weakly angular abaxially, $2-12 \mathrm{~cm}$ long, $1-1.5 \mathrm{~cm}$ diam.; geniculum $2-2.5 \mathrm{~cm}$ long; blades narrowly to broadly oblanceolate, coriaceous, $25-81 \mathrm{~cm}$ long, $7.5-29 \mathrm{~cm}$ wide, acuminate at apex, attenuate at base; upper surface glossy, lower surface semiglossy, conspicuously punctate; midrib broad and flat at base above, soon becoming convexly raised, narrowing and sunken toward apex, acutely raised below; primary lateral veins 7-15 per side, departing midrib at $45^{\circ}$ angle, sunken above, raised below, straight to collective vein; collective vein arising from base, sunken above, raised below, 1.5-2 $\mathrm{cm}$ from margin. INFLORESCENCE erectspreading; peduncle 10-27 cm long, subterete; spathe subcoriaceous, yellow-green tinged with violet-purple, oblong-elliptic, $5.5-11 \mathrm{~cm}$ long, $2.2-3.5 \mathrm{~cm}$ wide, withering and early deciduous; stipe becoming elongate to $29 \mathrm{~cm}$ at anthesis; spadix purple-violet (B \& K Red-purple 4/2.5), 10-20 cm long, $1-2.5 \mathrm{~cm}$ diam. at base, 7-12 $\mathrm{mm}$ diam. at apex; flowers sub-rhombic to 4 lobed, $2.4-3.6 \mathrm{~mm}$ long, 2-3.5 $\mathrm{mm}$ wide, the sides \pm straight to jaggedly sigmoid; 9-20 flowers visible in the principal spiral, the alternate spiral irregular with 9-12 flowers visible; tepals glossy, with numerous tiny droplets; pistils flat to weakly emergent, pinkish to dark violet-purple, butterfly-shaped; the stigma oblong-elliptic, ca. $0.4 \mathrm{~mm}$ long, having minute droplets for several days before first stamens emerge; stamens emerging in a moderately prompt sequence from middle of spadix to both ends, the lateral stamens pre- 
ceding alternates by several spirals, the stamens complete at apex before basal flowers complete, emitting a strong, sweet scent at anthesis; anthers dark violet-purple; exserted on fleshy, pale violet-purple filaments, soon retracting to level of tepals, held in a cluster covering pistils; thecae oblong, slightly divaricate; pollen white or cream turning lavender. INFRUCTESCENCE with spadix to $23 \mathrm{~cm}$ long; berries bright red (B \& $\mathrm{K}$ Red 6/5), narrowly obovoid, acute to mammilliform at apex, ca. $1 \mathrm{~cm}$ long, 4-5 $\mathrm{mm}$ wide; seeds 2, white, weakly flattened, 2.5-2.7 mm long, 1.7$2 \mathrm{~mm}$ wide, $1-1.5 \mathrm{~mm}$ thick. Figs. 78 and 82 .

The species is found from Costa Rica, Panama, and probably in Colombia in the Department of Chocó, ranging from sea level to $1,560 \mathrm{~m}$ and occurring principally in tropical wet forest, but also in premontane wet forest. In Costa Rica the species occurs in San José Province (El General Valley) and Puntarenas Province (Osa Peninsula and the adjacent valley of the Río Diguis). Although the species is restricted to the Pacific slope in Costa Rica, it is known in Panama only from the Atlantic slope and along the Continental Divide on the Pacific slope.

Anthurium hacumense is strikingly different from all other species and can easily be distinguished in flower or fruit by its exceptionally long stipe, the dark purplish-violet tepals, and bright red berries. Vegetatively the species can be recognized by the oblanceolate leaves with black punctations on the lower leaf surface and the conspicuous collective vein, (0.8)1-2.4 cm remote from the margin.

The species was placed by Engler in section Pachyneurium apparently owing to its large oblanceolate leaves and rosulate habit, but it should be placed instead in section Porphyrochitonium because of its glandular dotted lower surface and lack of involute leaf vernation.

Anthurium hacumense is perhaps most closely related to A. curvilaminum Croat (ined.), which also has short petioles, smaller but similarly coriaceous blades with a prominent collective vein relatively remote from the margin, and a spadix of precisely the same color, which has a pleasant aroma. The latter differs however in having a spadix that is essentially sessile whereas $A$. hacumense has a spadix which has a stipe equalling or often exceeding the length of the spadix.

Costa Rica. CARTAgo: near Selva, Taylor 11463 (NY). PUNTARENAS: Corcovado National Park, Liesner 2849,
2851 (MO); N of Palmar Norte, Croat 35194 (MO); Rincón de Osa, Liesner 1698 (MO); Utley 1190 (DUKE); Santo Domingo, Engler 10094 (BR); Playa Blanca, Valerio 323 (BR); vicinity San Vito de Java, Croat 32903 (MO). SAN JOSÉ: between San Isidro del General \& Dominical, Croat 35340 (MO).

Anthurium halmoorei Croat, sp. nov. TYPE: Mexico. Nayarit: along Hwy. 28 between Tepic and Jalcocotán at Km 15.5, elev. ca. 1,000 m, Croat 45337 (MO-2690192-193, holotype; CAS, K, MEXU, MICH, SEL, isotypes; Live at MO).

Planta epiphytica aut rupestris; caudex brevis, crassus, radicibus densis crassisque; petiolus $15-19 \mathrm{~cm}$ longus, $12-18 \mathrm{~cm}$ latus, lateribus complanatis, adaxile late sulcatus, abaxiale obtuse angulatus aut costatus; lamina oblanceolata aut oblanceolata-elliptica, subcoriacea, 52-108 cm longa, 15-43 cm lata, marginibus late undulatis, nervis primariis lateralibus ad marginem liberibus; inflorescentia effusa, foliis breviora; pedunculus 32-38 cm longus; spatha ovata aut ovataelliptica, viridis, 13-16 cm longa; spadix viridis aut purpurata, 9-21 cm longa; baccae flavovirentes.

Rosulate, epiphyte or on rocks on very steep slopes; stems thick; internodes and leaf scars obscured by root mass; roots dense, descending, ca. $1 \mathrm{~cm}$ diam.; cataphylls subcoriaceous, $20-23 \mathrm{~cm}$ long, apiculate at apex, drying tan to brown, persisting intact at apex, dilacerating at base. LEAVES erect-spreading; petioles $15-19 \mathrm{~cm}$ long, 12-18 mm wide, flattened laterally, broadly sulcate adaxially, obtusely angular or 1-ribbed abaxially; geniculum 1-1.5 cm long; blades oblanceolate to oblanceolate-elliptic, subcoriaceous, short-acuminate at apex, attenuate at base, 52-108 cm long, 15-43 cm wide, broadest at middle or just above, the margins broadly undulate; the upper surface semiglossy, the lower surface matte and much paler; midrib broad and flat at base, convexly raised at middle, narrowed and flat at apex above, acutely raised below, the abaxial rib of the petiole extending onto midrib; primary lateral veins $12-14$ per side, departing the midrib at a $40^{\circ}-55^{\circ}$ angle, prominently raised above, raised below; straight then curving toward apex near margin; interprimary veins less conspicuously raised above, visible and flat below; secondary veins prominulous above, flat below; collective vein arising from a primary lateral vein near the apex, 6-11 $\mathrm{mm}$ from margin, flat above, prominulous below. INFLORESCENCE spreading, shorter than leaves; peduncle $32-38 \mathrm{~cm}$ long, 9-10 mm diam., subterete, obscurely angled, 22.5 times longer than petioles; spathe subcoria- 
ceous, green (B \& K Yellow-green 6/10), sometimes tinged purple, ovate to broadly ovate, $13-$ $16 \mathrm{~cm}$ long, $6.2-9.7 \mathrm{~cm}$ wide, broadest near base, acuminate at apex, acute at base, the margins undulate, inserted at a $70^{\circ}$ angle on peduncle; spadix green, purple, or green heavily tinged purple (B \& K Red-purple 2/5), 9-21 cm long, 11 $27 \mathrm{~mm}$ diam. at base, 5-7 mm diam. at apex; flowers 4-lobed, 2.4-2.8 mm long, $2.7-3.2 \mathrm{~mm}$ wide, the sides sigmoid; $8-14$ flowers visible in the principal spiral, 12-20 flowers visible in the alternate spiral; tepals matte, weakly punctate, minutely papillate, lateral tepals $1.5-1.8 \mathrm{~mm}$ long, the inner margin convex; pistil slightly raised, green tinged with purple in area of stigma; stigma linear, 0.4-0.6 $\mathrm{mm}$ long, a minute droplet appearing 4-5 days before first stamens emerge, dry with white exserted papillae when anthers open; stamens emerging \pm rapidly from the base exserted on filament ca. $0.3 \mathrm{~mm}$ long, $0.8 \mathrm{~mm}$ wide, retracting to hold anthers held at edge of pistil, mounded with pollen; anthers orange; thecae ellipsoid, scarcely divaricate; pollen orange (B \& K Yellow 7/2.5), drying white. INFRUCTESCENCE pendent; spathe usually persisting; berries irregularly obovoid, pale yellow green, broadly rounded to almost flat with a scurfy, brown square around style, 12-15 $\mathrm{mm}$ long, 7$9 \mathrm{~mm}$ diam.; mesocarp fleshy with numerous raphide cells; seeds 2 , pale tan, subglobose, weakly flattened, 5-6.5 mm long, 3.5-4.1 mm wide, ca. $2.5 \mathrm{~mm}$ thick, with a sticky appendage at base and apex. Figs. 83 and 87.

Anthurium halmoorei is restricted to western Mexico in the states of Nayarit, Jalisco, Colima, and Michoacán in seasonally very dry forests from 450 to $1,450 \mathrm{~m}$ elevation. It occurs usually on rocks on very steep slopes in forested areas.

The species is in section Pachyneurium and is characterized by its generally oblanceolate or oblanceolate-elliptic blades with usually free-ending primary lateral veins, and by its petiole which is acute abaxially but especially by its ovate to ovate-elliptic spathe, green to purplish spadix and greenish-yellow mature berries.

The species is probably most closely related to A. schlechtendalii ssp. jimenezii, which differs in having the petiole subquadrangular, usually flat abaxially and in having a lanceolate spathe and red berries at maturity. That species occurs only in Guerrero and southern Oaxaca.

Mexico. Jalisco: vicinity Autlán de Navarro, McVaugh 10224 (MICH); Wilbur 2289 (MICH); be- tween El Tuito \& Puerto Vallarta, Delgado $359(\mathrm{MICH})$ Hernández 2608 (MEXU); Anderson 6113 (ENCB, $\mathrm{MICH}) ; \mathrm{S}$ of San Pedro, Koeppen \& Iltis 593 (BH); Talpa de Allende, McVaugh 23408 (MICH). MICHOACÁN: vicinity Aguililla, McVaugh 24741 (MICH); Coalcomán de Matamoros, Rzedowski 16707 (ENCB, MICH). NAYARIT vicinity Jalcocotán, Gentry \& Gilly 10734 (MEXU, US); McVaugh 12140 (MICH); Moore \& Bunting 8692 (BH); vicinity Jalisco, Norris \& Toranto, 12645 (CAS, MO); vicinity Mirador El Aguila, McVaugh 15281 (MICH); NE of Santa María del Oro, Feddema 703 (MICH); Tepic, Bates et al. 1554 (BH); N of Tepic, Dressler 339 (UC); NW of Tepic, Lewis s.n. (MICH); Ferris 6816 (DS); W of Tepic, Dressler 1024 (UC); between Tepic and Jalcocotán, Croat 45337 (CAS, K, MEXU, MICH, MO, SEL).

Anthurium hoffmannii Schott, Oesterr. Bot. Z. 8: 181. 1858. TYPE: Costa Rica. San José: Chica Uruca, Hoffmann 571 (B, destroyed; Photo of Schott Aroid Drawing \#662, NYBG Neg. \#N.S. 3897).

Anthurium torresianum Engl., Bot. Jahrb. Syst. 25: 428. 1898. Lectotype: Costa Rica. San José: San Francisco de Guadalupe, 1,100 m, Tonduz 7176 (US, hololectotype; F, M, NY, isolectotype; designated Croat \& Baker, 1979).

Epiphyte or terrestrial; stems to $60 \mathrm{~cm}$ or longer; internodes 1-2 cm long; leaf scars obscured by cataphylls; roots few, green, 3-8 $\mathrm{mm}$ diam.; cataphylls coriaceous, $7-15 \mathrm{~cm}$ long, drying reddish brown, persisting intact. LEAVES with petiole erect-spreading, $20-90 \mathrm{~cm}$ long, $4-8 \mathrm{~mm}$ diam., terete or weakly sulcate; geniculum 2-3.5 cm long; blades ovate, moderately thick, 14-55 $\mathrm{cm}$ long, 9-38 cm wide, acuminate at apex, deeply lobed at base; anterior lobes 11-44 cm long, posterior lobes $4-12 \mathrm{~cm}$ long; sinus parabolic to spathulate; the upper surface semiglossy, the lower surface glossy; the midrib convexly raised above, acutely raised below; primary lateral veins $4-5$ per side, weakly sunken above, raised below; basal veins 4-7 pairs, 3-4 coalesced 1-4 cm (rarely free to base); posterior rib naked, weakly turned upward; collective vein arising from first basal vein, sunken above, acutely raised below, 3-10 $\mathrm{mm}$ from margin. INFLORESCENCE erect to slightly arching; peduncle $16-50 \mathrm{~cm}$ long, 1-4 $\mathrm{mm}$ diam., terete; spathe, pale yellow-green, subcoriaceous, oblong-ovate to lanceolate, $6-13 \mathrm{~cm}$ long, $1.7-3 \mathrm{~cm}$ wide, inserted at $70^{\circ}$ angle on peduncle; spadix stipitate $6-10 \mathrm{~mm}$ in front, 1 $3 \mathrm{~mm}$ in back, pale green becoming white or cream colored, $4.5-8.5 \mathrm{~cm}$ long, ca. $8 \mathrm{~mm}$ diam. at middle, ca. $7 \mathrm{~mm}$ diam. at base and apex; flowers 4-lobed, 2.3-2.8 mm long, 2.6-3 mm wide, the sides straight to sigmoid, 5-8 flowers 

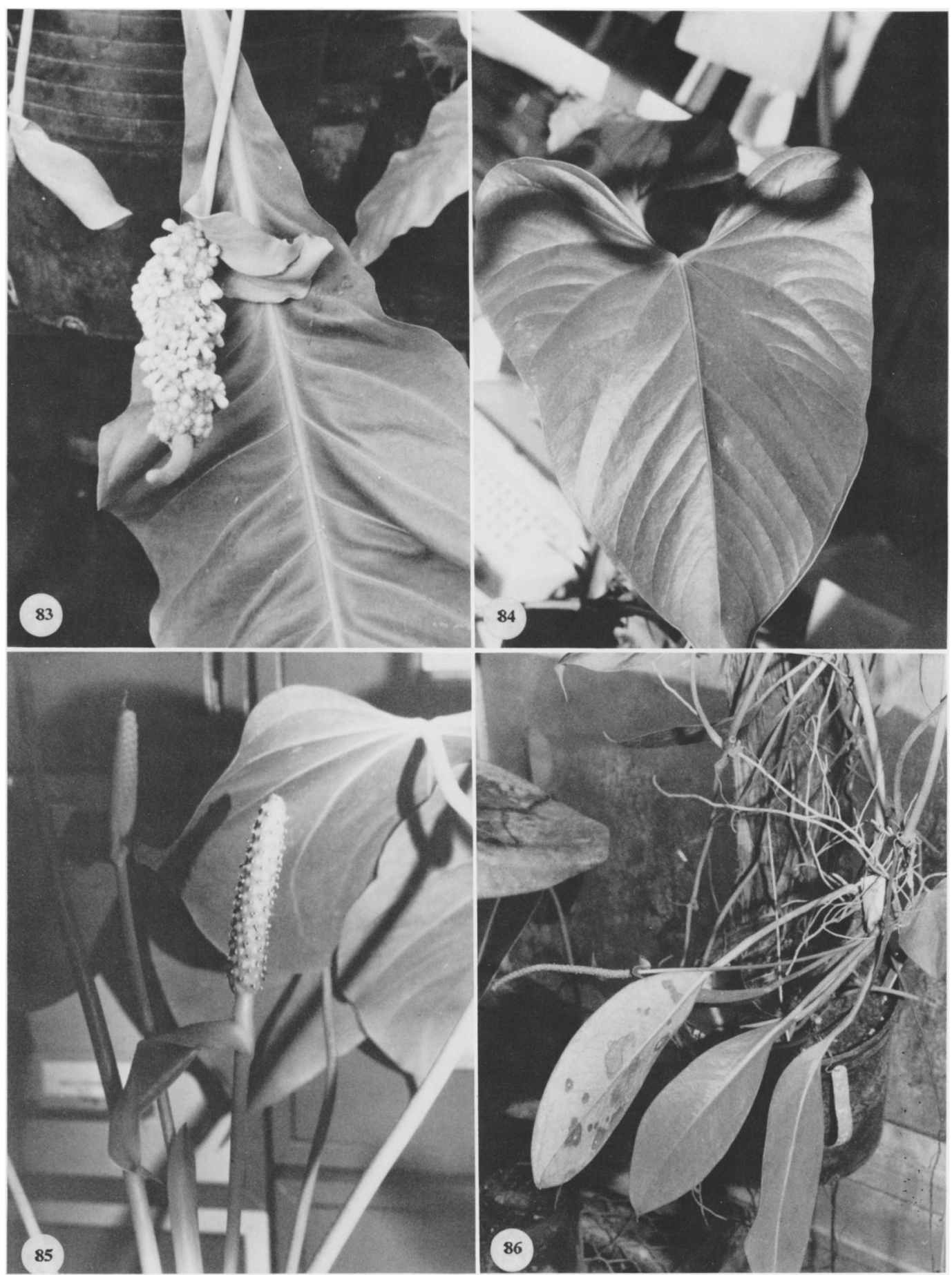

Figures 83-86. 83. Anthurium halmoorei Croat, Croat 45337 (Type). -84. Anthurium hoffmannii Schott, Hammel 3471.-85. Anthurium huixtlense Matuda, Croat 40583. -86. Anthurium interruptum Sodiro, Selby 58-1975-32. 

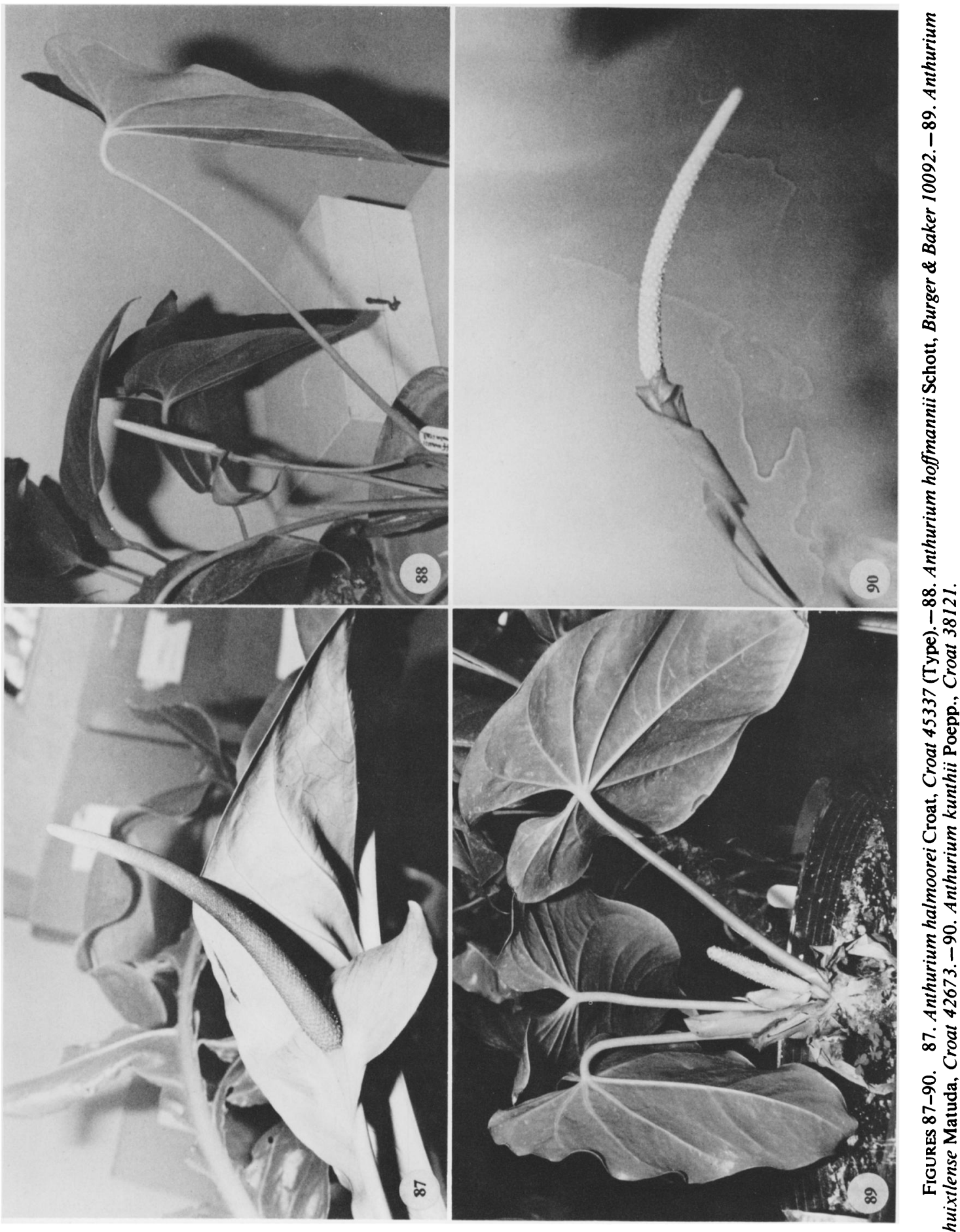
visible in the principal spiral; 8-13 flowers visible per alternate spiral; tepals glossy, obscurely punctate, lateral tepals $1.4 \mathrm{~mm}$ wide, the inner margin \pm straight; pistils weakly and acutely raised, white, minutely papillate; stigma linear, $0.3 \mathrm{~mm}$ long, a minute inconspicuous slit with minute droplets briefly apparent ca. 1 week before stamens emerge; stamens emerging rapidly, scattered throughout spadix, the lateral stamens first; anthers white, held in \pm contiguous square at edge of pistil, $0.4-0.7 \mathrm{~mm}$ long; thecae ovoid, weakly divaricate; pollen white. INFRUCTESCENCE arching-pendent; spadix to $15 \mathrm{~cm}$ long, to $2 \mathrm{~cm}$ diam.; berries red, ovoid, ca. $8 \mathrm{~mm}$ long, ca. $5 \mathrm{~mm}$ wide; pericarp with elongate raphide cells; mesocarp clear, gelatinous; seeds 2 , brown, ca. $4 \mathrm{~mm}$ long, ca. $2 \mathrm{~mm}$ wide. Figs. 84 and 88 .

Anthurium hoffmannii is found in Costa Rica and Panama at elevations mostly between 700 and $1,700 \mathrm{~m}$, principally in tropical wet, premontane rain and lower montane rain forest but also in premontane wet forest.

This species is in section Calomystrium and is closely related to (and perhaps not separate from) A. huixtlense, which ranges from Mexico (Chiapas) to northern Nicaragua, and to $A$. monteverdense from Costa Rica. It is also related to a number of unnamed taxa from Panama. All these species share a similar thick, ovate, prominently basally lobed blade, and thick, persistent cataphylls that dry reddish-brown and remain intact in age. Leaves generally have numerous short, linear, raphide cells on the upper surface which can be seen both before and after drying.

Costa Rica. No other location, Pittier 3867 (BR). alajuela: no other location, Austin Smith H991 (NY). CARTAGo, SE of Platanillo, Croat 36725 (MO). PUnTARENAS: Boruca, Pittier 4655 (BR); Buenos Aires, Pittier 3869, 6538 (BR); Las Cruces Botanical Garden, Croat 44396 (MO); Pan Am Highway, El General Valley, Williams et al. 28810 (F, GH, WIS); W of Rincón de Osa, Burger \& Gentry 8923 (F, MO, US); E of San Isidro, Webster et al. 12403 (US); S of San Vito, Raven 21768 (F). SAN JosÉ: no other location, Luteyn 3282 (DUKE); Pittier 455 (BR, UC, US); Standley 42015 , 42054 (US); Alajuelita, Pittier 8839 (BR); vicinity Guadalupe, Pittier 8485, 8764, 9858 (BR); Tonduz 7176 (NY, US); vicinity San Isidro del General, Burger \& Baker 10092 (MO); Burger \& Visconti 10679 (MO); Croat 35266 (MO); Jiménez 3836 (F); Molina et al. 17927 (CAS); Skutch 3076 (GH, MO, NY).

Anthurium huixtlense Matuda, Revista Soc. Mex. Hist. Nat. 11: 91, Fig. 1. 1950. TYPE: Mexico. Chiapas: near Cerro Piedra de Huixtla,
$20 \mathrm{~km} \mathrm{NE}$ of Huixtla, $900 \mathrm{~m}$ elev. Matuda 18615 (MEXU, holotype).

Anthurium bochilense Matuda, Bol. Soc. Bot. México 19: 21. 1956. TYPE. Mexico. Chiapas: Bochil, near San Cristóbal de Las Casas, MacDougall 363 (MEXU, holotype).

Terrestrial or epiphytic; stems to $14 \mathrm{~cm}$ long, $3 \mathrm{~cm}$ diam.; leaf scars $2-3 \mathrm{~cm}$ wide, obscured by cataphylls at upper nodes; roots few, ca. $5 \mathrm{~mm}$ diam., descending; cataphylls coriaceous, 5-23 $\mathrm{cm}$ long, long-acuminate at apex (the acumen apiculate ca. 1-2 mm), drying dark tan (B \& $\mathrm{K}$ Yellow 5/2.5), persisting intact. LEAVES erectspreading; petioles $15-70 \mathrm{~cm}$ long, 6-9 $\mathrm{mm}$ diam., terete; geniculum 1-5 cm long; blades subcoriaceous, ovate to broadly ovate, $17-70 \mathrm{~cm}$ long, $10.5-36 \mathrm{~cm}$ wide, broadest just below point of petiole attachment, short-acuminate at apex, deeply lobed at base; anterior lobe $14-50 \mathrm{~cm}$ long, the margins rounded; posterior lobes 5-20 $\mathrm{cm}$ long, flat to downturned, sometimes overlapping; the sinus triangular to hippocrepiform, sometimes \pm rhombic in larger leaves when flattened; the upper surface matte to semiglossy with sparse, obscure raphide cells, the lower surface glossy; the midrib sharply raised above, diminished and sunken at apex, convexly raised below; basal veins 5-6 pairs, the third to fifth coalesced $2-2.5 \mathrm{~cm}$, raised; the posterior rib naked, turned up on the outer margin; primary lateral veins 35 per side, prominulous above and below, departing midrib at $30^{\circ}-40^{\circ}$ angle, straight or arching near collective vein; lesser veins less conspicuous; collective vein arising from one of the lowermost primary lateral veins or from the first basal vein, flat to weakly raised, 4-10 $\mathrm{mm}$ from margin. INFLORESCENCE erect-spreading, shorter than leaves; peduncle 21-39 cm long, 4$7 \mathrm{~mm}$ diam., terete; spathe coriaceous, pale whitish-green (B \& K Yellow-green 9/10), oblonglanceolate, $4.5-15 \mathrm{~cm}$ long, $2.7-4.5 \mathrm{~cm}$ wide, broadest at middle, abruptly long-acuminate at apex, obtuse to rounded at base; the stipe $12 \mathrm{~mm}$ long in front, $2.5 \mathrm{~mm}$ long in back, pale green; spadix reddish-violet to lavender (B \& K Red 8/ 5 , red-purple $5 / 2.5$ to purple $6 / 5$ ), rarely white, 4.2-20 cm long, 6-10 $\mathrm{mm}$ diam. at base, 5-6 $\mathrm{mm}$ diam. at apex; the flowers 4-lobed, 2.3-3.1 $\mathrm{mm}$ long, $2.5-3.5 \mathrm{~mm}$ wide, the sides jaggedly sigmoid; 5-8 flowers visible in the principal spiral, 5-9 flowers visible in the alternate spiral; tepals semiglossy, with white inconspicuous punctations, smooth to very minutely papillate, 
lateral tepals $1.5-2.2 \mathrm{~mm}$ wide, the inner margin straight; pistil emergent, white, glossy; stigma 0.3$0.6 \mathrm{~mm}$ long, linear; stamens emerging moderately rapidly from the base, lateral stamens emerging to apex before alternates emerge at base, held in tight cluster obscuring pistil; anthers white to pale yellow, $0.6-0.7 \mathrm{~mm}$ long, $0.6-0.8 \mathrm{~mm}$ wide; thecae oblong, scarcely or not at all divaricate; pollen white. INFRUCTESCENCE spreading to pendent in large plants; spathe deciduous; spadix ca. $21 \mathrm{~cm}$ long, $2 \mathrm{~cm}$ wide; berries orange, globose; seeds green, up to 3 per berry. Figs. 85 and 89 .

Anthurium huixtlense ranges from southern Mexico (Chiapas) to Nicaragua.

The species is a typical member of section $\mathrm{Cal}$ omystrium and can be recognized by its thick, persistent cataphylls that turn reddish-brown and remain intact, and by its relatively long, usually reddish-violet to lavender spadix with early emergent pistils and orange berries. In Flora of Guatemala (Standley \& Steyermark, 1958) this species was called $A$. concinnatum, an unrelated species from high elevations in Costa Rica and Panama.

The species is closely related to and is perhaps only subspecifically distinct from $A$. hoffmannii, which ranges from Costa Rica to Panama. Anthurium hoffmannii has a moderately thick green spathe and a white spadix. In addition, the tepals of $A$. hoffmannii are generally matte. In $A$. huixtlense the tepals are glossy and the pistil is rather prominently exserted (although usually soon hidden by the tight cluster of stamens) giving the spadix a coarse, almost "prickly" look. The spadix of $A$. hoffmannii has the pistils scarcely exserted at or near anthesis so that the spadix does not have a "prickly" look.

Spathe and spadix color are quite variable for A. huixtlense. Spathe color may be green to white and spadix color ranges from creamy white to lavender or reddish-violet. For some populations the color remains consistent but since considerable color variation may be found within a population the spadix color is not a useful taxonomic character in A. huixtlense.

The plants of $A$. huixtlense with lavender spadices are similar to those of $A$. armeniense, which has somewhat pinkish spadices and a white spathe. However, that species is distinguished by having the tepals matte rather than glossy and in having an early emergent pistil that is as long or longer than the stamens when they emerge.
Another close relative of both $A$. hoffmannii and $A$. huixtlense is $A$. erythrostachyum Croat (ined.) from Panama. The latter species differs from both of the former species by its caudateacuminate spathe with the acumen up to $3 \mathrm{~cm}$ long. It differs also from $A$. hoffmannii in having the spadix colored somewhat lavender.

Anthurium huixtlense has been confused with A. fraternum Schott since the time of Engler. That species occurs in the Sierra Nevada de Santa Maria of northeastern Colombia. Anthurium huixtlense and $A$. fraternum share a similar leaf shape (as do most members of the section $\mathrm{Cal}$ omystrium) and a similar spathe and spadix shape, but $A$. fraternum differs in having a dense array of discrete, punctiform, glandlike dots on the upper surface of the blade on drying and has a dense array of minute, reddish-brown blotches on the lower surface. Anthurium fraternum is not known from Central America.

Belize. CAyo District: vicinity La Flor, Croat 23784 (MO).

El Salvador. SAN SAlvador: La Palma, Bernhardt s.n. (MO).

Guatemala. alta verapaz: vicinity Cobán, Croat 41470, 41479 (MO); Tuerckheim 3795 (GH); Finca Cubilhuitz, Tuerckheim 8611 (GH); Río Cobán, Johnson 723 (UC); N of church in Senahú, Luteyn \& Almeda 3524 (MO); W of Telemán, Croat 41572 (MO). escuintla: Volcán de Fuego, Standley 64529 (F). IZABAL: N of Highway CA9, Harmon \& Fuentes 1926 (MO). QUEZALTENANGO: vicinity Patzulín, Standley 86887 (F). SAN MArcos: Finca Armenia, Dwyer 14459 (MO), SOlalá: Volcán Atitlán, Steyermark 47997 (F, GH). SUCHITEPÉQUEZ: Santa Bárbara, Lind 12 (WIS). ZACAPA: Volcán de Monos, Steyermark $42387(\mathrm{~F})$.

Honduras. ATlantida:vicinity La Ceiba, Yuncker et al. 8741 (F, GH, MO); Lancetilla Valley, Chickering 204 (MICH); Croat 42673 (MO): Standley 55668 (F); Yuncker 4955 (MICH, MO); 5005 (MICH). COMAyagua: W of Siguatepeque, Molina 25976 (F). CORTÉs: vicinity El Jaral, Standley et al. 7060 (F); vicinity Peñas Blancas, Hernandez \& Hernandez 5302 (MO); Santa Cruz de Yojoa, Edwards P-714 (GH). OCOTEPEQUE: vicinity Nueva Ocotopeque, Molina \& Molina 30950 (MO). SANTA BÁRBARA: NW side of Lake Yojoa, Croat 42751 (MO); Yuncker 4859 (MICH, MO).

Mexico. Chiapas: Acacoyagua, Matuda 17969 (MEXU); vicinity Berriozábal, Miranda 6474 (MEXU); NE of Bochil, Breedlove 10219 (CAS); Bochil, MacDougall 363 (MEXU); Comaltitlán, Matuda 17881 (MEXU); Huixtla, Matuda 18599, 37686 (MEXU); N of Jitotol, Thorne \& Lathrop 46732 (RSA); Monserrate, MacDougall 26026 (MEXU); vicinity Ocosingo, Ton 3518 (DS, F, MICH); N of Ocozocoautla de Espinosa, Croat 40583, 40633 (MO); vicinity Pueblo Nuevo Solistahuacán, Croat 46428, 47773 (MO); vicinity San Fernando, Miranda 6162 (MEXU); Munc. Tenejapa, Breedlove 7560 (CAS); Tuxtla Gutiérrez, 
MacDougall 375 (MEXU). VERACRUZ: Hidalgotitlán, Valdivia 375, 686 (XAL); Vazquez 51 (XAL).

NicARAGUA. No other location, Williams et al. 24733 (F). NUEVA SEGOVIA: S of Jalapa, Neill 1666 (MO).

Anthurium interruptum Sodiro, Anales Univ. Centr. Ecuador 15: 301. 1902. TYPE: Ecuador. Western slopes of the Cordillera de Angamarca, Nov. 1899. Sodiro s.n. (B, holotype).

Anthurium radicosum Standl. \& Steyerm., Publ. Field Mus. Nat. Hist., Bot. Ser. 23: 210. 1947. TYPE: Guatemala. Alta Verapaz: along Río Icbolay, 300350 m, 6 March 1942, Steyermark 44776 (F, holotype).

Scandent epiphyte; stems elongate with 1 or more short internodes alternating with a long internode, $8-33 \mathrm{~cm}$ long, appearing to have several leaves at each node, often with a short, leafy, branch with several short internodes at these nodes; rooting profusely at each node; cataphylls 3-4.5 cm long, drying brown, dilacerating and ultimately deciduous. LEAVES spreading; petioles \pm terete, $1.8-13 \mathrm{~cm}$ long; blades lanceolate to elliptic, oblong-elliptic or oblanceolate, subcoriaceous, 5-21 cm long, $2.2-9.5 \mathrm{~cm}$ wide, acuminate at apex, acute to rounded at base, 5-21 $\mathrm{cm}$ long; the midrib raised above, flat to prominulous below; primary lateral veins 9-12 per side, departing midrib at $45^{\circ}-55^{\circ}$ angle, \pm obscure above, usually obscure below; collective vein arising from the base, prominulous above, flat below, 4-6 $\mathrm{mm}$ from the margin. INFLORESCENCE erect-spreading; peduncle $4.5-14 \mathrm{~cm}$ long, longer than petioles; spathe green, oblonglanceolate, $3.7-5 \mathrm{~cm}$ long, $1-1.5 \mathrm{~cm}$ wide, acuminate at apex, acute at base; spadix green, becoming brownish-purple, $2.5-4 \mathrm{~cm}$ long; flowers 4-lobed, ca. $3 \mathrm{~mm}$ in both directions, the sides sigmoid; ca. 3 flowers visible in either spiral; pistils emergent, green, mammilliform; stamens held above tepals; anthers about as long as broad, less than $1 \mathrm{~mm}$ long; pollen pale yellow. INFRUCTESCENCE spreading-pendent; spadix to $12 \mathrm{~cm}$ long; berries red, broadly obovoid, ca. 7 $\mathrm{mm}$ long, flattened at apex with central depression. Figs. 86 and 95.

The species is known from Guatemala to Panama, Ecuador, and surely will be found also on the Pacific slope of Colombia. In Costa Rica and Panama it is known from premontane wet, tropical wet, premontane rain, and lower montane rain forest at elevations from 150 to $1,000 \mathrm{~m}$. In Costa Rica the species is known on the Atlantic slope from northwestern Alajuela to southeastern Cartago Province. In Panama it is known from both the Atlantic and Pacific slopes.

Anthurium interruptum is in section Xialophyllium and can be recognized by its scandent stem with greatly, elongated internodes alternating with two or more successive abbreviated internodes giving the appearance of several leaves being clustered at a node. In addition, no other scandent, entire-leaved species is known to have bright red berries.

Anthurium interruptum most resembles $A$. pittieri and A. carnosum. Steyermark, in Flora of Guatemala (Standley \& Steyermark, 1958), combined $A$. radicosum and $A$. pittieri, apparently due to their vegetative resemblance. However, A. pittieri can be differentiated by the long-decurrent spathe and shorter internodes. They also differ in altitudinal and geographical distribution. Anthurium pittieri is known only from Costa Rica and Panama while $A$. interruptum ranges from Guatemala to Ecuador. The former species also has a range of 50 to $2,100 \mathrm{~m}$ altitude but mostly above $1,000 \mathrm{~m}$. In Ecuador the species may range to about $1,300 \mathrm{~m}$. Anthurium interruptum is most common in the lowlands between 100 and $1,000 \mathrm{~m}$. Anthurium carnosum differs from $A$. interruptum in its nearly uniform internode length, thicker leaves and altitudinal range of 1,500 to $2,600 \mathrm{~m}$.

Belize. TOledo district: Pueblo Viejo, Schipp S-678 (MICH, MO, S).

COSTA RicA. AlAJUEla: vicinity Bijagua, along road to Upala, Burger \& Baker 9861 (MO); Croat 36432 (MO). CARTAGO: road between Moravia \& Quebrada Platanillo, Croat 36631, 36655 (MO); SE of Platanillo, Croat 36715 (MO); between Río Taus \& Quebrada Azul, Lent 2550 (MO); between Tuis and Bajo Pacuare, Burger et al. 10029 (DUKE, MO, NY); Turrialba, along Río Reventazón, Lent 693 (MO). HEREdIA: La Selva, Puerto Viejo de Sarapiquí, Jiménez 101 (MO). Limón: $\mathrm{S}$ of Siguirres, Croat 43323 (MO).

Nicaragua. Zelaya: road to Colonia Agrícola Yolaina \& Colonia La Esperanza, Stevens 6311 (MO); Vincelli $182(\mathrm{MO})$; road from Siuna to Matagalpa, Stevens 7521 (MO).

Anthurium kunthii Poepp. in Poepp. \& Endl., Nov. Gen. et Spec. 3: 84. 1845. TyPE: Peru. Loreto: Maynas, Poeppigs.n. (W, destroyed; isotypes?).

Epiphyte, scandent; stems usually to $1 \mathrm{~m}$ or longer, $1-1.5 \mathrm{~cm}$ diam., internodes $4-20 \mathrm{~cm}$ long; leaf scars 8-14 mm wide; roots numerous at each node, descending; cataphylls subcoriaceous, 2.5$8.5 \mathrm{~cm}$ long, drying yellow to $\tan (\mathrm{B} \& \mathrm{~K}$ Yellow- 
red 9/10), persisting as linear fibers at each node. LEAVES spreading; petioles $20-60 \mathrm{~cm}$ long, 2$3 \mathrm{~mm}$ diam., terete, shallowly sulcate; geniculum $0.3-0.9 \mathrm{~cm}$ long, more deeply sulcate than petiole; blades ovate, $22-60 \mathrm{~cm}$ long, $20-40 \mathrm{~cm}$ wide, 5-, 7-, or 9-pedatisect, the leaflets moderately thin, elliptic to ovate-elliptic, $7-27 \mathrm{~cm}$ long, 3-8 $\mathrm{mm}$ wide, long-acuminate at apex, acute to attenuate at base; petiolules to $5.5 \mathrm{~cm}$ long, 1-2 $\mathrm{mm}$ diam., broadly and sharply sulcate; upper surface semiglossy, lower surface semiglossy to matte; midrib prominulous above, prominently raised below; primary lateral veins 5-18 per side, sunken above, raised below, departing midrib at $45^{\circ}-55^{\circ}$ angle, loop-connecting, weakly sunken above, raised below; collective vein arising from one of the lowermost primary lateral veins, 3-8 $\mathrm{mm}$ from margin. INFLORESCENCE spreading to arching, longer or shorter than the leaves; peduncle $20-55 \mathrm{~cm}$ long, terete; spathe green or sometimes slightly tinged purple, oblong-lanceolate, $5.5-15.5 \mathrm{~cm}$ long, $0.8-2.5 \mathrm{~cm}$ wide, acuminate at apex, acute to obtuse at base, inserted at $50^{\circ}-70^{\circ}$ angle on peduncle; stipe $5-9 \mathrm{~mm}$ long in front, $0.5-3.5 \mathrm{~mm}$ long in back; spadix pale green fading to tan at anthesis, 7-21 cm long, 5$10 \mathrm{~mm}$ diam. at base, $1-4 \mathrm{~mm}$ diam. at apex; the flowers rhombic to 4-lobed, 3.5-4 mm long, 2.5-3 mm wide, the sides straight to sigmoid; 59 flowers visible in the principal spiral, 5-7 flowers visible in the alternate spiral; tepals matte, minutely papillate, lateral tepals $1-1.5 \mathrm{~mm}$ long, the inner margin convex and upturned; pistils not emergent, pale green, matte, minutely papillate; stigma linear, ca. $0.5 \mathrm{~mm}$ long; stamens emerging slowly from base, the alternate pair emerging at base when the lateral stamens have emerged ca. one-third the length, held close around the pistil; anthers creamy white, 0.3-0.4 $\mathrm{mm}$ long, $0.6-0.9 \mathrm{~mm}$ wide; thecae ellipsoid, widely divaricate; pollen white. INFRUCTESCENCE pendent; spadix to $25 \mathrm{~cm}$ long; berries purple to violet-purple. Figs. 90 and 91 .

Anthurium kunthii ranges from Costa Rica to Peru. In Costa Rica it is known only from tropical moist forest in Limón Province. In Panama it occurs in tropical moist and premontane wet forest on both slopes at elevations below $500 \mathrm{~m}$.

Because of its palmately compound leaves, $A$. kunthii is confused only with $A$. pentaphyllum var. bombacifolium. Anthurium kunthii differs by having long, slender peduncles, nearly equal- ling the petioles in length, and by having a slender, elongate, usually greenish spadix. It also differs from $A$. pentaphyllum var. bombacifolium in having leaflets distinctly petiolulate and more or less equilateral at the base. Anthurium pentaphyllum var. bombacifolium usually has at least the outer leaflets inequilateral at the base, a short peduncle, and a pale violet-purple spadix. The species is a member of section Dactylophyllium.

Costa RicA. limón: Talamanca, Ocampo 1904 (MO). Nicaragua. Zelaya: Cerro Baká, Coperna; Pipoly 4920 (MO).

Anthurium lancetillense Croat, sp. nov. TYPE: Honduras. Atlántida: Lancetilla Valley, ca. $10 \mathrm{mi} \mathrm{SE}$ of Tela; in forest preserve along Río Lancetilla, on trail to water reservoir; 10-150 m elev., Croat 42672 (MO-258347879, holotype; EAP, K, MEXU, SEL, TEFH, US, isotypes; Live at MO).

Planta terrestris; caudex ad $15 \mathrm{~cm}$ longus; petiolus $17-82 \mathrm{~cm}$ longus, teres; lamina anguste ovata, 38-54 $\mathrm{cm}$ longa, $20-35 \mathrm{~cm}$ lata, basi cordata profunde; inflorescentia effusa-erecta, foliis breviora; pedunculus 3.5$36 \mathrm{~cm}$ longus; spatha viridis, interdum intra purpurea, lanceolata, $8.5-16 \mathrm{~cm}$ longa, 2-3.2 cm lata; spadix atropurpureus, $11-20.5 \mathrm{~cm}$ longus; pollen aurantiacum; baccae aurantiacae, ovoideae.

Terrestrial; stems to $15 \mathrm{~cm}$ long, $2.5-3 \mathrm{~cm}$ diam.; leaf scars conspicuous, $2.3-3 \mathrm{~cm}$ wide; roots tan, 6-8 $\mathrm{mm}$ diam., descending; cataphylls subcoriaceous, 9-13 cm long, acute at apex, minutely subapiculate, drying tan, dilacerating at base, remaining intact at apex, persisting around base of leaves. LEAVES with petioles erect, 17$82 \mathrm{~cm}$ long, 5-10 $\mathrm{mm}$ diam., terete; geniculum 1.5-3 cm long; blades narrowly ovate, moderately thick, gradually long-acuminate at apex, deeply lobed at base, $38-54 \mathrm{~cm}$ long, $20-35 \mathrm{~cm}$ wide, broadest midway between base and point of petiole attachment, margins weakly undulate; anterior lobe $24-37 \mathrm{~cm}$ long, the margins rounded to concave; posterior lobes $12-19 \mathrm{~cm}$ long; the sinus spathulate to hippocrepiform, acute to obtuse at apex; both surfaces semiglossy; the midrib convexly raised above, more acutely raised below; basal veins 6-7 pairs, first and second free, the remaining coalesced $3.5-4 \mathrm{~cm}$; posterior vein naked, weakly curved, rolled conspicuously upward; primary lateral veins 3-4 per side, departing midrib at $45^{\circ}-50^{\circ}$ angle, raised at midrib, sunken near collective vein above, raised below; lesser veins less conspicuous, flat above 
and below; collective vein arising from the first basal vein, sunken above, raised below, 2-10 $\mathrm{mm}$ from the margin. INFLORESCENCE erectspreading, shorter than leaves; peduncle 3.5-36 cm long, 4-7 mm diam.; spathe subcoriaceous, green, sometimes heavily tinged with violet-purple on inner surface, lanceolate, $8.5-16 \mathrm{~cm}$ long, $2-3.2 \mathrm{~cm}$ wide, gradually long-acuminate at apex (the acumen inrolled ca. $3.5 \mathrm{~cm}$ ) rounded at base, inserted at $45^{\circ}$ angle on peduncle; spadix dark violet-purple (B \& K Blue-purple 2/10), 11-20.5 $\mathrm{cm}$ long, 7-12 $\mathrm{mm}$ diam. at base, 3-5 $\mathrm{mm}$ diam. at apex; flowers rhombic to weakly 4-lobed, 3.3$5 \mathrm{~mm}$ long, $2.8-4.5 \mathrm{~mm}$ wide, the sides straight to weakly sigmoid; 5-7 flowers visible in the principal spiral, 4-12 visible in the alternate spiral; tepals matte, obscurely punctate, minutely papillate, lateral tepals $2.3-4 \mathrm{~mm}$ wide, the inner margin concave; pistils violet-purple around stigma, green below, weakly emergent; stigma ellipsoid, $1 \mathrm{~mm}$ long, opening ca. 2 weeks before first stamens emerge, large milky droplets apparent for several days, drying before first stamens emerge; stamens emerging in a relatively rapid sequence from the base, the lateral stamens emerging in basal one-quarter before alternates emerge, exserted on translucent filaments, 0.7 $\mathrm{mm}$ long, $0.5 \mathrm{~mm}$ wide; anthers pale orange, 0.6 $0.7 \mathrm{~mm}$ long, ca. $0.8 \mathrm{~mm}$ wide, held in a contiguous cluster around pistil; thecae ovoid-ellipsoid, somewhat divaricate; pollen orange. INFRUCTESCENCE pendent; spathe persistent; spadix 10-23 cm long, developing berries in basal onethird to one-half; berries, orange, ovoid, 10-13 $\mathrm{mm}$ long, $8-11 \mathrm{~mm}$ diam., acute at apex; mesocarp juicy with numerous, minute raphide cells; seeds $1-2$, pale green, ca. $6.8-8.0 \mathrm{~mm}$ long, $4.5-$ $6.2 \mathrm{~mm}$ wide. Figs. 92 and 96.

Anthurium lancetillense is known only from Honduras in the Lancetilla Valley at elevation from 10 to $600 \mathrm{~m}$. It occurs in wet forest.

The species is a member of section Belolonchium and is characterized by its narrowly ovate, moderately thick leaf blade, its green, subcoriaceous spathe that is sometimes tinged violet-purple on inner surface, its deep violet-purple spadix, orange pollen, and ovoid orange berries.

Anthurium lancetillense is most clearly related to A. umbrosum, which occurs only in Mexico in Oaxaca. It can be distinguished by its longer, more erect petioles and shorter more erect inflorescences. Anthurium lancetillense has larger, ovoid berries while A. umbrosum has smaller, globose berries with 4-radial ridges at apex. $A n$ thurium umbrosum is also found at much higher elevations ranging from 1,200 to $1,800 \mathrm{~m}$.

Honduras. atlántida: Lancetilla Valley, Croat 42672 (EAP, K, MEXU, MO, SEL, TEFH, US); Standley 53556 (F, US); Webster et al. 12706 (DAV, US); vicinity of San Alejo, Standley 7594 (F).

Anthurium lancifolium Schott, Oesterr. Bot. Z. 8: 180. 1858. TYPE: Costa Rica. Cartago: Volcán Turrialba, Wendland 518 (GOET).

Anthurium allenii Standl., Publ. Field Mus. Nat. Hist., Bot. Ser. 22: 66. 1940. TYPE: Panama. Coclé: north rim of El Valle, elev. 800-1,000 m, Allen 1854 (MO).

Anthurium firmum Engl., Bot. Jahrb. Syst. 25: 460 1898. TYPE: Costa Rica. Puntarenas: Cañas Gordas, 1,100 m, Pittier 11130 (B, holotype; BR, CR, isotypes).

Anthurium densinervium Engl., Bot. Jahrb. Syst. 25: 386. 1898. TYPE: Costa Rica. Along Río Hondo near Madre de Dios, elev. 200 m, Pittier 10346 (CR, holotype; $\mathrm{B}$, isotype).

Epiphyte or terrestrial, $30-90 \mathrm{~cm}$ tall; stems $1-1.5 \mathrm{~cm}$ diam.; the internodes very short; roots short, $3.5 \mathrm{~mm}$ diam.; leaf scars obscured by persisting cataphylls; cataphylls 4-7 cm long, drying reddish-brown weathering into coarse fibers. LEAVES spreading; petioles 15-45 cm long, 3$5 \mathrm{~mm}$ diam., obscurely and narrowly flattened adaxially sometimes with a faint medial rib; geniculum ca. $1.5 \mathrm{~cm}$ long, tinged purplish; blades subcoriaceous, lanceolate to ovate-lanceolate or oblong-elliptic, 20-30(50) cm long, 4-12 cm wide, long-acuminate at apex, cuneate at base; both surfaces semiglossy with black glandular punctations, more conspicuously so on lower surface; midrib narrowly and convexly raised above, becoming more acute at apex, prominently raised below; the primary lateral veins $15-25$ per side, departing the midrib at $35^{\circ}$ angle, sunken in valleys above, raised below; lesser veins obscure; collective vein arising from near the base, relatively straight, extending to the apex, 5-15 mm from the margin. INFLORESCENCE \pm erect, shorter than leaves; peduncle 26-60 cm long; spathe green, oblong-lanceolate, $4.3-8.5 \mathrm{~cm}$ long, $0.8-1.9 \mathrm{~cm}$ wide, broadest at base, abruptly cuspidate at apex; spadix gray- or greenish-white, $4.5-9.5 \mathrm{~cm}$ long, 5-7 $\mathrm{mm}$ diam. at base, $4-5 \mathrm{~mm}$ diam. at apex; flowers rhombic to 4-lobed, 3-3.3 $\mathrm{mm}$ long, $3.3-3.6 \mathrm{~mm}$ wide, the sides straight to 
broadly sigmoid; ca. 5 flowers visible in the principal spiral, ca. 8 flowers visible in the alternate spiral; tepals glossy, smooth, the lateral tepals ca. $2 \mathrm{~mm}$ long, the inner margin convex; the pistil emergent; stigma green, elliptic, ca. $3 \mathrm{~mm}$ long; stamens emerging 1 or 2 at a time, exserted on fleshy, flattened filaments; anthers white, held just above tepals, $0.5-0.8 \mathrm{~mm}$ in both directions; thecae not divaricate; pollen white. INFRUCTESCENCE pendent; spadix to $15 \mathrm{~cm}$ long; berries violet-purple, ovoid to globose, ca. 3-5 mm wide; mesocarp pulpy; seeds white, broadly ellipsoid, to $4 \mathrm{~mm}$ long, $3 \mathrm{~mm}$ wide, $2 \mathrm{~mm}$ thick, flattened. Fig. 93.

Anthurium lancifolium ranges from Costa Rica to Colombia (Antioquia and Chocó) at elevations of 100 to $1,600 \mathrm{~m}$ (especially 800 to 1,200 $\mathrm{m}$ ) in regions of premontane wet, tropical wet, premontane rain, and lower montane rain forest life zones. It is the most common and widespread species in section Porphyrochitonium and is also one of the most variable. Blades vary in shape from linear-lanceolate to oblong-lanceolate to narrowly ovate with their dried coloration varying from green to olive-green to brown.

The species is recognized by its short stems with persistent, weathered cataphylls, frequently terrestrial habit, generally elongate, gradually acuminate, glandular-punctate blades that more or less equal the petiole in length, by the green, lanceolate spathe, and especially by the grayishwhite, moderately short, weakly tapered spadix that has stamens persisting after anthesis, unlike most species in the section, that promptly retract their stamens. The species is known to have two varieties and more varieties or perhaps even distinct species are expected to be segregated from this variable, wide ranging species as living material of the group is studied in detail. The typical variety has dark violet-purple berries from the beginning of berry maturation, whereas the variety albifructum has berries that are white before maturity becoming faintly purple-violet at the base at maturity. Leaves of variety albifructum also differ from those of the typical variety found on Cerro Colorado where they occur together. Those of variety albifructum are narrowly ovate, rather than lanceolate, and dry yellowish-green on the lower surface. Most blades of the typical lancifolium dry rather dark.

Anthurium lancifolium is similar to A. aureum Engl. of South America, which has leaves drying golden green beneath.
A noteworthy collection (D'Arcy 11259) from Panama, in Colón Province at Río Iquanita (390 m elevation) may ultimately prove distinct. It has unusually small leaves, measuring only 21 $\times 4 \mathrm{~cm}$ but also has cataphylls that are not weathered to fibers as is the usual case in A. lancifolium.

Costa Rica. alajuela: near Cariblanco, Burger \& Antonio 11104 (MO). CARTAGO: between Moravia and Quebrada Platanillo, Croat 36629, 36693 (MO); Volcán Turrialba, Wendland 518 (GOET). HEREDIA: S of Cariblanco, Croat 35793 (MO). LIMÓN: vicinity of Guapiles, Standley 37512 (US). PUNTARENAS: Cañas Gordas, Pittier \& Tonduz 11130 (BR). SAN JOSÉ: Finca Navarro, Maxon 669 (NY).

NICARAGUA. ZELAYA: vicinity Quebrada El Toro, along Río Iyas, Vincelli $375 A$ (MO).

Anthurium lentii Croat \& Baker, Brenesia 16 (Supl. 1): 56. 1979.TYPE: Panama. Chiriquí: vicinity of Cerro Colorado Mine Development, 28 miles above San Felix, 1,200-1,500 m, Croat 33204 (MO-2381193, holotype; Live at MO).

Epiphyte or terrestrial, $56-120 \mathrm{~cm}$ tall; stems usually short, stout, $2-3 \mathrm{~cm}$ diam.; roots moderately dense, several at most nodes, ca. $6 \mathrm{~mm}$ thick, green or brownish, descending; cataphylls coriaceous, (5)8-19 cm long, turning brown, mucronate at apex, remaining intact, eventually dilacerating. LEAVES with petioles erect to erectspreading, 10-70 cm long, (5)8-9 $\mathrm{mm}$ diam., broadly sulcate above sheath, more deeply sulcate near apex with acute margins, rounded abaxially, sometimes tinged purplish; geniculum 1$4.5 \mathrm{~cm}$ long, sulcate, usually purplish; blades ovate to narrowly ovate, coriaceous, semi-erect or spreading from petioles, rounded to retuse and apiculate at apex, truncate to subcordate or cordate at base, $15-50 \mathrm{~cm}$ long, $12.5-37 \mathrm{~cm}$ wide, broadest at point of petiole attachment, the margin pale green, often slightly turned under; the anterior lobe to $46 \mathrm{~cm}$ long with margins convex and often irregular where basal veins meet the margin; the posterior lobes to $14 \mathrm{~cm}$ long, directed conspicuously upward; the sinus very narrow to broad (when present), obtuse to acute at apex; the upper surface semiglossy, the lower surface matte or semiglossy, conspicuously brownish glandular-punctate; the midrib convexly raised above, diminished toward apex, convexly raised below and usually tinged purple; basal veins usually 3 or 4 pairs, sometimes with as many as 6 pairs on cordate blades, up to 4 of them coalesced $0.5-3 \mathrm{~cm}$, sunken or raised in valleys near 
the midrib on upper surface, sharply raised and often tinged purple on lower surface; posterior rib naked, curved; primary lateral veins $10-20$ or more per side, departing midrib at $45^{\circ}$ angle, slightly sunken or flat above, raised below; interprimary veins numerous, nearly as prominent as the primary lateral veins, usually flat above, slightly raised below; secondary veins numerous, \pm straight and connecting pairs of basal veins, \pm flat and nearly as prominent as the primary lateral veins above, slightly raised below; collective vein arising from uppermost basal vein, 2$5 \mathrm{~cm}$ from the margin midway on blade, raised at base above, sunken at apex, tinged purple below. INFLORESCENCE erect to spreading, usually much longer than leaves; peduncle 30$88 \mathrm{~cm}$ long, 5-10 $\mathrm{mm}$ diam., terete, frequently mottled with purple, 0.66 to 3 times as long as petioles; spathe coriaceous, green tinged with purple (B \& K Yellow-green 6/7.5), narrowly ovate-oblong to oblong-lanceolate, $8-14 \mathrm{~cm}$ long, (2) $2.8-3.9 \mathrm{~cm}$ wide, broadest just above point of attachment, abruptly acuminate at apex, obtuse to acute at base, the margins often tinged purple, inserted at $45^{\circ}-80^{\circ}$ angle on peduncle; stipe 5$25 \mathrm{~mm}$ long in front, 2-6 $\mathrm{mm}$ long in back, ca. $8 \mathrm{~mm}$ wide, green, often mottled with purple; spadix violet-purple (B \& K Red-purple 3/10), $12-25 \mathrm{~cm}$ long, $8-13 \mathrm{~mm}$ diam. at base, $5-8 \mathrm{~mm}$ diam. at apex, sometimes weakly arched in basal fourth; flowers rhombic, 2.8-4.5 mm long, 2.3$3.5 \mathrm{~mm}$ wide, the sides straight to weakly sigmoid; 7-13(15) flowers visible in the principal spiral, 5-8(10) flowers visible in the alternate spiral; tepals glossy, green-punctate, with small droplets at anthesis, lateral tepals 2-2.3 mm wide, the inner margins \pm straight, not overlapping; pistils green, exposed at base as soon as the spathe opens; stigma ca. $1 \mathrm{~mm}$ long, green, usually square or hour-glass-shaped, brushlike with a small droplet appearing briefly, 1 or 2 days before the first stamens emerge, the papillae exserted above the tepals; stamens emerging moderately rapidly from the base, held in a close circle at edge of pistil; anthers white, held over pistil, opening as soon as they emerge, ca. $0.5 \mathrm{~mm}$ long, $1.5 \mathrm{~mm}$ wide; thecae ellipsoid, not divaricate; pollen white. INFRUCTESCENCE spreading; spathe persisting, the spadix $29-38 \mathrm{~cm}$ long, $1.5-2.5 \mathrm{~cm}$ diam.; berries oblong-linear, square in cross-section, tapered to \pm square at apex, ca. $10 \mathrm{~mm}$ long, pale green, white at maturity, exserted from tepals $2-5 \mathrm{~mm}$ before maturity, often not maturing in apical one-half to one-fifth of the spadix. Seeds not seen. Figs. 94 and 97.
The species ranges from Costa Rica to Colombia (mountains of northwest Chocó adjacent to Panama) at elevations of 350 to $1,800 \mathrm{~m}$. It occurs only along the central cordillera. In Costa Rica the species is known only from premontane rain and lower montane rain forest in the region around Tapantí but it possibly extends throughout the Talamanca mountain range. In Panama, the species has been collected in premontane wet, tropical wet, and lower montane wet forest from Cerro Colorado in Chiriquí Province to the Cerro Jefe region in Panamá Province, then appears again only near the Colombian border in Darién.

Anthurium lentii is in section Digitinervium and is perhaps most closely related to $A$. ovatifolium Engl., a species from Ecuador and Peru, which differs in having red berries. Anthurium lentii can be recognized by its thick, distinctively bicolorous, heavily punctate, truncate to cordate leaf blades with several, heavy, prominently ascending basal veins. Other distinctive features include the prominently exserted pistils and the white, oblong, more or less tetragonal mature berries.

Costa Rica. CARTAGo: road between Moravia \& Quebrada Platanillo, Croat 36591 (MO); beside Río Taus, SW of Taus, Lent 2989 (F); N of Tapantí, Lent 2219 (F, US); near Tapantí, N by ENE of Tapantí, Baker et al. 217 (CR, F, K, MO, US); Río Grande de Orosi, W of Tapantí, Lent 907, 908 (CR, F).

Anthurium leuconeurum Lem., Ill. Hort. 9, Pl. 314. 1862. TYPE: The description is based on a plant from southern Mexico collected by Ghiesbrecht and cultivated in Ghent, Belgium, by Ambr. Vershchaffelt; the illustration in Ill. Hort. (9: 5.314. 1862) serves as the type.

Terrestrial; stems and internodes very short; cataphylls moderately coriaceous, acute at apex, persistent. LEAVES erect-spreading; petioles 30 $70 \mathrm{~cm}$ long, 4-7 mm diam., terete or weakly sulcate adaxially, the blades held parallel to petiole; geniculum 1.5-3.5 cm long; blades narrowly ovate to ovate; abruptly acuminate at apex, deeply lobed at base, (12)20-38 cm long, (8)12-29 $\mathrm{cm}$ wide, broadest at point of petiole attachment; the anterior lobe (8) 14-28 cm long; posterior lobes (2.5)6-13 cm long, directed toward base; the sinus obovate to hippocrepiform, rounded at apex; the upper surface velvety, dark green, the lower surface much paler; midrib and basal veins flat to weakly sunken above, much paler than sur- 
face; the area on either side of the veins paler than rest of blade; basal veins 5-6(7) pairs, at least the third and fourth coalesced $1-4.5 \mathrm{~cm}$, arcuate-ascending, the second and sometimes the third joining the margin well above the middle of the blade; the posterior ribs straight to gradually curved, naked (at least on the larger blades); primary lateral veins 3-4 per side, departing the midrib at an acute angle, then gradually curved toward the margin, loop-connecting with collective vein; collective vein arising from the first basal vein or sometimes one of the lowermost primary lateral veins, $0.7-1.4 \mathrm{~cm}$ from margin. INFLORESCENCE erect, at least as long as leaves; peduncle 40-68 cm long, 4-6 mm diam., terete; spathe narrowly ovate to ovate-lanceolate, green, $4.5-10 \mathrm{~cm}$ long, $1-2.5(3.5) \mathrm{cm}$ wide, broadest just above base, narrowly acuminate at apex, weakly cordate and clasping at base, inserted at ca. $20^{\circ}$ angle on peduncle; spadix sessile or nearly so, green, (4)6-13 cm long, 6-8 mm diam. at base, $4-5 \mathrm{~mm}$ diam. at apex; the flowers rhombic, 3.8-4 $\mathrm{mm}$ long, 3-3.5 $\mathrm{mm}$ wide, the sides straight parallel to spirals, smoothly sigmoid perpendicular to spirals; $6-7$ flowers visible in the principal spiral, 4-5 flowers visible in the alternate spiral; tepals sparsely punctate, lateral tepals $2.1 \mathrm{~mm}$ wide, the margin broadly rounded, thin and turned up against pistil; pistils elevated but not emergent until after anthesis of stamens; the stigma $0.5 \mathrm{~mm}$ long, elliptic, slitlike; stamens emerging in a prompt sequence from the base, the stamens in the basal one-third complete before the alternates emerge in the apical one-third; anthers held above tepals and over pistil but not obscuring stigma, $0.9 \mathrm{~mm}$ long, $0.8 \mathrm{~mm}$ wide, evenly spaced; thecae oblong-elliptic, scarcely divaricate. INFRUCTESCENSE pendent; berries broadly obovoid, rounded at apex, bright orange, 9-10 mm long, 8-10 mm diam.; pericarp moderately thick, with dense raphide cells; seeds 2 , narrowly obovoid to obovoid, brown(?), slightly flattened, 6-7 mm long, 5-6.5 mm wide, 3.6-4 $\mathrm{mm}$ thick. Fig. 98.

Anthurium leuconeurum was collected in southern Mexico in about 1860 and apparently has not been recollected in the wild. All known herbarium collections are from living collections, presumably derived from the original living collection in Belgium. If the species still exists in the wild it is surely a narrow endemic similar to A. clarinervium. I have strong suspicions that $A$. leuconeurum represents a plant of hybrid origin, probably offspring of $A$. berriozabalense and $A$. clarinervium. This cross has been made by Banta [see Aroideana 6(1): 26-27. 1983] and the resulting hybrid looks much like the type drawing of A. leuconeurum.

The species is a member of section Cardiolonchium and is characterized by having a velvety leaf blade with usually paler major veins similar to A. clarinervium, to which it is apparently related. It is distinguished from the latter species by its generally larger and more narrowly ovate leaves that have the basal veins coalesced into a naked posterior rib, 1-4.5 cm long. Anthurium clarinervium generally has the basal veins free or if they are coalesced the posterior rib is never naked.

Engler (1905) cites Ghiesbreght (1877) (note difference in spelling). It is not certain whether this is his collecting number or not but it implies that he saw an actual specimen. If so, it is unlikely that the specimen still exists.

Anthurium leuconeurum was the subject of much hybridization after its introduction into Europe in the early 1860 s. Perhaps the most well known of these hybrids is $A$. macrolobum Hort. (A. dentatum André is a synonym), which is a cross between $A$. leuconeurum and A. pedatoradiatum.

Although the species was originally described by Lemaire as acaulescent and epiphytic, it was no doubt a terrestrial plant with a definite (although short) stem.

Since all known collections have been made from living collections in cultivation, no specimens are complete with the stem. In addition I have seen no bonafide living collection of the species. Because of these shortcomings the description is less complete than most.

Mexico. Cultivated at California Botanical Garden 54.1349 (UC); cultivated at Fairchild Tropical Garden, Frantz 3288 (FTG).

Anthurium lezamae Matuda, Bol. Soc. Bot. México 19: 19. 1956. TYPE: Mexico. Chiapas; Mun. Bochil, Bochil (cultivated in San Cristóbal de Las Casas), MacDougall 362 (originally collected by W. Lezama) (MEXU, holotype).

Terrestrial; the stems short, $1.5 \mathrm{~cm}$ diam., internodes very close; cataphylls thin, 5-7 cm long, 
drying reddish-brown, soon weathering at least at base into thin, mostly longitudinally oriented fibers. LEAVES with petioles $17-41 \mathrm{~cm}$ long, 2$4 \mathrm{~mm}$ diam., terete; geniculum $1-1.5 \mathrm{~cm}$ long; blades ovate to ovate-triangular, gradually acuminate at apex, deeply lobed at base, $13-28 \mathrm{~cm}$ long, $9-18.5 \mathrm{~cm}$ wide, broadest at the middle or at the base, the margin slightly hyaline (on drying), weakly revolute; anterior lobe $12.5-20.5 \mathrm{~cm}$ long, the margin almost straight to broadly rounded, (sometimes somewhat bulged at base of lobe), the margins sometimes somewhat variable with one margin slightly convex, the other slightly concave; the posterior lobes directed downward or slightly outward, $6-11.5 \mathrm{~cm}$ long, $3.5-6.5 \mathrm{~cm}$ wide; the sinus usually obovate, rarely parabolic, rounded or obtuse at apex; the upper surface with the epidermis drying with a characteristically raised, alveolate reticulation (papillate when fresh), the lower surface drying more or less smooth; the midrib raised on both surfaces; basal veins 4-5(6) pairs raised on both surfaces, the third and fourth (fifth) coalesced $4.5-6 \mathrm{~cm}$, all but the uppermost arcuate-ascending, joining the margin, the second basal vein joining the margin well above the sinus and sometimes well above the middle of the blade; the primary lateral veins 2-3 per side, usually scarcely apparent, departing the midrib at $70^{\circ}-80^{\circ}$ angle, sometimes curving laterally at almost a $90^{\circ}$ angle to the midrib, prominulous above and below, scarcely or not at all more prominent than the interprimary veins or tertiary veins; the tertiary veins weakly raised above and below; the collective vein arising from the uppermost basal vein, 5-13 $\mathrm{mm}$ from the margin, weakly raised on both surfaces. INFLORESCENCE usually held erect, well above the leaves; peduncles $37-78 \mathrm{~cm}$ long, 3-4 $\mathrm{mm}$ diam., longer than the petioles; spathe weakly coriaceous, green, lanceolate to oblong-lanceolate, 3.7$6.5 \mathrm{~cm}$ long, 7-14 $\mathrm{mm}$ wide, broadest just above the base or at the middle, acuminate at apex, weakly cordate and somewhat clasping at base, inserted at a $45^{\circ}$ angle on the peduncle; stipe 2$4 \mathrm{~mm}$ long in front, $1-3 \mathrm{~mm}$ long in back; spadix greenish, 4-6.5 cm long, 5-6 $\mathrm{mm}$ diam. at base, 3-4 mm diam. at apex, held at $180^{\circ}$ angle from peduncle; flowers rhombic, $3-4 \mathrm{~mm}$ long, (dry) 2.5-2.8 mm wide, (dry) the sides straight, parallel to spiral, gradually sigmoid perpendicular to the spiral; 4-6 flowers visible in the principal spiral, 3-4 flowers visible in the alternate spiral; tepals weakly glossy, minutely and densely punctate, lateral tepals $1.8-2 \mathrm{~mm}$ wide, the inner margin very broadly rounded, the alternate pair with inner margins straight to concave; pistil greenish, not emergent; stigma ca. $1 \mathrm{~mm}$ long, linear; stamens emerging promptly, from the base, the lateral stamens preceding the third and fourth stamens by only a few spirals, held just above the tepals in a close circle around the stigma; anthers $0.5 \mathrm{~mm}$ long, $0.7 \mathrm{~mm}$ wide; thecae semicircular, flat, not at all divaricate. INFRUCTESCENCE not seen. Figs. 99 and 100.

Anthurium lezamae is endemic to Mexico, in northern Chiapas at 900 to $1,500 \mathrm{~m}$ elevation. It is known from the municipios of Bochil, El Bosque, and Ocosingo. The plants grow on usually steep, rocky slopes in pine-oak forest in seasonally dry areas. A specimen from adjacent Oaxaca (Schultes \& Reko 867, ECON) is possibly also this species but it has a broader spathe and lacks the typically alveolate epidermal pattern on the upper blade surface.

The species is a member of section Cardiolonchium and is recognized by its narrowly ovatecordate leaf blades with the poorly developed primary lateral veins scarcely more prominent than the interprimary veins and the tertiary veins. Also characteristic is the unusual reticulation created by the epidermal cells on drying.

The species is perhaps most closely related to (and possibly inseparable from) A. leuconeurum, which differs in having the midrib and basal veins (and the area immediately adjacent to them) much paler than the rest of the blade surface. In addition, the blade surface of $A$. leuconeurum dries obviously papillate with the individual papillae distinguishable, whereas $A$. lezamae dries with the epidermal cells drying minutely alveolate (honey-combed). Unfortunately, A. lezamae has not been studied alive so I do not understand the significance of these differences.

MacDougall 302 and two unnumbered MacDougall collections from an area believed to be southwestern Oaxaca (between La Gloria and Río Grande and between Buena Vista and La Gloria) differ from $A$. lezamae only slightly in leaf shape but lack the alveolate epidermal pattern on the leaves typical of that species. It is possible that these represent a distinct species but too little is known about them to be certain.

Mexico. Chiapas: vicinity of Jitotol, Breedlove \& Dressler 29832 (DS); Breedlove \& Smith 32558 (DS); 


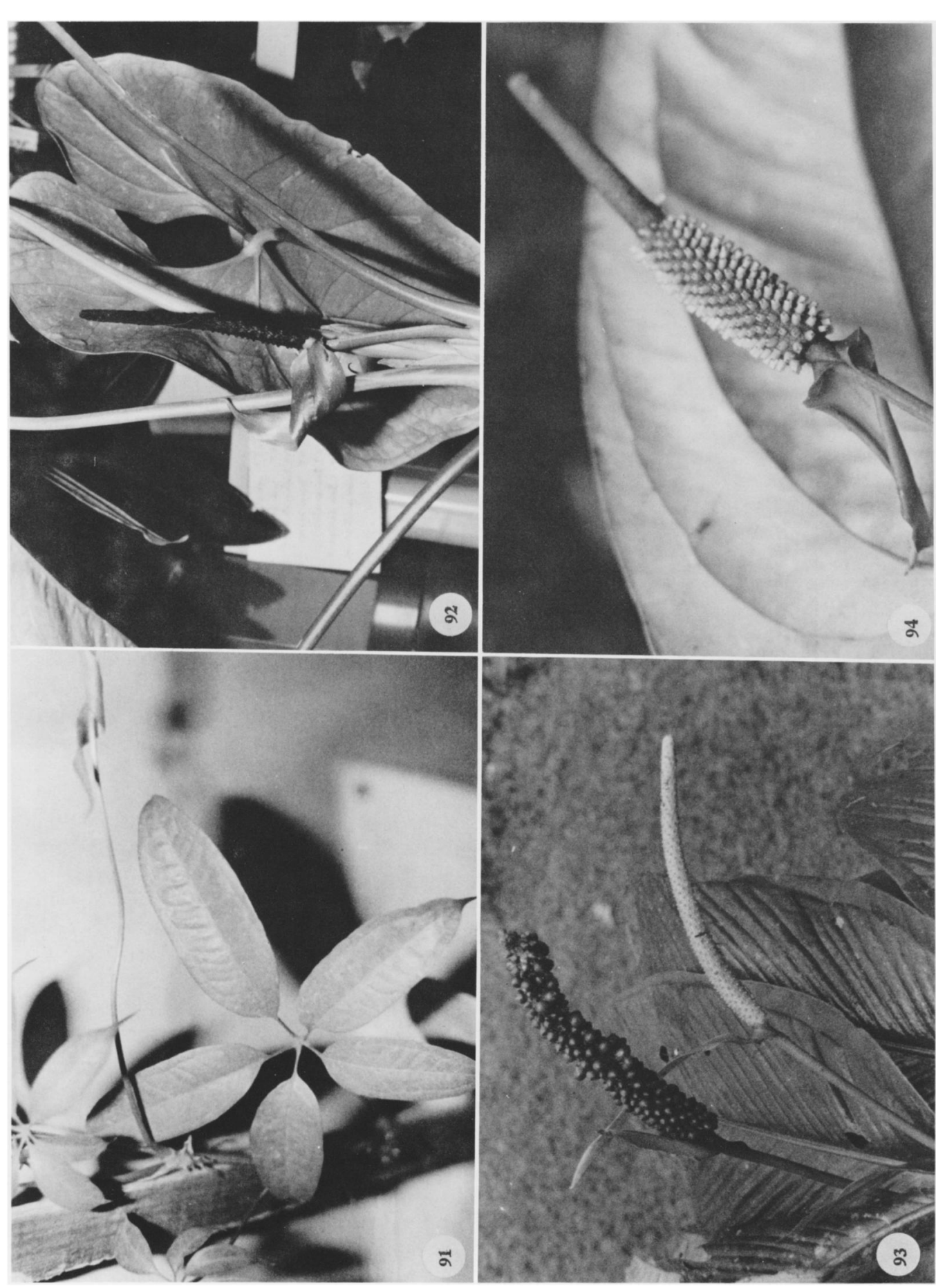



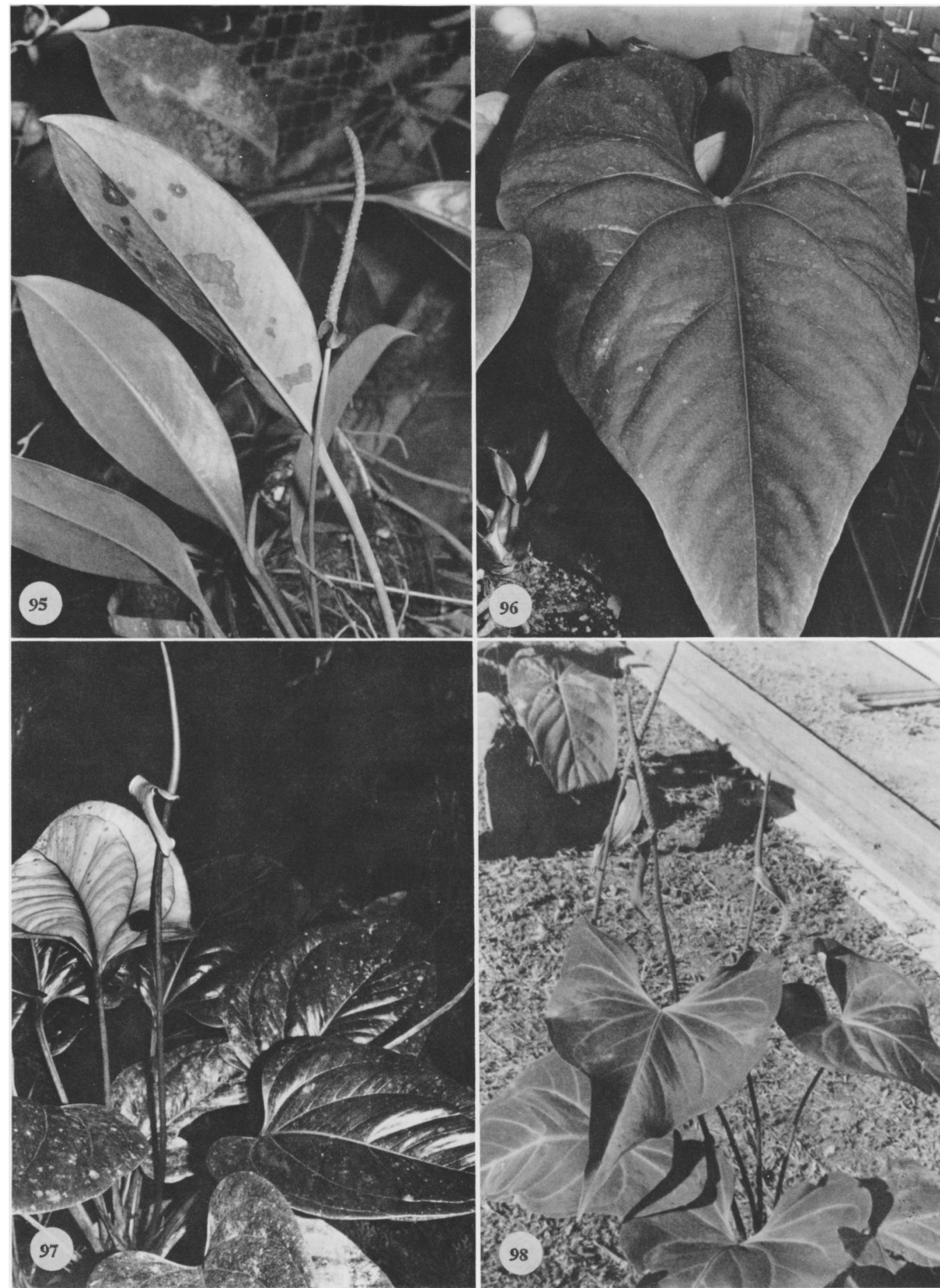

Figures 95-98. 95. Anthurium interruptum Sodiro, Selby 58-1975-32. -96. Anthurium lancetillense Croat, Croat 42672. -97. Anthurium lentii Croat \& Baker, Las Cruces Bot. Gard. -98. Anthurium leuconeurum Lem., (Cultivated at McLain's, Ayr, Australia). 


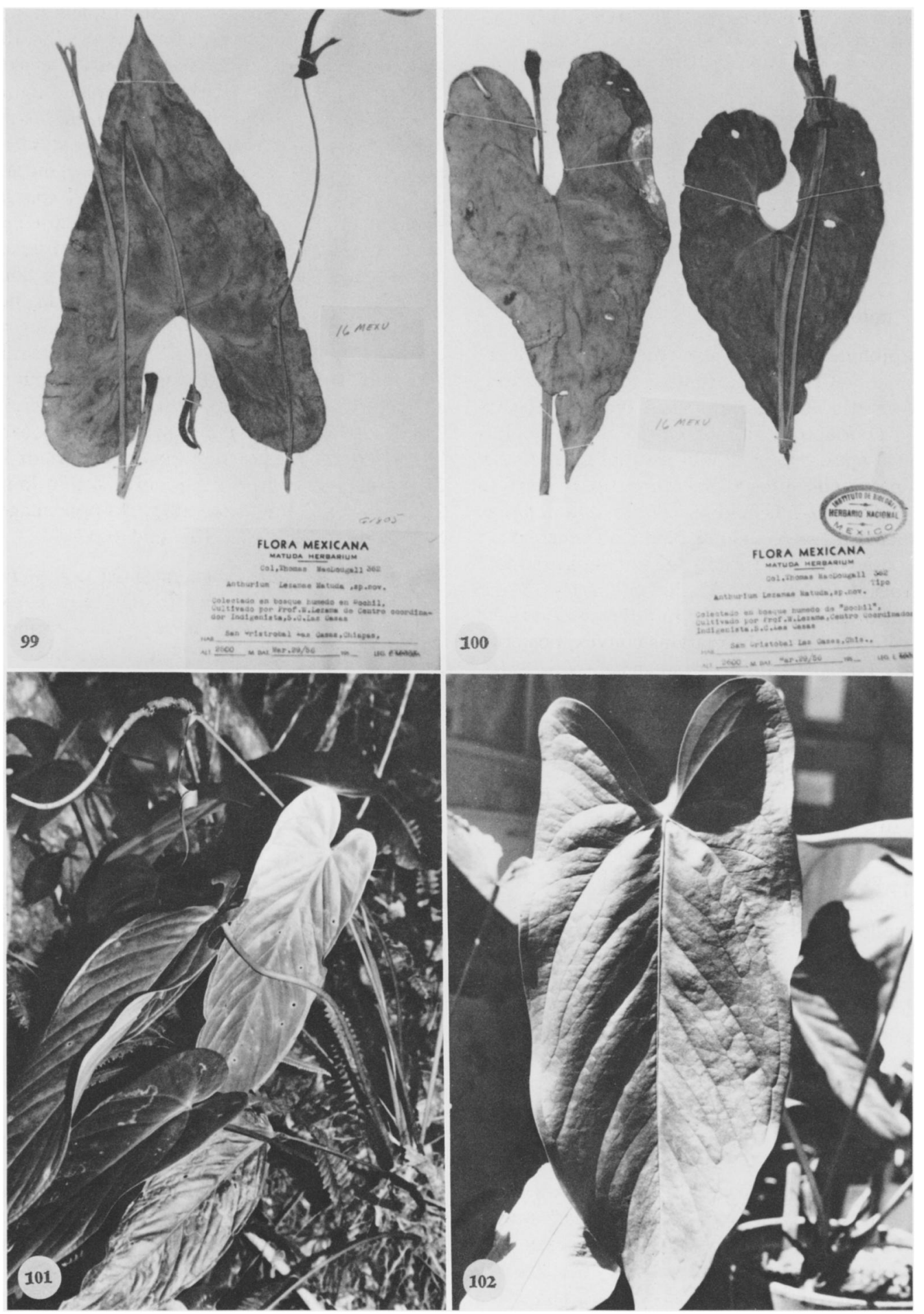

Figures 99-102. 99-100. Anthurium lezamae Matuda, MacDougall 362 (Type).-101. Anthurium longipeltatum Matuda, Croat 48326.-102. Anthurium longipeltatum Matuda, Croat 39755. 
vicinity Ocosingo, Breedlove 27925 (DS); San Cristóbal de Las Casas, MacDougall 362 (MEXU). OAXACA: between La Gloria \& Río Grande, MacDougall s.n. 302 (MEXU).

Anthurium longipeltatum Matuda, Anales Inst. Biol. Univ. Nac. México 37: 75, Fig. 1. 1967. TYPE: Mexico. Oaxaca: between Vista Hermosa and Puerto Eligio, Comaltepec Ixtlán de Juárez, elev. 1,200 $\mathrm{m}$ in humid forest, October 5, 1963, MacDougall 563 (MEXU, holotype).

Epiphyte or terrestrial; stems green, ca. $18 \mathrm{~cm}$ long, $2.5-3 \mathrm{~cm}$ diam.; roots few, dark greenishbrown, descending; leaf scars $2-3 \mathrm{~cm}$ wide; cataphylls coriaceous, $6.5-15 \mathrm{~cm}$ long, long-acuminate at apex, drying dark brown, splitting at base, subpersistent. LEAVES with petioles erect to spreading, 29-56 cm long, 5-7 $\mathrm{mm}$ diam., terete; geniculum 1-4.5 cm long; blades oblanceolate to oblong-ovate, moderately thick, long-acuminate at apex, lobed at base, $33-56 \mathrm{~cm}$ long, $14-28 \mathrm{~cm}$ wide, broadest just below middle; anterior lobe $34-40.5 \mathrm{~cm}$ long, the margins convex; posterior lobes $4.5-10 \mathrm{~cm}$ long; the sinus parabolic to triangular, sometimes the lobes overlapping, acute at apex; upper surface semiglossy to glossy, lower surface semiglossy, obscurely to conspicuously punctate; the midrib prominulous, convex above, more prominently raised below; basal veins 35 pairs, usually free, sunken or prominulous in valleys above, raised below; primary lateral veins $8-12$ per side, departing midrib at $35^{\circ}-50^{\circ}$ angle, sunken above, raised below, arcuate-ascending to collective vein; lesser veins flat to weakly sunken above, flat below; collective vein arising from the first basal vein, sunken above, raised below, 5-10 $\mathrm{mm}$ from margin. INFLORESCENCE erect-spreading, longer than leaves; peduncle $30-80 \mathrm{~cm}$ long, 3-8 $\mathrm{mm}$ diam., terete; spathe subcoriaceous, green sometimes faintly tinged purplish (B \& K Yellow-green 8/10), oblong-lanceolate, $9-14.5 \mathrm{~cm}$ long, $1.5-2.2 \mathrm{~cm}$ wide, narrowly acuminate at apex, obtuse at base, inserted on peduncle at $30^{\circ}-50^{\circ}$ angle; spadix olivegreen (B \& K Yellow-green 6/5) to dark purple (B \& K Blue-purple 2/10), 9-35 cm long, 7-9 $\mathrm{mm}$ diam. at base, 2-4 mm diam. at apex; flowers rhombic to 4-lobed, 2.5-4 mm long, 2.3-3 $\mathrm{mm}$ wide, the sides \pm straight parallel to spiral, gradually sigmoid perpendicular to spiral; 6-7 flowers visible in the principal spiral, 7-9 flowers visible in the alternate spiral; tepals glossy, mi- nutely papillate, sometimes with droplets as stamens emerge, lateral tepals $0.8-1 \mathrm{~mm}$ wide, the inner margin broadly rounded; pistils weakly emergent, green tinged with red-violet; stigma oblong-linear, $0.5-0.6 \mathrm{~mm}$ long, purplish with droplets apparent a few days before stamens emerge; stamens emerging from the base, the lateral stamens preceding alternates by $1-2$ spirals, exserted briefly on pinkish flattened filaments, which retract, holding stamens at edge of tepals against pistil; anthers pale yellow, held \pm contiguous, $0.3-0.4 \mathrm{~mm}$ long, $0.5-0.6 \mathrm{~mm}$ wide; thecae ellipsoid; pollen yellow to white, fading to cream. INFRUCTESCENCE pendent, spathe withered; berries subglobose to obovoid, rounded at apex, red to red-orange (B \& K Red 6/7.5), 8-8.5 mm long, 5.5-6.5 mm wide; mesocarp fleshy, \pm transparent with raphide cells; seeds $1-$ 2 , ovoid, cream or greenish-white, $4 \mathrm{~mm}$ long, $2.5 \mathrm{~mm}$ wide, $2 \mathrm{~mm}$ thick with sticky appendages at both ends. Figs. 101, 102, and 104

The species occurs in northern Oaxaca, Sierra de Juárez, Veracruz near Orizaba, and is expected in nearby Puebla in Mexico in tropical wet forest from 600 to $1,500 \mathrm{~m}$ elevation.

The species is a member of section Belolonchium and is distinguished by its moderately thick, deeply lobed, oblong-ovate blades, which are dark green above and paler below, by its long slender spadix, by having basal veins frequently free with little or no posterior rib, and red to redorange, subglobose berries.

The collections of $A$. longipeltatum from northern Oaxaca are somewhat obscurely punctate whereas those collected near Valle Nacional are more conspicuously punctate. The spadix color varies from olive-green to violet-purple.

Anthurium longipeltatum may be confused with $A$. verapazense, a species ranging from Belize to Honduras, but that species has a consistently violet-purple spadix and usually has a well developed posterior rib.

Matuda considered $A$. longipeltatum to be similar to $A$. titanium (A. xanthosomifolium) but it is in no way similar or related except that the two species have posterior lobes. Anthurium titanium differs principally in lacking punctate dots on the lower blade surface.

The etymology of the name is curious. Although Matuda named the plant "longipeltata" there is no part peltate. Perhaps this is a typographical error from the intended "longipetiolatum." 


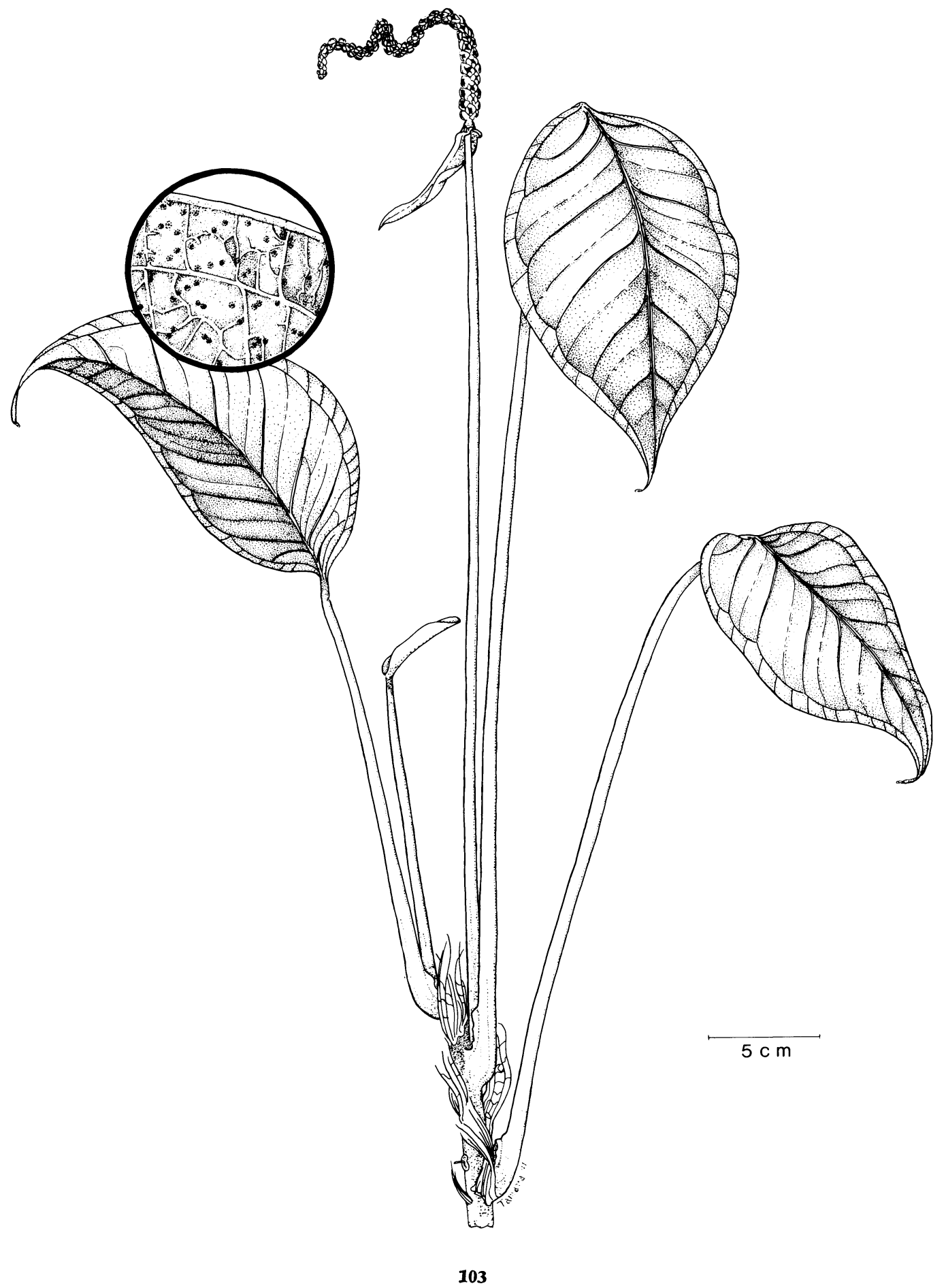

FIGURE 103. Anthurium louisii Croat \& Baker, Field Museum Drawing 82395. 


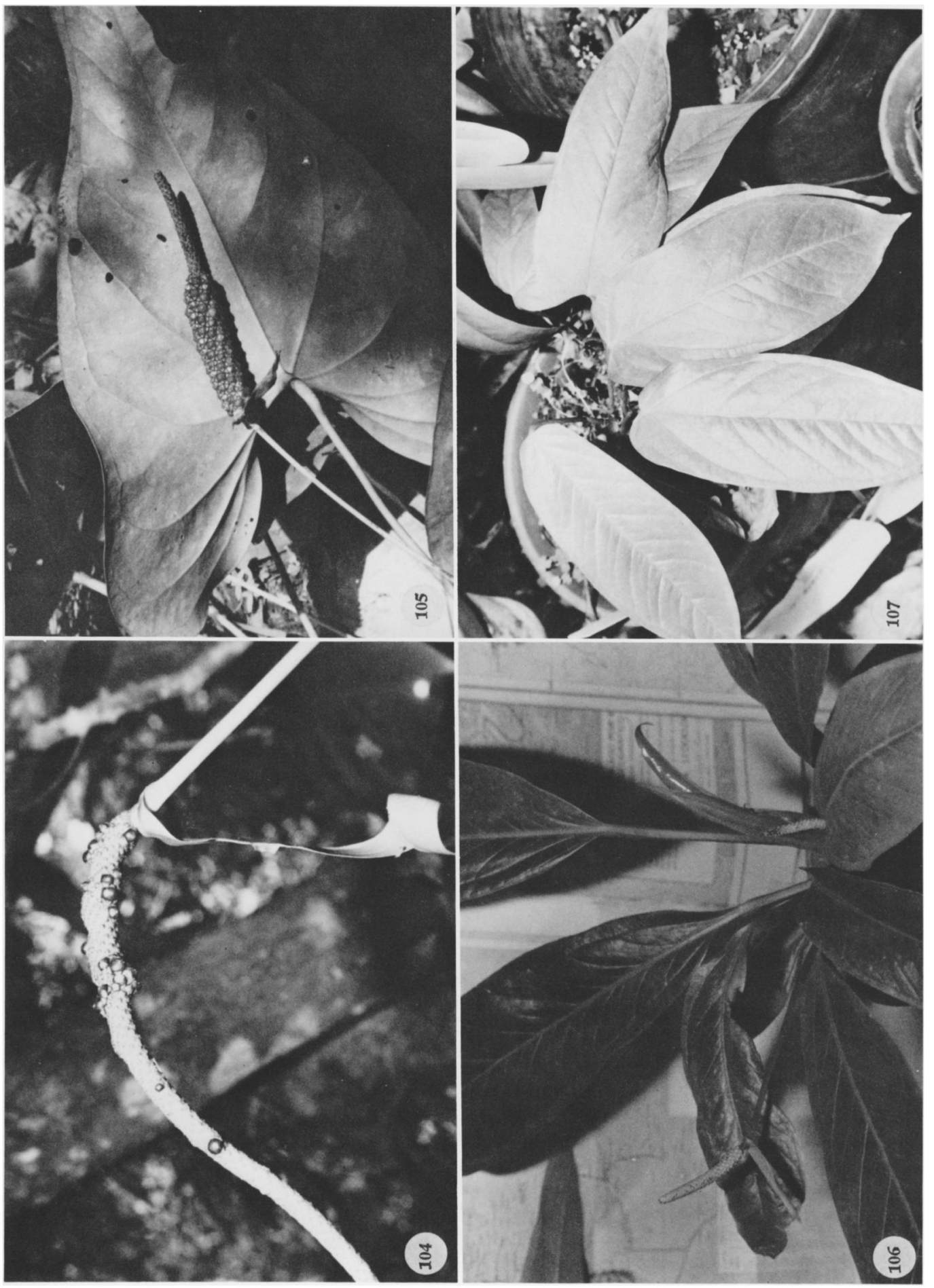

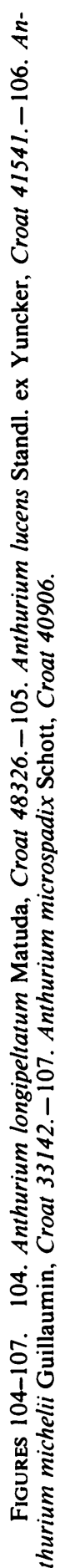


Mexico. oAxaca: Comaltepec, MacDougall 563 (MEXU); road from Teotitlán del Camino to Santa María Chilchotla, Croat 48326, 48366 (MO); vicinity Valle Nacional, Croat 39755, 39795, 43906, 43914, 47973, 48064 (MO); King 2143 (MICH); Moore \& Bunting 8917 (BH); summit of Cerro de Cuhuatepete, vicinity Tehuacán, Vera Santos 3340 (MICH).

Anthurium louisii Croat \& Baker, Brenesia 16 (Supl. 1): 59. 1979. TYPE: Costa Rica. Cartago: about $2.5 \mathrm{~km}$ north by east northeast of Tapantí, $9^{\circ} 45^{\prime} \mathrm{N}, 83^{\circ} 47^{\prime} \mathrm{W}, 1,500-1,600$ $\mathrm{m}$ elevation; forest remnants on steep slopes, Baker, Utley \& Utley 220 (F-1758200, holotype; MO-2385464, isotype.

Epiphyte or terrestrial, to $30 \mathrm{~cm}$ tall; stems erect, to $1 \mathrm{~cm}$ diam.; internodes $1-4 \mathrm{~cm}$ long; leaf scars obscured by cataphyll fibers; cataphylls 4-7 cm long, gradually acuminate at apex, drying brown, quickly weathering into coarse persistent fibers. LEAVES dispersed along stem at each node; petioles (15)20-30 cm long, ca. $3 \mathrm{~mm}$ diam., terete, narrowly sulcate; geniculum ca. $1.5 \mathrm{~cm}$ long; blades ovate to broadly ovate, subcoriaceous, gradually to abruptly long-acuminate at apex, obtuse or truncate to rounded at base, 14$17 \mathrm{~cm}$ long, $8-13.5 \mathrm{~cm}$ wide, broadest slightly below the middle; both surfaces conspicuously glandular-punctate; midrib raised above, diminished toward apex, prominently raised below; primary lateral veins $15-20$ per side, departing midrib at $45^{\circ}$ angle, \pm straight, loop-connected by the collective vein, raised above and below; lesser veins inconspicuous; collective vein arising from the base, $4-12 \mathrm{~mm}$ from the margin. INFLORESCENCE, erect-spreading; peduncle (15)25-38(45) cm long, considerably longer than the leaves; spathe somewhat thin, green becoming reddish, lanceolate-linear, $4-6.5 \mathrm{~cm}$ long, ca. $1 \mathrm{~cm}$ wide, broadest at base, gradually acuminate at apex, slightly clasping at base, inserted at ca. $20^{\circ}$ angle on peduncle; stipe very short or absent; spadix green to yellow-green, usually coiled at maturity, (4)6-18 cm long, 3-4 mm diam. at base, 2-3 mm diam. at apex (dry); flowers rhombic, $2-3.5 \mathrm{~mm}$ long, $2-2.5 \mathrm{~mm}$ wide; the sides \pm straight; $2-3$ flowers visible in either spiral; lateral tepals $1.6-2.1 \mathrm{~mm}$ wide, the inner margin broadly rounded; pistil green; stigma ca. $0.5 \mathrm{~mm}$ long, ellipsoid; stamens probably weakly exserted above the tepals, well spaced; filaments ca. $0.2 \mathrm{~mm}$ long; anthers ovate, $0.4-0.5 \mathrm{~mm}$ long, $0.5-0.6 \mathrm{~mm}$ wide; thecae ellipsoid, slightly divaricate. INFRUCTESCENCE with the spathe at least sometimes deciduous; spadix $8-15 \mathrm{~cm}$ long, 3-4 mm diam., usually coiled in age; berries ovoid to subglobose, green becoming orange-red, ca. $6 \mathrm{~mm}$ long and $5 \mathrm{~mm}$ wide, maturing simultaneously throughout the spadix, drying with a buttonlike beak. Fig. 103 .

Anthurium louisii is known only from Costa Rica in premontane or lower montane rain forest, apparently restricted to middle elevations on the Atlantic slopes of the Cordillera Central and the Cordillera de Talamanca, 1,300 to $1,800 \mathrm{~m}$.

The species is in section Porphyrochitonium and can be recognized by its broadly ovate leaves with glandular punctations on both surfaces and by its usually coiled spadix (in fruit). The type collection was found on a steep bank and formed the dominant ground cover.

Anthurium louisii is related to $A$. angusturense Engl. from Colombia. The latter species differs chiefly by its lanceolate leaf blades. Anthurium louisii also resembles $A$. circinatum Croat from Panama in Chiriquí Province.

Costa Rica. CARTAGO: NNE of Tapantí, Baker, Utley \& Utley 220 (CR, DUKE, EAP, F, MO, NY, SEL, US); $\mathrm{S}$ of Tapantí, Lent 1384 (F); on road between Tapantí and Tausito-Selva area, Utley \& Utley 2995 (F); Tapantí Hydroelectric Project, along trail to meteorological station, Utley \& Utley 4532 (DUKE); road from Tapantí to Taus and Tausito, NE of Río Grande de Orosi at Tapantí, Utley \& Utley 5035 (DUKE); near Copey, Cordillera de Talamanca, Williams \& Allen 16506 (EAP, F); region beyond Muñeco, $3 \mathrm{~km}$ from village church, SW of Orosi, Utley \& Utley 1839 (F). SAN JOSÉ: La Palma, Coronado, Werklé s.n. (CR).

Anthurium lucens Standl. ex Yuncker, Field Mus. Nat. Hist., Bot. Ser. 17: 317, Pl. 5. 1938. TYPE: Honduras. Comayagua: near El Achiote, hills above the plains of Siguatepeque, elev. 1,350 m, Yuncker, Dawson \& Vouse 5844 (F, holotype; GH, MICH, MO, US, isotypes).

Anthurium seamayense Standl., Publ. Field Mus. Nat. Hist., Bot. Ser. 22: 4, Pl. 5. 1940. TYPE: Guatemala. Alta Verapaz: Seraxcaj, Finca Seamay, virgin forest, elev. $960 \mathrm{~m}$, C. L. Wilson (F 968018 , holotype)

Anthurium yunckeri Standl. ex Yuncker, Field Mus. Nat. Hist., Bot. Ser. 17: 317, Pl. 6. 1938. TYPE: Honduras. Comayagua: near El Achiote; hills above the plains of Siguatepeque, elev. $1,350 \mathrm{~m}$, Yuncker, Dawson \& Vouse 5935 (F 857684, holotype).

Anthurium mapastepecense Matuda, Anales Inst. Biol. Univ. Nac. México 27: 339. 1957. Type: Mexico. Chiapas: Mapastepec, Finca Prusia, elev. 1,000 
m, MacDougall 337 (MEXU 109434, holotype; CAS, isotype).

Epiphyte or terrestrial; stems to $20 \mathrm{~cm}$ long, ca. $4.5 \mathrm{~cm}$ diam.; internodes and leaf scars obscured by roots and cataphylls; roots dark brown, medium thick, descending; cataphylls subcoriaceous, $6.5-7.5 \mathrm{~cm}$ long, heavily tinged red-violet, the apex acuminate with subapical apiculum 2$3 \mathrm{~mm}$ long, drying brown (B \& K Yellow 4/7.5), weathering to persistent reticulate fibers, the apex remaining \pm intact. LEAVES with petioles erect to spreading, (12)26-72 cm long, 0.6-1 cm diam., subterete; geniculum $2.5-3.5 \mathrm{~cm}$ long, sometimes faintly tinged red-violet; blades narrowly ovate to oblong-ovate or ovate-triangular, moderately thick, gradually acuminate at apex, deeply lobed at base, $30-46 \mathrm{~cm}$ long, $18-24 \mathrm{~cm}$ wide, broadest at the base or just below point of petiole attachment; the anterior lobe $22-32 \mathrm{~cm}$ long, the margins usually convex, sometimes \pm straight; posterior lobes $10-16 \mathrm{~cm}$ long, the sinus spathulate to hippocrepiform, obtuse to rounded, or sometimes acute at apex; both surfaces semiglossy, the lower surface punctate; the midrib acutely to convexly raised above, convexly raised below; basal veins 5-6 pairs, the first and second free, the remaining coalesced $2-2.5 \mathrm{~cm}$; posterior rib naked one half to one third its length, usually with inner margin turned up; primary lateral veins 2-7 per side, departing midrib at $55^{\circ}-60^{\circ}$ angle, straight or weakly curving to collective vein, sunken above, raised below; lesser veins scarcely visible above, visible and \pm flat below; collective vein arising from the first basal vein, in larger blades from fourth or sometimes fifth basal veins, sunken above, raised below, 6-15 $\mathrm{mm}$ from the margin. INFLORESCENCE usually held erect, arching or pendent in larger plants, shorter than or equalling petioles; peduncle $33-75 \mathrm{~cm}$ long, 5-8 $\mathrm{mm}$ diam., terete, sometimes tinged redviolet; spathe moderately thin, green heavily tinged with red-violet, lanceolate, $4-8.5 \mathrm{~cm}$ long, $1.4-1.7 \mathrm{~cm}$ wide, narrowly acuminate at apex, rounded at base, inserted at $45^{\circ}$ angle on peduncle; spadix deep violet-purple, $10.5-13 \mathrm{~cm}$ long, 9-10 $\mathrm{mm}$ diam. at base, $3-3.5 \mathrm{~mm}$ diam. at apex; flowers rhombic to weakly 4-lobed, 3-3.2 mm long, $2.6-3 \mathrm{~mm}$ wide, the sides straight to gradually or jaggedly sigmoid and somewhat obscure; 6-7 flowers visible in the principal spiral, 8-9 flowers visible in the alternate spiral; tepals matte to weakly glossy, weakly punctate, minutely papillate, with scattered droplets, lateral tepals 1.5-
$1.6 \mathrm{~mm}$ wide, the inner margin broadly rounded; pistils weakly raised, green, sometimes purplish; stigma linear, ca. $0.6 \mathrm{~mm}$ long, opening as stamens emerge; stamens emerging from the base in a moderately rapid sequence, the laterals first, soon followed by alternates, the leading stamens several spirals ahead of third or fourth stamens; anthers bright yellow, held at the edge of tepals, ca. $0.6 \mathrm{~mm}$ long, ca. $0.3 \mathrm{~mm}$ wide; thecae ovate, widely divaricate; pollen pale yellow. INFRUCTESCENCE pendent; the spathe usually deciduous; berries bright red, obovoid to oblong-ellipsoid, usually developing only in basal one quarter to one third, round to truncate at apex, 8-18 mm long, 6.5-18.5 mm diam.; mesocarp juicy, clear, with raphide cells; seeds $1-2$, greenish white, oblong-elliptic, slightly flattened, 4-5 $\mathrm{mm}$ long, 2.5-4 $\mathrm{mm}$ wide, $1.8-2.1 \mathrm{~mm}$ thick, obliquely concave at apex. Figs. 105 and 108.

Anthurium lucens ranges from Mexico (State of Chiapas) to Honduras usually from 350 to $1,500 \mathrm{~m}$ (rarely to as low as $150 \mathrm{~m}$ in Guatemala to as high as 2,000 $\mathrm{m}$ in Chiapas). In Mexico the species occurs only in "bosque pino-encino" and "selva alta perennifolia" in northern Chiapas. In Guatemala it has been collected only in the departments of Huehuetenango, Alta Verapaz and Izabal.

Leaf shape is extremely variable in A. lucens but all populations share in common coriaceous, punctate leaf blades, an inflorescence shorter than or equal in length to the petiole, a relatively short violet-purple spadix with a spathe usually more than half as long as the spadix at anthesis, and red, obovoid, 1-2-seeded berries. Generally the anterior lobe of the blade is convex along the margins, although rarely the margins are concave and are similar to $A$. chiapasense except that they dry greenish to greenish brown and not blackened as is the case with $A$. chiapasense.

Honduran collections of $A$. lucens are somewhat unusual in that they are geographically isolated, the species not usually collected in southern Guatemala.

Other collections worthy of mention are those of MacDougall 337 (type of A. mapastepecense) and Matuda 19647. While both of these collections are unusual in being south of the range of most A. lucens and in having anterior lobes somewhat broader than normal, they are believed to be within the range of variability for $A$. lucens considering that the species is so widespread and variable. 

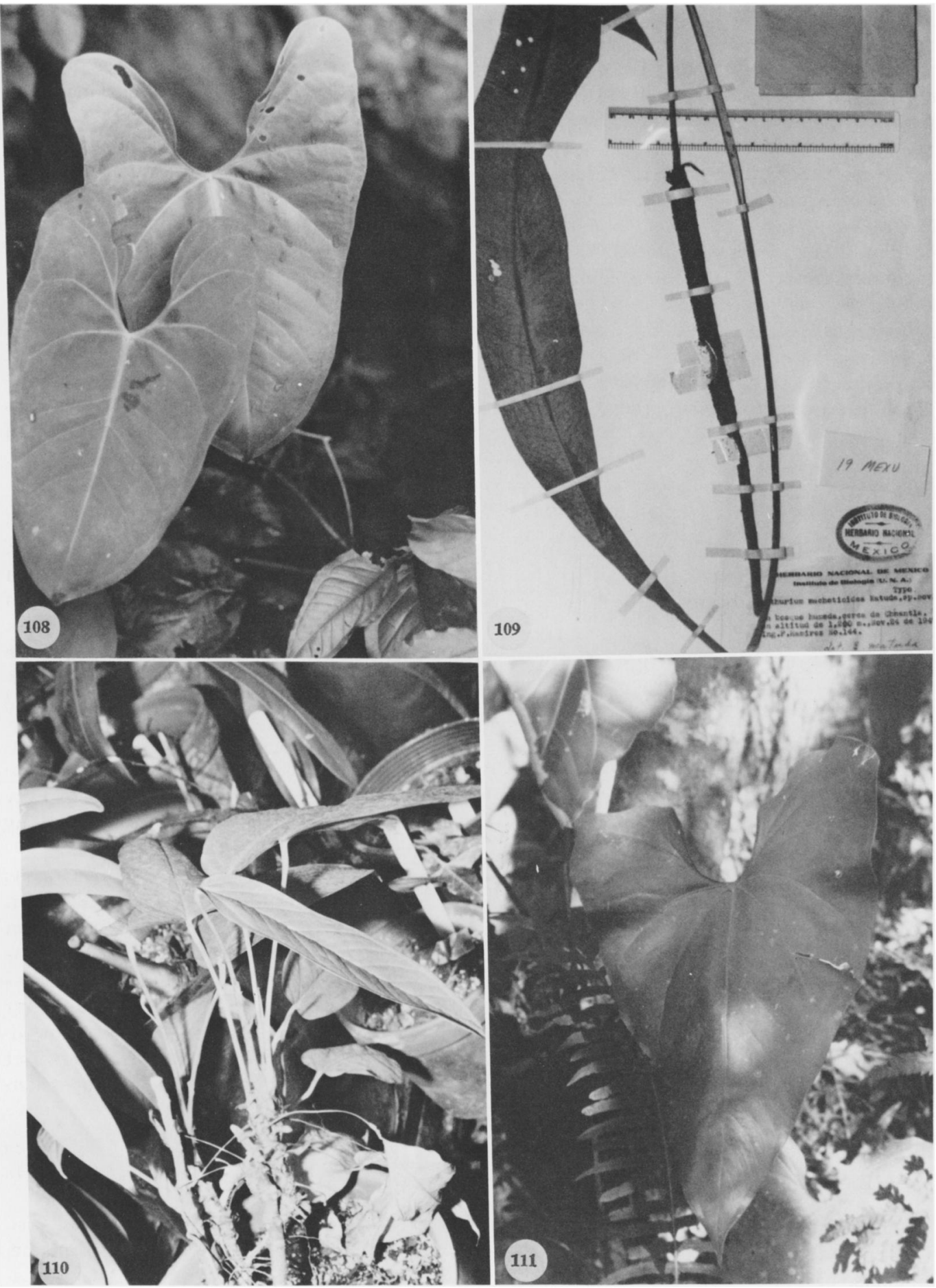

Figures 108-111. 108. Anthurium lucens Standl. ex Yuncker, Croat 41541.-109. Anthurium machetioides Matuda, Ramirez 144 (Type).-110. Anthurium microspadix Schott, Croat 40906.-111. Anthurium montanum Hemsl., Croat 47161. 
Anthurium lucens is in section Belolonchium and is easily confused with $A$. verapazense, but that species is distinguished by having the inflorescence 1.5 to 3 times longer than the petioles, and by having the spathe generally less than half as long as the spadix at anthesis.

Berry and seed size are quite variable in $A$. lucens. For example while Croat 41541 has berries ca. $7 \mathrm{~mm}$ long and seeds ca. $4 \mathrm{~mm}$ long, Breedlove 9709 and 4308 have berries 11 to 14 $\mathrm{mm}$ long and seeds 7 to $8.5 \mathrm{~mm}$ long respectively. Breedlove 9709 is particularly noteworthy in having a very large fruiting spadix, drying ca. $3 \mathrm{~cm}$ in diameter. Nevertheless the berries and seeds appear to be qualitatively similar and are all believed to represent the same species.

Guatemala. Alta verapaz: vicinity Telemán, Croat 41541 (MO); Cerro Chinajá, Steyermark 45570 (F, MO); 45624 (F, LL); 45649 (F); vicinity Finca Cubilhuitz, Steyermark 44740 (F); Finca Sipacate, Cook \& Griggs 434 (US); Seraxcaj, Finca Seamay, Wilson 211 (F); vicinity of Panzós. Croat 41612, 41697 (MO). HUEHUETENANGO: near Barillas, Steyermark 49736 (F, US). IZABAL: El Estor, Harmon \& Dwyer 4340 (MEXU, MO); NW of Lake Izabal, Jones \& Facey 3389 (NY); along Río Bonito, Steyermark 41723 (F, US).

Honduras. Comayagua: between San Antonio \& El Cedral, Molina 22588 (F, NY); vicinity Siguatepeque, Williams \& Molina $18083(\mathrm{~F})$; above the plains of Siguatepeque, Yuncker et al. 5844 (F, GH, MICH, MO, U, US); 5935 (F).

MeXICO. ChIAPAS: SE of Comitán, Carlson 1913, 2334 (MEXU); 2294 (MICH); Munc. Tenejapa, Breedlove 10968 (DS); Ton 1574 (CAS, DS, MEXU); E of La Trinitaria, Breedlove 9709 (CAS, DS, ENCB, F); 14971 (DS, LL, MEXU); Breedlove \& Raven 11308 (DS, CAS); 13027 (DS); Breedlove \& Thorne 21226, 27581 A (DS); Breedlove \& Smith 32104 (DS); Montebello National Park, Breedlove \& Dressler 29535 (DS); Breedlove 38754 (DS); Munc. Ocosingo, Dressler 1452 (GH, MICH, NY, US); NW of Ocozocoautla de Espinosa, Breedlove 27500 (DS); Cascada Siltepec, Matuda 19647 (MEXU); between Palenque \& Bonampak, Croat 40222 (MO); E of San Quintín, Breedlove 33385 (CAS, DS).

Anthurium machetioides Matuda, Anales Inst. Biol. Univ. Nac. México 22: 379, Fig. 7. 1952. TYPE: Mexico. Oaxaca? (see discussion): Chinantla, $1,200 \mathrm{~m}$, Ramirez 144 (MEXU, holotype).

Stems short, internodes short; cataphylls thin, to $6.5 \mathrm{~cm}$ long, drying brown, weathering to linear fibers, probably deciduous. LEAVES with petioles $6-7 \mathrm{~cm}$ long, 4-5 $\mathrm{mm}$ diam., broadly sulcate adaxially, rounded abaxially; geniculum 4-5 mm long; blades oblanceolate, narrowly acuminate at apex, narrowly cuneate at base, 45-48 $\mathrm{cm}$ long, 6-8 $\mathrm{cm}$ wide, broadest above middle, matte on both surfaces (dry); the midrib prominently and narrowly raised above and below (dry); primary lateral veins $10-15$ per side, departing midrib at $20^{\circ}-30^{\circ}$ angle, curving down and joining collective vein; reticulate venation prominulous in dry specimens; collective vein arising from one of the primary lateral veins near the base, 3-4 $\mathrm{mm}$ from margin. INFLORESCENCE equalling or longer than leaves; peduncle $40-48 \mathrm{~cm}$ long, to $5 \mathrm{~mm}$ diam., terete; spathe narrowly lanceolate, inserted at $45^{\circ}$ angle on peduncle; spadix green, $20-24 \mathrm{~cm}$ long, 1.3 $\mathrm{cm}$ diam. at base, $6 \mathrm{~mm}$ diam. at apex; the flowers rhombic, 2-2.4 mm long, 2.4-2.6 $\mathrm{mm}$ wide; 13-14 flowers visible in the principal spiral, 910 flowers visible in the alternate spiral; pistils not emergent; stigma elliptic, slitlike, $0.5 \mathrm{~mm}$ long; stamens held level with tepals; anthers ovate. INFRUCTESCENCE not seen. Fig. 109.

Anthurium machetioides is endemic to central Mexico on the Atlantic slope. The type was from the region of Chinantla in northeastern Oaxaca (a region comprising part of 4 districts south of Valle Nacional), at 1,200 $\mathrm{m}$ and a second collection was made relatively near at $200 \mathrm{~m}$ in the District of Tuxtepec (probably San José Tuxtepec between Valle Nacional and Tuxtepec).

The species is characterized by its oblong-linear leaves with a collective vein from near the base and primary lateral veins that are scarcely more prominent than the tertiary veins, and by the very elongate gradually tapered spadix.

In describing the species Matuda indicated its relationship as section Leptanthurium; however, despite the fact that it has a collective vein from the base, its affinities are most likely with $A n$ thurium schlechtendalii in section Pachyneurium, which often has a collective vein from near the base in juvenile leaves. It differs from $A$. schlechtendalii in its proportionally narrower leaves, the collective vein and by its proportionately much longer spadix.

Mexico. OAXACA: near Chinantla, Ramirez 144 (MEXU); Tuxtepec, Martinez-Calderon 844 (MICH).

Anthurium michelii Guillaumin, Bull. Mus. Hist. Nat. (Paris) 31: 263. 1925. TYPE: Panama. Bocas del Toro: hills beyond Fish Creek Lagoon, Wedel 2276 (P, holotype).

Anthurium amethystinum Croat \& Baker, Brenesia 16 (Supl. 1): 20. 1979. TYPE: Costa Rica. Cartago: along road between Moravia (east of Tuis, SE of Turrialba) and Quebrada Platanillo, 3-5 km from 
Finca Racine in Moravia; elev. 1,200-1,300 m; disturbed primary forest, Croat 36601 (MO 2395446, holotype; CR, F, K, NY, SEL, US, isotypes; Live plant at MO).

Epiphytic or terrestrial; stem usually very short, 6-25 cm long, 1.5-3 cm diam.; roots dense, 1.5$5 \mathrm{~mm}$ thick, descending; cataphylls subcoriaceous, $8-23 \mathrm{~cm}$ long, cordate-acuminate at apex, drying brown (B \& K Red 9/2.5), persisting, weathering into fibers. LEAVES held nearly erect; petioles 9-25 (40) cm long, 5-9 mm diam., flattened laterally, sulcate with sharp margins, acute to rounded abaxially; geniculum $1-1.6 \mathrm{~cm}$ long; blades elliptic to oblong-elliptic or oblong, gradually acuminate at apex (the acumen downturned), acute to obtuse at base, $8-54 \mathrm{~cm}$ long, $5.5-22 \mathrm{~cm}$ wide, broadest at the middle or slightly below the middle, the margin \pm flat, continuous with margins of the petiole; both surfaces matte to semiglossy; midrib convexly raised and diminished toward apex above, acutely raised below; basal veins consisting only of the lowest pair of primary lateral veins; primary lateral veins 6-15 per side, sunken above, prominulous below; interprimary veins weakly sunken above, prominulous below; collective vein moderately straight, prominent, continuous, arising from the second pair of primary lateral veins, sunken above, prominently raised below, 5-9 $\mathrm{mm}$ from the margin. INFLORESCENCE pendent or arching-pendent, usually shorter than the leaves; peduncle $30-58 \mathrm{~cm}$ long, 3-5 mm diam., much longer than petioles, prominently 4 - or 5-ribbed especially near the base, irregularly striate toward apex with one prominent sharp rib arising from beneath the spathe; spathe coriaceous, medium green (B \& K Yellow-green 7/10), oblong-lanceolate to oblong, $3-15 \mathrm{~cm}$ long, $1-2.5 \mathrm{~cm}$ wide, broadest in lower third, inserted at $45^{\circ}$ angle on peduncle; stipe $0.8-3.5 \mathrm{~cm}$ long; spadix yellowgreen (B \& K Yellow-green 6/7.5), (4.5) 8.5-20 cm long, 6-10 $\mathrm{mm}$ diam. at base, 4-6 $\mathrm{mm}$ diam. at apex; flowers rhombic, 3-4.2 mm long, 2.8$4.3 \mathrm{~mm}$ wide, the sides straight to jaggedly sigmoid; (4)7-11 flowers visible in the principal spiral, 5-7 flowers visible in the alternate spiral; tepals green, semiglossy, sometimes with scattered nectar droplets; lateral tepals $2-2.7 \mathrm{~mm}$ wide, the inner margin \pm straight, somewhat turned up against pistil; pistils exserted $0.5 \mathrm{~mm}$, pointed before maturity, the exserted portion broadly ovoid; stigma linear, $0.4-0.6 \mathrm{~mm}$ long, exserted, brushlike, with conspicuous droplets for about 10 days, becoming dry and brown, about
1 week before first stamens emerge, dry and exserted when stamens emerge; the lateral stamens emerging rapidly from the base, open in basal three-quarters before the first alternates begin to emerge at the base, sometimes emerging in a more scattered fashion, held in a close circle around pistil; anthers white, $0.5-0.6(0.8) \mathrm{mm}$ long, $0.4-1 \mathrm{~mm}$ wide; thecae elliptical, opening flat, moderately divaricate; pollen white. INFRUCTESCENCE becoming pendent; the spathe light green; the spadix $5-20 \mathrm{~cm}$ long, $2-3 \mathrm{~cm}$ diam.; berries obovoid to ovoid or pyramidal, pointed at apex, glossy, dark purple to violetpurple, 7-12 mm long when dry, paler violetpurple in lower third; mesocarp gelatinous; seeds 2, flattened, ca. $5 \mathrm{~mm}$ long, $4 \mathrm{~mm}$ wide, $3 \mathrm{~mm}$ thick. Fig. 106.

The species is known from Costa Rica and Panama on both slopes at altitudes from 400 to $1,400 \mathrm{~m}$, mostly in premontane wet and tropical wet forest.

Anthurium michelii is distinctive for its creamy green or whitish underleaf surface and bright purple berries. Also characteristic are the oblongelliptic leaves, broadly and sharply sulcate petiole, and the frequently conspicuously stipitate spadix.

The species is a somewhat atypical member of section Pachyneurium, and appears to be unrelated to any other species in the section.

The type specimen of $A$. michelii, not studied until recently, is aberrant and unusually small for the species and, despite the fact that it bears little resemblance to the type of $A$. amethystinum, the two are now known to represent the same species.

Costa Rica. alajuela: La Balsa de San Ramón, Utley \& Utley 1850 (F); Hacienda la Marina, Río San Rafael, canton de Aguas Zarcas, Williams et al. 29147 (F); E of Río San Rafael \& S of the hot springs, W of La Marina, Burger \& Stolze 5002 (F); La Palma de San Ramón, Brenes 5599 (CR, F); Methodist Rural Center Quebrada Marín, E of Ciudad Quesada, Burger \& Stolze 4994 (CR, F, MO, NY); San Luis de Zarcero, Austin Smith NY1258 (F, NY); road from Cariblanco to Lake Hule, W of Hwy. 9, Baker, Utley \& Utley 223 (F); NW of Cariblanco, Luteyn 3348 (DUKE); NNE of Bijagua along the new road to Upala, Burger $\&$ Baker 9862 (F, MO); $9862 A$ (F). CARTAGO: Moravia de Chirripó, Ocampo 1166 (CR); along Camino Raiz de Hule, SE of Platanillo, Croat 36743 (MO); along road between Moravia and Quebrada Platanillo, Croat 36601 (CR, F, K, MO, NY, SEL, US). HEREDIA: vicinity of Colonia Virgen del Socorro, E of Cariblanco on the finca of Sr. Carolo Molina, Utley \& Utley 2827 (F). SAN JOSÉ: La Hondura, Standley 36313 (US); Las Lajas, 
Leon $1148(\mathrm{CR})$; along road from San Isidro del General to Dominical, Burger \& Baker 10106 (F); Croat 35259 (MO); 1 mile beyond divide between San Isidro del General and Dominical, Croat 35323 (MO).

Anthurium microspadix Schott, Oesterr. Bot. Z. 8: 180. 1858. TYPE: Costa Rica, near Naranjo, Oersted s.n. (Type not found; Photo of Schott Aroid Drawing \#322, NYBG Neg. \#N.S. 3812).

Anthurium porrectum Schott, Oesterr. Bot. Z. 8: 180. 1858. TYPE: Costa Rica, near Desengaño, Wendland 841 (GOET).

Anthurium tapinostachyum Schott, Oesterr. Bot. Z. 8: 180. 1858. TYPE: Costa Rica, near Candelaria, Alto de La Cruz, Hoffmann s.n. (Photo of Schott Aroid Drawing \#331, NYBG Neg. \#N.S. 3818).

Anthurium colombianum Engl., Bot. Jahrb. Syst. 25: 379. 1898. TYPE: Colombia. Putomayo: valley of Sibundoy near Santiago, E of Pasto, elev. 2,000$2,500 \mathrm{~m}$.

Anthurium tuerckheimii Engl., Bot. Jahrb. Syst. 25: 380. 1898. TYPE: Guatemala. Alta Verapaz: Pansamalá, 1,200 m, Tuerckheim 864 (B, holotype; $\mathrm{K}$, US, isotypes).

Anthurium gracilescens Sodiro, Anales Univ. Centr. Ecuador 15: 393. 1902. TYPE: Ecuador. Pichincha: Nanegal, Sodiro s.n. (B).

Anthurium lepturum Sodiro, Anales Univ. Centr. Ecuador 15: 458. 1902. TYPE: Ecuador. Pichincha: western slopes of Volcán Pichincha, Sodiro s.n. (B).

Anthurium nanegalense Sodiro, Anales Univ. Centr. Ecuador 15: 460. 1902. TYPE: Ecuador. Pichincha: Gualea, Sodiro s.n. (B).

Anthurium silvaticum Sodiro, Anales Univ. Centr. Ecuador 22: 25. 1907. TYPE: Ecuador. Tungurahua, Sodiro s.n.

Anthurium barbanum K. Krause, Notizbl. Bot. Gart. Berlin-Dahlem 9: 270. 1925. TyPE: Costa Rica. Near Barba, A. C. Brade 2510 (B).

Anthurium gracilens Standl., Publ. Field Mus. Nat. Hist., Bot. Ser. 22: 68. 1940. TYPE: Panama. Chiriquí: Río Chiriquí Viejo Valley, 1,300-2,000 m, White 160 (F, holotype; MO, isotypes).

Scandent epiphyte or semierect, terrestrial herb; stems elongate, frequently to $1 \mathrm{~m}$ or more long, 4-7 mm diam., sparsely long-rooted at the nodes; the internodes (0.6)1-8(11) cm long; cataphylls thin, 4.5-7.5(11) cm long, acute and apiculate at apex, promptly weathering, soon deciduous, sometimes with a few pale fibers persisting. LEAVES persisting at the upper 6-10 or so nodes; petioles erect-spreading, subterete, narrowly and shallowly sulcate, 5-16(24) cm long, 2-2.3 mm diam.; geniculum 5-10 mm long; blades usually \pm oblong, sometimes lanceolate, narrowly oblong-elliptic or oblong-ovate, abruptly or gradually acuminate at apex, usually truncate to rounded at base, sometimes acute or subcordate, 9-25 cm long, $2.5-11 \mathrm{~cm}$ wide, moderately thin; the upper surface semiglossy; midrib raised in a valley above, diminished and sunken toward the apex, prominently raised below; primary lateral veins $4-11$ per side, departing midrib at ca. $45^{\circ}$ angle, sunken above, raised below, straight or slightly curving to collective vein; interprimary veins usually present; tertiary veins usually prominent on lower surface; basal veins 1-3 pairs, usually free at base, all but the uppermost soon joining the margin; collective vein arising from the first basal vein, 2-5 $\mathrm{mm}$ from the margin. INFLORESCENCE erect, shorter than the leaves; peduncle terete, $5-15 \mathrm{~cm}$ long; spathe lanceolateelliptic, olive-green or pale green, sometimes tinged purplish, 3-4(5) $\mathrm{cm}$ long, to $1.7 \mathrm{~cm}$ wide, abruptly acuminate at apex, weakly cordate at base, inserted at $45^{\circ}-50^{\circ}$ angle on peduncle; stipe usually $2-5 \mathrm{~mm}$ long, sometimes absent, or to $10 \mathrm{~mm}$ long; spadix pale yellow to yellow-green or green, sometimes tinged with purple, 1.5-4 $\mathrm{cm}$ long at anthesis, usually $4-5 \mathrm{~mm}$ diam. near base, $3-3.5 \mathrm{~mm}$ diam. near the apex; flowers square to weakly 4 -lobed, $2.5-3 \mathrm{~mm}$ wide in both directions, the sides straight to jaggedly sigmoid; 4-6 flowers visible in the principal spiral, 6-7 flowers visible in the alternate spiral; tepals semiglossy, minutely papillate, large nectar droplets scattered over the surface when anthers are emerging, lateral tepals $1.5-2 \mathrm{~mm}$ wide, the inner margin broadly convex; pistil weakly emergent, medium green, slightly darker than tepals, semiglossy; stigma colorless, raised, brushlike, ca. 0.5 $\mathrm{mm}$ long, with stigmatic droplets 1-3 days before anthers emerge; stamens emerging slowly from the base, the laterals preceding the third and fourth stamens by only a few spirals; anthers cream, inclined over pistil, ca. $0.5 \mathrm{~mm}$ long, ca. $0.8 \mathrm{~mm}$ wide; thecae ovate-elliptic, slightly divaricate; pollen creamy white. INFRUCTESCENCE with spadix to $8 \mathrm{~cm}$ long, to $2.5 \mathrm{~cm}$ diam.; berries yellowish-green, subglobose, ca. 5 $\mathrm{mm}$ diam. Figs. 107 and 110.

The species ranges from Mexico to Ecuador at elevations from 800 to $2,300 \mathrm{~m}$ in premontane rain, lower montane wet, and lower montane rain forest. It is one of the most variable species of Anthurium in North America. In Panama it is most easily confused with $A$. pallens (see that species for a discussion of the differences).

In South America it is apparently closely related to A. amoenum Kunth in Peru and Bolivia, 
A. tenuicaule Engl., and A. brachypodum Sodiro from Ecuador.

Sodiro described several species based on the presence or absence of a stipe, the comparative lengths of the peduncle and petioles, and the shape and relative size of the spathe in relation to the length of the spadix. These characters have been observed to be too variable even within a single population to warrant their use in the separation of species.

Anthurium microspadix has been placed in section Xialophyllium.

Mention should be made of an error in the translation of Lehmann's handwritten label by Engler. The type locality should read "Sibundoy" rather than "Dibundog."

\section{(NY).}

Belize. Camp 32, Guatemala Survey, Schipp S-679

Costa Rica. No other location, Bogner s.n. (MO); Pittier 66, 3863 (BR); Tonduz 1888 (BR). AlajUela, GUANACASTE, PUNTARENAS: at juncture of provinces, Burger et al. 10835 (MO) . ALAJUELA: no other location, Brenes $13611 a(\mathrm{NY})$; Peñas Blancas, Kennedy \& Guindon 3707 (MO); N of Los Ángeles de San Ramón, Almeda \& Nakai 3848 (MO); N of San Ramón, Utley 4590 (DUKE, MO); Volcán Barba, Tissine 1600 (WIS); S of Zapote, Utley 4655 (DUKE); vicinity Zarcero, Croat 43564 (MO); Smith 115, 404, 485 (MO); 638, 826, 1124 (NY). CARTAGO: trail to Meterological Station, Utley 4536 (DUKE); between Moravia \& Quebrada Platanillo, Croat 36617, 36677 (MO); SW of Muñeco, Luteyn 3873 (DUKE); S of Muñeco, Utley \& Utley 771 (MO); vicinity Palo Verde, Luteyn 3329 (DUKE); Luteyn \& Wilbur 4381 (DUKE); vicinity Platanillo, Croat 36819 (MO); between Quebrada Honda and the Río Sombrero, Luteyn 3237 (DUKE); near forest above Río Taus, Taylor \& Taylor 11459 (NY); vicinity Tapantí, Baker 212 (MO); Burger \& Liesner 6722 (MO); Burger \& Burger 7547 (MO); Lent 1035 (NY); Utley \& Utley 5190 (DUKE); Tapantí Hydroelectric Reserve, Croat 36175, 36217 (MO). GUANACASTE: near Monte Verde, Weston 5063 (MO, NY); between Santa Elena \& Monteverde, Croat 47119 (MO). HEREDIA: vicinity Bajo La Hondura, Croat 44503 (MO); S of Cariblanco, Croat 35847 (MO); Río Las Vueltas, Taylor 17705 (NY); Tarrazu, Tonduz 7865 (BR); N of Vara Blanca, Croat 35622, 36048 (MO); Vara Blanca de Sarapiquí, Skutch 3507 (MO, NY), 3593 (MICH, MO, NY); Volcán Barba near Sacramento, Burger \& Burger 7697, 9481 (MO); between Volcán Irazú \& Volcán Barba, Davidse \& Pohl 1702 (MO). puntarenas \& alajuela: Monteverde Nature Reserve, Burger \& Baker 9643 (MO). PUNTARENAS: Cañas Gordas, Pittier 11128 (BR); near Cotón, along Río Coto Brus, Croat 26643, $26650 \mathrm{~A}$ (MO); W of Finca Las Cruces, Luteyn 3847 (DUKE); vicinity of Monteverde, Burger \& Gentry 8567, 8672 (MO); Luteyn 3400 (DUKE, MO); Wilbur et al. 15810 (DUKE); Wilbur 14260 (DUKE); SE of Santa Elena, Almeda et al. 2035 (DUKE). SAN JOSÉ \& HEREDIA: slopes of Cerro Zurqui, Almeda 3688 (CAS); Río Para Blanca, Burger et al.
10268A (MO). SAN JOSÉ: NW of Canaán, Burger \& Liesner 7086 (MO); NW of Cascajal, Taylor \& Taylor 11341 (NY); Cordillera Central above La Palma, Luteyn 3307 (DUKE, MO); Copey, Stork 1550 (MICH); La Palma, Brenes 15055 (NY); Tonduz 9698 (BR); between La Palma and La Hondura, Luteyn 4255 (DUKE); Río Candelaria, Tonduz 7893 (BR); Rió Naranjo, Tonduz 7524 (BR); SW of San Isidro del General, Croat 35265, 35300 (MO); N of San Jerónimo, Utley \& Utley 2894 (MO); Santa María de Dota, Pittier 2339 (BR).

Guatemala. alta verapaz: Cobán, Tuerckheim 1297 (BR, NY, US); Cubilhuitz, Tuerckheim 8605 (NY, US); Finca Moca, Johnson 143 (US); Pansamalá, Tuerckheim 864 (P); SE of Tactic, William et al. 40601 (F, MO, U). BAJA verapaz: vicinity Purulhá, Croat 41177, 41284 (MO); Tuerckheim 1768 (US). HUEHUETENANGO: N of Barillas, Steyermark 48724 (F). SAN MARCOS: vicinity África, Croat 40955 (MO); above Finca El Porvenir, Steyermark 37975 (MO); La Trinidad, Croat 40906 (MO); vicinity San Rafael, Williams et al. 26202 (NY). ZACAPA: Mt. Virgen, Steyermark $42870(\mathrm{~F})$.

Honduras. Comayagua: El Achiote, Yuncker 6270 (MO); vicinity Siguatepeque, Molina 25472 (NY, US). LA PAZ: near Cordillera Guajiquiro, Molina \& Molina 13885 (NY). MORAZÁn: Volcán de Guaimaca, Molina 3184 (US). SANTA BÁRBARA: E of Lake Yojoa, Clewell \& Hazlett 3882 (MO).

MeXico. ChIAPAS: between Ixtapa \& Pichucalco, Croat 47798 (MO); vicinity Jitotol, Breedlove 15432, 26088 (DS); vicinity Lake Montebello, Croat 46677 (MO); Miranda 2689 (MEXU); Munc. La Trinitaria, Montebello National Park, Breedlove 35120, 38797 (DS); Munc. Ocosingo, Dressler 1517 (MEXU, MICH, US); near Pueblo Nuevo Solistahuacán, Raven \& Breedlove 20025 (DS); Thorne \& Lathrop 6505 (RSA); Lathrop 6509 (RSA); Thorne \& Lathrop 40280 (DS, LL, RSA); E of Río Napac, MacDougall 6894 (MEXU); SW slope of Volcán Tacaná, Breedlove 42509 (DS); Croat 47180 (MO). OAXACA: vicinity Ixtlán de Juárez, McAlpin 1048 (DUKE); Sierra de Juárez, Croat 39816 (MO); between Tuxtepec \& Oaxaca, Croat 48067 (MO); Vista Hermosa, Moore \& Bunting 8922 (BH).

NicARAGUA. JinOtEga: NW of Aranjuez, Stevens 9173 (MO); near Cerro Chimborazo, Atwood A221 (MO); Neill N163 (MO); Matagalpa: Highway 3 from Jinotega to Matagalpa, Croat 43069, 43106 (MO); N of Matagalpa, Croat 43114 (MO); above Santa María de Ostuma, Molina 20382 (NY); Molina \& Molina 30538 (MO); Neill 1575 (MO); Williams et al. 27592, 27724 (MO); El Porvenir, Molina 20545 (MO). zelaya: vicinity Cerro Saslaya, Neill 3812, Stevens 6713 (MO).

Anthurium montanum Hemsl., Diagn. Pl. Nov. Mexic. 36. 1878. TYPE: Guatemala, Volcán de Fuego, above Calderas at 2,700 m, Salvin (K).

Usually epiphytic, stems $5-15 \mathrm{~cm}$ long, 2.5-7 $\mathrm{cm}$ diam.; leaf scars $2.5 \mathrm{~cm}$ wide; roots numerous, thick, descending; cataphylls coriaceous, 6 $12 \mathrm{~cm}$ long, rounded at apex with subapical apic- 
ulum, ca. $3 \mathrm{~mm}$ long, drying reddish-brown (B $\& \mathrm{~K}$ Yellow-red 5/7.5) usually persisting as fibers around stem. LEAVES with petioles spreading to erect, (6.5)22-75(99) cm long, 5-15 mm diam., usually D-shaped, sometimes subterete, broadly sulcate, the margins acute; geniculum $1.5-3 \mathrm{~cm}$ long (sometimes tinged with red in larger plants); blades triangular to ovate, subcoriaceous, gradually to abruptly acuminate at apex, broadly to deeply lobed at base, $12-55 \mathrm{~cm}$ long, 7-30 cm wide, broadest at base; the anterior lobe 11-40 cm long; posterior lobes $5.5-18.5 \mathrm{~cm}$ long, usually directed upward; the sinus rarely arcuate, usually hippocrepiform or spathulate, rounded at apex; the upper surface semiglossy to glossy, the lower surface semiglossy; the midrib broadly raised at base above, acutely raised to middle, sunken at apex, convexly raised below; basal veins 3-7 pairs, the fourth to seventh coalesced 1-5.5 $\mathrm{cm}$, raised above and below; the posterior ribs naked, the outer margin rolled up; primary lateral veins 6-11 per side, departing the midrib at $45^{\circ}-60^{\circ}$ angle; weakly sunken above, raised below, straight to the collective vein; lesser veins sunken above, raised below; collective vein arising from the first basal vein, sunken above, raised below, 5-14 mm from margin. INFLORESCENCE spreading, shorter than or equalling leaves; peduncle 17-49(65) $\mathrm{cm}$ long, 3-8 $\mathrm{mm}$ diam., terete to weakly ribbed, shorter than petioles; spathe subcoriaceous, yellow-green to medium green, tinged with red-violet (B \& K Yellow-green $6 / 7.5$ to $5 / 10$ ), narrowly ovate to lanceolate, $6-8.5 \mathrm{~cm}$ long, $1.5-2.7 \mathrm{~cm}$ wide, broadest just above point of attachment, caudate-acuminate at apex, round to cordate at base, inserted at $90^{\circ}$ angle on peduncle; stipe $2.5 \mathrm{~cm}$ long, $4 \mathrm{~mm}$ diam., yellow to medium green; spadix green tinged with purple, deep purple or brown, 4-20 cm long, 5-11 mm diam. at base, 4-8 $\mathrm{mm}$ diam. at apex; flowers rhombic to sub4-lobed, 2.5-4.2 $\mathrm{mm}$ long, 2.6-4 $\mathrm{mm}$ wide, the sides straight to sigmoid; 5-9 flowers visible in the principal spiral, 5-6 flowers visible in the alternate spiral; tepals matte with pale punctations, minutely and densely papillate, droplets sparse; lateral tepals $1.5-2.5 \mathrm{~mm}$ wide, the inner margins convex to straight and turned up against pistil; pistils weakly emergent, green; stigma linear, 0.5-0.7 mm long; stamens developing promptly from the base, the full complement developed promptly, the leading stamens preceding alternates only by 2 or 3 spirals; anthers cream to tan, $0.2 \mathrm{~mm}$ long, $0.5 \mathrm{~mm}$ wide, exsert- ed on short, transparent filaments, quickly retracting; thecae oblong-ellipsoid, slightly divaricate; pollen yellow to cream, fading to white. INFRUCTESCENCE pendent; spadix to $20 \mathrm{~cm}$ long, to $2 \mathrm{~cm}$ diam.; berries oblong to obtusely triangular, truncate and usually broadest at apex, medium orange (B \& K Yellow-red 7/2.5), 10$13 \mathrm{~mm}$ in both directions; mesocarp firm, thick with few raphide cells; seeds 1-2, pale greenishwhite, weakly flattened, \pm reniform, $5-7.5 \mathrm{~mm}$ long, 4-6 $\mathrm{mm}$ wide, 3-4 $\mathrm{mm}$ thick, minutely appendaged at both ends. Figs. 111, 112, and 113.

Anthurium montanum is known only from southeast Chiapas and southwest Guatemala at elevations of 1,200 to $2,900 \mathrm{~m}$ in wet mountain forests and cloud forests (not designated as part of the Holdridge Life Zone system). In Chiapas the species is known principally from "bosque de oyamel" but probably also "bosque pinoencino." The type locality of $A$. montanum, namely Volcán de Fuego, is located in southwest Guatemala along the frontiers of the departments of Escuintla, Chimaltenengo, and Sacatepéquez. According to annotations by N. E. Brown on the type collection, it consists of a mixed collection of two species, namely $A$. andicola and A. montanum. Despite my reluctance to question the generally excellent observations of Brown, I can see no differences in the two parts of the collection and certainly one part does not appear to be $A$. andicola.

The species is in section Belolonchium and is recognized by its narrowly ovate blades, its usually D-shaped, weakly glaucous petioles, longpedunculate inflorescences with a matte, green to violet-purple spadix, and thin dilacerating cataphylls.

Anthurium montanum is confused with $A$. huixtlense, a more wide ranging species usually occurring from about 300 to $1,500 \mathrm{~m}$ (to 1,800 $\mathrm{m}$ fide Flora of Guatemala). The latter species is distinguished from $A$. montanum by having coriaceous cataphylls that turn reddish-brown and persist intact, and by having a reddish-violet to lavender, rarely white spadix with glossy tepals. In $A$. montanum the cataphylls are thin and soon weather to slender fibers while the tepals are matte and either green or violet-purple.

Anthurium montanum is also similar to $A$. umbrosum, a species from northern Oaxaca with similar narrowly ovate leaf blades and dilacerating cataphylls, but that species differs in having 

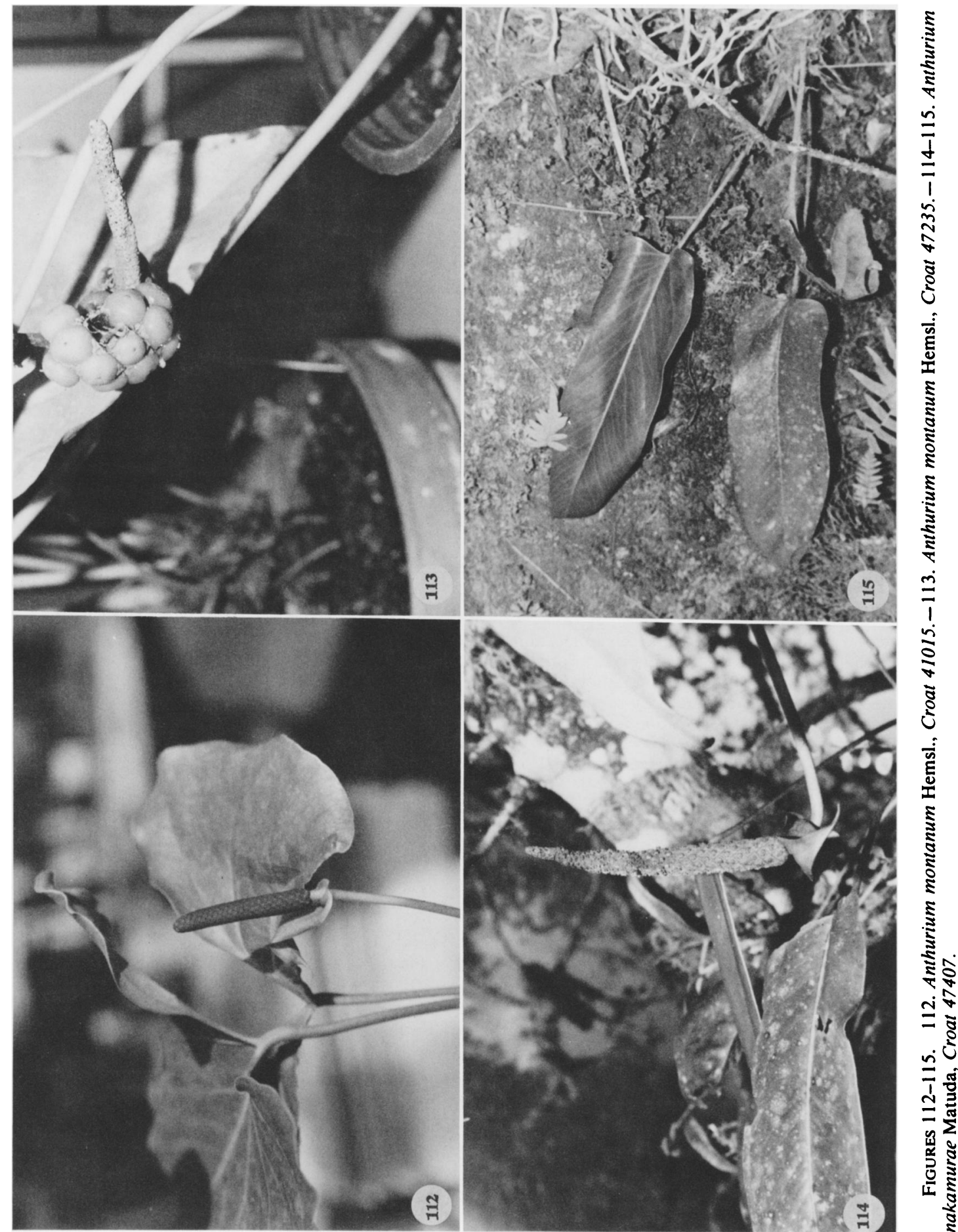
a terete petiole and a leaf blade that is relatively straight along the margin.

Anthurium montanum is perhaps most closely related to $A$. titanium, a species from southeast Chiapas and adjacent parts of Guatemala and sympatric with $A$. montanum in the lower parts of its elevational range (i.e., below $1,800 \mathrm{~m}$ ). The two species share a D-shaped, weakly glaucous petiole and leaf blades of similar color and texture, but those of $A$. titanium attain generally much larger size and are almost round to broadly ovate in outline, while those of $A$. montanum are generally narrowly ovate.

Another species with which $A$. montanum can be confused is $A$. chamulense, with which it is sympatric in eastern Chiapas. They share a similar blade shape but the latter species is distinguished by having blades more coriaceous.

Anthurium montanum is apparently closely related to $A$. cordatotriangulum, which differs in having a more deltoid leaf blade with conspicuously elevated veins, a generally longer and broader spathe, and a longer, more tapered spadix. Both species have been collected near Rosario south of Motozintla, but the only species apparently now occurring in the area is $A$. montanum.

Guatemala. Chimaltenango: no other location, Standley 62304 (F); above Las Calderas, Standley 80173, 80174, 80190, 87845 (F). HUEHUETENANGO: below La Libertad, Standley 51172 (F). QUEZALTENANGO: S of San Martín, Standley 83836, 84991 (F); Volcán de Zunil, Standley 65381 (F); above Zunil, Standley 85778,85821 (F). ESCUINTLA: above Calderas, Volcán de Fuego, Salvin s.n. (K). ReTAlHuleu: Volcán Pacaya, Harmon 4176 (UMO). SAN MARCOS: vicinity San Pedro, Almeda 3460 (DUKE); vicinity San Marcos, Croat 41015 (MO); San Pedro, Steyermark 47217 (F, NY); Sierra Madre Mountains, W of San Marcos, Williams et al. 27214 (F); west of San Pedro Sac, Luteyn \& Almeda 3460 (DUKE, MO); vicinity San Rafael, Standley 86482, 86529 (F); Williams et al. 26010 (NY, US); Volcán Tajumulco, Steyermark 37063 (F). SUCHITEPÉQUEZ: Volcań Santa Clara, Steyermark 46684, 46751 (F); Mazatenango, Tejada 308, 310 (US).

Mexico. ChIAPAs: vicinity El Rosario, Croat 40751, 47235 (MO); Escuintla, Monte Ovando, Matuda 2571 (MEXU, MICH); Matuda 4212 (DS, MEXU, MICH, NY, UC); Matuda 4219, 19663 (MEXU); Matuda 17744 (F, MEXU); Matuda 18167 (MEXU, NY); La Grandeza, Matuda 5604 (F, MEXU, MO); Mt. Pashtal, Matuda 17971 (MEXU); Motozintla, Breedlove 25786, 41725 (DS); San Luis, Siltepec, Matuda 18276 (MEXU); Saxchanal, Matuda 17805 (MEXU); E side of Volcán Tacaná, Breedlove 31706 (DS); Croat 47161 (MO).

Anthurium monteverdense Croat \& Baker, Brenesia 16 (Supl. 1); 62. 1979. TYPE: Costa
Rica. Puntarenas: Monte Verde Biological Preserve (operated by the Tropical Science Center), Kennedy 582 (F, holotype).

Epiphyte, to $1.5 \mathrm{~m}$ tall; stems thick, moderately short, the internodes very short; cataphylls thick, persistent, drying reddish-brown. LEAVES with petioles terete, $29-50 \mathrm{~cm}$ long, $6-8 \mathrm{~mm}$ diam.; geniculum moderately obscure, to $4 \mathrm{~cm}$ long; blades coriaceous, ovate, broadest just below the middle, acuminate and downturned at apex, conspicuously lobed at base, 29-50 cm long, $18.5-34 \mathrm{~cm}$ wide; the anterior lobe $22-36 \mathrm{~cm}$ long, the margins broadly convex; the posterior lobes 7-12 cm long; sinus spathulate to hippocrepiform, longer than broad, rounded at apex; upper surface semiglossy with sparse, \pm obscure, raphide cells, lower surface sparsely and obscurely dark dotted; the midrib raised above and below; primary lateral veins 3-5 per side, departing midrib at $40^{\circ}-50^{\circ}$ angle, \pm straight until near the margin, then prominently arcuate-ascending and joining the margin; basal veins 5-6 pairs, 2-4 of them coalesced $1.5-4 \mathrm{~cm}$, arcuate and joining the margin, \pm loop-connecting the secondary veins; posterior rib prominently curved, naked for most of its length, turned up along its outer margin; collective vein arising from the uppermost 1 or 2 primary lateral veins. INFLORESCENCE shorter than leaves; peduncle 35-40 (100) cm long, 6-8 $\mathrm{mm}$ diam.; spathe coriaceous, white, broadly ovate, $8-10(17.5) \mathrm{cm}$ long, $5-6(8.5) \mathrm{cm}$ wide, acuminate-cuspidate at apex, rounded at base, broadest at or slightly below middle, held erect, inserted at ca. $45^{\circ}$ angle on peduncle; spadix green to creamy yellow or yellowish-tan, 5.5$14.5 \mathrm{~cm}$ long, $1-2.2 \mathrm{~cm}$ diam.; flowers rhombic to weakly 4-lobed, 2-2.2 $\mathrm{mm}$ long, $2.2-2.5 \mathrm{~mm}$ wide (dry); 10-12 flowers visible in either spiral; the lateral tepals $1.2-1.3 \mathrm{~mm}$ long, the inner margin broadly convex; pistil and stamens not studied. INFRUCTESCENCE not seen.

The species is apparently endemic to the mountains in west central Costa Rica at elevations of 1,400 to $1,600 \mathrm{~m}$, in the Provinces of Alajuela and Puntarenas in lower montane moist and premontane wet forest.

Anthurium monteverdense belongs in the section Calomystrium and is closely related to $A$. hoffmannii, but that species differs in having an ovate-lanceolate spathe.

Costa Rica. alajuela: W of Monteverde Reserve, Dryer 1529 (F); Zapote, Austin Smith 2893 (F); Zarcero, Austin Smith H564 (F). PUNTARENAS \& ALAJUELA: 
Monteverde Reserve, Burger \& Baker 9710 (MO); Kennedy 582 (MO).

Anthurium nakamurae Matuda, Revista Soc. Mex. Hist. Nat. 11: 93, Fig. 2. 1950. TYPE: Mexico. Chiapas: Cascada, Siltepec, elev. 1,200 m, June 2, 1949. Matuda 18668 (MEXU-85863, holotype).

Epiphyte; stems very short; roots thick, green, descending; cataphylls subcoriaceous, $4-6 \mathrm{~cm}$ long, tinged red-violet, acuminate at apex with short subapical apiculum, drying medium brown (B \& K Yellow 4/2.5), weathering into reticulate fibers. LEAVES erect to spreading; petioles 10.5$40 \mathrm{~cm}$ long, 4-5 mm diam., usually terete, sometimes subterete to weakly sulcate; geniculum 1.5$2 \mathrm{~cm}$ long; blades lanceolate to narrowly triangular, acuminate at apex, truncate to weakly lobed at base, 14.5-45 cm long, 4.5-12 $\mathrm{cm}$ wide, broadest at middle or just above; the anterior lobe 15-42 cm long, the margins straight, sometimes convex in apical one half of blade; posterior lobes $2-5 \mathrm{~cm}$ long; sinus arcuate with petiole decurrent to parabolic; both surfaces semiglossy; midrib flat at base above, raised near middle, sunken at apex, raised below; basal veins 2-3 pairs, free to base, flat and \pm obscure above, prominulous below; primary lateral veins $10-12$ per side, departing midrib at $30^{\circ}$ angle, flat and \pm obscure above, flat to prominulous below; lesser veins obscure above and below; collective vein usually arising from the first or second basal vein, sometimes from one of the primary lateral veins near the base, flat above, prominulous below, 3-5 $\mathrm{mm}$ from the margin. INFLORESCENCE spreading, equal to or longer than leaves; peduncle $30-47 \mathrm{~cm}$ long, 3-5 $\mathrm{mm}$ diam.; spathe thin, lanceolate to narrowly ovate, green heavily tinged red-violet, $4.5-6 \mathrm{~cm}$ long, $1.9-2.5 \mathrm{~cm}$ wide, long-acuminate at apex, weakly cordate at base, inserted at $90^{\circ}$ angle on peduncle; spadix sessile or stipitate, the stipe sometimes to $1 \mathrm{~cm}$ (rarely to $4 \mathrm{~cm}$ long), olive-green or purple, $3.5-8.2 \mathrm{~cm}$ long, 6-7 $\mathrm{mm}$ diam. at base, $3-5 \mathrm{~mm}$ diam. at apex; the flowers 4-lobed, 3.2-3.5 mm long, 2.6$3.3 \mathrm{~mm}$ wide, the sides sigmoid; 5-6 flowers visible in the principal spiral, 8-10 flowers visible in the alternate spiral; tepals matte, densely papillate, lateral tepals $1-1.6 \mathrm{~mm}$ wide, the inner margin convex, turned up, the outer margins tinged red-violet; pistils emergent, red-violet; stigma linear, ca. $0.2 \mathrm{~mm}$ long, scarcely open; stamens developing rapidly from the base, the laterals first, followed quickly by the alternates, the leading stamens emerging only 1-2 spirals ahead of the third and fourth stamens; anthers pale yellow, $0.6 \mathrm{~mm}$ in both directions, held over pistil, retracting to edge of tepals but not contiguous; thecae ellipsoid, scarcely divaricate; pollen bright yellow, fading to white. INFRUCTESCENCE pendent; spathe persistent; spadix to 17 $\mathrm{cm}$ long; berries red, obovoid, round at apex, ca. $10 \mathrm{~mm}$ long, $7 \mathrm{~mm}$ wide; seeds 2 , pale green, flattened, 5-6 mm long, ca. $3 \mathrm{~mm}$ wide. Figs. 114 and 115 .

Anthurium nakamurae is apparently endemic to eastern Chiapas in the vicinity of Siltepec and La Grandeza at elevations of 1,200 to $2,100 \mathrm{~m}$. My collection was made in a cloud forest area that appeared to be either tropical wet forest or premontane rain forest.

The species is a member of section Belolonchium and is characterized by its usually subterete, sometimes weakly sulcate petiole, its moderately thick, oblong to oblong-elliptic leaf blade, which is usually truncate (rarely subcordate) at the base and usually broadest above the base. Blades are often weakly constricted somewhat above the base.

Anthurium nakamurae is most similar to $A$. parvispathum, which has leaf blades oblong to oblong-elliptic with the base rounded to truncate, but that species differs in having much thicker blades that are generally much paler and matte on the lower surface. Moreover, typical A. parvispathum is usually found growing on rocks while A. nakamurae is reported principally epiphytic and, where I have seen it, grows high up in trees.

Two collections made by Breedlove ( 31955 and 40413) vary somewhat in the thickness of the blade and in having relatively longer cataphylls that appear to persist intact rather than weather to reticulate fibers as in typical $A$. nakamurae.

Mexico. Chiapas: vicinity Siltepec on road to Huixtla, Breedlove 31955, 40413 (DS); vicinity Motozintla and Siltepec, Croat 47407, 47419, 47461 (MO); Cascada, Siltepec, Matuda 18668, 19660 (MEXU); La Grandeza, Matuda 5576 (F, MEXU).

Anthurium nelsonii Croat, sp. nov. TYPE: Mexico. Oaxaca: Reyes (Reyes Etla, NNW of city of Oaxaca) 2,500-3,466 m; E. W. Nelson 1758 (US-358640, holotype).

Planta terrestris, ca. $1 \mathrm{~m}$ alta; caudex ca. $4 \mathrm{~cm}$ diam.; petiolus $29-48 \mathrm{~cm}$ longus, sulcatus late acuteque; lamina ovata aut triangularis-ovata, 30-57 cm longa, 22$56 \mathrm{~cm}$ lata, basi cordata profunde, in pagina inferiore albida hebetataque; inflorescentia effusa-pendula; pe- 
dunculus $30-43 \mathrm{~cm}$ longus; spatha viridis, $10-13 \mathrm{~cm}$ longa, $1.5-3 \mathrm{~cm}$ lata; spadix purpureus, $6.5-15 \mathrm{~cm}$ longus; baccae obovoideae.

Terrestrial, less than $1 \mathrm{~m}$ tall; stems ca. $4 \mathrm{~cm}$ diam.; roots $3 \mathrm{~mm}$ diam.; tan, smooth to woolly pubescent (dry); cataphylls ca. $8 \mathrm{~cm}$ long, drying tan to reddish-brown, weathering to moderately thin fibers. LEAVES with petioles $29-48 \mathrm{~cm}$ long, 6-8 $\mathrm{mm}$ diam., sharply and broadly sulcate adaxially; the geniculum $1-1.5 \mathrm{~cm}$ long; blades broadly ovate to ovate-triangular, $30-57 \mathrm{~cm}$ long, 22-56 cm wide, broadest at base, acute to narrowly rounded and apiculate at apex, deeply lobed at base, the margin sinuate and undulate; anterior lobe 25-45 cm long; posterior lobes $11.5-$ $25 \mathrm{~cm}$ long from apex of sinus to the outermost point; the sinus arcuate or arcuate with petiole decurrent; upper surface semiglossy, lower surface matte, often whitish with glistening translucent circular cells scattered in the epidermis (visible at high magnification on dried leaves); midrib convexly raised above; the basal veins 5 9 , all except the first and second (third) coalesced $5-11.5 \mathrm{~cm}$, raised on both surfaces, drying darker than the surface; posterior ribs broadly arcuate, naked most their length; primary lateral veins 59 per side, almost straight or gradually curved upward, arcuate-ascending near margin and joining margin, raised on both surfaces; collective vein arising from one of the lowermost primary lateral veins (rarely as low as the first basal vein), 3-7 mm from margin, weakly raised on both surfaces. INFLORESCENCE spreading-pendent (?); peduncle $30-43 \mathrm{~cm}$ long, $3-5 \mathrm{~mm}$ diam., terete, shorter to longer than petioles; spathe subcoriaceous, green, lanceolate to ovate-lanceolate, $10-13 \mathrm{~cm}$ long, $1.5-3 \mathrm{~cm}$ wide, broadest just above base, narrowly acuminate at apex, rounded to subcordate at base, inserted at ca. $45^{\circ}$ angle on peduncle; the stipe 3-25 mm long in back, 1 $15 \mathrm{~mm}$ long in front, 3-4 mm diam.; the spadix violet-purple, $6.5-15 \mathrm{~cm}$ long, 6-9 $\mathrm{mm}$ diam. at base, 4-5 mm diam. at apex, sometimes curved; the flowers rhombic, 3.6-4.7 $\mathrm{mm}$ long, 2.6-3.9 $\mathrm{mm}$ wide (dry), the sides scarcely to jaggedly sigmoid; 6-8 flowers visible in the principal spiral, 4-6 flowers visible in the alternate spiral; tepals matte, very minutely papillate, lateral tepals $2.7-3 \mathrm{~mm}$ wide, the inner margin broadly rounded; pistils not emergent; stigma oblong, 1 $\mathrm{mm}$ long; stamens emerging from the base in a moderately slow progression; the anthers held in a close cluster completely obscuring the pistil, ca. $1 \mathrm{~mm}$ long, ca. $1.4 \mathrm{~mm}$ wide; thecae narrowly ovate, scarcely divaricate; pollen not seen. INFRUCTESCENCE pendent, berries often developing only in the basal one half or one third; spathe persistent; spadix ca. $20 \mathrm{~cm}$ long, $3 \mathrm{~cm}$ diam.; berries obovoid, truncate to broadly rounded and scurfy, $10-13 \mathrm{~mm}$ long, $9-10 \mathrm{~mm}$ diam.; pericarp moderately thick, leathery at apex, small raphide cells, very dense in lower three quarters of berry; seeds $1-2, \pm$ lens-shaped, brown, considerably flattened, raphide cells sparse and minute, 9-13 $\mathrm{mm}$ long, 7-9 mm wide, 3-4 $\mathrm{mm}$ thick, weakly depressed at apex, with a sticky, gelatinous appendage sometimes as large as seed. Figs. 117 and 118.

Anthurium nelsonii is endemic to Mexico, occurring in the State of Oaxaca in the arid region north northeast of the city of Oaxaca between latitudes $17^{\circ} 10^{\prime} \mathrm{N}$ and $18^{\circ} \mathrm{N}$ at elevations of 1,000 to $2,500 \mathrm{~m}$. The principal vegetation types of the region are "selva baja caducifolia" and "bosque pino-encino."

The species is named in honor of the first collector, E. W. Nelson, who made the first collections in 1894. The collections have in part been confused with $A$. andicola, a species occurring in wetter parts of northern Oaxaca.

Anthurium nelsonii is a member of section $\mathrm{Be}$ lolonchium and is distinguished by its broadly ovate-triangular blade with well developed posterior lobes and a broad sinus and by its sharply and broadly sulcate petiole. The most characteristic feature and the principal feature by which it is distinguished from $A$. andicola is its matte, often whitish lower blade surface. The latter species is semiglossy on the lower surface.

MeXico. OAXACA: no other location, Conzatti 1724 (US); Mirador, Ernest 2500 (US); Oaxaca City, Nelson 1758 (US); Santa Catarina Cañon, Conzatti \& Gonzalez $1180(\mathrm{GH})$; vicinity Telixtlahuaca, Delgadillo 225 (MEXU); Tomellín Cañon, Rose \& Rose 11351 (NY, US).

Anthurium nizandense Matuda, Bol. Soc. Bot. México 24: 35, Fig. 1. 1959. TYPE: Mexico. Oaxaca: Nizanda near the Isthmus of Tehuantepec $\left(16^{\circ} 40^{\prime} \mathrm{N}, 95^{\circ} 2^{\prime} \mathrm{W}\right)$ dry, rocky hill, MacDougall s.n. (January 6, 1959) (MEXU, holotype).

Anthurium kruseanum Matuda, Anales Inst. Biol. Univ. Nac. México 36: 107, Fig. 1. 1966. TYPE: Mexico. Guerrero: La Junta (at junction of Río Omitlán and Río Papagayo) south of Tierra Colorada, on rocks in shade, Hubert Kruse 881 (MEXU, holotype). 


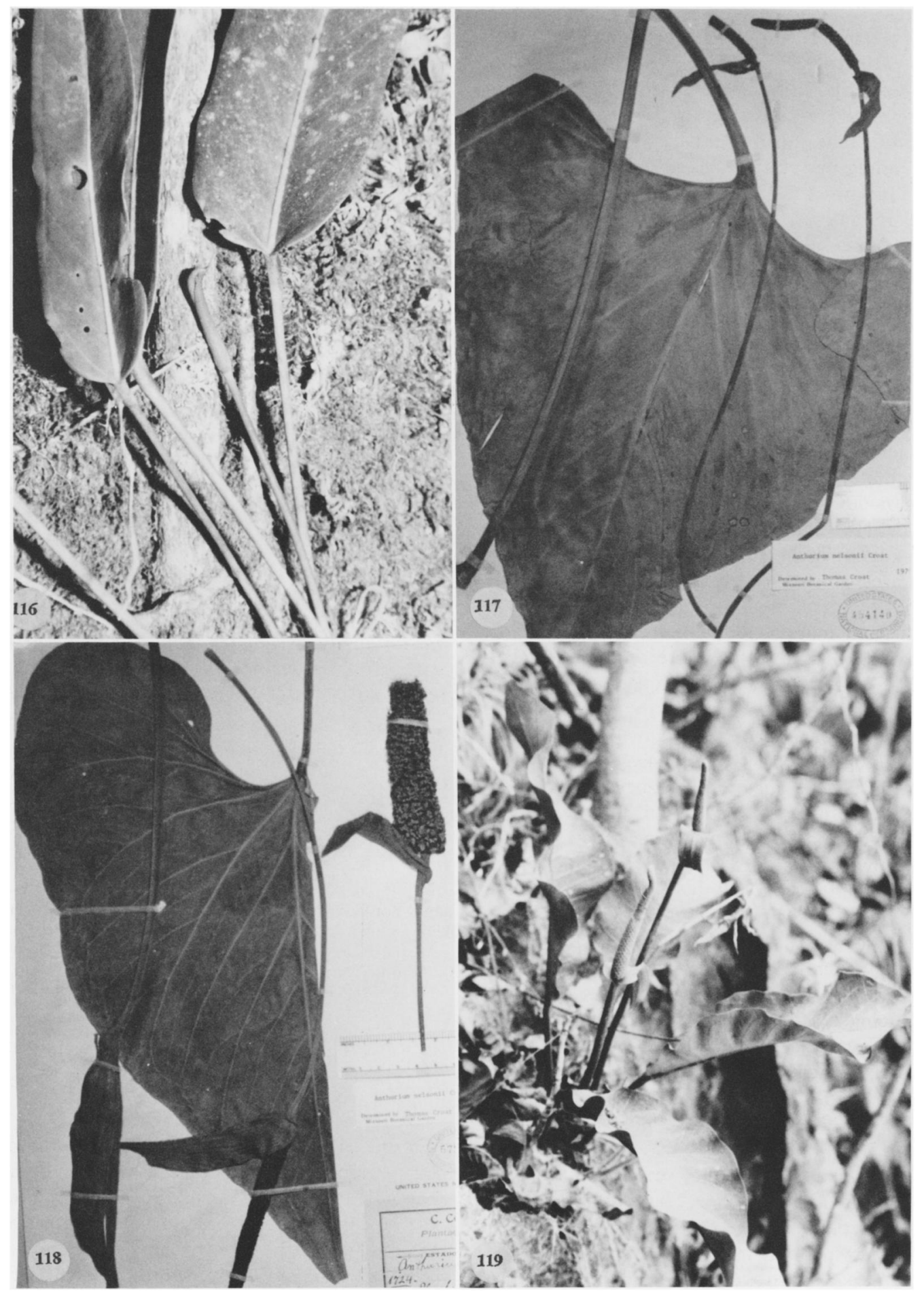

Figures 116-119. 116. Anthurium nakamurae Matuda, Croat 47407.-117-118. Anthurium nelsonii Croat, Rose \& Rose 11357 (Type). -119. Anthurium nizandense Matuda, Croat 45756. 
Usually terrestrial or epipetric; stems thick; leaf scars $0.7-1.2 \mathrm{~cm}$ long; roots numerous, thick, tan; cataphylls subcoriaceous, 3-7 cm long, rounded and minutely apiculate at apex, drying dark brown, persisting intact at apex, weathering to reticulate fibers at base. LEAVES erectspreading; petioles $6-15 \mathrm{~cm}$ long, 5-6 $\mathrm{mm}$ diam., subquadrangular to subterete, broadly and sharply sulcate, sometimes tinged with red-violet; geniculum 1-1.5 cm long; blades narrowly obovate to obovate-elliptic, subcoriaceous, 25$36.5 \mathrm{~cm}$ long, $10.7-18 \mathrm{~cm}$ wide, broadest just above middle, acute at apex and base (the tip glandular); the upper surface matte to semiglossy, the lower surface matte, both surfaces having short, linear raphide cells, the epidermal cells mounded (i.e., raised and convex); the midrib acutely raised above, convexly raised below; primary lateral veins $6-8$ per side, departing midrib at $50^{\circ}-60^{\circ}$ angle, prominent above and below; straight to weakly arcuate-ascending to collective vein; lesser veins scarcely visible and flat on both surfaces; collective vein arising from one of the primary lateral veins near middle of blade, 3-9 $\mathrm{mm}$ from margin, loop-connected with the remaining primary lateral veins. INFLORESCENCE erect, equalling or longer than leaves; peduncle $31-55 \mathrm{~cm}$ long, 5-8 $\mathrm{mm}$ diam., terete; spathe subcoriaceous, green, ovate-lanceolate, ca. $8 \mathrm{~cm}$ long, $2.5 \mathrm{~cm}$ wide, broadest near the base, inserted at $45^{\circ}$ angle on peduncle; spadix pale green becoming reddish-brown, $12-14 \mathrm{~cm}$ long, 9-11 $\mathrm{mm}$ diam. at base, $4 \mathrm{~mm}$ diam. at apex; the flowers rhombic, $1.8-2.5 \mathrm{~mm}$ long, $2.8-3$ $\mathrm{mm}$ wide, the sides sigmoid; 7-9 flowers visible in the principal spiral, 5-6 flowers visible in the alternate spiral; lateral tepals $1.5 \mathrm{~mm}$ wide, broadly rounded to weakly concave; the pistils not emergent; stigmas broadly ellipsoid; stamens emerging in a prompt, complete sequence, held just above tepals in a contiguous circle around stigma; anthers ca. $0.4 \mathrm{~mm}$ long, $0.6 \mathrm{~mm}$ wide; thecae ellipsoid, weakly divaricate. INFRUCTESCENCE pendent; the spathe withered; spadix $6.5 \mathrm{~cm}$ long, $1.5 \mathrm{~mm}$ wide; berries round, greenish-white, $8 \mathrm{~mm}$ long; mesocarp transparent, juicy, pulpy; seeds 1 (2?) per berry, broadly obovoid, pale yellow (B \& K Yellow 9/2.5), tinged with brown at base and on one side, $5.2-5.4 \mathrm{~mm}$ long, $4.5-4.7 \mathrm{~mm}$ wide, $3.4-4 \mathrm{~mm}$ thick, enveloped by a gelatinous sack; appendage minute, translucent, \pm gnarled at apex on side, tinged with brown. Figs. 119 and 120 .
Anthurium nizandense is endemic to Mexico in southern Guerrero and southern Oaxaca, where it occurs at less than $850 \mathrm{~m}$ in seasonally very dry habitats on steep, rocky cliffs. It is known only from the vicinity of Tierra Colorada in Guerrero and at Nizanda in Oaxaca.

The species is a member of section Pachyneurium and is recognized by its greenish-white berries and by its thick, narrowly to broadly elliptic or oblanceolate-elliptic, relatively long-petiolate leaves that are matte on the lower surface and sometimes exhibit a dense array of minute, linear raphide cells on drying. It has at least the lower primary lateral veins extending to the margin. Matuda reported the petiole to be subquadrangular, but this was possibly due to a misinterpretation of the dried specimen since this character is not apparent on the live material. The epidermal cells on both surfaces of the blade are convexly raised.

In the area of Mexico where it occurs, $A$. $n i$ zandense could be confused only with $A$. schlechtendalii ssp. jimenezii, which is more generally abundant and occurs in similar habitats. $A n^{-}$ thurium nizandense is distinguished by its proportionately longer petioles and its more typically elliptic blade, which is distinctly matte on the lower surface. In $A$. nizandense the blades are 1.3-2.5 times longer than the petioles. In $A$. schlechtendalii ssp. jimenezii, the leaf blades are usually semiglossy beneath and usually 6-10 times longer (rarely as little as 3 times longer) than the petiole.

Mexico. Guerrero: between bridge over Río Omitlán \& confluence of Río Papagayo, Croat 45756 (MO); Tierra Colorada, Kruse 1595 (MEXU). OAXACA: Nizanda near Isthmus of Tehuantepec, MacDougall s.n. (MEXU).

Anthurium obtusilobum Schott, Oesterr. Bot. Z. 8: 181. 1858. TYPE: Costa Rica, near San Miguel, Wendland 777 (GOET, holotype; $\mathrm{W}$, isotype).

Epiphyte or terrestrial; stems ca. $1.5 \mathrm{~cm}$ thick, to $30 \mathrm{~cm}$ long; roots numerous, moderately thin; cataphylls 10-15 cm long, drying tan, persisting intact. LEAVES with petioles \pm erect, subterete, obscurely sulcate, $19-60 \mathrm{~cm}$ long, 6-9 mm diam.; geniculum ca. $2 \mathrm{~cm}$ long; blades ovate, moderately thick, $15-46 \mathrm{~cm}$ long, $9.5-28 \mathrm{~cm}$ wide, gradually to abruptly acuminate at apex, deeply lobed at base; anterior lobe $21-33 \mathrm{~cm}$ long, the 


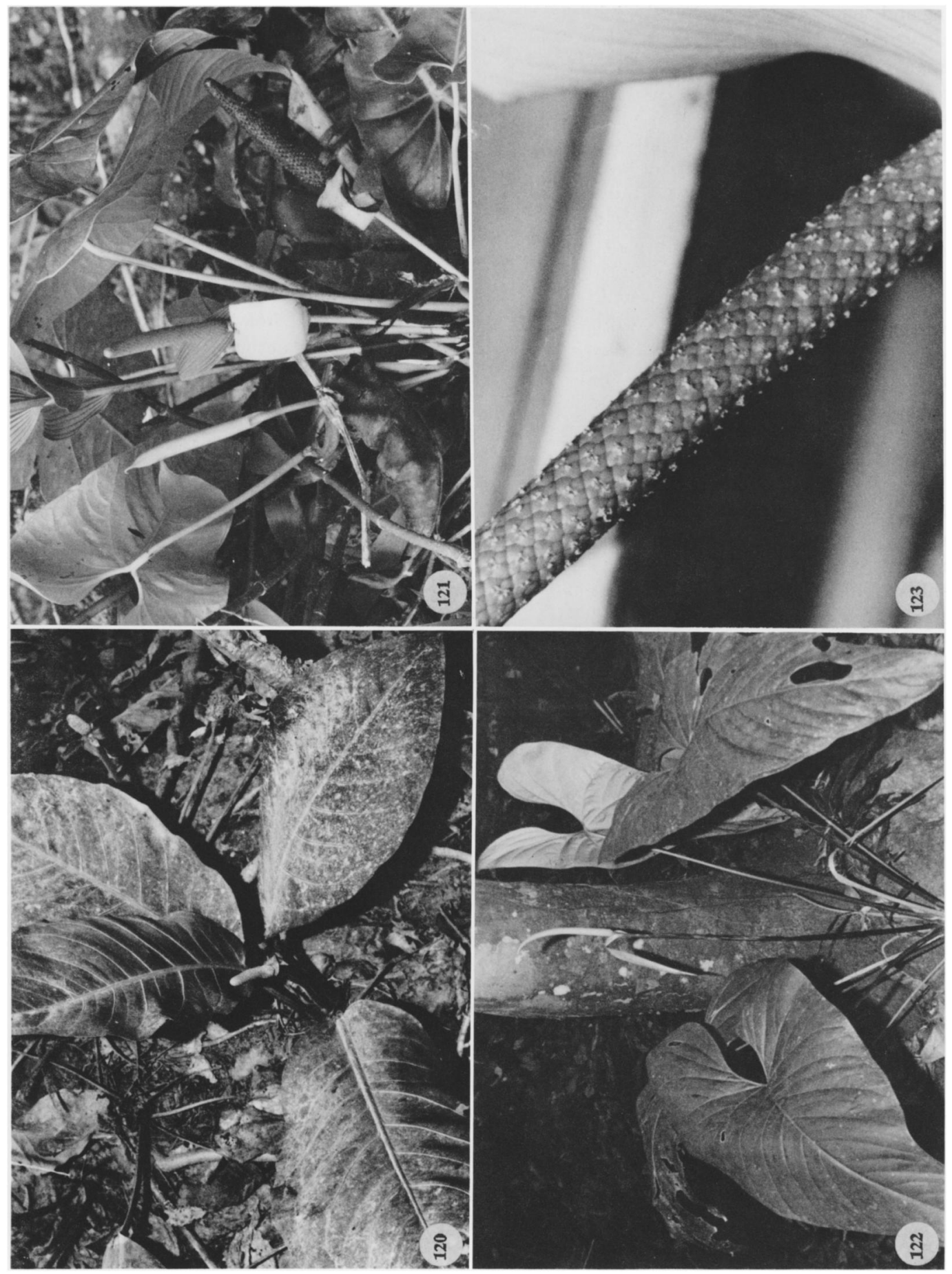


margins convex; posterior lobes $9-16 \mathrm{~cm}$ long; sinus spathulate, rounded at apex; both surfaces matte; midrib convexly raised at base above, narrowing and acute at apex, raised below; primary lateral veins 3-6 per side, departing midrib at $45^{\circ}$ angle, raised above and below; lesser veins sunken above, raised below; basal veins ca. 8 pairs, 3-4 coalesced $2.5-4 \mathrm{~cm}$; posterior ribs naked, turned up along the outer margin; collective vein arising from one of the lowermost basal veins, extending to apex, 3-7 $\mathrm{mm}$ from margin. INFLORESCENCE spreading, shorter than leaves; peduncle (7) $15-43 \mathrm{~cm}$ long, shorter than petioles; spathe oblong-elliptic, pale green to white, $7-11.5 \mathrm{~cm}$ long, $2.3-2.7 \mathrm{~cm}$ wide, longacuminate at apex, obtuse at base; spadix cream to pale yellow-green, turning dark lavender to violet-purple, weakly tapered at apex, 4.5-7.6 $\mathrm{cm}$ long, 8-11 $\mathrm{mm}$ diam. at base, 5-7 $\mathrm{mm}$ diam. at apex; the flowers 4-lobed, ca. $3 \mathrm{~mm}$ long, ca. $4 \mathrm{~mm}$ wide, the sides jaggedly sigmoid; 5-10 flowers visible in the principal spiral, 8-9 flowers visible in the alternate spiral; tepals glossy, lateral tepals ca. $1.8 \mathrm{~mm}$ wide, the inner margin upturned; pistils raised, white to pale green; stigma brushlike, 0.4-1 $\mathrm{mm}$ long, glistening papillae exserted 4-5 days before first stamens emerge, turning brown; stamens emerging slowly from base, exserted on short white filaments, held over and obscuring pistil; anthers white, $0.3-0.5 \mathrm{~mm}$ long, $0.3-0.9 \mathrm{~mm}$ wide; thecae ellipsoid, not divaricate; pollen white. INFRUCTESCENCE with spadix to $15 \mathrm{~cm}$ long; berries red-violet, ovate, acute at apex; seeds not seen. Fig. 121.

Anthurium obtusilobum ranges from Costa Rica to Colombia (Chocó) at elevations of 600 to 1,550 $\mathrm{m}$ in premontane wet, tropical wet, premontane rain, and lower montane wet forest.

The species is in section Calomystrium and is closest to $A$. hoffmannii, sharing with that species thick, persistent, reddish-brown, entire cataphylls and a similar inflorescence. It is readily separated from other members of the section by having the collective vein arising from one of the lowermost basal veins and continuing to the apex close to the margin.

Costa RicA. Near San Miguel, Wendland 777 (GOET). AlAJUELA: NW of Cariblanco, Luteyn 3222 (DUKE); 3341 (DUKE, MO); W of Fortuna, NW of Volcán Arenal, Taylor \& Taylor 11585 (MO); between Naranjo \& Aguas Zarcas, Croat 46953 (MO); between Naranjo \& Quesada, N of Zapote, Croat 46920 (MO); vicinity San Ramón, Almeda \& Nakai 3849 (CAS); Primack \& Luteyn 374 (DUKE); Utley \& Utley 4582
(DUKE, MO); vicinity of Vara Blanca, Luteyn 3906 (DUKE); San Luis de Zarcero, Smith 1259 (NY); vicinity Zarcero, Smith 4991 (MO). CARTAGO: E of Cachí, Croat 47081 (MO); Muñeco Standley \& Torres 51712 (US); near Selva above Río Taus, Taylor \& Taylor 11436 (NY); near Tapantí, Lent 27 (DAV, NY); SE of Tapantí, Lent 840 (NY, US, WIS); road from Tapantí to Taus, Utley \& Utley 5593 (DUKE); NE of Turrialba, Croat 43356, 43358 (MO). HEREDIA: N of Vara Blanca, Vicinity Río La Paz Grande, Croat 36024 (MO). LiMÓN: Toro Amarillo, Tessene 1422 (WIS). PUNTARENAS: Las Cruces Botanical Garden, Croat 32966 (MO). SAN JosÉ: Laguna la Chonta, Standley 42358 (US); La Palma, Luteyn 2999 (DUKE).

Anthurium ochranthum C. Koch, Ind. Sem. Hort. Berol. App. 6. 1853. TYPE: Costa Rica, Wendland s.n. (P, hololectotype; $\mathrm{B}, \mathrm{BP}, \mathrm{LE}$, $\mathrm{W}$, isolectotypes; designated Croat \& Baker, 1979).

Anthurium lapathifolium Schott, Oesterr. Bot. Wochenbl. 7: 309. 1857. Type: Panama, Fendler 429 (K).

Anthurium triangulum Engl., Bot. Jahrb. Syst. 25: 383. 1898. TYPE: Costa Rica. Limón: Talamanca, in forest near Shirores, $100 \mathrm{~m}$ elev., Pittier \& Tonduz 9225 (B).

Anthurium tsakianum Engl., Bot. Jahrb. Syst. 25: 423. 1898. TYPE: Costa Rica, Talamanca, in forest near Tsakí, 200 m elev., Tonduz 9510 (B, holotype; $\mathrm{CR}$, isotype).

Anthurium baileyi Standl., Publ. Field Mus. Nat. Hist., Bot. Ser. 22: 66. 1940. TYPE: Panama. Canal Zone: Barro Colorado Island, Bailey \& Bailey $196(\mathrm{~F}$, holotype).

Terrestrial, rarely more than $1.5 \mathrm{~m}$ tall; stem to $45 \mathrm{~cm}$ long, 2-4 cm diam.; cataphylls $11.5-$ $13 \mathrm{~cm}$ long, drying brown, weathering to coarse linear fibers. LEAVES erect-spreading; petioles terete or obscurely sulcate, 30-70(90) cm long, 5-8 mm diam., blades ovate-triangular, moderately thin, $39-75 \mathrm{~cm}$ long, $18-48 \mathrm{~cm}$ wide, acuminate at apex, deeply lobed at base; the anterior lobe 23-52 cm long; posterior lobes 11$22 \mathrm{~cm}$ from sinus to outermost point; sinus narrowly triangular; the upper surface matte to semiglossy, the lower surface matte; the midrib raised above and below; primary lateral veins $4-6$, raised in valleys above, raised below; collective vein arising from the uppermost basal vein. INFLORESCENCE erect, usually shorter than or sometimes longer than leaves; peduncles $24-63 \mathrm{~cm}$ long; spathe, green or pale green sometimes tinged with red-violet, lanceolate, 10-15(32) cm long, 3-5 $\mathrm{cm}$ wide; spadix green turning bright yellow, 7-22 cm long, 5-8 $\mathrm{mm}$ diam. at base, $4-6 \mathrm{~mm}$ diam. at apex; flowers 4-lobed, ca. $2.6 \mathrm{~mm}$ long 
(dry), ca. $2.3 \mathrm{~mm}$ wide (dry), the sides jaggedly sigmoid; ca. 6 flowers visible in the principal spiral, ca. 9 flowers visible in the alternate spiral; tepals glossy, lateral tepals $1.7-2 \mathrm{~mm}$ wide, the inner margin convex; pistil weakly emergent, green; stigma brushlike; stamens emerging scattered throughout length of spadix, usually the lateral stamens first, the alternates quickly following; anthers held over pistil; thecae yelloworange; pollen orange. INFRUCTESCENCE with spadix 11-24 cm long; berries violet-purple at apex, white at base, obovoid, 7-9 mm long. Figs. 122 and 123.

Anthurium ochranthum is known from Costa Rica to Panama from sea level to $1,350 \mathrm{~m}$, most commonly in tropical wet forest but also in wetter parts of tropical moist forest and in premontane wet and premontane rain forest.

The species is placed in section Belolonchium and is recognized by its terrestrial habit, bright yellow, long-tapered spadix, violet-purple and white berries, and the leaf blades that have the anterior lobe sometimes concave along the margins. It is most closely related to A. pluricostatum. See the discussion following that species for differences.

Costa Rica. Alajuela: NNE of Bijagua, Croat 36285 , 36471 (MO); between Naranjo \& Aguas Zarcas, Croat 46951 (MO); near Río Segundo, Croat 36857 (MO). CARTAGO: SE of Platanillo, Croat 36809, 36733 (MO). GUANACASTE: Volcán Miravalles, Burger \& Gentry 9100 (MO). LIMÓN: between Siguerres \& Río Pacuare, Burger \& Liesner $6880(\mathrm{MO}, \mathrm{NY})$

Anthurium oerstedianum Schott, Oesterr. Bot. Z. 8: 180. 1858. TYPE: Costa Rica, near Naranjo, Oersted s.n. (W, destroyed?; Photo of Schott Aroid Drawing \#228, NYBG Neg. \#N.S. 3817).

Anthurium cuspidifolium Schott, Oesterr. Bot. Z. 8: 180. 1858. TYPE: Costa Rica, Oersted s.n. (W, destroyed?; Photo of Type at W, Field Mus. \#29812 (MO); Photo of Schott Aroid Drawing \#314, NYBG Neg. \#N.S. 3816).

Terrestrial; stems short, to $2 \mathrm{~cm}$ diam.; roots numerous, short, tan; cataphylls $7-12 \mathrm{~cm}$ long, moderately thin, apiculate at apex, drying brown, persisting intact, ultimately deciduous. LEAVES usually \pm erect; petioles \pm quadrangular, (12)30$65 \mathrm{~cm}$ long, ca. $0.6 \mathrm{~cm}$ wide; the geniculum $1.5-$ $2 \mathrm{~cm}$ long, remote from base of blade $10-20 \mathrm{~cm}$; blades ovate to narrowly ovate or lanceolateelliptic, moderately thin, 20-66 cm long, 8.5-30 $\mathrm{cm}$ wiae, cauaate-acumınate at apex, obtuse to truncate, sometimes rounded to subcordate at base, abruptly decurrent on petiole; both surfaces semiglossy; midrib convexly raised above, raised and obscurely ribbed below; primary lateral veins 11-20 per side, raised in valleys above, raised below; lesser veins sunken above, obscure below; collective vein arising from one of the lowermost primary lateral veins, $2-8 \mathrm{~mm}$ from the margin, sunken above, raised below. INFLORESCENCE erect, longer than leaves; peduncle (30) $70-130 \mathrm{~cm}$ long; spathe ovate-lanceolate, pale green, $8-13 \mathrm{~cm}$ long, $2.5-4.8 \mathrm{~cm}$ wide, acuminate at apex, rounded at base; spadix pale green, 5-12 cm long, ca. $9 \mathrm{~mm}$ diam. at base, ca. $6 \mathrm{~mm}$ diam. at apex; flowers sub-rhombic to 4-lobed, 2.2-2.5 $\mathrm{mm}$ long, $2.2-2.7 \mathrm{~mm}$ wide, the sides parallel to spirals usually straight, those perpendicular to spirals sigmoid; 8-9 flowers visible in the principal spiral, 12-18 flowers visible in the alternate spiral; tepals matte, minutely and densely papillate, lateral tepals $1.4-1.8 \mathrm{~mm}$ long, the inner margin straight; pistils weakly emergent, green; stigma brushlike and weakly exserted, glistening for 3 or 4 days before stamens emerge; stamens emerging in a scattered manner on fleshy, greenish, translucent filaments, lateral stamens emerged throughout before alternates appear, held at sides of pistil; anthers creamy white, $0.7-1 \mathrm{~mm}$ long, $1-1.2 \mathrm{~mm}$ wide; thecae ellipsoid, mounded with abundant, creamy white pollen. INFRUCTESCENCE not seen. Fig. 128.

Anthurium oerstedianum is endemic to Costa Rica at elevations of 900 to $1,300 \mathrm{~m}$, principally from the Pacific slope in the southwest in premontane wet, tropical wet, and premontane rain forest.

Anthurium oerstedianum is distinguished by its strictly terrestrial habit as an understory forest herb and by its geniculum which is located 10$20 \mathrm{~cm}$ below the base of the blade. Other distinguishing features are its 4-sided petiole and its greenish spadix. The species is a member of section Pachyneurium despite its somewhat atypical elongate petioles, its remote geniculum, and lack of a densely rosulate habit.

Anthurium cuspidifolium, which is synonymous with $A$. oerstedianum, was reported by MacBride (1936) from Peru. However, the specimens cited by him [MacBride 5622 (F); Schunke $572(\mathrm{~F})]$ are referable to A. flavescens Poepp.

COSTA RICA. SAN JOSÉ: between San Isidro del General and Dominical, Croat 35267 (MO); about one mile 


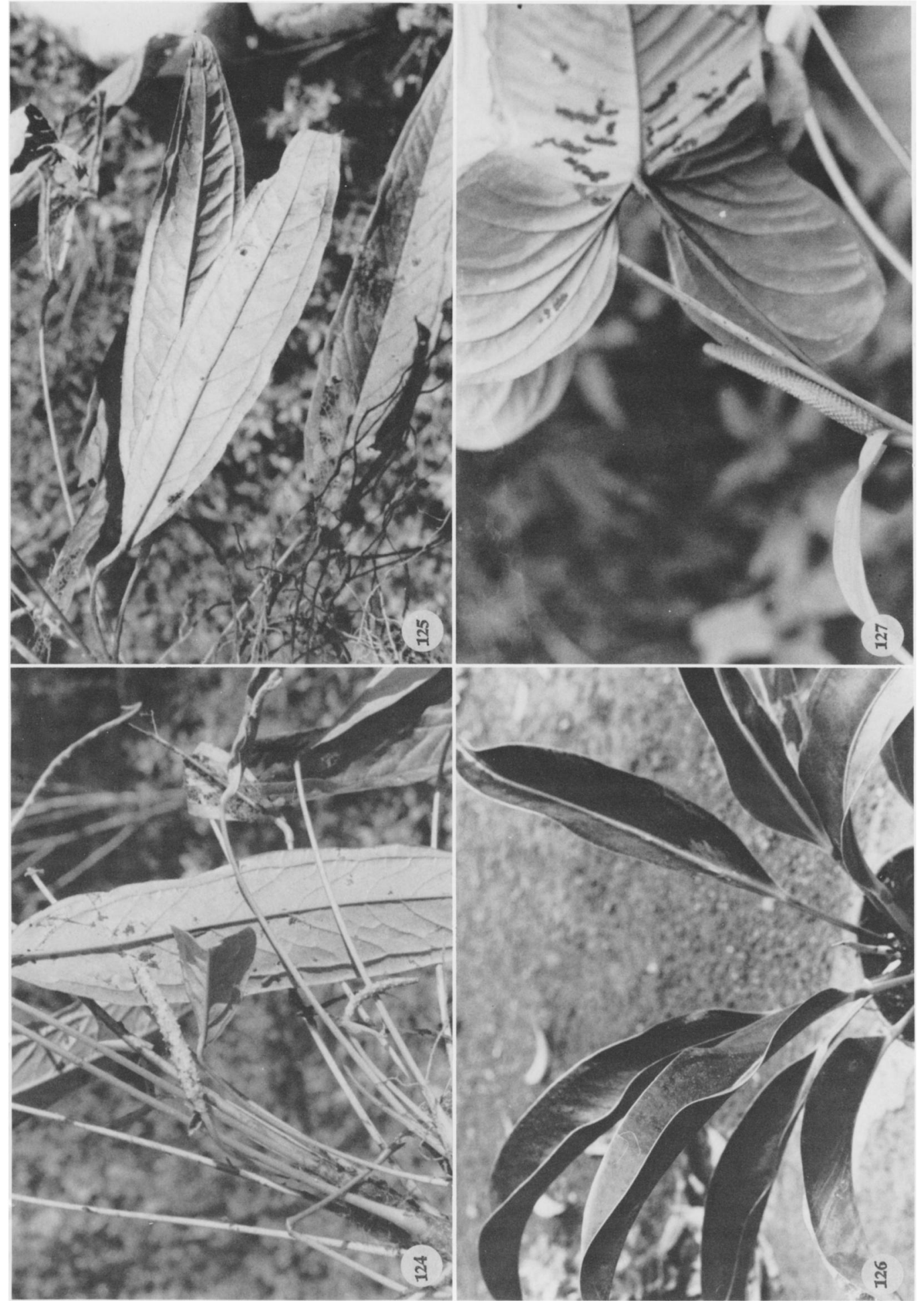

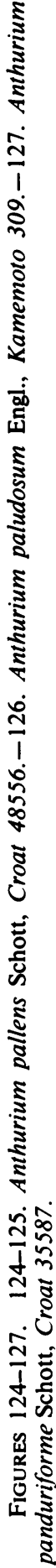



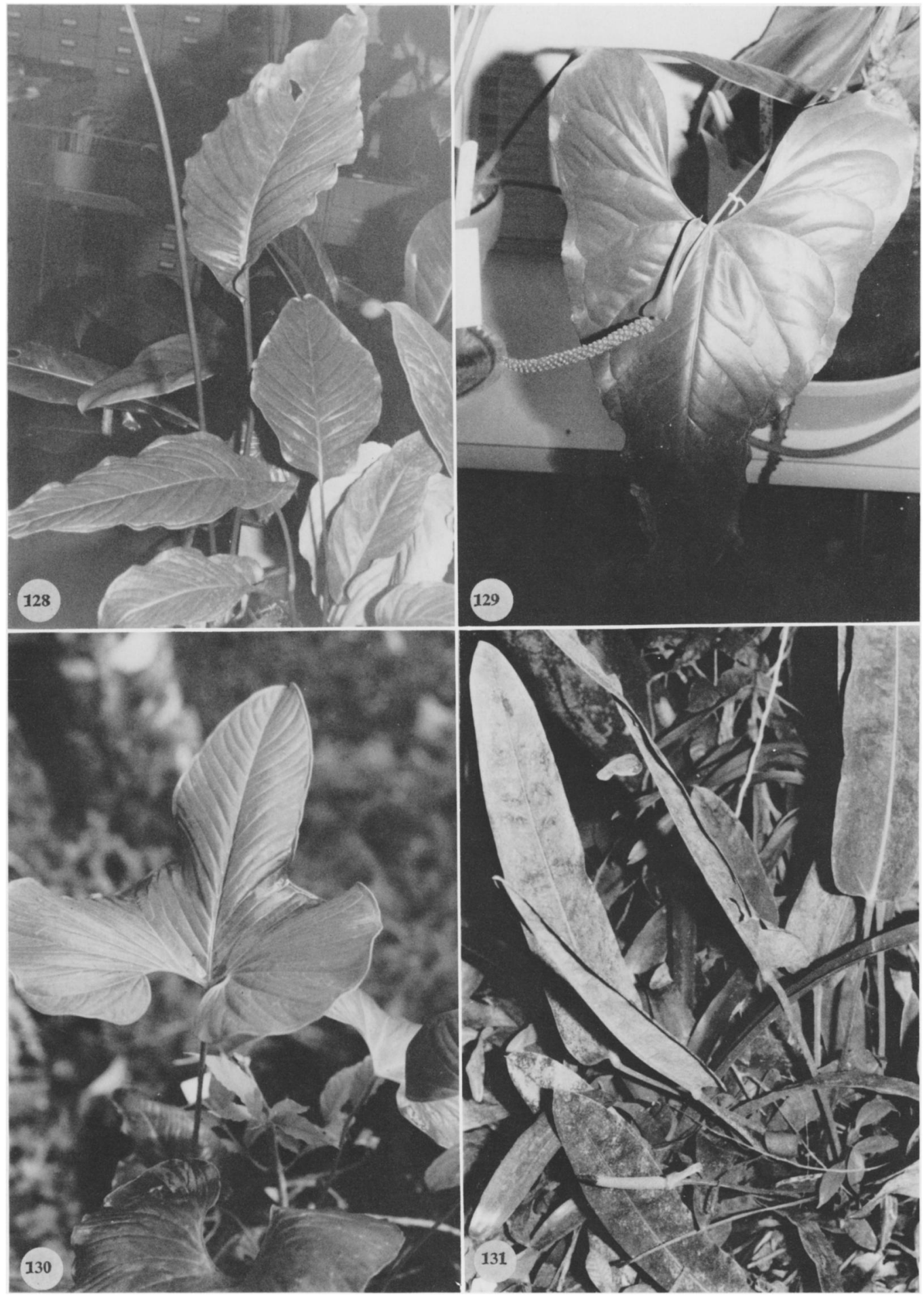

FIGURES 128-131. 128. Anthurium oerstedianum Schott, Croat 35293.-129. Anthurium ovandense Matuda, Croat 46164.-130. Anthurium panduriforme Schott, Las Cruces Bot. Gard. 74-513.-131. Anthurium parvispathum Hemsl. (Cultivated at Birdsey's). 
beyond divide between San Isidro del General and Dominical, Croat 35293 (MO).

Anthurium ovandense Matuda, Anales Inst. Biol. Univ. Nac. México 30: 113-115, Fig. 7. 1960. TYPE: Mexico. Chiapas: Municipio Escuintla, Cerro Ovando (north of town of Escuintla) 1,400 m elev., Matuda 32769 (MEXU, holotype). Note: Type description lists Matuda 32768 as the type but the only specimen found at MEXU is numbered 32769.

Anthurium ocotepecense Matuda, Anales Inst. Biol. Univ. Nac. México 27: 345, Fig. 4. 1957. TYPE: Mexico. Oaxaca: Cerro de Larion, Santo Tomás, Ocotepec, MacDougall 321 (MEXU, holotype (?) not seen).

Epipetric or terrestrial to $1 \mathrm{~m}$ tall; stems $10-$ $30 \mathrm{~cm}$ long, 2-3 cm diam.; leaf scars $2-2.7 \mathrm{~cm}$ wide; roots numerous, 5-6 mm diam., scurfy, brown; cataphylls green, $8-11 \mathrm{~cm}$ long, narrowly rounded at apex (acumen with subapical apiculum), drying tan, weathering at base into coarse fibers, remaining intact at apex. LEAVES erectspreading; petioles terete, 29-75 cm long, 5-8 $\mathrm{mm}$ diam., weakly glaucous; geniculum $1.8-2$ $\mathrm{cm}$ long, sometimes narrowly sulcate; blades narrowly-triangular, chartaceous, narrowly acuminate at apex, lobed at base, $18-53 \mathrm{~cm}$ long, 12$26 \mathrm{~cm}$ wide, broadest at base, the margins undulate to subcrispate; anterior lobe $14-38 \mathrm{~cm}$ long; posterior lobes $5.5-18 \mathrm{~cm}$ long; the sinus usually hippocrepiform, sometimes somewhat broader than deep; both surfaces matte to semiglossy with numerous linear raphide cells obscurely visible when fresh, clearly visible when dry; midrib weakly and convexly raised above and below, sunken at apex above; basal veins 45 pairs, the fourth and fifth coalesced $4-5.5 \mathrm{~cm}$, raised above and below; primary lateral veins 510 per side, sunken above, raised below; interprimary veins sunken above, flat below; collective vein arising from the uppermost basal vein, 8-27 $\mathrm{mm}$ from margin. INFLORESCENCE erect to pendent; peduncle $32-72 \mathrm{~cm}$ long, 4-5 $\mathrm{mm}$ diam., terete; spathe green, subcoriaceous, lanceolate, $5-7.5 \mathrm{~cm}$ long, $1.5-2.4 \mathrm{~cm}$ wide, cuspidate-acuminate at apex, truncate to weakly clasping at base; stipe to $2.5 \mathrm{~cm}$ long in front, to $2.2 \mathrm{~cm}$ long in back; spadix green, $5-11 \mathrm{~cm}$ long, 6-9 mm diam.; flowers rhombic, 3-4 $\mathrm{mm}$ long, 2.5-3.5 mm wide, the sides straight to weakly sigmoid; 4-7 flowers visible in the principal spiral, 2-4 flowers visible in the alternate spiral; tepals glossy with abundant sticky droplets; pistils weakly raised; stigma linear, $0.5 \mathrm{~mm}$ long; stamens emerging rapidly from base, held in tight cluster over pistil; filaments white, translucent, retracting; anthers pale yellow; thecae ovoid, slightly divaricate; pollen pale yellow. INFRUCTESCENCE pendent; berries red, subglobose, usually developing only in lower one quarter of spadix. Fig. 129.

Anthurium ovandense is endemic to Mexico in southern Oaxaca and Chiapas in moist forest at elevations of 800 to $1,600 \mathrm{~m}$.

The species is a member of section Belolonchium and is characterized by its usually epipetric habit, its thin narrowly ovate leaf blades with conspicuous posterior lobes, naked, gradually curved posterior rib, and an anterior lobe that is concave and generally undulate along the margins.

The species is similar to $A$. umbrosum from northern Oaxaca in generally much wetter areas and also to $A$. lezamae mostly from central Chiapas but both of these species are characterized by having their anterior lobe distinctly convex.

Matuda 37655, a sterile collection made at the type locality of $A$. andresloviense Matuda, was identified as that species by Matuda, but it is probably best placed with $A$. ovandense. It differs from typical $A$. ovandense in that the blade dries relatively more glossy on the upper surface and in having a distinct constriction at the base of the anterior lobe.

Although the type of $A$. ocotepecense was not seen, the illustration of the type appears to indicate that it is a synonym of $A$. ovandense. The type locality was not determined. Although I investigated part of the Municipio of Ocotepec and found it extremely arid, perhaps there may be other parts of the region that are more mesic. I was unable to locate a "Cerro de Larion" at Santo Tomás where the type was collected. The region where the type of $A$. ocotepecense was collected is substantially to the north of other collections.

Mexico. Chiapas: Escuintla, Monte Ovando, $\mathrm{Ma}$ tuda 32729 (MEXU). OAXACA: Cerro Concordia, Morton \& Makrinius 2727 (F, US); vicinity La Galera, Croat 46164 (MO); Pluma Hidalgo, MacDougall 715 (MEXU).

Anthurium pallens Schott, Oesterr. Bot. Z. 8: 180. 1858. TYPE: Costa Rica, near Desengaño, 2,600 $\mathrm{m}$, Wendland 840 (GOET).

Epiphyte, scandent; internodes 5-9 mm long; 
cataphylls $4.5-5 \mathrm{~cm}$ long, drying reddish-brown, weathering into linear fibers and persisting. LEAVES erect-spreading; petioles subterete, 7$25 \mathrm{~cm}$ long, $2.5-6.5 \mathrm{~cm}$ diam., narrowly sulcate; blades lanceolate-linear to narrowly oblong-elliptic, $18-34.5 \mathrm{~cm}$ long, $2.5-6.5 \mathrm{~cm}$ wide, longacuminate at apex, acute to obtuse or rounded at base; midrib raised above and below; primary lateral veins 5-9 per side, sunken above, raised below; lesser veins inconspicuous; collective vein arising from near the base. INFLORESCENCE \pm erect, shorter than leaves; peduncle 10-16 cm long; spathe green, lanceolate, 2.5-3.2 $\mathrm{cm}$ long, $0.8-1 \mathrm{~cm}$ wide; spadix green turning yellow (sometimes orange), 3-4.5 cm long, 3-6 mm diam. (dry) at base, weakly tapered at apex; the flowers rhombic, ca. $3.1 \mathrm{~mm}$ long, $3 \mathrm{~mm}$ wide (dry); ca. 3 flowers visible in the principal spiral, ca. 5 flowers visible in the alternate spiral. INFRUCTESCENCE with spadix to $6 \mathrm{~cm}$ long; berries green to yellow-green (?), \pm globose. Figs. 124 and 125.

Anthurium pallens is known from Costa Rica and Panama at 1,000 to $2,000 \mathrm{~m}$ elevation in premontane rain forest and lower montane rain forest life zones.

Anthurium pallens is easily confused with $A$. microspadix with which it shares similar habitats. It differs from $A$. microspadix by having blades acute to rounded at the base and clustered at the ends of relatively short branches with short internodes. It also has longer petioles and blades that dry characteristically gray-green and weakly glossy on the lower surface. Anthurium microspadix has long internodes with the leaves more widely and regularly spaced and blades that are rounded to subcordate at the base and generally matte on the lower surface upon drying. While both species may be epiphytic, A. microspadix generally is rooted in the soil and is an erect or semierect, vine-like plant, reclining or using trees for support. Anthurium pallens is usually a shortstemmed epiphyte that is frequently pendent.

Although mature berries have not been seen, they are no doubt yellowish-green and subglobose like those of $A$. microspadix. The species is a member of section Xialophyllium.

Costa Rica. Alajuela: La Peña, Smith 2121 (UC). HEREDIA: vicinity of Cerro Chompipe, Wilbur \& Luteyn 18584 (DUKE); Río Las Vueltas, Burger \& Liesner 6375 (MO); Lellinger \& White 988 (MO); Lent 2638 (NY); Wilbur \& Luteyn 4414 (DUKE); Taylor 17687 (NY); San Rafael, Almeda et al. 2156 (DUKE, MO); Wilbur et al. 15982 (DUKE); pass between Vol- cán Irazú and Volcán Barba, Davidse \& Pohl 1702A (MO).

Anthurium paludosum Engl., Bot. Jahrb. Syst. 25: 401. 1898. TYPE: Colombia. Valle: near Buenaventura, Lehmann 3811 (B, holotype).

Epiphyte; stems to $30 \mathrm{~cm}$ long; roots numerous, grayish-green, smooth, descending; cataphylls coriaceous, $5-6 \mathrm{~cm}$ long, persisting \pm intact, drying brown, ultimately deciduous. LEAVES spreading-pendent; petioles 3-14 cm long, 3-5 mm diam., D-shaped to subterete, broadly and obtusely sulcate; geniculum 1-1.5 cm long; blades narrowly elliptic to oblanceolate, subcoriaceous, $10-38 \mathrm{~cm}$ long, $3-13.5 \mathrm{~cm}$ wide, short-acuminate at apex, acute to attenuate (rarely obtuse to subrounded) at base; both surfaces semiglossy, sparsely punctate; midrib convexly raised above and below, sunken at apex above; primary lateral veins $12-14$ per side, departing midrib at $40^{\circ}$ angle, sometimes weakly sunken, usually \pm obscure on upper surface, prominulous on lower surface; collective vein arising from the base and extending \pm straight to apex, 3-12 mm from margin, flat and nearly obscure on upper surface, prominulous on lower surface. INFLORESCENCE erect-spreading, shorter than leaves; peduncle $7.5-15.5 \mathrm{~cm}$ long, 3-5 mm diam., terete, tinged red-violet; spathe moderately thin, whitish to green or purplish, withering soon after anthesis, oblong-lanceolate, 5.5-7 cm long, 4-14 $\mathrm{mm}$ wide, acuminate at apex, rounded at base, inserted at ca. $60^{\circ}$ angle on peduncle; spadix green, tinged orange, becoming violet-purple, 8-14.5 cm long, 6-7 mm diam. at middle, scarcely tapered at apex; flowers rhombic, $2.8-3.2 \mathrm{~mm}$ long, $2.5-2.7 \mathrm{~mm}$ wide, the sides straight or weakly sigmoid; 5-6 flowers visible in the principal spiral, 7-9 flowers visible per alternate spiral; tepals matte to semiglossy, tinged violet-purple at outer margins, lateral tepals 1.9-2 $\mathrm{mm}$ long, the inner margin broadly rounded; pistils green, weakly emergent; stigma linear; stamens emerging from base, the lateral stamens emerging with only the apex of the anther visible, retracting before alternate stamens emerge, leaving only traces of white pollen. INFRUCTESCENCE with spadix 6-25 cm long; berries orange, red-orange, or white tinged with orange, \pm globose to ovoid, $4-6 \mathrm{~mm}$ diam.; seeds 3-4, ellipsoid-oblong; $2-2.5 \mathrm{~mm}$ long, yellowish, except green on one end. Fig. 126. 
Anthurium paludosum is known from Costa Rica to Colombia at elevations from sea level to $400 \mathrm{~m}$. It ranges along the Atlantic slope only west of the Isthmus of Panama. To the east of the Isthmus of Panama it occurs on both slopes until reaching South America, where it is restricted to the Pacific slope. The species occurs in wetter parts of tropical moist forest and premontane wet and tropical wet forest life zones.

Anthurium paludosum is a member of section Porphyrochitonium and is recognized by its coriaceous, almost oblong leaf blades that are more or less the same color on both sides with a pale green midrib on the upper surface, and by its thick, persistent, nondilacerating cataphylls and reddish-orange berries. No other species in this section is known to have cataphylls that remain intact.

In the revision of the Costa Rican Anthurium (Croat \& Baker, 1979), A. eggersii Engl. was included as a synonym of this species, but examination of the type now precludes that possibility because that species has prominently dilacerating cataphylls. In other respects the two species appear to be markedly similar.

Costa Rica. No other location, Pittier 6837 (BR). LIMÓN: road between Bribrí \& Bratsi, Burger et al. 10470 (MO); between Limón \& Puerto Viejo, Baker \& Burger 175 (MO).

Anthurium panduriforme Schott, Prod. Aroid. 536. 1860. TYPE: Costa Rica. San Miguel, Wendland 776 (GOET).

Anthurium panduratum Schott, Oesterr. Bot. Z. 8: 182. 1858, non Mart. ex Schott, 1855. TYPE: Costa Rica. San Miguel, Wendland 776 (GOET, holotype).

Epiphyte or occasionally terrestrial; stems usually less than $30 \mathrm{~cm}$ long, occasionally to $1 \mathrm{~m}$ long; roots numerous, scattered along stem; cataphylls moderately thin, $15-25 \mathrm{~cm}$ long, narrowly acuminate at apex, drying $\tan (\mathrm{B} \& \mathrm{~K}$ Yellowred 9/10) usually deciduous, with a few thin fibers sometimes persisting. LEAVES moderately thin; petioles $25-73 \mathrm{~cm}$ long, 3-7 $\mathrm{mm}$ diam., terete, sometimes weakly sulcate; geniculum 1.5$2 \mathrm{~cm}$ long; blades hastate-trilobate, erect or spreading from the erect petioles, $20-65 \mathrm{~cm}$ long, $10-43 \mathrm{~cm}$ wide, gradually to abruptly acuminate at apex, prominently lobed at base; anterior lobe $21-55 \mathrm{~cm}$ long, constricted near base; posterior lobes nearly orbicular (or rarely oblong), some- times directed conspicuously upward from point of petiole attachment; sinus usually spathulate or hippocrepiform sometimes parabolic, usually rounded at apex; both surfaces semiglossy to glossy; midrib obtusely raised above, sunken toward apex, prominently raised below; primary lateral veins $15-30$ per side, departing midrib at $45^{\circ}-50^{\circ}$ angle, sunken above, raised below; lesser veins less conspicuous; basal veins 5-9 pairs, 34 coalesced $1-4.5 \mathrm{~cm}$; posterior rib naked, weakly turned up along outer margin; collective vein arising from one of the lowermost basal veins and extending to apex, 3-7 $\mathrm{mm}$ from the margin. INFLORESCENCE erect, shorter than leaves; peduncle (5)11-20(32) cm long, 4-6 mm diam., terete; spathe moderately thin, pale green, sometimes tinged reddish, oblong-lanceolate, 6.3-19 cm long, $2.7-3.5 \mathrm{~cm}$ wide, abruptly acuminate at apex, rounded at base, inserted at $60^{\circ}$ angle on peduncle; spadix golden yellow (B \& $\mathrm{K}$ Yellow-red 8/10), 7-18 cm long, 7-9 mm diam. midway, tapered to $4-6 \mathrm{~mm}$ at apex; the flowers sub-4-lobed, 2.5-3 mm long, 2.9-3.3 mm wide, the sides \pm straight to jaggedly sigmoid; 6-9 flowers visible in the principal spiral, 6-10 flowers visible in the alternate spiral; tepals yellow, glossy, lateral tepals $1-1.5 \mathrm{~mm}$ wide, the inner margin convex; pistils weakly emergent, pale green, translucent; stigma linear, ca. $0.3 \mathrm{~mm}$ long, brushlike and glistening as anthers emerge; stamens emerging in scattered manner slowly from base to apex, exserted to ca. $1.3 \mathrm{~mm}$ on white or translucent, flat filaments, the exserted portion of the filaments ca. $0.3 \mathrm{~mm}$ long, ca. $0.5 \mathrm{~mm}$ wide; anthers yellow, 0.5-0.6 mm long, 0.7-0.9 $\mathrm{mm}$ wide; thecae divaricate; pollen golden yellow. INFRUCTESCENCE arching-pendent; the spadix to $23 \mathrm{~cm}$ long; berries pale green, ovoid, 5-7 mm long; seeds 2 , greenish-white, $2.6-3 \mathrm{~mm}$ long, $2.3-2.5 \mathrm{~mm}$ wide, $0.8-1 \mathrm{~mm}$ thick. Figs. 127 and 130.

The species is known from Costa Rica to Colombia and probably Ecuador at 400 to $1,560 \mathrm{~m}$ elevation in tropical wet, premontane rain, and lower montane rain forest. In Costa Rica, the species ranges from Bijagua in the north to $\mathrm{Ta}$ pantí in the south on the Atlantic slope. In Panama the species occurs on both slopes.

Anthurium panduriforme is distinguished by its almost orbicular posterior lobes (sometimes more elongate in Panama, particularly collections made at Cerro Tute, near Santa Fe, Vera- 
guas), its characteristically yellow-green, shiny lower blade surface, and its golden yellow spadix with yellow pollen. The species is apparently not related to any other Central American species. It is probably best placed in section Polyneurium and is no doubt related to other South American species such as A. argyrostachyum Sodiro of Ecuador that have numerous closely parallel primary lateral veins.

Costa Rica. San Miguel, Wendland 776 (GOET). ALAJUELA: NNE of Bijagua, Croat 36286 (MO); N of Coliblanco, Utley \& Utley 4687 (DUKE, MO); between Naranjo \& Aguas Zarcas, Croat 46974 (MO); N of San Ramón, Luteyn 3372 (DUKE); N of La Balsa de San Ramón, Utley \& Utley 4583 (DUKE); valley of Río Sarapiquí, between Vara Blanca \& Cariblanco, Moore 6614 (BH). HEREDIA: vicinity Bajo La Hondura, Croat 44515 (MO); N of Vara Blanca, Croat 35587 (MO). LIMÓN: vicinity Guapiles, Standley 37255 (US).

Anthurium parvispathum Hemsl., Biol. Cent. Amer., Bot. 3: 432. 1885. TYPE: Guatemala. Baja Verapaz: Santa Rosa, Salvin \& Godman 408 (K, holotype).

Anthurium hypoleucum Standl., J. Wash. Acad. Sci. 17: 246. 1927. Anthurium brevipetiolatum Engl. ex K. Krause, Notizbl. Bot. Gart. Berlin-Dahlem 11: 610. 1932. TYPE: Guatemala. Baja Verapaz: Santa Rosa, 1,600 m, Tuerckheim II.2214 (US932125 , holotype; B, isotype).

Epipetric; stem short; roots thick, tan, sometimes directed upward; cataphylls ca. $7 \mathrm{~cm}$ long, drying brown, persistent, weathering to coarse linear fibers. LEAVES spreading; petioles 16-50 cm long, 6-9 mm diam., broadly and sharply sulcate, weakly glaucous; geniculum $1.3-1.5 \mathrm{~cm}$ long; blades oblong to lanceolate, subcoriaceous, acute at apex, truncate at base, $27-64 \mathrm{~cm}$ long, $6.5-12 \mathrm{~cm}$ wide; both surfaces matte and glaucous, the lower surface only slightly paler; midrib convexly raised above, diminished and sunken at apex, more acutely raised below; basal veins one pair, sunken above, raised below; primary lateral veins $6-10$ per side, departing midrib at $40^{\circ}$ angle, sunken above, raised below; interprimary veins weakly sunken above, flat below; lesser veins obscure; collective vein arising from the basal vein, $8-10 \mathrm{~mm}$ from margin, sunken above, raised below. INFLORESCENCE spreading, shorter to as long as leaves; peduncle 31-52 cm long, subterete, 1-2 faint ribs; spathe subcoriaceous, green (B \& K Green 5/7.5), lanceolate, $3.5-7 \mathrm{~cm}$ long, 1-2 cm wide, long-acuminate at apex, clasping at base, inserted at $180^{\circ}$ angle on peduncle; spadix sessile, green (B \& K
Yellow-green 7/7.5) becoming pale yellow, 3.5$9 \mathrm{~cm}$ long, 7-10 $\mathrm{mm}$ diam. at base, $3-5 \mathrm{~mm}$ diam. at apex; flowers 4-lobed, ca. $2.3 \mathrm{~mm}$ in both directions, the sides jaggedly sigmoid; 5-7 flowers visible in the principal spiral, 7-9 flowers visible in the alternate spiral; tepals matte, lateral tepals ca. $1 \mathrm{~mm}$ wide, the inner margin convex; pistils green, weakly emergent; stigma slit-like; stamens emerging from the base, laterals emerging first, followed quickly by alternates, the leading stamen preceding fourth stamen by 1-3 spirals. INFRUCTESCENCE pendent, mature berries not seen. Fig. 131.

Anthurium parvispathum is endemic to Guatemala and is known principally from Baja Verapaz at 1,500 to $1,800 \mathrm{~m}$ elevation, but it is also known from single collections from the Sierra de la Minas in Zacapa Department and at Mazatenango in the Dept. of Suchitepéquez on the Pacific Coast. The species occurs principally in open or exposed areas on rocks in areas of dry forest.

The species is a member of section Belolonchium and is characterized by having a sessile spadix and oblong-lanceolate leaves that are at least initially glaucous (often drying whitish) on the lower surface and by having the primary lateral veins equally as prominent as the basal vein. The species is also characterized by occurring on rocks.

Anthurium parvispathum is similar to $A$. nakamurae from southeast Chiapas but differs in having thicker leaves, which are generally much paler and weakly glaucous on the lower surface. In addition, it is always found growing on rocks rather than as an epiphyte. The spadix of $A$. parvispathum is always sessile whereas that of $A$. nakamurae is stipitate at least to some extent.

Anthurium parvispathum has also been confused with $A$. retiferum, which has a similar leaf shape and venation, but that species has much broader leaves that have conspicuously elevated tertiary veins on drying and is not glaucous or pale on the lower surface. It has also been confused with some leaf forms of $A$. subcordatum, but that species differs in having the basal veins much more conspicuous than the primary lateral veins.

Guatemala. baja verapaz: N of Salamá, near Pantín, Williams et al. 42194 (F, NY); above Pantín, Williams et al. 43354 (F); Santa Rosa, Standley 69692, 91242, 91258, 91271 (F); Tuerckheim 2214 (US). SUCHITEPÉQUEZ: Mazatenango, Tejada 306 (US). ZACAPA: Río Nuevo Sitio, between Santa Rosalía \& 1st waterfalls, Steyermark 42212 (NY). 
Anthurium pedatoradiatum Schott, Bonplandia 7: 337.1859

a. Anthurium pedatoradiatum ssp. pedatoradiatum. TYPE: Mexico, cultivated in Vienna, illustrated by Schott Aroid Drawing \#781, 782, NYBG Neg. \#3920, 3921; Photo MO.

Anthurium pedatifidum Regel \& Linden, Gartenflora 15: 66. 1866. TYPE: Plate 501 accompanying the description (see discussion).

Anthurium mirandae Matuda, Anales Inst. Biol. Univ. Nac. México 22: 375. 1951. TYPE: Mexico. Chiapas: El Ocote, NW of Ocozocoautla, elev. $575 \mathrm{~m}$, Miranda 6312 (MEXU).

Terrestrial, usually more than $1 \mathrm{~m}$ tall; stem $1.7-3 \mathrm{~cm}$ diam.; leaf scars $2 \mathrm{~cm}$ wide; roots moderately thick, directed downward; cataphylls subcoriaceous, $3.5-4 \mathrm{~cm}$ long, rounded at apex, drying medium brown (B \& K Yellow 5/5), persisting intact at apex, splitting at base. LEAVES erect; petioles $35-87 \mathrm{~cm}$ long, 5-6 $\mathrm{mm}$ diam., terete; geniculum 1-1.2 cm long; blades broadly ovate, $22-33 \mathrm{~cm}$ long, $38-60 \mathrm{~cm}$ wide, broadest at middle or just below, to 13-pedatisect, the lobes confluent 4-7 cm from base, the base broadly lobed, the apices of the lobes narrowly acuminate, the margin of the lobes entire, the median lobe $18-33 \mathrm{~cm}$ long, the outermost lobes 18-27 cm long, inequilateral and auriculate, falcate; sinus hippocrepiform, rounded at apex; upper surface semiglossy, the lower surface matte; midrib of the median lobe sharply raised above and below; basal veins 3-5 pairs, the third to fifth coalesced $1.5-1.8 \mathrm{~cm}$, the fourth to fifth coalesced to $5.5 \mathrm{~cm}$, raised above and below; primary lateral veins of the median lobe $4-8$ per side, departing the midrib at ca. $40^{\circ}$ angle, sunken above, raised below, loop-connecting; collective vein of the median lobe arising from the first or second primary lateral vein. INFLORESCENCE erect, shorter than leaves; peduncle 5-23 cm long, $3 \mathrm{~mm}$ diam.; spathe green (B \& K Yellow-green $7 / 7.5$ ), lanceolate, $7-9.2 \mathrm{~cm}$ long, $1.5 \mathrm{~cm}$ wide, inserted at $50^{\circ}$ angle on peduncle; stipe $18 \mathrm{~mm}$ long in back; spadix greenish tinged with purpleviolet to dark purple-violet (B \& K Red-purple 2/10), 4-7.5 cm long, 5-7 $\mathrm{mm}$ diam. at base, 3$4 \mathrm{~mm}$ diam. at apex; flowers rhombic to sub-4lobed, 4-4.8 $\mathrm{mm}$ long, 4.2-4.4 $\mathrm{mm}$ wide, the sides sigmoid; $6-7$ flowers visible in the principal spiral, 4-5 flowers visible in the alternate spiral; tepals matte, minutely papillate, the lateral tepals 2.4-2.5 mm wide, the inner margins broadly rounded; pistil raised but not emergent; stigmas obscure; stamens emerging in a slow progression from base, the alternate stamens following soon after emergence of both lateral stamens, exserted above the tepals and held in a tight circle over pistil; filaments whitish, translucent $0.5 \mathrm{~mm}$ long, $0.1 \mathrm{~mm}$ wide, flattened; anthers white to pale yellow, $0.5-0.6 \mathrm{~mm}$ long, $0.5-0.6 \mathrm{~mm}$ wide; thecae narrowly ovate, slightly divaricate; pollen pale yellow to cream, fading to white. INFRUCTESCENCE unknown. Figs. 134 and 141.

Anthurium pedatoradiatum consists of two subspecies, both endemic to Mexico. The species occurs in southern Veracruz, Chiapas, and Tabasco ranging in elevation from near sea level to $800 \mathrm{~m}$. Most collections have been made above $500 \mathrm{~m}$ in a region of "selva alta perennifolia" north of Ocozocoautla, a region with extensive outcrops of limestone.

The species is in section Schizoplacium and is distinguished by the pedatisect leaf blades with entire lobes, erect inflorescences that are shorter than the leaves, and the green, lanceolate spathe.

In Mexico it is possible to confuse the species with some forms of $A$. podophyllum, which may have the leaf segments entire. The latter occur only in northern Oaxaca and can be distinguished by having much thicker leaf blades.

The subspecies pedatoradiatum is distinguished by its terrestrial habit and differs from subspecies helleborifolium by having leaf segments rather uniformly united at the base with no segments divided to the base of the leaflet. In subspecies helleborifolium, one or more of the segments is free or nearly free to the base.

The plate accompanying the type description of A. pedatifidum shows a plant with one leaf blade divided in the manner characteristic of subspecies pedatoradiatum and another seemingly divided to the base, but nothing is mentioned in the description about this range of variation and it can only be assumed that the second leaf represents an error by the artist. The taxon that is here considered a synonym was supposed to differ from $A$. pedatoradiatum by a supposedly different geniculum and fewer number of blade segments.

Mexico. Chiapas: $\mathrm{N}$ of Ocozocoautla, Breedlove 38250 (DS); Croat 40654 (MO); Kennedy 1482 (DUKE, MO); MacDougall s.n. (MEXU); Miranda 6312, 25931 (MEXU); Ton 3800 (DS, LL). OAXACA: Río de la Venta, MacDougall s.n. (MEXU). TABASCO: Munc. Huimanguillo, Gilly \& Hernandez $103(\mathrm{MICH})$.

b. Anthurium pedatoradiatum ssp. helleborifolium (Schott) Croat, comb. nov. Anthurium 

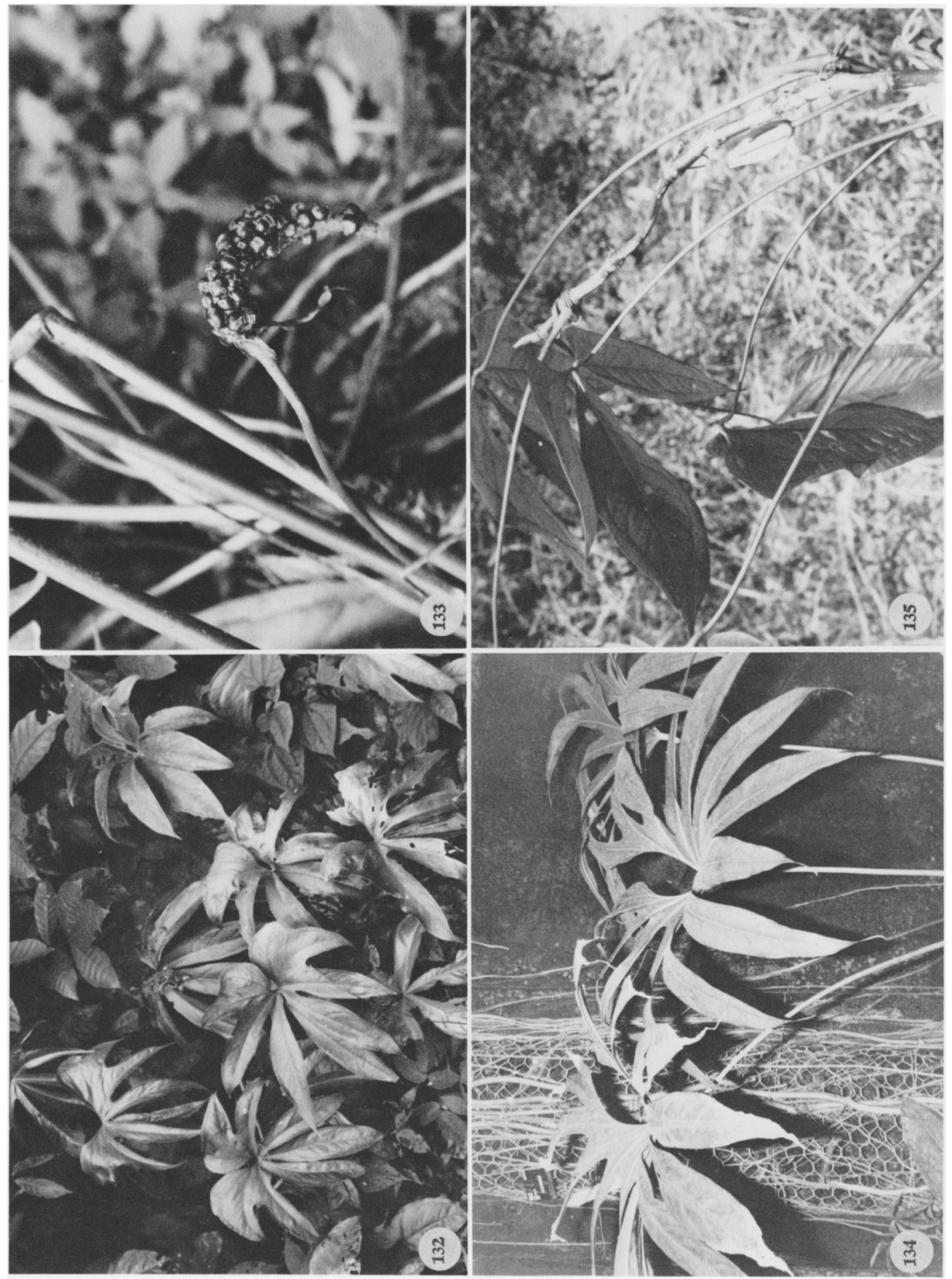

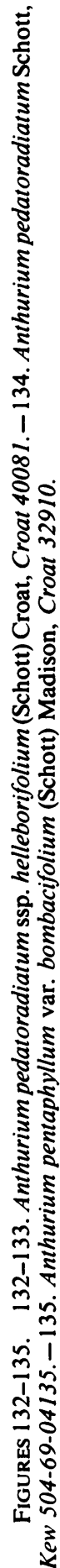




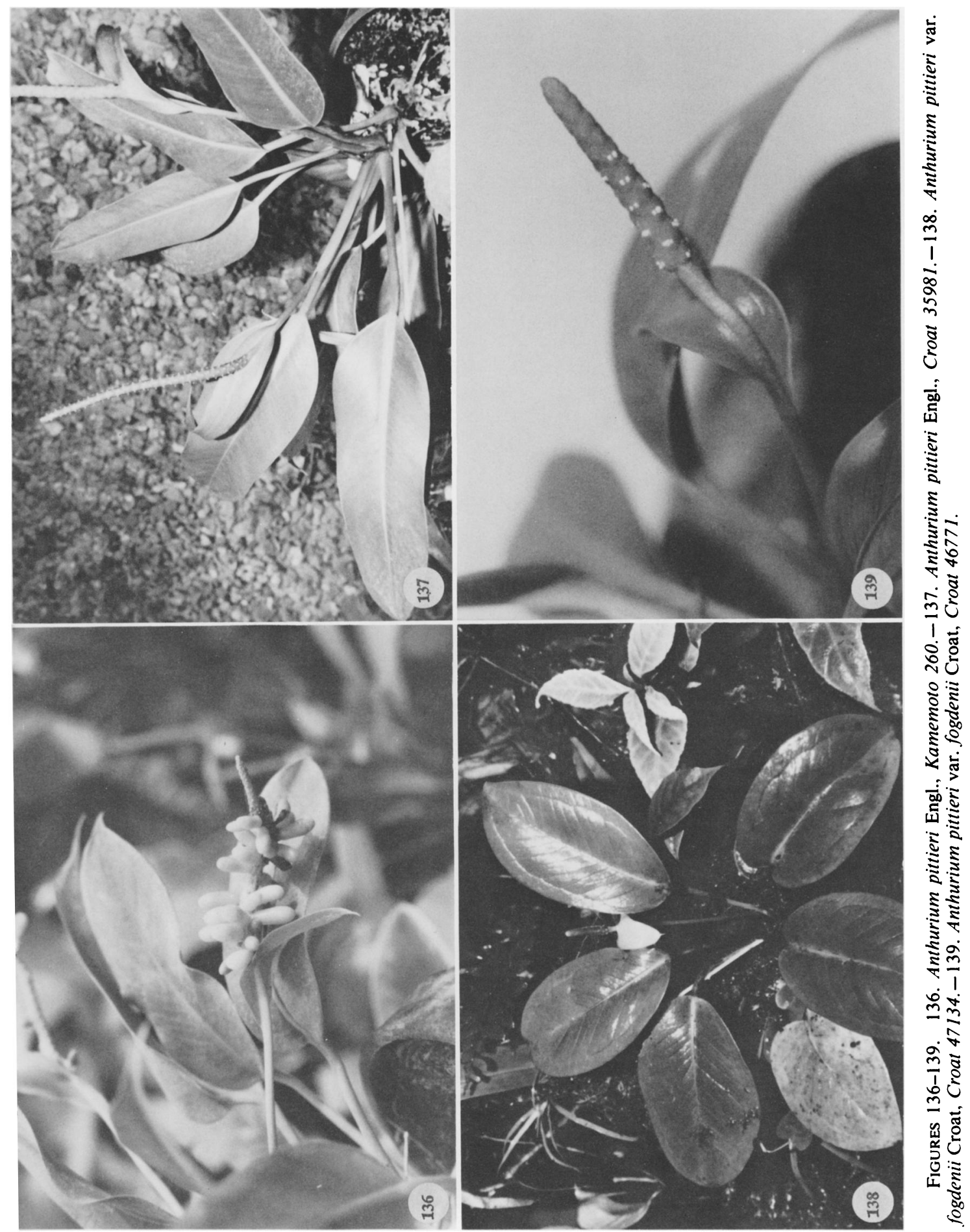



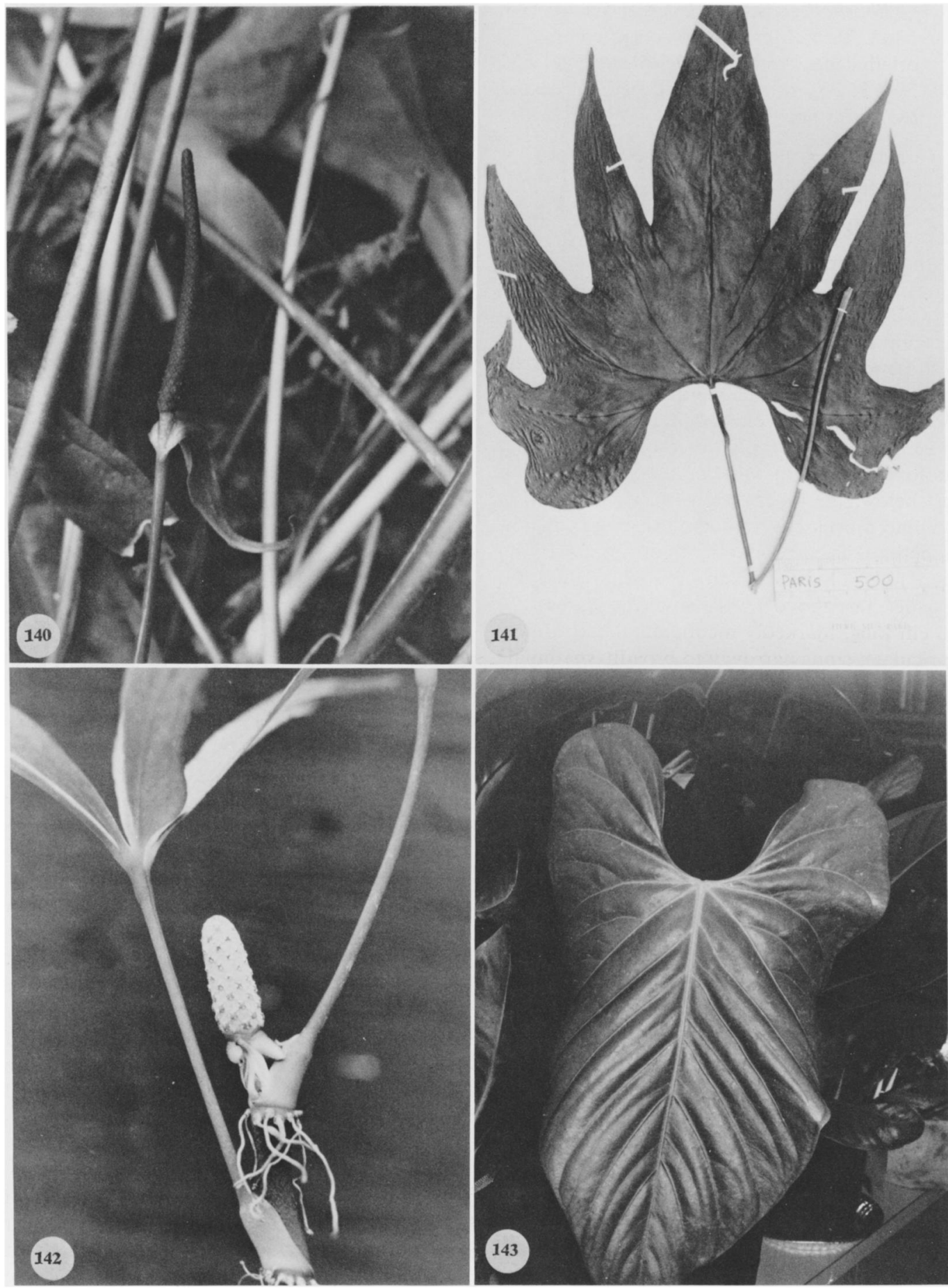

141

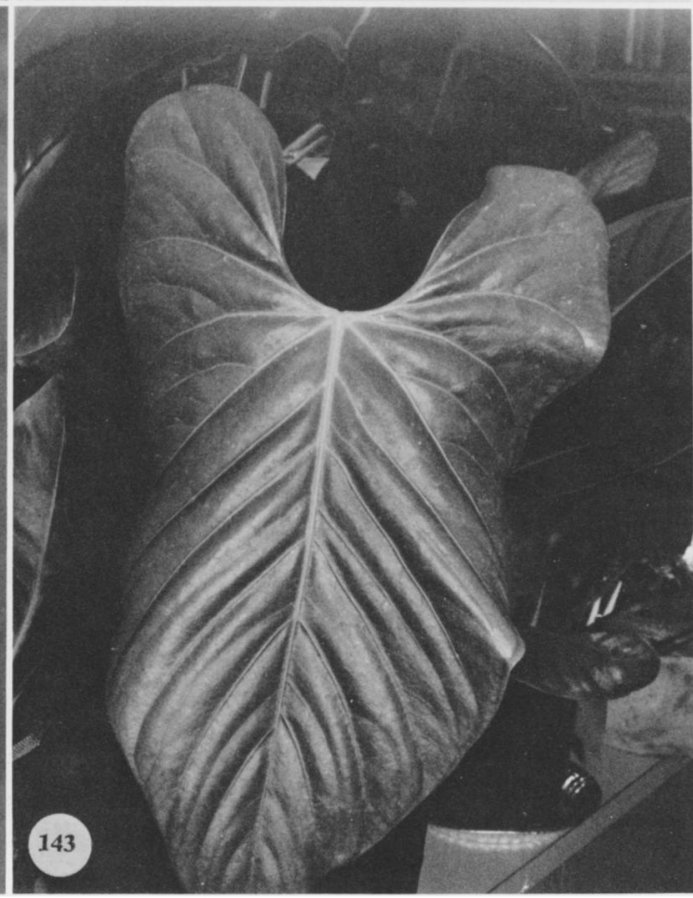

Figures 140-143. 140. Anthurium pedatoradiatum ssp. helleborifolium (Schott) Croat, Croat 40081.141. Anthurium pedatoradiatum Schott, (Hort. Paris, Croat Neg. \#500). - 142. Anthurium pentaphyllum var. bombacifolium (Schott) Madison, Folsom s.n.-143. Anthurium pluricostatum Croat \& Baker, Croat 43206. 
helliborifolium Schott, Bonplandia 10: 148. 1862. TYPE: Mexico. No specimen cited in original description ( $\mathrm{F}$, hololectotype, FM 29818; Photo of cultivated plant prepared by Schott here designated).

Terrestrial; ca. $1 \mathrm{~m}$ or less tall; stems thick, 9$25 \mathrm{~cm}$ long, 2-3 cm diam.; internodes very short; leaf scars $2 \mathrm{~cm}$ wide, usually obscured by cataphylls; roots medium thick, descending; cataphylls subcoriaceous, $2.5-5.3 \mathrm{~cm}$ long, sometimes tinged reddish, drying medium brown (B \& $\mathrm{K}$ Yellow 5/5), splitting at base, remaining intact at apex, persisting around stem. LEAVES with petioles erect, (27)48-56(63) $\mathrm{cm}$ long, 8-9 $\mathrm{mm}$ diam., terete; geniculum 1-1.7 cm long; blades, 7-11 pedatisect, moderately thick, broadly ovate in outline, deeply lobed at base, 27-33.5 cm long, $18-48 \mathrm{~cm}$ wide, broadest at middle or just below; the lobes free or nearly so to base, the outermost lobes confluent to a greater degree, sometimes falcate, acuminate at apex, the median lobe 21-27 cm long, 5.7-7.9 $\mathrm{cm}$ wide, broadest just above middle, outermost lobes 12 $18 \mathrm{~cm}$ long, markedly inequilateral and usually auriculate; sinus narrowly to broadly spathulate to hippocrepiform, acute to rounded at apex; the upper surface glossy, lower surface semiglossy; the midrib of the median lobe acutely raised above, diminished and sunken at apex, raised below; primary lateral veins $3-4$, departing midrib at $40^{\circ}-50^{\circ}$ angle, sunken and nearly obscure above, raised below; basal veins 5-6 pairs, the first and second free to base, the remaining coalesced 1.5-4 cm, raised above and below; the posterior ribs weakly curved, naked ca. one half their length; collective vein arising near the base of lobe, or from one of the primary lateral veins near middle, $1-5 \mathrm{~mm}$ from margin. INFLORESCENCE erect, shorter than leaves; peduncle (8) 20-30 cm long, 3-5 mm diam., terete; spathe moderately thin, green, lanceolate, $5.5-11 \mathrm{~cm}$ long, $0.6-1.5 \mathrm{~cm}$ wide, gradually acuminate at apex, rounded at base, inserted at ca. $45^{\circ}$ angle on peduncle; spadix green (B \& K Yellow-green 5/7.5), 4-8 cm long, 4-6 mm diam. at base, 2$3 \mathrm{~mm}$ diam. at apex; the flowers rhombic to sub4-lobed, 2.5-3 mm long, 2.8-3.2 $\mathrm{mm}$ wide, the sides smoothly sigmoid; 3-5 flowers visible in the principal spiral, 4-6 flowers visible in the alternate spiral; tepals matte, densely papillate, lateral tepals $1-1.5 \mathrm{~mm}$ wide, the inner margin straight; pistils emergent, only slightly raised, green, densely papillate; stigma linear, $4-5 \mathrm{~mm}$ long, dark slit with red-violet punctations; stamens emerging from the base, lateral stamens preceding alternates by $1-2$ spirals, exserted on long, translucent filaments, $0.5-0.8 \mathrm{~mm}$ long, 0.9$1 \mathrm{~mm}$ wide, retracting to hold stamens at edge of pistil; anthers yellow to tan, sometimes deep purple; thecae ellipsoid, somewhat divariate; pollen cream to yellow. INFRUCTESCENCE not seen. Figs. 132, 133, and 140.

Anthurium pedatoradiatum ssp. helleborifolium is endemic to southern Mexico in Chiapas and Tabasco where it is common in "selva alta perennifolia" in the vicinity of Teapa, Tabasco. All collections seen were made at elevations of less than $300 \mathrm{~m}$. Plants are terrestrial, commonly well rooted in the soil but generally on well drained soil, usually over porous limestone, commonly on rocky slopes.

Anthurium pedatoradiatum ssp. helleborifolium differs from ssp. pedatoradiatum in having 1-3 of the medial blade segments free or nearly free to the base. In addition, those collections of ssp. helleborifolium grown side by side in the greenhouses with ssp. pedatoradiatum have consistently darker green, thicker leaves. Madison (1978) treated ssp. helleborifolium as synonymous with $A$. pedatoradiatum but I feel they are separable at least at the subspecific level. All of the material observed thus far has been easily separable on the key characters although some specimens with a poor state of preservation appeared to have free segments because of torn segments. A collection of Bunting and Davies (117) collected near Teapa was deemed intermediate by Bunting (1965) who reported that it differed in "having the outline of the former but with the central lobe free to the very base." I have found that the outline of the leaf blades of the species are very generally the same and the division of the leaf blade of the Bunting and Davies specimen is well within the range of variation for the species.

Since no type specimen was cited I have selected as a lectotype a collection prepared and annotated by H. C. Schott from a cultivated plant in Vienna. Although the specimen itself has been destroyed, the photographs of the specimen are widely distributed as Field Museum plate \#29818.

Mexico. ChiApas: between Ixtapa and Teapa, Croat 47899 (MO); vicinity Pichucalco, Croat 40081 (MO). 
TABASCO: N of Cerro de Azufre, Gilly \& Hernandez 296 (MEXU, MICH); base of Cerro de Madrugal, Croat 47906 (MO); Tacotalpa, Cowan 2062 (MO); E of Teapa, Croat 40130 (MO); Conrad \& Gallegos 2869 (MO).

Anthurium pentaphyllum (Aubl.) G. Don in Sweet, Hortus Brit. ed. 3: 633. 1839.

Anthurium pentaphyllum var. bombacifolium (Schott) Madison, Selbyana 2: 278. 1978. Anthurium bombacifolium Schott, Oesterr. Bot. Z. 8: 182. 1858. TYPE: Costa Rica. Near Atenas, Hoffmann 779 (B, destroyed; Photo of Schott Aroid Drawing \#829, NYBG Neg. \#N.S. 3934).

Anthurium aemulum Schott, Bonplandia 7: 165. 1859. TYPE: Mexico. Colipa, Liebmann 15799 (C?, not seen).

Anthurium karwinskyi Schott, Oesterr. Bot. Z. 9: 101. 1859. TYPE: Mexico. Veracruz: Colipa, Karwinsky (LE).

Epiphyte; stems creeping up tree trunks; internodes 2-9 cm long; cataphylls caducous or persisting as coarse fibers. LEAVES erect-spreading; petioles $19-44 \mathrm{~cm}$ long, ca. $5 \mathrm{~mm}$ diam., terete; blades digitately compound with 5-1 1 leaflets, moderately thin, leaflets oblanceolate to narrowly elliptic, $13-30 \mathrm{~cm}$ long, $2.5-9 \mathrm{~cm}$ wide, the medial leaflet equilateral, the lateral leaflets inequilateral, abruptly to cuspidate-acuminate at apex, cuneate-attenuate at base; midrib raised above and below; primary lateral veins 6-8 per side in each leaflet, sunken above, raised below; lesser veins obscure above, raised below; collective vein arising from base, 6-14 $\mathrm{mm}$ from margins, \pm straight to apex of leaflet. INFLORESCENCE erect; peduncle 1-6 cm long; spathe pale green to purple, lanceolate to ovate, moderately thick, 6-10 cm long, $1-2.8 \mathrm{~cm}$ wide, early deciduous; spadix pale purple-violet, $2.2-10(15) \mathrm{cm}$ long, 8-20 mm diam. at base, tapering at apex. INFRUCTESCENCE erect-spreading; berries red to dark red-violet, \pm globose, $5-8 \mathrm{~mm}$ diam.; seeds ovoid to oblong, ca. $5.3 \mathrm{~mm}$ long and 4 $\mathrm{mm}$ wide. Figs. 135 and 142.

Anthurium pentaphyllum var. bombacifolium is known from Mexico to Panama at elevations from near sea level to $800 \mathrm{~m}$, occurring principally on the Atlantic slope in Mexico and Middle America but on both slopes in Costa Rica and Panama. The species occurs in premontane moist, tropical moist, premontane wet, and tropical wet forest life zones, making it one of the most ecologically variable species of Anthurium in Central America.
The species is a member of section Dactylophyllium and is most easily confused with $A$. kunthii, which has similar leaves, but $A$. kunthii differs in having a longer peduncle, three-quarters the length of the petiole, and in having a long, slender, greenish spadix and lateral leaflets which are more or less equilateral at the base.

Belize. Belize: Gracy Rock, Sibun River, Gentle 1741, 1744 (MICH); Gentle 1491 (MICH, MO). CAYO DISTRICT: near Camp 6, Gentle 2417 (MICH); Caves Branch, Base of Mountain Cow, Whitefoord 1082 (MO); Cuevas, Little John's Hunting Camp, Dwyer 11560 (MO); Macaw River, road to Millionario, Dwyer \& Liesner 12343 (MO); Mountain Cow Ridge, Gentle 3553, 3526 (MICH); Vaca, Gentle 2551 (MICH); Valentin Camp, Lundell 6197 (MICH). STANN CREEK District: Big Creek, Gentle 2651 (MICH); S of Lyman Agricultural School, Spellman 1604 (MO); Middlesex, Gentle 2950 (MICH); Stann Creek Railroad, Gentle 2109 (MICH); near Railway, Schipp S-279 (MICH, MO, UC); N of Victoria Peak, Gentry 8025 (MO). TOLEDO: W of Columbia Forest Station, Croat 24300 (MO); Dwyer 9859 (MO); Punta Gorda, Cosminsky 224 (F); Río Grande, Gentle 4679 (LL, MICH); near San Antonio, Gentle 6648 (LL); Swasey Branch, Monkey River, Gentle 3955, 4010 (MICH).

Costa Rica. Alajuela: vicinity Bijagua, Croat 36265 , 36424 (MO); Fortuna, Taylor 11615 (NY); beyond San Ramón, Luteyn 3384A (DUKE); NW of Zarcero, Croat 43585 (MO). HEREDIA: Puerto Viejo, Croat 35684 (MO). LIMÓN: between Limón \& Shirores, Croat 43297 (MO); between Siguerres and Río Pacuare, Burger \& Liesner 6948 (MEXU, MO). PUNTARENAS: Corcovado National Park, Liesner 2831 (MO); above Palmar Norte, Croat 35124 (MO); between Palmar Sur and Piedras Blancas, Croat 32910 (MO); S of Puerto Armuelles, Liesner 181 (MO).

Guatemala. alta verapaz: Finca Argentina above Papalhú, Croat 41565 (MO); road to Oxec, between Tucurú and El Estor, Croat 41685 (MO). IZABAL: vicinity of Puerto Barrios, Croat $41824 A$ (MO). PETÉN: no other location, Lundell 2990 (MICH); Cerro Ceibal, Steyermark 46104 (LL); vicinity Archeological camp, $\mathrm{N}$ shore of Lake Yaxja, Croat 24677 (MO); La Libertad, Lundell 3054 (MICH); Tikal, Bartlett 12581 $(\mathrm{MICH})$; Uaxactún, Bartlett $12466(\mathrm{MICH}) ;$ Bartlett 12269 (MICH, UC).

Honduras. ATLÁNTIDA: vicinity La Ceiba, Yuncker et al. 8597 (MO); Lancetilla, Chickering $134(\mathrm{MICH})$; Croat 42637 (MO); Yuncker 4932 (MICH). COPÁN: S of Nueva Arcadia, Harmon \& Fuentes 6421 (UMO).

Mexico: Chiapas: Municipio of Berriozábal, Breedlove 26341 (DS); $\mathrm{N}$ of El Truinfo, Almeda 3427A (DUKE); NE of Escuintla, Croat 43824 (MO); Matuda 980 (MEXU, MO); Matuda 16566 (DS, MEXU); $M a-$ tuda 17793 (DS, MEXU, UCLA); Matuda 17794 (DUKE, MEXU); Matuda 18720 (MEXU); Matuda 37678 (DS); Islamapa, Huehuetán, Matuda 18021 (MEXU); Nandolopez, Acapetagua, Matuda 17867 (MEXU); Municipio Ocosingo, Breedlove 34003, 34496 (DS); N of Ocozocoautla, Croat 40637 (MO); Municipio of Palenque, Breedlove 26543, 34997 (DS); Croat $40235,40268,40339$ (MO); vicinity of Pichucalco, Croat 40072, 40148 (MO); N of Tapachula, Croat 
43793 (MO); NW of Turquiz, Croat 47476 (MO); E of Zapata, Davidse \& Davidse 9432 (MO); OAXACA: Chiltepec, Sousa 1726 (MEXU); between Palomares and Río del Corte, MacDougall s.n. (MEXU); Temascal, Sousa 1826 (MEXU); S of Valle Nacional, Croat 39719 (MO); NE of Valle Nacional, Moore \& Bunting 8916 (BH). SAN LUIS POTOSí: vicinity Tamazunchale, Croat 39274 (MO); Rzedowski 10992 (CAS, MICH). TABASCO: along Río Chinal above Mascupan, Gilly \& Hernandez 383 (MEXU, MICH). VERACRUZ: Coatzacoalcos, Williams 8721 (MICH); vicinity of Martínez de La Torre and Misantla, Gomez-Pompa \& Riba 201 (MEXU); Moore \& Bunting 8948 (BH); Tuxpan, Sarukhán \& Martinez s.n. (MEXU). PUEBLA: La Granja, Sarukhan \& Martinez s.n. (MEXU).

Nicaragua. Zelaya: Caño Costa Riquita, Stevens 5057 (MO); S of bridge at Colonia Agrícola Yolaina, Stevens 4820, 6353 (MO); W of Río Wawa Ferry, Stevens 8646 (MO); near Río Yaoya, Neill 3801 (MO); SW of Waspán, Atwood 3716 (MO).

Anthurium pittieri Engl., Bot. Jahrb. Syst. 25: 372. 1898.

a. Anthurium pittieri. var. pittieri. TYPE: Costa Rica. Heredia: Rancho Flores, Volcán Barba, 2,505 m, Pittier \& Durand 865 (BR, hololectotype, designated Croat \& Baker, 1979).

Epiphyte, sometimes somewhat scandent; stems less than $30 \mathrm{~cm}$ long; internodes short, 1$1.5 \mathrm{~cm}$ diam., leaf scars conspicuous; roots few, descending; cataphylls subcoriaceous, (3)8$12.5(14) \mathrm{cm}$ long, apiculate at apex, drying dark tan, persisting intact, ultimately deciduous. LEAVES spreading; petioles 3-15 cm long, 4-7 mm diam., subterete, usually bluntly sulcate to weakly flattened; geniculum $2-3 \mathrm{~cm}$ long; blades narrowly lanceolate to lanceolate-elliptic to ovateelliptic or oblong, moderately thick, (8.5)10-43 cm long, $1.5-9 \mathrm{~cm}$ wide, acuminate at apex, acute to obtuse or rarely rounded at base; upper surface matte to semiglossy, lower surface semiglossy; midrib broad and convexly raised above and below, diminished and sunken at apex above; primary lateral veins $17-20$ per side, \pm obscure above, prominulous to flat and \pm obscure below, departing midrib at ca. $50^{\circ}$ angle, straight to collective vein; collective vein arising near the base, weakly sunken above and prominulous below, 3-6 $\mathrm{mm}$ from margin. INFLORESCENCE \pm erect, usually shorter than leaves; peduncle (5)11$14 \mathrm{~cm}$ long; spathe green, subcoriaceous, oblonglanceolate, (3)7-15 cm long, $1.2-2.5 \mathrm{~cm}$ wide, caudate-acuminate at apex, decurrent onto peduncle $1-1.5 \mathrm{~cm}$, acute to attenuate at base, inserted at $80^{\circ}$ angle on peduncle; spadix green (B \& K Yellow-green 5/7.5), (2.2)11-14.5 cm long, (3)7-8 mm diam. at base, (2)4-5 $\mathrm{mm}$ diam. at apex; flowers rhombic, $6-6.3 \mathrm{~mm}$ in both directions, the sides straight to weakly sigmoid; $2-3$ flowers visible in the principal spiral, 3-5 flowers visible in the alternate spiral; tepals matte, minutely papillate, larger plants with tepals usually mounded giving spadix a knobby appearance, lateral tepals ca. $5 \mathrm{~mm}$ wide, the inner margin straight; pistils usually exserted, green, matte; stigma elliptic, ca. $0.6 \mathrm{~mm}$ long, brushlike, exserted and glistening with a small droplet for 3 or 4 days ca. 2-3 weeks before anthers emerge, dry and black as stamens emerge; stamens emerging slowly in scattered manner throughout spadix, exserted on minute, green filaments that retract holding anthers at sides of pistil; anthers cream-colored ca. $0.5 \mathrm{~mm}$ long, ca. $1 \mathrm{~mm}$ wide; thecae tan, ellipsoid, not divaricate; pollen pale yellow fading to white, soon dispersing. INFRUCTESCENCE pendent; spadix $5-15 \mathrm{~cm}$ long; berries yellow to orange in Panama or reportedly white in Costa Rica, obovoid, acute at apex, $1-1.5 \mathrm{~cm}$ long, $7 \mathrm{~mm}$ wide; seeds 2 , green, flattened. Figs. 136 and 137.

The species is known from Costa Rica and Panama at 50 to $2,100 \mathrm{~m}$ elevation in tropical wet and premontane rain forest life zones. A specimen recently collected by Ernesto Ancuash (1230) under the auspices of Brent Berlin's anthropological studies in Peru (Dept. of Amazonas, Río Cenepa) is apparently also this species. It would be the first collection of the species from South America.

Anthurium pittieri is a member of section $O x y$ carpium and is distinguished by its coriaceous, epunctate leaf blades, premature emergent berries, and especially by the long-decurrent spathe.

The species is variable in leaf blade shape and in the degree of emergence of the pistils. Smaller plants tend to have the tepals flat with the pistils not noticeably emergent while larger plants have the pistils somewhat protrudent with the tepals turned somewhat upward. Specimens with unusual leaf shape include Antonio 2139 from Panama with oblong leaves, 6.5 times longer than wide and Croat 35295 from Dominical (Puntarenas, Costa Rica) with leaves almost as wide as long.

It is most easily confused with $A$. interruptum and $A$. carnosum, both of which differ in usually having more elongate internodes, in lacking a conspicuously decurrent spathe, and in having either green or reddish berries. Anthurium pittieri is reportedly related to $A$. decurrens Poepp. from 
Amazonian Peru but differs from that species in having a much shorter stipe.

Costa RicA. No other location, Bogner 917 (M). ALAJUELA AND PUNTARENAS: Monteverde, Utley \& Utley 2396 (MO); Burger \& Baker 9645 (MO); 8750 (F). alajuela: Hacienda Santa Elena, Austin Smith 1511 (NY); Santa Rosa National Park, Liesner 5215 (MO); road from Sucré towards Lake Pozo Verde, $L u$ teyn et al. 4500 (DUKE); region Zarcero, Austin Smith 114, 293 (MO). CARTAGO: no other location, Madison 6968 (MO); La Carpintera, Allen 512 (MO); Brade 2514 (BR); Rodrigues 496 (UC); El Muñeco, Standley \& Torres 51671 (US); between Moravia \& Quebrada Platanillo, Croat 36646 (MO); vicinity Orosi, Standley 39903 (US); S of Tapantí, Burger \& Liesner 6724A (MO); Lent 904 (CAS); SE of Turrialba, Holm \& Iltis 194 (NY). guanacaste: Hacienda Santa María, Dodge et al. 6366 (MO); Monteverde, Primack et al. 436 (DUKE). HEREDIA AND SAN JOSÉ: Slopes of Cerro Zurquí, Luteyn \& Wilbur 4468 (DUKE, MO). HEREDIA: Las Lajas, vicinity San Isidro, Pittier 14057 (NY); N of San Isidro, Cerro de Las Lajas, Standley \& Valerio 51634, 51564 (US); Monte Cristo, Rojas s.n. (MO); Rancho Flores, Pittier \& Durand 865 (BR); Pittier 2157 (BR); Río Las Vueltas, Gomez 2228 (MO); Vara Blanca, Skutch 3650 (MICH); 3687 (MICH, MO, NY); 3694 (MICH, NY, US); 3704 (MICH); Utley \& Utley 4978 (DUKE); slopes of Volcán Barba, Almeda 519 (DUKE); Burger \& Stolze 6068 (NY). PUNTARENAS: Monteverde, Utley 150 (DUKE); S of San Vito de Java, Raven 21927 (CAS). SAN JOSÉ: slopes of Cerro Zurquí, Utley 404 (DUKE); La Palma, Luteyn 3303 (DUKE); between San Isidro del General \& Dominical, Croat 35925 (MO); San Josecito, Primack \& Luteyn 352 (DUKE); Tablazo, Pittier 7990 (BR); Utley \& Utley 3876 (DUKE).

b. Anthurium pittieri var. fogdenii Croat, var. nov. TYPE: Costa Rica. Guanacaste: along the road between Santa Elena and Monteverde, ca. $2 \mathrm{mi}$ from Santa Elena-Monteverde junction, elev. ca. $1,500 \mathrm{~m}, 10^{\circ} 20^{\prime} \mathrm{N}$, $84^{\circ} 47^{\prime} \mathrm{W}$, Croat 47134 (MO-2769759, holotype; CR, K, SEL, US, isotypes; Live at $\mathrm{MO})$.

Planta epiphytica, parva; caudex 3-6 cm longus, gracilis; lamina ovata-elliptica aut ovata, $4.5-8 \mathrm{~cm}$ longa, $2.3-3.5 \mathrm{~cm}$ lata, subcoriacea, epunctata, nervis supra leviter impressis subtus obscuris; inflorescentia effusaerecta, foliis breviora; pedunculus $3.5-4.5 \mathrm{~cm}$ longus; spatha viridis, $2-3 \mathrm{~cm}$ longa, $6-9 \mathrm{~mm}$ lata; spadix viridis, $1.5-2.2 \mathrm{~cm}$ longus; antherae albae; baccae ignotae.

Epiphyte; stems 3-6 cm long, $0.7-1 \mathrm{~cm}$ diam.; roots green, moderately thin; cataphylls subcoriaceous, 1.5-2 cm long, rounded at apex, drying dark tan, splitting at base, persisting around stem. LEAVES spreading; petioles $1.3-7.3 \mathrm{~cm}$ long, 2$3 \mathrm{~mm}$ diam., terete, shallowly and sharply sulcate at base of blade; geniculum not apparent; blades ovate to ovate-elliptic, moderately thick, short- acuminate at apex, round to obtuse at base, 4.5$14 \mathrm{~cm}$ long, $2.3-4.7 \mathrm{~cm}$ wide, broadest at middle; upper surface glossy, lower surface semiglossy; midrib raised at base above, sunken in apical one quarter of blade, convexly raised below; primary lateral veins $5-10$ per side, departing midrib at $50^{\circ}$ angle, straight to collective vein, etched above, obscure below; lesser veins scarcely visible; collective vein arising near the base or from a primary lateral vein in the basal one half of blade, 2-4 $\mathrm{mm}$ from the margin. INFLORESCENCE erect-spreading, shorter than or as long as leaves; peduncle 3.5-11.5 cm long; spathe green (B \& K Yellow-green 7/10), subcoriaceous, elliptic to obovate, $2-5.2 \mathrm{~cm}$ long, $6-15 \mathrm{~mm}$ wide, decurrent on petiole $0.8-1.5 \mathrm{~cm}$, obtuse at base, short acuminate at apex, the apex tightly inrolled, the apiculum hooked toward spadix; stipe ca. $1 \mathrm{~cm}$ long; spadix green, $1.5-4 \mathrm{~cm}$ long, 3-4 $\mathrm{mm}$ diam. at base, $2-3 \mathrm{~mm}$ diam. at apex; flowers 4-lobed, ca. $2.5 \mathrm{~mm}$ long, $2.3 \mathrm{~mm}$ wide, the sides weakly to jaggedly sigmoid; ca. 3 flowers visible in the principal spiral, ca. 4 flowers visible in the alternate spiral; tepals matte, densely papillate, lateral tepals ca. $0.8 \mathrm{~mm}$ wide, the inner margin straight to convex; pistils weakly emergent; stigma minute, elliptic; stamens emerging from the base, lateral stamens emerging to midway before alternate stamens emerge at base; anthers white, ca. $0.4 \mathrm{~mm}$ in both directions, held over pistil in tight cluster; thecae ellipsoid, scarcely divaricate; pollen white. INFRUCTESCENCE not seen. Figs. 138 and 139.

Anthurium pittieri var. fogdenii is endemic to the vicinity of Monteverde (a biological preserve operated by the Tropical Science Center in San José), where it occurs with the typical variety of $A$. pittieri. The variety fogdenii is known only from the type locality in tropical wet or premontane wet forest life zones and is named in honor of Mike and Patricia Fogden who were kind enough to permit me to collect on their property near the Monteverde Preserve.

Anthurium pittieri var. fogdenii is distinguished by its small size, green spadix with white anthers, slender stems, and ovate to ovate-elliptic, subcoriaceous, epunctate leaf blades with etched veins on the upper surface and with obscure veins beneath.

The taxon differs from var. pittieri by having the veins prominently etched on the upper surface. This character disappears on drying so that in the dried condition it is not possible to sep- 
arate the two taxa readily. Although $A$. pittieri is placed in section Oxycarpium, var. fogdenii looks much like members of section Porphyrochitoni$u m$, differing only in the absence of glandular punctations on the leaves.

Costa Rica. guanacaste: between Santa Elena and Monteverde, Croat 47134 (CR, K, MO, SEL, US); vicinity Monte Verde Preserve, Croat 46771 (MO); PUNTARENAS AND ALAJUELA: in and around Monteverde Preserve, Burger \& Baker 9722 (F).

Anthurium pluricostatum Croat \& Baker, Brenesia 16 (Supl. 1): 68. 1979. TYPE: Costa Rica. Limón: ca. 1 mile NE of Bribrí, ca. 40 miles SW of Limón (on coastal road); steep ravine above Río Catarata, elev. 50-100 m, Croat 43243 (MO 2584480-81, holotype; $\mathrm{CR}, \mathrm{F}, \mathrm{K}$, US, isotypes; Live at MO).

Terrestrial; stem $2.5-3 \mathrm{~cm}$ diam., to $23 \mathrm{~cm}$ long; leaf scars conspicuous, ca. $2.5 \mathrm{~cm}$ diam.; roots greenish, ca. $4 \mathrm{~mm}$ diam., moderately numerous and long, descending; cataphylls moderately thin, 6-12 cm long, acute to acuminate at apex, soon turning brown and weathering into a dense mass of persistent, coarse fibers. LEAVES with petioles erect, $26-68 \mathrm{~cm}$ long, $6-8 \mathrm{~mm}$ diam., subterete, narrowly flattened to weakly and obscurely sulcate adaxially, almost smooth to characteristically several-ribbed or -striate; geniculum 1.2-1.7 cm long; blades narrowly ovate, moderately thin, acuminate at apex, deeply lobed at base, $40-68 \mathrm{~cm}$ long, $20-38 \mathrm{~cm}$ wide, broadest near the point of petiole attachment, the margins broadly convex; anterior lobe $32-52 \mathrm{~cm}$ long, posterior lobes 10-19 cm long, directed downward or inward; the sinus spathulate, obtuse to rounded at apex; upper and lower surfaces semiglossy; midrib obtusely raised at base above, becoming acutely raised and then diminishing toward apex, prominently raised below; basal veins 3-6 pairs, 3 or 4 of them coalesced $3-4 \mathrm{~cm}$, prominently raised above and below; the posterior rib thick, naked, almost straight, the outer margin flat or weakly rolled upward; primary lateral veins 6-9 per side, departing midrib at $30^{\circ}-45^{\circ}$ angle, almost straight to collective vein, raised near midrib but sunken towards apex above, raised below; interprimary veins usually few, scarcely raised above, flat below; secondary veins weakly sunken above, darker than surface and flat below; collective vein arising from the uppermost basal vein, 3-5 $\mathrm{mm}$ from margin, slightly sunken above, slightly raised and darker below. INFLORESCENCE erect-spreading, equalling or much shorter than the leaves; peduncle $17-43 \mathrm{~cm}$ long, 4-5 $\mathrm{mm}$ diam., terete to obscurely angular, sometimes heavily suffused with dark purple, $0.33-0.75$ times as long as petioles; spathe subcoriaceous, pale purple-violet or green slightly suffused throughout with purplishviolet, especially on the inner surface (B \& K Red-purple 7/7.5), oblong-lanceolate, 13-18.5 $\mathrm{cm}$ long, 2-3.7 cm wide, broadest in lower quarter, gradually long-acuminate at apex, rounded to obtuse at base, stiffly spreading, sometimes twisting, inserted at $50^{\circ}-70^{\circ}$ angle on peduncle; stipe ca. $9 \mathrm{~mm}$ long in front and $3 \mathrm{~mm}$ long in back, ca. $6 \mathrm{~mm}$ diam.; spadix pale lavender or green tinged with pale lavender (B \& K Redpurple $8 / 10$ ), yellowish-green near the tip or sometimes pale reddish-purple throughout (B \& K Red-purple 3/5), 8.5-14.5 cm long, 7-9 mm diam. at base, 3-4 mm diam. at apex; flowers rhombic to weakly 4-lobed, $2.6-3.5 \mathrm{~mm}$ long, 2.4-3.6 mm wide, the sides straight to smoothly sigmoid, rarely jaggedly sigmoid; 7-9 flowers visible in the principal spiral, (8)10-15 flowers visible in alternate spiral; tepals semiglossy, papillate, with a few droplets when anthers are opening, the lateral tepals $1.3-1.8 \mathrm{~mm}$ wide, 3-5-sided, the inner margin straight or nearly so; pistils pale green becoming salmon-lavender (as tepals) with purplish dots, slightly mounded and weakly exserted above the tepals; stigma linear, 0.6-0.8 mm long, a pale, darker-edged slit, exuding droplets about 1 week before first stamens emerge, the nectar persisting even after all stamens are open; stamens emerging rapidly from the base, the lateral stamens emerging throughout before the alternate stamens begin to emerge at base, held just above the tepals in a circular cluster ca. $1.3 \mathrm{~mm}$ diam. (or sometimes only half emergent with the exposed part ephemeral); anthers white, 0.5-0.6 mm long, 0.9-1 mm wide, peeping out and opening while still small or the thecae standing on end, opening vertically and disintegrating when touched; thecae obovoid, slightly divaricate; pollen white. INFRUCTESCENCE with purplish berries, acute at apex. Figs. 143 and 152.

The species is known from Costa Rica, and in Panama in Chiriquí Province on the Burica Peninsula. It is certainly to be expected in Bocas del Toro Province as well. It occurs in a wide variety of life zones in Costa Rica, ranging from premontane wet transition forest to premontane wet and tropical wet forest at elevations from near 


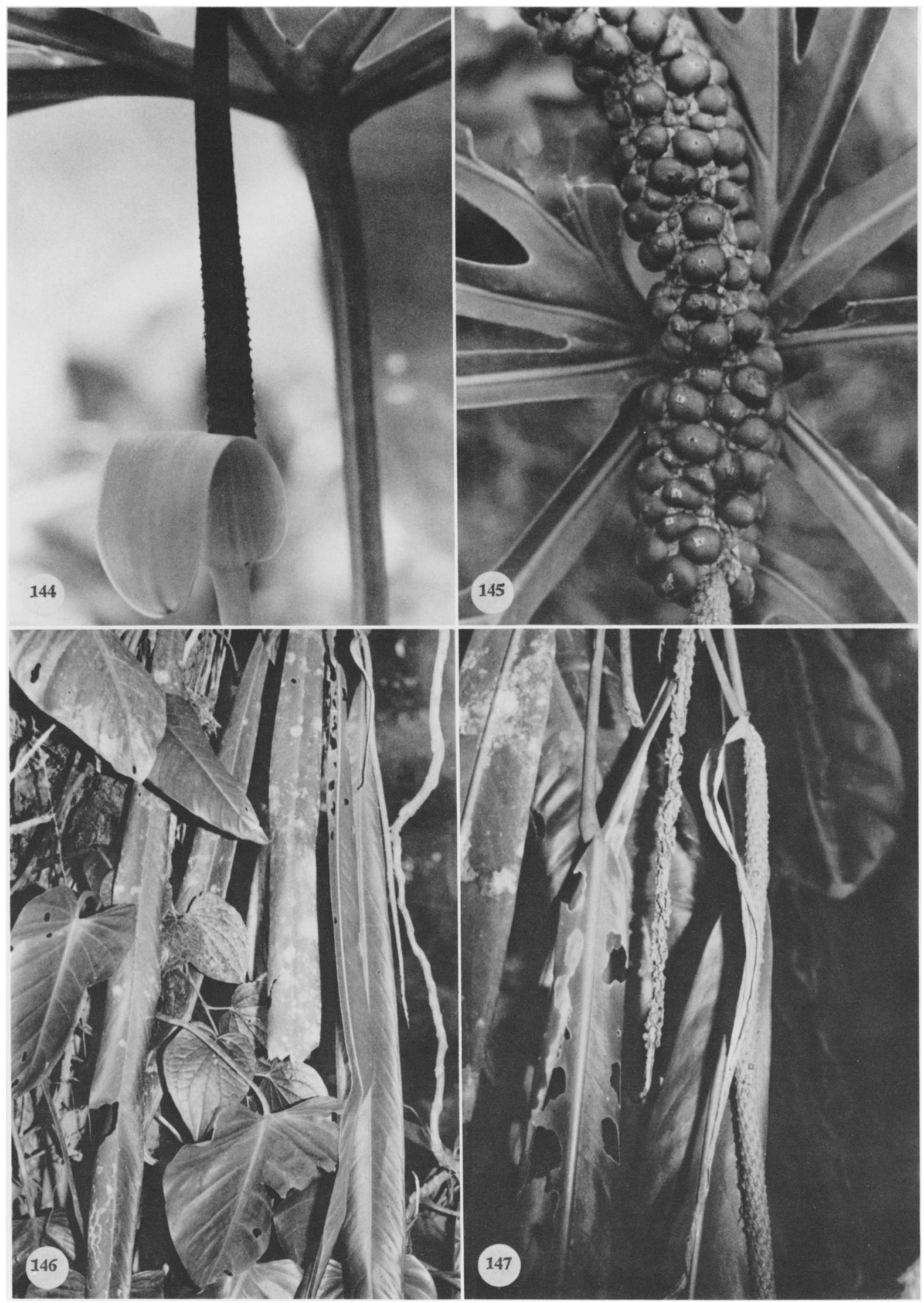

Figures 144-147. 144. Anthurium podophyllum (Cham. \& Schlecht.) Kunth, Hiwan 263. - 145. Anthurium podophyllum (Cham. \& Schlecht.) Kunth (Cultivated at Antosh's). - 146. Anthurium prolatum Croat \& Baker, Croat 47087.-147. Anthurium prolatum Croat \& Baker, Croat 46979. 

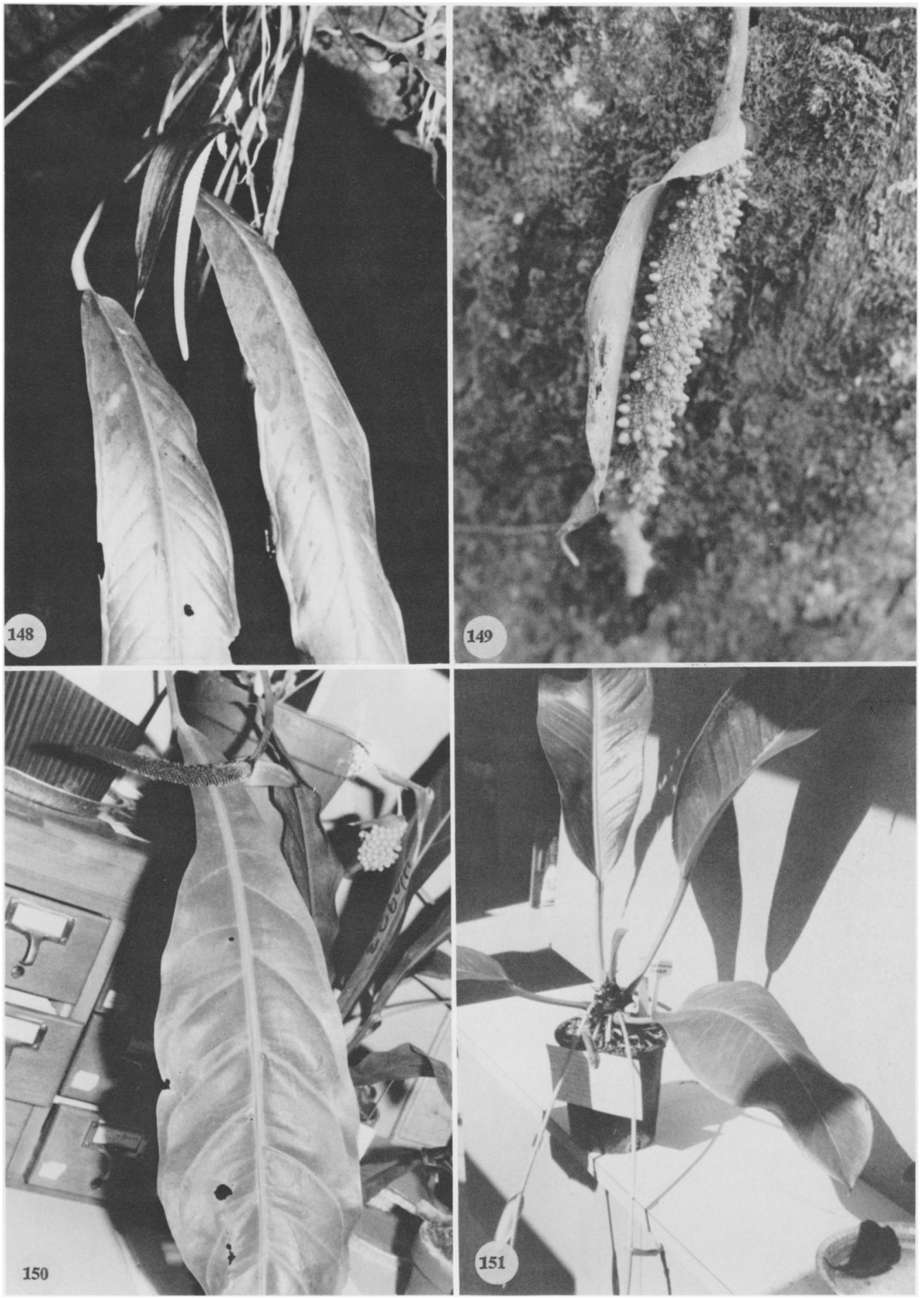

FIGURES 148-151. 148. Anthurium protensum Schott, Croat 47113. - 149. Anthurium protensum Schott, Croat 35566. - 150. Anthurium purpureospathum Croat, Croat 38094 (Type). - 151. Anthurium ramonense Engl. ex K. Krause, Croat 33984. 

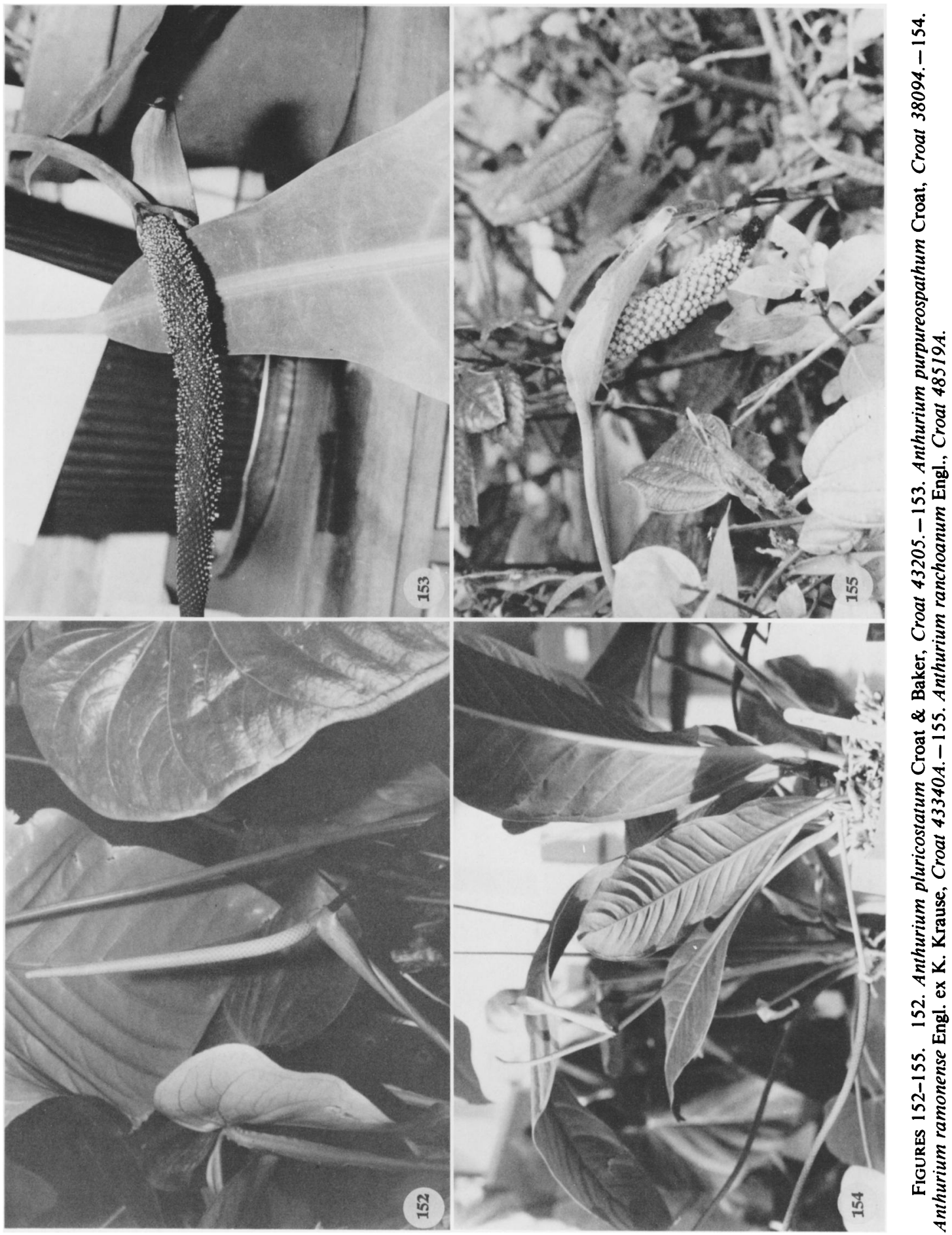
sea level to $1,000 \mathrm{~m}$ on both the Pacific and Atlantic slopes.

Anthurium pluricostatum is a member of section Belolonchium and is characterized by its terrestrial habit, subterete petiole with 7-10 low ridges, and spadix that is lavender to reddishpurple or green tinged with lavender, usually with a discolorous yellowish-green portion near the apex. The species is also unusual in having flowers with stigmatic droplets persisting while stamens emerge.

Anthurium pluricostatum is related to $A$. ochranthum. The latter species, although occurring in the same altitudinal range and life zones, has a very different inflorescence, including a bright yellow spadix (at anthesis), and stamens with pollen being extruded in slender ribbons. Both $A$. pluricostatum and $A$. ochranthum have a consistently terrestrial habit that is a diagnostic feature for species occurring at medium to low elevations (the character being of much less value in cloud forest regions).

Staminal dehiscence is somewhat variable. Usually the anthers are fully exserted although the filaments are not exposed. Sometimes (even in the same population) anthers are only about half emergent and the exposed portion of the thecae loses its form when the pollen matures.

The species displays an unusual pollination possibility since the stigmas produce copious droplets slightly before the stamens emerge, the droplets persisting until all anthers are open. Thus the species is only weakly protogynous and might best be considered homogamous. The behavior presents a clear possibility for self fertilization.

Costa Rica. alajuela: Finca Los Ensayos, NW of Zarcero, Croat 43580 (MO). CARTAGO: Pacuare, Turrialba, Ocampo 1432 (CR). LIMÓN: Hwy. between Siguirres and Limón, S of Siguirres, Croat 43334 (MO); along Río Sixaola, E of Bratsi between Limón \& Shirores, Croat 43291 (MO); near Río Sixaola, SW of Bambu, NE of Bratsi, Croat 43265 (MO); NE of Bribrí, SW of Limón, above Río Catarata, Croat 43243 (CR, F, K, MO, US); along Río Catarata between Bribrí and Caribbean coast, Croat 43205, 43206 (MO); near the Río Catarata in the hills between Bribri on the Río Sixaola and the Caribbean costal plain, Baker \& Burger $64(\mathrm{~F}) ; 106 A$ (CR, F, MO). PUNTARENAS: near Rincón de Osa, Liesner 2209 (F, MO); Quebrada del Palo, Croat 22604 (F); hills above Palmar Norte, Croat 35103 (MO); Utley \& Utley 1109 (F). SAN JOSÉ: about 1 mile beyond divide between San Isidro del General and Dominical, Croat 35269, 35324 (MO).

Anthurium podophyllum (Cham. \& Schlect.) Kunth, Enum. Pl. 3: 80. 1841. Pothos podo- phyllum Cham. \& Schlecht., Linnaea 6: 22. 1831. TYPE: Mexico. Veracruz: Hacienda de la Laguna, Schiede \& Deppe (B; not seen, illustrated by Schott Aroid Drawing \#791, W).

Pothos laciniatus M. Martens \& Galeotti, Bull. Acad. Roy. Sci. Bruxelles 10(1): 122. 1843. TyPE: Mexico. Veracruz: Zacualpan, Galeotti 6055 (BR).

Anthurium polytomum Schott, Bonplandia 7: 337. 1859. TYPE: Mexico. (Photo of Schott Aroid Drawing \#805, NYBG Neg. \#N.S. 3924; Photo MO).

Anthurium pseudopodophyllum Schott, Bonplandia 7: 338. 1859. TYPE: Cultivated in Vienna (Photo of Schott Aroid Drawing \#811, NYBG Neg. \#N.S. 3926; Photo MO).

Anthurium ghiesbreghtii Linden ex Schott, Prod. Aroid. 538. 1860. TYPE: none listed.

Anthurium membranuliferum Schott \& Ohlend. ex Engl., Monogr. Phan. 2: 196. 1879. (Known only in cultivation.)

Usually terrestrial or epipetric, often more than $1 \mathrm{~m}$ tall; stems $2.5-3.5 \mathrm{~cm}$ diam.; roots descending; cataphylls, coriaceous, $7.5-11 \mathrm{~cm}$ long, gradually acuminate at apex, drying medium brown, persisting as linear fibers. LEAVES with petioles erect-spreading, 39-69 cm long, ca. $9 \mathrm{~mm}$ diam., D-shaped; geniculum $5 \mathrm{~cm}$ long; blades subcoriaceous, broadly ovate, deeply to broadly lobed at base, (3)5-10 pedatisect, the lobes usually 5-12 pinnatifid, fused $8-10 \mathrm{~cm}$ at base, $16-47 \mathrm{~cm}$ long; the outermost lobes $7.5-27 \mathrm{~cm}$ long, auriculate; sinus hippocrepiform to nearly arcuate, rounded at apex; upper surface glossy, lower surface semiglossy; midrib of median lobe raised, rounded, diminished and flat at apex above, raised below; primary lateral veins 2-3 per side, departing midrib at $40^{\circ}$ angle, sunken above, raised below; basal veins $3-5$ pairs, second and third coalesced to $2 \mathrm{~cm}$, the third and fourth coalesced $3.2 \mathrm{~cm}$; the posterior ribs straight; collective vein arising from the first primary lateral vein, $8-9 \mathrm{~mm}$ from the margin, sunken above, raised below. INFLORESCENCE spreading-pendent, longer than leaves; penduncle $38-100 \mathrm{~cm}$ long, to $6 \mathrm{~mm}$ diam., terete, equal to or longer than petioles; spathe subcoriaceous, yellow-green (B \& K Yellow-green 7/7.5), lanceolate, 4.5-9 cm long, 1.6$2.2 \mathrm{~cm}$ wide, broadest just above base, acuminate at apex, inserted at $45^{\circ}$ angle on peduncle; stipe $9 \mathrm{~mm}$ long in front, $5 \mathrm{~mm}$ long in back, $4 \mathrm{~mm}$ diam.; spadix green, sometimes tinged with purple (B \& K Yellow-green 6/5), 4-14 cm long, 7$11 \mathrm{~mm}$ diam. at base, $3-5 \mathrm{~mm}$ diam. at apex; flowers rhombic, 3.2-4.6 mm long, 2.5-4.6 mm wide, the sides straight to weakly sigmoid; $6-8$ 
flowers visible in the principal spiral, 7-9 flowers visible in the alternate spiral; tepals matte, minutely papillate, lateral tepals $1.2-2.2 \mathrm{~mm}$ wide, the inner margins broadly rounded, turned up against pistils; pistil emergent, green; stigma linear, $0.6 \mathrm{~mm}$ long, dry, brown, crusty before stamens emerge; stamens emerging in a moderately slow sequence from base, exserted above pistil, then withdrawing, the leading stamens in any phase only a few spirals ahead of succeeding stamens; filament green; anthers white, held over pistil in tight cluster, ca. $0.6 \mathrm{~mm}$ in both directions; thecae narrowly ovoid, dark brown, slightly divaricate; pollen cream-colored. INFRUCTESCENCE pendent, spathe persisting; spadix to $4.5 \mathrm{~cm}$ diam.; berries dull orange (B \& K Yellow-red 7/5), obovoid to obovoid-ellipsoid, rounded at apex, 13-19 $\mathrm{mm}$ long, 7-15 $\mathrm{mm}$ diam.; mesocarp thick, juicy, orange with small raphide cells; seeds 1 or 2 , pale green, flattened, oblong to oblong-obovoid, 9-10 mm long, 5-6 $\mathrm{mm}$ wide, $3.3-4.3 \mathrm{~mm}$ thick (sometimes with one large almost subterete seed) with appendages at both ends, the lower appendage flattened, about as broad as the seed. Figs. 144 and 145.

Anthurium podophyllum is endemic to the Atlantic coast of Mexico in Veracruz and Oaxaca at elevations of 750 to $2,000 \mathrm{~m}$ in "selva mediana subperennifolia." The Oaxaca populations occur at higher elevations (up to ca. 2,000 m), and have leaf lobes mostly entire to sinuate, rarely lobed as in pre-adult plants of $A$. podophyllum from Veracruz. Veracruz populations usually occur below 1,000 $\mathrm{m}$ and have more finely dissected leaves with the lobes pinnatifid.

Anthurium podophyllum is in section Schizoplacium and is characterized by its subcoriaceous, pedatisect leaf blades with the lobes usually sinuate to pinnatifid, and by its long inflorescence usually equalling or exceeding the length of the leaves. The Oaxaca populations have leaves similar in shape to A. pedatoradiatum, but the latter is recognized by its much thinner leaf blades, lobes with uniform margins, and generally shorter peduncles.

The species is rare in the wild, having been collected in only a few relatively adjacent localities since the type collection was made in $\mathrm{Za}$ cualpan.

Mexico. No other location, Karwinski s.n. (F); Martens 137 (BR). OAXACA: between Teotitlán del Camino \& Santa María Chilchotla, Croat 48367 (MO). verACRUZ: Barranca de Santa María, Moore \& Bunting 8852
(BH); Jalapa, Sousa \& Ramos 4744 (MEXU); Mirador, Liebmann s.n. (P); Municipio Totutla, Ventura 3660 (ENCB); Zacualpan, Galeotti 6013 (BR); Purpus 6364 (MO, NY, UC, US); Purpus 11130 (F, MO).

Anthurium prolatum Croat \& Baker, Brenesia 16 (Supl. 1): 72. 1979. TyPE: Costa Rica. Heredia: Istaru Farm, Tirimbina, Sarapiquí; primary forest; $220 \mathrm{~m}$ elev., Sept. 1971, Roy Lent 2140 ( 2 sheets) (F-1724125, holotype).

Epiphyte; stems 2-2.5 cm diam.; cataphylls thick, 30-36 cm long, subpersistent, acuminate at apex, drying tan, weathering into fibers at the base. LEAVES pendent; petioles $30-35 \mathrm{~cm}$ long, 6-8 mm diam., terete, sulcate; geniculum 1-1.2 $\mathrm{cm}$ long; blades strap-shaped, gradually longacuminate at apex, narrowly acute at base, 108$142 \mathrm{~cm}$ long, $8-10 \mathrm{~cm}$ wide, broadest near the middle; midrib prominently raised above to very near the apex, raised below; primary lateral veins numerous, departing midrib at ca. $55^{\circ}$ angle, scarcely or not at all distinguishable from the interprimary veins on upper surface, only slightly more prominent on lower surface; interprimary veins usually numerous; collective vein arising from near the base, 3-4 $\mathrm{mm}$ from margin throughout. INFLORESCENCE pendent; peduncle to $39 \mathrm{~cm}$ long, ca. $4 \mathrm{~mm}$ diam., slightly longer than petioles; spathe medium thick, pale green, spreading, lanceolate-linear, to $29 \mathrm{~cm}$ long, ca. $1.5 \mathrm{~cm}$ wide, broadest near base, acuminate at apex, acute at base, inserted at $70^{\circ}$ angle on peduncle; spadix brown (fide label), to $60 \mathrm{~cm}$ long, 7-8 $\mathrm{mm}$ diam. at base, ca. $4 \mathrm{~mm}$ diam. at apex; the flowers (dry) rhombic, 3.4-4.5 $\mathrm{mm}$ long, $1.8-2.2 \mathrm{~mm}$ wide, the sides jaggedly sigmoid; $5-$ 6 flowers visible in the principal spiral, 7-8 flowers visible in the alternate spiral; tepals smooth, the lateral tepals $2-2.5 \mathrm{~mm}$ wide, the inner margin convex; the pistil green, ca. $1 \mathrm{~mm}$ long, ca. $0.8 \mathrm{~mm}$ wide, emerging evenly throughout; the stigma ca. $0.7 \mathrm{~mm}$ long (dry), oblong; stamens perhaps only partly exserted above the tepals (at least partly retracted on drying). INFRUCTESCENCE pendent; berries probably orange. Figs. 146 and 147.

Anthurium prolatum is known only from northern Costa Rica in Alajuela and Heredia Provinces in tropical wet forest at 200 to $600 \mathrm{~m}$ elevation.

The species is a member of the section Pachyneurium and can be distinguished by the unusual, very long and narrow leaves, cataphylls, spadix, 
and spathe. It is most easily confused with $A$. protensum, however, A. prolatum differs from that species by having its spadix more than twice as long as any observed for even the largest $A$. protensum, a spathe considerably more narrow and lacking the purple markings characteristic of $A$. protensum, and the flowers twice as long $(0.5-$ $2.5 \mathrm{~mm}$ long in $A$. protensum, $3.4-4.5 \mathrm{~mm}$ long in $A$. prolatum). In addition, the common $A$. protensum has not been collected below $1,000 \mathrm{~m}$ and is most common at $1,800 \mathrm{~m}$ elevation.

Costa RicA. Alajuela: along Hwy. 15, between Naranjo and Aguas Zarcas, NE of Villa Quesada, Croat 46979 (MO). CARTAGO: E of Cachí, Croat 47087 (MO). HEREDIA: Istaru Farm, Tirimbina, Sarapiquí, Lent 2140 (F).

Anthurium protensum Schott, Oesterr. Bot. Z. 8: 181. 1858

Anthurium protensum. ssp. protensum. TYPE: Costa Rica. Heredia: Volcán Barba, 2,5002,700 m, Oersted 1992 (type not found; Photo of Schott Aroid Drawing \#427, NYBG Neg. \#N.S. 3848).

Anthurium joseanum Engl., Pflanzenr. IV 23B: 68. 1905. TYPE: Costa Rica. Cartago: Las Vueltas, Tucurrique, $635 \mathrm{~m}$, Tonduz 12818 (B, holotype; $\mathrm{P}$, US, isotypes).

Anthurium costaricense Engl., Bot. Jahrb. Syst. 25: 398. 1898. TYPE: Costa Rica. Above Agua Caliente, $1,800 \mathrm{~m}$, Lehmann s.n. (Drawing of Engler Arac. 274 at B, P).

Epiphyte, often pendent; stems short; cataphylls $12-22 \mathrm{~cm}$ long, drying tan, weathering into coarse fibers at base and persisting. LEAVES spreading-pendent; petioles $11-35 \mathrm{~cm}$ long, 5-7 $\mathrm{mm}$ diam., \pm terete, sometimes flat or weakly sulcate adaxially; geniculum $1.5-2 \mathrm{~cm}$ long; blades strap-shaped $32-80 \mathrm{~cm}$ long, long-acuminate at apex, acute to rounded at base; upper surface matte to semiglossy, lower surface semiglossy; the midrib acutely raised above, convexly raised below; primary lateral veins numerous, sunken above, raised below; secondary veins distinct; collective vein arising from near the base, 4-5 $\mathrm{mm}$ from margin. INFLORESCENCE spreading-pendent, shorter than leaves; petioles 15-45 cm long, 6-7 mm diam.; spathe oblong-lanceolate, yellow-green to purple, usually at least tinged with purple, $10-15 \mathrm{~cm}$ long, $2.5-4 \mathrm{~cm}$ wide, usually held \pm erect; spadix pale violet-purple, 8 $12 \mathrm{~cm}$ long, 6-9 $\mathrm{mm}$ diam. at base, $2-4 \mathrm{~mm}$ diam. at apex; the flowers rhombic to 4-lobed, 2.5-2.7 $\mathrm{mm}$ long, 2-2.2 $\mathrm{mm}$ wide; 4-9 flowers visible in the principal spiral, 6-12 flowers visible in the alternate spiral; tepals matte; pistils green, emergent; stigmas with droplets 2-4 days before stamens emerge; stamens emerging from base, laterals first, preceding alternates by $2-3$ spirals, held over pistil in a tight cluster; thecae brown, elliptic; pollen pale orange. INFRUCTESCENCE with spadix $14-32 \mathrm{~cm}$ long; berries orange, \pm ovoid, weakly beaked, 11-13 mm long, 6-8 $\mathrm{mm}$ wide; seeds 2 , pale brown, subovoid, weakly flattened, ca. $6 \mathrm{~mm}$ long, $4.5 \mathrm{~mm}$ wide, $3 \mathrm{~mm}$ thick. Figs. 148 and 149.

The species is found in Costa Rica and Panama from 635 to $2,700 \mathrm{~m}$, principally in premontane rain and lower montane rain forest.

Anthurium protensum is a member of section Pachyneurium and is distinguished by its elongate, narrow leaf blades with many primary lateral veins, by its more or less terete petiole, and by its long, ovate to lanceolate spathe, pale violet-purple to lavender or greenish spadix and orange berries.

The species is closely related to $A$. prolatum, $A$. brenesii, and $A$. seibertii, all species with similar, elongate leaves. See the commentary following these species for distinguishing characteristics.

Anthurium protensum consist of two subspecies. The subspecies protensum occurs only in Costa Rica, while ssp. arcuatum Croat (ined.) occurs in Panama, ranging from Chiriquí to Veraguas at 1,300 to $1,750 \mathrm{~m}$ in premontane rain forest. The latter differs in being an erect plant with smaller leaves with fewer, more prominent sunken veins, an acute lower midrib, an arching inflorescence with shorter, usually ovate spathe, and a smaller spadix.

Costa Rica. Alajuela \& PUntarenas: Monteverde Nature Preserve, Burger et al. 10792 (F). AlAJUELA: Zapote, Smith 1268 (NY); vicinity Zarcero, Croat 43533 (MO); Austin Smith A692 (MO). CARTAGO: Carpintera, Brade 2513 (BR); vicinity La Congreja, Williams et al. 24182 (NY); NE of Pacayas, Luteyn 3250 (DUKE); SE of Platanillo, Croat 36714 (MO). GUANACASTE: La Palma, Greenman \& Greenman 5465 (MO); Monteverde, Palmer 158 (NY); between Santa Elena and Monteverde, Croat 47113 (MO). HEREDIA \& SAN JOSÉ: Cerro de Zurquí, Burger et al. 10290 (MO). HEREDIA: vicinity Bajo La Hondura, Croat 44501 (MO); N of Concepción, Primack et al. 276 (DUKE); Monte Cristo, Rojas 513 (MO); near Rio Pará Blanco, Lent 2874 (MO); N of Vera Blanca, Croat 35566 (MO); Maxon \& Harvey 8304 (US); Skutch 3652 (MO, NY); 3706 (MICH, US). PUNTARENAS: vicinity Jalaca Farm, Golfo Dulce Area, Allen 5211 (US); Monteverde, Ken- 
nedy 605 (US); Luteyn 3406 (DUKE); SE of Santa Elena, Almeda et al. 2031 (DUKE). SAN JOSÉ: between Aserri and Tarbaca, Standley 41402 (US); Bajo La Hondura, Lent 1446 (WIS); Standley 36334 (US); La Palma, Luteyn 3301 (DUKE); above Piedra, Luteyn 3291 (DUKE); vicinity Vito San Cristóbal Sur, Utley \& Utley 3059 (MO).

Anthurium purpureospathum Croat, Selbyana 5 (3-4): 328. 1981. Type: Panama. Bocas del Toro: Station Milla 7.5 on Changuinola-Almirante Railroad, less than $100 \mathrm{~m}$ above sea level, along slender ridge to WW II communications facility, ca. $2 \mathrm{~km} \mathrm{NW}$ of ruins of U.S. Army military barracks, Croat 38094 (MO-2388335, holotype; CAS, F, K, MO, PMA, SEL, US; isotypes; Live at MO).

Epiphyte or terrestrial at higher elevations; stem hidden by roots; roots dense, 3-4 $\mathrm{mm}$ diam., descending; cataphylls coriaceous, $7-14 \mathrm{~cm}$ long, acuminate at apex, reddish, drying dark tan (B \& K Yellow 5/2.5), subpersistent, remaining as reticulate fibers. LEAVES erect to spreading; petioles $12-31 \mathrm{~cm}$ long, 4-10 mm diam., \pm quadrangular, flat to broadly and sharply sulcate, usually prominently 3 -ribbed abaxially; geniculum $1-2.5 \mathrm{~cm}$ long; blades oblong-oblanceolate to oblong-elliptic, coriaceous, acuminate at apex, obtuse to acute or attenuate at base, $27-74 \mathrm{~cm}$ long, $7.5-40 \mathrm{~cm}$ wide, broadest at or above the middle; upper surface matte to semiglossy, lower surface glossy to semiglossy; midrib acutely raised above and below, diminishing at apex above; primary lateral veins (6) 11-14 per side, departing midrib at $45^{\circ}$ angle, raised in valleys above, raised below, arcuate-ascending, loop-connected in upper half; interprimary veins flat or prominulous above, prominulous below; secondary veins flat above and below; collective vein arising from one of the primary lateral veins near the middle, 4-8(13) $\mathrm{mm}$ from the margin, sunken above, raised below. INFLORESCENCE erect; peduncles 3-38 cm long, $0.8-2 \mathrm{~cm}$ diam., purplish or green, subterete, equal to or as long as petioles; spathe medium thick, purple to purplish with green mottling especially near base at center or green mottled with purple (B \& K Red-purple 2/ 5) at anthesis, oblong to narrowly ovate, 4.5$17.5 \mathrm{~cm}$ long, $1.5-4 \mathrm{~cm}$ wide, broadest just above the base, cuspidate at apex, obtuse to rounded at base; spadix violet-purple (B \& K Purple 2/ 7.5), (4)5-22 cm long, $1-2.5 \mathrm{~cm}$ diam. at base, 4-8 mm diam. at apex; flowers rhombic to weakly 4-lobed, 2-2.3 $\mathrm{mm}$ long, $2.5-3 \mathrm{~mm}$ wide, the sides gradually to jaggedly sigmoid; ca. 14 flowers visible in the principal spiral, ca. 7 flowers visible in the alternate spiral; tepals matte, with small scattered droplets, lateral tepals $1.4-1.6 \mathrm{~mm}$ wide, the inner margin flat against pistil; pistils slightly raised, purple becoming green and finally orange; stigma linear, ca. $5 \mathrm{~mm}$ long, with droplets for 4-10 days, drying with exserted papillae 4-6 days before first stamen emerges; stamens exserted ca. $1 \mathrm{~mm}$, emerging in a slow progression from the base, the lowermost flowers with their full complement before the middle flowers have any stamens exserted, held in a tight, contiguous circle; filaments $0.2-1 \mathrm{~mm}$ long, flattened, transparent, tapered to anther, retracting to hold anther at edge of tepals; anthers ca. $0.7 \mathrm{~mm}$ in both directions; thecae ellipsoid, usually held closely parallel; pollen golden yellow (B \& K Yellow 8/2.5), drying white. INFRUCTESCENCE erect to spreading; the spathe drying, usually persisting; spadix 9-19 cm long, to $4 \mathrm{~cm}$ diam.; berries narrowly ovoid, acute at apex with a round, minute, mammilliform style, orange, red-orange to red (B \& K Red 6/7.5), to $10 \mathrm{~mm}$ long; the mesocarp pasty, transparent; seeds 1 or 2 , ca. $4 \mathrm{~mm}$ long and $2 \mathrm{~mm}$ wide, pale greenish-yellow. Figs. 150 and 153 .

The species is endemic to Panama and occurs principally from near sea level to $200 \mathrm{~m}$ in Bocas del Toro Province in wetter parts of tropical moist forest and premontane wet forest. It is to be expected in Limón Province in Costa Rica. A population on Cerro Colorado, in tropical wet or premontane rain forest at 1,200 to $1,500 \mathrm{~m}$ appears to differ in no way from the populations at lower elevations except that it has thicker leaves and consistently terrestrial habit. The terrestrial habit is not unusual for populations at higher elevations where a greater accumulation of debris exists and where the steeper slopes provide better drainage. The species should be expected at medium elevations as well.

Anthurium purpureospathum is distinguished by its rosulate habit, more or less oblanceolate leaf blades, almost quadrangular petioles often 3-ribbed abaxially, generally short peduncles, usually violet-purple reflexed spathe, usually short violet-purple spadix, early emergent pistils and long, sharply pointed, orange to red-orange berries.

The species is a member of section Pachyneurium, although the leaves sometimes have a collective vein arising from below the middle. It is closely related to no other known species. 
Anthurium ramonense Engl. ex K. Krause, Notizbl. Bot. Gart. Berlin-Dahlem 11: 611. 1932. TYPE: Costa Rica. Alajuela: at San Ramón, 1,200 m elev., Tonduz 17703 (B, holotype; $\mathrm{CR}$, isotype).

Anthurium isonervium Standl. \& L. O. Wms., Ceiba 3: 104. 1952. TYPE: Nicaragua. Río San Juan: San Juan del Norte (Greytown), sea level, Charles Smith 61 (EAP, holotype; MO, US, isotypes).

Epiphyte; stems short; roots pale green, in dense mass, ascending; cataphylls $8-11 \mathrm{~cm}$ long, coriaceous, drying brown, weathering into fibers and persisting at base of leaves. LEAVES erectspreading; petioles subterete, narrowly and bluntly sulcate, 4-17 cm long, 4-7 mm diam.; geniculum 1.5-2 cm long; blades elliptic to broadly elliptic to obovate or oblanceolate, moderately thick, 22-54 cm long, 9.5-24 cm wide, abruptly acuminate at apex, acute to obtuse at base; semiglossy above and below, conspicuously punctate below; the midrib raised and \pm flattened (sometimes shallowly sulcate near base) above, convexly to acutely raised below; primary lateral veins $15-18$ per side, departing midrib at $45^{\circ}$ angle, sunken above, raised below, straight to collective vein, loop-connecting with collective vein; lesser veins obscure; collective vein arising from base, 3-6 $\mathrm{mm}$ from the margin. INFLORESCENCE spreading-pendent, shorter or longer than leaves; peduncle 9-34 cm long, 3-9 $\mathrm{mm}$ diam., sometimes tinged reddish-violet, conspicuously ribbed beneath opening of spathe; spathe coriaceous, yellow-green sometimes suffused with purple, lanceolate or oblong, $6-12 \mathrm{~cm}$ long, $1.5-2.8 \mathrm{~cm}$ wide, short-acuminate at apex, obtuse to rounded at base, inserted at $40^{\circ}-45^{\circ}$ angle on peduncle; spadix green, tinged red-violet in later stages, $13-36 \mathrm{~cm}$ long, 5-11 cm diam. at base, $4-7 \mathrm{~cm}$ diam. at apex; flowers rhombic, 4-5 mm long, 3-3.5 mm wide, the sides straight to weakly sigmoid; 4-8 flowers visible in the principal spiral, 6-10 flowers visible per alternate spiral; tepals matte, minutely papillate, lateral tepals $2.5-3.5 \mathrm{~mm}$ wide, the inner margin \pm straight; pistil emergent but not raised, pale red-violet; stigma greenish, linear, not conspicuously open; stamens emerging rapidly throughout, anthers barely visible at edge of pistil, soon retracting leaving only sparse amount of white pollen. INFRUCTESCENCE with spadix to 48 $\mathrm{cm}$ long, berries pale red, to faintly lavender or grayish-white, flattened at apex (depressed around style), 4-5 $\mathrm{mm}$ long, 5-7 $\mathrm{mm}$ wide (direction of axis), $4.5-5 \mathrm{~mm}$ wide (perpendicular to axis); seeds 3-4, greenish-white, 1.6-3 mm long, 1.3$2.1 \mathrm{~mm}$ wide, $1.2-1.5 \mathrm{~mm}$ thick; mesocarp juicy, gelatinous, translucent. Figs. 151 and 154.

The species is known from Nicaragua to Panama from sea level to $1,400 \mathrm{~m}$ elevation in wetter parts of tropical moist forest and in premontane wet, tropical wet, premontane rain, and lower montane wet forest life zones. In Costa Rica, the species is widespread on the Atlantic slope and rare on the Pacific slope. In Panama, the species is most abundant on the Atlantic slope but occurs also on the Pacific slope near the Continental Divide.

Anthurium ramonense is most closely related to $A$. paludosum, A. durandii, A. alatipedunculatum and $A$. acutangulum, which all share similar retracting stamens and densely punctate lower blade surfaces. Anthurium ramonense can be distinguished by a combination of its proportionally shorter, stouter petioles, generally larger blades and long, tapered, generally stout inflorescence. Anthurium paludosum differs in having thick, nondilacerating, persisting cataphylls and proportionally narrower, usually smaller, concolorous leaves with a conspicuous whitish-green midrib. Anthurium durandii differs in having proportionally longer petioles and in being geographically isolated in southwestern Costa Rica. Anthurium alatipedunculatum differs in having an alate peduncle and a 3-sided petiole. Anthurium ramonense is most easily confused with $A$. acutangulum because both share similar features including thin, dilacerating, promptly deciduous cataphylls and long inflorescences. Anthurium acutangulum differs, however, in having smaller, typically elliptic blades and a proportionally longer, more slender petiole. The petiole ranges from equally as long as the blade to one third as long as the blade in A. acutangulum, whereas the petiole of $A$. ramonense ranges from one sixth to one third as long as the blade. The spadix of $A$. ramonense is also proportionally longer and stouter than that of $A$. acutangulum. Anthurium ramonense is a member of section Porphyrochitonium.

Engler (1905) mentioned the affinity of A. ramonense with $A$. filiforme Engler of Colombia. This is perhaps another species in the complex but it is inadequately known at present.

Costa Rica. Alajuela: N of Bijagua, Croat $36502 \mathrm{~A}$, 36516 (MO); road from Cariblanco to Lake Hule, $\mathrm{Lu}$ teyn \& Wilbur 4300 (DUKE); Lake María Aguilar, Lent 
1530 (NY); from San Pedro to San Ramón, Brenes $16171 a(\mathrm{NY})$; Santa María National Park, Liesner 5156 (MO); N of Zapote, Croat 46918 (MO); Zarcero, Smith 865 (NY). CARTAGo: El Muñeco, Luteyn 3233 (DUKE); between Moravia \& Quebrada Platanillo, Croat 36604, 36620, 36689 (MO); SE of Platanillo, Croat 36814 (MO); Tapantí, Valerio 1612 (F); Tucurrique, Tonduz 12818 (US); W of Turrialba, Croat 36831 (MO). HEREDIA: Puerto Viejo de Sarapiquí, Croat 44302 (MO). LIMÓN: E of El Carmen, Lent 2439 (MO); S of Siguirres, Croat 43320 (MO). PUNTARENAS: SW of Cañas Gordas, Croat 22278 (MO). SAN JosÉ: between San Isidro del General and Dominical, Croat 35446 (MO).

Nicaragua. Río SAn JuAn: NE of El Castillo, Neill 3331 (MO); San Juan del Norte (Greytown), C. L. Smith 61 (GH). ZELAYA: Colonia Agrícola Yolaina, Stevens 6309 (MO).

Anthurium ranchoanum Engl., Bot. Jahrb. Syst. 25: 421. 1898. TYPE: Costa Rica. Rancho Flores in territorio Bacha, Volcán Barba, 2,100 m, Pittier 2295 (B, holotype; BR, G, isotypes).

Anthurium valerii Standl., Publ. Field Mus. Nat. Hist., Bot. Ser. 18: 137. 1937. TyPE: Costa Rica. Heredia: Vara Blanca, Valerio 1600 (F, holotype).

Anthurium vinicolor Standl. \& L. O. Wms., Ceiba 3: 106. 1952. TyPE: Costa Rica. San José: Cordillera de Talamanca near Copey, cloud forest, $1,800 \mathrm{~m}$, 23 April 1949, L. O. Williams 16538 (EAP, holotype; F, US, isotypes).

Epiphytic or terrestrial; roots thick, green, fuzzy, 3-7 mm diam., descending; cataphylls coriaceous, $13-30 \mathrm{~cm}$ long, apiculate at apex, drying tan (B \& K Yellow-red 9/2.5), persisting intact at apex, splitting at base of leaves. LEAVES with petioles erect-spreading, subterete, shallowly and bluntly sulcate, $11-79 \mathrm{~cm}$ long, $5-15 \mathrm{~mm}$ diam.; geniculum $1.5-3 \mathrm{~cm}$ long; blades narrowly ovate or ovate-deltoid, moderately thick, acuminate at apex, shallowly to deeply lobed at base, 17-64 cm long, 9-34 $\mathrm{cm}$ wide, broadest between base and midway; the anterior lobe 12-29 $\mathrm{cm}$ long; the posterior lobe $7-13 \mathrm{~cm}$ long from sinus to outermost point; the sinus arcuate to parabolic; both surfaces semiglossy; midrib convexly raised above, diminished and sunken at apex, convexly raised below; primary lateral veins 4-9 per side, departing midrib at $40^{\circ}$ angle, raised above and below; secondary veins conspicuous, sunken above, prominulous below; basal veins 3-6 pairs, the first pair usually free to the base, the third to sixth coalesced $1-2 \mathrm{~cm}$, the fourth to sixth coalesced $3.5-6 \mathrm{~cm}$; posterior rib naked, turned up; collective vein usually arising from one of the primary lateral veins, sometimes from the first basal vein, erect to weakly sunken above, raised below, 3-9 $\mathrm{mm}$ from margin. INFLORESCENCE erect-spreading, much shorter than leaves; peduncle 13-56 cm long; spathe subcoriaceous, lanceolate to narrowly ovate, green, tinged with purple on inner surface, 4-35 cm long, 2$6.5 \mathrm{~cm}$ wide; spadix sessile or with stipe 1.6-2.5 cm long, dark violet-purple, $3.5-19 \mathrm{~cm}$ long, 0.9$1.5 \mathrm{~cm}$ diam. at base, $6-9 \mathrm{~mm}$ diam. at apex; the flowers rhombic, $2-3.2 \mathrm{~mm}$ long, $2.6-3 \mathrm{~mm}$ wide, the sides jaggedly sigmoid; 5-10 flowers visible in the principal spiral, 7-20 flowers visible in the alternate spiral; tepals matte, lateral tepals 1-1.8 mm long; pistils green; stigma linear, ca. $0.5 \mathrm{~mm}$ long; lateral stamens emerging throughout, followed by alternates, exserted on flat filaments ca. $0.5 \mathrm{~mm}$ long, ca. $1 \mathrm{~mm}$ wide; anthers white, ca. $0.6 \mathrm{~mm}$ long, $0.7 \mathrm{~mm}$ wide; thecae ovoid-ellipsoid, slightly divaricate; pollen white. INFRUCTESCENCE arching-pendent; spadix to $50 \mathrm{~cm}$ long, to $3 \mathrm{~cm}$ diam.; berries orange, narrowly obovoid, acute at apex, to 14 mm long. Figs. 155 and 156.

Anthurium ranchoanum is found in Costa Rica and Panama at elevations of 500-2,300 m (usually above $1,000 \mathrm{~m}$ ), usually in tropical wet, premontane rain, and lower montane rain forest life zones.

The species is an atypical member of section Pachyneurium and is recognized by its thick, ovate to ovate-triangular blades, with heavy, rather numerous veins, obtusely sulcate petioles; ovate to lanceolate, green, hooding spathe, tinged with purple; dark violet-purple, relatively stubby, scarcely tapered spadix with tight clusters of white stamens; orange berries; and especially by the fruiting spathe, which is stiffly erect. Also characteristic is the way the spadix is turned downward at anthesis. The source of the collective vein is variable, arising from first basal veins or, more frequently, in Costa Rica, from one of the primary lateral veins and, in Panama, from the first basal veins or primary lateral veins but more frequently from the lower basal veins.

The species is most easily confused with $A$. cotobrusii, which sometimes has similar leaves. The latter can be distinguished by its stiffly erect, conspicuously tapered spadix and prominently reflexed spathe.

The species is also related to A. colonicum $\mathrm{K}$. Krause and $A$. nervatum Croat (ined.), both from Panama; and to A. spectabile, which ranges from Nicaragua to Costa Rica. The latter species has similar leaves (especially when dried) and a sim- 

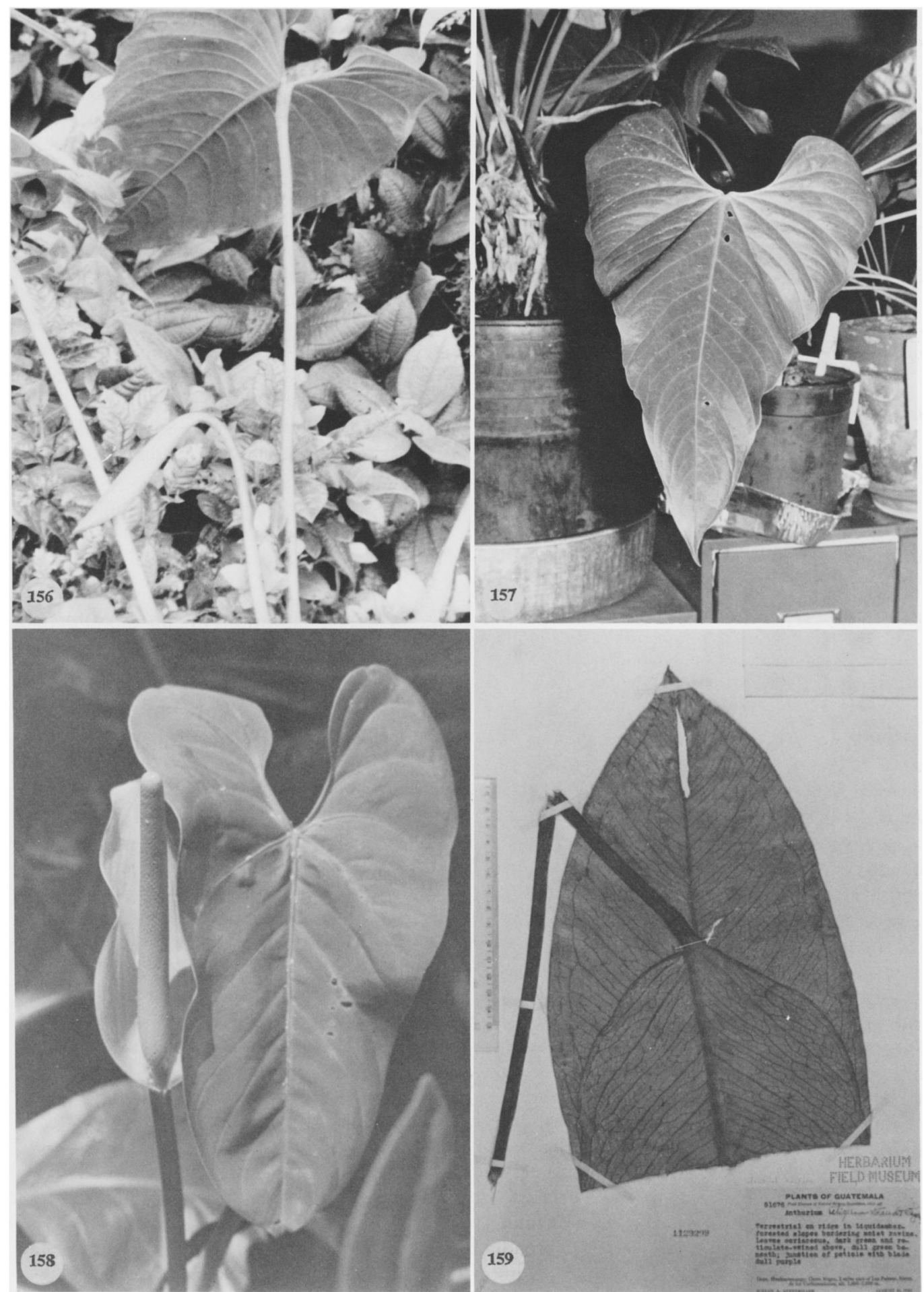

FIGURES 156-159. 156. Anthurium ranchoanum Engl., Croat 48519A.-157. Anthurium ravenii Croat \& Baker, Croat 32897. - 158. Anthurium ravenii Croat \& Baker, Croat 11529 (Type). - 159. Anthurium retiferum Standl. \& Steyerm., Steyermark 51676. 
ilar inflorescence but differs in having usually more or less pendent leaves, and an elongate, more or less thin, spreading spathe, whereas $A$. ranchoanum has leaves more or less erect and a spathe that is more nearly ovate, thick, and stiffly erect. Anthurium colonicum has similar leaves but differs from $A$. ranchoanum in its reflexed and prominently undulate-margined and often contorted spathe, sharply protrudent, early emergent pistils, and narrowly oblong-elliptic, sharply pointed berries. Anthurium nervatum differs in having a reflexed spathe and a spadix that is usually much longer and more gradually tapered.

Costa Rica. alajuela: on road from Sucré to Lake Pozo Verde, Luteyn et al. 4502 (DUKE). CARTAGO: near Copey, Williams \& Allen 16538 (US); SW of El Empalme, Antonio 721 (MO). GUANACASTE: between Santa Elena and Monteverde, Croat 47130 (MO). HEREDIA: S slopes of Cerros Caricias \& Zurquí, Luteyn 3275 (DUKE); NNE of Heredia, Lellinger \& White 981, 1012 (US); vicinity Cerro Chompipe, Luteyn \& Wilbur 4422 (DUKE); NE of Los Cartagos, Lent 1898 (MO); Monte Cristo, Rojas 511 (MO); on road to Sacramento, Utley \& Utley 4564 (DUKE); vicinity San Isidro, Pittier 14058 (US); NE of San Isidro, Standley \& Valerio 50243, 50798, 51455, 51620, 52345 (US); N of San Rafael, Lems s.n. (K, NY); N of Vara Blanca, Croat 36052, 36053 (MO); between Cerro Chompipe and Volcán Barba, Baker 239 (MO); E slope of Volcán Barba, Burger \& Liesner 6369 (US); Volcán Barba, Lems s.n. (NY); Pittier 2295 (BR); Skutch 3657 (MICH, US). PUNTARENAS: Las Cruces Botanical Garden, Croat 44443 (MO). SAN JoSÉ: NE of Cascajal, Lent 2181 (MO); $\mathrm{N}$ of San Isidro del General, Utley 407 (DUKE); $\mathrm{S}$ of Santa María de Dota, Luteyn 3324 (DUKE); Standley \& Valerio 44077 (US); Standley 41767 (US); Santa Rosa del Copey, Tonduz 12266, 12267, 12269 (US).

Anthurium ravenii Croat \& Baker, Brenesia 16 (Supl. 1): 75. 1979. TYPE: Panama. Panamá: north of Tocumen airport on road to Cerro Jefe, 2.5 miles north of Lago Cerro Azul, elev., ca. 700 m, Croat 11529 (MO-2205477, holotype; F, K, PMA, US, isotypes; Live at MO).

Epiphyte; stem $1.5-2.5 \mathrm{~cm}$ diam., often to 40 $\mathrm{cm}$ long; the leaf scars almost contiguous, ca. 2 $\mathrm{cm}$ wide; roots relatively few, green to greenishbrown, 2-3 mm diam.; cataphylls subcoriaceous, to $17.5 \mathrm{~cm}$ long, drying brown, remaining intact, soon deciduous. LEAVES with petioles broadly and stiffly spreading, $19-70 \mathrm{~cm}$ long, 6-10 mm diam., subterete, obscurely and narrowly sulcate (the sulcus less than $1 \mathrm{~mm}$ wide); geniculum 2$2.5 \mathrm{~cm}$ long; blades moderately thick, ovate-triangular, narrowly to abruptly acuminate at apex, prominently lobed at base, $30-75 \mathrm{~cm}$ long, 16$40 \mathrm{~cm}$ wide, broadest at or near point of petiole attachment; the anterior lobe $25-44 \mathrm{~cm}$ long, the margin broadly rounded to weakly concave; the posterior lobes $10-19 \mathrm{~cm}$ long; the sinus spathulate, elliptic or obovate, acute, truncate or rounded at apex, usually broader than deep; the basal veins 5-9 pairs, the first and second free, the remainder coalesced $1-8 \mathrm{~cm}$; the posterior rib curved, marginal to the sinus, $2.5-4.5 \mathrm{~cm}$, the outer margin turned upward; blades semiglossy above, often broadly undulate, the lower surface semiglossy to matte; the midrib raised above and below; primary lateral veins 5-11 per side, departing midrib at $40^{\circ}-50^{\circ}$ angle, raised in valleys above, raised below; lesser veins conspicuous, flat above, weakly raised below; the collective vein arising from the first basal vein or one of the lowermost primary lateral veins, sunken above, raised below, 2-4 $\mathrm{mm}$ from margin. INFLORESCENCE erect-spreading; peduncles 15$40 \mathrm{~cm}$ long, 7-8 $\mathrm{mm}$ diam., terete, sometimes weakly ribbed on adaxial side, running the full length of the peduncle (continuous to the decurrent spathe); spathe greenish-white to pale green, sometimes tinged purplish at base, oblong-elliptic or ovate-elliptic, moderately thin, $8-18 \mathrm{~cm}$ long, $2.5-5.8 \mathrm{~cm}$ wide, broadest just above point of petiole attachment, abruptly acuminate at apex, the margins sometimes turned downward in lower half, rounded at base then decurrent to $15 \mathrm{~mm}$; spadix cream, white, to pale green, usually sessile (rarely with a stipe $2-10 \mathrm{~mm}$ long), $8.5-24 \mathrm{~cm}$ long, $12-15 \mathrm{~mm}$ diam. at base, $10-12 \mathrm{~mm}$ diam. at apex; flowers weakly and irregularly 4-lobed, 2.2-3.5 mm long, 2.3-3.2 mm wide, sometimes conspicuously wider than long, the sides sometimes straight, usually jaggedly sigmoid; 8-12 flowers visible in the principal spiral, 8-15 flowers visible in the alternate spiral; tepals smooth, matte or weakly glistening with numerous minute droplets, the inner margins straight to convex, the lateral tepals $1.1-1.5 \mathrm{~mm}$ wide, 3 -sided or more commonly 4-sided, with one lateral tepal acute on one end and obtuse on the other (proximal and distal ends), the opposite lateral tepal being a mirror image; pistil emergent but not raised, cream or whitish and difficult to discern from the adjacent tepals; stigma round, brushlike, somewhat elevated with short dense papillae, sometimes forming minute droplets about 7 days before first anthers emerge; the first stamens exposed in 2 or 3 days throughout spadix, all stamens emerged in about 10 days after 
first appears, usually exserted above the tepals, $1.2-1.5 \mathrm{~mm}$, held in a very tight cluster; filaments flattened, fleshy, $0.6-0.8 \mathrm{~mm}$ wide, slightly longer than the anther, sometimes retracting but usually remaining exserted, drying and twisting; anthers white, $0.5-0.6 \mathrm{~mm}$ long, $0.6-1 \mathrm{~mm}$ wide; thecae not divaricate; pollen pale lemonyellow, fading dirty white. INFRUCTESCENCE arching-pendent; the spathe usually deciduous; spadix 14-44 cm long, ca. $2.5 \mathrm{~cm}$ diam. (with berries emerged); berries usually evenly emerged (even before maturity), narrowly ovoid, acute at apex, bright red, usually white in lower half; mesocarp gelatinous, transparent; seeds 2 , white to brown with white punctations, green at apex, flattened, broadly elliptic, 3.7-4 $\mathrm{mm}$ long, 2.5-2.7 $\mathrm{mm}$ wide, ca. $2 \mathrm{~mm}$ thick. Figs. 157 and 158 .

Anthurium ravenii ranges from Honduras to the Pacific slope of Ecuador. It usually occurs in tropical wet and premontane wet forest from near sea level to $1,000 \mathrm{~m}$ elevation, but it has also been found in tropical moist forest in Darién Province in Panama.

The species is a member of section Calomystrium and is unusual in having an orbicular, brushy, elevated stigma rather than a slitlike depressed stigma (in dried material a darkened slitlike area becomes visible). Distinguishing features include major veins that dry reddish-brown, the weak and brittle spathe, the scarcely tapered, whitish spadix, the usually long-exserted stamens, and bright red berries. The species is not close to any other species although for many years material of this species was called $A$. concinnatum, a completely unrelated species of higher elevations.

Costa Rica. No other location, Winters 9928 (US). ALAJUela: N of Bijagua, Utley \& Utley 5310 (DUKE); between San Lorenzo and Bajo Rodríguez, Utley 4612 (DUKE); near Quebrada Guillermina, $\mathrm{N}$ side of Volcán Arenal, Lent 3409 (F, NY); road from Cañas to Upala, $\mathrm{N}$ of Bijagua, Croat 36425 (MO); S of Canalete near the Río Zapote and along the new road to Upala, Burger \& Baker 9975 (F, MO). GUANACASTE: slopes of Volcán Miravalles, above Río Naranjo, Primack, Stone \& Luteyn 446 (DUKE); Río Naranjo forest, Pittier 7541 (B). LIMÓN: $2.5 \mathrm{~km}$ east of Guapiles, Jiménez 2093 (NY); Río Hondo, plains of Santa Clara, Cook \& Doyle 514 (US); Hacienda Tapezco, Hacienda La Suerte, W of Tortuguero, Davidson 6871, 7020 (LA). PUNTARENAS: between Puerto Cortez and Palmar Norte, $J i$ ménez 2241 (CR, F); vicinity Palmar Norte, Croat 35209 (MO); Allen 5245 (EAP, F, US); E of Las Cruces on Property of R. Wilson, Burger \& Matta 4435 (F); Corcovado National Park, Liesner 2901A (MO); W of Rincón de Osa, Burger \& Stolze 5445, 5465 (CR, F);
Raven 21531 (DH, F); Burger \& Liesner 7200 (CR, F, US); Burger \& Gentry $8868(\mathrm{~F}), 8981 A(\mathrm{~F}, \mathrm{MO})$; Playa Blanca near Rincón de Osa, Liesner 2178 (MO, US); Rincón de Osa, region SW of airstrip, Utley \& Utley 1058 (CR, F, MO, SEL), 1106, 1120 (F); Vicinity San Vito de Java, Croat 32897 (MO). SAN JOSÉ: road between San Isidro del General and Dominical, SW of Río Pacuare, Croat 35213, 35265, 35338 (MO).

Honduras. ATLANTIDA: vicinity La Ceiba, Yuncker et al. 8741 (NY).

Nicaragua. Río San JUAN: valley of Río Indio, Neill 1550 (MO); Río San Juan, near Caño Chontaleño, NE of El Castillo, Neill 3418, 3621 (MO).

Anthurium retiferum Standl. \& Steyerm., Publ. Field Mus. Nat. Hist., Bot. Ser. 23: 211. 1947. TYPE: Guatemala. Huehuetenango: Sierra de los Cuchumantes, Cerro Huitz, between Nimahuitz and Yolhuitz, elev. 1,5002,600 m, Steyermark 48621 (F, holotype).

Terrestrial or epiphytic. LEAVES with petioles 26-37 cm long, 6-8 $\mathrm{mm}$ diam., flattened adaxially with sharp margins, terete abaxially; geniculum $1.5 \mathrm{~cm}$ long, dull purple; blades coriaceous, narrowly to broadly oblong-elliptic, 33$47 \mathrm{~cm}$ long, 12-22 cm wide, broadest just below middle, short-acuminate at apex, truncate to round at base; both surfaces semiglossy; midrib raised above and below, red-violet above; basal veins $1-2$ pairs; primary lateral veins $6-12$ per side, departing midrib at $40^{\circ}-50^{\circ}$ angle, equally as prominent as the basal veins, all veins drying prominently raised above and below; collective vein arising from one of the primary lateral veins, ca. $1.5 \mathrm{~cm}$ from margin. INFLORESCENCE with peduncle $19 \mathrm{~cm}$ long, $4 \mathrm{~mm}$ diam., peduncle and spathe red-violet; spathe lanceolate, reflexed, ca. $6.5 \mathrm{~cm}$ long, $1.3-1.5 \mathrm{~cm}$ wide, cuspidate-acuminate at apex; spadix sessile, dull purple, 8.5$9 \mathrm{~cm}$ long, 4-5 $\mathrm{mm}$ diam. at base, 3-4 $\mathrm{mm}$ diam. at apex. INFRUCTESCENCE unknown. Fig. 159.

Anthurium retiferum is endemic to Guatemala in the Sierra de los Cuchumantes in the Department of Huehuetenango at 1,500 to $2,600 \mathrm{~m}$.

The species is in section Belolonchium and is characterized by its sessile, purplish spadix and its coriaceous, oblong-elliptic leaf blades with the primary lateral veins equally as prominent as the basal veins and with prominently raised tertiary veins (on drying).

The species is perhaps closest to A. parvispathum but differs in having much broader leaves and in having the tertiary veins prominently raised on drying. 
Guatemala. huehuetenango: Cerro Huitz, between Nimahuitz and Yolhuitz, Steyermark 48621 (F); Cerro Negro, E of Las Palmas, Steyermark 51676 (F, US).

Anthurium riograndicolum Matuda, Anales Inst. Biol. Univ. Nac. México 27: 347. 1957. TyPE: Mexico. Oaxaca: between La Gloria and Río Grande, MacDougall s.n. (MEXU, holotype).

Terrestrial; stems $2 \mathrm{~cm}$ diam. or larger; cataphylls triangular, drying reddish-brown, weathering into moderately thin longutudinal fibers. LEAVES with petioles to $50 \mathrm{~cm}$ long, 7-9 $\mathrm{mm}$ diam., bluntly sulcate adaxially; geniculum 1.5 $\mathrm{cm}$ long, thicker than petiole, obtusely and narrowly sulcate; blades coriaceous, narrowly ovate, acute at apex with short apiculum, deeply lobed at base, to $35 \mathrm{~cm}$ long, $22.5 \mathrm{~cm}$ wide, broadest just below point of attachment; the anterior lobe $25.5 \mathrm{~cm}$ long; the posterior lobes $12.5 \mathrm{~cm}$ long from apex of sinus to tip of lobe; sinus obovate, rounded at apex; upper surface semiglossy, with sparse glandular punctations, lower surface semiglossy with dense glandular punctations (the punctae irregular, to $0.4 \mathrm{~mm}$ diam.); the midrib prominently raised above, diminished and sunken at apex, sharply raised below; basal veins 56(7) pairs, the 4-5(6)th coalesced ca. $3.5 \mathrm{~cm}$; posterior ribs slightly curved, the outer margin curled up and inward; the primary lateral veins $4-5$ per side, scarcely visible, departing midrib at $50^{\circ}$ angle, curved to the collective vein, raised below, interprimary veins scarcely less prominent than primary lateral veins; collective vein arising from one of the basal veins, $2-10 \mathrm{~mm}$ from margin. INFLORESCENCE erect-spreading (?); peduncle to $69 \mathrm{~cm}$ long, $7 \mathrm{~mm}$ diam., terete, longer than petioles; spathe subcoriaceous, green tinged with purple, oblong-lanceolate, to $11.5 \mathrm{~cm}$ long, to $1.2 \mathrm{~cm}$ wide, broadest just above the base, meeting on peduncle at ca. $90^{\circ}$ angle; spadix sessile, to $17.5 \mathrm{~cm}$ long, to $1 \mathrm{~cm}$ diam. at base, to $4 \mathrm{~mm}$ diam. at apex; flowers rhombic, 3.7-4 mm long (dry), 2.7-3 mm wide (dry), the sides straight to sigmoid; $8-10$ flowers visible in the principal spiral, 6-7 flowers visible in the alternate spiral; lateral tepals ca. $2 \mathrm{~mm}$ wide (dry), the inner margins concave; pistils weakly emergent; the stigma ellipsoid, $1 \mathrm{~mm}$ long; stamens exserted just above edge of tepals; anthers held at edges of pistil, 0.5 $\mathrm{mm}$ long (dry), $0.7 \mathrm{~mm}$ wide; thecae broadly elliptic, scarcely divaricate; pollen not seen. INFRUCTESCENCE not seen. Fig. 160.
Anthurium riograndicolum is known only from the type specimen collected perhaps in eastern Oaxaca, although no typical aroid collecting area is represented there. The notes by MacDougall attribute the collection from between "La Gloria and Río Grande." There are a number of towns with either name in Oaxaca.

The species is a member of section Belolonchium and is distinguished by its coriaceous, ovate, glandular-punctate blade with an acute apex and conspicuous posterior lobes with an obovate sinus.

The species resembles $A$. rzedowskii, which also has thick, ovate, lobed leaves but that species has a much broader spathe and lacks glandular punctations. Anthurium riograndicolum is probably most closely related to $A$. lucens and may prove to be inseparable from it, but the species is currently represented by only the incomplete type specimen that differs from $A$. lucens primarily in having thicker blades that are acute rather than acuminate at the apex.

Mexico. oAXACA: between La Gloria \& Río Grande, MacDougall s.n. (MEXU).

Anthurium rionegrense Matuda, Anales Inst. Biol. Univ. Nac. México 36: 109, Fig. 4. 1966. TYPE: Mexico. Oaxaca: Río Negro between the states of Chiapas and Oaxaca, MacDougall 459 (MEXU).

Epiphyte; stems short. LEAVES with petioles 19-28 cm long, sulcate adaxially; the geniculum $1.5 \mathrm{~cm}$ long; blades subcoriaceous, ovate, 20-22 $\mathrm{cm}$ long, $16-23 \mathrm{~cm}$ wide, gradually acuminate at apex, broadly lobed at base, broadest at point of petiole attachment; the anterior lobe $14-15 \mathrm{~cm}$ long; posterior lobes 7-9 cm long; sinus hippocrepiform, rounded at apex; midrib raised above and below; basal veins 4-6 pairs, fourth to sixth coalesced $1.5-2.1 \mathrm{~cm}$; posterior ribs naked; primary lateral veins $2-4$ per side, departing midrib at $50^{\circ}$ angle, raised above and below; collective vein arising from first basal vein, $8-10 \mathrm{~mm}$ from margin. INFLORESCENCE longer than leaves; peduncle terete, $27-61 \mathrm{~cm}$ long; spathe linearlanceolate, $2.5-8.5 \mathrm{~cm}$ long, 5-12 $\mathrm{mm}$ wide, broadest below middle, acuminate at apex, clasping at base; spadix green, $2-5 \mathrm{~cm}$ long, $3-5 \mathrm{~mm}$ diam. at base, $2 \mathrm{~mm}$ diam. at apex; the flowers rhombic, $4 \mathrm{~mm}$ long, $2.8 \mathrm{~mm}$ wide, the sides straight; 4 flowers visible in the principal spiral, 5 flowers visible in the alternate spiral; tepals 

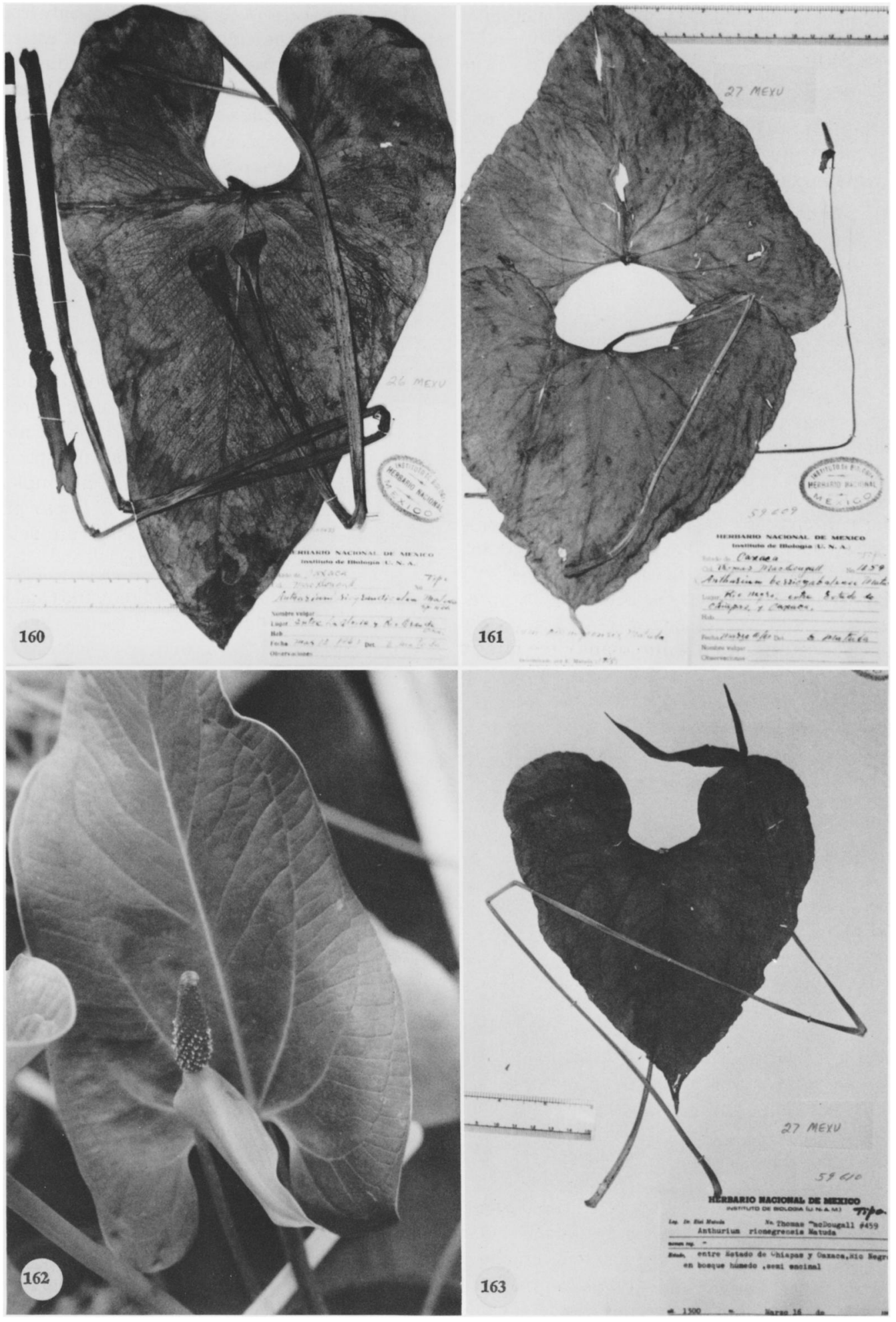

FIGURES 160-163. 160. Anthurium riograndicolum Matuda, MacDougall s.n. (Type).-161. Anthurium rionegrense Matuda, MacDougall 459 (Type). - 162. Anthurium rzedowskii Croat, Croat 45520.-163. Anthurium rionegrense Matuda, MacDougall 459 (Type). 
punctate, lateral tepals $1.5 \mathrm{~mm}$ wide, inner margin convex, turned up; pistil emergent, green; stigma slitlike, $7 \mathrm{~mm}$ long; stamens held over pistil; anthers cream, ovoid, $3 \mathrm{~mm}$ long, $4 \mathrm{~mm}$ wide; thecae ellipsoid, scarcely divaricate. IN FRUCTESCENCE not seen. Figs. 161 and 163.

Anthurium rionegrense is known only from the Río Negro and Río Mono Blanco in the vicinity of the Oaxaca and Chiapas frontiers. Neither location has been located so the elevation is uncertain, but most elevations along the western Chiapas border range from 200 to $1,000 \mathrm{~m}$, and only Cerro Baúl on the Oaxaca border, southwest of Cintalapa, is very high, extending up to about $1,800 \mathrm{~m}$.

The species is a member of the section Belolonchium and is recognized by its thin, broadly ovate leaves with short, linear raphide cells visible on the upper surface on drying and by its slender tapered, greenish spadix with the tepals thin and clear along the inner margins and otherwise distinctly punctate with raphide cells.

Anthurium rionegrense is perhaps most easily confused with two other thin leaved, basically ovate-cordate species, $A$. ovandense and $A$. lezamae. Anthurium ovandense differs in having the anterior lobe usually concave along the margins whereas $A$. lezamae differs in being more narrowly ovate and in having an alveolate epidermal pattern on drying.

Mexico. OAXaca: Río Negro, between Chiapas and Oaxaca, MacDougall 459(MEXU); Río Mono Blanco, MacDougall 7940 (MEXU).

Anthurium rzedowskii Croat, sp. nov. TYPE: Mexico. Guerrero: along road between Hwy. 95 near Milpillas and $3.5 \mathrm{mi}$ west of junction with road to Chichihualco, elev. $2,425 \mathrm{~m}$, Croat 45520 (MO-2690028-31, holotype; Live at MO).

Planta epiphytica aut terrestris; caudex ad $30 \mathrm{~cm}$ longus, $2-3 \mathrm{~cm}$ diam.; lamina ovata aut ovata-triangularis, 24-64 cm longa, $15-46 \mathrm{~cm}$ lata, basi cordata coreacea, nervo collectivo plerumque e nervo basi primo aut interdum e nervo laterali exorienti, saepe nervo collectivo secondario; inflorescentia effusa-erecta, foliis breviora; spatha viridis, $3.5-13 \mathrm{~cm}$ longa, 1.6-6 $\mathrm{cm}$ lata; spadix viridis, $3.8-13 \mathrm{~cm}$ longus; baccae immaturae purpureae.

Epiphytic or terrestrial; stems green, less than $30 \mathrm{~cm}$ long, $2-3 \mathrm{~cm}$ diam.; leaf scars $1.5 \mathrm{~cm}$ wide; roots 5-6 mm diam., pale green to tan, descending; cataphylls subcoriaceous, $6-10 \mathrm{~cm}$ long, pale green, acute at apex with slender subapical apiculum to $3 \mathrm{~mm}$ long, drying dark brown, the apex remaining intact, splitting at base and persisting. LEAVES with petioles erect to spreading, subterete or flattened adaxially, rarely with single abaxial rib; geniculum $2-2.5 \mathrm{~cm}$ long; blades ovate to ovate-triangular, acuminate at apex, shallowly to deeply lobed at base, 24-64 cm long, $15-46 \mathrm{~cm}$ wide, broadest below middle or near point of petiole attachment; anterior lobe 16-49 $\mathrm{cm}$ long, the margins convex; posterior lobes 7$20 \mathrm{~cm}$ long; sinus arcuate to parabolic, frequently with decurrent petiole; upper surface semiglossy, lower surface matte to semiglossy; the midrib flat to weakly, convexly raised above, narrowing and sunken at apex, prominently raised below; basal veins 3-7 pairs, the first free, the remainder coalesced $1-3.5 \mathrm{~cm}$, the fourth to sixth sometimes coalesced up to $6 \mathrm{~cm}$, raised above, prominulous below; primary lateral veins $7-17$ per side, departing midrib at $35^{\circ}-65^{\circ}$ angle, weakly raised in valleys or sunken above, raised below, straight to weakly curving to collective vein; interprimary veins flat above, prominulous below; collective vein $1.5-3.5 \mathrm{~mm}$ from the margin, arising from the first basal vein, frequently with a secondary collective vein $0.4-1 \mathrm{~mm}$ from the margin, arising from the second basal vein and extending irregularly to apex or running to margin in apical quarter of blade, sunken above, raised below. INFLORESCENCE erect-spreading, shorter than leaves; peduncle 19-56 cm long, 4$7 \mathrm{~mm}$ diam., terete; spathe moderately thick, medium green (B \& $\mathrm{K}$ Yellow-green 7/7.5), narrowly to broadly ovate, $3.5-13 \mathrm{~cm}$ long, $1.6-6$ $\mathrm{cm}$ wide, abruptly acuminate at apex, rounded at base, inserted at $80^{\circ}-90^{\circ}$ angle on peduncle; stipe $9 \mathrm{~mm}$ long in front, $5 \mathrm{~mm}$ long in back; spadix green (B \& $\mathrm{K}$ Yellow-green 7/7.5), 3.8$13 \mathrm{~cm}$ long, 8-10 $\mathrm{mm}$ diam. at base, $6-9 \mathrm{~mm}$ diam. at apex; the flowers rhombic to sub-4-lobed, ca. $2.3 \mathrm{~mm}$ long, ca. $2.9 \mathrm{~mm}$ wide, the margin \pm obscure, straight to weakly sigmoid; 6-7 flowers visible in the principal spiral, 8-9 flowers visible in the alternate spiral; tepals matte, densely and minutely papillate, small droplets on tepals as stamens emerge, lateral tepals ca. $2.1 \mathrm{~mm}$ wide, the inner margin broadly rounded; pistils weakly emergent before stamens emerge, green, darker than tepals and conspicuously punctate; stigma linear, ca. $0.5 \mathrm{~mm}$ long, nearly obscure; stamens emerging from the base in a rapid sequence, the lateral stamens emerging first, quickly followed by alternates; the anthers creamy white usually 
not opening until the third or fourth stamens emerge, exserted briefly on translucent filament, held inward over pistil, ca. $1.1 \mathrm{~mm}$ long, ca. 1.2 $\mathrm{mm}$ wide; thecae oblong-ovoid, slightly divaricate; pollen creamy white, fading to white. INFRUCTESCENCE pendent; spathe persisting; immature berries purplish, round at apex, mature berries not seen. Figs. 162 and 164 .

Anthurium rzedowskii is known only from Mexico in the states of Guerrero, Oaxaca, and Chiapas at elevations of 1,400 to $2,900 \mathrm{~m}$ in "bosque pino-encino." It is named in honor of Dr. J. Rzedowski of the Instituto Polytechnica in Mexico City, one of the first collectors of the species.

The species is a member of section Belolonchium and is characterized by its coriaceous, ovate blades with the collective vein usually arising from the first basal vein or sometimes arising from one of the primary lateral veins and frequently with a secondary collective vein extending irregularly along the margin to the apex or almost to the apex.

It is probably most similar to $A$. subcordatum in having coriaceous leaf blades with the collective vein arising from the first basal vein or one of the primary lateral veins, and in frequently having a secondary collective vein arising from the second basal vein and extending along the margin to the apex or almost to the apex. $A n$ thurium subcordatum differs in having truncate to subcordate leaf blades, a violet-purple spadix; it occurs in Guatemala, El Salvador, and Honduras.

Mexico. Chiapas: Municipio of Siltepec, Breedlove \& Smith 31867 (DS); Croat 47367 (MO); Matuda 38524 (DS, MEXU). GUERRERO: between Milpillas and Atoyac de Alvarez, Croat 45520 (MO); Municipio of Tlacotepec, Rzedowski 16528 (ENCB, MICH); Omiltemi, Lachica s.n. (ENCB); Sierra Madre del Sur along the Milpillas-Atoyac Road, Reveal et al. 4252, 4331 (US). OAXACA: between Oaxaca and Pochutla, Croat 46056, $46188(\mathrm{MO})$.

Anthurium salvadorense Croat, Selbyana 5 (34): 333. 1981. TYPE: El Salvador. Ahuachapán: 1.5 miles SW of Tacuba on road to San Francisco Menéndez; riverbank, Rió Chokama, $700 \mathrm{~m}$ elev. Croat 42169 (MO2583750, holotype; CAS, F, ITIC, K, SEL, US, isotypes; Live at MO).

Terrestrial or rupicolous; stems $2-3 \mathrm{~cm}$ diam., usually well rooted; roots to $1 \mathrm{~cm}$ thick, descend- ing; cataphylls moderately thick, $5-8 \mathrm{~cm}$ long, apiculate at apex, pale green, drying light brown (B \& K Yellow 5/5), persisting intact or dilacerating. LEAVES erect-spreading; petioles \pm quadrangular, 11-22 cm long, 6-8 $\mathrm{mm}$ wide, broadly rounded to slightly 3 -ribbed abaxially, broadly and sharply sulcate, sometimes with a medial rib; geniculum 1-1.5 cm long; blades elliptic to oblanceolate, medium thick, gradually acuminate at apex, turned downward (the acumen ca. 1.5 $\mathrm{cm}$ long), obtuse to rounded and auriculate at base, $25-50 \mathrm{~cm}$ long, $8-26 \mathrm{~cm}$ wide, broadest at or above the middle; upper surface matte to semiglossy, lower surface matte; midrib obtusely raised above, diminishing and sunken at apex, convexly raised below, ribbed near base; primary lateral veins $8-14$ per side, departing midrib at ca. $45^{\circ}$ angle, raised at midrib, diminishing and sunken near margin above, prominently raised below, straight to near margin, loop-connected in upper half; lesser veins flat above, raised below; collective vein arising from middle or above, ca. $5 \mathrm{~mm}$ from margin, sunken above, raised below. INFLORESCENCE erect-spreading; peduncle 13-45 cm long, 5-7 $\mathrm{mm}$ diam., faintly striate, 1 -ribbed adaxially and sometimes abaxially, longer than petioles; spathe ovate-lanceolate, medium thick, pale green (B \& K Yellowgreen $8 / 10$ ), held erect, enshrining and wrapped around base of spadix, $4.5-6.5 \mathrm{~cm}$ long, 2.4-2.7 $\mathrm{cm}$ wide, broadest just above base, narrowly acute, inserted at $10^{\circ}-25^{\circ}$ angle on peduncle; spadix pale green (B \& $\mathrm{K}$ Green $8 / 5$ ), $2.5-6.5 \mathrm{~cm}$ long, 8-12 mm diam. at base, $4-7 \mathrm{~mm}$ diam. at apex, held at a slight angle from the peduncle; flowers \pm irregularly 4-lobed, $2-3.3 \mathrm{~mm}$ long, $2.5-3.6 \mathrm{~mm}$ wide, the sides jaggedly sigmoid; ca. 10 flowers visible in the principal spiral, ca. 9 flowers visible in the alternate spiral; tepals matte, densely papillate, lateral tepals 1.4$1.7 \mathrm{~mm}$ wide, turned up against emerging pistil; pistils weakly emergent, green; the stigma elliptic, ca. $0.4 \mathrm{~mm}$ long, erect and brushlike, with a small droplet apparent 2-4 days before first stamens emerge; stamens emerging rapidly in a complete progression from the base, lateral stamens emerging at apex when the third and fourth stamens are emerging at the base; anthers pale green, $0.8-1.2 \mathrm{~mm}$ long, $0.7-1.3 \mathrm{~mm}$ wide, held in a close, contiguous circle around and over the stigma, held at about the same height as the style; thecae weakly divaricate; pollen pale yellow, soon fading white. INFRUCTESCENCE spreading; spathe persisting and erect; the spadix to $9 \mathrm{~cm}$ 


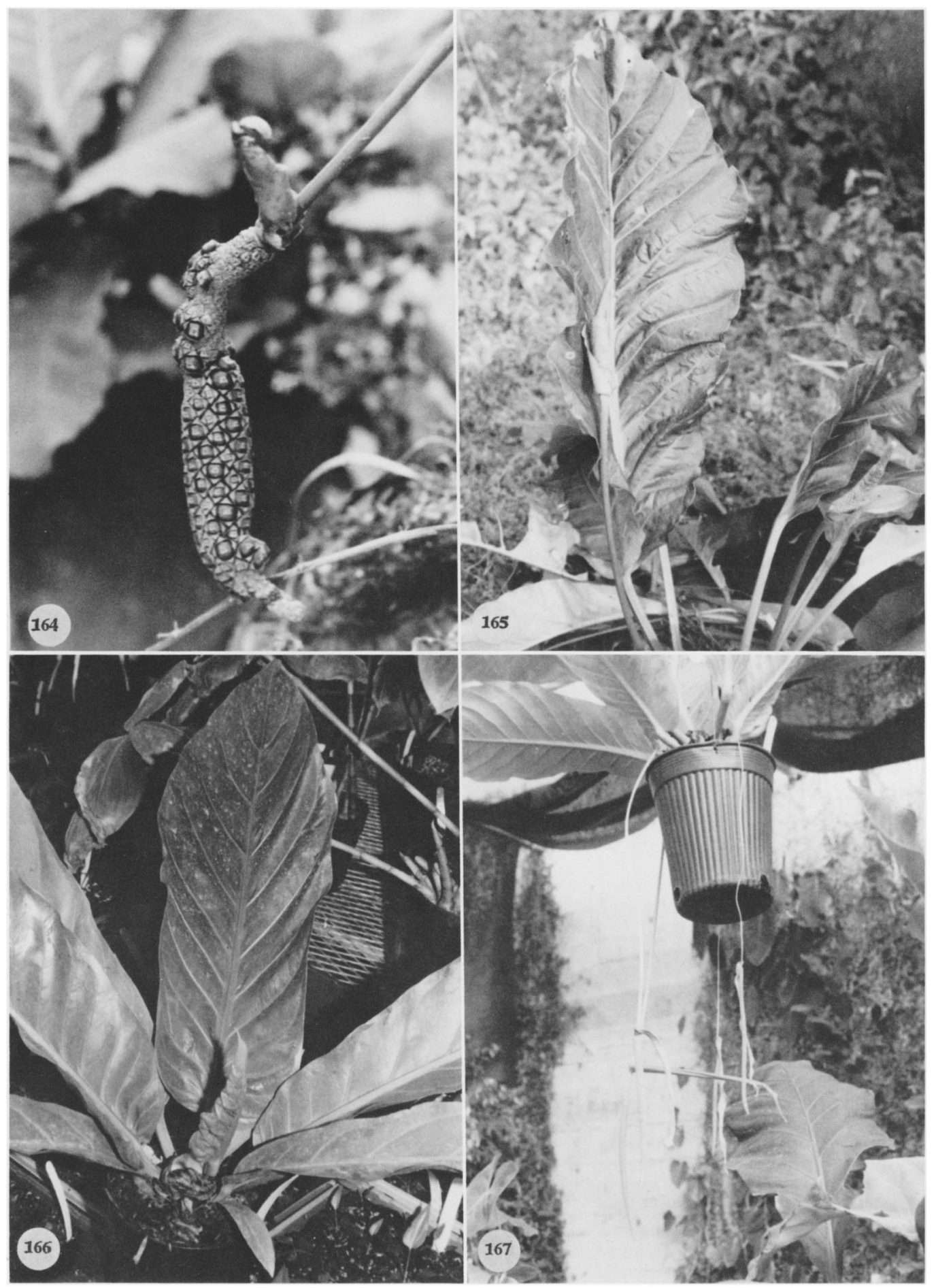

FIGURES 164-167. 164. Anthurium rzedowskii Croat, Croat 47367.-165. Anthurium salvadorense Croat, Croat 42169 (Type). - 166. Anthurium salviniae Hemsl. (Cultivated at Selby Gardens). -167. Anthurium salviniae Hemsl., Croat 36480. 
long, ca. $2 \mathrm{~cm}$ diam.; berries broadly obovoid, 5.5-9 mm long, 4-9 $\mathrm{mm}$ wide, rounded to flat or weakly indented at apex, orange-red (B \& K Yellow-red 5/2.5 to Red 4/10); pericarp moderately thick, with dense punctiform raphide cells, especially in apical half; mesocarp pulpy or mealy with numerous raphide cells; seeds 1 or 2 , obovoid to broadly obovoid, yellowish-white to tan, 6-6.5 $\mathrm{mm}$ long and $5-5.8 \mathrm{~mm}$ wide, $3 \mathrm{~mm}$ thick, densely covered with punctiform raphide cells. Figs. 165 and 168.

Anthurium salvadorense is known only from El Salvador and Guatemala at 500 to $800 \mathrm{~m}$ elevation. It was first collected by Sisto Alberto Padilla in 1922 in the Department of Ahuacapán in El Salvador. The species was later collected by Paul C. Standley in the adjacent Department of Jutiapa in Guatemala.

The species is a typical member of section Pachyneurium and the earlier collections were confused with $A$. schlechtendalii, to which it is related. Anthurium salvadorense is distinguished by being usually a well rooted plant with fewer, very large fleshy roots and a usually almost elliptic blade, but especially by its inflorescence, which has a pale green, ovate-lanceolate spathe that is weakly convolute at the base and erect, enshrining the usually short, pale green spadix. Anthurium schlechtendalii differs in having usually oblanceolate blades, a coriaceous, more lanceolate, prominently reflexed, usually purplish spathe, and a more elongate, purplish spadix.

El SAlVAdOR. AHUACHAPÁN: no other locality, Padilla 296 (US); El Imposible, vicinity San Francisco Menéndez, Bernhardt s.n. (MO); Croat 42092 (MO), 42169 (CAS, F, ITIC, K, MO, SEL, US).

Guatemala. Jutiapa: vicinity Jutiapa, Standley 76313 (F, US); SW of San Cristóbal, Dunn et al. 23222 (UMO). ZACAPA: road to Finca Agua Fría, Croat 41879 (F, MO).

Anthurium salviniae Hemsl., Diagn. Pl. Nov. Mexic. 36. 1878. TYPE: Guatemala. Volcán de Fuego, Salvin s.n. (K).

Anthurium giganteum Matuda, Madroño 10: 169. 1950, non Engl., 1898. Anthurium enormispadix Matuda, Revista Soc. Mex. Hist. Nat. 11: 94. 1950. TyPE: Mexico. Chiapas: Escuintla, Salto de Agua, Matuda 18043 (MEXU, holotype; UC, isotype).

Robust rosulate epiphyte, rarely on rocks; stems short with mass of thick roots; cataphylls thick, fist-like, cucullate, rounded at apex, drying brown, remaining intact, ultimately becoming fibrous at base. LEAVES erect; petioles flattened or sulcate adaxially, rounded abaxially, 5-23 cm long, 1$2 \mathrm{~cm}$ diam.; geniculum $1.6-2 \mathrm{~cm}$ long; blades obovate to oblanceolate, moderately thick, acuminate at apex, attenuate, sometimes cuneate (rarely rounded or subcordate) at base, (32) 40$180 \mathrm{~cm}$ long, (9)13-50 cm wide; both surfaces semiglossy; the midrib acutely raised above and below; primary lateral veins 9-14 per side, raised above and below; lesser veins less conspicuous. INFLORESCENCE usually pendent, shorter than leaves; peduncle 16-80 cm long; spathe lanceolate-linear, moderately thin, purple or green sometimes tinged purple, 4-45(50) $\mathrm{cm}$ long, 1$5 \mathrm{~cm}$ wide; gradually cuspidate-acuminate at apex, rounded to truncate at base; spadix dull green soon tinged throughout with lavender (B \& K Purple 6/5), 6-34(47) cm long, 0.6-1.5 cm diam. at base, $2-7 \mathrm{~mm}$ diam. at apex; flowers rhombic, $2.4-2.5 \mathrm{~mm}$ in both directions, the sides straight to sigmoid; 6-7 flowers visible in the principal spiral, 8-12 flowers visible in the alternate spiral; tepals matte, lateral tepals 1.2-1.3 $\mathrm{mm}$ wide, the inner margins broadly rounded; pistils green, emergent but not raised; stigma linear, ca. $0.9 \mathrm{~mm}$ long; stamens emerging in a slow progression from the base; anthers pale yellow, held at edge of tepals and laying over pistil; thecae ellipsoid; pollen pale yellow-orange, fading to white. INFRUCTESCENCE with spadix to $60 \mathrm{~cm}$ long; berries red, oblong-elliptic, rounded at apex, $1-1.5 \mathrm{~cm}$ long; seeds 2 , oblong, flattened, $3.3 \mathrm{~mm}$ long. Figs. 166 and 167.

The species occurs in western Mexico (Chiapas) along the Pacific slope of Guatemala and along both the Atlantic and Pacific slopes from Nicaragua to Panama. There is also a single collection from Honduras (Atlantic slope) that appears to be this species. The species also occurs in Colombia and has been collected in Chigorodó and Dabeiba in Antioquia. Anthurium salviniae occurs from near sea level to $1,400 \mathrm{~m}$, in wetter parts of tropical moist forest, in premontane wet, tropical wet, and also, rarely, in premontane rain forest.

Anthurium salviniae has long been called $A$. tetragonum but that name is a synonym of $A$. schlechtendalii, a species ranging from Mexico to Honduras or Nicaragua on the Atlantic slope. Although leaves of the two species are very similar, A. salviniae is a member of section Pachyneurium and can be distinguished by its longtapered, pale lavender spadix, long-tapered 


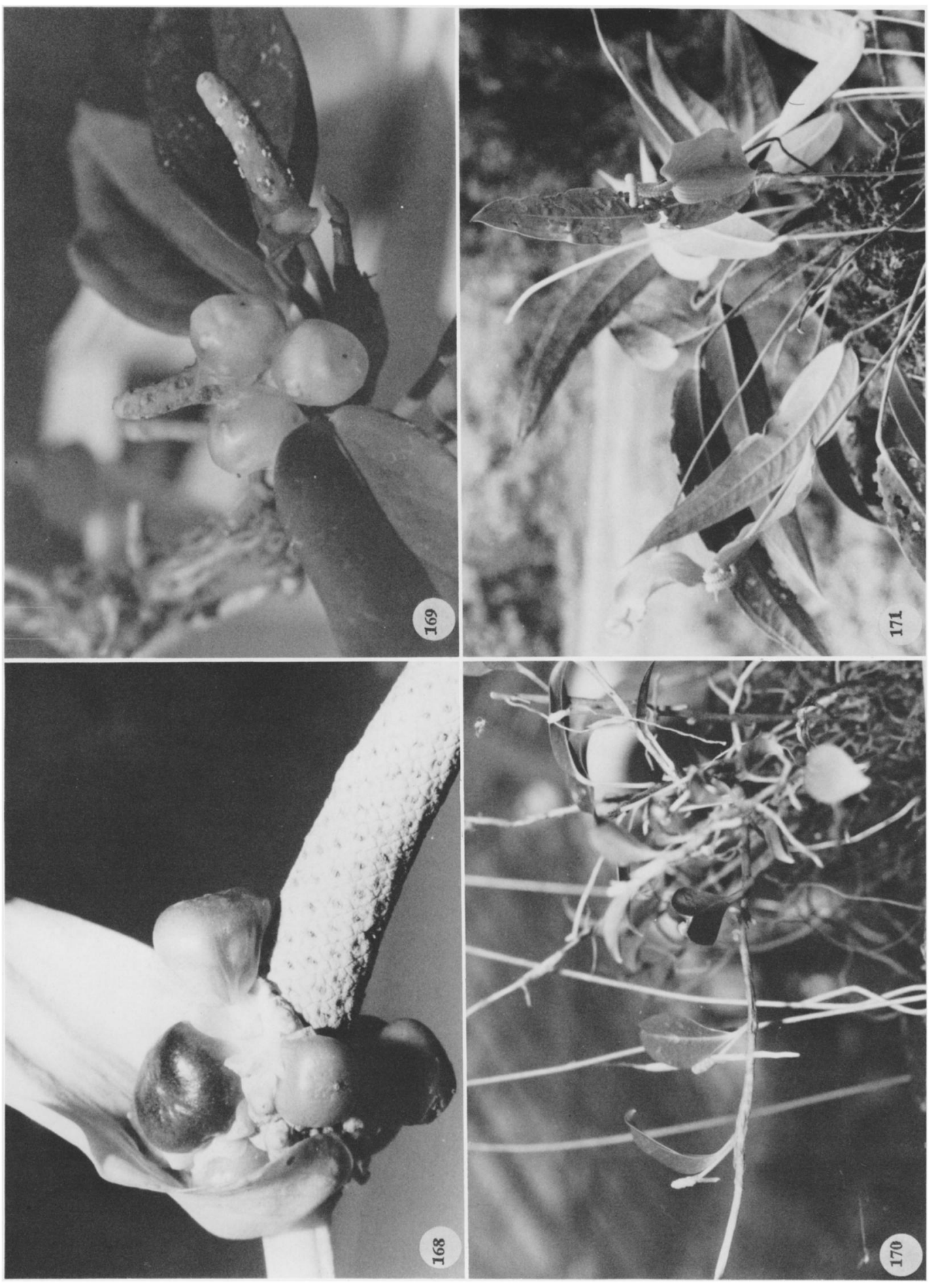


spreading spathe, and fist-shaped, cucullate cataphylls. In addition the leaves of $A$. salviniae usually dry darker and thinner. Anthurium schlechtendalii usually has a shorter, blunter spadix and a short, thick spathe that is usually reflexed and often twisted. The spadix is darker violet-purple and is not at all glaucous at anthesis.

A collection in cultivation at Missouri Botanical Garden from the Río Maje region of Panama in Panamá Province is unusual in having dark violet-purple rather than red berries.

Costa Rica. alajuela: N of Bijagua, Croat 36480 (MO); NW of Zarcero, Croat 43640 (MO). CARTAGO: SE of Platanillo, Croat 36808 (MO); NE of Tapantí, Lent $1034(\mathrm{GH})$. GUANACASTE: vicinity of Tilarán, Standley \& Valerio 44445 (US). PUNTARENAS: vicinity San Vito de Java, Croat 32898 (MO).

GuATEMALA. ESCUINTLA: between Escuintla and Santa Lucía Cotz, Standley 63469 (F). RETALHule: region of Ajaxá, Standley 88227 (F); W of Retalhule, Standley 87499,88391 (F). SAN MARCOS: La Trinidad, Croat 40902, 40903 (MO). SANTA ROSA: near Cuilapilla, Standley 78060 (F); Naranjo, Hyde \& Lux 4278 (NY, US). SACATEPEQUEZ: near Las Lajas, Standley 58294 (F). SUCHITEPEQuez: E of Mazatenango, Croat 32786 (MO).

HondurAs. ATLÁNTIDA: Lancetilla Valley near Tela, Standley 53228 (US).

Mexico. ChiApas: Escuintla, Croat 43845, 43877 (MO); Matuda s.n., 18630 (MEXU); Matuda 16377 (F, MEXU, MO); Matuda 16776 (F, MEXU); Matuda 18043 (MEXU, UCLA); Matuda 18381 (DS, MEXU); Matuda 18519 (DS, MEXU, UCLA); between Finca California and summit of Monte Ovando, Croat 47572, 47573 (MO); Guatimoc, Miranda 1763 (MEXU).

Nicaragua. Río SAN JUAN: San Juan del Norte (Greytown), Smith 87 (MO). ZELAYA: S slope of Cerro El Inocente, Stevens 6793 (MO).

Anthurium scandens (Aubl.) Engl., Mart. Fl. Bras. III. 2: 78. 1878 .

a. Anthurium scandens ssp. scandens. Dracontium scandens Aubl., Hist. Pl. Guiana Franc. 2: 836. 1775. TYPE: French Guiana. (Drawing by Plumier in Amer. Nascentium Icon. tab. 74. 1703. BM, P.)

Pothos violacea Swartz, Prodr. 32. 1788. TYPE: Jamaica, Swartz S.n. (not seen).

Dracontium repens Descourt., Fl. Antill. 7: t. 499. 1829. TYPE: (Plate 499 serves as the type.)

Anthurium violaceum (Swartz) Schott, Melet. 22. 1832. TYPE: Swartz S.n. (not seen)

Anthurium violaceum forma latifolia Kunth, Enum. Pl. 3: 68. 1841. TYPE: (not seen).

Anthurium violaceum forma angustifolia Kunth, Enum. P1. 3: 68. 1841. TYPE: (not seen).

Anthurium leucocarpum Schott, Oesterr. Bot. Wochenbl. 7: 53. 1857. TYPE: Mexico. Schiede (Not seen.) (Photos of Schott Aroid Drawing \#279,
NYGB Neg. \#N.S. 3804 and Schott Aroid Drawing \#282, NYBG Neg. \#N.S. 3805.)

Anthurium dolosum Schott, Oesterr. Bot. Z. 8: 179.

1858. TYPE: Guatemala. Near San Pedro and San Lucia, Wendland 273 (GOET, hololectotype; K, isolectotype; here designated).

Anthurium rigidulum Schott, Oesterr. Bot. Z. 8: 180. 1858. Type: Costa Rica. San José, Hoffmann 508 (Photo of Schott Aroid Drawing \#270, NYBG Neg. \#N.S. 3807).

Anthurium virgosum Schott, Oesterr. Bot. Z. 9: 100 1859. TYPE: Brazil. Río de Janeiro, Riedel (K).

Epiphytic creeper; stems usually less than $1 \mathrm{~m}$ long; roots numerous along stem, ca. $3 \mathrm{~mm}$ diam., gray-green; cataphylls 3-6 cm long, drying brown, weathering to reticulate fibers and persisting around stem. LEAVES spreading; petioles sharply sulcate, rounded abaxially, $2-8.5 \mathrm{~cm}$ long, 2$3 \mathrm{~mm}$ diam.; geniculum $2-3 \mathrm{~mm}$ long, nearly obscure; blades ovate-elliptic to lanceolate-elliptic, moderately thick, (3.5)6-13 cm long, (1.5)2$5 \mathrm{~cm}$ wide, short-acuminate at apex, acute to rounded at base; upper surface semiglossy, lower surface conspicuously brown punctate; the midrib acutely raised above, diminished and sunken in apical half of blade, convexly raised below; primary lateral veins 3-10 per side (sometimes more), departing midrib at $35^{\circ}-40^{\circ}$ angle, weakly sunken above, \pm obscure above and below; collective vein arising from the base, extending straight to apex, 3-5 $\mathrm{mm}$ from the margin. INFLORESCENCE erect to pendent, shorter than leaves; peduncle $1.5-6.5 \mathrm{~cm}$ long, $1-1.3 \mathrm{~mm}$ diam., equalling or longer than petioles; spathe pale green, ovate to narrowly ovate, $8-16 \mathrm{~mm}$ long, ca. $4 \mathrm{~mm}$ wide, reflexed at anthesis, abruptly acuminate at apex; spadix yellow-green, sometimes becoming lavender, $1.3-2 \mathrm{~cm}$ long, 2-3 $\mathrm{mm}$ diam. midway; flowers rhombic, $2-4 \mathrm{~mm}$ in both directions, the sides straight to sigmoid; 2-3 flowers visible in either spiral; tepals semiglossy, lateral tepals ca. $1.2 \mathrm{~mm}$ wide, the inner margin weakly concave to \pm straight; pistil greenish-white, scarcely emergent; stigma brushlike, exserted, ca. $0.2 \mathrm{~mm}$ long; stamens emerging in a prompt and complete sequence from the base, held at edge of tepals and inclined over pistil; anthers white; thecae ovate, somewhat divaricate; pollen white. INFRUCTESCENCE spreading, the spathe persisting; spadix $2.5-3.5$ $\mathrm{cm}$ long, to $7 \mathrm{~mm}$ diam.; berries usually pale violet to almost white, sometimes purple, obovoid, rounded at apex, 5-8 $\mathrm{mm}$ wide; seeds 1 or 2 per locule, pale yellow, ovoid, ca. $2 \mathrm{~mm}$ long, $1 \mathrm{~mm}$ wide. Fig. 169. 
Anthurium scandens is known from southern Mexico and the West Indies to southern Brazil, ranging from sea level to $2,700 \mathrm{~m}$. This is the most widespread aroid in the New World and, doubtless, the most ecologically diverse as well, occurring in tropical moist, premontane wet, tropical wet, premontane rain, and lower montane rain forest life zones.

The species is a member of section Tetraspermium and is distinguished by its more or less scandent habit, elongate internodes with usually persistent cataphylls, usually oblong-elliptic, glandular-punctate blades, reflexed green, more or less ovate spathe, cylindroid, usually pale green spadix, and pale lavender to almost white berries.

According to Sheffer et al. (1980), the great variability in the species is due at least in part to the fact that it represents a polyploid complex containing diploids, tetraploids, and heptaploids. The cytology of the group is insufficiently known, so it is not certain whether the different ploidy levels are correlated with morphological variation.

The species is closely related to $A$. trinerve, with which it has long been confused. The differences separating the two species are outlined in the key. Anthurium scandens is most easily distinguished by its spathe, which is reflexed at anthesis, whereas the spathe of $A$. trinerve is persistently erect even after anthesis.

BELIZE. CAYO DISTRICT: no other location, Lundell 6255 (MICH); vicinity of Cuevas, S of Millionario, Croat 23592 (MO); Roaring Creek, Dwyer 12690 (MO). STANN CREEK DISTRICT: Stann Creek Railroad, Schipp 78 (MICH, MO, UC); N of Victoria Peak, Gentry 7912 (MO). TOLEDO DISTRICT: W of Columbia Forest Station, Croat 24309 (MO, DAV); Dwyer 9946 (MO).

CosTA RicA. No other location, Brade 2518 (BR). ALAJUELA: Laguna de A. Ruiz, Rodrigues 264, 280 (UC); NW of Cariblanco, Luteyn 3216 (MO); W of Fortuna, Taylor 11711 (MO); NW of Zarcero, Croat 43530 (MO); Smith 230 (MO). CARTAGO: no other location, Brade 2506 (BR); E of Cachí, Croat 47082, 47083 (MO); Cartago, Brade 2500 (BR); SE of Cartago, Harmon \& Fuentes 6315 (MO, UMO); La Carpintera, Allen 514 (MO); Brade 2515 (BR); near Las Cancavas, Hunnewell 16564 (WIS); between Moravia and Quebrada Platanillo, Croat 36632 (MO); Peralta, Stork 494 (UC); Tapantí, Tissene 1284 (WIS); Trinidad, Luteyn \& Wilbur 4484 (DUKE, MO); SE of Trinidad, Wilbur \& Luteyn 18682 (DUKE); W of Turrialba, Croat 36846 (MO); Volcán Irazú, Moore 6670 (BH). GUANACASTE: Aguas Calientes, Pittier 1160 (BR); La Lagunilla, Pittier 10473 (BR); NW edge of Lake Arenal, Croat 1033 (MO); La Palma, Greenman \& Greenman 5446 (MO). HEREDIA: S of San Miguel, Lent 36 (DAV); Vara Blanca,
Skutch 3665 (MICH, MO); Volcán Barba, Brade 2509 (BR). LIMÓN: Hacienda Tapezco-Hda. La Suerte, W of Tortuguero, Davidson 6935 (MO); vicinity USDA Rubber Experimental Station, Talamanca, Pittier \& Tonduz 9227, 9235 (BR); Tonduz 9511 (BR). PUNTARENAS: Las Cruces Botanical Garden, Peterson J-2243 (BH); Osa Peninsula, W of park headquarters at Sirena, Liesner 2906 (MO); Rincón de Osa, Liesner 1701, 1804, 1997 (MO); N of San Vito, Davidson 7153 (MO); Stevens 232 (MO); SAN JOSÉ: without further locality, Brade 2501 (BR); Pittier 2445 (BR); at Cascajal, Utley 5237 (DUKE); Lent 2090 (MO); N of Hwy. 12, Croat 43386 (MO); between Río Paquita and Río Viejo, Dodge \& Goerger 9826 (MO); N of San Isidro del General, Harmon \& Fuentes 6229 (MO, UMO); between San Isidro del General and Dominical, Croat 35333 (MO); vicinity San José, Pittier 1240 (BR); Tonduz 1255 (BR); Santa María de Dota, Pittier 2488 (BR); lower eastern slopes of Volcán Barba, Luteyn 3575 (MO); beyond end of Calle Yerbabuena, Luteyn 3369 (MO). SAN JOSÉ \& CARTAGO: SE of Casa Mata, Utley 4743 (DUKE).

El Salvador. Santa ana: Finca La Cumbre, Montalvo 3252 (MO); Weberling \& Lagos 1086 (GOET).

Guatemala. alta verapaz: Cobán, Tuerckheim 1355 (MO), 1923 (BR, MO); vicinity Cubilhuitz, Steyermark 44357 (MO); road to El Estor, Croat 41489 (MO); near Tucurú, Standley 70725 (MO). BAJA VERAPAZ: along hwy. ca. $14 \mathrm{mi}$ to Cobán, about $1 \mathrm{mi} \mathrm{S}$ of turnoff to Salamá, Croat 41146 (MO). HUEHUETENANGO: between Maxbal and Xoxlac, Steyermark 48978 (MO). PETÉN: El Rosario, Harmon \& Fuentes 5780 (UMO); Santa Teresa, Lundell 2671 (MICH); Tikal National Park, Lundell 16671 (DS); Tikal, Contreras 1128 (DAV); Harmon \& Fuentes 5833 (UMO). SACATEPEQUEZ: SW of Alotenango, Croat 42029 (MO). SAN MARCOS: Finca El Porvenir, Steyermark 37542 (MO). SUCHITEPEQUEZ: near Mazatenango, Bernoulli 388 (BR). ZACAPA: along Rillito from Volcán de Monos, Steyermark 42342 (MO).

Honduras. ATLÁNTIDA: above Lancetilla, Yuncker 4557 (MICH). COMAYAGUA: Jardines, Barkley \& Smith 40875 (MO); near El Achiote, Yuncker et al. 5980 (MO). COPÁN: W of Copán, Croat 42519 (MO); Forest Monte Grueso, Cuellar \& Hernandez 5181 (MO). CORTÉS: N of Lake Yojoa, Croat 42727, 42738 (MO); Lake Yojoa, Yuncker 4836, 4880 (MICH, MO). EL PARAíso: trail, Danlí to Finca La Emilia, Carlson 2563 (MICH). MORAZÁN: Hoya Grande, Williams \& Molina 10037 (MO); between Tegucigalpa and El Zamorano, Clewell 3664 (MO).

Mexico. Chiapas: Munic. of Berriozábal, Breedlove 20286 (MICH, MO); Miranda 6723 (MEXU); Moore \& Brossard 6327 (BH); Cerro Baúl, Croat 47669 (MO); SW of Comitán, Carlson $1820(\mathrm{MICH})$; vicinity Comitán, Miranda 2697 (MEXU); between Ixtapa and Pichucalco, Croat 47837 (MO); Lake Montebello, Croat 46658 (MO); Monte Ovando, Matuda 2097, 4205 (MEXU, MICH); Matuda 17911 (MEXU); Ocozocoautla de Espinosa, Carlson 2103 (MICH); Rzedowski 614 (MEXU); S of Palenque, Thorne \& Lathrop 40565 (RSA); Munic. Pichucalco, Gilly \& Hernandez 113 (MICH); Munic. Pueblo Nuevo Solistahuacán, Kennedy et al. 1443 (MO); San Juan Panama, Matuda 18175 (MEXU); Siltepec, Matuda 18301 (MEXU); between Tapachula and Unión Juárez, Croat 47207 (MO); ruins of Bonampak, Hoover 192, 208 (MO). JALISCO: 
Autlán, McVaugh 10219 (MEXU, MICH); Wilbur \& Wilbur 1738 (MICH). OAXACA: between Teotitlán del Camino and Santa María Chilchotla, Croat 48323, 48385 (MO); between Tuxtepec and Oaxaca, Croat 47983 (MO). PUEBla: Hueytamalco, Conrad 88, 152 (MEXU); Teziutlán, Gold 253 (MEXU). TABASCO: Sheffer 225, 226 (UH); Teapa, Birdsey 235 (UC); Conrad 2873 (MO); Gilly \& Hernandez 213 (MEXU, $\mathrm{MICH})$. VERACRUZ: Schnee $V(\mathrm{MEXU})$; Rancho la Laguna, Chazaro 771 (JAL); near Pedre al Rumbo, Lot et al. 1815 (MEXU); Coatepec, Dorantes 1800 (MICH, MO); Ventura 10382 (MEXU, UMO); Zola \& Baker 98 (XAL); Atoyac, Matuda 1411 (MEXU, MICH, MO); Lake Catemaco, Gonzales 856 (MEXU, MICH); Sousa 19 (MEXU); E of Córdoba, Lundell \& Lundell 12532 (MICH); Matuda S-150 (MICH); Matuda 838 (MEXU, MICH); between Córdoba \& Fortín, Miranda 620, 4836 (MEXU); Córdoba, Rowell et al. 17 M663 (MEXU); Rzedowski 18895 (MEXU, MICH); Coyame, Beaman 5296 (MEXU); El Mirador, E of Huatusco, Croat 44011 (MO); vicinity of Huatusco, Moore \& Bunting 8854 (BH); vicinity of Mirador, Ventura 5421 (MICH); Fortín, Kerber 293 (MICH); Kerber 294 (BR); Lot 537 (XAL); Hidalgotitlán, Dorantes 3002 (XAL); Dorantes 3088 (MEXU); Valdivia 113, 225, 439, 952, 1048, 1404, 1567, 1615 (MEXU, MO); 382 (XAL); 1127, 1680 (MO); 1217 (MEXU); Valdivia \& Matuda 517 (XAL, MO); 1099 (XAL); Jalapa, Barkley et al. 2600 (MEXU, MICH); Boege 2058 (MEXU); Dorantes 124 (BR, MO, XAL); Sousa 4844 (MEXU); Jesús Carranza, Vazquez 703 (XAL); Misantla, Ventura 7153 (DS, MICH, MO); Ocotal Grande, Beaman 5451 (MEXU); Orizaba, Moore 6211 (BH, UC); Pedregal, Yanez 538 (F); San Andrés Tuxtla, Kennedy \& Howitz 3677 (MICH, MO); Trigos 88 (MEXU); 160 (XAL) vicinity Santiago Tuxtla, Beaman 6411 (F, XAL); Sousa 2419 (MEXU); vicinity Barra de Sontecomapan, Beutelspacher s.n. 15/3/69 (MEXU); Hernandez y Trigos s.n. (MEXU); vic. Tlapacoyan, Goméz-Pompa \& Nevling 1144 (XAL); Zomajapa, Valdivia 2112 (XAL); Yecuatla, Goméz-Pompa \& Riba 161 (MEXU); GomézPompa 1838 (MEXU); vicinity Zacualpan, Galeotti 6052 (BR); Purpus 5764 (UC, MO); Zongolica, Santos 3680 (MICH); Valdivia 2141 (XAL).

Nicaragua. Granada: Finca Cutirre, Atwood AN64 (MO); Volcán Mombacho above Finca Las Delicias, Atwood A50 (MO); SE flank of Mombacho, Neill N30, N56 (MO); Stevens 4365 (MO); Croat 39116 (MO). JiNOTEGA: Cerro Zamaria, Atwood AN118 (MO); NW side of Lake Abanas, Croat 42989 (MO); vicinity El Crucero, Stevens 3500 (MO); between La Danta and La Luna, Stevens 9630 (MO). MATAgalpa: vicinity Matagalpa, Williams \& Molina 42548 (MICH); vicinity Sébaco, Webster et al. 12506 (DAV); Tuma Village, Atwood A69 (MO). NUEVo SEGOVIA: N of San Fernando, Stevens 3300 (MO). ZElAYA: Caño Zamora, Stevens 8826 (MO); trail from Cerro El Inocente to Cerro Saslaya, Stevens 6696 (MO); vicinity Waní, Stevens 7341 (MO).

b. Anthurium scandens ssp. pusillum Sheffer, Aroideana 3(3): 86. 1980. TYPE: Costa Rica. Cartago: Southeast of Tapantí, Río Grande de Orosi, 1,400 m, 16 April 1967, R. W. Lent 830 (F, holotype).
Anthurium scandens ssp. pusillum occurs from Honduras to Colombia and Venezuela at elevations of 600 to $2,500 \mathrm{~m}$ in lower montane moist, premontane wet, lower montane rain, and premontane rain forest life zones.

The subspecies pusillum differs from the typical subspecies in usually having a much smaller spadix (usually with fewer than 13 flowers), usually 2-10 mm long. Sheffer (1974) believes that the subspecies may represent one of the diploids upon which the polyploid complex has been built. Fig. 170.

Costa Rica. Cartago: E of Cachí, Croat 47062 (MO); Carpintera, Stork 1143 (MICH); S of Muñeco, Luteyn 3880 (DUKE, MO); Tapantí, Croat 47048 (MO). SAN JosÉ: along CR 220, Luteyn 3593 (DUKE); San Josecito, Primack \& Luteyn 353 (DUKE).

NICARAGUA. JinOtega: vicinity Aranjuez, Stevens 5606, 5936 (MO). ZELAYA: trail from Cerro El Inocente to Cerro Saslaya, Stevens 6695 (MO).

Anthurium scherzerianum Schott, Oesterr. Bot. Wochenbl. 7: 53. 1857. TYPE: Guatemala, Scherzers.n. (B, holotype (2 sheets); BP, isotype).

Epiphytic or terrestrial; stems very short, roots numerous, thin; cataphylls thick, to $1.5 \mathrm{~cm}$ long, caudate at apex, drying brown, persisting as fibers. LEAVES spreading; petioles terete, 4-20 cm long, 1-3 mm diam.; geniculum 4-7 mm long; blades moderately thick, linear to elliptic or lanceolate, 5-26 cm long, $1.5-6.5 \mathrm{~cm}$ wide, narrowly acuminate at apex, obtuse to cuneate at base; upper surface semiglossy, the lower surface matte, both surfaces densely punctate; the midrib acutely raised above, sunken at apex; prominulous below; primary lateral veins 8-11 per side, departing midrib at $45^{\circ}$ angle, nearly obscure above and below, loop-connecting to collective vein, lesser veins obscure; collective vein arising from near the base or one of the lowermost primary lateral veins, $1-3 \mathrm{~mm}$ from the margin. INFLORESCENCE erect, equalling or longer than leaves; the peduncle $14-52 \mathrm{~cm}$ long, ca. $2 \mathrm{~mm}$ diam.; spathe moderately thick, bright red-orange (B \& K Red 7/2.5), elliptic to ovate, $3.7-12 \mathrm{~cm}$ long, $2.4-6 \mathrm{~cm}$ wide, abruptly short-acuminate at apex, cordate at base (the lobes sometimes overlapping); spadix pale orange to red, 2-8 $\mathrm{cm}$ long, ca. $4 \mathrm{~mm}$ diam. midway, tapered at apex and usually coiled; flowers square, $2 \mathrm{~mm}$ in both directions, the sides straight to \pm sigmoid, 2-3 flowers visible in the principal spiral, 5-6 flowers visible in the alternate spiral; 
tepals glossy, sparsely and minutely papillate, lateral tepals ca. $1.3 \mathrm{~mm}$ long; pistil weakly emergent, somewhat translucent; stigma linear, 0.4$0.6 \mathrm{~mm}$ long; stamens emerging from base, the first lateral preceding second by $2-3$ spirals, the laterals emerged well above midway before alternates emerge, exserted on flattened, short filaments, ca. $3 \mathrm{~mm}$ long, $0.5 \mathrm{~mm}$ wide; anthers white, held at edge of tepals, ca. $0.3 \mathrm{~mm}$ long, 0.5-0.7 mm wide; thecae ellipsoid, slightly divaricate; pollen white. INFRUCTESCENCE with orange to red berries. Fig. 171.

The species is found in Costa Rica at elevations of 1,300 to $2,100 \mathrm{~m}$ in premontane rain, lower montane rain, and montane rain forest life zones on the Atlantic slope of the Cordillera Central and the Cordillera de Talamanca. It has been collected most commonly in the Tapantí and La Hondura areas.

Anthurium scherzerianum is a member of section Porphyrochitonium and is easily recognized by the large, showy, bright orange or red-orange to red spathe, and coiled spadix. The species is now commonly cultivated throughout the world and about 40 different forms are recognized in cultivation. The species has no close relatives.

The type of $A$. scherzerianum was believed to have been collected in Guatemala; however since that time no other collections have been seen from that country. So far the species has been found only in Costa Rica, where it is plentiful, and it is likely that the type was collected there.

Costa Rica. alajuela: edge of Lake Hule, Luteyn 3221, 3351 (DUKE). CARTAGO: no other location, Burger \& Stolze 5621 (NY, WIS); S of Cartago, Maxon 503 (NY); Stork 1913, 4534 (UC); Navarro Valley, Stork 1701 (MICH); between Quebrada Honda and Río Sombrero, Luteyn 3232 (DUKE, MO); SE of Orosi, Lellinger \& White 1486 (MO); below Palo Verde, Luteyn 3339 (DUKE, MO); Río Sombrero, Luteyn et al. 4528 (DUKE); Tapantí, Croat 36077 (MO); Lent 836 (NY); Taylor 4468 (MO, NY); Tessene 1296 (WIS); Turrialba, Brade 2504 (BR). HEREDIA: S of Cariblanco, Croat 35800 (MO); N of Vara Blanca, Croat 35583 (MO). SAN José: Santa María de Dota, Stork 1883 (MICH, UC); Tablazo, Pittier 7909 (BR).

Anthurium schlechtendalii Kunth, Enum. Pl. 3: 75. 1841 .

a. Anthurium schlechtendalii ssp. schlechtendalii. TYPE: Mexico. Hacienda de la Laguna, Schiede \& Deppe (not seen).

Anthurium mexicanum Liebm., Vidensk. Meddel. Dansk Naturhist. Foren. Kjøbenhavn 1: 21. 1849.
TYPE: Mexico. Veracruz: between Colipa \& Misantla (not seen).

Anthurium kunthianum Liebm., Ann. Sci. Nat. Bot., Ser. IV, 2: 372. 1854. TYPE: Mexico (no type cited). Anthurium brachygonatum Schott, Prod. Aroid. 468. 1860. TYPE: Mexico. Veracruz: Cordoba, Kerber s.n. (B) (see discussion).

Anthurium tetragonum Hook. ex Schott, Prod. Aroid. 475. 1860. TYPE: Locality unknown (not seen).

Anthurium fortinense Engl., Bot. Jahrb. Syst. 25: 366. 1898. TyPE: Mexico. Veracruz: Fortin, Kerber $9 b$ (B).

Anthurium tikalense C. Lundell, Wrightia 3: 161, Fig. 55. 1966. TYPE: Guatemala. Petén: Tikal National Park, on temple in Group "H," March 1, 1961, C. L. Lundell 18198 (LL).

Usually epiphytic, sometimes epipetric; stem usually short, $2.5-5.5 \mathrm{~cm}$ diam.; internodes and leaf scars hidden by dense mass of thick, greenish roots, 3-8 $\mathrm{mm}$ diam.; cataphylls moderately thick, $7.5-16 \mathrm{~cm}$ long, caudate-apiculate at apex, drying brown, persisting as reticulate fibers. LEAVES erect; petioles $12-23 \mathrm{~cm}$ long, $0.5-2$ $\mathrm{cm}$ wide, trapezoidal, the abaxial margins sometimes sharply to obtusely ribbed, widest adaxially, shallowly sulcate; geniculum 1-2 cm long; blades obovate-elliptic, thick, acute to short-acuminate at apex, acute to obtuse at base, 30-112 cm long, $10-58 \mathrm{~cm}$ wide; broadest near or above middle; both surfaces matte to semiglossy; midrib flat to weakly rounded at base above, becoming more acute sometimes weakly ribbed, diminished and sunken at apex, raised and square at base below, rounded at apex; primary lateral veins 15-16 per side, raised on both surfaces, departing midrib at $50^{\circ}$ angle, straight nearly to margin, then arching toward apex, lesser veins scarcely visible; collective vein arising from primary lateral vein in apical one quarter of blade, 2-5 $\mathrm{mm}$ from margin, sunken above, raised below. INFLORESCENCE spreading, shorter than leaves; peduncle 33-43 cm long, 6-11 mm diam., terete to weakly flattened and ribbed; spathe coriaceous, green heavily tinged with violet-purple, linear-lanceolate to lanceolate, $15-28 \mathrm{~cm}$ long, $1.5-5 \mathrm{~cm}$ wide, acuminate at apex, obtuse at base, strongly reflexed, inserted at $70^{\circ}$ angle on peduncle; spadix green, 8-29 cm long, $1.7-2 \mathrm{~cm}$ diam. at base, 4-6 $\mathrm{mm}$ diam. at apex; flowers square, $2.2-2.6 \mathrm{~mm}$ in both directions, the sides straight to weakly sigmoid; 7-17 flowers visible in the principal spiral, 10-14 flowers visible in the alternate spiral; tepals green, matte, with purple punctations, the outer margins purplish, lateral tepals $1.1-1.3 \mathrm{~mm}$ wide, the inner margins convex, turned up against pistils; pistils emergent 
to $1 \mathrm{~mm}$, dark purple; stigma linear, $0.8 \mathrm{~mm}$ long, with minute droplet ca. 4 days before stamens emerge, dry, black as stamens emerge; stamens emerging rapidly from the base, lateral stamens emerging to midway before alternate stamens emerge, exserted on translucent filaments, ca. $0.5 \mathrm{~mm}$ long, $1 \mathrm{~mm}$ wide, which retract to hold anthers at side and inclined over pistil; anthers pale orange, $0.9 \mathrm{~mm}$ in both directions; thecae \pm oblong, scarcely divaricate; pollen pale orange fading to cream. INFRUCTESCENCE arching-pendent; spathe brown, persistent; spadix up to $65 \mathrm{~cm}$ long, $5 \mathrm{~cm}$ diam.; berries bright red, lanceolate-elliptic $1-1.5 \mathrm{~cm}$ long; pericarp thick; mesocarp pulpy, white, with numerous raphide cells; seeds 2 , greenish-white, 5.5-6 mm long, ca. $1.5 \mathrm{~mm}$ wide. Figs. 172 and 173.

Anthurium schlechtendalii is in section Pachyneurium and consists of two subspecies. The subspecies schlechtendalii ranges from Mexico (central Veracruz) to Nicaragua on the Atlantic slope at an elevational range from near sea level to $1,600 \mathrm{~m}$ (most commonly below 1,000 m).

This species is most closely related to A. schlechtendalii ssp. jimenezii from the Pacific slope of Mexico, which differs by occurring in seasonally drier habitats, by its generally smaller leaves, and by its frequently narrowly ovate, usually erect spathe.

Anthurium schlechtendalii merges into the range of $A$. salviniae only in a few areas in the mountains of southeastern Chiapas, such as on Monte Ovando, where both species were seen growing. Specimens collected in the municipios of Siltepec, Escuintla, and Acacoyagua tend to have leaf blades approaching the texture of those of $A$. salviniae but have the inflorescences and cataphylls of typical $A$. schlechtendalii. See discussion following $A$. salviniae for separation characters for these two taxa.

In discussing Mexican aroids, Bunting (1965) included an illustration of a plant cultivated at Cornell University and reputedly collected by $\mathrm{H}$. Moore in Mexico. This is almost certainly $A$. crenatum (L.) Kunth from the West Indies and perhaps represents a mixing of labels in the greenhouse. Two vouchers presumably prepared from this plant (Bunting 1579 and Nicolson 603) tend to confirm this. Anthurium crenatum so far as is known is restricted to Puerto Rico and the Virgin Islands.

Studies of populations of $A$. schlechtendalii in Mexico and elsewhere show most morphological characters to be variable. Petiole shape, although usually trapezoidal in cross-section with the angles moderately acute, may be broadly rounded abaxially, such as those illustrated by Schott for A. brachygonatum [see Schott drawing No. 473 (W)]. Although Bunting (1965) considered this distinct from $A$. schlechtendalii, it is believed to be a form of an unusually variable species.

BeLize. No other location, Schipp S-402 (MICH, MO, NY, UC) BELIzE: Northern River, Gentle 1291 (F); no other location, Bartlett 11325 (MICH); Gracy Rock, Croat 23851, 23896 (MO); Liesner \& Dwyer 1472 (MO). CAYO DISTRICT: no other location, Chanek 53 (MICH, MO); W of Hummingbird Highway, Spellman \& Newey 1984 (MO); vicinity La Flor, S of Grano de Oro, Croat 23811 (MO); Waterhole camp near Vaca, Gentle 2567 (MICH). COROZAL DISTRICT: no other location, Gentle 597 (MICH). ORANGE WALK DISTRICT: Indian Church, Arnason \& Lambert 17186 (MO). TOLEDO DISTRICT: S of Mayan Village of San José, Croat 24297, 24333, 24431 (MO); Vanderveen 658 (MO); Moffredge Lagoon, Gentle 5372 (TEX); Río Grande, Gentle 4723 (TEX).

Guatemala. Alta verapaz: La Tinta, Smith $1530 a$ (US); W of Teleman, Croat 41536, 41551 (MO); between Tucurú and El Estor, Croat 41525, 41529 (MO). ESCUINTLA: SW of Palín, Harmon 2420 (UMO). HUEHUETENANGO: between Ixcán \& Finca San Rafael, Steyermark 49411 (F); below La Libertad, Steyermark 51171 (MO). IZABAL: E of El Estor, Jones \& Facey 3456 (NY, TEX); vicinity Lago Izabal, Jones \& Facey 3437 (NY, TEX); S of Modesto Mendez, Harmon \& Fuentes 2115 (MO, UMO); S of Puerto Barrios, Croat 41802, 41839 (MO); vicinity Quiriguá Viejo, Standley 24053 (NY, US); between Virginia and Lake Izabal, Steyermark 38769 (F). PETÉN: Dolores, Contreras 2254 (LL); El Paso, Herman 14664, 14671 (MICH); Lundell 1573 (MICH); La Libertad, Lundell 2873 (MICH); Macanché Lake, Contreras 920 (LL); Santa Teresa, Lundell 2708 (MICH); 2889 (MICH, NY); Tikal, Bernhardt T6 (MO); Contreras 1618 (LL); Croat 24753 (MO); Lundell 15410 (TEX); Uaxactún, Bartlett 12295 , 12296 (MICH). SAN MARCos: Volcán Tajumulco, Steyermark $37078(\mathrm{~F})$.

HONDURAS. COPÁN: E of Copán, Croat 42508, 42521 (MO). CORTÉs: SW of Omoa, Croat 42564 (MO); vicinity La Pimienta, Molina 5623 (F); S of Porterillos, Croat 42706 (MO); W of Puerto Cortés, Nelson et al. 2904 (MO). SANTA BÁRBARA: NW side of Lake Yojoa, Croat 42757 (MO). YORO: vicinity Coyoles, Yuncker et al. 8132 (MO, NY, US); 8174 (F, MO).

Mexico. ChIAPAS: Acacoyagua, Matuda 19646 (DS); Angel Albino Corzo, Ton 3880 (MAD, DS); vicinity Bochil, Roe et al. 1132 (WIS); Ton 2587 (DS); vicinity Chiapa de Corzo, Breedlove 26872 (DS); Croat 46437 (MO); Miranda 2646 (MEXU); SW of El Jocote, Croat 40706 (MO); Escuintla, Croat 43879 (MO); Matuda 17973, 19645 (MEXU); between Huixtla and Motozintla, Breedlove 28609 (DS); Croat 40766, 47225 (MO); Ixtapa, Laughlin 723 (DS, MICH, NY); 1599 (DS, MEXU, TEX); vicinity Jitotol, Thorne \& Lathrop 41341 (DS); vicinity Las Margaritas, Breedlove 33199, 33446 (DS); vicinity Siltepec, Croat 47250 (MO); $M a-$ 

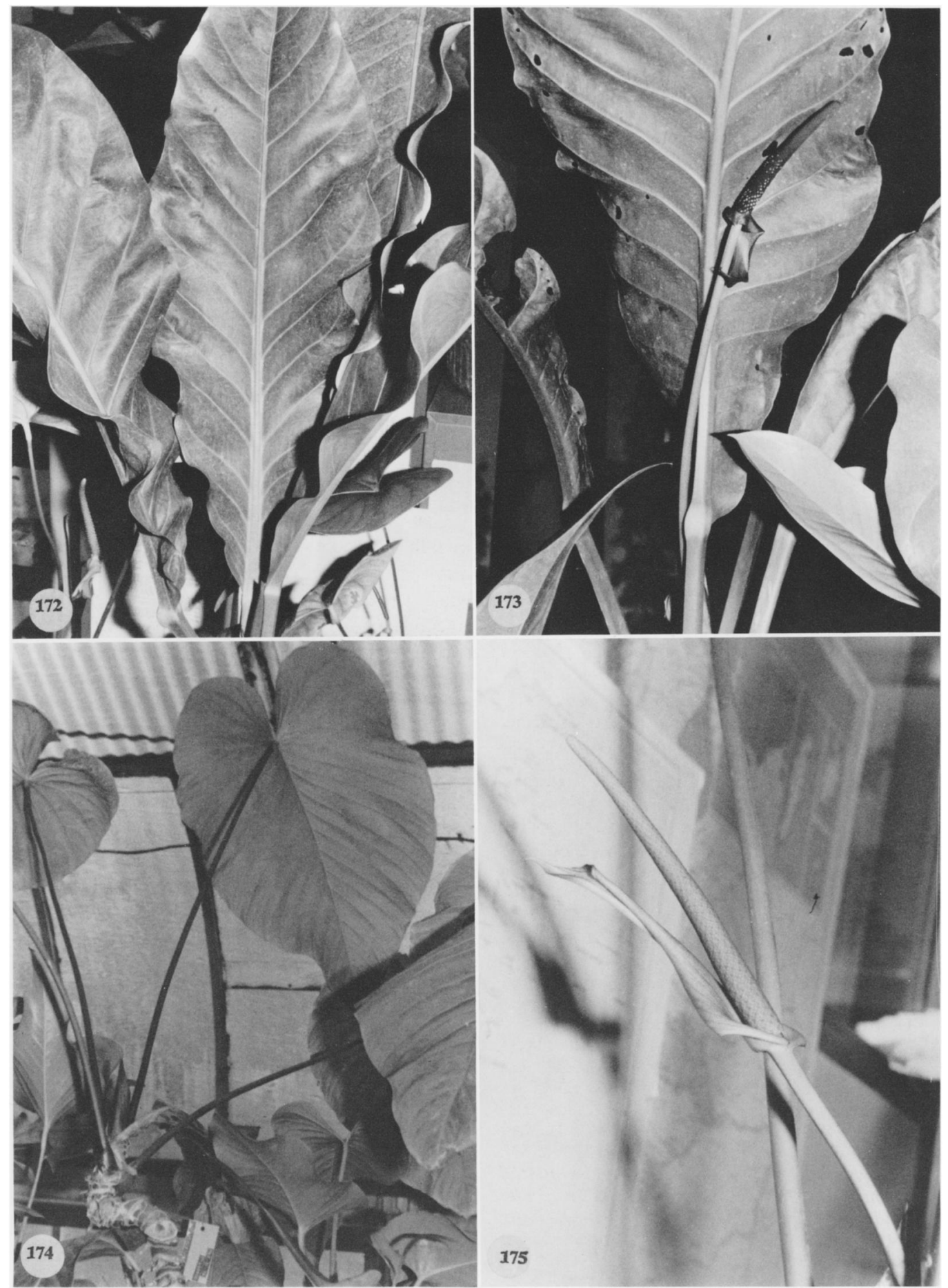

Figures 172-175. 172. Anthurium schlechtendalii Kunth, Croat 40068. - 173. Anthurium schlechtendalii Kunth, Croat 43879. - 174-175. Anthurium schottianum Croat \& Baker, Croat 43247. 
tuda 18798 (MEXU); Ocosingo, ruins of Yaxchilan, Breedlove 33872 (DS); between Palenque and Ocosingo, Croat 40319 (MO); Ocozocoautla de Espinosa, Breedlove \& Smith 21982 (DS, MO); Breedlove 29004, 30358, 36555, 38332 (DS); Croat 40587, 40626, 40653 (MO); MacDougall H261 (NY); vicinity Palenque, Croat 40215 (MO); Hoover 282 (MO); Pichucalco, Breedlove 35048(DS); Croat 40074, 40086 (MO); Gilly \& Hernandez 182 (MICH); vicinity Pueblo Nuevo Solistahuacán, Breedlove 26042 (DS); Roe et al. 1239 (US); Raudales Mal Paso, Quintero 3441 (MEXU); Tenejapa, Breedlove 6242 (DS, F, MICH); 11731 (F, MICH, TEX); Ton 350 (DS); Tuxtla Gutiérrez, Guzmán 13 (MEXU). Guerrero: Minas, Hinton 10125 (GH). NAYARIT: vicinity Tepic and Jalcocotán, Croat 45337 (MO); Dressler 339 (MO); Gentry et al. 10734 (MO). OAXACA: no other location, Calderon $145(\mathrm{GH})$; Cerro Concordia, Morton \& Makrinius 2731 (F, US); Chinantla, Ramirez 144 (MEXU); Matatengo Gorge (Cultivated at MO), Croat 32712, 32717 (MO); Santo Domingo Tehuantepec, Williams 70, 83 (MICH); Temascal, Sousa 936, 1037, 1801 (MEXU); S of Teotitlán del Camino, Croat 48296, 48374 (MO); vicinity Tuxtepec, Calderón 844 (MICH); Conrad \& Conrad 3251 (MO); Miranda 4274 (MEXU); Moore \& Bunting 8907 (BH); Quintero 1820 (MEXU); Rzedowski 25480 , 25483 (US); Sousa 1809, 1825 (MEXU); Webster \& Breckon 15400 (DAV); S of Valle Nacional, Croat 39707, 39708, 39738, 39756 (MO). TABASCO: Balancán, Valdivia 2028, 2052 (XAL); NW of Cardenas, Barlow 26/10 (WIS); E of Teapa, Croat 40109, 47894 (MO); S of Villahermosa, Conrad et al. 2866 (MO); Croat 40068 (MO). verACRUZ: Laivaparu, Purpus 1400 (MICH); Actopan, Ortega-Ortiz 563 (F, XAL); Atoyac, Rosas 1126 (F, XAL); Barra Platanar, Dorantes et al. 1287 (MEXU); Catemaco, Sousa \& Sousa 14 (MEXU); on road to Jalapa, Dorantes 505 (CAS, F, MEXU); Coatepec, Castillo \& Dillon 483, 715 (MO); Cordillera, Galeotti 6055 (BR); Córdoba, Miranda 4894 (MEXU); Cuichapa, Rosas 910 (XAL); Municipio de Dos Ríos, Ventura 930 (MO); vicinity Fortín, Croat 39414 (MO); Fortuno, Coatzacoalcos River, Williams $8940(\mathrm{MICH}$, US); Hidalgotitlán, Dorantes 2862, 3099 (XAL); Valdivia 23, 138, 614, 689, 799, 870, 1038, 1045, 1115, $1315,1343,1622$ (XAL); 171, 236 (XAL, MO); 191, 309, 476, 533 (MEXU); 222, 291, 421, 731, 1165, 1285,1674 (MO); 275, 667, 907, 931, 1196 (XAL, MEXU, MO); 458, 1094 (XAL, MEXU); Vazquez 582 (BM, MO, XAL); vicinity Huatusco, Croat 44000 (MO); Ghiesbreght 70 (P); Moore \& Bunting 8867, 8868 (CU); vicinity Ixhuatlán, Lot 869 (CAS, MEXU); SE of Jalapa, Barkley et al. 2596 (MEXU, TEX); Lake Catemaco, Boege 1257 (MEXU); Minatitlán, Gilly \& Hernandez 253 (MICH); Naolinco, Ortega 556 (MO); Nautla, Fay \& Calzada 925 (XAL); Orizaba, Botteri \& Lumichrast 1602 (P); Croat 39548 (MO); Muller 1314, 1335 (NY); Palmasola, Nevling \& Gomez-Pompa 1274 (MO, XAL); Rancho Viejo, Purpus 15711 (UC); San Andrés Tuxtla, Calzada 455 (MEXU); Dressler \& Jones 8 (MICH, NY, UC); Hernandez \& Vazquez 552 (MEXU); Moore \& Cetto 6232 (BH, MEXU); Soto et al. 16 (F, MO, XAL); above San José de Gracia, Croat 39611 (MO); Santiago Tuxtla, Sousa 2158, 2373 (MEXU); E slopes of Sierra de Los Tuxtla, Cochrane \& Cochrane 8625 (MO); Barra de Sontecomapan, Her- nandez 608 (MEXU); Tapalapa, Gomez-Pompa 5105 (MO); Zacualpán, Purpus 11130 (MY, UC). YUCATÁN: Chichén Itzá, Steere 1124 (MICH); Thompson 437, 438 (MO); S of Mérida, Gaumer 741 (F, MO); Schott 638 (F); N of Muna, Luteyn 2528 (DUKE); Córdoba, Bourgeau 1787 (MEXU, P).

Nicaragua. Chontales: N of Cuapa, Atwood \& Neill $A N 35$ (MO); road from Juigalpa to La Libertad, Stevens 4030 (MO). ESTELí: N of entrance to Estelí, Stevens 5786, 9095 (MO). ZELAYA: near El Recreo, Atwood \& Neill AN233 (MO); S of Siuna, Neill 4226, 4289, 4521 (MO); Stevens 7377, 7383, 7386, 8736, 8753, 8755 (MO).

\section{b. Anthurium schlechtendalii ssp. jimenezii (Ma-} tuda) Croat, comb. nov. Anthurium jimenezii Matuda, Anales Inst. Biol. Univ. Nac. México 32: 147. 1961. Type: Mexico. México: Barranca de Zacualpan on volcanic rocks, $1,300 \mathrm{~m}$ elev., Matuda 37245 (MEXU, holotype).

Usually terrestrial or on rocks, usually $0.5-1$ $\mathrm{m}$ tall; stems less than $30 \mathrm{~cm}$ long, ca. $3-4 \mathrm{~cm}$ diam.; roots moderately thick, directed downward, sometimes curved upward; cataphylls coriaceous, $6-7 \mathrm{~cm}$ long, acute at apex with minute subapical apiculum, drying reddish-brown, remaining \pm intact in upper nodes, ultimately deciduous. LEAVES erect-spreading; petioles 2-15 cm long, 8-9 $\mathrm{mm}$ diam., subquadrangular, broadly and sharply sulcate; geniculum $1-1.5 \mathrm{~cm}$ long; blades oblanceolate to lanceolate, gradually acuminate at apex (the acumen apiculate), obtuse to narrowly rounded at base, broadest at middle, 36-104 cm long, 6-32 cm wide; both surfaces semiglossy, lower surface sometimes having a bluish-green color; midrib slightly raised at base, more acutely raised midway and sunken at apex above, quadrangular and prominently raised below, becoming convex at apex; primary lateral veins $9-14$ per side, departing midrib at $50^{\circ}$ angle, raised above, usually raised below, arcuateascending; interprimary veins weakly sunken above, prominulous below; lesser veins obscure above, visible below; collective vein arising from one of the primary lateral veins in the lower half of blade, 2-4 mm from margin, flat above, prominulous below. INFLORESCENCE erect, shorter than leaves; peduncle $10-54 \mathrm{~cm}$ long, $3-5 \mathrm{~mm}$ diam., terete, longer than petioles; spathe subcoriaceous, green weakly tinged with purple (B \& K Yellow-green 6/5), 4-8.5 cm long, 1-2.5 cm wide, lanceolate, oblique and narrowly acuminate at apex, subcordate at base, broadest just above base, inserted at $30^{\circ}$ angle on peduncle; 
spadix usually sessile, greenish tinged with purple (B \& K Yellow-green 6/5), 3.5-14 cm long, 5-10 $\mathrm{mm}$ diam. at base, $2-5 \mathrm{~mm}$ diam. at apex; the flowers rhombic to sub-4-lobed, $2.7-2.8 \mathrm{~mm}$ long, 2.3-2.5 $\mathrm{mm}$ wide, the sides straight to jaggedly sigmoid; $11-12$ flowers visible in the principal spiral, 7-8 flowers visible in the alternate spiral; the tepals matte, obscurely and sparsely punctate with numerous, irregular droplets at anthesis, lateral tepals $1.5 \mathrm{~mm}$ wide, the inner margin broadly rounded, the outer margin 3-4 sided; pistils weakly emergent, medium green; the stigma $0.5 \mathrm{~mm}$ long, oblong-elliptic; stamens emerging in a prompt complete sequence from the base; the anthers creamy white, leaning over edge of pistol, $0.8 \mathrm{~mm}$ long, $1 \mathrm{~mm}$ wide; thecae oblongelliptic, slightly divaricate; pollen white. INFRUCTESCENCE pendent; berries red, oblongellipsoid, rounded at apex, $11 \mathrm{~mm}$ long, $9 \mathrm{~mm}$ wide; mesocarp with raphide cells dense and numerous throughout; seeds 2, oblong-ellipsoid, tan, flattened, $6 \mathrm{~mm}$ long, $4 \mathrm{~mm}$ wide, $2 \mathrm{~mm}$ thick with pale, punctiform raphide cells, encased in a slender, sticky, gelatinous, apically elongated envelope. Fig. 180.

Anthurium schlechtendalii ssp. jimenezii is endemic to Mexico and is restricted to Guerrero and southern Oaxaca in seasonally very dry forests at 250 to $1,350 \mathrm{~m}$ elevation.

Subspecies jimenezii is recognized by its exclusively terrestrial or rupicolous habit, its thick, oblanceolate leaf blades with usually free-ending primary lateral veins, its purplish spadix, green, lanceolate spathe, and red berries.

This subspecies is geographically isolated from the typical subspecies of $A$. schlechtendalii, which is found in northern Oaxaca and also on the eastern side of the Isthmus of Tehuantepec but not in eastern Oaxaca. Subspecies jimenezii differs from the typical subspecies in being generally smaller, by occurring exclusively on rocks and in seasonally much drier habitats, and by having usually thicker leaf blades. Matuda (1961) stressed that the taxon has peduncles relatively much longer than typical in A. schlechtendalii. While it is generally true that the inflorescences of ssp. jimenezii are commonly as long as or longer than the leaves they may also be much shorter than the leaves.

Subspecies jimenezii is also similar to $\mathrm{A}$. halmoorei, which differs in having an ovate to ovateelliptic spathe and mature berries that are pale greenish-yellow. Also similar is A. nizandense, which is endemic to southern Guerrero and southern Oaxaca. Anthurium nizandense differs in having proportionately much longer petioles and elliptic to oblong-elliptic blades that are matte on the lower surface. In $A$. nizandense the blades are 1.3-2.5 times longer than the petioles whereas in $A$. schlechtendalii ssp. jimenezii the leaf blades are usually 6 to 10 times longer (rarely only as little as 3 times longer).

Mexico. Guerrero: El Ocotito, between Tierra Colorada and Agua de Obispo, Crisman \& Willis 199 (MICH); Carreceras, Hinton et al. 10098 (US); Trincheras, Hinton et al. 10125 (K, US); Malinaltenango, S of Zacualpan, Matuda 37245 (MEXU); beyond Acapulco to Chilpancingo, Moore 5099 (BH); between Acahuizotla and Agua de Obispo, Moore 5120 (BH, UC); highway above Acahuizotla, Moore 6957 (BH); Tierra Colorada, Rodriguez 51 (US); Rzedowski 22809 (MICH, US). OAXACA: N of Putla de Guerrero, Croat 45926 (MO); between Oaxaca and Pochutla, S of Miahuatlán, Croat 46093 (MO); N of Pluma Hidalgo, Croat 46142 (MO); vicinity Santa Rosa, Km 195 on road to Oaxaca-Puerto Escondido, Rzedowski 19592 (MEXU).

Anthurium schottianum Croat \& Baker, Brenesia 16 (Supl. 1): 83. 1979. TYPE: Costa Rica. Limón: ca. 1 mile $\mathrm{N}$ of Bribrí, ca. 40 miles SW of Limón; steep ravine above Río Catarata, 50-100 m elev., Croat 43247 (MO2584489 , holotype; CR, F, K, SEL, US, isotypes; Live at MO).

Large terrestrial; stems usually less than $50 \mathrm{~cm}$ long, 3-5 cm diam.; leaf scars conspicuous, 2-4 $\mathrm{cm}$ wide; roots few, green, ca. $5 \mathrm{~mm}$ diam. descending, often short and blunt; cataphylls coriaceous, dark purple, 9-12 cm long, apiculate at apex, drying brown with tinges of reddishpurple, subpersistent. LEAVES with petioles erect to spreading, 40-150 $\mathrm{cm}$ long, 5-8 $\mathrm{mm}$ diam., shallowly sulcate to flat adaxially, rounded with a few faint ridges abaxially, tinged dark purple from the base; geniculum $2-3 \mathrm{~cm}$ long; blades ovate, gradually acuminate at apex (the acumen long apiculate, turned down), lobed at base, 44$100 \mathrm{~cm}$ long, $33-50 \mathrm{~cm}$ wide, broadest near point of petiole attachment, the margin shallowly undulate; the anterior lobe $32-80 \mathrm{~cm}$ long with margins convex; posterior lobes 12-19 cm long; the sinus usually narrowly triangular, sometimes closed, acute at apex; the upper surface matte to semiglossy, lower surface semiglossy; the midrib acutely raised above, diminishing toward apex and sunken, prominently raised below; basal 

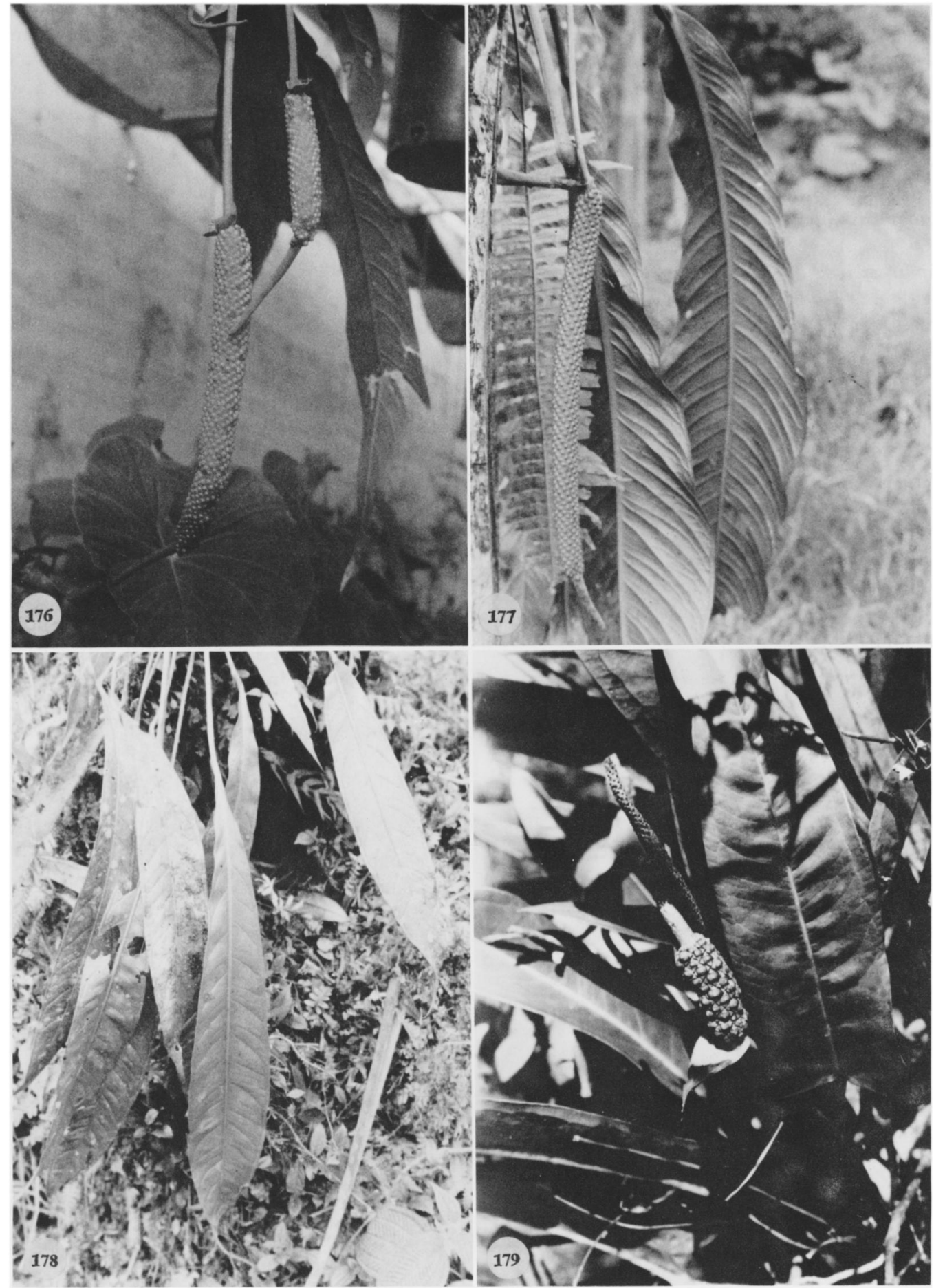

Figures 176-179. 176. Anthurium seibertii Croat \& Baker, Croat 26976 (Type). -177-178. Anthurium seibertii Croat \& Baker, Croat 48568. - 179. Anthurium seleri Engl., Croat 46505. 


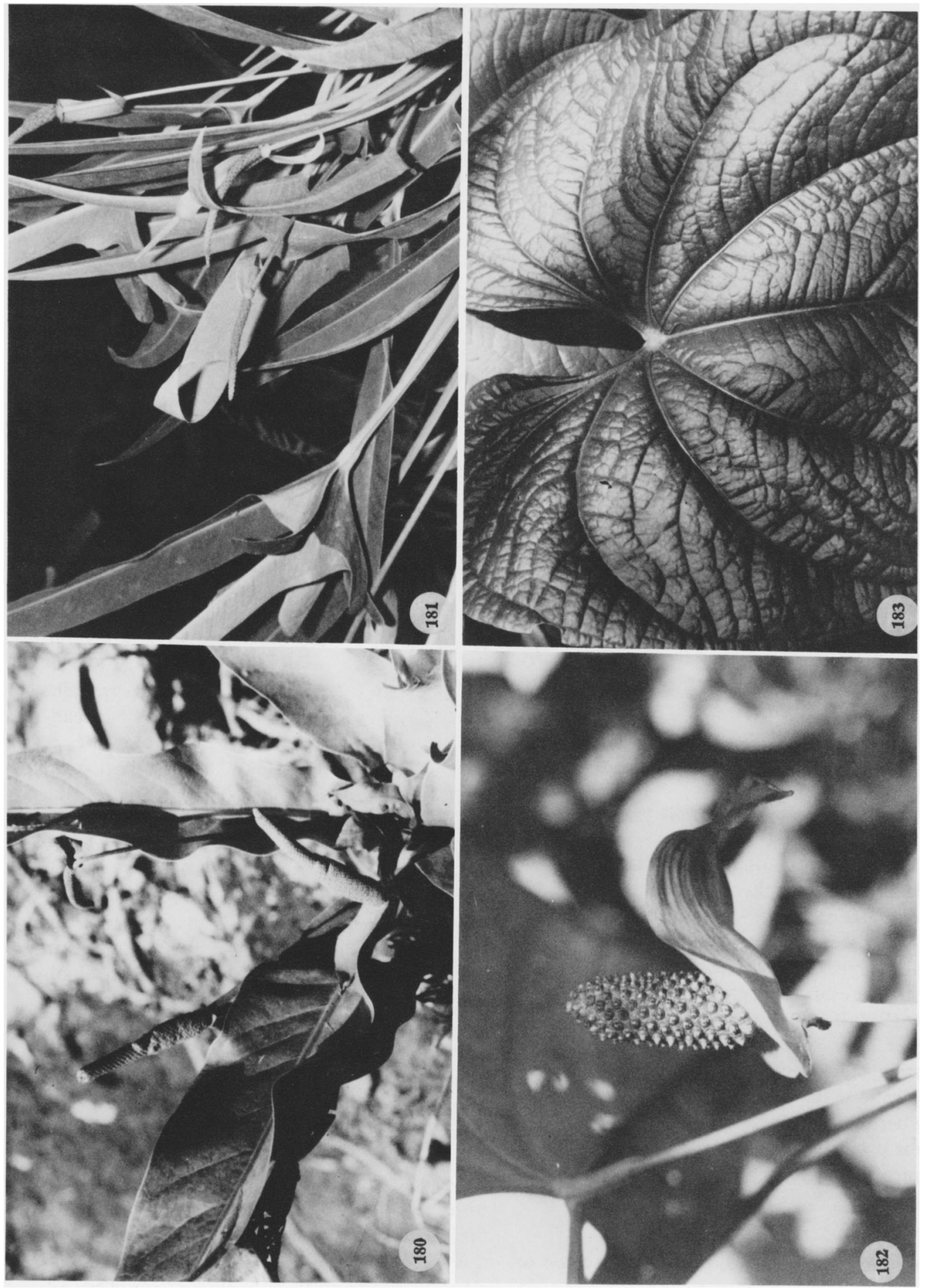

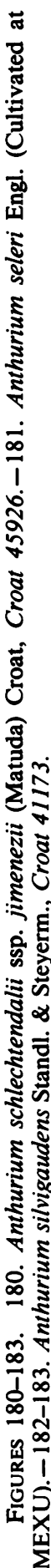


veins 5-8 pairs, not coalesced, raised above and below; primary lateral veins $9-20$ per side, departing midrib at $35^{\circ}-50^{\circ}$ angle, slightly arcuateascending, faintly loop-connecting, sharply raised above and below; interprimary veins very few, slightly raised near apex of leaf above, raised below; secondary veins mostly flat above, in part raised, especially in posterior lobes, somewhat raised below; tertiary veins scarcely visible above, scarcely raised below; collective vein usually arising from the second basal vein, inconspicuous, slightly sunken above, slightly raised below, 2-6 $\mathrm{mm}$ from the margin. INFLORESCENCE erect, much shorter than the leaves; peduncle sometimes absent or to $20 \mathrm{~cm}$ long, 4$5 \mathrm{~mm}$ diam., dark purple, terete; spathe coriaceous, dark purple with green splotches (B \& K Red-purple 2/7.5), ovate-lanceolate, $6.5-15 \mathrm{~cm}$ long, $1.6-3.5 \mathrm{~cm}$ wide, broadest at base, abruptly acuminate at apex, rounded to subcordate at base, stiffly curled back lengthwise, frequently twisted at anthesis, inserted at ca. $45^{\circ}$ angle on peduncle; spadix purple (B \& K Purple 2/7.5), 4-14 cm long, 7-9 $\mathrm{mm}$ diam. at base, $4-5 \mathrm{~mm}$ diam. at apex; flowers square, $2.6-3 \mathrm{~mm}$ long, 1.5-3.5 $\mathrm{mm}$ wide, the sides nearly straight; $4-6$ flowers visible in the principal spiral, 5-8 flowers visible in the alternate spiral; tepals matte, densely punctate, minutely papillate, the lateral tepals to $1.9 \mathrm{~mm}$ wide, the inner margin straight to convex, held flat against pistil; pistil violet-purple, minute and barely exposed 1 or 2 spirals ahead of emerging stamens, gradually larger as stamens emerge; stigma a dry, linear slit when stamens are emerging; stamens emerging slowly from the base, exserted on short filaments which retract to hold anthers in a tight cluster around the pistil; filaments flattened, milky, the exposed part ca. $0.3 \mathrm{~mm}$ long. $0.6-0.7 \mathrm{~mm}$ wide; anthers yellow, held above pistil, $0.5-0.6 \mathrm{~mm}$ long, $0.7-0.9 \mathrm{~mm}$ wide; thecae ellipsoid, scarcely divaricate; pollen yellow (B \& K Yellow 9/5), drying pale yellow. INFRUCTESCENCE pendent; spathe usually persisting; spadix to $35 \mathrm{~cm}$ long, to $2.5 \mathrm{~cm}$ wide, the apical one half to one third often not developing berries; berries obovoid, acute to rounded at apex, pinkish with a metallic sheen, darker in the apical third, 9-10 mm long; seeds 2 , tan, to $6 \mathrm{~mm}$ long, $5 \mathrm{~mm}$ wide, flattened, ca. $2 \mathrm{~mm}$ thick. Figs. 174 and 175.

The species is known only from the region of premontane wet forest-basal belt transition in extreme southwestern Costa Rica at elevations of less than $100 \mathrm{~m}$. It will no doubt be found elsewhere in Costa Rica and Panama on the Atlantic Slope.

Anthurium schottianum is a member of section Pachyneurium and is distinguished by its large, thin, ovate leaf blades with scarcely any posterior rib (i.e., all basal veins are free to the petiole) and by its short peduncle, its purple spadix and its ovate-lanceolate, often purplish, frequently twisted spathe.

Costa RicA. LIMÓN: near the Río Catarata between Bribrí on the Río Sixaola and the Caribbean costal plain, Baker \& Burger 69 (MO); Burger et al. 10391 (F, MO); NE of Bribrí, ca. $40 \mathrm{mi} \mathrm{SW}$ of Limón, Croat 43247 (CR, F, K, MO, SEL, US); N of Bribrí on banks of Río Catarata, Utley 5500 (DUKE).

Anthurium seibertii Croat \& Baker, Brenesia 16 (Supl. 1): 85. 1979. TYPE: Panama. Chiriquí: wooded slopes on Cerro Horqueta, 1,650 m, Croat 26976 (MO-2251853, holotype; CR, F, NY, PMA, US, isotypes; Live at MO).

Epiphyte; stems thick, short, 3-6 cm diam.; leaf scars mostly hidden, ca. $2 \mathrm{~cm}$ wide; roots numerous, descending, ca. $6 \mathrm{~mm}$ diam., green with crusty tan epidermis; cataphylls coriaceous, $12-21 \mathrm{~cm}$ long, caudate-acuminate at apex, the apiculum ca. $5 \mathrm{~mm}$ long, drying $\tan$ (B \& K Yellow-red 8/5), splitting at base, the apex remaining \pm intact. LEAVES held stiffly erect-spreading; petioles $10-55 \mathrm{~cm}$ long, 6-10 $\mathrm{mm}$ wide, \pm quadrangular, 5-ribbed with 3 ribs on the abaxial side, sometimes with 2 additional ribs on the lower corners; geniculum 1.5-3 cm long, ribbed as the petiole; blades strap-shaped, gradually acuminate at apex, obtuse to slightly rounded at base, 45-85 $\mathrm{cm}$ long, 4-16 $\mathrm{cm}$ wide, broadest at middle, the margin flat to slightly undulate; upper surface semiglossy, lower surface matte to semiglossy; midrib convexly raised above, diminished at apex, sharply and obtusely raised below; primary lateral veins numerous on each side, departing midrib at $50^{\circ}-60^{\circ}$ angle, sunken above, sharply raised below, arcuate-ascending, prominently loop-connecting; interprimary veins numerous, slightly sunken above, prominulous below; secondary veins flat above, flat or slightly raised and darker below; collective vein arising from near base, about as prominent as the primary lateral veins, sunken above, prominently raised below, 2-7 $\mathrm{mm}$ from margin. INFLORESCENCE erect or spreading at anthesis, ca. two thirds as long as leaves; peduncle $30-60 \mathrm{~cm}$ 
long, 6-10 mm diam., terete with a single dorsal rib, sometimes tinged purplish; spathe medium thick, green or green tinged with purple (B \& K Yellow-green 7/10), oblong-lanceolate, $10-17 \mathrm{~cm}$ long, $2.5-4.3 \mathrm{~cm}$ wide, broadest at point of attachment, gradually and narrowly long-acuminate at apex, rarely short-acuminate, rounded at base, inserted at $50^{\circ}$ angle on peduncle, often becoming coiled; stipe ca. $13 \mathrm{~mm}$ long in front, $1 \mathrm{~mm}$ long in back, $8 \mathrm{~mm}$ wide, tinged purple; spadix violet-purple (B \& K Blue-purple 2/10), 10-20 cm long, 7-13 $\mathrm{mm}$ diam. at base, 5-6 $\mathrm{mm}$ diam. at apex; flowers 4-lobed, $2-2.5 \mathrm{~mm}$ in both directions, the sides jaggedly sigmoid, 7-9 flowers visible in principal spiral, 7-10 flowers visible in alternate spiral; tepals matte, the lateral tepals ca. $1.5 \mathrm{~mm}$ wide, the inner margin straight; the pistil emergent, orange-yellow; the stigma ca. 0.7 $\mathrm{mm}$ long, $0.2-0.3 \mathrm{~mm}$ wide, with conspicuous stigma droplets for several days before stamens emerge; stamens emerging \pm rapidly from the base, the lower fourth with stamens emergent while apical flowers still are producing droplets on the stigmas; anthers pale orange, held just above tepals in a tight cluster, ca. $0.5 \mathrm{~mm}$ long, $1 \mathrm{~mm}$ wide; the thecae ellipsoid, scarcely divaricate; pollen white. INFRUCTESCENCE pendent; spathe often missing; spadix usually 22-30 $\mathrm{cm}$ long, ca. $2 \mathrm{~cm}$ wide; berries orange, obovoid, flat to rounded at apex, 10-12 mm long; mesocarp orange, mealy, sweet tasting but pungent; seeds $2, \pm$ oblong with rounded corners, ca. 5 $\mathrm{mm}$ long, $4 \mathrm{~mm}$ wide, $2 \mathrm{~mm}$ thick. Figs. 176, 177 , and 178 .

Anthurium seibertii is known from higher altitudes in Chiriquí Province (1,300-2,000 m) and from one collection at 1,040 m in San José Province of Costa Rica (Skutch 2626, MO, US).

The species is a member of the section Pachyneurium and is very similar to $A$. protensum. They share similar strap-shaped leaves, pale violet-purple spadices and orange berries. Anthurium protensum differs in having a nearly terete petiole while $A$. seibertii has petioles that are prominently ribbed abaxially and rectangular. Anthurium protensum also has leaves that are usually pendent and are generally smaller than those of $A$. seibertii.

COSTA RICA. SAN JOSÉ: El General, 1,040 m, Skutch 2626 (F, MO).

Anthurium seleri Engl., Bot. Jahrb. Syst. 25: 459. 1898. TYPE: Guatemala. Huehuetenango: near Chaculá, Seler 2643 (B, holotype).
Anthurium andresloviense Matuda, Anales Inst. Biol. Univ. Nac. México 36: 108. 1966. TyPE: Mexico. Oaxaca: San Andrés Lovene, Munic. Miahuatlán (N of Pluma Hidalgo), 1,200 m elev., MacDougall 384 (MEXU, holotype; F, isotype).

Terrestrial; internodes and leaf scars obscured by cataphylls and roots; roots numerous, medium thick, descending; cataphylls subcoriaceous, 6-11 cm long, sometimes faintly tinged reddish at apex, sometimes with long hair-like subapical apiculum, drying reddish brown, splitting at base, remaining intact at apex and persisting. LEAVES with petioles erect to spreading, (7) $14-48 \mathrm{~cm}$ long, 4-6 mm diam., sharply and shallowly sulcate; geniculum 1.4-1.6 cm long; blade moderately thick, narrowly triangular to oblong-lanceolate or oblong-lanceolate with hastate posterior lobes, gradually acuminate at apex, usually broadly lobed, sometimes deeply lobed or \pm rounded to truncate at base, (9) $24-50 \mathrm{~cm}$ long, (5) $10-50 \mathrm{~cm}$ wide, broadest at base; anterior lobe (8.5)25-41 $\mathrm{cm}$ long, margins convex to straight; posterior lobes $6-18 \mathrm{~cm}$ long, from sinus to outermost point; the sinus usually parabolic, sometimes arcuate with petiole decurrent, broader than deep, rounded at apex; the upper surface matte to semiglossy, the lower surface matte; midrib bluntly and weakly raised above, convexly raised below; basal veins 2-5 pairs, the second to fifth coalesced to $8 \mathrm{~cm}$; posterior rib straight, naked, turned up on outer margin; primary lateral veins 9-11 per side, departing midrib at $45^{\circ}-50^{\circ}$ angle, usually straight, loop-connecting to collective vein, sunken and nearly obscure above, flat below; collective vein arising from one of the lowermost basal veins, sunken above, flat below, 2$6 \mathrm{~mm}$ from margin. INFLORESCENCE erectspreading, longer than leaves; peduncle 25-50(86) $\mathrm{cm}$ long, terete, sometimes faintly tinged with purple; spathe moderately thin, lanceolate, pale green, tinged reddish at base, 5-9 cm long, 0.9$1.5 \mathrm{~cm}$ wide, long-acuminate at apex, acute to rounded at base, inserted on peduncle at $50^{\circ}-70^{\circ}$ angle; stipe 4-20 mm long in front, $1-15 \mathrm{~mm}$ long in back; spadix green, tinged red-violet along inner margins of tepals, $6-13 \mathrm{~cm}$ long, $6-8 \mathrm{~mm}$ diam. at base, $2-4 \mathrm{~mm}$ diam. at apex; flowers rhombic to sub-4-lobed, 3.5-3.7 mm long, 3-3.5 $\mathrm{mm}$ wide, the sides \pm straight to gradually sigmoid; 4-5 flowers visible in the principal spiral, 4-10 flowers visible in the alternate spiral; tepals matte, minutely punctate, abundant droplets when stamens begin to emerge, lateral tepals 1.4$1.6 \mathrm{~mm}$ wide, the inner margin straight to convex, \pm transparent; pistils emergent to $4 \mathrm{~mm}$, 
white to pale green with minute purple punctations; stigma linear, ca. $0.5 \mathrm{~mm}$ long; stamens emerging slowly from the base in a \pm complete sequence, lateral stamens first followed by alternates, the basal spirals complete as lateral stamens emerge above middle, exserted on short filaments, ca. $0.2 \mathrm{~mm}$ long, soon retracting and held in a circle at edge of pistil; anthers tan, 0.5$1 \mathrm{~mm}$ long, $0.7-1.2 \mathrm{~mm}$ wide, inclined over pistil; thecae ellipsoid, slightly divaricate; pollen white to pale yellow. INFRUCTESCENCE pendent; berries red, obovoid, 6-7 $\mathrm{mm}$ long, $4 \mathrm{~mm}$ wide. Figs. 179, 181, and 184.

Anthurium seleri is known primarily from a relatively small geographic area ranging from eastern Mexico (central Chiapas) to adjacent areas of west central Guatemala in the Department of Huehuetenango at elevations from 700 to 1,900 $\mathrm{m}$. The species has also rarely been collected in southern Oaxaca in the Sierra Madre del Sur, and while these appear to be outlying populations, both regions probably consist of vegetation that is "bosque pino-encino" on the Mexican vegetation maps, which are generally quite arid. Plants are usually found growing on rocks or on steep cliffs in shaded canyons but have also been found in open almost deforested areas.

The species is a member of section Belolonchium and is recognized by its coriaceous blades, which are either oblong or narrowly triangular with usually little or no development of posterior lobes or with the posterior lobes directed outward almost at a $90^{\circ}$ angle from the midrib. An extreme development of the posterior lobes is found in some collections from the northern and western part of the range of the species and a few collections such as Carlson 1523, Reko 6203, and MacDougall 686 have posterior lobes of the blade almost as long as the anterior lobe.

An interesting feature exhibited by $A$. seler $i$ is that while most collections dry matte and greenish, some collections, such as Croat 46505, dried brown with the surfaces glossy. Since no other differences were apparent it is assumed that these differences were a matter of differences in drying.

Anthurium seleri collections with well developed posterior lobes can be confused with collections of $A$. berriozabalense. See the discussion following that species for ways of distinguishing the two species.

The designated type of $A$. andresloviense (MacDougall 384) represents a mixed collection. Specimens from MEXU, numbers 59608 and 59838 correspond to the type description and to the photograph, respectively, presented by Matuda. Another MacDougall collection of 384 has been assigned the number $384 A$. It is actually $A$. ovandense.

As mentioned in the introductory paragraph, MacDougall had often recollected what he believed to be the same plants again; when he did, he had the unusual practice of assigning them the same number as he did the first time he collected the plant. In this case the plants he recollected were in fact of some other species, even though they both have similar leaves and were both collected at San Andrés Lovene.

Mexico. Cultivated Miami, Florida, origin Mexico, Croat 44760 (MO). CHIAPAs: Aguatenango, Breedlove 6612 (DS, MICH); Arriaga, Breedlove \& Thorne 30579 (DS); between Bochil and Sayulo, MacDougall 686 (MEXU); Cintalapa, SE of Cerro Baúl, Breedlove 24716 (DS); Cintalapa, MacDougall 703 (NY); vicinity Comitán, Webster et al. 12897 (DAV, MO, US); La Independencia, Breedlove 33460 (DS); Las Margaritas, Breedlove 34732 (CAS, DS), Ocozocoautla de Espinosa, Breedlove 28997 (DS); Breedlove 29187, 32876 (CAS, DS); Carlson 1523 (DS, UC); Croat 40541 (MO); MacDougall H260 (NY); Pueblo Nuevo Solistahuacán, Thorne \& Lathrop s.n. (LL); 40392 (DS, RSA); vicinity Teopisca, Croat 46505 (MO); Breedlove 26201 (CAS, DS, DUKE, LL, MICH, MO); Venustiano Carranza, Laughlin 1947 (CAS, DS); Breedlove 10564 (CAS, DS, LL, MICH); Breedlove 11187 (CAS, DS, LL); Raven \& Breedlove 20104 (CAS, DS, LL). OAXACA: Pochutla, Reko 6204 (GH); San Andrés Lovene, MacDougall 384 (MEXU).

Anthurium silvigaudens Standl. \& Steyerm., Publ. Field Mus. Nat. Hist., Bot. Ser. 22: 69. 1940. TYPE: Guatemala. Alta Verapaz: near Tactic, elev. ca. 1,500 m, Standley 70505 (F, holotype).

Epiphytic or usually terrestrial to $120 \mathrm{~cm}$ tall; stems green, $2 \mathrm{~cm}$ diam.; internodes $1-2 \mathrm{~cm}$ long; leaf scars $1.4 \mathrm{~cm}$ wide; roots medium thick, pale green, directed downward; cataphylls subcoriaceous, $6-13 \mathrm{~cm}$ long, the apex round with a minute apiculum, drying tan (B \& K Yellow-red 9/ $10)$, weathering to linear fibers and persisting. LEAVES usually erect; petioles $23-54 \mathrm{~cm}$ long, 5-6 mm diam., terete; geniculum $1.5-2 \mathrm{~cm}$ long; blades ovate, moderately thin, gradually acuminate at apex, lobed at base, $22-48 \mathrm{~cm}$ long, $13-31 \mathrm{~cm}$ wide, broadest just below middle; anterior lobe $17-33 \mathrm{~cm}$ long, the margins convex; posterior lobes $8.2-15 \mathrm{~cm}$ long, directed upward; the sinus hippocrepiform to spathulate, round to acute at apex; both surfaces matte (cells on lower surface glistening and weakly papillate); the midrib sharply raised above, diminishing at center, 


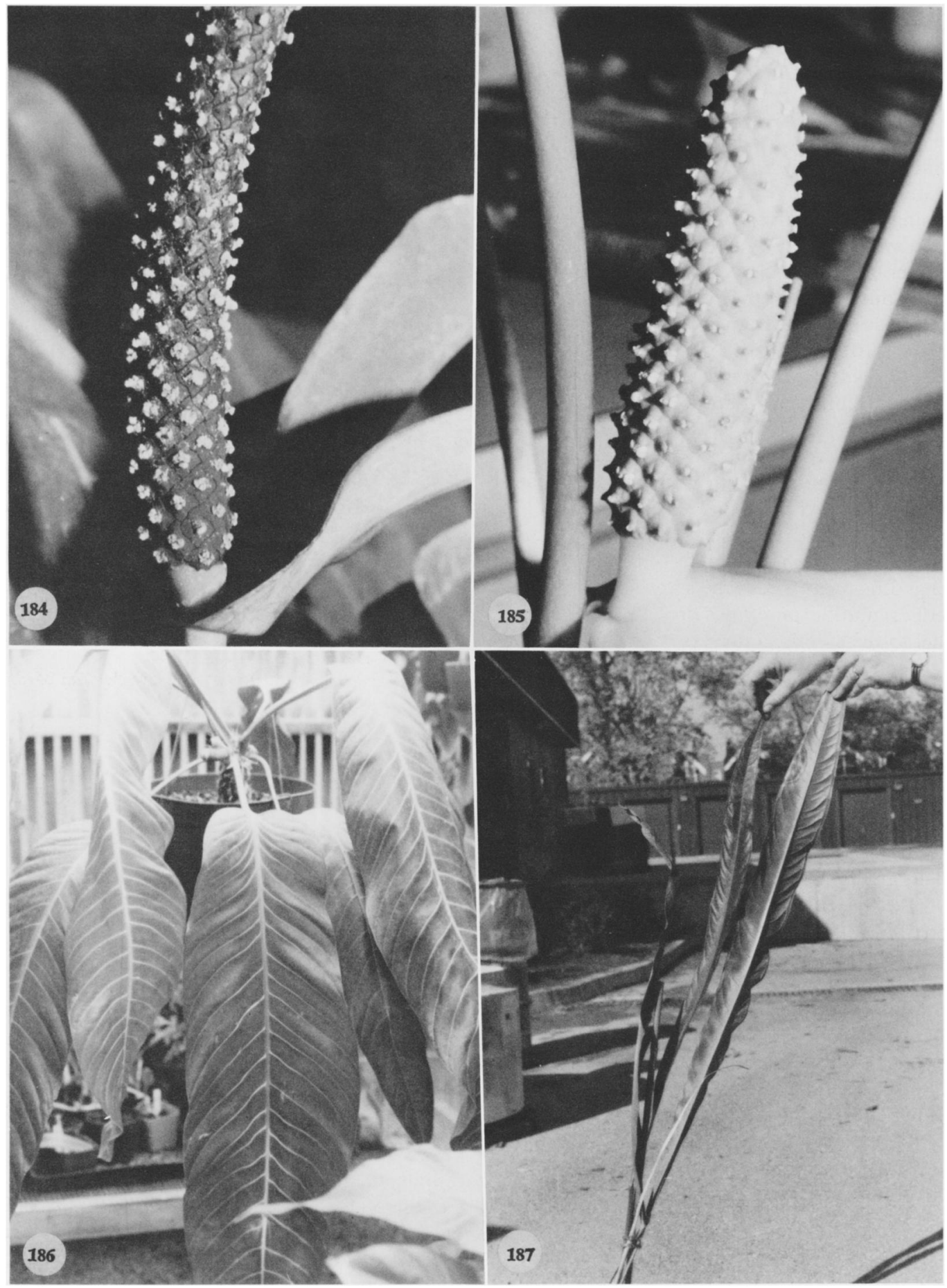

FIGURES 184-187. 184. Anthurium seleri Engl., Croat 44760.-185. Anthurium silvigaudens Standl. \& Steyerm., Croat 41475.-186. Anthurium spectabile Schott, Croat 1-26-78N. -187. Anthurium spathiphyllum N. E. Brown, Croat 44309. 
sunken at apex, bluntly raised below; basal veins 4-7 pairs, the first and second (sometimes third) free to base, the third to seventh coalesced 1-3.5 $\mathrm{cm}$; posterior ribs naked, upturned; primary lateral veins $4-6$ per side, departing midrib at $45^{\circ}-$ $55^{\circ}$ angle, sunken in valleys above, raised below, straight or arching to collective vein; lesser veins prominulous above and below; collective vein arising from first or second basal vein, $4-10 \mathrm{~mm}$ from margin. INFLORESCENCE erect, much shorter than leaves; peduncle $3.5-10 \mathrm{~cm}$ long, 6$7 \mathrm{~mm}$ diam., terete, shorter than petioles; spathe subcoriaceous, medium green (B \& $\mathrm{K}$ Yellowgreen $7 / 10$ ), ovate, $5.5-8.5 \mathrm{~cm}$ long, $4.3-6 \mathrm{~cm}$ wide, broadest just above point of attachment, abruptly acuminate at apex, cordate at base, inserted at $40^{\circ}$ angle on peduncle; the stipe $7-15$ $\mathrm{mm}$ long in front, $4 \mathrm{~mm}$ long in back, tapered at base of spadix, medium green; spadix medium green (B \& K Yellow-green 7/2.5), $2.5-5.2 \mathrm{~cm}$ long, $1.4-2 \mathrm{~cm}$ diam. at base, $5-8 \mathrm{~mm}$ diam. at apex; flowers rhombic to sub-4-lobed, 3.5-4 mm long, 3.6-4 $\mathrm{mm}$ wide, the sides sigmoid to jaggedly sigmoid, sometimes broadly rounded parallel to the spirals; 5 flowers visible in the principal spiral, 7 flowers visible in the alternate spiral; tepals matte to semiglossy, lateral tepals 2.2-2.5 $\mathrm{mm}$ wide, the inner margin broadly rounded and turned up against the pistil; the pistil emergent to ca. $0.7 \mathrm{~mm}$, darker green than tepals; stigma $0.3 \mathrm{~mm}$ long, round, brushlike, glistening; stamens emerging promptly throughout the spadix (sometimes beginning at apex), the lateral stamens emerging throughout before the alternates emerge, the third and fourth stamens following in rapid sequence after 1 or 2 days; filaments exserted, $0.5 \mathrm{~mm}$ long, translucent; anthers pale yellow, retracted to upper edge of tepals, $0.7-0.8$ $\mathrm{mm}$ long, $1 \mathrm{~mm}$ wide; thecae oblong-ellipsoid, slightly divaricate; pollen creamy white. INFRUCTESCENCE erect; spathe persistent; spadix 4-6 cm long, 2.5-4 cm diam.; berries obovoid, vermillion-coral (see Steyermark 51703), rounded at apex, 11-13 $\mathrm{mm}$ long, 6-8 $\mathrm{mm}$ diam.; seeds 2 , oblong-obovoid, weakly flattened, 5.5$7.5 \mathrm{~mm}$ long, $3.5-4 \mathrm{~mm}$ wide, $2-2.5 \mathrm{~mm}$ thick. Figs. 182, 183, and 185 .

Anthurium silvigaudens is found in Guatemala and Honduras at 1,500 to 2,000 m elevation in tropical wet forest. In Guatemala it has been collected in the Department of Alta Verapaz in the vicinity of Purulhá and Tactic as well as in the Department of Huehuetenango in the Sierra de los Cuchumantes. It is certainly expected to be found in the Department of Quiché as well. In Honduras it was collected near Lepaera.

The species is characterized by its moderately thin, ovate, prominently lobed leaf blades with weakly impressed secondary and tertiary veins, by its short peduncle, its ovate, cordate, green spathe, stubby greenish spadix, and orange-red berries. Its sectional placement is uncertain but may best be placed in section Belolonchium.

Although Standley and Steyermark in the type description compare the species with $A$. fraternum Schott it bears little resemblance or relationship with that species except for having a blade of similar shape. It is unlikely that the species is even in section Calomystrium. It is apparently not closely related to any other species in Central America.

Guatemala. alta verapaz: road to El Estor, E of Highway 14 to Cobán, Croat 41440, 41475 (MO); vicinity Tactic, Standley 70505 (F). BAJA VERAPAZ: No other location, Molina \& Molina 27728 (F); Tuerckheim 1825 (US); NE of Purulhá, Croat 41306 (MO); $\mathrm{S}$ of Purulhá, Croat 41173, 41753 (MO). HUEHUETENANGO: E of Las Palmas, Sierra de los Cuchumantes, Steyermark $51703(\mathrm{~F})$. (F).

HONDURAS. LEMPIRA: vicinity Lepaera, Molina 24135

Anthurium spathiphyllum N. E. Brown, Gard. Chron. 652. 1877. TYPE: Origin unknown: Hort. Kew, Nov. 8, 1876, N. E. Brown s.n. (K).

Epiphyte; stems ca. $10 \mathrm{~cm}$ long, ca. $2 \mathrm{~cm}$ diam.; covered by numerous, moderately thick, fuzzy roots; cataphylls chartaceous, $7-8 \mathrm{~cm}$ long, cuspidate at apex with long, subapical apiculum ca. $1.5 \mathrm{~cm}$ long, pale tan (B \& K Yellow 9/7.5), weathering into coarse, longitudinal fibers and persisting. LEAVES spreading; petioles usually triangular or sharply 3-5 ribbed; geniculum 7$10 \mathrm{~cm}$ long, conspicuously bulging adaxially; blades linear to linear-lanceolate, subcoriaceous, $46-80 \mathrm{~cm}$ long, $5.5-12.5 \mathrm{~cm}$ wide, broadest at middle, the margins broadly undulate; both surfaces semiglossy; the midrib scarcely raised and broad at base, narrowing and convexly raised at middle, acute nearly to apex, sunken at apex above, sharply raised below; primary lateral veins 20-30 per side, departing midrib at $40^{\circ}-45^{\circ}$ angle, straight to collective vein, sunken above, raised below; interprimary veins flat to scarcely sunken above, prominulous below; collective vein 
arising from near the base, 3-6 $\mathrm{mm}$ from the margin, sunken above, raised below. INFLORESCENCE spreading, shorter than leaves; peduncle flattened, 2-4 ribbed, 33-48 cm long, 1$1.5 \mathrm{~cm}$ wide, 2 times longer than petioles; spathe coriaceous, green, lanceolate to broadly lanceolate $6.5-8 \mathrm{~cm}$ long, $1.7-3 \mathrm{~cm}$ wide, broadest below middle, short acuminate at apex, rounded at base, inserted at $50^{\circ}$ angle on peduncle; spadix pale yellow to creamy white, (1.7)3-4 cm long, 0.9-1.1 cm diam. midway; flowers 4-lobed, ca. $1.4 \mathrm{~mm}$ long, $2.2 \mathrm{~mm}$ wide, the sides sigmoid; ca. 12 flowers visible in principal spiral, 15 flowers visible in the alternate spiral; tepals matte, the lateral tepals $0.7 \mathrm{~mm}$ wide, the inner margins straight; pistils emergent, pale yellow; stigma minute, drying before stamens emerge; lateral stamens scattered throughout before alternates appear, exserted on fleshy filaments, held over and obscuring pistil; thecae oblong, not divaricate; pollen pale yellow fading to cream. INFRUCTESCENCE unknown. Fig. 187.

Anthurium spathiphyllum is known from Costa Rica to Panama from sea level to $380 \mathrm{~m}$ (with the exception of Croat 35571, which was collected at 1,350 m elevation) on the Atlantic slope in wetter parts of tropical moist forest and in premontane wet and tropical wet forest life zones.

The species can be recognized by its epiphytic habit, chartaceous leaves, usually triangular, sometimes 3-5 ribbed petiole, lanceolate to broadly lanceolate cucullate spathe, and short, scarcely tapered, pale yellow spadix.

Anthurium spathiphyllum is in section Pachyneurium and is most closely related to $A$. cuneatissimum. The latter species differs in having fewer, less sunken primary lateral veins (commonly 10-15 versus $20-30$ for A. spathiphyllum) and in having a spathe that is ovate and about as long as the spadix (versus lanceolate to broadly lanceolate and about two times longer than the spadix in A. spathiphyllum).

Costa Rica. alajuela: N of San Miguel, Croat 35651 (MO). HEREDIA: upstream on Rio Puerto Viejo, Burger \& Matta 4258 (F); N of Vara Blanca, Croat 35571 (MO). LIMÓN: Hacienda Tapezco-Hda. La Suerte, W of Tortuguero, Davidson \& Donahue 8954 (MO); Pandora, Ocampo 1987 (MO); W of Dos Bocas, beside Río Parismina, Lent 2444 (F).

NicARAgua. Zelaya: N of Limbaika, Stevens 8255 (MO); between Rosita and Puerto Cabezas, SW of Río Kukalaya, Stevens 8504 (MO).
Anthurium spectabile Schott, Oesterr. Bot. Z. 8: 181. 1858. TyPE: Costa Rica. Cartago: Volcán Turrialba, Wendland 506 (GOET, 2 sheets).

Anthurium longispathum Schott, Prod. Aroid. 520. 1860. TYPE: Costa Rica. Turrialba, Oersted (Photo of Schott Aroid Drawing \#707, NYBG Neg. \#N.S. 3952).

Epiphyte; cataphylls subcoriaceous, $17-38 \mathrm{~cm}$ long, obtuse at apex with subapical apiculum ca. $2 \mathrm{~mm}$ long, drying light tan (B \& K Yellow-red 9/10), splitting at base, the apex remaining intact, persisting. LEAVES spreading; petioles quadrangular, $14-53 \mathrm{~cm}$ long, 7-10 mm wide, broadly sulcate adaxially, with a faint convex rib abaxially; geniculum 1.3-1.9 cm long; blades oblonglanceolate to oblong or oblong-triangular, moderately thick, long-acuminate at apex, rounded to truncate at base, 37-135(160) cm long, 8$35(45) \mathrm{cm}$ wide; the upper surface semiglossy to glossy, the lower surface glossy; the midrib acutely raised above, broad at base, narrow and sunken at apex, convexly raised below becoming more acute at apex; primary lateral veins numerous, departing midrib at $45^{\circ}$ angle, raised above and below; lesser veins conspicuous but not raised above and below; collective vein arising from one of the primary lateral veins in the basal one half of the blade, sunken above, raised below, 2-3 $\mathrm{mm}$ from margin. INFLORESCENCE spreading, shorter than leaves; the peduncle 13$25 \mathrm{~cm}$ long, terete; spathe subcoriaceous, narrowly ovate to oblong-lanceolate, green or violetpurple inside, green outside, $10.5-32 \mathrm{~cm}$ long, 3-7 cm wide, acuminate at apex, rounded to subcordate at base, inserted at $45^{\circ}$ on peduncle, usually twisted or coiled and strongly reflexed; spadix yellow-green, 16-38 cm long, ca. $9 \mathrm{~mm}$ diam. at base, $7 \mathrm{~mm}$ diam. at apex; the flowers rhombic to 4-lobed, $2.5-4 \mathrm{~mm}$ in both directions, the sides sigmoid; 7-11 flowers visible in principal spiral, ca. 9 flowers visible in the alternate spiral; tepals matte to semiglossy, 2-2.5 mm long, ca. $2.7 \mathrm{~mm}$ wide, the inner margins convex; pistils emergent, green, violet-purple at apex; stigma ca. $1 \mathrm{~mm}$ long, elliptic; stamens emerging promptly throughout length of spadix in a complete sequence; anthers held around exserted pistil; thecae narrowly ovoid, slightly divaricate; pollen cream-colored. INFRUCTESCENCE with spadix to $50 \mathrm{~cm}$ long; berries oblong-linear, probably orange at maturity, 10-14 mm long, ca. 3.5 mm diam., tapered to a blunt apex; seeds 2, 3.4- 


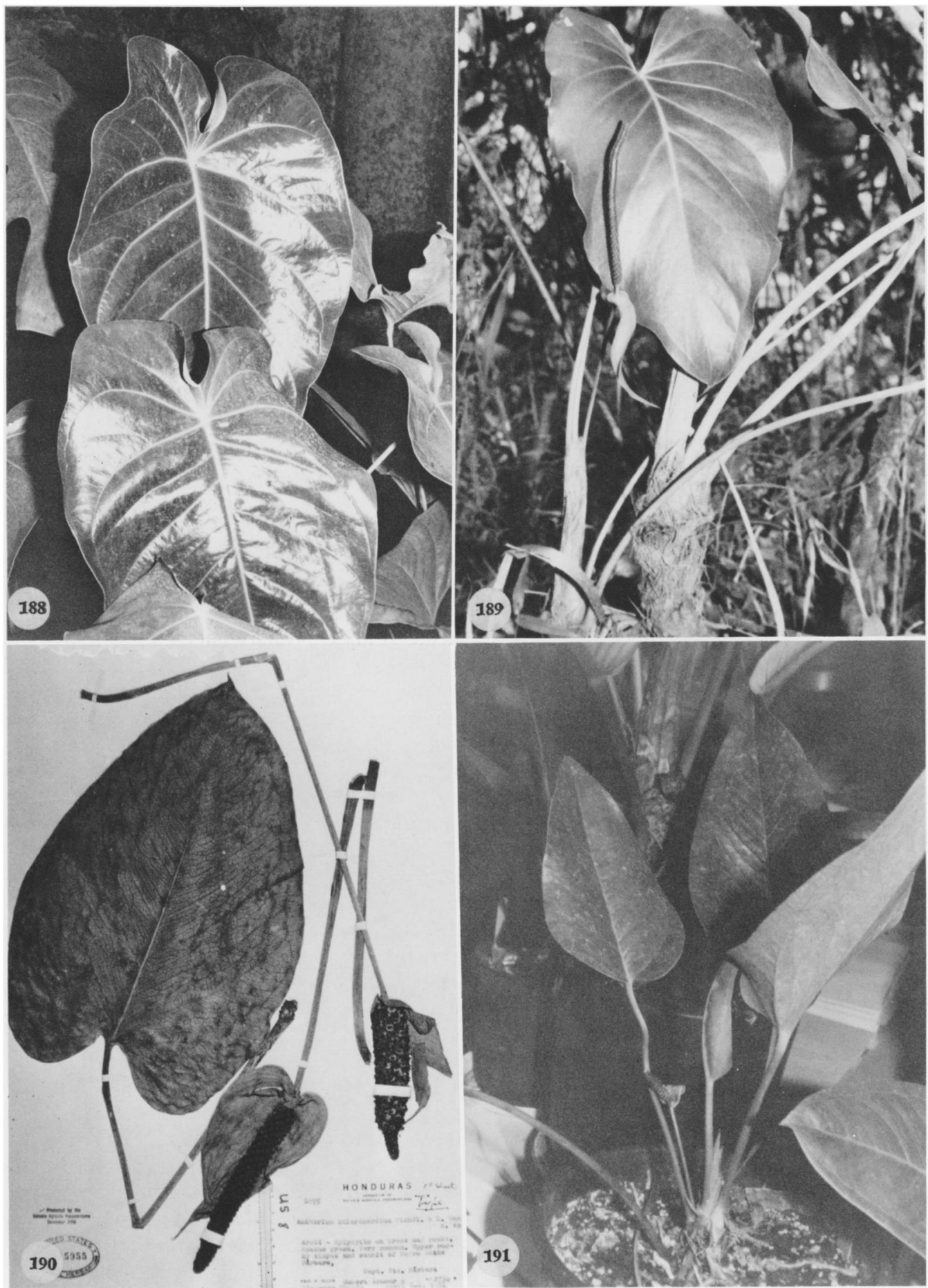

FiguREs 188-191. 188. Anthurium standleyi Croat \& Baker (Cultivated at KEW). - 189. Anthurium standleyi Croat \& Baker, Croat 43431.-190. Anthurium subcordatum ssp. chlorocardium (Standl. \& L. O. Wms.) Croat, Allen et al. 6075 (Type).-191. Anthurium subcordatum Schott, Croat 42500. 

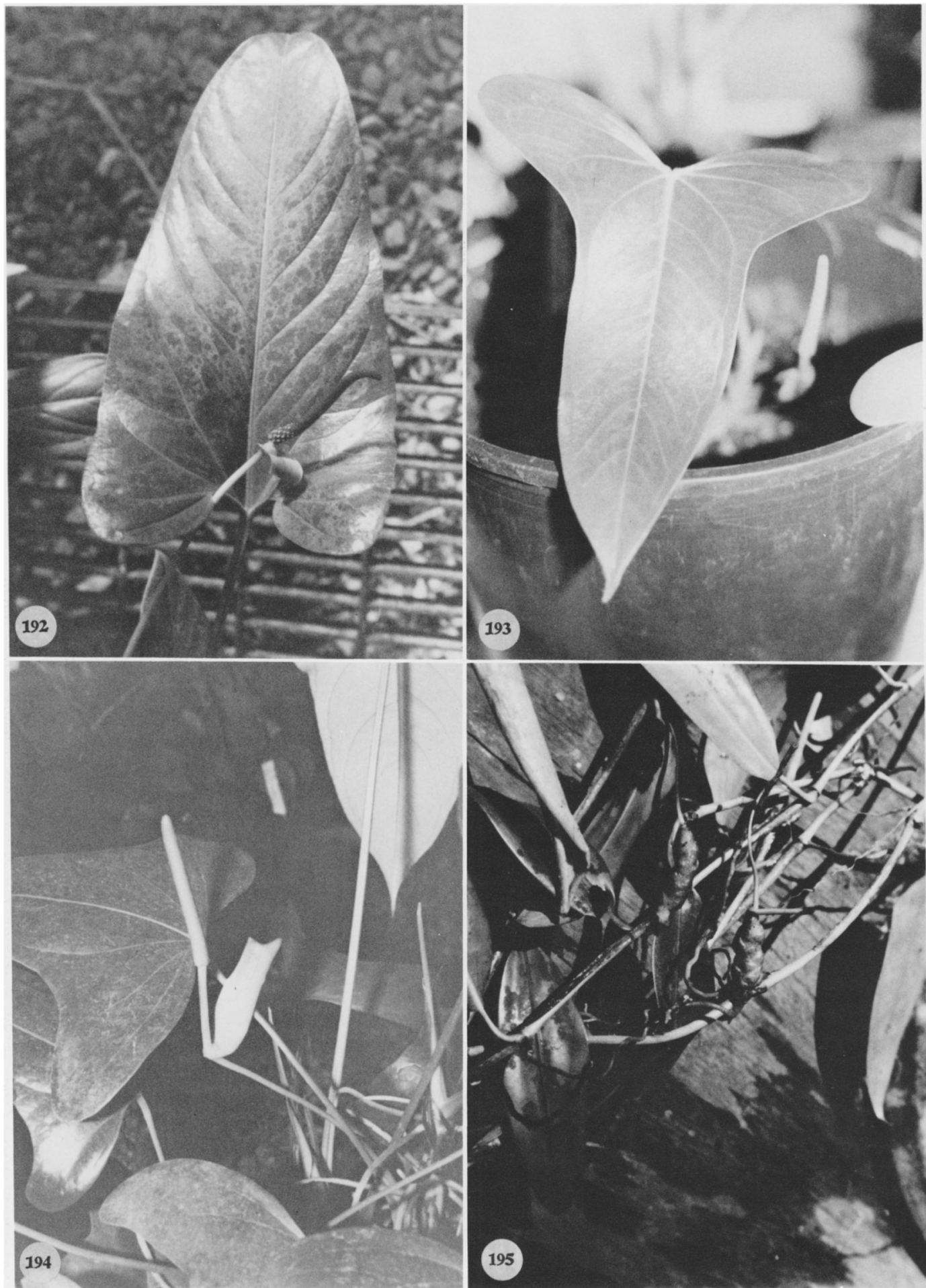

Figures 192-195. 192. Anthurium subovatum Matuda, Croat 39815. - 193. Anthurium subsignatum Schott, Croat 36455. - 194. Anthurium subsignatum Schott (Cultivated at KEW). - 195. Anthurium tenerum Engl., Croat 47089. 

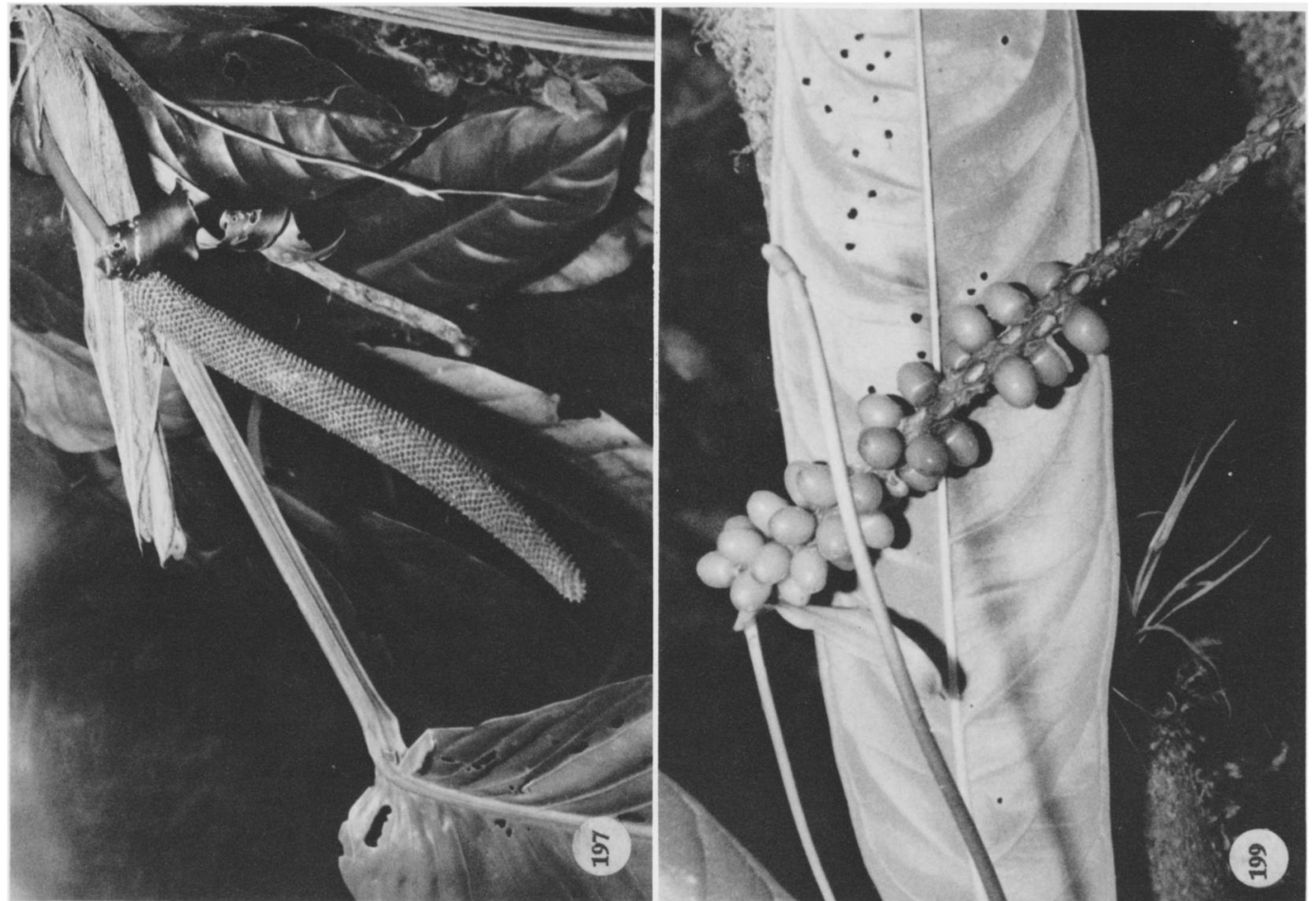

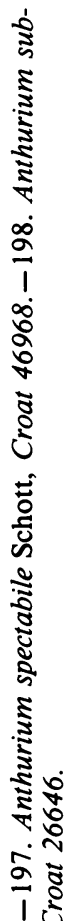
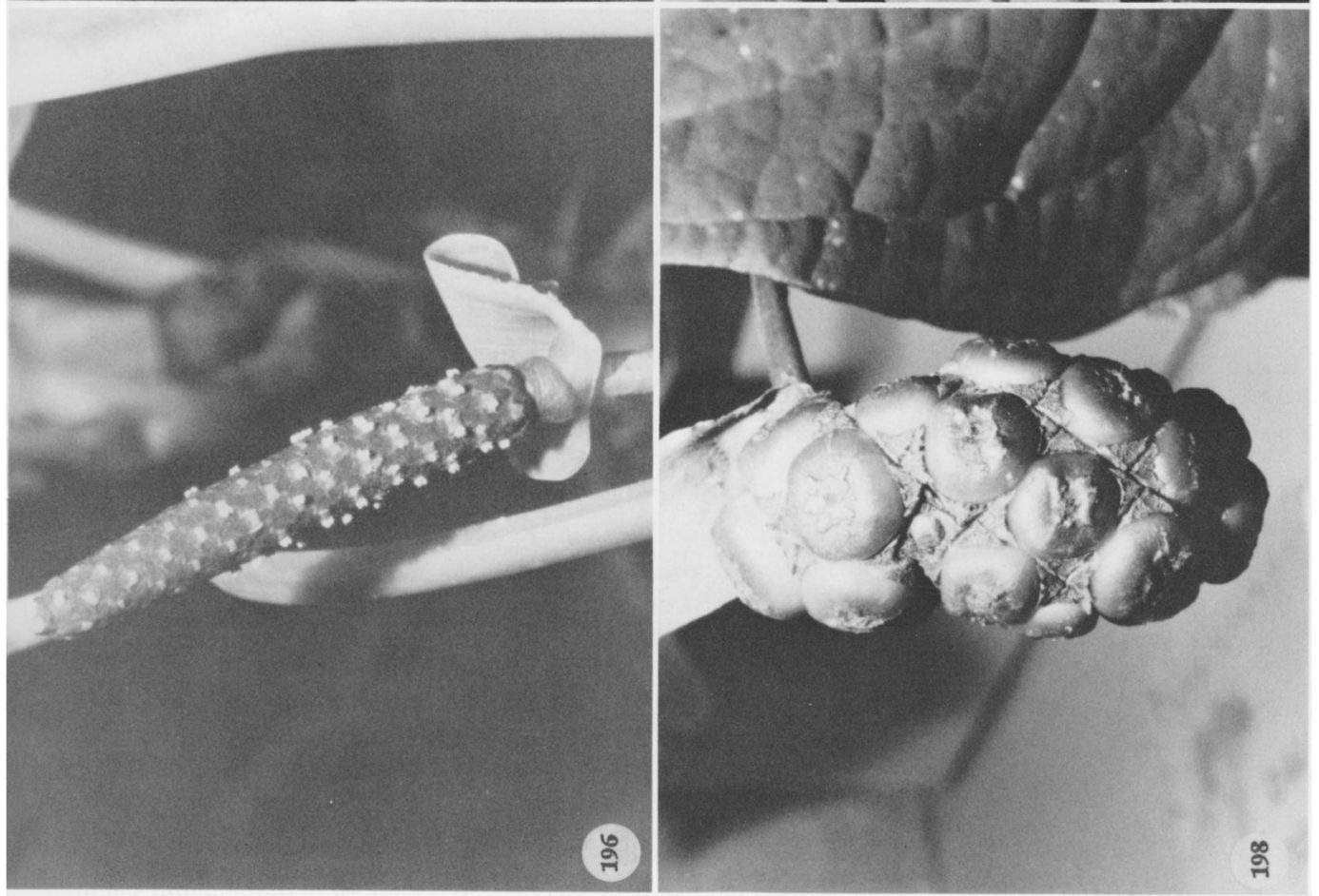

它

テั

ఫे

已

Еし

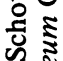

ह

胥

อิ

辛

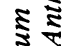

ฐ

₹ 1

ㅇㅇㅇ

ลำ

10

음

色

㟧

位志

ธิ 
$3.6 \mathrm{~mm}$ long, ca. $1.6 \mathrm{~mm}$ wide with minute, triangular appendage at base. Figs. 186 and 197.

Anthurium spectabile occurs in Costa Rica at 500 to $900 \mathrm{~m}$ in premontane wet forest and tropical wet forest.

The species is recognized by its elongate, pendent leaf blades with numerous, prominent, primary lateral veins supported on an erect, 4-sided petiole. Also distinctive is the inflorescence with its short peduncle, large, narrowly ovate, often violet-purple spathe and yellow spadix. Anthurium spectabile has been placed in section Pachyneurium.

Anthurium spectabile is easily confused with A. ranchoanum, which has similar leaves (especially on dried herbarium material) and a similar inflorescence. Anthurium ranchoanum, however, has a subterete petiole and a leaf blade held more or less erect or in line with the petiole. Anthurium spectabile also has an elongate, more or less spreading spathe, while the spathe of $A$. ranchoanum is shorter and usually stiffly erect.

Anthurium spectabile is also similar to A. pseudospectabile (Croat ined.) from Panama, but the latter has longer blades with more undulate margins, terete petioles, and occurs in premontane rain forest.

Costa Rica. alajuela: Cariblanco, Lent 3543 (F); NE of Villa Quesada, Croat 46968 (MO); Molina et al. 17287 (F). Lımón: Guápiles, Smith 4982 (US); S of Siguirres, Croat 43325 (MO).

Anthurium standleyi Croat \& Baker, Brenesia 16 (Supl. 1): 88. 1979. TYPE: Costa Rica. San José: ca. 5 miles SW of Canaán along gravel road from Rivas; steep slopes, ca. $900 \mathrm{~m}$ elev. 14 August 1977, Croat 43439 (MO2582987, holotype; CR, F, K, NY, PMA, SEL, US, VEN, isotypes; Live at MO).

Terrestrial, ca. $1.75 \mathrm{~m}$ tall; stems to $90 \mathrm{~cm}$ long, 3-5 cm diam.; internodes ca. $1 \mathrm{~cm}$ long; leaf scars $2-3 \mathrm{~cm}$ wide; roots dense, tan, fuzzy, descending, ca. $1.2 \mathrm{~cm}$ thick at stem, tapering slightly; cataphylls curled into a tubular cylinder, $15-30 \mathrm{~cm}$ long, somewhat coriaceous, short-acuminate and apiculate at apex, the apiculum ca. $1.5 \mathrm{~cm}$ below apex of cataphyll, drying tan (B \& K Red 9/10), weathering into long, subpersistent fibers. LEAVES with petioles erect to spreading, 43$120 \mathrm{~cm}$ long, 7-16 $\mathrm{mm}$ diam., terete; geniculum $2-4.5 \mathrm{~cm}$ long; blades ovate, moderately thin, obtuse to usually short-acuminate at apex, lobed at base, $40-75 \mathrm{~cm}$ long, $25-56 \mathrm{~cm}$ wide, broadest at point of petiole attachment or slightly above; anterior lobe $33-55 \mathrm{~cm}$ long, the margins broadly convex; posterior lobes $8-21 \mathrm{~cm}$ long; sinus spathulate to obovate, often overlapping, the inner edges turned up, acute at apex; upper surface semiglossy to glossy, lower surface semiglossy; midrib triangularly raised above, diminishing toward apex, convexly raised below; basal veins 4-6 pairs, 4 or 5 of them coalesced $1-4 \mathrm{~cm}$, raised above and below; posterior rib slightly curved, naked, the outer margin sharp and often rolled up; primary lateral veins 5-9 per side, departing midrib at $45^{\circ}-65^{\circ}$ angle, straight then arcuateascending, usually only the uppermost loop-connecting, convexly raised above and below; interprimary veins obscure or occasionally raised in valleys above, raised below; secondary veins slightly sunken in posterior lobes above, flat and slightly darker than surface below; collective vein arising from one of the primary lateral veins in the upper half of the leaf, 4-11 $\mathrm{mm}$ from margin, slightly sunken above, raised below. INFLORESCENCE erect to spreading, much shorter than the leaves; peduncle $29-76 \mathrm{~cm}$ long, 4-9 mm diam., terete; spathe moderately thick, green (B \& K Yellow-green 6/7.5), oblong-lanceolate, 10.5-18 cm long, $2-4 \mathrm{~cm}$ wide, broadest ca. 1 $\mathrm{cm}$ above point of attachment, narrowly acuminate at apex, obtuse to rounded at base, inserted at $60^{\circ}$ angle on peduncle; stipe $11-70 \mathrm{~mm}$ long in front, $6-60 \mathrm{~mm}$ long in back, ca. $5 \mathrm{~mm}$ wide, medium green; spadix green before anthesis, soon heavily tinged with violet-purple, turning yellowish-brown, $10-30 \mathrm{~cm}$ long, $7-10 \mathrm{~mm}$ diam. at base, 4-6 $\mathrm{mm}$ diam. at apex; flowers rhombic to weakly 4-lobed, 3.5-3.6 mm long, 2.9-3.3 mm wide, the sides nearly straight parallel to spirals, smoothly sigmoid perpendicular to spirals; 5-7 flowers visible in the principal spiral, 5-10 flowers visible in the alternate spiral; tepals semiglossy, smooth, with numerous nectar droplets, lateral tepals $1.9-2 \mathrm{~mm}$ wide, the inner margin broadly rounded; pistil weakly raised, medium green; the stigma linear, $0.4-0.7 \mathrm{~mm}$ long, a slight slit briefly filling with nectar a few days before first stamens appear, dry and slightly darkened when stamens emerge; stamens beginning to emerge from or near the base, all 4 stamens in a spiral opening soon after the first, held in a close circle around pistil, obscuring pistil; anthers orange to greenish-yellow, $0.6-1 \mathrm{~mm}$ long, ca. $1 \mathrm{~mm}$ wide; thecae ellipsoid; pollen orange, fading creamy white. INFRUCTES- 
CENCE arching; spathe reflexed; spadix to 30 $\mathrm{cm}$ long, $2 \mathrm{~cm}$ wide; berries broadly ovoid, rounded at apex, orange; mesocarp pulpy, bitter tasting; seeds 2, white, to $5 \mathrm{~mm}$ long. Figs. 188 and 189.

The species is in section Pachyneurium and is known for certain only from Costa Rica in the Cordillera de Talamanca. It was first collected by Paul Standley at two sites, La Verbena and San Sebastian south of San José, in what is probably premontane wet forest. It has been collected more recently in the region northeast of San Isidro del General. The species ranges from 900 to $1,900 \mathrm{~m}$ elevation and may be restricted to premontane wet forest.

A cultivated collection from the University of Hawaii was reportedly based on a Dressler collection from Achiote, a region of tropical moist forest in the Isthmus of Panama. The species has never been collected in Panama to our knowledge, and the collection cultivated in Hawaii is probably mislabelled.

Costa Rica. SAN JosÉ: Cerro Tapezco, Jimenez 627 (US); $1 / 2$ mile above turnoff to Canaán at Rivas, Croat 43431 (MO); 43439 (CR, F, K, MO, NY, PMA, SEL, US, VEN); vicinity La Verbena, Standley 32243 (US); vicinity San Sebastian, Standley 49296 (US); along banks of Río Buena Vista, S of Buena Vista, NE of San Isidro del General, Luteyn 3287 (DUKE); Río Herradura, NW of Canaán, Burger \& Liesner 7093 (MO, US); Talamanca, Tonduz 8721 (NY).

Anthurium subcordatum Schott, Oesterr. Bot. Z. 8: 181.1858.

a. Anthurium subcordatum ssp. subcordatum. TYPE: Guatemala. Quetzaltenango: Las Nubes on slopes of Volcán Zunil, 8,000', Wendland 330 (GOET).

Anthurium basiattenuatum Standl. ex Yuncker, Field Mus. Nat. Hist., Bot. Ser. 17:316, Pl. 4. 1938. TYPE: Honduras. Comayagua: ridge above $\mathrm{El}$ Achiote, Yuncker et al. 6268 (F, holotype).

Anthurium coibionii Standl. \& Steyerm., Publ. Field Mus. Nat. Hist., Bot. Ser. 23: 209. 1947. TYPE: Guatemala. Zacapa: Sierra de Las Minas, Steyermark 42212 (F, holotype; US, isotype).

Epiphytic or terrestrial; stem thick, $1.5-4 \mathrm{~cm}$ diam.; leaf scars $2.5 \mathrm{~cm}$ wide; roots moderately thick, green, descending; cataphylls subcoriaceous, 5-11.2 cm long, narrowly rounded, apiculate at apex, drying light brown, dilacerating at base, persisting. LEAVES spreading; petioles sharply and shallowly sulcate, 16-44 cm long,
6-9 mm diam.; geniculum 1.5-2.2 cm long; blades ovate to narrowly triangular, moderately thick, gradually acuminate at apex, rounded, truncate or shallowly lobed at base, $28-62 \mathrm{~cm}$ long, $10.5-25 \mathrm{~cm}$ wide, broadest well above base; anterior lobe $28-40 \mathrm{~cm}$ long, the margins \pm straight; posterior lobes $4-8 \mathrm{~cm}$ long; sinus arcuate, to parabolic, rarely hippocrepiform, rounded at apex; both surfaces semiglossy, the lower surface sometimes glaucous; the midrib convexly raised above and below, sunken toward apex above; basal veins $2-3$ pairs, usually free to base; posterior ribs naked, the outer margins weakly rolled up; primary lateral veins 6-9 per side, departing midrib at $40^{\circ}-70^{\circ}$ angle, sunken above; intermediate and secondary veins sunken above; tertiary veins conspicuous below, flat; collective arising from the first basal vein, $6-11 \mathrm{~mm}$ from margin. INFLORESCENCE erect-spreading, shorter than leaves; peduncle $10-38 \mathrm{~cm}$ long, 2-4.5 $\mathrm{mm}$ diam., terete, sometimes tinged violet-purple; spathe thin, green sometimes suffused with violet-purple (B \& K Yellow-green 7/ 10), lanceolate to narrowly ovate, $2.5-7.6 \mathrm{~cm}$ long, $1.4-2.7 \mathrm{~cm}$ wide, abruptly acuminate at apex, truncate to rounded at base, inserted at $30^{\circ}$ angle on peduncle; stipe to $17 \mathrm{~mm}$; spadix dark violet-purple or green heavily tinged violet-purple, $3.5-13.5 \mathrm{~cm}$ long, $5.5-9 \mathrm{~mm}$ diam. at base, 3-6 mm diam. at apex; flowers rhombic to sub4-lobed, 2.5-3.5 mm long, 3-3.5 $\mathrm{mm}$ wide, the sides straight to sigmoid, difficult to discern; 57 flowers visible in the principal spiral, 8-11 flowers visible in the alternate spiral; tepals matte to semiglossy, minutely papillate, lateral tepals 1.3-1.8 mm wide, the inner margins \pm straight; pistils emergent, green; stigma oblong-elliptic to linear, $0.4-0.9 \mathrm{~mm}$ long; stamens emerging in a moderately rapid sequence from the base, the laterals emerged from one fifth to two thirds the length of spadix before third to fourth emerge at base, held above and obscuring pistil then retracting and opening; anthers tan or orangebrown, $1 \mathrm{~mm}$ long, $0.8-12 \mathrm{~mm}$ wide; thecae oblong-ellipsoid, scarcely divaricate; pollen cream to yellow. INFRUCTESCENCE erect to spreading; berries obovoid, red, ca. $1 \mathrm{~cm}$ long, $1.2 \mathrm{~cm}$ wide; seeds 2, ca. $6 \mathrm{~mm}$ long, $5.5 \mathrm{~mm}$ wide. Figs. 191 and 196.

The species ranges from western Guatemala in the Departments of Huehuetenango, Quiché and Alta Verapaz to northern El Salvador and western Honduras at elevations from 1,100 to 
$2,800 \mathrm{~m}$. The species occurs in moist and wet forest.

Anthurium subcordatum is in section Belolonchium and, like a number of Mexican and Central American species, is quite variable, characterized by its thick, truncate to subcordate leaf blades, sharply sulcate petioles, violet-purple spadix (or sometimes green heavily tinged violetpurple), and bright red, ovoid berries. The species is probably most closely related to $A$. subovatum from the Sierra de Juárez in northern Oaxaca (Mexico) but differs in having the blade generally broadest well above the base (even on cordate blades as the posterior lobes are turned inward) with most of the tertiary veins obscure, in having the basal veins usually fewer in number (1-3) and usually widespread, sometimes having the second basal vein running to the apex or to the margin well above the middle, Anthurium subovatum has 3-4 basal veins, usually tinged with red and these are generally directed toward the apex at a more acute angle than those of $A$. subcordatum. In addition, the berries of $A$. subcordatum are bright red whereas those of $A$. subovatum are orange. In his discussion of $A$. subcordatum in Flora of Guatemala, Steyermark (Standley \& Steyermark, 1958) referred to $A$. quinquinervium Kunth of South America as a close relative and believed that the two species might be synonymous. Although I have not seen live material of the latter species, it is unlikely that the two are synonymous.

Anthurium subcordatum consists of two subspecies. Subspecies subcordatum extends throughout the range of the species. Subspecies chlorocardium is endemic to the slopes of Cerro Santa Bárbara (Dept. of Santa Bárbara) in western Honduras.

Populations of $A$. subcordatum from southwestern Honduras were described as $A$. basiattenuatum by Standley based on the more acute leaf base, but they are well within the expected range of variation of ssp. subcordatum and are connected to the more typical populations from El Salvador and Guatemala by another Honduran collection (Molina 22322).

It is somewhat unusual that both extremes of the leaf shape variation occur in Honduras since ssp. chlorocardium is at the opposite extreme from $A$. basiattenuatum, with well developed posterior lobes.

El Salvador. Chalatenango: E slope of Los Esesmiles, Tucker 1048 (F, UC, US). SANTA ANA: Cerro
Montecristo, Molina et al. 16836, 16914 (F, NY, US); Wilbur et al. 16358 (DUKE, MO); Croat 42395, 42396, 42500 (MO); Molina \& Molina 12680 (F); Cerro Miramundo, Carlson $940(\mathrm{~F})$.

Guatemala. alta verapaz: W of San Cristóbal, Standley 89750 (F); San Juan Chamelco, Wilson 40926 (F). ChIQuimula: near Village of El Brujo, Steyermark 30935 (F). EL PROGRESSO: Sierra de las Minas, N of Finca Piamonte, Steyermark 43608 (F, NY, US) HUEHUETENANGo: San Juan Ixcoy, Steyermark 50017 (F); 50041 (F, NY); San Mateo Ixtatán, Breedlove 8786 (DS, F, US); Sierra de los Cuchumantes, Cerro Cananá, Steyermark 49109 (F, US). JALAPA: between Jalapa and Lake Ayarza, Steyermark 32814 (F). QUEZALTENANGO: vicinity Quezaltenango, Standley 86557 (F). QUICHÉ: no other location, Aguilar $1276(\mathrm{~F}) ;$ Hyde \& Lux 3516 (GH, K, US); Nebaj, Skutch 1697 (F, GH). ZACAPA: Río Sitio Nuevo, near Santa Rosalía, Steyermark 42212 (F, US); Sierra de Las Minas, Steyermark 29877, 42541 (F).

honduras. COMAyagua: El Achiote, Yuncker et al. 6268 (F, GH, MICH, MO); 6272 (F, GH, MO). OCOTEPEQUE: vicinity Nueva Ocotepeque, Molina $22322(\mathrm{~F})$.

\section{b. Anthurium subcordatum ssp. chlorocardium} (Standl. \& L. O. Wms.) Croat, comb. nov. A. chlorocardium Standl. \& L. O. Wms., Ceiba 3: 103. 1952. TYPE: Honduras. Santa Bárbara: upper rocky slopes and summit of Cerro Santa Bárbara, alt. 2,750 m, April 56, 1951, Allen et al. 6075 (US, F).

Epiphyte; cataphylls 6-10 cm long, weathering to longitudinal fibers. LEAVES with petioles 27 $44 \mathrm{~cm}$ long, 6-8 mm diam.; blades ovate, moderately thick, $26-37 \mathrm{~cm}$ long, $18-24 \mathrm{~cm}$ wide, broadest just below middle, acute at apex, lobed at base; the anterior lobe $24-29 \mathrm{~cm}$ long; posterior lobes $6.5-8 \mathrm{~cm}$ long; the sinus parabolic, round at apex; the midrib drying \pm flat above, raised below; basal veins 3-5 pairs; primary lateral veins 6-8 per side, drying raised on both surfaces; lesser veins drying prominulous on both surfaces; collective vein arising from the first or second basal vein. INFLORESCENCE with peduncle 13.5-39.5 cm long, 4-5 mm diam.; spathe green, thick, $5-12 \mathrm{~cm}$ long, $1.5-6.5 \mathrm{~cm}$ wide, narrowly ovate to ovate, long-acuminate at apex, cordate at base, broadest just above base; spadix 4-12 cm long, $1.5-2 \mathrm{~cm}$ diam.; flowers rhombic, 5-6 mm long; 4.5-6 mm wide, 6-7 flowers visible in the principal spiral, $6-8$ flowers visible in the alternate spiral; lateral tepals $1.5-1.8 \mathrm{~mm}$ wide; pistils raised; stigmas linear, ca. $0.6 \mathrm{~mm}$ long, drying brown; stamens exserted on filaments ca. $0.5 \mathrm{~mm}$ long, ca. $0.9 \mathrm{~mm}$ wide; thecae ellipsoid. INFRUCTESCENCE with subglobose 
berries, ca. $6 \mathrm{~mm}$ diam., immature berries yellow. Fig. 190.

Anthurium subcordatum ssp. chlorocardium is endemic to Honduras on Cerro Santa Bárbara (Department of Santa Bárbara) at elevations of 2,200 to $2,750 \mathrm{~m}$.

Subspecies chlorocardium is a member of section Belolonchium and is distinguished by its narrowly ovate to ovate spathe and its geographical isolation.

Honduras. SANTA BÁRBARA: summit of Cerro Santa Bárbara, Allen et al. 6075 (F, US); E of Lake Yojoa, Clewell \& Hazlett 3916 (MO, US).

Anthurium subovatum Matuda, Bol. Soc. Bot. México 24: 36. 1959. TyPE: Mexico. Oaxaca: road between Cerro Pelón and Yetla, elev. 1,900 m, January 12, 1959, MacDougall 406 (MEXU, holotype).

Terrestrial or epiphytic; stem to $2.5 \mathrm{~cm}$ diam.; leaf scars ca. $2.3 \mathrm{~cm}$ wide; roots tan, numerous, 3-8 mm diam.; cataphylls moderately thick, 5$8.5 \mathrm{~cm}$ long, acute at apex, subapical apiculum $1.9-2.7 \mathrm{~cm}$ long, drying brown, persistent, splitting at base, remaining intact at apex. LEAVES with petioles erect-spreading, 20-51 cm long, 5$7 \mathrm{~mm}$ diam., shallowly and broadly sulcate, the margins sharp, rounded abaxially; geniculum 1$2 \mathrm{~cm}$ long, usually tinged red-violet; blade narrowly ovate-triangular to ovate, moderately thick, acute and apiculate at apex (acumen 2-5 mm long), weakly to prominently lobed at base, 27$44 \mathrm{~cm}$ long, $10-26 \mathrm{~cm}$ wide, broadest at base or just above point of petiole attachment; anterior lobe $26-41 \mathrm{~cm}$ long, the margins \pm straight to convex; posterior lobe $4.5-13 \mathrm{~cm}$ long, usually directed upward from point of petiole attachment; sinus arcuate with petiole decurrent to arcuate to parabolic (when flattened), round to truncate at apex; upper surface semiglossy, lower surface matte, both surfaces sometimes glaucous; midrib weakly, convexly raised above, broad at base, narrowing and sunken at apex, convexly raised almost to apex below; basal veins $3-5$ pairs, the first free, second to fifth coalesced $1-3 \mathrm{~cm}$; posterior rib naked; primary lateral veins $3-7$ per side, departing midrib at $30^{\circ}-50^{\circ}$ angle, loopconnecting to collective vein, sunken above, raised below; secondary and tertiary veins clearly visible, weakly sunken above, raised below; midrib, basal, and primary lateral veins usually tinged red-violet on lower surface, sometimes faintly tinged on upper surface; collective vein usually arising from the first or second basal vein, sunken above, raised below, 4-7 $\mathrm{mm}$ from the margin. INFLORESCENCE spreading to pendent, ca. as long as leaves; peduncle $28-49 \mathrm{~cm}$ long, $4-6 \mathrm{~mm}$ diam., sometimes weakly glaucous or tinged redviolet; spathe moderately thick, lanceolate, green sometimes suffused with red-violet, matte on both surfaces, $6-9.5 \mathrm{~cm}$ long, $1.5-2.7 \mathrm{~cm}$ wide, gradually acuminate at apex, rounded to obtuse at base, inserted at $40^{\circ}-50^{\circ}$ angle on peduncle; spadix green turning dark violet-purple, $10.3-19 \mathrm{~cm}$ long, 7-11 mm diam. at base, 3-4 mm diam. at apex; flowers rhombic to 4-lobed, $3.7-4.2 \mathrm{~mm}$ long, 3.2-3.9 mm wide, the sides weakly to jaggedly sigmoid; 5-7 flowers visible in the principal spiral, 6-1 2 flowers visible in the alternate spiral; tepals matte, minutely punctate, with sparse droplets as stamens emerge, lateral tepals 1.5$2.6 \mathrm{~mm}$ wide, the inner margin broadly rounded, usually turned up against pistil; pistil green, tinged violet-purple, weakly emergent; stigma linear, ca. $0.8 \mathrm{~mm}$ long; lateral stamens emerging slowly from the base, one at a time, the alternates following by $1-3$ spirals; faint yeasty odor as stamens emerge; anthers creamy white, held in tight circle, retracting slightly as pollen disperses; thecae ovoid; pollen pale yellow to creamy white. INFRUCTESCENCE spreading-pendent; spathe green, persistent; berries bright orange, sometimes developing only in the basal one half, broadly obovate, rounded to truncate at apex, 6-9 mm long, 7-9 $\mathrm{mm}$ wide; mesocarp thick, juicy with numerous raphide cells; seeds 1 or 2 , pale green, obovoid-ellipsoid, weakly flattened, 4.5-5.6 mm long, $3.5-5 \mathrm{~mm}$ wide, $2.8-3 \mathrm{~mm}$ thick, with sticky appendages at both ends. Figs. 192 and 198.

Anthurium subovatum is restricted to Mexico in the Sierra de Juárez of northern Oaxaca at 1,500 to $2,100 \mathrm{~m}$ in cloud forests in what appears to be a premontane rain forest life zone.

The species is a member of section Belolonchium and is characterized by its sharply sulcate petioles, thick subcordate to truncate leaf blades with sharply ascending reddish basal veins, numerous clearly visible tertiary veins, violet-purple spadix, and obovoid, more or less truncate, bright orange berries. It is similar to $A$. subcordatum in having a similar leaf shape, but the blades of $A$. subovatum are generally broadest at the base with the posterior lobes often directed 
somewhat upward on well developed plants. $A n$ thurium subovatum also generally has the spadix sessile or nearly so and has orange berries, whereas the spadix of $A$. subcordatum is often conspicuously stipitate and the berries are red. For additional characters see the discussion following $A$. subcordatum.

Anthurium subovatum is also similar to $A$. nakamurae, a species apparently endemic to eastern Chiapas. That species differs in having blades more typically oblong and usually broader toward the apex. Considering the variability in Anthurium it is possible that $A$. subcordatum, $A$. subovatum and $A$. nakamurae may ultimately be proven to be no more than subspecifically distinct.

Mexico. OAXACA: highway between Cerro Pelón and Yetla, MacDougall 406 (MEXU); N of Ixtlán de Juárez on the road to Tuxtepec, Rzedowski 30615 (MO); along road between Valle Nacional and Oaxaca, McAlpin 1047 (DUKE); between Tuxtepec and Oaxaca at Valle Nacional, Croat 39815, 39847, 48066, 48082 (MO); $\mathrm{S}$ of Valle Nacional, Rzedowski 33574 (ENCB).

Anthurium subsignatum Schott, Bonplandia 9: 368. 1862. TYPE: Costa Rica. Limón: Pedregal, Wendland 919 (GOET).

Epiphytic creeper; stems green, $10 \mathrm{~cm}$ or more long; internodes $1.5-11 \mathrm{~cm}$ long; roots pale green, 2-4 mm diam.; cataphylls subcoriaceous, 3.5$10 \mathrm{~cm}$ long, rounded at apex, with thick subapical apiculum ca. $4 \mathrm{~mm}$ long, drying reddish brown, weathering into longitudinal fibers, persisting at nodes. LEAVES with petioles spreading, 14.5-56 $\mathrm{cm}$ long, 3-7 $\mathrm{mm}$ diam., terete, sometimes sharply and narrowly sulcate; geniculum $1.5-3 \mathrm{~cm}$ long, obscurely sulcate, blades ovate-deltoid, short-acuminate at apex, broadly lobed to arcuate at base, 16-48 cm long, 11-52 $\mathrm{cm}$ wide, broadest at base; the anterior lobe 13.5$38 \mathrm{~cm}$ long, the margins \pm straight to convex; posterior lobes $4-21 \mathrm{~cm}$ long; sinus arcuate to parabolic, obtuse to rounded at apex; upper surface matte to semiglossy, lower surface semiglossy; the midrib convexly to \pm acutely raised above, diminished and sunken at apex, acutely raised below; basal veins $3-5$ pairs, the first usually free, the remaining coalesced $2-5 \mathrm{~cm}$; posterior rib naked, weakly turned up; primary lateral veins 4-9 per side, weakly sunken above, prominulous below, loop-connecting; lesser veins less conspicuous; collective vein usually arising from the first basal vein, rarely from one of the lowermost primary lateral veins, sunken above, prominulous below, 3-5 $\mathrm{mm}$ from margin. IN-
FLORESCENCE erect, shorter than leaves; the peduncle 7.5-28 cm long, 3-6 $\mathrm{mm}$ diam.; spathe moderately thin, yellow-green, oblong-lanceolate, 5-25 cm long, $1.3-4 \mathrm{~cm}$ wide, long-acuminate at apex, truncate at base, inserted at $45^{\circ}$ angle on peduncle; spadix yellow to yellow-green, 5.5-26 cm long, 6-9 mm diam. at base, $3-5 \mathrm{~mm}$ diam. at apex; flowers 4-lobed, ca. $2 \mathrm{~mm}$ long, $2.2 \mathrm{~mm}$ wide, the sides jaggedly sigmoid; 4-7 flowers visible in the principal spiral, ca. 9 flowers visible in the alternate spiral; tepals glossy, lateral tepals ca. $1 \mathrm{~mm}$ wide, the inner margin convex; pistil minutely emergent, white, glossy; stigma ca. $2 \mathrm{~mm}$ long, brushlike, with very small droplets for 5-6 days about 7-8 days before first stamens emerge, dry, white to tan when stamens emerge; stamens emerging from base in moderately rapid sequence, the second lateral stamen emerging 1 or 2 days after first stamen; anthers yellow-orange; pollen pale yellow-orange. INFRUCTESCENCE with spadix to $30 \mathrm{~cm}$ long; berries obovoid, violet-purple at apex, white at base, acute at apex, ca. $5 \mathrm{~mm}$ long; seeds 1-2, white, $1.5 \mathrm{~mm}$ long. Figs. 193 and 194.

Anthurium subsignatum is endemic to northern Costa Rica at sea level to $200 \mathrm{~m}$ elevation in tropical wet and premontane wet forest life zones.

This species is a member of section Semaeophyllium and was mistakenly included as a synonym of $A$. trilobum André in "Anthurium in Costa Rica" (Croat \& Baker, 1979). It is closely related to $A$. garagaranum Standl. of Panama and Colombia, which has a similar bright yellow spadix at anthesis. The latter species differs in having more deeply lobed leaf blades. Madison (1978) included $A$. garagaranum as a synonym of $A$. trilobum with admitted misgivings, but additional field work is needed in South America to make an analysis of this complex.

Costa Rica. alajuela: Cañas-Upala road, $\mathrm{N}$ of $\mathrm{Bi}-$ jagua, Croat 36429, 36455, 36485 (MO). HEREDIA: Chilamate, Leon 1784 (US); La Selva Field Station, Grove 34 (MO); Croat 44234 (MO); near Puerto Viejo along road near Río Sucio, Croat 35748 (MO). LIMÓN: vicinity Guapiles, Standley 37458 (US); Hacienda Trapezco-Hda. La Suerte, W of Tortuguero, Davidson \& Donahue 8366, 8654 (MO).

Anthurium tenerum Engl., Bot. Jahrb. Syst. 25: 377. 1898. TYPE: Colombia. Antioquia: Cerro El Plateado in western Andes, dense humid forest, 1,800-2,200 m, Lehmann 7354 (B, K). 
Scandent epiphyte; stems elongate with internodes $1.5-7.5 \mathrm{~cm}$ long; roots moderately thin, usually 2-4 at each node; cataphylls 4-6 cm long, thin, acute at apex, drying tan, persisting intact at nodes. LEAVES spreading; petioles $1-3 \mathrm{~cm}$ long, 2-3 $\mathrm{mm}$ diam., terete, sheath extending $1.5-2 \mathrm{~cm}$ onto petiole, minutely free at apex; geniculum absent; blades oblong or lanceolate, moderately thin, 9-15 cm long, $2.5-4 \mathrm{~cm}$ wide, broadest at middle or just below, acuminate at apex, obtuse to rounded at base; the upper surface semiglossy to glossy, lower surface semiglossy; midrib acutely raised above and below, sunken at apex above; primary lateral veins numerous, nearly obscure above and below; collective vein arising from the base, obscure above and below. INFLORESCENCE spreading, shorter than leaves; peduncle $2.5-4 \mathrm{~cm}$ long; spathe green, ovate, 1.5-2 cm long, 2-9 mm wide; spadix green (B \& K Yellow-green $6 / 2.5$ ), ca. $3 \mathrm{~cm}$ long, scarcely tapered at apex; flowers 4-lobed, the sides sigmoid; 4-5 flowers visible in the principal spiral, 3-4 flowers visible in the alternate spiral; tepals semiglossy, punctate, the inner margin convex; pistils green, emergent, \pm mounded; stigma elliptic, brushlike. INFRUCTESCENCE pendent; spathe absent; spadix to $3.5 \mathrm{~cm}$ long; berries subglobose flat at apex, greenish-white immature, mature berry color unknown, probably $5 \mathrm{~mm}$ diam. at maturity. Fig. 195.

Anthurium tenerum is known from Costa Rica and Colombia (probably in Panama as well) at elevations of 800 to $2,000 \mathrm{~m}$. In Costa Rica the species is known from lower montane rain forest at 1,300 m. It is apparently also rare in Colombia since few collections have been made.

The species is in section Xialophyllium and is most easily confused with $A$. scandens because of its similar habit, size, and leaf shape. Anthurium tenerum can be distinguished by its lack of leaf punctations and by its long slender peduncle which is, at least initially, borne in the conspicuous petiole sheath.

COSTA RICA. CARTAGO: vicinity of Cachí, Croat 47089 (MO); vicinity Río Naranjo, Lent 1583 (NY). HEREDIA: Vara Blanca, Skutch 3658 (MICH).

Anthurium testaceum Croat \& Baker, Brenesia 16 (Supl. 1): 92. 1979. TYPE: Costa Rica. Alajuela: Atlantic side of Alto de las Palomas, 1,900 m, Lent 1820 (F, holotype).

Epiphytic or terrestrial; stems elongate, ca. 1 $\mathrm{m}$ long, 1-1.5 cm diam., drying irregularly grooved on 1 or more sides; internodes 1.5-2.5 $\mathrm{cm}$ long; leaf scars moderately inconspicuous, ca. $1 \mathrm{~cm}$ wide; roots few, scattered at the nodes; cataphylls moderately thin, 6-15 cm long, green, sometimes tinged purplish, apiculate at apex, drying greenish-yellow to brown, dilacerating and often persisting, ultimately deciduous. LEAVES spreading, scattered in upper part of stem; petioles (8)14-48 cm long, 3-6 mm diam., terete; geniculum 5-15 mm long; blades oblong-lanceolate to lanceolate or oblong-elliptic, moderately thin, gradually acuminate to cuspidate-acuminate at apex (the acumen 1-3 cm long), obtuse to rounded (rarely acute) at base, $18-50 \mathrm{~cm}$ long, 4-12.5 cm wide, broadest usually below the middle, the margin \pm straight; upper surface matte to semiglossy, lower surface matte; midrib weakly raised in a valley above, prominently raised below; primary lateral veins $10-16$ per side, departing midrib at $60^{\circ}-80^{\circ}$ angle, weakly sunken above, raised below, loop-connecting to collective vein; lesser veins obscure; collective vein usually arising from the first to third primary lateral vein, 1-8 $\mathrm{mm}$ from margin. INFLORESCENCE spreading, usually shorter than leaves; peduncle 14-40 cm long, 3-5 mm diam., terete, three quarters to equally as long as petioles; spathe \pm thin, green, lanceolate, 3-7 cm long, 7-14 mm wide, acuminate at apex, slightly clasping and rounded at base; spreading, inserted at $60^{\circ}$ angle on peduncle; stipe $2-8 \mathrm{~mm}$ long in front, 1-7 $\mathrm{mm}$ long in back, ca. $3 \mathrm{~mm}$ diam.; spadix green, sometimes tinged with violet-purple, 4-12 cm long, 4-6 mm diam. at base, 2-4 $\mathrm{mm}$ diam. at apex; flowers rhombic, $1.8-4 \mathrm{~mm}$ long, $1.5-3 \mathrm{~mm}$ wide, the sides straight to slightly jaggedly sigmoid; 2-4 flowers visible in either spiral; tepals matte to semiglossy, densely and minutely papillate, turned up against the emerging pistils, lateral tepals $1.8-5 \mathrm{~mm}$ wide, inner margin convex, thin, pale, the alternate pair with inner margins convex; pistils early emergent, green; stigma ca. $0.5 \mathrm{~mm}$ long, elliptic; stamens held at or above the tepals on translucent filaments $0.5 \mathrm{~mm}$ long, $0.3 \mathrm{~mm}$ wide, lateral stamens developing throughout, followed quickly by alternates; anthers orange, $0.5-0.8 \mathrm{~mm}$ long, ca. $1 \mathrm{~mm}$ wide; thecae ellipsoid, slightly divaricate; pollen orange fading to yellow. INFRUCTESCENCE with spadix 7-14 cm long; berries oblong-ellipsoid, rounded at apex, bright red, 9$13 \mathrm{~mm}$ long, 5-7 mm diam., prominently exserted before maturity, mesocarp gelatinous; seeds 2, oblong-ellipsoid to elliptic, rounded at both 
ends, tan, scarcely flattened, 3-7 mm long, 3-4 $\mathrm{mm}$ wide, $2.5-3.4 \mathrm{~mm}$ thick, an appendage enveloping the seed, extending beyond both ends and at least one side. Fig. 199.

The species is found in Costa Rica and Panama at 800 to $2,000 \mathrm{~m}$ elevation in premontane wet and premontane rain forest life zones. In Costa Rica the species ranges from Monteverde in Puntarenas and Alajuela Provinces to San Vito de Java near the Panamanian border. In Panama the species is known only from western Panama near Costa Rica.

Anthurium testaceum can be distinguished by its elongate, narrow stem, long, thin, persistent cataphylls, bright red, prematurely exserted berries, few-flowered spadix spirals, and lanceolate leaf with the midrib and primary lateral veins drying very pale tan.

The species is probably closest to A. cerropirrense Croat (ined.) from Darién Province in eastern Panama, but that species differs in having 57 flowers per spiral and tepals that are not at all elevated. It also has shorter internodes and purple berries.

Live material of this species has been confused with specimens of $A$. pallens. Anthurium pallens differs, however, by its smaller, yellow berries, the midrib and primary lateral veins not significantly different in color from the blade, and the secondary veins more numerous and prominent than in A. testaceum. The veins of A. testaceum probably appear more striking because of the great contrast between the rich green lower leaf surface and the light, almost bleached appearance of the veins. In "Anthurium in Costa Rica" (Croat \& Baker, 1979) it was suggested that it would best be placed in section Leptanthurium; it is, however, best placed in section Xialophyllium.

Costa RicA. Junction of Alajuela, Guanacaste, Puntarenas, Burger et al. 10840 (MO). PUNTARENAS: along Río Coto Brus, near Cotán, $\mathrm{N}$ of La Unión, Croat 26646 (MO). SAN JosÉ: above Río Cascajal, Lent 4040 (MO).

Anthurium tilaranense Standl., J. Wash. Acad. Sci. 17: 245. 1927. TyPE: Costa Rica. Guanacaste: Quebrada Serena, southeast of Tilarán, 700 m, Jan. 1926, Standley \& Valerio 46310 (US, holotype).

Anthurium latihastatum Engl. ex K. Krause, Notizbl. Bot. Gart. Berlin-Dahlem 11: 612. 1932.
SynTYPes: Costa Rica. near San Ramón, 1,3001,400 m, May 1913, Tonduz 17708 (not seen); near San Ramón, 1,200 m, Tonduz 17704 (not seen).

Epiphyte; stems to $1 \mathrm{~m}$ long; internodes short; cataphylls $7-17 \mathrm{~cm}$ long, round at apex with subapical apiculum, drying reddish-brown (B \& K Yellow-red 7/10), persisting intact. LEAVES with petioles spreading, (8) $16-45 \mathrm{~cm}$ long, 4-6 $\mathrm{mm}$ diam.; blades subcoriaceous, 3-lobed, $20-46 \mathrm{~cm}$ long, 10-60 $\mathrm{cm}$ wide; the median lobe oblong, acuminate at apex, the lateral lobes falcate, the inner margin concave, the outer margin convex; the lateral lobes $5.5-15 \mathrm{~cm}$ long; the median lobe 17-24 cm long, the margins straight, shallowly lobed at base; sinus usually arcuate, usually rounded to truncate at apex; both surfaces semiglossy; midrib of the median lobe convexly raised to just below middle, diminished and sunken at apex above, prominently and acutely raised below; basal veins $1-3$ pairs, 2 of them coalesced to $4 \mathrm{~cm}$; posterior ribs submarginal, prominently raised; primary lateral veins $7-10$ per side, departing midrib at $40^{\circ}-60^{\circ}$ angle, flat above, \pm obscure below, straight or curving near collective vein; lesser veins obscure; collective vein arising from second basal vein and extending along outer edge of posterior lobes to the apex of the median lobe, 3-4 $\mathrm{mm}$ from the margin. INFLORESCENCE \pm erect, shorter than leaves; peduncle (7) 10-25(30) cm long; spathe subcoriaceous, pale green, broadly lanceolate to oblong or oblongelliptic, $5.5-11 \mathrm{~cm}$ long, $1.7-3 \mathrm{~cm}$ wide, abruptly acuminate at apex, acute at base; spadix pale green to white (B \& K Yellow-green 8/10), 4.5$14 \mathrm{~cm}$ long, ca. $8 \mathrm{~mm}$ diam. midway; flowers rhombic to sub-4-lobed, 2.4-2.8 $\mathrm{mm}$ long, 2.8$3.3 \mathrm{~mm}$ wide, the sides straight to jaggedly sigmoid; 7-8 flowers visible in the principal spiral and 5-7 flowers visible in the alternate spiral; tepals smooth, glossy, the lateral tepals 1.4-1.5 $\mathrm{mm}$ wide, the inner margin obtusely angular, the outer margin 5 -sided; pistils weakly emergent ca. $0.3 \mathrm{~mm}$; stigma round, $0.2 \mathrm{~mm}$ diam., brushlike; stamens emerging in a rapid progression beginning in the apical half of spadix, the laterals exserted throughout before the alternates emerge, scarcely exserted above tepals on fleshy filaments; anthers white, ca. $0.3 \mathrm{~mm}$ long, $0.5 \mathrm{~mm}$ wide, held close but not contiguous; thecae ovateellipsoid, slightly divaricate; pollen white. INFRUCTESCENCE with spadix to $22 \mathrm{~cm}$ long; berries red (at least apically), obovoid, ca. $7 \mathrm{~mm}$ 


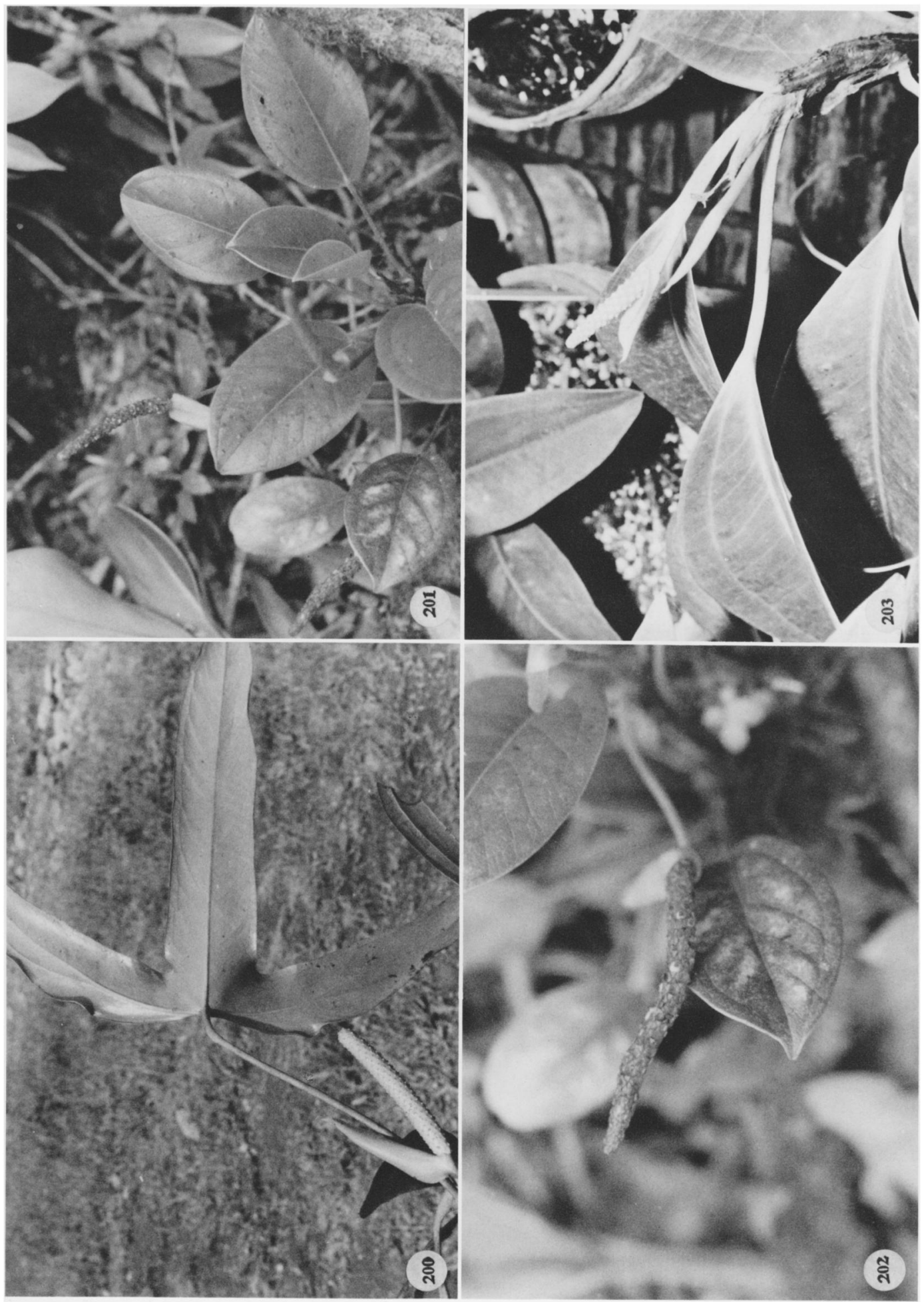

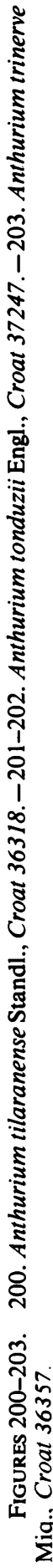


long, $5 \mathrm{~mm}$ diam., obtuse at apex; mesocarp clear, gelatinous; seeds 2 , greenish, ca. $3.5 \mathrm{~mm}$ long, $2.5 \mathrm{~mm}$ wide, $1.5 \mathrm{~mm}$ thick. Fig. 200 .

The species is known from Costa Rica and Panama at 400 to $1,500 \mathrm{~m}$ elevation in premontane wet, tropical wet, and lower montane forest. It is a member of section Semaeophyllium and is not close to any other species in the section. It is distinguished by its deeply 3-lobed leaf blade, with the lateral lobes falcate, persistent cataphylls, and pale green to white spadix that is slightly tapered at both ends. In Costa Rica it can be confused only with $A$. subsignatum, which has blades only weakly 3 -lobed and a bright yellow spadix. In Panama it has leaves similar to A. madisonianum Croat (ined.), which has a longer, reddish-violet spadix and prominently dilacerated cataphylls.

Costa Rica. Alajuela: Cañas-Upala Road, NNE of Bijagua, Croat 36257, 36318 (MO); between Naranjo and Quesada, N of Zapote, Croat 46922 (MO); N of Río Naranjo on road to Upala, Utley \& Utley 4039 (DUKE, MO). CARTAGO: vicinity Moravia, Croat 36685 (MO); between Las Vueltas de Tucurrique and El Oriente, Bogner s.n. (MO). GUANACASTE: Los Ayotes near Tilarán, Standley \& Valerio 45586 (US); slopes of Volcán Miravalles, Luteyn 3409 (DUKE). HEREDIA; vicinity of Vara Blanca, Skutch 3735 (MICH). PUNTARENAS: Monteverde, Jiménez s.n. (MO).

Anthurium titanium Standl. \& Steyerm., Publ. Field Mus. Nat. Hist., Bot. Ser. 23: 211. 1947. TYPE: Guatemala. San Marcos: south facing slopes of Volcán Tajumulco, above Finca El Porvenir, along Río Cabuz to within $2 \mathrm{mi}$ of Cueva de las Palomas, alt. 1,3001,500 m, March 16, 1940, Steyermark 37963 (F, holotype).

Anthurium xanthosomifolium Matuda, Revista Soc. Mex. Hist. Nat. 11:92. 1950. TyPE: Mexico. Chiapas: Municipio Siltepec, Cascada, on wet rock at 1,800 m, April 11, 1949, Matuda 18644 (MEXU, holotype; DS, isotype).

Epipetric or terrestrial; stems short, 2-4 cm diam.; leaf scars $2.5-2.8 \mathrm{~cm}$ wide; roots thick, tan, 5-6 mm diam.; cataphylls subcoriaceous, $4.5-12 \mathrm{~cm}$ long, round to weakly emarginate at apex with a conspicuous subapical apiculum ca. $2 \mathrm{~mm}$ long, drying medium brown (B \& K Yellow $4 / 7.5$ ), weathering into coarse fibers. LEAVES with petioles erect-spreading, 31-90(112) cm long, 5-10(15) mm diam., D-shaped, sometimes weakly sulcate and glaucous; geniculum 1.5-4 cm long; blades moderately thick, ovate to broadly ovate or nearly round, abruptly to gradually acuminate at apex (the acumen apiculate 2-7 mm long), deeply lobed at base, $27-120 \mathrm{~cm}$ long, $29-80 \mathrm{~cm}$ wide, broadest at middle or just below, the margins sometimes markedly undulate, weakly revolute; anterior lobe $19-100 \mathrm{~cm}$ long, the margins broadly rounded; posterior lobes 10-40 cm long; sinus obovate to hippocrepiform, acute to rounded at apex; both surfaces semiglossy; midrib convexly raised above, more acutely raised below, narrowing and diminishing, \pm flat at apex above; basal veins 710 pairs, the first and second free to base, those remaining coalesced $2-4(7) \mathrm{cm}$, raised above and below; posterior ribs conspicuously upturned, naked; primary lateral veins 3-5 per side, departing midrib at $45^{\circ}$ angle, \pm straight to collective vein, loop-connecting to collective vein, weakly raised above and below; interprimary veins conspicuous, flat above and below, lesser veins visible; collective vein arising from the first basal vein in smaller blades or one of the primary lateral veins in the larger blades, weakly sunken above, raised below, 7-15 mm from margin. INFLORESCENCE erect-spreading, as long as or shorter than leaves; peduncle $26-47 \mathrm{~cm}$ long, 7-15 mm diam., terete; spathe subcoriaceous, green, faintly to heavily tinged red-violet, broadly lanceolate, (5)9-26 cm long, $1.8-3.2 \mathrm{~cm}$ wide, broadest just above base, long-acuminate at apex, inrolled $1-2.5 \mathrm{~cm}$, rounded at base, inserted at $25^{\circ}-30^{\circ}$ angle on peduncle, held at ca. $45^{\circ}$ angle from peduncle; stipe 5.5-9 $\mathrm{mm}$ long in front, $4.5-7 \mathrm{~mm}$ long in back; spadix olive-green (B \& K Yellow-green $5 / 5$ ), sometimes weakly to heavily tinged redviolet, (6)11-24 cm long, 1-3 cm diam. at base, 5-10 mm diam. at apex; flowers rhombic to sub4-lobed, 3.7-5 $\mathrm{mm}$ long, 3.8-4 $\mathrm{mm}$ wide, the sides \pm straight to weakly sigmoid; 7-10 flowers visible in the principal spiral, 6-13 flowers visible in the alternate spiral; tepals matte, minutely papillate, lateral tepals $1.8-2.9 \mathrm{~mm}$ wide, the inner margin broadly rounded, thin, paler green; pistil green, emergent, raised; stigma linear, 0.7 $\mathrm{mm}$ long, ca. as long as pistil; stamens emerging at base, 3 or 4 stamens emerging in the first 23 spirals before first emerges in next spiral, held over pistil, retracting to edge of tepals before opening; filaments weakly exserted, translucent, as wide as anthers; anthers pale yellow, 0.9-1.2 $\mathrm{mm}$ long, 1.2-1.4 $\mathrm{mm}$ wide; thecae ellipsoid, 

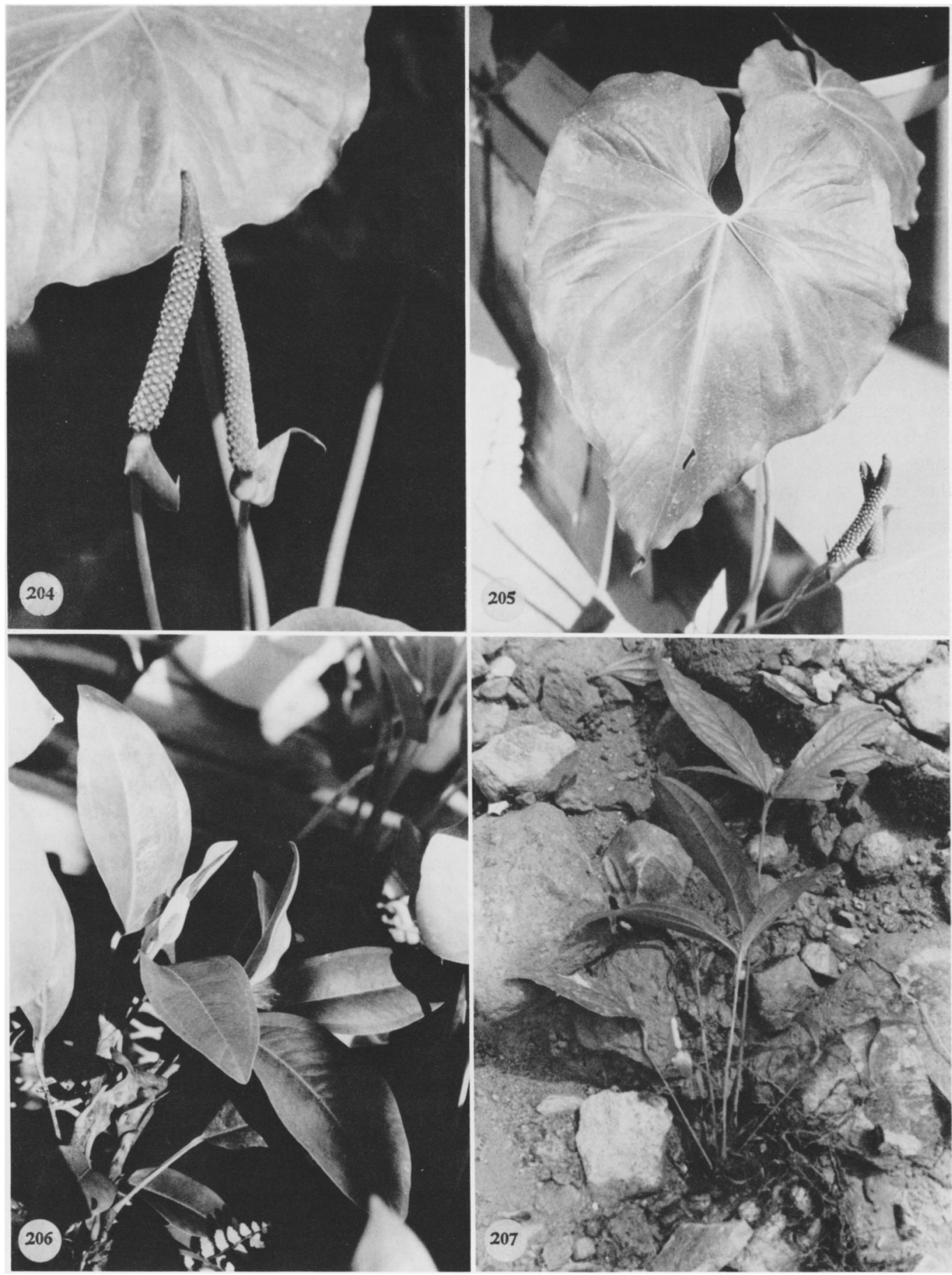

Figures 204-207. 204-205. Anthurium titanium Standl. \& Steyerm., Croat 47253.-206. Anthurium trinerve Miq., Croat 34371.-207. Anthurium trisectum Sodiro, Croat 25633. 
scarcely divaricate; pollen cream. INFRUCTESCENCE probably with orange berries. Figs. 204 and 205.

Anthurium titanium is endemic to a small area in southeastern Chiapas in Mexico and adjacent western Guatemala in the Department of San Marcos from 900 to $1,800 \mathrm{~m}$, mostly from 1,300 to $1,800 \mathrm{~m}$.

The species is a member of section Belolonchium and is characterized by its broadly ovate to subrounded blade with prominent posterior lobes and a weakly glaucous petiole, D-shaped in cross-section.

The species is probably most closely related to $A$. montanum, with which it is sympatric and shares a similar leaf texture and coloration, weathered cataphylls, and petioles that are usually D-shaped in cross-section and somewhat glaucous. The latter species differs in having a narrowly ovate blade which is generally smaller than A. titanium.

The type specimen is unusually large (perhaps twice as large as other collections in most aspects) but otherwise compares well with the material from Chiapas described by Matuda as $A$. xanthosomifolium. The species is by far the largest Anthurium in Mexico.

Guatemala. San marcos: La Trinidad, $2 \mathrm{~km}$ from Finca Armenia, Croat 40904 (MO); Volcán Tajumulco, above Finca El Porvenir, Steyermark 37963 (F).

MeXICO. CHIAPAS: Escuintla, Matuda 18456 (MEXU); 18628 (CAS, DS, NY); 19502 (DS, MEXU); W of Motozintla, Croat 47253(MO); Siltepec, Matuda 5077 (MEXU); 18639 (NY, UC); 18644 (DS, MEXU, MO); 18799, 38603 (MEXU, MO); 19668 (MEXU, MO, NY, UC).

Anthurium tonduzii Engl., Bot. Jahrb. Syst. 25: 376. 1898. TYPE: Costa Rica. San José: near San Marcos, in forest near Alto de Pito, 1,400 $\mathrm{m}$, Tonduz 7683 (B, holotype).

Epiphytic or terrestrial, usually creeping; stems elongate, rooting at nodes; the internodes 2-21 $\mathrm{cm}$ long; cataphylls to $8 \mathrm{~cm}$ long, early deciduous. LEAVES erect-spreading; petioles subterete, narrowly and obscurely sulcate, $1.5-12 \mathrm{~cm}$ long, 2$3 \mathrm{~mm}$ diam.; geniculum 1.4-2.3 cm long; blades ovate to ovate-elliptic, moderately thick, gradually to abruptly acuminate at apex, obtuse to rounded or rarely subcordate at base, $6-13 \mathrm{~cm}$ long, $3.5-8.5 \mathrm{~cm}$ wide; both surfaces glossy, the lower surface conspicuously punctate; 1 (rarely 2) pair of basal veins, the innermost serving as the collective vein; primary lateral veins 3-6 per side, scarcely more conspicuous than the interprimary veins, sunken above, raised below; collective vein arising from the base, $4-5 \mathrm{~mm}$ from the margin. INFLORESCENCE erect-spreading, longer than leaves; the peduncle $3.5-14 \mathrm{~cm}$ long; spathe lanceolate, green tinged reddish, subcoriaceous, $1.5-3 \mathrm{~cm}$ long, $0.5-1 \mathrm{~cm}$ wide, abruptly acuminate at apex, acute at base; spadix green to red, scarcely tapered, $2.5-3 \mathrm{~cm}$ long, 4$5 \mathrm{~mm}$ diam. midway (dry); flowers rhombic to 4-lobed, ca. $2.2 \mathrm{~mm}$ long, $1.9 \mathrm{~mm}$ wide (dry), the sides straight to weakly sigmoid; 4-5 flowers visible in the principal spiral, ca. 7 flowers visible in the alternate spiral; lateral tepals $1.6 \mathrm{~mm}$ wide (dry), the inner margins straight to convex, pistils raised, weakly emergent; stigmas linear, 0.3-0.4 $\mathrm{mm}$ long; stamens emerging in a \pm complete sequence from the base; anthers held in a tight cluster over pistil; thecae broadly ellipsoid. INFRUCTESCENCE with spadix to $8 \mathrm{~cm}$ long; berries white, turning purple at maturity, oblong, ca. $1 \mathrm{~cm}$ long; mesocarp clear, gelatinous; seeds 2, dark violet-purple, ca. $4 \mathrm{~mm}$ long, $2 \mathrm{~mm}$ wide and $1.5 \mathrm{~mm}$ thick. Figs. 201 and 202.

Anthurium tonduzii occurs in Costa Rica and Panama at 800 to $1,500 \mathrm{~m}$ elevation in premontane rain and lower montane rain forest. It has been collected on Cerro Pirre in Darién Province of Panama and is to be expected in Colombia in the Department of Chocó.

The type collection was made in 1893 and no collections have subsequently been made in Costa Rica but the species has been collected five times between 1975 and 1977 in Panama.

Anthurium tonduzii is in section Tetraspermium and does not appear to be related to any other species (certainly to no Central American species), but it looks superficially like $A$. scandens and $A$. trinerve because of similar small, punctate leaves and scandent habit. It differs from both by its longer internodes and entire deciduous cataphylls. The cataphylls of $A$. scandens and $A$. trinerve soon weather into fibers and persist, densely covering the stem.

Anthurium trinerve Miq., Linnaea 17: 67. 1843. Anthurium scandens var. trinerve (Miq.) Matuda, Anales Inst. Biol. Univ. Nac. México 15: 189. 1954. TYPE: Surinam. Palmar Awara, Forbe $120(\mathrm{U})$.

Anthurium brachyspathum C. Koch \& Bouché in C. Koch, Allg. Gartenzeitung 25: 233. 1857. TYPE: Surinam? 
Anthurium trinerve var. obtusum Engl., Bot. Jahrb. Syst. 25: 357-358. 1898. TYPE: Ecuador. Valle Pallatanga, Sodiro 2 (not seen).

Anthurium trinerve var. angustifolium K. Krause, Bot. Jahrb. Syst. 54 (118): 123. 1916. TyPE: Bolivia Antahuacana at Espiritu Santo, 750 m, Buchtien (not seen).

Anthurium codajasii G. M. Barroso, Arch. Jard. Bot. Río de Janeiro, 15: 97. 1957. TyPE: Brazil. Amazonas: Codajás, Logos de Badajós, R. L. Froes 26590 (not seen).

Epiphyte; stems elongate, creeping, usually less than $50 \mathrm{~cm}$ long, 6-9 $\mathrm{mm}$ diam.; internodes 1$3.5 \mathrm{~cm}$ long; roots numerous, $2-3 \mathrm{~mm}$ diam., grayish-brown; cataphylls moderately thin, to 6 $\mathrm{cm}$ long, drying brown, weathering to longitudinal fibers and persisting around stem. LEAVES spreading; petioles $1.3-6 \mathrm{~cm}$ long, $2.5-3.5 \mathrm{~mm}$ diam., \pm D-shaped, broadly and sharply sulcate; geniculum 3-5 mm long; blades moderately thick, elliptic to ovate-elliptic to lanceolate, $8-17 \mathrm{~cm}$ long, 3-7.5 $\mathrm{cm}$ wide, acute at apex, obtuse to attenuate at base; the upper surface semiglossy, lower surface glossy and conspicuously punctate; the midrib acutely raised above, convexly raised below; usually 2 pairs of basal veins, the innermost serving as a collective vein, 5-12 $\mathrm{mm}$ from margin in basal one quarter, closer to margin near apex; primary lateral veins numerous on each side, weakly sunken above, prominulous below; lesser veins obscure. INFLORESCENCES erect, shorter than leaves; peduncle 2$6.5 \mathrm{~cm}$ long; spathe thick, oblong-elliptic, greenish-white, $2.5-3.5 \mathrm{~cm}$ long, $0.5-1.1$ (1.9) $\mathrm{cm}$ wide, abruptly acuminate at apex, obtuse at base, inserted at $35^{\circ}$ angle on peduncle, held erect at anthesis; spadix dark lavender or green to white, 2-4 cm long, 5-7 $\mathrm{mm}$ diam. at base, $2-3 \mathrm{~mm}$ diam. at apex; flowers square, $2.5-4.2 \mathrm{~mm}$ in both directions, the sides straight to gradually sigmoid; 3-6 flowers visible in the principal spiral, 4-5 flowers visible in the alternate spiral; tepals matte to semiglossy, sometimes weakly and sparsely punctate; lateral tepals to $2 \mathrm{~mm}$ wide, the inner margin broadly concave; pistils emergent, white to pale green; stigma linear, ca. $4 \mathrm{~mm}$ long, exserted, brushlike with conspicuous stigmatic droplets 2-3 spirals ahead of emerging stamens; stamens emerging slowly from the base in a prompt and complete sequence, exserted on translucent filaments ca. $1 \mathrm{~mm}$ wide, $0.5 \mathrm{~mm}$ long; anthers white, held against pistil at same level as emerged pistil; thecae ovate-ellipsoid, widely divaricate; pollen white. INFRUCTESCENCE with spadix $4.5-6.5 \mathrm{~cm}$ long; berries white or sometimes pale lavender, globose, 5-7 mm diam.; seeds 4-10, oblong. Figs. 203 and 206.

The species is found in Guatemala and Belize to the Guianas and central Brazil at elevations of 0 to $800 \mathrm{~m}$, in tropical moist, premontane wet, and tropical wet forest life zones. In Middle America the species has been collected only on the Atlantic slope but it occurs on both slopes in Costa Rica and Panama.

Anthurium trinerve is easily confused with $A$. scandens. It is generally found at lower elevations (to $800 \mathrm{~m}$ ) than $A$. scandens. Other differences are discussed under $A$. scandens. It is a member of section Tetraspermium.

Belize. CAyo District: Mountain Cow Ridge, Gentle 3522 (MICH). STANN CREEK DISTRICT: Middlesex, Gentle 2785,2829 (MICH). TOLEDO DISTRICT: Temash River, Dwyer 12841 (MO).

Costa Rica. No other location, Pittier 9511 (BR). Alajuela: Llanuras de San Carlos, Brade 2546 (BR); Villa Quesada, San Carlos, Smith 2528 (MO). GUANACASTE: NW of Lake Arenal, Croat 260 (MO). LIMÓN: between Bribrí \& Bratsi along Río Sixaola, Burger et al. 10421 (MO); Limón, Kuntze 1954 (NY). PUNTARENAS: Golfo de Nicoya, Stork C523 (UC); Terraba, Pittier 3865 (BR); Tinoco Station, Allen 5472 (DS).

Honduras. ATLÁNTIDA: Lancetilla, Chickering 72, 110 (MICH); Yuncker 4557 (MO). GRACIAS A DIOS: Río Plátano behind village of Ras, Gentry et al. 7561 (MO).

Nicaragua. Río SAN JUAN: San Juan del Norte (Greytown), Smith 35 (MO). ZELAYA: Boca Río La Tigra, Río Rama, Stevens 8925 (MO); small Caño at Salto La Oropéndola, Río Rama, Stevens 8964 (MO); vicinity Quebrada El Toro, along Río Iyas, Vincelli 401 (MO); N or NW of Colonia San Antonio, Stevens 9042 (MO); near El Recreo, Atwood \& Neill AN228 (MO); beyond Kururia on road to San Jerónimo, Stevens 7575 (MO); road to Mina Nueva America, N of El Empalme, Stevens 8373 (MO); road between Rosita \& Puerto Cabezas, SW of Río Kukalaya, Stevens 8507 (MO); near Río Okanwás, E of Rosita, Neill 4476(MO); along Río Sucio, E of Bonanza, Neill 4027 (MO).

Anthurium trisectum Sodiro, Anales Univ. Centr. Ecuador 20: 100. 1905. TYPE: Ecuador. Esmeraldas: en la orilla del Río San Antonio, Sodiro 8/904 (B, holotype).

Usually terrestrial, sometimes epiphytic, creeping; stems elongate; internodes 1-6 cm long; cataphylls thin, 2-9 cm long, weathering into fine longitudinal fibers, ultimately deciduous. LEAVES with petioles erect, 18-36(40) cm long, weakly sulcate; blades 3-parted, moderately thin, leaflets sessile or on petiolules to $2 \mathrm{~cm}$ long; median leaflet \pm elliptic to ovate, $12-25 \mathrm{~cm}$ long, 4-11 cm wide, long-acuminate at apex, obtuse at base, lateral leaflets inequilateral ca. two-thirds 
as long as median leaflet, short-acuminate at apex, inner margin attenuate at base, outer margin rounded; the midrib in the median leaflet sunken above, raised below; primary lateral veins 3-5 per side, sunken above, raised below; departing midrib at $35^{\circ}-45^{\circ}$ angle, the collective vein arising from the base, $3-5 \mathrm{~mm}$ from margin. INFLORESCENCE erect, shorter than leaves; peduncle 9-22 cm long, terete; spathe lanceolate or ovate, green becoming white or yellow, $4-6 \mathrm{~cm}$ long, $1.2-2.5 \mathrm{~cm}$ wide, acuminate at apex, rounded at base; spadix green to yellow, scarcely tapered, $3.7-5 \mathrm{~cm}$ long, 4-6 mm diam. at base; the flowers 4-lobed, ca. $1.7 \mathrm{~mm}$ in both directions, the sides sigmoid; ca. 6 flowers visible in the principal spiral, ca. 5 flowers visible in the alternate spiral; lateral tepals $0.9-1 \mathrm{~mm}$ wide, the inner margin convex; pistils emergent; stigma elliptic; stamens emerging irregularly throughout spadix, held at edge of tepals; thecae ellipsoid. INFRUCTESCENCE with spadix to $6.5 \mathrm{~cm}$ long, berries violet-purple, globose to ovoid, with a short beak. Figs. 207 and 208.

The species occurs from Costa Rica to Ecuador at elevations from sea level to $500 \mathrm{~m}$ in tropical wet forest life zones. In Costa Rica the species is known only from the OTS La Selva research area, 100 to 200 m elevation in Heredia. In Panama, the species is known only from 300 to $700 \mathrm{~m}$ elevation in Coclé and Veraguas Provinces, principally on the Atlantic slope.

Anthurium trisectum is in section Dactylophyllium and is distinguished by its usually terrestrial habit and thin, 3-parted leaf blades with conspicuously impressed veins. No other Costa Rican Anthurium has completely 3-parted blades and $A$. trisectum is not closely related to $A$. subsignatum, the only other species tending to have 3-lobed blades.

Costa Rica. Heredia: La Selva (field Station of Organization for Tropical Studies) (previously Finca La Selva), Folsom et al. 8825, 9171; Grayum 1833; Hammel 8274, 10457, 11496; MacDougall 999; Damon Smith 133; Sperry 834, 1083; Todzia 1171; Wilbur 28111, 30024, 30363, 33542 (DUKE).

Anthurium umbrosum Liebm., Vidensk. Meddel. Dansk Naturhist. Foren. Kjøbenhavn 1: 21. 1849. TyPE: Mexico. Oaxaca: near Mirador, Liebmann 15790 (C, holotype; F, US, isotypes).

Anthurium liebmannii Schott, Bonplandia 7: 165. 1859. TYPE: Mexico. Oaxaca: near Teotalcingo, 5,000', Liebmann (C).
Terrestrial to $1 \mathrm{~m}$ tall; stems $2.5-3 \mathrm{~cm}$ diam.; internodes very short; leaf scars to $2 \mathrm{~cm}$ wide; roots few, moderately thin, descending; cataphylls coriaceous, sometimes tinged with purple, 5-9 cm long, emarginate and long-apiculate at apex, drying dark tan (B \& K Yellow 6/7.5), weathering into longitudinal fibers and persisting. LEAVES with petioles arching, subterete, sometimes narrowly and bluntly sulcate, or weakly flattened adaxially, $12-46 \mathrm{~cm}$ long; geniculum $0.7-1.1 \mathrm{~cm}$ long; blades medium thick, narrowly ovate to ovate-triangular, gradually long-acuminate at apex, deeply lobed at base, $20-43 \mathrm{~cm}$ long, $12-27 \mathrm{~cm}$ wide, broadest at base or midway between base and point of petiole attachment, the margin broadly undulate; anterior lobe $15-32 \mathrm{~cm}$ long, margin broadly convex, posterior lobes 4-14.5 cm long; sinus hippocrepiform to spathulate or parabolic, rounded to acute at apex; both surfaces semiglossy; the midrib convexly raised above, raised and conspicuously more acute below; basal veins 4-6 pairs, prominulous above, and below, third to sixth coalesced $2-3.5 \mathrm{~cm}$, posterior rib straight to weakly curved, almost completely naked, the outer margin turned conspicuously upward; primary lateral veins 3-5 per side, departing midrib at ca. $50^{\circ}$ angle, straight to weakly arching to collective vein, sunken above, flat to prominulous below; lesser veins visible, \pm flat above and below; collective vein arising from the first basal vein, sunken above, raised below, $8-12 \mathrm{~mm}$ from the margin. INFLORESCENCE usually longer than leaves, spreading to pendent; peduncle $25-84 \mathrm{~cm}$ long, $2.5-3.5 \mathrm{~mm}$ diam., terete, at least twice as long as petioles; spathe coriaceous, green, sometimes tinged with violet-purple, oblong-lanceolate to narrowly ovate-triangular, $5.5-13 \mathrm{~cm}$ long, $1.5-3.3 \mathrm{~cm}$ wide, gradually long-acuminate at apex, narrowly inrolled to $2.5 \mathrm{~cm}$ long, rounded to subcordate at base, inserted at $45^{\circ}-60^{\circ}$ angle on peduncle; spadix green turning dark violetpurple to brownish at anthesis, $4.8-12.2 \mathrm{~cm}$ long, 5-12 mm diam. at base, 3-6 mm diam. at apex; flowers rhombic to sub-4-lobed, $3.3-4.1 \mathrm{~mm}$ in both directions, the sides straight to gradually to jaggedly sigmoid; 6-7 flowers visible in the principal spiral, 6-8 flowers visible in the alternate spiral; tepals matte, weakly punctate, minutely papillate with scattered droplets, lateral tepals 2$2.5 \mathrm{~mm}$ wide, the inner margins broadly convex; pistils green, weakly exserted just before anthesis; stigma elliptic, conspicuously raised, large stigma drop apparent shortly before stamens emerge; stamens emerging from base in a regular pattern, 


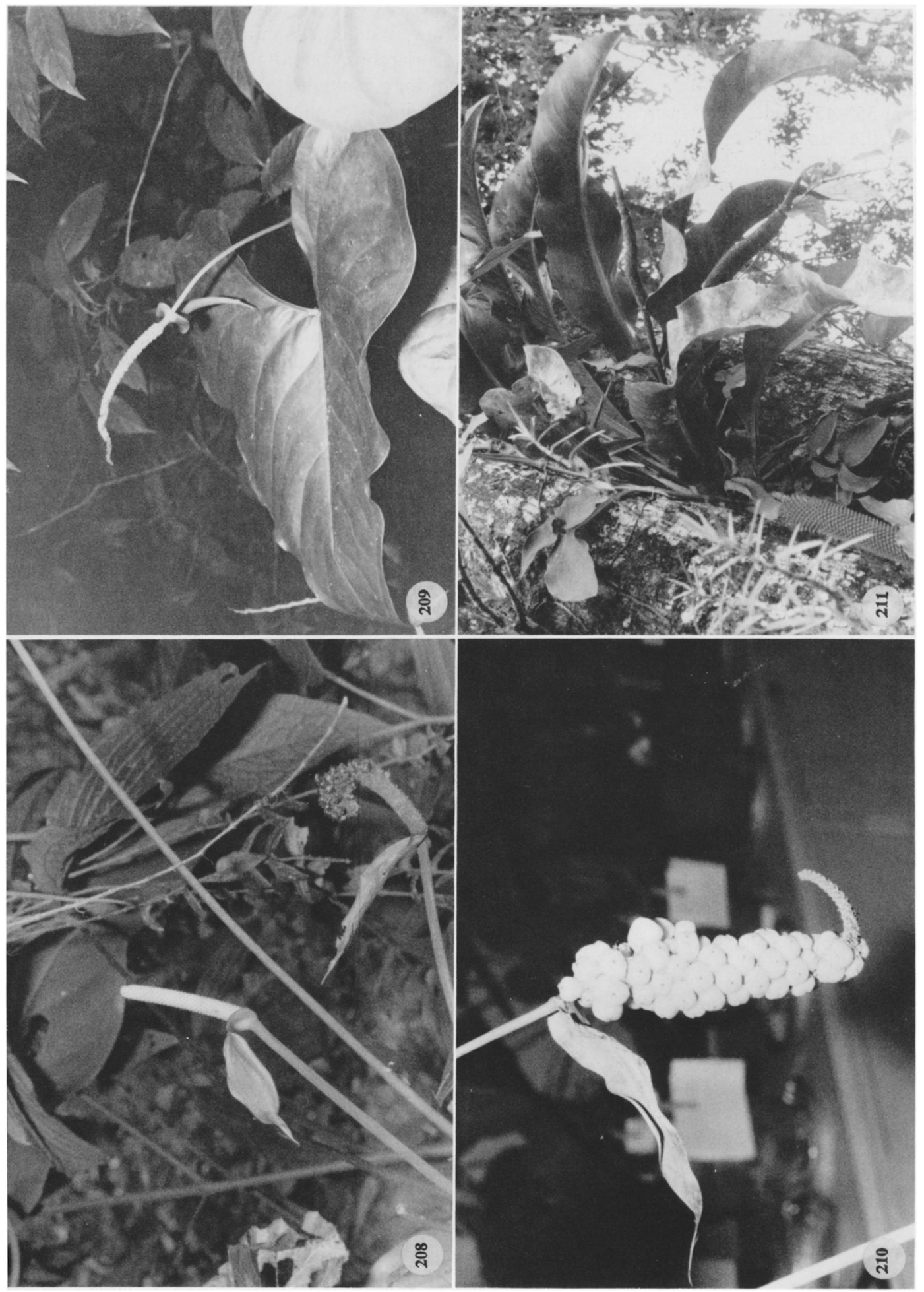

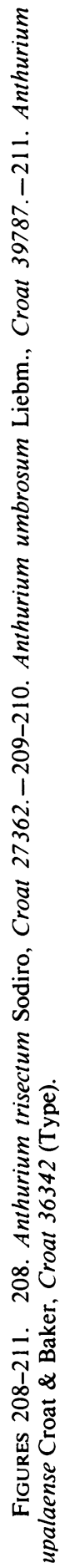


the laterals first, soon followed by alternates, complete in basal one quarter before the laterals emerge just above midway; anthers cream, held in noncontiguous circle around pistil, ca. $1 \mathrm{~mm}$ long, $1-1.1 \mathrm{~mm}$ wide; thecae ovoid, slightly divaricate; pollen cream. INFRUCTESCENCE spreading to pendent; the spathe persistent; spadix $11-13 \mathrm{~cm}$ long, $1.7-2 \mathrm{~cm}$ diam., berries usually developing in basal one half to two thirds; berries bright orange, \pm globose, usually with 4 radial ridges, the apex broadly rounded to nearly truncate; mesocarp juicy, somewhat pulpy, orange with numerous raphide cells; seeds 2 , obovoid, $6-7.5 \mathrm{~mm}$ long, $4.5-6 \mathrm{~mm}$ wide, $3-4 \mathrm{~mm}$ thick, depressed at apex. Figs. 209 and 210.

Anthurium umbrosum is endemic to Mexico and known only from northern Oaxaca, principally in the Sierra de Juárez, south of Valle Nacional on the Atlantic slope at 1,200 to $1,800 \mathrm{~m}$ elevation. It occurs in wet cloud forests on usually steep slopes.

The species is characterized by its terrestrial habit, moderately thick, usually narrowly ovate, long-acuminate leaf blades, green, coriaceous, lanceolate spathe, which curls under along margins, spadix green in early stages, becoming violet-purple, and orange, 4-ridged berries.

Anthurium umbrosum is in section Belolonchium and is closely related to A. lancetillense. It is distinguished from that species in having shorter, more flexible peduncles, longer, more pendent inflorescences, somewhat smaller, distinctively 4-ridged berries, and a thicker spathe. Anthurium umbrosum occurs at much higher elevations, $A$. lancetillense having been collected only in the Lancetilla Valley in Honduras at elevations of 10 to $600 \mathrm{~m}$.

The species is also similar to $A$. ovandense from southern Oaxaca and Chiapas, but that species has a much thinner blade that is minutely undulate along the margin and that usually has anterior lobes concave along the margin.

Anthurium umbrosum is also similar to $A$. lezamae from northern Oaxaca, but that species differs in having a minutely alveolate epidermal pattern (at least on drying).

Mexico. OAXaca: Mirador, Liebmann 15790 (C, F, P, US); Río Mono Blanco, MacDougall 7940 (MEXU); Teotalcingo, Liebmann 22349 (Neg. \#3903, Schott Aroid Drawing MO); along Highway 175 between Tuxtepec \& Oaxaca, S of village of La Esperanza, Croat $39787,43905,48026$ (MO); $\mathrm{S}$ of Valle Nacional on road to Ixtlán de Juárez, King $2130(\mathrm{MICH})$; from bridge at Valle Nacional along highway to Oaxaca, Moore \& Bunting 8896 (MEXU); S of Valle Nacional,
Rzedowski 33844 (ENCB, MEXU, MO). VERACRUZ: Plan de Cediño, Munc. Acajeta, Ventura 4665 (MICH).

Anthurium upalaense Croat \& Baker, Brenesia 16 (Supl. 1): 97. 1979. TYPE: Costa Rica. Alajuela: along road between Cañas (Guanacaste) and Upala, near Río Zapote, 1.8-2.7 $\mathrm{km}$ south of Río Canalete, ca. $100 \mathrm{~m}$ elev., disturbed margin of primary forest, 25 June 1976, Croat 36342 (MO-2381219, holotype; $\mathrm{CR}, \mathrm{F}$, isotypes; Live at $\mathrm{MO}$ ).

Rosulate, epiphyte; stems less than $20 \mathrm{~cm}$ long, $1.5-2 \mathrm{~cm}$ diam.; leaf scars hidden by persisting cataphylls and roots; roots moderately thick and long, 2-4 $\mathrm{mm}$ diam., brown, moderately dense and numerous; cataphylls coriaceous, $11-22 \mathrm{~cm}$ long, narrowly acuminate at apex, sometimes tinged lightly with red, turning brown on drying, remaining firm and intact, ultimately deciduous. LEAVES erect-spreading; petioles (6)10-39 cm long, 7-10 mm diam., subquadrangular, broadly and sharply sulcate, prominently 3-ribbed abaxially, the sides flat to somewhat concave; geniculum 1-1.5 cm long, sometimes reddish abaxially; blades narrowly oblong-elliptic to oblong-oblanceolate, moderately thick, gradually acuminate at apex (the acumen apiculate, downturned), broadly to narrowly acute at base, (30)40$106 \mathrm{~cm}$ long, (4.5)8-23 cm wide, broadest at the middle or slightly above; both surfaces semiglossy; the midrib flat at base above, narrowed and becoming triangular toward apex, prominently raised below, 3-ribbed near base; primary lateral veins more than 20 per side, departing midrib at ca. $60^{\circ}$ angle, raised above and below, \pm straight to collective vein, loop-connecting in upper half; the interprimary veins flat or slightly raised above, flat and slightly darker than surface below; lesser veins less conspicuous; collective vein arising in the upper half, flat above and below, 3-5 mm from margin. INFLORESCENCE erect to spreading or arching-pendent; peduncle (18)40-48 cm long, 4-9 mm diam., terete or 1-ribbed below opening of spathe (faintly many ribbed), sometimes tinged purplish at base, longer than petioles; spathe moderately thick, yellow-green (B \& K Yellow-green 6/7.5, $7 / 2.5,7 / 5$ ), sometimes heavily tinged with violet-purple, oblong-lanceolate to lanceolate, (4.5) $8-20 \mathrm{~cm}$ long, $1-4 \mathrm{~cm}$ wide, broadest at base, gradually short-acuminate at apex, acute at base, inserted at $60^{\circ}-75^{\circ}$ angle on peduncle; spadix sessile, green to purplish (B \& K Yellow-green 6/5), sometimes red, 9-30 cm long, 6-15 mm 
diam. at base, 4-6 mm diam. at apex; the flowers square to rhombic, $2.3-3.4 \mathrm{~mm}$ long, $1.7-2.8$ $\mathrm{mm}$ wide, the sides straight to weakly sigmoid; 7-15 flowers visible in the principal spiral, 1020 flowers visible in the alternate spiral; tepals matte, inconspicuously pale punctate, with droplets usually after 2 or more stamens emerge, lateral tepals $0.8-1.8 \mathrm{~mm}$ wide, the inner margin straight to slightly convex; the pistil raised ca. $0.5 \mathrm{~mm}$, green to purplish; stigma elliptic, 0.4 $1.1 \mathrm{~mm}$ long, green, brushlike, exserted ca. 0.1 $\mathrm{mm}$, with droplets for 5-15 days beginning 12 22 days before the first stamens emerge, dry and black when stamens emerge; stamens emerging rapidly from the base or near the base, emerging one at a time ca. $1 \mathrm{~cm}$ ahead of one another on spadix, the apical stamens usually preceding the basal ones, exserted on short greenish filaments, ca. $0.2 \mathrm{~mm}$ long, $0.5-1 \mathrm{~mm}$ wide, which retract to hold anthers in a tight circle around pistil or separately at sides of pistil; anthers pale orange, 0.5-0.6 mm long, 0.7-1 mm wide; thecae ellipsoid, scarcely divaricate, opening flat; pollen orange, fading to pale orange or lavender, white or tan. INFRUCTESCENCE pendent; the spathe reflexed; the spadix to $55 \mathrm{~cm}$ long, $6 \mathrm{~cm}$ diam.; berries oblong, red, tapered to both ends, 9-15 $\mathrm{mm}$ long, acute at apex, emerging \pm uniformly throughout spadix, well above tepals before fully mature; mesocarp mealy, sweet, white; seeds 2 , oblong, to $4 \mathrm{~mm}$ long, $3 \mathrm{~mm}$ wide, $2.5 \mathrm{~mm}$ thick, creamy white, obliquely truncate at apex with a short appendage, greenish at base. Figs. 211 and 212.

The species is known from the Atlantic slope of Nicaragua and Costa Rica at elevations from near sea level to usually less than $600 \mathrm{~m}$ in regions of tropical wet forest, premontane wet forest, and wetter parts of tropical moist forest life zones. A collection from Cartago Province, northeast of Río Grande de Orosi at $1,300 \mathrm{~m}$ is apparently also this species.

Anthurium upalaense is a member of section Pachyneurium and is apparently most closely related to $A$. concolor K. Krause from Panama but differs in having the inflorescence pendent, the spadix long-tapered and more or less green at anthesis, the spathe longer and recurled, the fresh anthers pale orange, the major lateral veins scarcely raised, often forming a collective vein from near the middle or above, the reticulate veins clearly visible when fresh, weakly raised and prominulous when dried. Anthurium con- color, on the other hand, has the inflorescence stiffly erect, the spathe usually less than $10 \mathrm{~cm}$ long, usually not recurled at apex, the spadix not tapered, dark purple-violet, and usually less than $7 \mathrm{~cm}$ long at anthesis. Its flowers form minute globules of nectar on the tepals and the pollen is pale violet-purple, its major lateral veins are prominently raised and seldom form a collective vein except near the apex, and the reticulate veins are more or less obscure. Anthurium concolor is known only from the Atlantic slope in central Panama.

Costa RicA. Cultivated at Kew, from Costa Rica, N. E. Brown S.n. (K); Bull 467/1873(K). Alajuela: W of Fortuna, NW of New Volcán Arenal, Taylor \& Taylor 1170 (NY); San Juan de Lajas, Austin Smith 1498 (NY); near Artezalea and Methodist Rural Center, NE of Ciudad Quesada, Molina et al. 17264 (EAP, F); vicinity Los Chiles, Río Frío, Holm \& Iltis 771 (NY); 811 (P, U); road between Cañas and Upala, $\mathrm{N}$ of Río Zapote, Croat 36342 (CR, F, MO); 36380 (MO); road between Cañas and Upala, NNE of Bijagua, Croat 36319 (MO); S of Canalete near the Río Zapote, and along the new road to Upala, Burger \& Baker 1001 (CR, F, MO, US); 9964 (F); NNE of Bijagua along the new road to Upala, Burger \& Baker 9859 (CR, F); Lake Arenal, Alto de la Carpintera, near Tilarán, Brenes 18194, 18195 (CR). CARTAGO: NE of Río Grande de Orosi at Tapantí, Utley 5062 (MO); Forest of Tuis, near Turrialba, Pittier 12720 (US); Lake Bonilla, Pacheco 92 (F). GUANACASTE: El Arenal, Standley \& Valerio 45328 (US). HEREDIA: Finca La Selva, Puerto Viejo de Sarapiquí, Croat 44297 (MO); near Puerto Viejo along road to Río Sucio, Croat 35708 (MO); SW of Puerto Viejo along road to San José, Burger \& Matta 4343 (F, CR). LIMÓN: between Hone Creek and NW on a trail paralleling the Río Carbón, Utley \& Utley 660 (F); Taskí, Talamanca Valley, Tonduz 9507 (BR, CR); Pittier 9509(BR); Forests of Shirores, Talamanca, Tonduz 9228 (BR); Hamburg Finca on Río Reventazon below Cairo, Standley \& Valerio 48869 (US); along Hwy. 32 near Río Madre, SW of Limón, Croat 43305 (MO); vicinity of Bribrí near Río Catarata, Croat 43221 (MO); general Vicinity Limón, Burger \& Burger 8446 (CR, F); along shore at Cahuita, Baker \& Burger $17 \mathrm{~A}$ (CR, F); $17 B(\mathrm{CR}, \mathrm{F}, \mathrm{MO})$; along the new road between Limón and Puerto Viejo, Baker \& Burger 174 (F). SAN JosÉ: Forests of Las Vueltas, Tucurrique, Tonduz 13319 (US).

Nicaragua. Matagalpa: Cerro Musún, W \& NW side above Salto Grande of Quebrada Negra and in valley of Río Bilampí, Neill 1782 (MO). RíO SAN JUAN: Neill 1552 (MO). zELAYA: along stream $\mathrm{N}$ of settlement "Las Mercedes," Vincelli 328 A (MO).

Anthurium utleyi Croat \& Baker, Brenesia 16 (Supl. 1): 100. 1979. TyPE: Costa Rica. Alajuela: $2 \mathrm{~km}$ N of Ángeles Norte de San Ramón, 4,000', Luteyn 3695 (DUKE-233270, holotype).

Epiphyte; stems short, densely covered by 


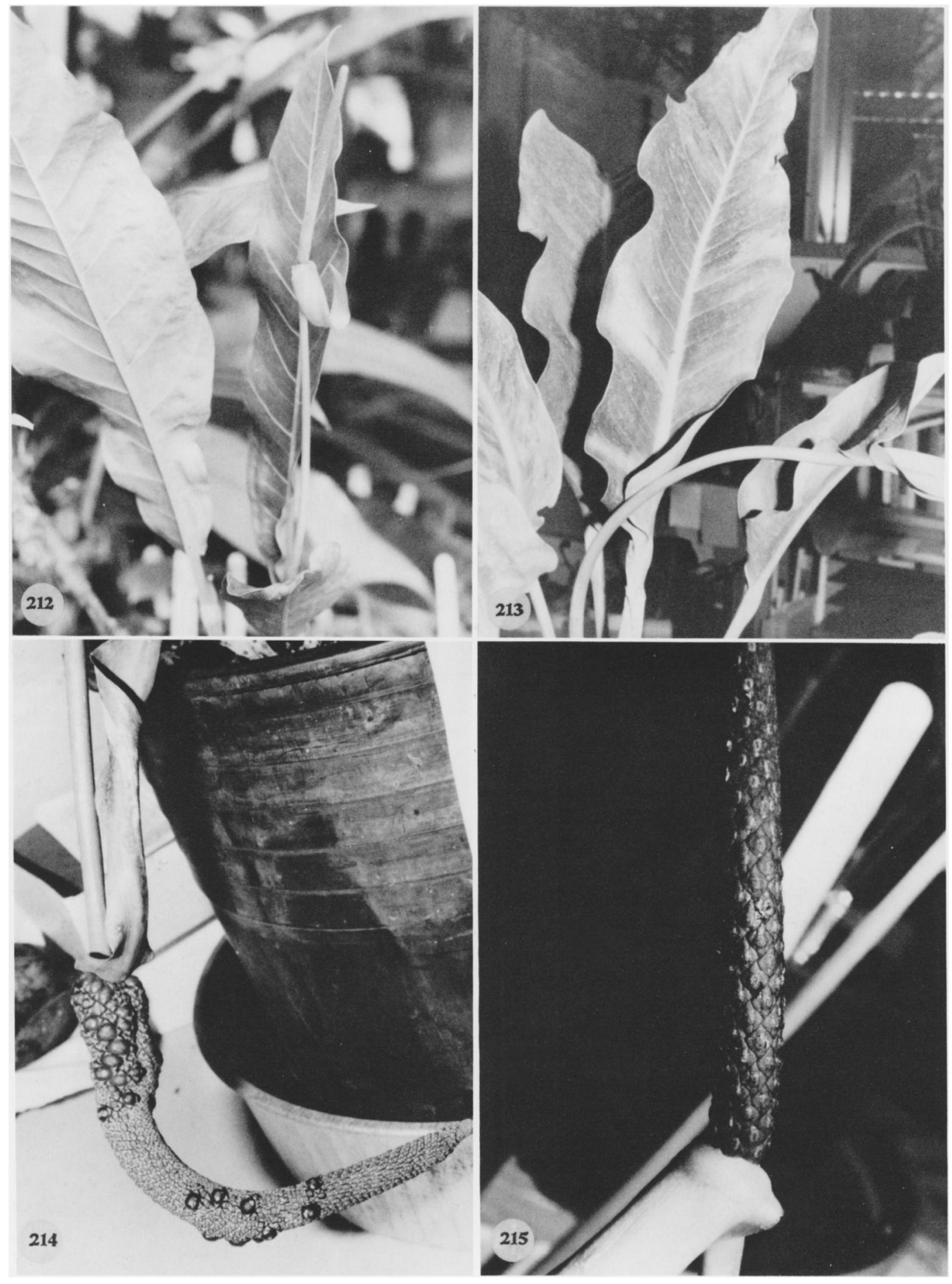

Figures 212-215. 212. Anthurium upalaense Croat \& Baker, Croat 43305.-213-214. Anthurium validifolium K. Krause, Croat 10667.-215. Anthurium verapazense Engl., Boutin 5122. 
cataphyll fibers; roots few, moderately long, descending, 2-3 mm diam.; cataphylls 3-6 cm long, apiculate at apex, drying tan, weathering into dense, tangled, persisting fibers. LEAVES spreading; petioles $8.5-24 \mathrm{~cm}$ long, $2-5 \mathrm{~mm}$ diam., subterete, shallowly sulcate to weakly flattened adaxially, rounded abaxially; geniculum $0.8-2 \mathrm{~cm}$ long; blades moderately thick, oblong to oblong-elliptic or oblong-oblanceolate, acuminate at apex, acute to obtuse or narrowly rounded at base, $15-35 \mathrm{~cm}$ long, $3.3-7.5 \mathrm{~cm}$ wide, broadest near middle or just above; both surfaces punctate, conspicuously black punctate on lower surface; midrib convexly raised near base above, narrowed toward apex, prominulous below; primary lateral veins $14-20$ per side, departing midrib at ca. $45^{\circ}$ angle, \pm obscure above, scarcely visible below; collective vein arising from the base, scarcely visible above and below, $2-7 \mathrm{~mm}$ from margin (often more remote from margin in lower half of blade than in upper half). INFLORESCENCE usually erect-spreading, equalling or shorter than leaves; peduncle 10-27 cm long, 2-3 mm diam., as long as or longer than petioles; spathe green to purple, narrowly lanceolate, 3.4$6 \mathrm{~cm}$ long, $1-1.5 \mathrm{~cm}$ wide, broadest at base, acuminate at apex, obtuse to rounded at base, inserted at $45^{\circ}$ angle on peduncle; stipe $1-6 \mathrm{~mm}$ in front, to $3 \mathrm{~mm}$ in back, ca. $2 \mathrm{~mm}$ diam.; spadix green to brownish-red or purplish-green, 2-15 $\mathrm{cm}$ long, 7-9 $\mathrm{cm}$ diam. at base, 3-5 $\mathrm{mm}$ diam. at apex; flowers rhombic to 4-lobed, 2.1-2.5 mm long, 2-2.5 $\mathrm{mm}$ wide, the sides sigmoid; 4-5 flowers visible in the principal spiral, 5-9 flowers visible in the alternate spiral; tepals glossy, densely, weakly and minutely papillate, lateral tepals $1.2-2.5 \mathrm{~mm}$ wide, the inner margin convex; pistils emergent $0.3-0.5 \mathrm{~mm}$, white; stigmas elliptic, ca. $0.4 \mathrm{~mm}$ long with small droplets before stamens emerge; stamens emerging rapidly from the base, lateral stamens preceding alternates by only 1-2 spirals, exserted on filament ca. $0.5 \mathrm{~mm}$ long, which quickly retract to hold anthers at edge of tepals; anthers ca. $0.4 \mathrm{~mm}$ long, $0.6 \mathrm{~mm}$ wide; thecae white, dish-like, ellipsoid; pollen white. INFRUCTESCENCE with orange, ovoid berries. Fig. 216.

The species is known from Costa Rica in forests in vicinity of San Ramón and near Monteverde at elevations of 760 to $1,690 \mathrm{~m}$.

Anthurium utleyi is in section Porphyrochitonium and is most closely related to $A$. friedrichs- thalii, but differs from it in its shorter and broader leaves and its beaked berries. The species is named in honor of John and Kathy Utley, who made many important collections of Araceae in Costa Rica.

Costa Rica. alajuela: S of Balsa de San Ramón, Lent 3519, 3520 (F); Utley \& Utley 1851 (F); Los Ángeles de San Ramón, Brenes $14844 a$ (NY); N of Ángeles Norte de San Ramón, Luteyn 3695 (DUKE); Catarates de San Ramón, Brenes 14222 (NY); along road out of San Ramón, beyond Ángeles Norte, Luteyn et al. 4274 (DUKE). GUANACASTE: near E edge of Monteverde Preserve along road between Santa Elena and Monteverde, ca. 2.5 miles from Santa Elena, Croat 47135 (MO). HEREDIA: S of Cariblanco, Croat 35795 (MO). alajuela \& Puntarenas: Monteverde, Palmer 90 (NY); Dryer 1337 (F); Luteyn 3398 (DUKE); upper drainage of Río Peñas Blancas below Monteverde Cloud Forest, Lawton 1165 (F).

Anthurium validifolium K. Krause, Notizbl. Bot. Gart. Berlin-Dahlem 11: 607. 1932. TYPE: Panama. Chiriquí: forests along Río Ladrillo, above El Boquete, 1,200-1,300 m, Pittier 3052 (US).

Epiphyte; stems to $16 \mathrm{~cm}$ long, $12 \mathrm{~cm}$ diam.; leaf scars $2.5 \mathrm{~cm}$ wide; roots numerous, green, descending, 1-1.5 cm diam.; cataphylls subcoriaceous, ca. $20 \mathrm{~cm}$ long, acuminate at apex, drying $\tan (B \& \mathrm{~K}$ Yellow-red 9/10), persisting \pm intact. LEAVES erect-spreading; petioles 20 $27 \mathrm{~cm}$ long, 7-10 $\mathrm{mm}$ wide, \pm quadrangular, broadly and shallowly sulcate; geniculum 3-3.5 cm long; blades lanceolate, coriaceous, $47-69 \mathrm{~cm}$ long, 10-19 cm wide, acuminate at apex, rounded at base, broadest at middle, the margins broadly undulate; both surfaces matte; midrib broadly and convexly raised at base above, more acutely raised toward apex, diminishing and sunken at apex, raised and square at base below, more acute toward apex; primary lateral veins numerous, departing midrib at $60^{\circ}-70^{\circ}$ angle, \pm straight, arching near margin, sunken in valleys above, raised below; interprimary veins scarcely visible; collective vein arising from one of the primary lateral veins in the apical one quarter of the blade, 5-6 $\mathrm{mm}$ from margin, weakly sunken above, raised below. INFLORESCENCE spreading, shorter than leaves; peduncle 33-39 $\mathrm{cm}$ long, 9-12 cm diam., subterete, twice as long as petioles; spathe coriaceous, dark green (B \& $\mathrm{K}$ Yellow-green 5/10), turning yellow, ovate-lanceolate, $16-17 \mathrm{~cm}$ long, ca. $4 \mathrm{~cm}$ wide, acuminate at apex, rounded at base, inserted at ca. $45^{\circ}$ angle 

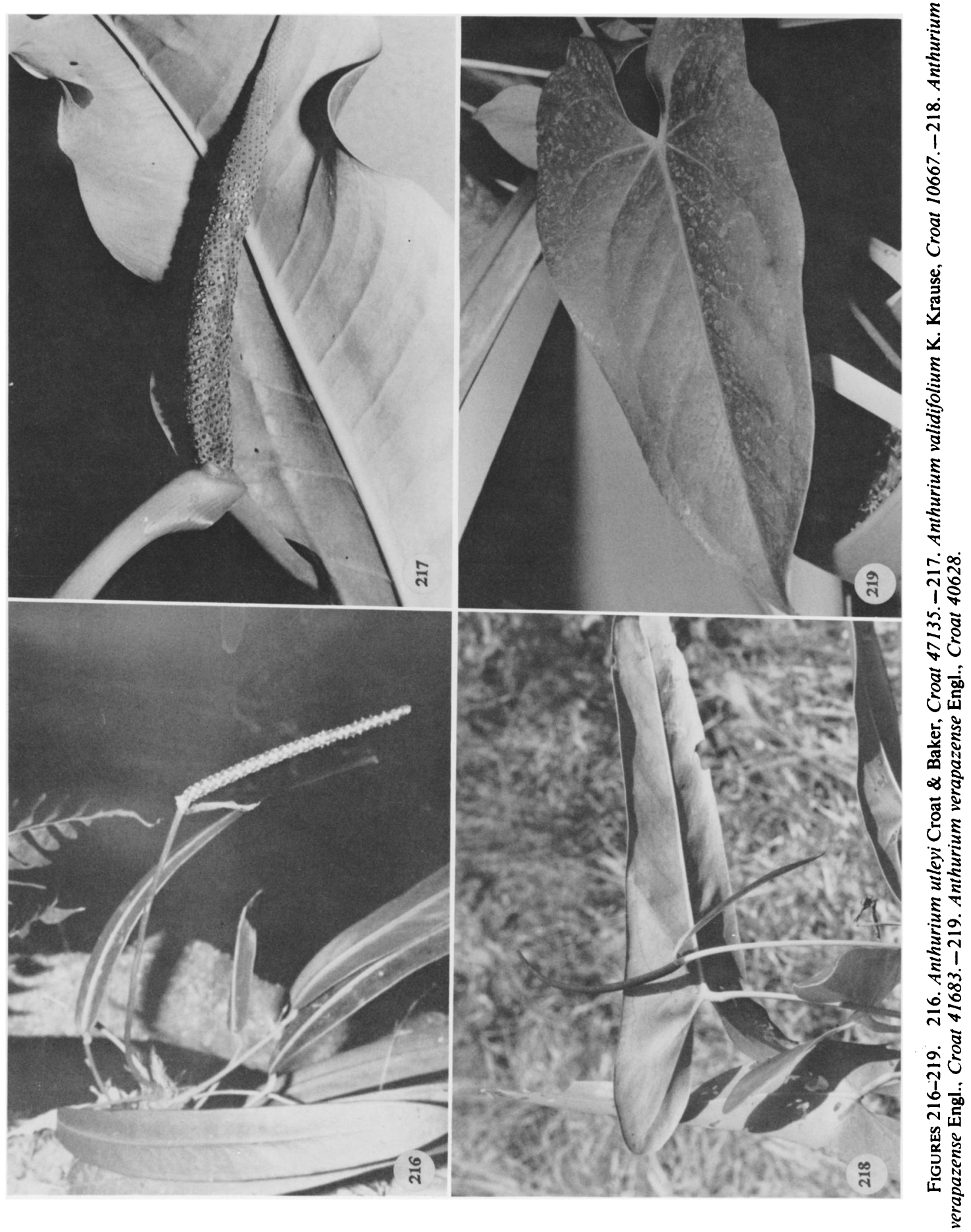
on peduncle, reflexed and held parallel to peduncle; stipe 7-13 mm long in front, ca. $3 \mathrm{~mm}$ long in back; spadix pale lavender to violet-purple (B \& K Purple $6 / 5$ to $5 / 2.5$ ), green at apex in early stages, $15-23 \mathrm{~cm}$ long, $1.2-3.5 \mathrm{~cm}$ diam. at base, $5-10 \mathrm{~mm}$ diam. at apex; flowers rhombic, 3-3.5 $\mathrm{mm}$ long, 3.1-3.6 $\mathrm{mm}$ wide, the sides straight to weakly sigmoid; 7-8 flowers visible in the principal spiral, 8-10 flowers visible in the alternate spiral; tepals matte, lateral tepals $1.5-$ $1.8 \mathrm{~mm}$ wide, the inner margin broadly rounded; pistils scarcely emergent, green; stigma elliptic, ca. $0.6 \mathrm{~mm}$ long, droplets apparent for ca. 1 week before stamens emerge; stamens emerging promptly from near base (but usually not the lowermost spiral) or sometimes at middle, the lateral stamens emerging in ca. three quarters the length of spadix before alternates emerge; anthers yellow-orange, held inward and partially covering stigma at level of tepals, ca. $1 \mathrm{~mm}$ long, 1.2 $\mathrm{mm}$ wide; thecae oblong-ellipsoid, scarcely divaricate; pollen yellow-orange (B \& $\mathrm{K}$ Yellowred 8/5). INFRUCTESCENCE pendent; spathe twisted; spadix $24-26 \mathrm{~cm}$ long, $2.3-2.5 \mathrm{~mm}$ diam.; berries bright orange, obovoid, flattened at apex, $0.8-15 \mathrm{~mm}$ long, pericarp thin, \pm transparent, orange; mesocarp fleshy, orange with minute raphide cells; seeds 1-2, ovoid, pale yellow, tinged brown at apex and base with somewhat flattened appendage at both ends, encased in a somewhat dry, sac-like structure. Figs. 213, 214, and 217.

Anthurium validifolium is a member of section Pachyneurium. It is known for certain only from Chiriquí Province of Panama, but a cultivated plant at Las Cruces Botanical Garden near San Vito de Java near the Panamanian border in Costa Rica may be a native to the area according to the owner, Mr. Bob Wilson. Most collections have been made in lower montane wet forest and lower montane rain forest from 1,600 to 2,000 $\mathrm{m}$. One Panamanian collection was made in premontane wet forest, which corresponds to the life zone at the Las Cruces Botanical Garden. This further substantiates that $A$. validifolium is also native to Costa Rica.

Anthurium validifolium is characterized by its large, moderately thick, lanceolate leaf blade, lavender to purple spadix, and bright orange, obovoid berries. It is perhaps most closely related to $A$. seibertii and $A$. protensum, which share a similar inflorescence and orange berries. It difiers from both of those species in having broader and thicker leaf blades. Its petiole is subquad- rangular and somewhat intermediate between the terete petiole of $A$. protensum and the sharply quadrangular petiole of $A$. seibertii. Although this suggests $A$. validifolium may be a hybrid between $A$. protensum and $A$. seibertii, its thicker, proportionally shorter blades are not found on either of these species.

Costa Rica. puntarenas: Las Cruces Botanical Gardens, Croat 44445 (MO).

Anthurium verapazense Engl., Pflanzenr. IV 23B: 191. 1905. TYPE: Guatemala. Alta Verapaz: Cubilhuitz (Finca Cubilhuitz $15^{\circ} 40^{\prime} \mathrm{N}$, $90^{\circ} 25^{\prime} \mathrm{W}$ ) elev. $350 \mathrm{~m}, H$. von. Tuerckheim 7788 (US, holotype).

Usually epiphytic, sometimes terrestrial; stems 4-8 cm long, 5-6 cm diam.; internodes and leaf scars hidden by persisting cataphylls and thick, descending, dark brown roots; cataphylls subcoriaceous, $6-9 \mathrm{~cm}$ long, acuminate at apex, sometimes tinged red-violet, subapical apiculum ca. $2 \mathrm{~mm}$ long, drying dark brown (B \& K Yellow $4 / 7.5$ ), persisting as reticulate fibers. LEAVES with petioles erect-spreading, 26-61 cm long, 6$7 \mathrm{~mm}$ diam., subterete; geniculum 3-4 cm long, conspicuously sulcate; blades moderately thick, triangular, sometimes ovate-triangular, gradually acuminate at apex, prominently lobed at base, 24-60 cm long, 14-27 cm wide, broadest at base or sometimes at point of petiole attachment; anterior lobe 24-49 $\mathrm{cm}$ long, convex to almost straight; posterior lobes $8-17 \mathrm{~cm}$ long; sinus hippocrepiform to spathulate to sometimes ovate, usually rounded at apex; both surfaces semiglossy, the lower surface densely punctate; midrib acutely raised above, diminished and sunken from just above the middle to the apex, convexly raised below; basal veins 4-6 pairs, the first free to base, those remaining coalesced $2.5-4 \mathrm{~cm}$, sunken above, raised below; primary lateral veins 7-9 per side, departing midrib at $45^{\circ}-55^{\circ}$ angle, loop-connecting to collective vein, sunken above, prominulous below; lesser veins less conspicuous; collective vein arising from the first basal vein, sunken above, raised below, 4-6 $\mathrm{mm}$ from the margin. INFLORESCENCE arching-pendent; peduncle 53-90 cm long, 4-6 $\mathrm{mm}$ diam.; spathe moderately thin, oblong-lanceolate, green (B \& K Yellow-green 7/10), sometimes tinged violet-purple at margins, $8.5-15 \mathrm{~cm}$ long, $1-2$ $\mathrm{cm}$ wide, broadest near base, narrowly acuminate at apex, obtuse at base, inserted at $45^{\circ}$ angle on peduncle; spadix violet-purple (B \& K Red- 
purple 2/5), 10-25 cm long, 6.5-8 $\mathrm{mm}$ diam. at base, 3-5 $\mathrm{mm}$ diam. at apex; flowers rhombic, 3.6-3.8 $\mathrm{mm}$ long, $2.3-2.8 \mathrm{~mm}$ wide, the sides straight parallel to the spiral, gradually sigmoid perpendicular to the spiral; 6-7 flowers visible in the principal spiral, 8-10 flowers visible in the alternate spiral; tepals matte to semiglossy, obscurely and sparsely punctate, minutely papillate, the lateral tepals ca. $2 \mathrm{~mm}$ wide, the inner margin \pm concave and turned up against pistil; pistils weakly emergent, violet-purple slightly paler than tepals; stigma slit-like, oblong, ca. 0.6 $\mathrm{mm}$ long; stamens emerging in a moderately rapid sequence from the base, the laterals first, followed shortly by alternates, the leading stamens preceding third and fourth by several spirals, briefly exserted on purplish filaments, withdrawing to level of tepals; anthers yellow, ca. $0.2 \mathrm{~mm}$ long, $0.6 \mathrm{~mm}$ wide, held in a close, tight circle around pistil; thecae ellipsoid, divaricate; pollen lemon-yellow fading to white. INFRUCTESCENCE pendent; spadix 15-34 cm long, 1-2.8 $\mathrm{cm}$ diam.; spathe often withered or deciduous; berries subglobose to obovoid, rounded at apex, developing in the basal one third to one half, ca. $7 \mathrm{~mm}$ long, ca. $6.7 \mathrm{~mm}$ diam.; mesocarp juicy, with numerous whitish raphide cells; seeds $1-2$, 3.5-4.2 mm long, 3-3.6 mm wide, $2-2.5 \mathrm{~mm}$ thick, broadly ellipsoid to subrounded, flattened, emarginate at apex, pale purplish-violet with numerous, clear punctations, the surface sticky, the hypocotyl small. Figs. 215, 218, and 219.

Anthurium verapazense ranges from Belize to Guatemala along the Atlantic slope in principally moist forest habitats at elevations of 100 to 800 m. It is easily confused with $A$. lucens, which is more wide ranging, occurring throughout much of Chiapas and northern Guatemala as well as in northern Honduras. The latter is generally found at higher elevations, from 350 to $2,000 \mathrm{~m}$.

Anthurium verapazense is in section Belolonchium and is distinguished by its usually long, narrow spathe, much less than half as long as the spadix at anthesis. In addition the inflorescence is usually 1.5 to 3 times longer than the longest petioles. Anthurium lucens differs in having a relatively short spadix with the spathe usually over half as long as the spadix at anthesis, by the relatively shorter inflorescence which is shorter than the leaves or rarely more than 1.5 times longer than the petioles, and by the red, obovoid berries with 2 relatively much larger seeds.

Leaf shape in $A$. verapazense is greatly vari- able, ranging from deltoid to ovoid to deltoidhastate. The lobes may be directed downward, sharply outward, or even somewhat inward. Even plants within a single population may show great variability. Neither $A$. verapazense or $A$. lucens show correlation with regard to leaf shape although collections from the same area show similar trends in variation. Worthy of mention is a collection of $A$. verapazense made by Dr. R. Tejada (307) purportedly collected in Mazatenango, a town on the Pacific slope. I believe it is unlikely that the species ever occurred there and perhaps there was (in 1914) another village called Mazatenango located on the Atlantic slope or perhaps the collection was cultivated in Mazatenango. Other species were also collected by Tejada at Mazatenango that are likewise not believed to have ever occurred there.

It is possible that additional work will prove that the taxon as constituted here consists of two species. A live collection made by Hans Wiehler near Purulhá in Alta Verapaz (Guatemala) and cultivated at Selby Botanical Gardens produced subglobose, red-orange berries that had 6-9 small seeds. This has been vouchered as Madison 3739. A second Madison collection (6965) from a live plant purportedly also from Purulhá had similar berries with 2 large seeds. These were similar to the berries of other collections studied, namely Jones \& Facey 3389 from the department of Izabal and Boutin 5122 from Belize. The latter is live at the Missouri Botanical Garden. These drastic differences are not easily explained and have not been exhibited in other species of $A n$ thurium. The problem warrants additional investigation.

Belize. Belize District: S of Gales Point, cultivated at Kew, Hunt 7043 (K, MO); Gracy Rock, Sibun River, Gentle 1667 (MICH, MO, NY); Manatee Lagoon, Peck 24 (GH); 22 miles south of Western Highway, Dwyer \& Liesner 1512 (MO); Croat 23852 (MO). CAYO DISTRICT: no other location, Lundell 6341 (MICH); La Flor hunting camp, S of Grano de Oro, Gentry 7833 (MO); Mountain Pine Ridge, Bartlett 13054 (MICH, US); Hunt 416 (US); Lundell 6780 (MICH); Wiley $325 \mathrm{~A}$ (MO); between San Luis and Cuevas at Río Macal, Croat 23533 (MO); Waterhole Camp near Vaca, Gentle 2445 (MICH). STANN CREEK DISTRICT: Stann Creek Railroad, Schipp $S 177$ (F). TOLEDO DISTRICT: Maya Mountains, Union Camp, Boutin \& Schlosser 5122 (MO).

Guatemala. Alta verapaz: Chamá, Johnson 896 (UCLA); along road to Finca Trece Aguas, $\mathrm{N}$ of Church in Senahú, Luteyn \& Almeda 3523 (DUKE); vicinity of Laguna Sapalau, SW of Sibicté, Steyermark 44924 (MO); 4-9 miles up road to Oxec, along gravel road which turns $\mathrm{N}$ off Highway $7 \mathrm{E}$ between Tucurú and $\mathrm{El}$ 
Estor ca. $6 \mathrm{~km} \mathrm{NE}$ of Panzós, Croat 41605, 41683 (MO); vicinity Purulhá, cultivated at Selby, Madison 3739, 6965 (MO). IZABAL: vicinity Exmibal, NW of Lake Izabal, Jones \& Facey 3389 (LL, NY). PETÉN: Poptún, Molina 15613 (NY).

Mexico. Chiapas: Finca Prusia, Mapastepec, NW of Huixtla, MacDougall 337 (CAS, DS, MEXU); Lagos de Montebello, $3 \mathrm{mi} \mathrm{W}$ of Dos Lagunas, Croat 46656 (MO); Ocozocoautla de Espinosa, Breedlove 27489(DS); $\mathrm{N}$ of Ocozocoautla de Espinosa on gravel road to Apitpac, Croat 40628 (MO). verACRUZ: Lake Catemaco, Soteapan, Beaman 6142 (XAL).

Anthurium watermaliense Hort. ex L. H. Bailey, Stand. Cycl. Hort. 1: 303. 1922. TYPE: Colombia. Not seen (introduced into horticulture via Watermall, Belgium).

Terrestrial; stems to $25 \mathrm{~cm}$ long; cataphylls thin, 4.5-9 cm long, rounded at apex, weathering into coarse fibers. LEAVES with petioles erectspreading, 12-88 cm long, \pm terete, weakly flattened or sulcate; geniculum 1-1.5 cm long; blades ovate-triangular, moderately thick, gradually acuminate at apex, deeply lobed at base, 30-60 cm long, 19-36 cm wide; the anterior lobe 20$45 \mathrm{~cm}$ long; posterior lobes $14-26 \mathrm{~cm}$ long; sinus parabolic to hippocrepiform; both surfaces semiglossy; midrib convexly raised above and below; basal veins $5-8$, the second to eighth coalesced $4.5-8 \mathrm{~cm}$, prominulous above and below, yellow below, posterior rib mostly naked, weakly turned up; primary lateral veins $4-8$ per side, departing midrib at $40^{\circ}-45^{\circ}$ angle, prominulous in valleys above, prominulous below; lesser veins less conspicuous; collective vein arising from the first or second basal vein, raised above and below, 3-6 $\mathrm{mm}$ from margin. INFLORESCENCE spreading, shorter than leaves; peduncle $12-66 \mathrm{~cm}$ long, 5-7 mm diam., spathe lanceolate-triangular, green to dark violet-purple, subcoriaceous, 5-21 $\mathrm{cm}$ long, $2.3-8.5 \mathrm{~cm}$ wide, long-acuminate at apex, obtuse to rounded at base, inserted at $75^{\circ}$ angle on peduncle; stipe $0.3-3 \mathrm{~cm}$ long; spadix white to greenish, yellow or purple, $7-10 \mathrm{~cm}$ long, 5-10 $\mathrm{mm}$ diam. at base, $2-5 \mathrm{~mm}$ diam. at apex; the flowers rhombic to 4-lobed, $1.5-3.4 \mathrm{~cm}$ long, $1.8-3.1 \mathrm{~mm}$ wide, the sides straight to jaggedly sigmoid; 5-12 flowers visible in the principal spiral, 6-16 flowers visible in the alternate spiral; tepals matte, green with purple on inner and outer edges, punctate, with sparse droplets when stamens are fresh, lateral tepals $1.5-2.2 \mathrm{~mm}$ wide, the inner margin convex to \pm straight; pistil dark green, glossy, raised, weakly exserted just before stamens emerge; stigma narrowly elliptic, ca. 0.5 $\mathrm{mm}$ long, with papillae not exserted, a small stig- ma droplet apparent 2-3 days before stamens emerge, dry and gray as stamens open; stamens emerging rapidly from base, or sometimes scattered throughout, exserted on short translucent filaments, $0.3-0.4 \mathrm{~mm}$ long, $0.6 \mathrm{~mm}$ wide, which retract holding stamens in a tight cluster over pistil; anthers creamy white, $0.9 \mathrm{~mm}$ long, 0.9 $1 \mathrm{~mm}$ wide; thecae ellipsoid, divaricate; pollen white. INFRUCTESCENCE with spadix to 22 cm long; berries yellow to orange, ovoid to obovoid, beaked, $1-1.5 \mathrm{~cm}$ long. Figs. 224 and 225 .

The species is known from Costa Rica to Colombia, usually from 750 to $2,400 \mathrm{~m}$ elevation in premontane rain and lower montane rain forest. Some populations also occur near sea level in tropical moist forest and premontane wet forest. The species is extremely variable, especially in leaf size and shape, and spathe and spadix color. It is strange that the species has not been found in tropical wet forest or at elevations between 100 and $700 \mathrm{~m}$. Perhaps further study will show that the lower elevation populations are a distinct species.

Anthurium watermaliense is an atypical member of section Pachyneurium and is not generally confused with any other species in Central America. It can be recognized by the ovate-triangular to sub-3-lobed leaf blades, the broad, frequently dark purple spathe, green to purple, stipitate spadix with long-exserted stamens, and yellow to orange berries.

The species has long been known in horticultural circles, being first introduced from Colombia to Watermall, Belgium, by an unknown collector; although the name was validated by a short note by Bailey in the Standard Cyclopedia of Horticulture (1: 303. 1922), no type was designated. I have as yet seen no Colombian material of the species and therefore decline to name a lectotype at this time.

Costa RicA. No other location, Lankester 349-49 (K). Alajuela: Monteverde Biological Reserve, Kennedy \& Guidon 3799 (MO). CARTAGO: Camino Raiz de Hule, SE of Platanillo, Croat 36713 (MO); vicinity Palo Verde, Luteyn \& Wilbur 4376 (MO). HEREDIA \& SAN JOSÉ: S facing slopes of Cerro Zurquí, Almeda 3706 (MO); Río Para Blanca, Cerro de Zurquí, Burger et al. 9342 (MO); Cerro Zurquí, N of San Luis Norte, Stolze 1548 (MO). LIMÓN: between Bribrí and Bratsi, along Río Sixaola, Burger et al. 10444 (MO); vicinity Bribrí, Río Catarata, Croat 43224 (MO); N of Limón, Lent 347 (MO).

Anthurium wendlingeri G. M. Barroso, Bol. Soc. Venez. Ci. Nat. 26: 151. 1965. TYPE: Costa 


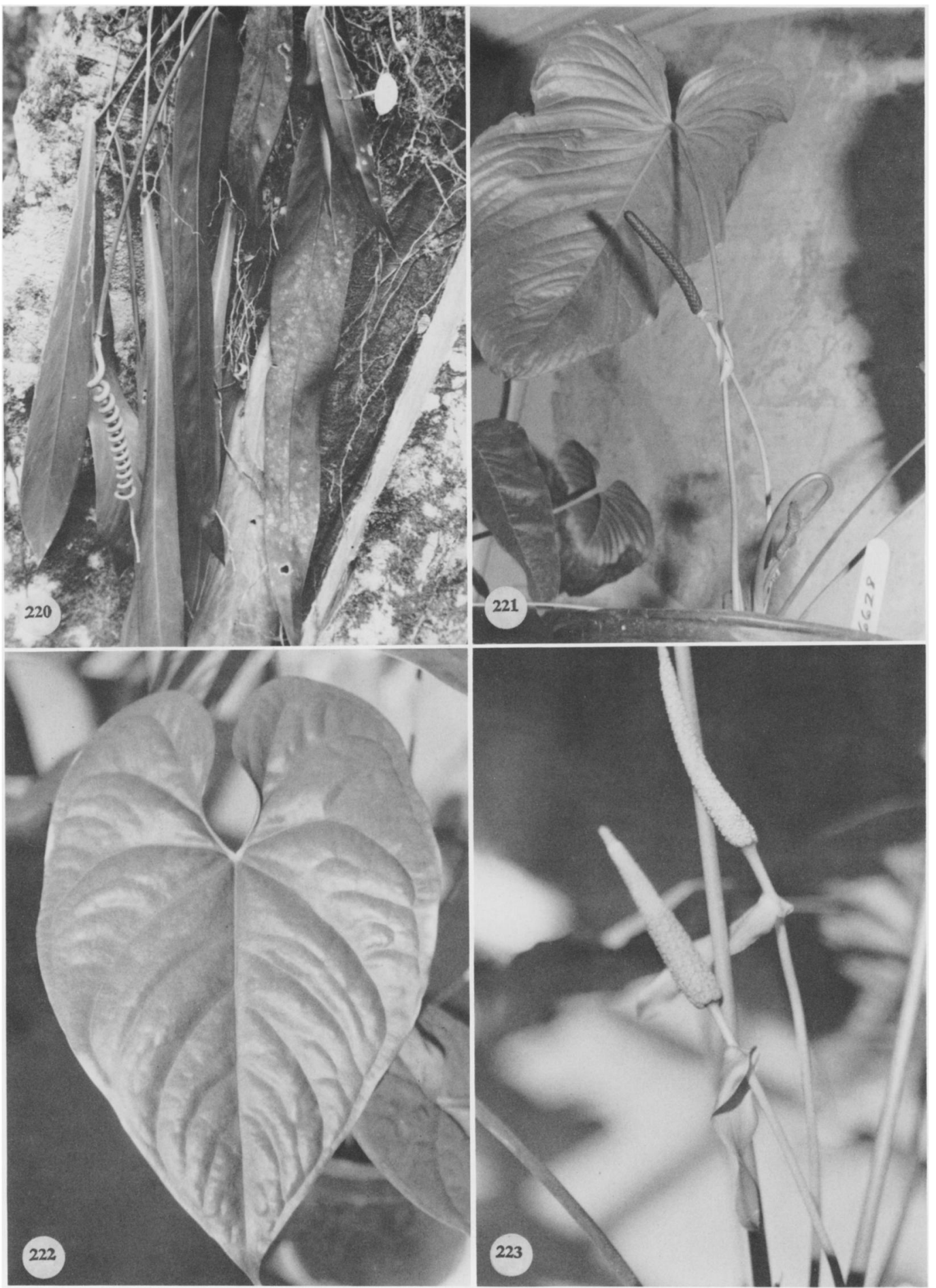

Figures 220-223. 220. Anthurium wendlingeri G. M. Barroso, Croat 34295.-221. Anthurium williamsii K. Krause, Croat 36628.-222-223. Anthurium yetlense Matuda, Croat 39768. 


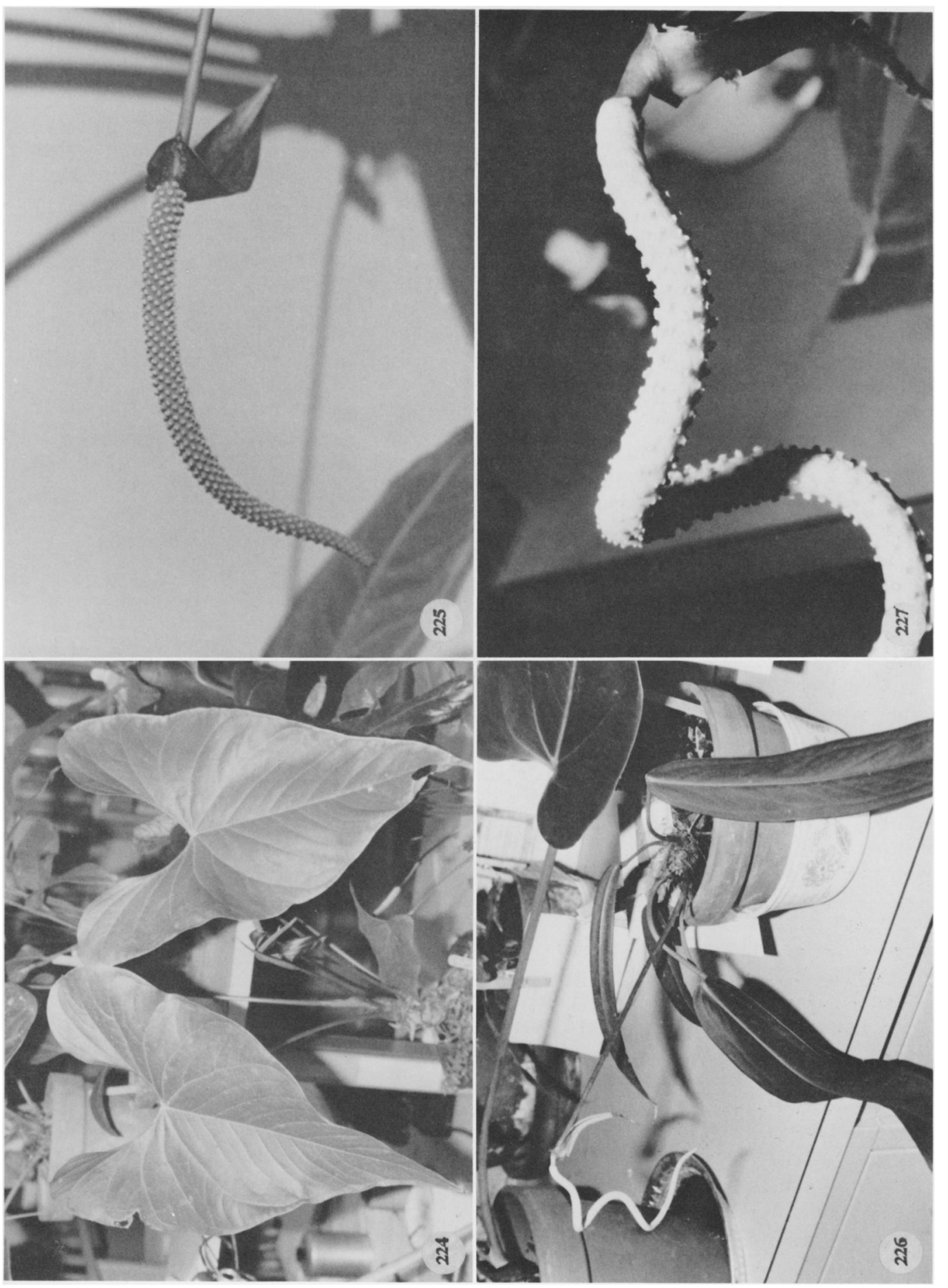

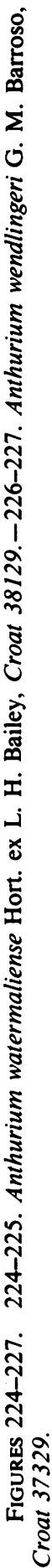


Rica. Cartago: Turones (Pavones), Turrialba, $700 \mathrm{~m}$, Wendlinger s.n. (RB, holotype).

Pendent epiphyte; stems ca. $20 \mathrm{~cm}$ long; the internodes $1.5-2 \mathrm{~cm}$ long, except near apex; roots moderately thick; cataphylls moderately thick, $5.5-15 \mathrm{~cm}$ long, acuminate at apex, drying brown, weathering into coarse persistent, longitudinal fibers. LEAVES spreading-pendent; petioles terete, (5)8-30 cm long, 2-4 mm diam.; geniculum $1-1.5 \mathrm{~cm}$ long; blades oblong, moderately thick, 32-80 cm long, 3-11 cm wide, acuminate at a apex, round to truncate at base; upper surface weakly velvety, obscurely and sparsely glandular-punctate, lower surface semiglossy, sparsely glandular-punctate; midrib convexly raised at base above, more acute toward apex, diminishing and flat at apex, raised at base below, flat from ca. midway to apex; primary lateral veins 11-24 per side, departing midrib at $30^{\circ}-40^{\circ}$ angle, raised and nearly obscure above, flat below; lesser veins obscure; collective vein arising from the lowermost primary lateral vein, weakly sunken above, flat to weakly raised below, 5-9 $\mathrm{mm}$ from margin. INFLORESCENCE spreading to pendent, usually shorter than leaves; peduncle 13-42 cm long, 3-7 mm diam.; spathe moderately thin, pale green tinged purplish, \pm oblong, 7-11 cm long, 8-13 mm wide, gradually acuminate at apex, inserted at ca. $45^{\circ}$ angle on peduncle, withering and curling horizontally or deciduous; spadix pale green to white or grayishwhite, straight when young, becoming spiralled in age, $12-80 \mathrm{~cm}$ long, 3-5 mm diam. at base, narrowly-tapered to apex; flowers \pm 4-lobed, 3$3.1 \mathrm{~mm}$ long, 2.4-2.6 $\mathrm{mm}$ wide, the sides smoothly sigmoid; 4-5 flowers visible in the principal spiral, ca. 10 flowers visible in the alternate spiral; tepals matte, weakly punctate, minutely papillate, the lateral tepals $1.6-1.7 \mathrm{~mm}$ wide, the inner margin broadly rounded; pistils weakly emergent, pale green, glossy; stigmas linear, $0.3 \mathrm{~mm}$ long; lateral stamens emerging scattered throughout length of spadix, alternate stamens soon following with no apparent pattern; anthers cream, held at edge of tepals against sides of pistil, ca. $0.7 \mathrm{~mm}$ long, ca. $0.6 \mathrm{~mm}$ wide; thecae ellipsoid, not divaricate; pollen creamywhite. INFRUCTESCENCE pendent; berries reddish, \pm oblong or globose, ca. $5 \mathrm{~mm}$ long, flattened at apex with a central depression. Figs. 220, 226, and 227.

Panamanian plants considered $A$. wendlingeri range from Veraguas in the west to Coclé, $\mathrm{Pa}$ - namá, and Colón Provinces on the Atlantic slope and along the Continental Divide in tropical wet forest and premontane rain forest at elevations of 350 to $900 \mathrm{~m}$.

Anthurium wendlingeri was described from live material collected in Cartago Province of Costa Rica. The type description reports the inflorescences as being "atropurpureus" and no other flowering material has been seen for Costa Rica. Panamanian collections closely matching this species in vegetative condition, habit and all other aspects consistently have spadices that are white to grayish-white at anthesis. More material must be seen from Costa Rica to determine if those populations really do have purple spadices and to determine if the Panamanian plants are the same or if they should be considered distinct. One collection from Coclé (Croat 37329) was reported to have a reddish spadix but it has consistently flowered with a white spadix in cultivation.

The species is in section Porphyrochitonium and is distinguished by its coriaceous, oblong, glandular-punctate leaf blades, very elongate, whitish, corkscrew-like spadix and reddish berries. The blades are weakly velvety and obscurely punctate above and below. It is most easily confused with another Panamanian species, A. pendens Croat (ined.), which occurs in similar habitats in Colón and Panamá Provinces. That species differs, however, in having narrowly oblanceolate blades that are acute at the base and that dry conspicuously blackened, and especially by its stouter, relatively short, greenish-purple to brownish spadix, which never coils.

Costa Rica. Heredia: S of Cariblanco, Croat 35830 (MO).

Anthurium williamsii K. Krause, Notizbl. Bot. Gart. Berlin-Dahlem 11: 610. 1932. TYPE: Panama. Darién: near Cana, Williams 817 (not seen).

Terrestrial; stems short; cataphylls subcoriaceous, 3-12 cm long, acute at apex, drying brown (B \& K Yellow-red 2/5), weathering into longitudinal fibers. LEAVES with petioles erectspreading, 23-61 cm long, 5-8 $\mathrm{mm}$ diam., subterete, sometimes faintly $2-3$ - or more ribbed; geniculum $2-3.5 \mathrm{~cm}$ long; blades narrowly ovate to broadly ovate, thin, \pm membranous, long acuminate to cuspidate at apex, lobed at base, 26$48 \mathrm{~cm}$ long, $19.5-36 \mathrm{~cm}$ wide, broadest at middle; anterior lobe $21-35 \mathrm{~cm}$ long, the margins 
broadly rounded; posterior lobes $9-16 \mathrm{~cm}$ long from apex of sinus to outermost point; sinus triangular, sometimes closed, acute at apex; matte to semiglossy on both surfaces; midrib weakly and convexly raised above, prominently raised below; basal veins 6-7 pairs, usually all free to base; posterior ribs absent; primary lateral veins $8-10$ per side, departing midrib at $35^{\circ}-50^{\circ}$ angle, sunken in valleys above, prominently raised below, basal and primary lateral veins drying conspicuously yellow; lesser veins scarcely visible; collective vein arising from one of the uppermost basal veins, 2-3 $\mathrm{mm}$ from the margin. INFLORESCENCE erect; peduncle (16)40-53 cm long, 4-5 mm diam., shorter or equalling petiole; spathe membranous, pale green (B \& K Green 7/5), sometimes withering early, lanceolate, $7-12.5 \mathrm{~cm}$ long, $1.5-2.8 \mathrm{~cm}$ wide, caudate-acuminate at apex, subcordate at base, inserted on peduncle at $25^{\circ}$ angle; stipe $3-5 \mathrm{~mm}$ long in front, $1-3 \mathrm{~mm}$ long in back; spadix violet-purple or green tinged violet-purple, (7)11-20 cm long, (6)7-10 mm diam. at base, $4-5 \mathrm{~mm}$ diam. at apex; flowers square, $2.5-3 \mathrm{~mm}$ long, $2.1-3 \mathrm{~mm}$ wide, the sides weakly sigmoid; 4-5 flowers visible in the principal spiral, 7-9 flowers visible in the alternate spiral; tepals glossy, lateral tepals $1.7-2 \mathrm{~mm}$ wide, the inner margin convex; pistils dark purple, scarcely emergent before anthers emerge; stigmas minute, scarcely visible; stamens emerging rapidly from the base, the leading stamens emerging at apex as third and fourth are emerged twothirds the length of spadix, exserted on white, translucent, flattened filaments, ca. $0.4 \mathrm{~mm}$ long, retracting to hold anthers over pistil; anthers purple to red-violet $0.4-0.5 \mathrm{~mm}$ in both directions; thecae ellipsoid; pollen orange (B \& $\mathrm{K}$ Yellowred 7/5). INFRUCTESCENCE pendent; berries deep red-violet, obovoid; mesocarp gelatinous with numerous raphide cells; seeds 2 , pale yellow, tinged reddish brown at apex, green at base, ovoid, flattened, $4.6 \mathrm{~mm}$ long, 3.3-3.7 $\mathrm{mm}$ wide, $2 \mathrm{~mm}$ thick, encased in a sticky substance. Fig. 221.

Anthurium williamsii ranges from Costa Rica to Ecuador from near sea level to $1,800 \mathrm{~m}$ elevation. In Costa Rica it has been collected in premontane rain forest. In Panama it has been collected in premontane wet forest, tropical wet forest, and premontane rain forest.

The species is placed in section Polyneurium and is closest to A. cuspidatum (see that species for differences). One collection from Costa Rica
(Croat 36721) is somewhat intermediate between $A$. williamsii and $A$. cuspidatum and may be a hybrid.

Costa Rica. CARTAgo: vicinity of Moravia, Croat $36628,36721,36790(\mathrm{MO})$.

Anthurium yetlense Matuda, Anales Inst. Biol. Univ. Nac. México 32: 151, Fig. 7. 1961. TYPE: Mexico. Oaxaca: near Yetla (San Mateo Yetla?), January 14, 1959, MacDougall 410 (MEXU, holotype).

Terrestrial; stems ca. $30 \mathrm{~cm}$ long, $3.5 \mathrm{~cm}$ diam., green; internodes short; roots thick, tan, pubescent, directed downward; cataphylls subcoriaceous, 7-9 cm long, tinged red-violet, rounded at apex, acumen apiculate, subapical apiculum 2-5 mm long, drying brown, persistent, splitting at base, the apex intact. LEAVES erect-spreading; petioles $28-45 \mathrm{~cm}$ long, 4-7 $\mathrm{mm}$ diam., terete, heavily tinged red-violet in early stages; geniculum $2.3-2.5 \mathrm{~cm}$ long, weakly sulcate; blades broadly ovate to rounded, moderately thick, gradually long-acuminate at apex, deeply lobed at base, $20-44 \mathrm{~cm}$ long, $15.5-29 \mathrm{~cm}$ wide, broadest at point of petiole attachment or slightly above; anterior lobe 15-29 cm long, the margins rounded; posterior lobes 7-15 cm long from apex of sinus to outermost point; sinus obovate to campaniform, sometimes closed, acute at apex; both surfaces matte to semiglossy, lower surface much paler; midrib convexly raised above, flat at apex, acutely raised below; basal veins $4-5$ pairs, first and second free, third to fifth coalesced 2.5-3 $\mathrm{cm}$, raised in valleys above, raised below; posterior ribs \pm straight, inner margins sharply rolled up; primary lateral veins 4-6 per side, departing midrib at $40^{\circ}-50^{\circ}$ angle, curving toward apex and joining collective vein, sunken above, raised below; interprimary veins flat above, prominulous below; lesser veins scarcely visible; collective vein arising from the first basal vein, sunken above, raised below, 7-12 $\mathrm{mm}$ from margin. INFLORESCENCE erect-spreading, shorter than leaves; peduncles 18-20 cm long, 4-5 mm diam., terete, green heavily tinged with red-violet, one third to one half as long as petioles; spathe coriaceous, green tinged with red-violet, broadly lanceolate, $7.5-9 \mathrm{~cm}$ long, $2.5-3 \mathrm{~cm}$ wide, broadest at base, acuminate at apex, subcordate at base, inserted at $45^{\circ}$ on peduncle; stipe $2-2.5 \mathrm{~cm}$ long in front, $1.5-1.8 \mathrm{~cm}$ long in back, $5 \mathrm{~mm}$ wide, green tinged with red-violet; spadix green $(\mathrm{B} \&$ $\mathrm{K}$ Yellow-green, 6/7.5), 8-8.2 cm long, 1.2-1.5 
$\mathrm{cm}$ diam. at base, 7-9 mm diam. at apex; flowers rhombic to 4-lobed, 3-3.2 mm long, 4-4.5 mm wide, the sides sigmoid; ca. 5 flowers visible in the principal spiral, ca. 7 flowers visible in the alternate spiral; tepals matte, weakly punctate, densely and minutely papillate, lateral tepals ca. $2.3 \mathrm{~mm}$ wide, the inner margin straight; pistils emergent, weakly raised, green; stigma linear, nearly obscure; lateral stamens emerging from base to apex, rapidly followed by third and fourth, exserted on short, translucent filaments; anthers yellow, ca. $0.5 \mathrm{~mm}$ long, $0.3 \mathrm{~mm}$ wide, held in a contiguous circle over pistil then retracting and opening at edge of tepals; thecae ellipsoid, scarcely divaricate; pollen yellow, fading to white. INFRUCTESCENCE pendent; berries dark orange, ovoid, 1.2-1.5 cm long, 1.2-1.4 cm diam., rounded at apex with 4 faint ridges; seeds 2 , green, $1-1.3 \mathrm{~cm}$ long, $7-8 \mathrm{~mm}$ thick, markedly flattened on one side. Figs. 222 and 223.

Anthurium yetlense is endemic to Mexico in the Sierra de Juárez in northern Oaxaca. It is known only from the area south of Valle $\mathrm{Na}$ cional from 600 to $1,500 \mathrm{~m}$ in wet cloud forests.

The species is a member of section Belolonchium and occurs with and is similar to $A$. umbrosum. Both species are terrestrial; however, $A$. yetlense differs from $A$. umbrosum in that the inflorescence is much shorter than the leaves and the leaf is broadly ovate rather than ovate-triangular. The spadix of $A$. yetlense is green at anthesis whereas the spadix of $A$. umbrosum becomes violet-purple.

Mexico. OAXACA: near Yetla (San Mateo Yetla), MacDougall 410 (MEXU); between Valle Nacional and Oaxaca, W of Valle Nacional, Croat 39768 (MO).

\section{SPeCIES EXCluded}

Anthurium eggersii Engler. This species is a distinct species known only from Pacific Coastal Ecuador. Croat and Baker (1979) in the treatment of Anthurium for Costa Rica considered the species a synonym of $A$. paludosum, but further investigations show it to lack the entire cataphylls so characteristic of $A$. paludosum.

Anthurium crassinervium (Jacq.) Schott. This species is restricted to the Coastal Cordillera of Venezuela. Specimens cited as this species are $A$. salviniae or A. schlechtendalii.

Anthurium fraternum Schott. This species is restricted to northern Colombia in the mountainous region south of Santa Marta. Material with which it has been confused in Central America belongs to $A$. huixtlense.

\section{Literature Cited}

Berlin, B. \& P. Kay. 1969. Basic Color Terms, Their Universality and Evolution. University of California Press, Berkeley.

Bunting, G. S. 1965. Commentary on Mexican Araceae. Gentes Herbarum 9, Cornell University, Ithaca, NY.

Croat, T. B. 1976. Studies in Araceae I: Section Leptanthurium Schott, the Anthurium gracilefriedrichstalii complex of Central and South America. Selbyana 1: 357-364.

_- 1979. The distribution of Araceae. In K. Larson \& L. B. Holm-Nielsen, editors, Tropical Botany. Academic Press, London.

- 1980. Flowering behavior of the Neotropical genus Anthurium (Araceae). Amer. J. Bot. 67: 888904.

- \& R. BAKer. 1978. Studies in Araceae II: Anthurium Section Polyphyllium. Selbyana 2: 230238.

\& - 1979. The genus Anthurium (Araceae) in Costa Rica. Brenesia 16, Supl. 1, Department of Natural History, Museo Nacional De Costa Rica.

- \& G. S. Bunting. 1979. Standardization of Anthurium descriptions. Aroideana 2: 15-25.

ENGLER, A. 1877. Vergleichende Untersuchen über die morphologischen Verhältnisse der Araceae. II Theil. Über Blattstellung und Sprossberhaltnisse der Araceae. Nova Acta der Ksl. Leop.-Carol.Deutschen Akademie der Naturforsher 39: 159232.

. 1905. Araceae-Pothoideae. Das Pflanzenr. IV. 23B, Heft 21, pp. 1-330.

Flores, G., L. Jimenez, X. Madrigal, R. Moncayo \& F. TAKAAKI. 1971. Mapa de Tipos de Vegetacion de la Republica Mexicana 1:200,000. Secretaria de Recursos Hidraulicos.

Holdridge, L. R., W. C. Grenke, W. H. Hatheway, T. Liang \& J. A. Tosi. 1971. Forest Environments in Tropical Life Zones. Pergammon Press, New York.

Macbride, J. F. 1936. Araceae: Flora of Peru. Field Mus. Nat. Hist., Bot. Ser. 13, 1(3): 428-486.

Madison, M. 1978. The species Anthurium with palmately divided leaves. Selbyana 2: 239-281.

Matuda, E. 1954. Las Araceas Mexicanas. Anales Inst. Biol. Univ. Nac. Mexico 24: 98-218.

_. 1961. Nuevas plantas de Mexico. Anales Inst. Biol. Univ. Nac. Mexico 32: 143-155.

SHEFFER, R. D. 1974. Chromosome number and compatibility in the genus Anthurium (Araceae) with a taxonomic revision of the Section Tetraspermium. Doctoral dissertation, University of Hawaii.

—, W. L. Theobald \& H. Kamemoto. 1980. Taxonomy of Anthurium scandens (Araceae). Aroideana 3: 86-93.

Standley, P. C. 1944. Araceae. Part II. Fascicle 3. In R. E. Woodson, Jr. \& R. W. Schery, Flora of Panama. Ann. Missouri Bot. Gard. 31: 1-60.

- \& J. A. STeyermark. 1958. Araceae: Flora of Guatemala. Fieldiana, Bot. 24(1): 304-363. 